\title{
FAU
}

UNIVERSIDAD NACIONAL DE LA PLATA

FACULTAD DE ARQUITECTURA Y URBANISMO

DOCTORADO EN ARQUITECTURA Y URBANISMO

\section{LA CONSTRUCCIÓN EN ALTURA COMO UNA OPCIÓN EFICIENTE PARA LA VIVIENDA DE INTERÉS SOCIAL EN GRANDES CIUDADES: TIPOLOGÍA Y COSTOS, DE SALVADOR A BUENOS AIRES (1937 A 2017)}

\author{
Tesis doctoral presentada por \\ EDNILSON LUIZ SANTANA MENEZES \\ Ante la \\ Facultad de Arquitectura y Urbanismo de la \\ Universidad Nacional de La Plata \\ para acceder al grado académico de \\ DOCTOR EN ARQUITECTURA Y URBANISMO \\ Dirección de tesis: \\ Director: Arq. Jorge Lombardi \\ Codirector: Dr. Ing. Marcos Jorge Almeida Santana
}

La Plata, Argentina, 4 de junio de 2021 


\section{LA CONSTRUCCIÓN EN ALTURA COMO UNA OPCIÓN EFICIENTE PARA LA VIVIENDA DE INTERÉS SOCIAL EN GRANDES CIUDADES: TIPOLOGÍA Y COSTOS, DE SALVADOR A BUENOS AIRES 1937 A 2017)}

Tesis presentada como requisito para la obtención del grado de Doctor en Arquitectura y Urbanismo, Facultad de Arquitectura y Urbanismo, Universidad Nacional de La Plata.

Aprobada el 4 de junio de 2021

Arq. Jorge Lombardi - Director

Dr. Ing. Marcos Jorge Almeida Santana - Codirector

Miembros de la Comisión Evaluadora:

Dr. Ing. Arq. Ernesto Kuchen

Dr. Arq. Gustavo A. San Juan

Arq. Uriel Néstor Jáuregui 
in memoriam

A los inolvidables padres, Juvenal Menezes e Idalia Santana Menezes, así como a los importantísimos y queridos que también ya se fueron... y que formaron parte de la Vida de manera muy especial: tíos Raymundo Santana, Haydé Santana y Ana Menezes; Yeda Martins; Maria Célia Neu; “Velho” Dorgon Magalhães; Jaime Menezes; D. Eunice Góes y dos amigos, desde la adolescencia en el Colegio: Clarival Cézar y Luiz Murta. 


\section{AGRADECIMIENTOS}

Es indispensable mencionar el incentivo y la colaboración permanente del Prof. Marcos Jorge, codirector de esta tesis, así como la imprescindible y firme acogida que recibí de inmediato por parte del Prof. Jorge Lombardi, director de esta tesis. A ambos agradezco con profunda gratitud por los aciertos hasta aquí obtenidos, dejando en claro que los vacíos que puedan ser señalados son de mi exclusiva responsabilidad.

Es obligatorio rendir mi agradecimiento a la ingeniera Prof. Dra. Marta Rosen, al ingeniero Ernesto Selzer y al arquitecto Dr. Jorge Sarquís del Doctorado de la Facultad de Ingeniería de la Universidad de Buenos Aires (UBA), que, siempre muy atentos, anticiparon las primeras contribuciones para que esta tesis se desarrollara en Argentina inicialmente bajo la dirección del ingeniero Selzer y la codirección del arquitecto Jorge Sarquís.

Dado el gran número de personas que colaboraron tanto en Brasil como en Argentina y el poco espacio disponible para nombrarlas una por una, solicito que, una vez más, sean comprensivos y mantengan válidos los agradecimientos ya dados individualmente.

A los moradores de las seis comunidades investigadas, tanto de Argentina como de Brasil, así como a los profesionales que colaboraron para fundamentar el texto a seguir, agradezco infinitamente y pido perdón por la insistencia de algunos momentos en que necesitaba acelerar los trabajos y la solicitada colaboración no se hizo presente, como desafortunadamente sucedió algunas veces. Aun así, extiendo mis agradecimientos a estas personas también, así como el pedido de comprensión y de disculpas por la insistencia.

Agradezco a la familia, amigos y compañeros de trabajo que permanentemente me apoyaron con cariño y comprensión, aunque no lo mereciera ni haya podido retribuir como corresponde a lo largo de estos últimos años, como sería lo más adecuado y esperado.

Agradezco también a estas personas que fueron muy importantes y sin las cuales esta tesis no sería más que un sueño. Así, externo mis más sinceros agradecimientos:

A la Familia: Analice, "Dida", Jacineide, Vera, Veronildes, Doracy, Assis, Graça y Arnaldo Menezes; A D. Albertina y su hija "Binha".

A Ramon Cotinguiba, Wilson Bastos y Lukas Kruschewsky. 
A los ingenieros Alex Abiko, Alex Ramos, Inálvaro Sorares, José Oduquey, Marcos Bastos, Marcelo Bonfim, Otávio Ayres y Tiago Bastos.

Al estadista Alex Amorim, al y a los arquitectos Fausto Júnior, José Luiz Mota Menezes, Maria do Espírito Santo, y Nancy Nery.

A los compañeros de trabajo del Colégio Estadual Evaristo da Veiga, los docentes: Albene Piau, Daniela Lordello, Erica Nascimento, Elvira Lima, Frederico Bomsucesso, Isnard Silva, Luciene Ayres, Luzia Calhau, Luzia Santana, Patricia Giudice, Rosângela Barreto y Roseane Prates; y a los Profesores Edna Cunha, Emilson Piau, Lúcia Olveira y Rui Oliveira.

A la reportera Nardele Gomes.

A los profesionales de Conder, la arquitecta Bárbara Rego, el ingeniero Luis Jenkins, la asistente social Indira Calhau y la pedagoga Manuela Verzegnassi.

A los profesionales de la Fundação Mário Leal Ferreira: la urbanista Renée Buzar, los arquitectos Elaine Menezes y João Costa.

A los moradores de las tres Comunidades brasileras: Paraíso Azul/Recanto Feliz, Adjaci Oliveira, Merian Alves y Rôse; Condomínio 27 de Abril/SINDOMÉSTICO, Maria José y Ana Maria; Condomínio Perseverança, Janiraldo Rocha, Araci Brito, Jurandir y Andrea.

A los profesionales de la UFBA, del PPGAU: profesores Heliodorio Sampaio y Pascoalino Magnavita; del Instituto de Letras: profesores Camila Santero, Carlos Pinto, Cecilia Aguirre, Mailson Lopes, Sebastian Stanley y Vítor Lima; de la Faculdade de Filosofia e Ciências Humanas: profesores George Evergton, João Reis, Jorge Nóvoa, Lina Aras y Maria Inês Cortês.

A todos los colaboradores de Argentina y en especial a las señoras Analia Armenderiz, Carmen Cirano, Estela Mantz, Giovanna Loyaza, Liliana Beatríz Gimenez, Luisazar Correa, Verónica Marchat, y al señor Marcelo Mansilla; a los abogados Mauro Chellillo y Vanina Morrone; a la antropóloga Cristina Cravino; a los arquitectos Claudio Freidin, Cristina Domínguez, Diego Fiscarelli, Fernando Aliata, Gabriela Zimerman, Graciela Guiliane, Juan Etulain, Juan Maquieyra, Juan Pablo Negro, Juan Pfiefer, Sebastian Miguel, Silvia Garrido; al asistente social Eduardo López; al geógrafo Juan Pablo Del Río; al ingeniero Santiago Paz; a la pedagoga Liliana Paredes; a la politóloga Silvina Cobertta; a los profesores Fabiana Vega, Sebastián Grynberg y Silvia Cederbauma; a la psicóloga Raquel Kielmanowicz; a los universitarios "casoneros" y demás de La Casona de San Telmo; e in memoriam al Sr. Carlos Chile y al Sr. Mingo. 
"Pero ¿de dónde procede la penuria de la vivienda? ¿Cómo ha nacido? Como buen burgués, el Sr. Sax debe ignorar que es un producto necesario del régimen social burgués; que no podría existir sin penuria de la vivienda una sociedad en la cual la gran masa trabajadora no puede contar más que con un salario y, por tanto, exclusivamente con la suma de medios indispensables para su existencia y para la reproducción de su especie; una sociedad donde los perfeccionamientos de la maquinaria, etc., privan continuamente de trabajo a masas de obreros; donde el retorno regular de violentas fluctuaciones industriales condiciona, por un lado, la existencia de un gran ejército de reserva de obreros desocupados y, por otro lado, echa a la calle periódicamente a grandes masas de obreros sin trabajo; donde los trabajadores se amontonan en las grandes ciudades y de hecho mucho más de prisa de lo que, en las circunstancias presentes, se edifica para ellos, de suerte que pueden siempre encontrarse arrendatarios para la más infecta de las pocilgas; en fin, una sociedad en la cual el propietario de una casa tiene, en su calidad de capitalista, no solamente el derecho, sino también, en cierta medida y a causa de la concurrencia, hasta el deber de exigir sin consideración los alquileres más elevados. En semejante sociedad, la penuria de la vivienda no es en modo alguno producto del azar; es una institución necesaria que no podrá desaparecer, con sus repercusiones sobre la salud, etc., más que cuando todo el orden social que la ha hecho nacer sea transformado de raíz. Pero esto no tiene por qué saberlo el socialismo burgués. No se atreve en modo alguno a explicar la penuria de la vivienda por razón de las condiciones actuales. No le queda, pues, otra manera de explicarla que por medio de sermones sobre la maldad de los hombres, o por decirlo así, por medio del pecado original."

Engels (1981, p. 347)

"Un hombre fuerte puede guiar su pueblo, pero un pueblo fuerte no carece de quien lo guíe".

Zapata, personaje interpretado por Marlon Brando (KAZAN, 1952). 


\section{RESUMEN}

La presente tesis se fundamenta en el problema del creciente déficit habitacional en los sectores de más bajos ingresos. El objeto de esta investigación es el resultado de la aplicación de la tipología arquitectónica de construcción en altura como instrumento de combate al citado creciente déficit habitacional. La pregunta guía de la mencionada investigación es: “¿Cuáles fueron los principales elementos facilitadores y restrictivos en la adopción de políticas públicas de VIS a través de la tipología arquitectónica en altura durante el período de 1937 a 2017 en Salvador y Buenos Aires?" El objetivo general de esta investigación es ofrecer un instrumento, a las autoridades y demás responsables que actúen en todos los momentos de gestión (desde las decisiones de planificación, proyecto arquitectónico, hasta la ejecución de los trabajos y post-ocupación), aplicado a la tipología arquitectónica de construcción en altura -VIS- que colabore a conseguir un producto de mejor calidad y con el mejor nivel de excelencia posible para combatir el gran y creciente déficit de viviendas entre los sectores de más bajos ingresos. Los objetivos específicos son: Describir y analizar comparativamente las principales semejanzas y diferencias ocurridas por la adopción de políticas públicas de VIS a través de la tipología arquitectónica en altura durante el período de 1937 a 2017 entre Salvador y Buenos Aires; Comparar y analizar el déficit habitacional en ochenta años (1937/2017) bajo el desarrollo histórico, político, cultural y socioeconómico entre ambas ciudades; Identificar y esclarecer los principales efectos, así como sus variables positivas y negativas, resultantes de las experiencias realizadas que, en su conjunto, fueron los motivos por los cuales las políticas públicas de VIS no fueron suficientes para resolver el problema del déficit habitacional de ambas ciudades; Demostrar la viabilidad de la adopción de la tipología arquitectónica de construcción en altura, según los parámetros presentados y defendidos en esta tesis, como instrumento de combate y solución ante el creciente déficit habitacional a través de políticas públicas de VIS, en especial las direccionadas a los sectores de más bajos ingresos. La primera hipótesis de esta tesis es que, para combatir eficientemente el problema del creciente déficit habitacional entre los sectores de más bajos ingresos es conveniente hacer uso de la tipología arquitectónica de construcción en altura a gran escala, con una mayor calidad de construcción y de materiales, como instrumento para las políticas públicas de VIS. La segunda hipótesis consiste en la posible interferencia negativa de algunos sujetos públicos y privados, mancomunados, en pro de sus intereses en la realización de políticas de VIS. El argumento que justifica esta investigación es la necesidad de resolver el progresivo déficit habitacional en el campo de la VIS, tanto en Brasil como en Argentina, para los sectores de más bajos ingresos a través de la mencionada tipología arquitectónica, optimizando la calidad de los proyectos habitacionales y proporcionando un mejor nivel de vida al ciudadano que no dispone de renta para obtener un techo por vía del mercado formal. La investigación siguió seis ejes de análisis: el proyecto arquitectónico; el presupuestario; el suelo (lotes); el tecnológico; el gerenciamiento gubernamental y la legislación edilicia. Los datos obtenidos provienen de seis estudios de caso comparados (visitas de campo y entrevistas a moradores de las comunidades investigadas a través de la Evaluación Pos-Ocupación) realizados en seis proyectos, tres de Salvador y tres de la Ciudad Autónoma de Buenos Aires, construidos mediante programas públicos de VIS con tipología arquitectónica en altura: Paraíso Azul/Recanto Feliz, 27 de Abril/SINDOMÉSTICO y Perseverança/Luiz Inácio Lula da Silva; Conjunto Parque Patricios/Monteagudo, Complejo Luzuriaga y Complejo Padre Mujica. Se espera que con esta investigación se promueva la optimización de la calidad de los proyectos habitacionales, ofreciéndose viviendas de mejor calidad, y que se contribuya con la expansión y el enriquecimiento del acervo en la Academia.

Palabras clave: Evaluación Pos-ocupación; Políticas públicas urbanas; Proyectos de Vivienda de Interés Social; Vivienda de Interés Social en Argentina; Vivienda de Interés Social en Brasil. 
This thesis is based on the growing housing deficit of lower-income sectors. The object of this research is the result of the application of the architectural typology of vertical construction as an instrument to combat the aforementioned housing deficit. The guiding question of the research is: "What were the main facilitating and restrictive elements in the adoption of public policies for SIH through the vertical architectural typology during the period from 1937 to 2017 in Salvador and Buenos Aires?". The general objective of this research is to offer an instrument to the authorities and other responsible people that participate in all moments of the management (from the planning decisions, architectural design, to the execution of the works and post-occupation), applied to the architectural typology of vertical construction $-\mathrm{SIH}$ - that collaborates in obtaining a product of better quality and with the best possible level of excellence to combat the large and growing housing deficit among the lower-income sectors. The specific objectives are: Describing and comparatively analyzing the main similarities and differences that occurred with the adoption of SIH public policies through the vertical architectural typology during the period from 1937 to 2017 between Salvador and Buenos Aires; Comparing and analyzing the housing deficit in eighty years (1937/2017) under the historical, political, cultural, and socioeconomic development between both cities; Identifying and clarifying the main effects such as positive and negative variables that arise from the experiences applied that, together, they became the reason why the SIH public policies were not enough to solve the problem of housing deficit in both cities; To demonstrate the feasibility of adopting the vertical architectural typology, according to the parameters presented and defended in this thesis, as an instrument of combat and solution in the face of the growing housing deficit through public policies of $\mathrm{SIH}$, especially those directed to the lower-income sectors. The first hypothesis of this thesis is that, in order to efficiently combat the increasing housing deficit among lower-income sectors, it is proper to make use of the vertical architectural typology in large-scale, with higher quality materials and buildings, as an instrument to $\mathrm{SIH}$ public policies. The second hypothesis consists of the possible negative interference of some public and private people that work together in favor of their own interests in the realization of SIH policies. The reasoning that justifies this research is the need to solve the progressive housing deficit in the SIH area, both in Brazil and in Argentina, for lower-income sectors through the aforementioned vertical architectural typology which can optimize the quality levels of housing projects and providing a better quality of life for the citizens that have no money to buy a house in the formal market. The research work followed six axes of analysis: the architectural project; the costs; the ground; the technology; the government management and building legislation. The obtained data derived from six compared case studies (field visits and interviews to residents of the investigated communities through Post-Occupation Assessment) carried out in six projects, three in Salvador and three in the Autonomous City of Buenos Aires, built by SIH public programs with vertical architectural typology, Paraíso Azul/Recanto Feliz, April 27th/SINDOMÉSTICO and Perseverança/ Luiz Inácio Lula da Silva; Conjunto Parque Patrícios/Monteagudo, Complejo Luzuriaga and Complejo Padre Mujica respectively. It is expected that this investigation may promote the optimization of the quality of housing projects, offering buildings of better quality and it is also expected that it may contribute to the expansion and enrichment of the collection at the Academy.

Key-Words: Post-Occupation assessment; Urban public policies; Projects of Social Interest Housing; Social Interest Housing in Argentina; Social Interest Housing in Brazil. 


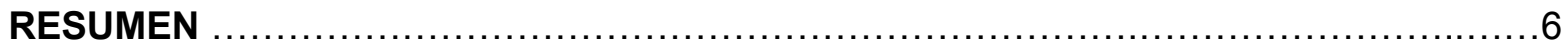

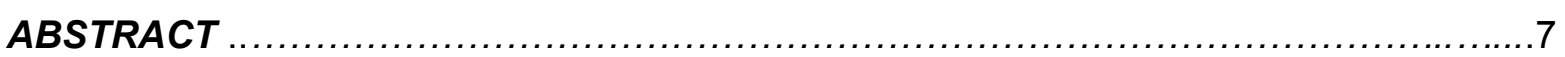

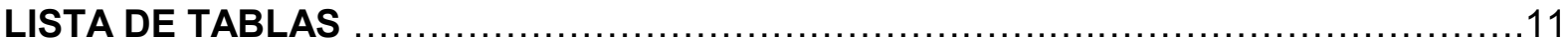

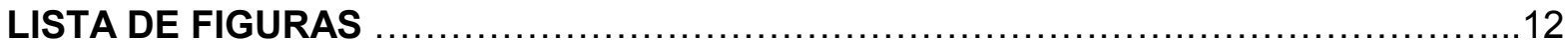

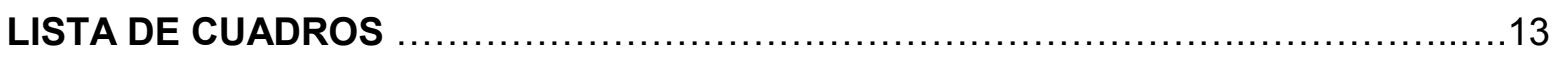

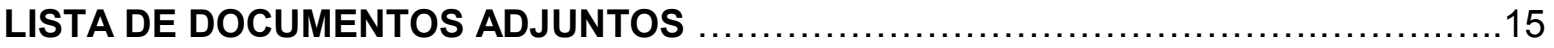

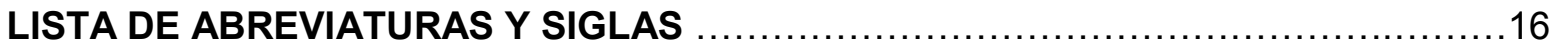

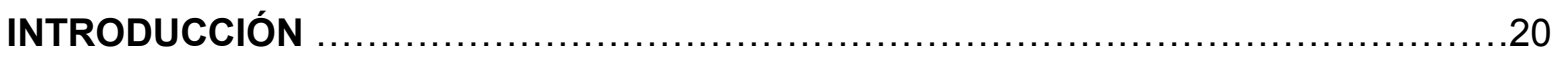

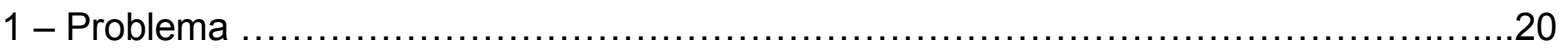

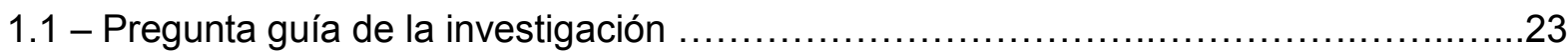

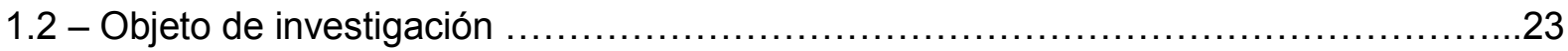

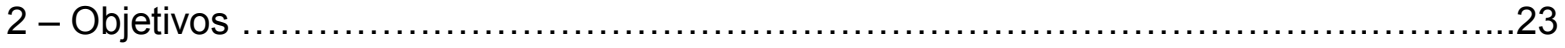

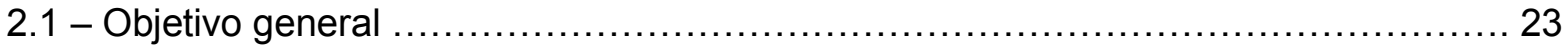

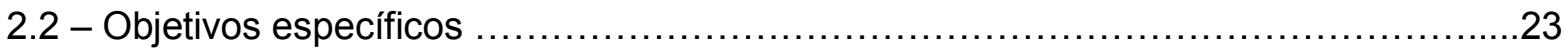

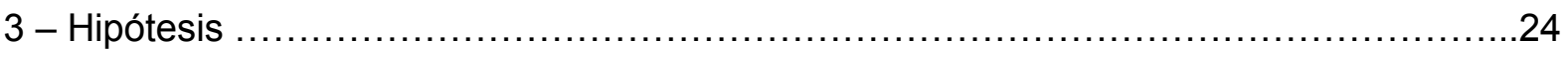

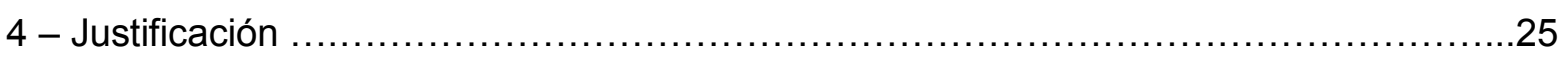

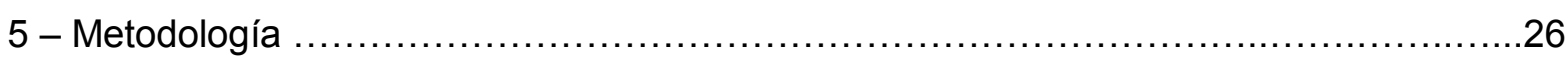

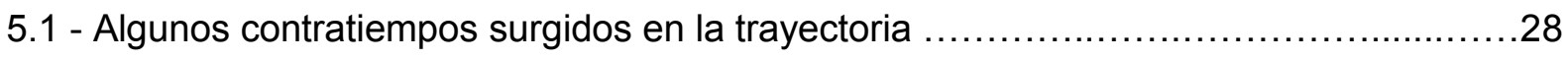

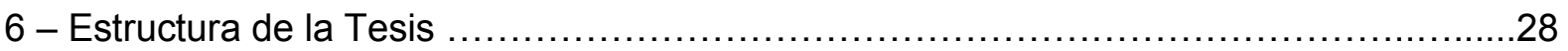

CAPÍTULO 1 - CONTEXTO HISTÓRICO DE LAS OCUPACIONES INFORMALES EN

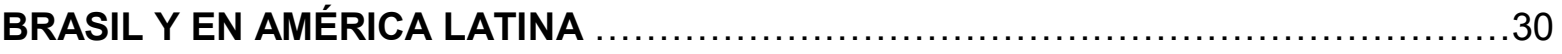

1.1 - Las ocupaciones informales en los grandes centros urbanos .......................30

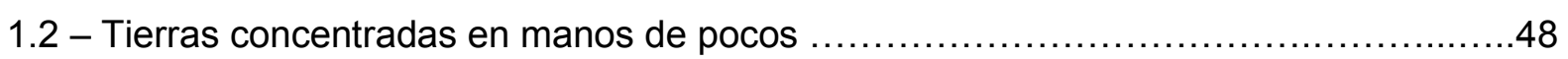

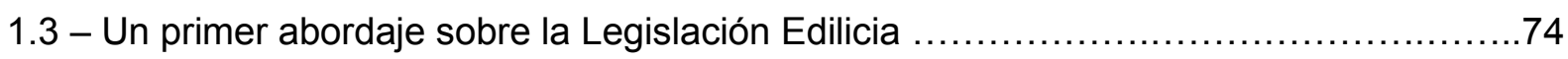

1.4 - Las propuestas de los técnicos: arquitectos, ingenieros y urbanistas ..................94

1.5 - Las intervenciones del Estado en materia de vivienda popular $\ldots \ldots \ldots \ldots \ldots \ldots \ldots \ldots \ldots . . . \ldots 8$

1.6 - Transformaciones visuales de la tipología arquitectónica en el tejido urbano ..........108

1.7 - Repasando el concepto e importancia de la tipología en Arquitectura .................110

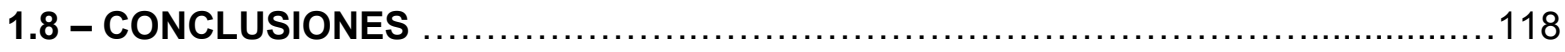

CAPÍTULO 2 - ESTRATEGIAS APLICADAS EN BRASIL, ARGENTINA Y URUGUAY

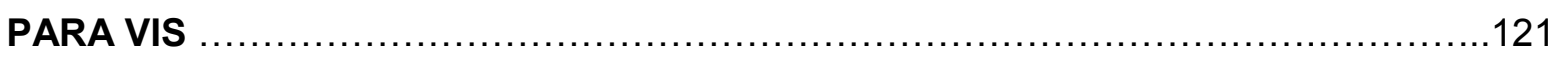

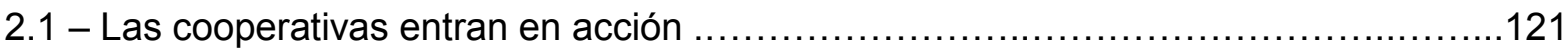

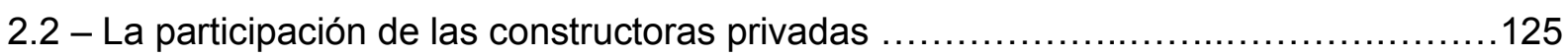


2.3 - Redes institucionales (Estado, ONGs, Asociaciones, Academia) ....................126

2.4 - Revisión de la Legislación (Estatuto da Cidade, PDDU, ZEIS, LOOUS)....................128

2.5 - Tecnología y técnicas constructivas disponibles ..................................139

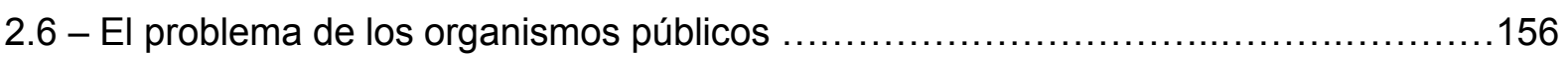

2.7 - La oferta de tierras y la especulación del suelo ............................................159

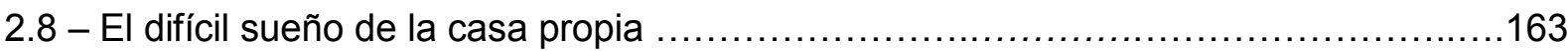

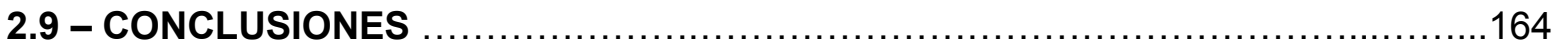

CAPÍTULO 3 - LOS COSTOS DIRECTOS E INDIRECTOS ….........................169

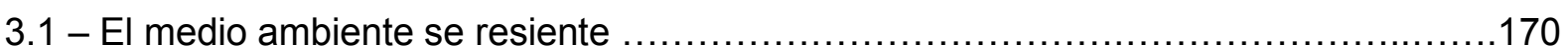

3.2 - Los moradores de bajos ingresos levantan sus techos ............................ 174

3.3 - El Estado y el retardo de inversiones en viviendas populares .......................177

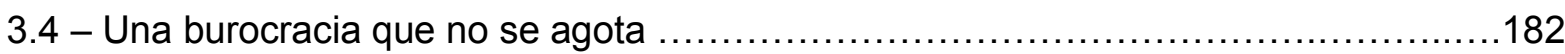

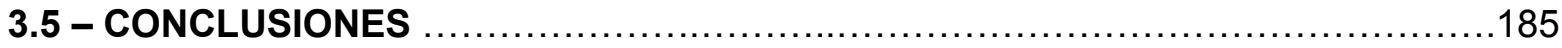

CAPÍTULO 4 - PRÁCTICAS E INTERVENCIONES RECIENTES DE VIS EN ALTURA EN 6

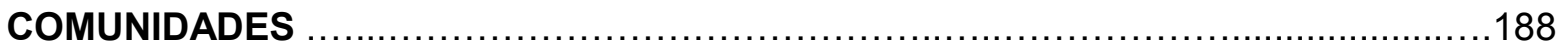

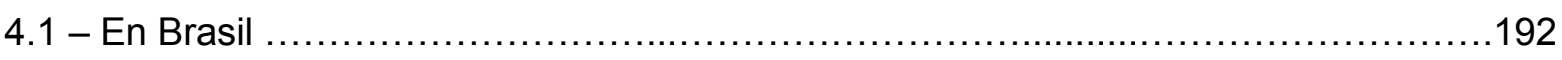

4.1.1 - Conjunto Recanto Feliz/Paraíso Azul (Costa Azul) .................................195

4.1.2 - Conjunto 27 de Abril/SINDOMÉSTICO (Dorón) ......................................199

4.1.3 - Conjunto Perseverança (Pernambues) ..............................................200

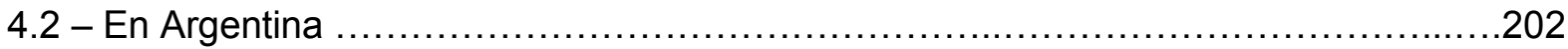

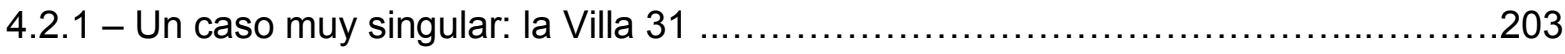

4.2.2 - Complejo Parque Patricios/Monteagudo (Parque Patricios) ..................................208

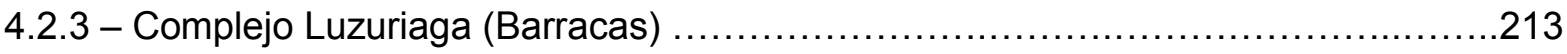

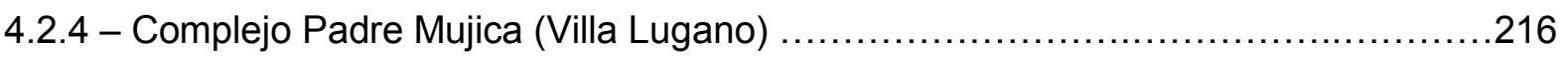

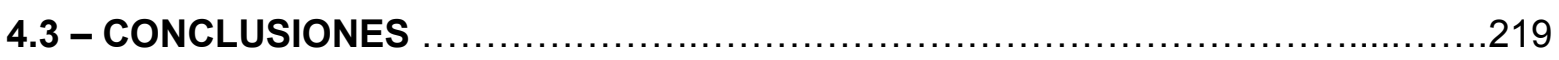

CAPÍTULO 5 - DESDE EL DESARROLLO DE LOS PROYECTOS Y HASTA LA EPO:

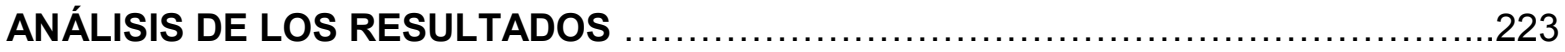

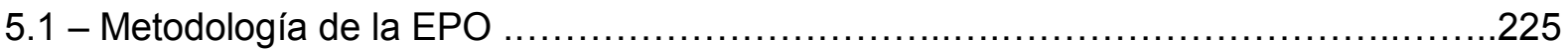

5.2 - Análisis de los resultados de la Encuesta Tipo 1 en las comunidades de Salvador ..229

5.2.1 -. Perfil sociodemográfico de los moradores de las comunidades de Salvador .......229

5.2.2 - Respuestas de la Encuesta Tipo 1 de las comunidades de Salvador .................235

5.2 .3 - Opinión de los moradores de las comunidades de Salvador .........................243

5.2 .4 - Consideraciones sobre las opiniones de los moradores de Salvador ..................253

5.3 - Análisis de los resultados de la Encuesta Tipo 1 en las comunidades de CABA .....256

5.3.1 - Perfil sociodemográfico de las comunidades de CABA .............................256

5.3.2 - Respuestas de la Encuesta Tipo 1 de las comunidades de CABA ..................264 
5.3.3 - Opinión de los moradores de las comunidades de CABA ….....................272

5.3.4 - Consideraciones sobre la opinión de las comunidades de CABA .....................274

5.4 - Opinión de los profesionales y líderes comunitarios involucrados en la VIS ...........274

5.4.1 - Entrevista del arquitecto J. Pfifer responsable del proyecto de Parque Patricios .. 275

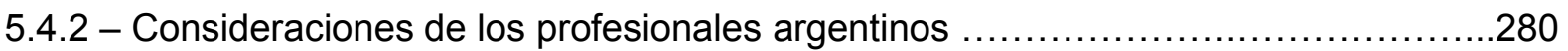

5.4.3 - Proyecto de la comunidad de Paraíso Azul/Recanto Feliz, Salvador .................291

5.4.3.1 - Opinión de los profesionales del sector técnico: arquitectura, ingeniería y

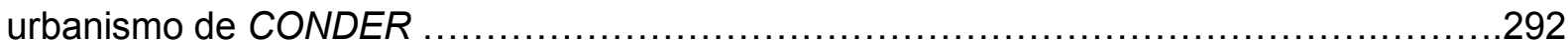

5.4.3.2 - Opinión de los profesionales del sector social de CONDER .....................297

5.4 .3 .3 - Opinión del líder comunitario de la comunidad ..................................300

5.4.4 - Proyecto de la comunidad de Luiz Inácio Lula da Silva/Perseverança, Salvador ...303

5.4.4.1 - Opinión de los profesionales del sector técnico: arquitectura, ingeniería y

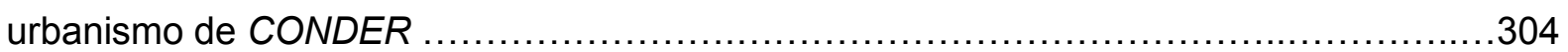

5.4.4.2 - Opinión de los profesionales del sector social de CONDER ......................306

5.4.4.3 - Opinión del líder comunitario de la comunidad .................................309

5.4 .5 - Proyecto de la comunidad de 27 de Abril/SINDOMÉSTICO, Salvador .................312

5.4.5.1 - Opinión de los profesionales del sector técnico: arquitectura, ingeniería y

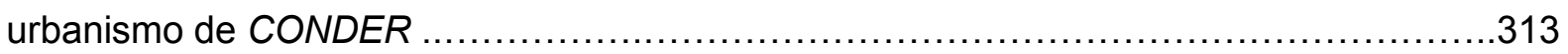

5.4.5.2 - Opinión de los profesionales del sector social de CONDER ......................315

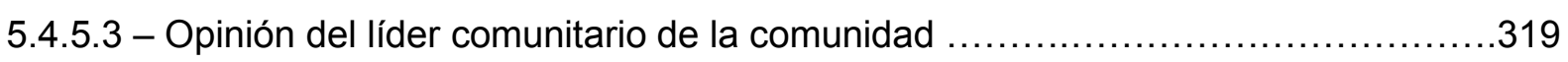

5.4 .6 - Críticas y sugerencias de los profesionales sobre VIS ..........................323

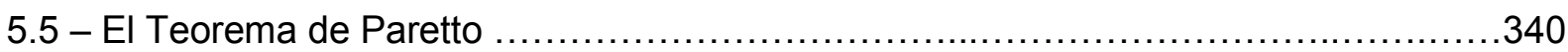

5.5.1 - Análisis sobre lo que piensan los moradores a la luz del Teorema de Paretto ......340

5.5 .2 - La realidad de los proyectos según los moradores brasileños .......................341

5.5 .3 - La realidad de los proyectos según los moradores argentinos ......................345

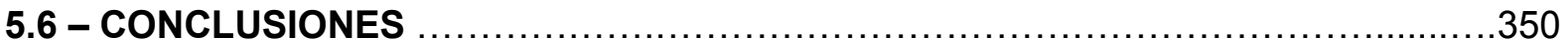

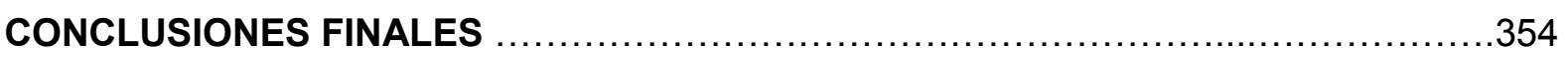

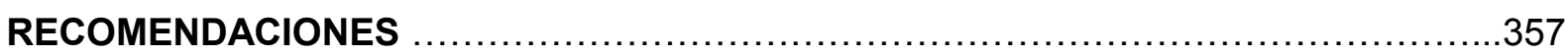

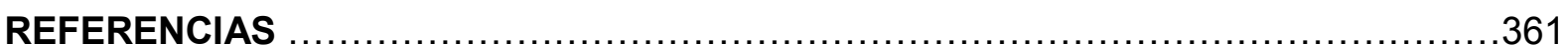

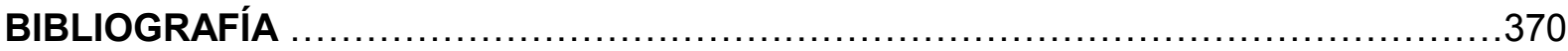

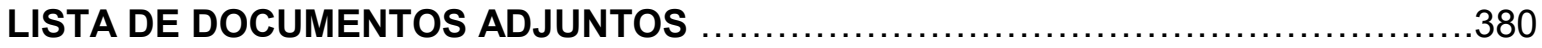

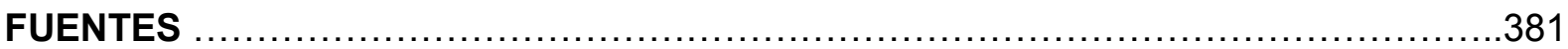

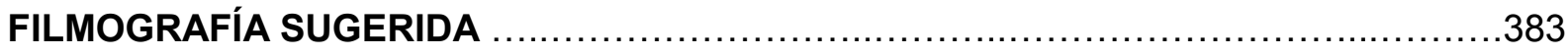

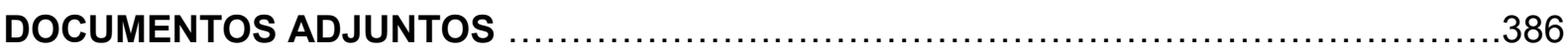




\section{LISTA DE TABLAS}

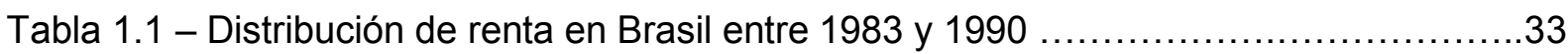

Tabla 1.2 - Distribución de ingresos (en \%) en Argentina y Brasil entre 1980 y 2016 .......34

Tabla 1.3 - Los 15 municipios brasileros con mayor número de favelas en 2000 .............35

Tabla 1.4 - Evolución de la situación deficitaria (1991-2001-2010) ...........................44

Tabla 1.5 - Variación relativa de la población, hogares y viviendas ocupadas (1991-2001-

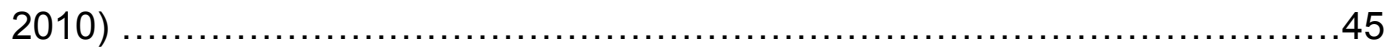

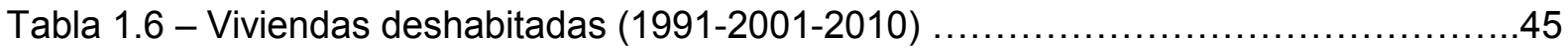

Tabla 1.7 - Evolución de las formas de tenencia (1991-2001-2010) ......................45

Tabla 1.8 - Evolución de la población atendida con red de agua y servicio sanitario (1991-

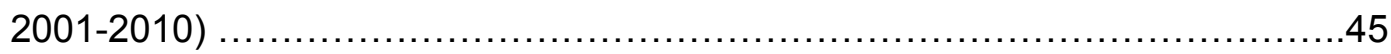

Tabla 2.1 - Tipos de cooperativas registradas en Brasil en 2016 ...........................124

Tabla 2.2 - Tipos de cooperativas registradas en Argentina en 2001 y 2014 ...............124

Tabla 3.1 - Evolución de CUB de 2008 a 2017 en el estado de Bahia ......................181

Tabla 3.2 - Proyección 2007 de costos medios por unidad habitacional en Salvador ......183

Tabla 4.1 - Datos comparativos de familias/domicilios entre EEUU, Brasil y Argentina.....192

Tabla 4.2 - Datos cuantitativos y de costos de los 3 proyectos brasileños.................194

Tabla 4.3 - Datos cuantitativos y de costos de los 3 proyectos argentinos ..................203

Tabla 4.4 - Parámetros urbanísticos para reubicación ....................................208

Tabla 4.5 - Habitaciones y valores monetarios del Complejo Parque Patricios-Monteagudo, por tipo de planta de departamento

Tabla 4.6 - Habitaciones y valores monetarios del Complejo Luzuriaga, por tipo de planta de departamento 215

Tabla 5.1 - Respuestas de la Encuesta Tipo 1 de las 3 comunidades de Salvador (Paraíso Azul/Recanto Feliz; 27 de Abril/SINDOMÉSTICO y Perseverança) ................236

Tabla 5.2 - Respuestas de la Encuesta Tipo 1 por comunidad de Salvador ................. 237

Tabla 5.3 - Respuestas de la Encuesta Tipo 1 de las comunidades de CABA (Parque Patricios/Monteagudo; Luzuriaga y Padre Mugica, conjuntamente) .............265

Tabla 5.4 - Respuestas de la Encuesta Tipo 1 por comunidad de CABA ....................266

Tabla 5.5 - Índices de insatisfacción por ítem en Brasil según el Teorema de Paretto .....342

Tabla 5.6 - índices de insatisfacción por ítem en Argentina según el Teorema de Paretto 346 


\section{LISTA DE FIGURAS}

Fig. 2.1 - Relación entre costo de urbanización y densidad de habitantes ..................146

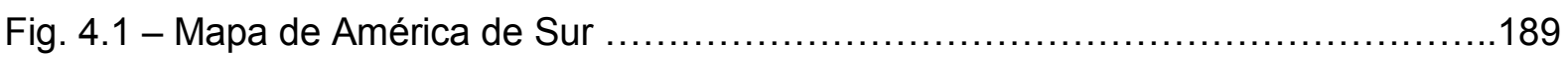

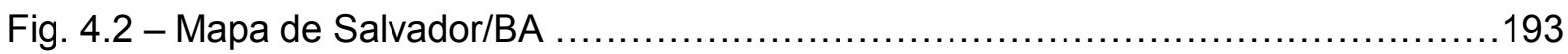

Fig. 4.3 - Localización de las 3 comunidades investigadas de Salvador ....................194

Fig. 4.4 - Localización de la Comunidad Recanto Feliz/Paraíso Azul, Salvador .............196

Fig. 4.5 - Comunidad Recanto Feliz/Paraíso Azul, Salvador - Fase inicial ..................197

Fig. 4.6 - Comunidad Paraíso Azul/Recanto Feliz, Salvador - Fase final de la $1^{\text {a }}$ etapa ...198

Fig. 4.7 - Localización de la Comunidad 27 de Abril/SINDOMÉSTICO, Salvador ..........199

Fig. 4.8 - Condominio 27 de Abril/SINDOMÉSTICO, Salvador ...........................200

Fig. 4.9 - Localización de la Comunidad Perseverança, Salvador ..........................201

Fig. 4.10 - Conjunto Luiz Inácio Lula da Silva/Perseverança, Salvador ...........................201

Fig. 4.11 - Localización de las 3 comunidades investigadas en CABA ...................202

Fig. 4.12 - Localización de la Comunidad Parque Patricios/Monteagudo, CABA ...........209

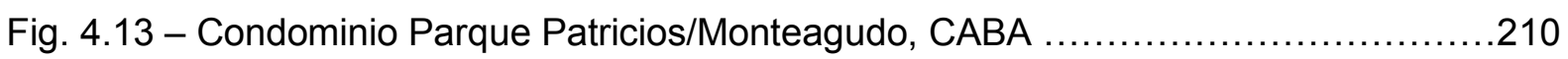

Fig. 4.14 - Condominio Parque Patricios/Monteagudo, CABA ..........................210

Fig. 4.15 - Localización de la Comunidad Luzuriaga, CABA ............................214

Fig. 4.16 - Complejo Habitacional Luzuriaga/Barracas, CABA ..........................214

Fig. 4.17 - Localización de la Comunidad Padre Mugica, CABA …......................217

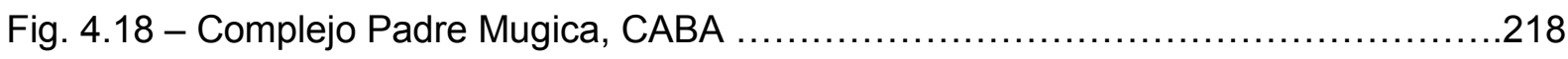

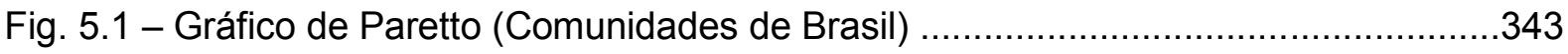

Fig. 5.2 - Gráfico del grado de satisfacción de las comunidades de Brasil ...................344

Fig. 5.3 - Tiempo de morada de los encuestados en las comunidades de Brasil ............345

Fig. 5.4 - Piso en que moran los encuestados en las comunidades de Brasil ................345

Fig. 5.5 - Gráfico de Paretto (Comunidades de Argentina) ................................347

Fig. 5.6 - Gráfico del grado de satisfacción de las comunidades de Argentina ...............348

Fig. 5.7 - Tiempo de morada de los encuestados en las comunidades de Argentina .......349

Fig. 5.8 - Piso en que moran los encuestados en las comunidades de Brasil .................349 


\section{LISTA DE CUADROS}

Cuadro 5.1 - Perfil sociodemográfico de la comunidad Paraíso Azul/Recanto Feliz 229

Cuadro 5.2 - Perfil sociodemográfico de la comunidad 27 DE Abril/SINDOMÉSTICO ....232

Cuadro 5.3 - Perfil sociodemográfico de la comunidad Luiz Inácio Lula da Silva/Perseverança .234

Cuadro 5.4 - Generalidades de la comunidad Paraíso Azul/Recanto Feliz ..................244

Cuadro 5.5 - Críticas de la comunidad Paraíso Azul/Recanto Feliz .........................245

Cuadro 5.6 - Generalidades de la comunidad 27 de Abril/SINDOMÉSTICO ...............247

Cuadro 5.7 - Críticas de la comunidad 27 de Abril/SINDOMÉSTICO ......................248

Cuadro 5.8 - Generalidades de la comunidad Perseverança .............................250

Cuadro 5.9 - Críticas de la comunidad Perseverança ...................................250

Cuadro 5.10 - Perfil de la Comunidad Parque Patricios/Monteagudo .......................257

Cuadro 5.11 - Perfil de la Comunidad del Complejo Luzuriaga ............................259

Cuadro 5.12 - Perfil de la Comunidad del Complejo de Padre Mugica .....................262

Cuadro 5.13 - Generalidades y críticas de la comunidad Parque Patricios/Monteagudo ...273

Cuadro 5.14 - Generalidades y críticas de la comunidad Complejo Luzuriaga ..............273

Cuadro 5.15 - Generalidades/críticas de la comunidad Complejo Padre Mugica .............273

Cuadro 5.16 - Resumen de la opinión de la comunidad Paraíso Azul/Recanto Feliz expuesta a los profesionales del sector técnico de CONDER .........................296

Cuadro 5.17 - Resumen de la opinión de los profesionales del sector técnico de CONDER de la comunidad Paraíso Azul/Recanto Feliz ................................296

Cuadro 5.18 - Resumen de la opinión de la comunidad Paraíso Azul/Recanto Feliz expuesta a los profesionales del sector social de CONDER . 299

Cuadro 5.19 - Resumen de la opinión de los profesionales del sector social de CONDER de la comunidad Paraíso Azul/Recanto Feliz 299

Cuadro 5.20 - Resumen de la opinión de la comunidad Paraíso Azul/Recanto Feliz expuesta al líder comunitario 302

Cuadro 5.21 - Resumen de la opinión del líder de la comunidad Paraíso Azul/Recanto Feliz.. 303

Cuadro 5.22 - Resumen de la opinión de la comunidad Perseverança expuesta a los profesionales del sector técnico de CONDER 305

Cuadro 5.23 - Resumen de la opinión de los profesionales del sector técnico de CONDER de la comunidad Perseverança 305

Cuadro 5.24 - Resumen de la opinión de la comunidad Perseverança expuesta a los profesionales del sector social de CONDER. 308 
Cuadro 5.25 - Resumen de la opinión de los profesionales del sector social de CONDER de la comunidad Perseverança ..................................................

Cuadro 5.26 - Resumen de la opinión de la comunidad Perseverança expuesta al líder

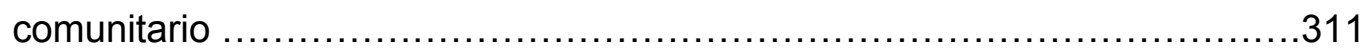

Cuadro 5.27 - Resumen de la opinión del líder de la Comunidad Perseverança .............311

Cuadro 5.28 - Resumen de la opinión de la comunidad 27 de Abril/SINDOMÉSTICO

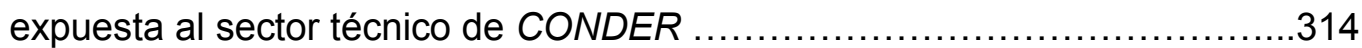

Cuadro 5.29 - Resumen de la opinión de los profesionales del sector técnico de CONDER de la comunidad 27 de Abril/SINDOMÉSTICO ..............................315

Cuadro 5.30 - Resumen de la opinión de la comunidad 27 de Abril/SINDOMÉSTICO expuesta al sector social de CONDER .............................................318

Cuadro 5.31 - Resumen de la opinión de los profesionales del sector social de CONDER de la comunidad 27 de Abril/SINDOMÉSTICO ...................................319

Cuadro 5.32 - Resumen de la opinión de la comunidad 27 de Abril/SINDOMÉSTICO

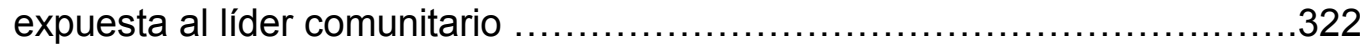

Cuadro 5.33 - Resumen de la opinión del líder de la comunidad 27 de

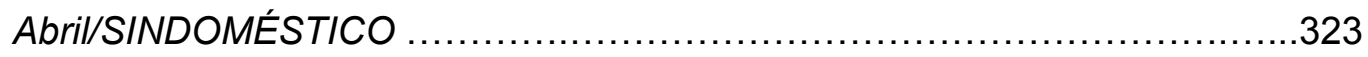




\section{LISTA DE DOCUMENTOS ADJUNTOS}

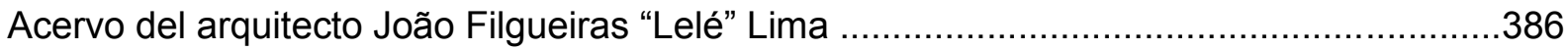

Tabla 1 - Proyección por edad de la población en la CABA $(2001 / 2020)$.....................388

Tabla 2 - Proyección preliminar de la población brasilera para 2020) …...................390

Resumen 1 del programa de Tv Entre aspas ..........................................

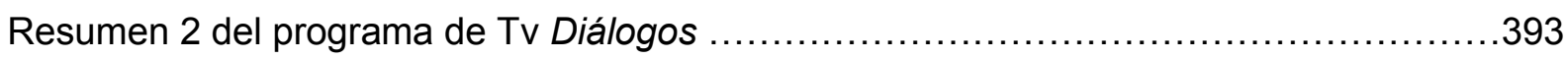

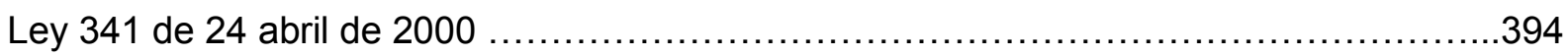

Código de Edificación de la CABA, Sección 4 (Ley 962 de accesibilidad del 05 diciembre de

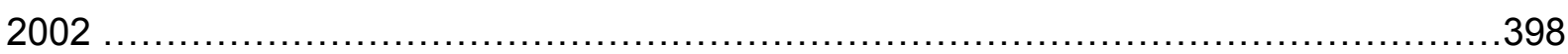

Encuesta Tipo 1: "Sondeo de los moradores de la comunidad" ..............................399

Encuesta Tipo 2: "Sondeo de los profesionales que actúan con VIS" ......................403

Encuesta Tipo 3: "Al equipo de técnicos: arquitectos, ingenieros y urbanista" ..............405

Encuesta Tipo 4: "Al equipo de asistencia social” ....................................408

Encuesta Tipo 5: "Tópicos para la caracterización del Proyecto de Viviendas de Interés

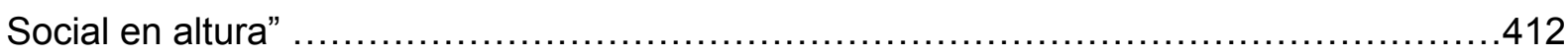

Encuesta Tipo 6: "Factores condicionantes que interfieren en la cuestión de lotes para la VIS

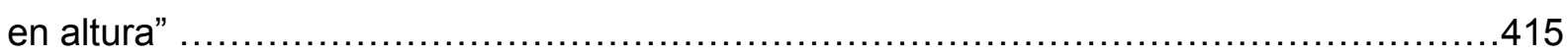

Encuesta Tipo 7: "A la Coordinación del Proyecto (Empadronamiento y atención a familias

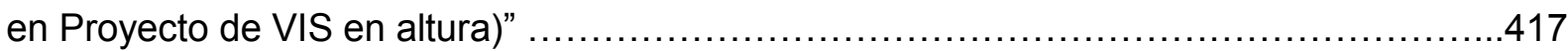

Plantas arquitectónicas de las comunidades encuestadas .............................421 


\section{LISTA DE ABREVIATURAS Y SIGLAS}

ACl: Aliança Cooperativa Internacional

AISAM: Avaliação das Ações de Saneamento Ambiental em Áreas Pauperizadas de Salvador

ANSUR: Associação Nacional do Solo Urbano

APO: Avaliação Pós-Ocupação

APSE: Área de Proteção Sócio Ecológica

AVSI: Associação Voluntários para o Serviço Internacional

BA: Bahia

BID: Banco Interamericano de Desarrollo

BIRD: Banco Internacional para la Reconstrucción y el Desarrollo

BNH: Banco Nacional de Habitação

CABA: Ciudad Autónoma de Buenos Aires

CAl: Centro Argentino de Ingenieros

CAO: Comissão de Acompanhamento de Obras

CCP: Comisión Coordinadora de Participación

CEPAL: Comisión Económica para América Latina y Caribe

CEVE: Centro Experimental de La Vivienda Económica

CGT: Confederación General del Trabajo de los Argentinos

CIAMs: Congressos Internacionais de Arquitetura Moderna

CMV: Comisión Municipal de la Vivienda

CNCB: Comissão Nacional de Casas Baratas

COHAB: Companhia de Habitação

CONDER: Companhia de Desenvolvimento Urbano do Estado da Bahia

CO2: Dióxido de Carbono

CPU: Consejo de Planificación Urbana

CTRS: Centro de Tecnologia da Rede Sarah

CURA: Comunidade Urbana para Recuperação Acelerada

CVM: Comissão de Valores Mobiliários

CYTED: Programa Iberoamericano de Ciencia y Tecnología para el Desarrollo

DA: Documentos Adjuntos

DIEESE: Departamento Intersindical de Estatística e Estudos Socioeconômicos

DUE: Distritos de Urbanización Especial

EAD: Ensino a Distância

ECC: Engineered Cement Composite

EPH: Encuesta Permanente de Hogares

EPO: Evaluación Pos-Ocupación 
EPUCS: Escritório de Planejamento e Urbanismo da Cidade do Salvador

FADU-UBA: Facultad de Arquitectura, Diseño y Urbanismo de la Universidad de Buenos

Aires

FAU-UNLP: Facultad de Arquitectura y Urbanismo de la Universidad Nacional de La Plata

FCO: Fundação da Casa Operária

FCP: Fundação da Casa Popular

FGTS: Fundo de Garantia do Tempo de Serviço

FEDEVI: Federación de Villas y Barrios Marginados de la Ciudad de Buenos Aires

FIESP: Federação das Indústrias do Estado de São Paulo

FII: Fundos de Investimentos Imobiliários

FI-UBA: Facultad de Ingeniería de la Universidad de Buenos Aires

FMI: Fondo Monetario Internacional

FNHIS: Fundo Nacional de Habitação de Interesse Social

FONAVI: Fondo Nacional de la Vivienda

FOS: Factor de Ocupación del Suelo

FOT: Factor de Ocupación Total

FJP: Fundação João Pinheiro

HABITAT: Programa de las Naciones Unidas para los Asentamientos Humanos

HIS: Habitação de Interesse Social

IAPs: Institutos de Aposentadoria e Pensões

IAPI: Instituto de Aposentadoria e Pensões dos Industriários

IBGE: Instituto Brasileiro de Geografia e Estatística

IC: Instituto de la Construcción

IDH: Indicadores de Desarrollo Mundial

IL-UFBA: Instituto de Letras da Universidade Federal da Bahia

INAES: Instituto Nacional de Asociativismo y Economía Social

IPEA: Instituto de Pesquisa Econômica Aplicada

INDEC: Instituto Nacional de Estadística y Censos de la República Argentina

IRAM: Instituto Argentino de Normalización y Certificación

ISSB: Instituto de Serviços Sociais do Brasil

IPTU: Imposto sobre Propriedade Territorial Urbana

IVC: Instituto de Vivienda de la Ciudad

LOUOS: Lei de Ordenamento do Uso e da Ocupação do Solo

MCMV: Minha Casa Minha Vida

MG: Minas Gerais

MSTS: Movimento dos Sem Teto de Salvador

MTL/CTA: Movimiento Territorial de Liberación/Central de Trabajadores de la Argentina MVOTMA: Ministerio de Vivienda, Ordenamiento y Medio Ambiente 
NAP: Núcleo de Apoio à Produção

NIS: Número de Inscrição Social

OCB: Organização das Cooperativas Brasileiras

OCESP: Organização das Cooperativas do Estado de São Paulo

OMS: Organización Mundial de la Salud

ONGs: Organizaciones No Gubernamentales

OODC: Outorga Onerosa do Direito de Construir

PAC: Programa de Aceleração do Crescimento

PAIH: Plano de Ação Imediata para Habitação

PAM: Plano de Ajuda Mútua

PAR: Programa de Arrendamento Residencial

PAU: Programa de Agricultura Urbana

PDDU: Plano Diretor de Desenvolvimento Urbano

PE: Pernambuco

PEP: Plano Empresário Popular

PEVE: Programa de Erradicación de Villas de Emergencia

PIB: Produto Interno Bruto

PLANHAP: Plano Nacional de Habitação Popular

PLANDURB: Plano de Desenvolvimento Urbano de Salvador

PMCMV: Programa Minha Casa Minha Vida

PNUD: Programa de las Naciones Unidas para el Desarrollo

Poli-UFBA: Escola Politécnica da Universidade Federal da Bahia

POUSO: Posto de Orientação Urbanística e Social

PPG-AU/UFBA: Programa de Pós-Graduação em Arquitetura e Urbanismo da Universidade

Federal da Bahia

PROHAP: Programa de Habitação Popular

PROFILURB I: Programa de Lotes Urbanizados

PROMEBA: Programa de Mejoramiento de Barrios

PROSUR: Proyecto Sur

PUA: Plan Urbano Ambiental

RENURB: Companhia de Renovação Urbana de Salvador

RJ: Rio de Janeiro

RS: Rio Grande do Sul

SC: Santa Catarina

SP: São Paulo

SCA: Sociedad Central de Arquitectos

SEHAB: Secretaria Municipal de Habitação

SETHA: Secretaria de Terras e Habitação 
SFH: Sistema Financeiro Habitacional

SFI: Sistema de Financiamento Imobiliário

SIEMPRO: Sistema de Información Monitoreo y Evaluación de Programas Sociales

SINDEC: Secretaria Municipal de Infraestrutura e Defesa Civil

SINDOMÉSTICO-BA: Sindicato dos Trabalhadores Domésticos da Bahia

SINDUSCON-BA: Sindicato da Indústria da Construção Civil no Estado da Bahia

SINDUSCON-MG: Sindicato da Indústria da Construção Civil no Estado de Minas Gerais

SM: Salario Mínimo

SNHIS: Sistema Nacional de Habitação de Interesse Social

SUPA: Sindicato Único de Portuarios Argentinos

TRANSCOL: Transportes Urbanos de Salvador

TRANSCON: Transferência do Direito de Construir

UCSal: Universidade Católica do Salvador

UdelaR: Universidad de la República Oriental del Uruguay

UBA: Universidad de Buenos Aires

UGU: Unidad de Gestión Urbana

VLT: Veículo Leve sobre Trilhos

VIS: Vivienda de Interés Social

ZEIS: Zona Especial de Interesse Social 


\section{INTRODUCCIÓN}

1 - Problema

A partir de la Segunda Guerra Mundial gran parte de los países de América Latina intentaron sumarse al fenómeno de Bienestar Social basado en la teoría del subdesarrollo económico capitaneada por los intelectuales que fundaron la Comisión Económica para América Latina y el Caribe (CEPAL), creada en 1948 con el objetivo de promover estudios y soluciones referentes al atraso económico de este continente. En este período, a raíz de la industrialización y la implementación de la política de sustitución de importación, hubo un aumento del proceso de migración rural hacia los grandes centros urbanos en varios países latinoamericanos como Brasil y Argentina, lo que produjo un aumento significativo en las diferencias sociales y económicas entre ricos y pobres, característica estructural de la formación cultural de este continente desde los inicios coloniales. Así, la población de los grandes centros urbanos aumentó progresivamente en ausencia de una política consistente de oferta de unidades habitacionales particularmente para los sectores sociales de más bajos ingresos, lo que generó un significativo agravamiento del creciente déficit habitacional y de los problemas sociales inherentes a esta compleja realidad.

Brasil estableció históricas afinidades con Argentina a lo largo del tiempo bajo varios aspectos de sus realidades, sobre todo con relación al tema de la escasez de vivienda para los sectores de más bajos ingresos que junto a otros se tornaron puntos de intersección entre las dos mayores naciones de América del Sur que serán explicitados a lo largo de esta tesis.

En Brasil, las políticas habitacionales ejecutadas por el Estado a partir de la década del (19)30 y hasta la de los (19)80, cuando se realizó la implementación de un mayor número de conjuntos de viviendas, con centenares de unidades unifamiliares y multifamiliares, generalmente en los barrios más alejados del centro de las grandes ciudades, penalizando buena parte de sus moradores en su rutina diaria, resultaron insuficientes para la solución del problema (BONDUKI, 2011, p. 100-101).

Salvador, primera capital colonial de Brasil a partir de 1549 y hasta 1763, es hoy la cuarta capital de estado brasileña por cantidad de habitantes, con cerca de tres millones de personas en 2016, según estimativas del Instituto Brasileiro de Geografia e Estatística (IBGE), región topográficamente accidentada por cerros y 
valles en prácticamente toda su extensión. Históricamente los sectores más pobres de Salvador fueron impelidos por los más ricos a resolver sus problemas de habitación en las áreas periféricas de la ciudad o en regiones inhóspitas como por ejemplo las pendientes de los cerros, donde en épocas de lluvias se producen derrumbes y muertos por la falta de protección.

En Argentina el problema de la falta de habitación entre los sectores de más bajos ingresos de la población pasó a ser relevante ya a inicios del siglo pasado con la llegada de millones de inmigrantes europeos durante y después de la Primera Guerra Mundial, cuadro que se vio progresivamente agravado por las sucesivas crisis económicas que atravesó y atraviesa el país, como por ejemplo la huelga de inquilinos de 1907 de los barrios de La Boca y Barracas de la entonces Ciudad de Buenos Aires, según Suriano (apud RODRÍGUEZ, 2009, p. 96-97), hoy Ciudad Autónoma de Buenos Aires (CABA), con cerca de 3 millones de habitantes, sin contar el área metropolitana, según el censo de 2010. En la década del (19)40, ante la insostenible situación de la falta de habitación, el Estado argentino resolvió construir conjuntos habitacionales "en altura" 1 para los sectores de más bajos ingresos.

La solución estatal para resolver el problema de los asentamientos informales se realizó entonces mediante la implementación de la Vivienda de Interés Social $(\mathrm{VIS})^{2}$, conjuntos residenciales de bloques multifamiliares que, a partir de las recomendaciones de la Conferencia Hábitat I de 1976 en Vancouver, pasaron a ser del tipo arquitectónico en altura y prioritariamente en áreas donde los asentamientos ya existían, evitándose así, dentro de lo posible, la erradicación de las poblaciones asentadas. Sin embargo, por una serie de factores que serán discutidos en esta

\footnotetext{
${ }^{1}$ Los términos "en altura" y "construcción horizontal" se corresponden en portugués brasileño a "verticalização" y "construcción vertical" y se utilizan para identificar edificios con más de un piso además de la planta baja, de igual manera sucede con los términos equivalentes VIS: Vivienda de Interés Social e HIS: Habitación de Interés Social, respectivamente. En tiempo, se aclara que esta tesis ha sido desarrollada en portugués, lengua madre del Doctorando, corregida con Director y coDirector simultáneamente en Idioma español y en portugués y, finalmente editada en español por razones reglamentarias del Doctorado de la FAU-UNLP. No obstante quedará una versión en portugués para un más fácil acceso de los interesados en Brasil. Por ejemplo, se decidió utilizar, entre otros, el término "morador" en lugar de "habitante" ya que es aceptado por ambos idiomas y como símbolo de empatía del problema tratado.
}

${ }^{2}$ Cuando se hace referencia a VIS, salvo se mencione lo contrario, se refiere a VIS multifamiliar, en bloque residencial de hasta 3 ó 4 pisos, por encima o por debajo de la planta baja y sin ascensor, salvo para la CABA ya que la legislación impone el uso obligatorio de ascensor en construcciones con más de dos pisos además de la planta baja. En los casos en que la topografía lo favorezca y que otros requisitos arquitectónicos y urbanísticos lo permitan, incluso mediante la relación costo/beneficio, dicho número de pisos puede verificarse tanto por encima como por debajo de la planta baja, sin ascensor u otro dispositivo de movilidad electromecánico para personas y/o cargas. 
tesis, el problema del progresivo aumento del déficit habitacional en Brasil y Argentina continúa presente.

A inicios de la primera década de este siglo, con la llegada al gobierno tanto en Brasil como en Argentina de grupos políticos con un discurso de fuerte tenor social que incluía la promesa de un mayor presupuesto y acciones destinadas a la construcción de VIS, nunca visto hasta entonces en gobiernos pasados, se abrió un nuevo período con la ampliación de capital inmobiliario para VIS en altura. EI presidente argentino Néstor Kirchner y su sucesora y esposa, la presidenta Cristina Fernández de Kirchner y el presidente brasileño Luiz Inácio Lula da Silva y su sucesora, la presidenta Dilma Rousseff, son los responsables de dicho período.

En Brasil, además, entre 2000 y 2008, aconteció un verdadero boom inmobiliario como no sucedía en décadas, el que, de cierta forma, fue favorable, repercutiendo en la producción de cientos de miles de VIS en todo el país a través del Programa de Aceleração do Crescimento (PAC), lanzado en 2007, y del Programa Minha Casa Minha Vida (PMCMV), iniciado en 2009 y vinculado al PAC, predominando en las grandes ciudades del país la tipología arquitectónica en altura. Sin embargo, el efervescente boom inmobiliario dio lugar a una grave crisis económica por diversos motivos, a partir de 2014 y hasta 2017, año en el que, según analistas, la recesión habría llegado al "fondo del pozo", y después de la cual, según indicadores, paulatinamente habría comenzado a mejorar.

A pesar de la progresiva escasez de tierras en los grandes centros urbanos, de la favorable relación costo/beneficio del uso del mencionado tipo arquitectónico en áreas que ya dispongan de infraestructura básica y de que las familias afectadas hayan promovido informalmente la construcción en altura de sus modestas habitaciones, esta tipología arquitectónica no ha sido utilizada adecuada y suficientemente para solucionar, y ni siquiera para disminuir a niveles aceptables, el problema en cuestión.

Esta tesis se fundamenta en el problema del creciente déficit habitacional, en especial entre los sectores de más bajos ingresos.

El análisis de este problema se fue desarrollando desde la conclusión del curso de Maestría en Arquitectura y Urbanismo (FAU-UFBA) y durante la participación en el grupo de investigación REFAVELA ${ }^{3}$, entre 2004 y 2008, y se aborda formalmente en la presente tesis.

\footnotetext{
${ }^{3}$ Proyecto de Investigación aprobado y financiado por la Financiadora de Estudos e Projetos (FINEP) en el ámbito del Programa Tecnologia de Habitação (HABITARE), desarrollado entre el 1 de
} 


\section{1 - Pregunta guía de la investigación}

La pregunta guía de esta investigación es: ¿Cuáles fueron los principales elementos facilitadores y restrictivos en la adopción de políticas públicas de VIS a través de la tipología arquitectónica en altura durante el período de 1937 a 2017 en Salvador y Buenos Aires?

\section{2 - Objeto de investigación}

El resultado de la aplicación de la tipología arquitectónica de construcción en altura como instrumento de combate al creciente déficit habitacional, en especial entre los sectores de más bajos ingresos.

\section{2 - Objetivos}

\section{1 - Objetvivo general}

El objetivo general de esta investigación es ofrecer un instrumento, a las autoridades y demás responsables que actúen en todos los momentos de gestión (desde las decisiones de planificación, proyecto arquitectónico, hasta la ejecución de los trabajos y post-ocupación), aplicado a la tipología arquitectónica de construcción en altura -VIS- que colabore a conseguir un producto de mejor calidad y con el mejor nivel de excelencia posible para combatir el gran y creciente déficit de viviendas entre los sectores de más bajos ingresos.

\section{2 - Objetivos específicos}

a) Describir y analizar comparativamente las principales semejanzas y diferencias ocurridas por la adopción de políticas públicas de VIS a través de la tipología

noviembre de 2004 y el 1 de agosto de 2008 entre la Universidade de São Paulo (USP), ejecutora y coordinadora general, la Universidade Federal do Rio de Janeiro (UFRJ), la Universidade Federal de Minas Gerais (UFMG) y la Universidade Católica do Salvador (UCSal), co-ejecutoras, y los colaboradores institucionales: Fundação de Apoio à Universidade de São Paulo (FUSP), institución contratante, Prefeitura Municipal de Sabará (MG), The Cities Alliance, Secretaria Municipal de Habitação de São Paulo (SEHAB) y la Companhia de Desenvolvimento Urbano do Estado da Bahia (CONDER), intervinientes y co-financiadores. 
arquitectónica en altura durante el período de 1937 a 2017 entre Salvador y Buenos Aires;

b) Comparar y analizar el déficit habitacional en ochenta años (1937/2017) bajo el desarrollo histórico, político, cultural y socioeconómico entre ambas ciudades;

c) Identificar y esclarecer los principales efectos, así como sus variables positivas y negativas, resultantes de las experiencias realizadas que, en su conjunto, fueron los motivos por los cuales las políticas públicas de VIS no fueron suficientes para resolver el problema del déficit habitacional de ambas ciudades

d) Demostrar la viabilidad de la adopción de la tipología arquitectónica de construcción en altura, según los parámetros presentados y defendidos en esta tesis, como instrumento de combate y solución ante el creciente déficit habitacional a través de políticas públicas de VIS, en especial las direccionadas a los sectores de más bajos ingresos.

\section{3 - Hipótesis}

La primera hipótesis de esta tesis es que, para combatir eficientemente el problema del creciente déficit habitacional, en especial entre los sectores de más bajos ingresos, es conveniente hacer uso de la tipología arquitectónica de construcción en altura a gran escala, admitiéndose que se lo haga con una mayor calidad de construcción y de materiales, como instrumento para las políticas públicas de VIS.

Se impone suponer que, en los diferentes procesos de implementación de políticas públicas de VIS durante el período analizado, ciertos agentes de la iniciativa privada, mancomunados con otros del poder público, tanto en Brasil como en Argentina, tendieron a direccionar dichas políticas públicas para sacar provecho propio en contra de los intereses de la colectividad. Explicitando mejor esta segunda hipótesis, se entiende que, en Brasil, la herencia cultural bajo la que se han forjado los principales agentes decisores, tanto de la iniciativa privada como de la esfera pública, facilitó la implementación de diferentes prácticas -creación de leyes edilicias, acciones estimuladoras o que cohíben, políticas habitacionales y de distribución de renta, entre otras-, que han actuado como fuertes condicionantes impeditivos y cercenadores ya sea de la implementación de tecnologías constructivas racionales, eficaces y eficientes, como de la reducción de los costos de la habitación popular, lo que explica la gran resistencia por parte de varios de estos agentes a la utilización a 
larga escala de la mencionada tipología arquitectónica, tipología que permitiría acelerar la producción de unidades de viviendas frente a la gran demanda de los sectores sociales de más bajos ingresos, postura que sólo ha servido para retroalimentar el proceso del progresivo aumento del déficit habitacional en el país, un verdadero círculo vicioso, lo que también puede verificarse en Argentina, manteniendo las debidas proporciones y particularidades de la realidad de ambos países.

4 - Justificación

El principal argumento para justificar esta investigación es la necesidad que se tiene como ciudadano y como profesional de afrontar el problema del progresivo déficit habitacional en el campo de la VIS para los sectores de más bajos ingresos, tanto en Brasil como en Argentina, a través de la tipología arquitectónica en altura bien utilizada, analizando los resultados a partir de las conclusiones y aprendizajes obtenidos para alcanzar los objetivos propuestos, optimizando la calidad de los proyectos habitacionales en general, proporcionando, por tanto, un mejor nivel de vida -con dignidad, seguridad y confort- al destinatario final: el ciudadano que no dispone de renta para obtener un techo por vía del mercado formal. Para esto se usó una metodología basada no sólo en los documentos y títulos bibliográficos relacionados al tema en la construcción del "estado del art", sino sobre todo en trabajos de campo como entrevistas y en la composición de un harto material de consultas a través de encuestas a profesionales y moradores de ambos países, sin duda una originalidad para una investigación de esta naturaleza.

Se espera que esta investigación pueda aportar alguna contribución relevante e innovadora para enriquecer la discusión sobre el tema, así como también colaborar para estimular a que se apliquen políticas públicas más consistentes, que abran un camino sostenible, sin retrocesos, con el objetivo de eliminar el déficit habitacional que viene condenando a millones de personas a sobrevivir en viviendas indignas, un problema social que persiste y preocupa tanto a argentinos como a brasileños.

Se espera también que esta investigación permita reflexionar a las autoridades y demás responsables que actúen en la dirección de proyectos de VIS, así como a la ciudadanía en general, sobre el flagelo del déficit habitacional de ambas ciudades y las consecuencias culturales y sociales que tal problema implica 
en la sociedad como un todo, donde es inadmisible que millones de personas se encuentren sumergidas en esta difícil e inaceptable situación de precariedad.

Asimismo, el resultado de esta investigación puede contribuir para fomentar en la Academia, tanto en Brasil como en Argentina, una mayor reflexión sobre el tema en cuestión, tanto cuantitativa como cualitativamente, y así, permitir avanzar cada vez más, indicar nuevos caminos, consolidar lo hasta entonces visto y superar los vacíos y debilidades que por cierto surgen y existen.

\section{5 - Metodología}

La investigación fue estructurada siguiendo seis ejes de trabajo: a) el proyecto arquitectónico; b) el presupuestario (costos); c) el suelo (loteos para la construcción); d) el tecnológico; e) el gerenciamiento gubernamental (políticas públicas); y f) la legislación edilicia.

En función de los seis mencionados ejes, en esta investigación se siguieron dos rumbos principales: uno referente a la construcción del "estado del art", consultando la bibliografía especializada, entrevistas sobre la cuestión urbana, en especial sobre las condiciones de habitabilidad de los sectores de más bajos ingresos desde diferentes ópticas: histórica, política, cultural y socioeconómica, privilegiando principalmente autores oriundos de los países investigados y de trayectoria consolidada en relación con el tema abordado y, adicionalmente, obras literarias, material fílmico, documental, y programas de televisión.

El otro, la principal originalidad de esta investigación, se constituyó a través de un harto y laborioso conjunto de informaciones obtenidas directamente en las seis comunidades mediante siete tipos de encuestas aplicadas, en las unidades habitacionales, como se puede comprobar, principalmente, en el Capítulo 5, lo cual expresa básicamente los análisis de los resultados encontrados. Estas encuestas fueron aplicadas a través de Evaluación Pos-Ocupación (EPO), a los moradores, a los representantes comunitarios y a los profesionales -ingenieros, arquitectos, urbanistas, asistentes sociales y abogados- involucrados con el tema de la VIS, participantes directos o no de los proyectos analizados. También se han realizado entrevistas parcialmente estructuradas a algunos colaboradores de estos segmentos consultados en ambos países. Cuanto a la composición y aplicación de dichas encuestas, así como los detalles, serán abordados al comienzo del referido Capítulo 5 , específico sobre el análisis de los datos. 
Se reitera que de modo general para alcanzarse los objetivos arriba enumerados en el tópico 2 (objetivos general y específicos) se tomó partido del conjunto de acciones e informaciones descritas y explicitadas adelante en la Metodología pero de manera sintética se menciona que para el (objetivo) a y el $b$ la bibliografía, los documentos obtenidos (DA), y la filmografía fueron esenciales. Además aún para el $b$ y el $c$, los aportes mediante las consultas (entrevistas y encuestas) a partir de la EPO junto a moradores, profesionales y gerentes públicos de políticas de VIS, significaron la profundización tanto cuantitava como cualitativa de los datos. Al fin y al cabo a todos estos expedientes metodológicos se agregó la tabulación estadística de los datos provenientes de las respuestas a la Encuesta Tipo 1 (moradores) mediante el principio del Teorema de Paretto. Asimismo se puso énfasis en las muy ricas críticas y sugerencias propuestas por aquellos sujetos y detalladas en los varios cuadros presentados en el Capítulo 5, a partir de los cuales se elaborara un sucinto conjunto de Recomendaciones al fin de este citado Capítulo para que se reforzara el alcanze del objetivo general.

Cabe mencionar que los citados estudios de caso comparados entre Brasil y Argentina involucraron los seis proyectos investigados, siendo de éstos, tres implantados en Salvador y tres en la CABA, mediante programas públicos de VIS con la tipología arquitectónica en altura, y uno de ellos construido en la década pasada y los dos restantes a inicio de ésta, tanto en uno como otro país.

En CABA: excepto el Conjunto Parque Patricios/Monteagudo, el Complejo Luzuriaga y el Complejo Padre Mujica, por la mencionada restricción legal de BsAs, locus principal de esta investigación en Argentina, poseen ascensores en el interior de sus estructuras. En Salvador, de igual modo, se han hecho consultas a los moradores y a los profesionales de CONDER, responsable de la implementación de los tres proyectos habitacionales: Paraíso Azul/Recanto Feliz, 27 de Abril/SINDOMÉSTICO y Perseverança/Luiz Inácio Lula da Silva.

El recorte temporal adoptado, como ya se adelantó, ha sido el de los últimos 80 años (1937- 2017) ya que fue a partir del inicio de este periodo que por primera vez en Brasil el Estado tomara la decisión de producir a nivel nacional y a larga escala conjuntos habitacionales en altura -de 3 a 4 pisos, predominantemente, además de la planta baja- a través de los Institutos de Aposentadoria e Pensões (IAPs) y de la Fundação da Casa Popular (FCP), para afrontar el problema de la falta de habitación de los sectores de más bajos ingresos. En 2017 tanto en Brasil 
como Argentina la predominancia de políticas sociales direccionadas para VIS por gobiernos nacionales populistas hace poco había sido disminuida.

\subsection{Algunos contratiempos surgidos en la trayectoria}

Con relación a los resultados obtenidos se hacen dos observaciones: la primera es que el gran volumen de información recabada fue obtenido directamente de los propios interesados -moradores y profesionales- y refleja sus percepciones y opiniones a partir de sus experiencias directas con los trámites relacionados al tema ( $y$ es parte de la originalidad de este trabajo). La segunda observación deriva del mencionado volumen de información y refleja una gran carga de insatisfacción, no propiamente por causa de la tipología arquitectónica propuesta y sí debido a las inúmeras imperfecciones detectadas, ya sea por errores de los proyectos o durante su ejecución -vicios de construcción- tanto en Argentina como en Brasil, donde los moradores abundaron en críticas con relación a diferentes e importantes ítems de análisis que se verán en mayor profundidad en el Capítulo 5 de esta tesis.

Esta realidad, muy probablemente, estuvo asociada a una gran dificultad para la obtención de los datos y documentos necesarios al desarrollo de la investigación, no sólo con las instituciones y los profesionales, sino también con los moradores y sus líderes comunitarios, tanto en Brasil como en Argentina, donde por diversos motivos alegados por varios de éstos, el retraso de las actividades desafortunadamente se mantuvo presente, salvo raras excepciones.

6 - Estructura de la Tesis

La conformación principal de este trabajo consiste básicamente del cuerpo de la tesis en sí, desde la Introducción a las Conclusiones finales, Recomendaciones, Referencias y Bibliografía, y complementariamente con las Fuentes, Filmografía Sugerida y los Documentos Adjuntos (DA).

En el Capítulo 1 se tratan las primeras leyes y ejecuciones de políticas públicas propuestas por técnicos y autoridades para hacer frente al creciente déficit de viviendas de los grandes centros urbanos y los problemas sociales derivados tanto en Brasil como en Argentina. En el Capítulo 2 se analiza cómo las leyes edilicias y las instituciones involucradas con el tema de políticas públicas para vivienda intervinieron en la realidad inmobiliaria, promovieron la escasez de tierras 
urbanas y la carencia de un techo para los sectores de más bajos ingresos. En el Capítulo 3 se abordan las experiencias de las últimas décadas en Brasil, Argentina y Uruguay con relación al medio ambiente, la gestión de los proyectos y el impacto del factor costo/beneficio. En el Capítulo 4 se presentan informaciones técnicas y de costos de los seis proyectos investigados, así como un panorama sociodemográfico de las comunidades. En el Capítulo 5 se describe la metodología y se analizan los datos. Por último, se presentan las Conclusiones Finales de la tesis y las Recomendaciones. 


\section{CAPÍTULO 1 \\ CONTEXTO HISTÓRICO DE LAS OCUPACIONES INFORMALES EN BRASIL Y EN AMÉRICA LATINA}

\section{1- Las ocupaciones informales en los grandes centros urbanos}

El contexto histórico de las condiciones enfrentadas por los sectores de más bajos ingresos en cuanto a la solución del problema habitacional está fuertemente determinado por prácticas culturales provenientes del período de la colonización, muchas de ellas mantenidas hasta ahora, como por ejemplo la pobreza, la expoliación y la discriminación, reforzadas por el surgimiento de otras prácticas que serán analizadas a lo lardo de este capítulo.

La recesión económica que se abatió duramente en Brasil durante las décadas de los (19)80 y (19)90 condujo a que fueran llamadas "décadas perdidas". La realidad social brasileña incorporó un fenómeno hasta entonces desconocido y que se definió "violencia urbana", evidenciado por una escalada en el aumento del número de homicidios.

Datos de IPEA dan cuenta de que el $33 \%$ de los pobres brasileños se concentraron en la región Sudeste, predominantemente en las metrópolis, lo que refuerza la tesis de que "a concentração da pobreza é urbana" (MARICATO, 2011, p. $22)^{4}$.

Yendo un poco más lejos en la búsqueda de las razones de los infortunios sociales brasileños, se puede encontrar el motivo no sólo en el modelo de industrialización y desarrollo excluyente, sino también en los cinco siglos de formación de la sociedad y, en cuanto al problema de la vivienda popular, hay que considerar, en especial, la privatización de tierras de 1850 y la abolición de la esclavitud en 1888.

Dichos infortunios sociales se desarrollan en una "gigantesca ilegalidad" que:

[...] é resultado, de um lado, de um processo de urbanização/industrialização baseado em baixos salários e, de outro, de uma tradição de especulação fundiária alimentada por investimentos públicos regressivos e concentrados, além de uma

\footnotetext{
${ }^{4}$ Según DIEESE, la distribución de renta de las dos décadas mencionadas presentó la siguiente situación: de 1981 , con un $50 \%$ de pobres, un $10 \%$ de ricos y un $1 \%$ de los más ricos, poseyendo, el $14,5 \%, 44,9 \%$ y el $13,4 \%$ de la renta del País, se pasó, respectivamente, en 1995 al: $13,3 \%, 47,1 \%$ y $14,4 \%$ de la renta producida en Brasil (MARICATO, 2011, p. 30).
} 
legislação, cuja forma de aplicação exclui e segrega [... De ahí se percibe que] $A$ incrível desigualdade social no Brasil é uma construção que tem na aplicação arbitrária da lei além da concentração espacial da infraestrutura e serviços públicos, sua argamassa fundamenta. (MARICATO, 2011, p. 155-156)

Las medidas implantadas por el Estado, que se fortalecía para combatir los mencionados infortunios, a mediados del siglo pasado, como, por ejemplo, la de la creación de la CEPAL en 1948, no han sido suficientes para resolver el problema social en cuestión. Tampoco lo fueron los esfuerzos de algunos intelectuales que animaron las expectativas revolucionarias de partidarios de izquierda de este continente, en consonancia con la teoría del capitalismo dependiente, en el auge de las décadas del (19)60 y (19)70, que no pudieron resolver el problema, considerando que:

[...] a estratégia da revolução democrático-burguesa ou nacional e democrática [... planteada por los adeptos al Partido Comunista do Brasil, y de otros países, desde la década del (19)20 y hasta por lo menos cincuenta años después] cujo objetivo principal era garantir o desenvolvimento de um capitalismo autônomo no Brasil [...] se mostrara equivocada, pois o capitalismo dependente do capital internacionalizado encontrara caminhos para se desenvolver sem o recurso à revolução, como diversos estudiosos da realidade brasileira já haviam constatado. (PRESTES, 2015, p. 495)

Lo que la historia demuestra es que, civismos y nacionalidades aparte, las burguesías y oligarquías locales, con raras excepciones, con relación a sus intereses económicos y del mantenimiento de su status quo en el medio social y político en que estuvieron inseridas, se alinearon con quien tuviera el poder, esto es, con quien tuviera el capital, independientemente de la nacionalidad de éste.

Esta realidad evidencia uno de los motivos que explican por qué la cuestión de la VIS permanece sin solución desde hace décadas en gran parte de la mayoría de los países de este continente. Por ejemplo, al pensarse en una transformación radical a través de una solución que pasara por la autogestión y participación en políticas públicas involucrando a los principales sujetos sociales que necesitan de una habitación, Leonardo Tomasetta (1972) alerta que esta vía conlleva el admitir que, en un primer momento, la autogestión suscitaría una repulsa a la participación institucionalizada de estos sujetos, en el sentido de que dicha participación:

[...] significa contribuir a la consolidación y supervivencia de un sistema ordenado de valores ajenos a los verdaderos intereses de 
los productores directos (e incluso transforman a éstos en consumidores permanentes del proprio trabajo enajenado) [...] En cuanto a la participación, es muy evidente la comprobación de que en ella convergen dos tendencias: una dirigida a contraponer los intereses de los trabajadores a los del empresario, y la otra a establecer la convivencia entre las dos partes como 'subordinación' de los trabajadores a la jerarquía empresarial. (TOMASETTA apud RODRÍGUEZ, 2009, p. 159).

Rodríguez (2009), a su vez, señala el riesgo de lo que esta ambivalencia tienda a promover en el desarrollo de las relaciones sociales, y argumenta, con las propias palabras de Tomasetta (1972), para quien esta ambivalencia puede:

[...] hacer pasar la autogestión (que es un sistema radicalmente antinómico a toda sociedad de clases) por una de las tantas variantes de la cogestión... presentando ante los obreros como un progreso, una participación que es una colaboración con los empresarios y, por lo mismo, un reforzamiento del predominio de clase. (TOMASETTA apud RODRÍGUEZ, 2009, p. 159)

Al respecto de este antiguo conflicto de producción de vivienda bajo el capitalismo, el Equipo de Política y Planes de la Dirección General de Planeamiento y Presupuesto (Minvu-Chile), así expuso, durante el gobierno del presidente Salvador Allende, basado en lo que dijo Paul Baran ([¿1974?]) en su obra Capitalismo monopolista:

Además de esta contradicción que obstaculiza este posible papel dinamizador del sector de vivienda, hay inclusive desde un punto de vista del sistema global, intereses y mecanismos que también impiden la acción del sector en este sentido. En consecuencia, desde el punto de vista de una racionalidad económica para el sistema, sería conveniente incentivar y actuar a través del Estado en el sentido de incrementar la importancia del gasto en vivienda; sin embrago, desde el punto de vista político y social no le interesa ni conviene al sistema, pues entraría en choque con fuertes intereses privados (empresas constructoras y capitalistas rentistas) que son parte importante para su manutención. De ahí que, para estos países [desarrollados como EEUU], la política económica manejada por el Estado está mucho más orientada a incentivar otros gastos, como son los militares, jugando la vivienda un papel muy insignificante. (SUMMA, 1974, p. 32)

A pesar de que este análisis haya sido expuesto en la década del (19)70 para explicar la realidad del papel del sector de la habitación en la coyuntura económica de países desarrollados, lo que se intenta destacar en esta tesis es que en países 
en desarrollo, como es el caso de Brasil y Argentina, y otros de este continente, hasta la presente década aún es muy evidente la influencia de poderosas constructoras interfiriendo fuertemente en las políticas económicas del Estado, incluso de forma inescrupulosa con gobernantes y políticos en pro de sus intereses y en detrimento de la colectividad. Algo que, infelizmente, tiene mucho que ver con lo que Rodríguez (2009, p. 221 - 222) también reclama en Argentina.

Santana (1994, p. 14), basado en una publicación de DIEESE de 1993, resume el cuadro de distribución de renta (en \%) en el período entre 1983 y 1990 en Brasil según la Tabla 1.1.

Tabla 1.1 - Distribución de renta en Brasil entre 1983 y 1990

\begin{tabular}{|c|c|c|c|c|c|c|c|c|}
\hline Grupos & $\mathbf{1 9 8 3}$ & $\mathbf{1 9 8 4}$ & $\mathbf{1 9 8 5}$ & $\mathbf{1 9 8 6}$ & $\mathbf{1 9 8 7}$ & $\mathbf{1 9 8 8}$ & $\mathbf{1 9 8 9}$ & $\mathbf{1 9 9 0}$ \\
\hline Los 50\% más pobres & 13,4 & 13,4 & 12,6 & 13,5 & 13,0 & 12,0 & 11,2 & 12,0 \\
\hline Los 10\% más ricos & 46,7 & 46,8 & 47,6 & 47,3 & 46,9 & 49,7 & 51,5 & 48,1 \\
\hline
\end{tabular}

Fuente: Santana (1994, p. 14).

Para el periodo anterior a la década del (19)80, el economista brasileño Carlos Langoni (1973), en su obra Distribuição de renda e desenvolvimento econômico no Brasil, revela algo que seguramente no era novedad para muchos, puesto que había:

[...] uma polarização salarial que se reflete na distribuição de renda da população como um todo. Assim, a parcela da renda pessoal apropriada pelos $10 \%$ mais ricos passa de $39,66 \%$, em 1960 , para $47,79 \%$ em 1970, inaugurando uma tendência que se consolida. No mesmo período, a parcela da renda apropriada pelos $50 \%$ mais pobres caiu de $17,71 \%$ para $14,90 \%$. (SOUZA, 2018, p. 139)

A su vez, Taschner (2004) informa, con base en el periódico Folha de São Paulo del 5 de abril de 2001, que:

Em 1999, tal como em 1992, os 50\% mais pobres da população ficavam com $14 \%$ da renda do país, enquanto que o $1 \%$ mais rico detinha 13\% da riqueza gerada. Entre 1992 e 1999, o rendimento dos $10 \%$ mais ricos e o dos $40 \%$ mais pobres cresceu percentualmente na mesma proporção. Isso significa que, em termos absolutos, o fosso aumentou. (TASCHNER apud FERNANDES y SOUZA, 2004, p. 146) 
Además de esto, se suma a dicho contexto trágico el hecho de que la informalidad producida en las grandes ciudades brasileñas, agravada en las últimas décadas bajo la conveniente indiferencia del Estado, salvo momentos específicos, mediante la perversa lógica intrínseca al capitalismo periférico de transferir a los trabajadores los costos de su propia morada a través de la autoconstrucción de sus viviendas mediante la ocupación irregular del suelo, con vistas al "barateamento da força de trabalho, de um lado, e manutenção de um mercado residencial restrito ao 'produto de luxo' de outro" (MARICATO, 2012, p. 20).

Maricato (2012) sintetiza muy bien la realidad del brasileño en general, señalando algunas aberraciones sociales aún existentes en este país y que se reflejan en la forma y la calidad de vida: herencia esclavista, desprestigio del trabajo, patriarcado, machismo, patrimonialismo, privatización de la esfera pública, personalismo, rechazo a las relaciones impersonales y profesionales, clientelismo y la universalización de la política del favor contrariamente al reconocimiento de los derechos, tradición autoritaria que niega la ciudadanía. Todo esto, afirma la autora, se encuentra en cada metro cuadrado de la ciudad periférica. Sólo le faltó agregar que éstos son los condicionantes esenciales de la corrupción, amplia e indudablemente comprobada en diversos segmentos de la sociedad, fenómeno que persiste al no ser controlado y que ha sido el otro lado perverso con que gran parte de la sociedad se ve obligada a convivir, aún en la actualidad, y desde tiempos remotos. Y la rica producción intelectual de Max Weber (WEBER, 1966; SAINTPIERRE, 2004) sobre ese tema continúa tan presente como válida, como lo fuera en el siglo XIX.

Datos más recientes del Banco Mundial, explicitados con más detalles en la Tabla 1.2, traducen la triste realidad de la distribución de renta en Brasil y Argentina, aún vigente en estas cuatro últimas décadas, incluso considerando los eventuales avances sociales que han ocurrido en estos países.

Tabla. 1.2 - Distribución de ingresos (en \%) en Argentina y Brasil entre 1980 y 2016

\begin{tabular}{|c|c|c|c|c|c|c|c|c|c|}
\hline País & Grupos & $\mathbf{1 9 8 0}$ & $\mathbf{1 9 8 6}$ & $\mathbf{1 9 9 2}$ & $\mathbf{1 9 9 6}$ & $\mathbf{2 0 0 1}$ & $\mathbf{2 0 0 6}$ & $\mathbf{2 0 1 1}$ & $\mathbf{2 0 1 6}$ \\
\hline \multirow{4}{*}{ Argentina } & $10 \%$ más pobres & 2,0 & 2,0 & 1,6 & 1,0 & 0,7 & 1,2 & 1,7 & 1,8 \\
\cline { 2 - 10 } & $20 \%$ más pobres & 5,3 & 5,1 & 4,6 & 3,5 & 2,6 & 3,7 & 4,8 & 5,0 \\
\cline { 2 - 10 } & $40 \%$ de la población & 10,2 & 9,8 & 9,2 & 8,2 & 7,1 & 8,6 & 9,7 & 9,6 \\
\cline { 2 - 10 } & $60 \%$ de la población & 15,4 & 14,8 & 13,9 & 13,1 & 12,3 & 14,2 & 15,1 & 15,0 \\
\hline
\end{tabular}




\begin{tabular}{|c|c|c|c|c|c|c|c|c|c|}
\hline & $80 \%$ de la población & 22,6 & 21,9 & 21,5 & 21,2 & 21,1 & 22,7 & 22,9 & 22,7 \\
\hline & $20 \%$ más ricos & 46,6 & 48,4 & 50,9 & 54,0 & 57,0 & 50,7 & 47,4 & 47,6 \\
\hline & $10 \%$ más ricos & 30,2 & 32,4 & 34,3 & 36,9 & 39,5 & 33,6 & 30,6 & 30,9 \\
\hline \multirow{8}{*}{ Brasil } & Grupos & 1981 & 1986 & 1992 & 1996 & 2001 & 2006 & 2011 & 2015 \\
\hline & $10 \%$ más pobres & 0,8 & 0,9 & 0,8 & 0,7 & 0,8 & 1,0 & 1,1 & 1,2 \\
\hline & $20 \%$ más pobres & 2,7 & 2,7 & 2,8 & 2,2 & 2,5 & 3,0 & 3,3 & 3,6 \\
\hline & $40 \%$ de la población & 6,2 & 6,0 & 7,1 & 5,7 & 6,0 & 6,7 & 7,5 & 7,9 \\
\hline & $60 \%$ de la población & 10,5 & 10,3 & 12,2 & 10,0 & 10,5 & 11,2 & 12,2 & 12,7 \\
\hline & $80 \%$ de la población & 18,4 & 18,2 & 20,8 & 18,2 & 18,5 & 18,8 & 19,5 & 19,7 \\
\hline & $20 \%$ más ricos & 62,3 & 62,8 & 57,1 & 63,9 & 62,5 & 60,1 & 57,5 & 56,1 \\
\hline & $10 \%$ más ricos & 45,9 & 46,6 & 39,7 & 47,4 & 46,1 & 44,1 & 41,7 & 40,4 \\
\hline
\end{tabular}

Fuente: adaptación de Banco Mundial ([s/f]).

De este perverso e inadmisible cuadro social resulta que, en Brasil, el mercado residencial formal, el cual se vuelca preferencialmente hacia el producto de lujo, sólo alcanza del $15 \%$ al $30 \%$ de la población, a depender de las características de las regiones y de las ciudades, y esto porque, también, dentro de la lógica retrógrada y expoliadora de quien domina el sector de producción inmobiliario, no le interesa la regulación y control latifundistas, al contrario de la burguesía de los países centrales que en ese sentido fueron más progresistas en relación a los movimientos revolucionarios de liberación del trabajador de las condiciones serviles (MARICATO, 2012, p. 129-131).

De esta manera:

A favela, no Brasil, é um fenômeno predominantemente metropolitano: em 1980, $79,16 \%$ das moradias faveladas estavam nas 9 regiões metropolitanas. Em 1991, 2.391 favelas (74\%), de um total de 3.211 e 817.603 (78\%) dos domicílios favelados se alocavam nas metrópoles. [... ver Tabla 1.3] Esse modelo perverso, das favelas e pobres na periferia, já começa a se espalhar pelas cidades grandes e médias do Brasil, tanto que no Perfil Municipal, praticamente todas as cidades com mais de 500 mil pessoas relataram a existência de favelas. (TASCHNER apud FERNANDES y SOUZA, 2004, p. 156157).

Tabla 1.3 - Los 15 municipios brasileros con mayor número de favelas en 2000

\begin{tabular}{|c|c|c|c|}
\hline Orden & Municipio & Estado & No de favelas $^{\circ}$ \\
\hline $1^{\circ}$ & São Paulo & São Paulo & 612 \\
\hline $2^{\circ}$ & Rio de Janeiro & Rio de Janeiro & 513 \\
\hline
\end{tabular}




\begin{tabular}{|c|c|c|c|}
\hline $3^{\circ}$ & Fortaleza & Ceará & 157 \\
\hline $4^{\circ}$ & Guarulhos & São Paulo & 136 \\
\hline $5^{\circ}$ & Curitiba & Paraná & 122 \\
\hline $6^{\circ}$ & Campinas & São Paulo & 117 \\
\hline $7^{\circ}$ & Belo Horizonte & Minas Grerais & 101 \\
\hline $8^{\circ}$ & Osasco & São Paulo & 101 \\
\hline $9^{\circ}$ & Salvador & Bahia & 99 \\
\hline $10^{\circ}$ & Belém & Pará & 93 \\
\hline $11^{\circ}$ & Diadema & São Paulo & 89 \\
\hline $12^{\circ}$ & Volta Redoinda & Rio de Janeiro & 87 \\
\hline $13^{\circ}$ & Teresina & Piauí & 85 \\
\hline $14^{\circ}$ & Porto Alegre & Rio Grande do Sul & 76 \\
\hline $15^{\circ}$ & Recife & Pernambuo & 73 \\
\hline
\end{tabular}

Fuente: basado en Taschner (apud FERNANDES y SOUZA, 2004, p. 156).

El combate a esta herencia cultural arcaica, proveniente del período colonial, es uno de los motivos más importantes para que se avance en las prácticas de gobernanza en el sentido más relevante del concepto de gobernabilidad, teniendo en cuenta que una gran parte de las sociedades, desprovistas de efectivos mecanismos para hacer frente a antiguas y viciadas prácticas autoritarias por parte de muchos gestores y políticos, tienden a tener dificultades "de produzirem resultados credíveis para a superação da pobreza e o conjunto da vida social nos espaços circunscritos e microssociais", conforme afirma Ivo (apud FERNANDES y SOUZA, 2004, p. 34).

Este desorden social que prevalece en Brasil se relaciona a lo que la autora sostiene:

Salvador não se diferencia das demais metrópoles brasileiras. Nesse aspecto, alguns autores entendem que a produção no nosso país de uma ordem socioeconômica desigual quanto à distribuição de renda e dos bens públicos é resultado do caráter patrimonialista e centralizador [d]o Estado brasileiro. Permeado por relações clientelistas, pelo caráter restrito das políticas de seguridade social e pelo volume da pobreza e sua grandeza expressiva. Assim, as ações governamentais desempenham papel fundamental para consolidação ou eliminação de políticas públicas inclusivas ou excludentes. (IVO apud OLIVEIRA, 2013, p. 198)

Por lo expuesto, no es extraño que la producción espacial urbana brasileña exprese una síntesis radicalmente desigual del desorden social autoritario 
prevaleciente, consecuencia de las relaciones de privilegio y arbitrariedad de nuestras ciudades, algo que, dada la intensidad y duración con que viene ocurriendo, dificulta enormemente la construcción de propuestas alternativas, democráticas e igualitarias para aquellas ciudades cuya situación, según Maricato (2011, p. 50-51), se agrava por la dificultad de lidiar con la máquina pública brasileña, en la cual, de acuerdo con la tradición, quien tiene el poder económico y político tiene el don de influir en el cómo y cuándo la ley se aplica. Se agregue a este escenario, por ejemplo, la constatación de que, en Brasil:

Municípios como Salvador, Belo Horizonte, Recife e Vitória apresentaram, no ano de 1998, aumento insignificante no estoque de unidades habitacionais legais: 1,2\%; $7 \%$; $10 \%$; e $13 \%$, respectivamente. Isso faz do mercado formal de habitação, 'um mercadinho', na expressão de Ermínia Maricato. (FARRET apud FERNANDES y SOUZA, 2004, p. 62)

De esta manera, en teoría, diagnosticada una de las principales causas estructurales de la problemática en cuestión, la de la ocupación irregular para fines de habitación popular, se podría suponer que la solución para sanear el problema estaría en manos de las autoridades: gobernantes, legisladores y de la Justicia. Desafortunadamente, como se ve, y se sabe, la lógica y lo obvio raramente se hacen presentes en estos casos, pues, al final, entre tantos nudos que progresivamente se atan, se da, por ejemplo, en algunas ciudades de administraciones progresistas, el fenómeno denominado "espaço dual de participação no contexto municipal" (MARICATO, 2011, p. 71-73), o sea, que a pesar de los avances de los sectores de más bajos ingresos en las conquistas de leyes que aseguren sus reivindicaciones sobre necesidades básicas, dichos avances se ven anulados por los consejos gestores, que impiden la aplicación de esas leyes, protegiendo los intereses de las élites locales. Se percibe este fenómeno en instancias superiores, inclusive a nivel federal, y esto tiene que ver con lo que generalmente, en Brasil, se escucha, se dice, se escribe y se lee, que en el discurso y en las buenas intenciones de promover leyes avanzadas, la cosa pública va muy bien, pero en la práctica es bien diferente, lo que acaba por generar en la sociedad una sensación de embuste: mucha charla y poca acción, es decir, poca voluntad y decisión política.

Dentro de esta "irracionalidad" confusa que desde hace décadas se materializa en la trama urbana de Salvador, y de tantos otros grandes centros de América Latina, hay que cuestionarse por qué después de tantos discursos e 
inúmeros proyectos de intervención en el espacio urbano, que pretenciosamente dicen querer modernizar, los resultados fueron tan ínfimos para la gran parte de la población que hasta ahora continúa excluida. En ese caso, como en otros similares, quién de hecho espera mejorías para la sociedad como un todo, y no sólo para una parcela diminuta de la misma, debe tener en cuenta que:

\begin{abstract}
Assim, mais estrutural e profunda de como os fatos contradizem os discursos modernos ou 'pós-modernos', pode-se até concordar que tanto o modernismo, como o pós-modernismo, no âmbito da arquitetura e do urbanismo, a rigor, podem ser vistos como sintomas de uma época ou momento, mas nunca podem equivaler a uma solução dos problemas mais estruturais da sociedade. Arquitetura e urbanismo, como superestruturas, se circunscrevem nos limites precisos da estrutura econômica e de poder que lhe dão causa. (SAMPAIO, 1999, p. 326)
\end{abstract}

Entonces, en la expectativa que se tiene en el contribuir para mitigar y resolver esta problemática, que en diferentes momentos históricos viene siendo mascarada con discursos que no se adecúan a las prácticas impuestas en el medio urbano, se tiene, también, que admitir que:

\begin{abstract}
Se os grupos possuem 'interesses' próprios - convergentes e divergentes - o processo decisório é por natureza conflituoso e fragmentário, e, o que qualquer 'teoria explicativa' vai demonstrar, são os limites e possibilidades para negociações, aclarando o campo dos reais cenários alternativos. Via de regra, as reflexões explicativas apontam mais os limites impeditivos da ação e menos as potencialidades do contexto no âmbito da transformação. Nisto, a 'teoria normativa' pode levar vantagem, quando, ao explicitar um 'vira-ser' alternativo qualquer, com chances de negociação entre os 'agentes', fatalmente anteponha aos 'jogos de linguagem' das classes heterogêneas uma outra [sic] visão. Embora essas classes continuem influenciando na gestão (Estado) e interferindo no funcionamento da cidade, as mesmas não possuem um 'controle centralizado' e único sobre todos e tudo. No campo propositivo, normativo, os limites e as brechas do 'sistema' só são expostos e confrontados com o 'sentido social' das ações de forma prática, quando submetidos à crítica, no confronto dos interesses divergentes. (SAMPAIO, 1999, p. 386 y 387 )
\end{abstract}

Se espera que, entre las brechas existentes, las promesas de avances sociales y las argumentaciones inconsistentes puedan ser expuestas a todos y así, los grupos en permanente desventaja puedan valerse de estudios, análisis y propuestas confiables para revertir este cuadro histórico desfavorable a la sociedad como un todo. 
Sampaio (1999), basado en la clasificación de las vertientes de la concepción moderna, contemporánea, propuesta por Vergara-Gómez (1968), con énfasis en el planeamiento y urbanismo, explica en su obra cómo Salvador, desde fines del siglo XIX y hasta finales del siglo XX, experimentó diversas transformaciones en su formaurbana, además de su estructura de producción, de consumo, de cambio y de gestión, y cómo tales transformaciones fueron impuestas, en cada momento histórico, basadas en lo que fuera conveniente a los promotores de tales transformaciones a partir de los presupuestos de dichas vertientes: Urbanismo de la Composición, Enfoque Funcionalista, Enfoque organicista, Enfoque Sistémico, Enfoque Participativo, Enfoque Morfológico y Enfoque Normativo. Siempre en la perspectiva de transformar la forma-urbana en forma-mercadería sin perder de vista el logro del bien mayor de los "agentes" interesados y de los responsables institucionales: el lucro (SAMPAIO, 1999, p. 364-407).

Se añade al contexto socio urbano mencionado el hecho de que, en Brasil, según datos de la Associação Nacional de Transportes Públicos (ANTP, 2009), "nas seis maiores metrópoles brasileiras, $29 \%$ das viagens são feitas por transporte público, 9\% por meio de automóvel e 44\% a pé." (MARICATO, 2012, p. 148). ${ }^{5}$ Según el especialista en movilidad urbana Nazareno S. Affonso (1987) el transporte consume cerca del $26 \%$ de la renta familiar de los sectores de más bajos ingresos y el $10 \%$ de los más ricos. Y, aun así, el foco principal de las políticas públicas con relación a la locomoción de las personas continúa siendo, al menos en Brasil, el de priorizar la utilización de automóviles en detrimento de los colectivos ${ }^{6}$.

Existen también otro detalle que no siempre se lleva en consideración y que involucra el modelo de uso del suelo, el control de los contaminantes ambientales, la modalidad de transporte, la densidad urbana y el estilo de vida de la población:

Los modelos de uso del suelo también ejercen un gran impacto en las emisiones de $\mathrm{CO}_{2}$. Las ciudades dispersas, donde el suelo se destina a un único uso, generan una cantidad de $\mathrm{CO}_{2}$ mucho mayor que los barrios tradicionales, donde se combinan usos mixtos. El transporte privado y la construcción de edificios aislados, mucho

\footnotetext{
${ }^{5}$ Consulta hecha en 2006 a 480 jefes de familia en relación al medio de transporte utilizado para ir al trabajo en villas miseria y asentamientos del Gran Buenos Aires, incluyendo la CABA, la que tuvo como resultado que: el $28,8 \%$ no sale del barrio, el $21,9 \%$ va a pie, el $13,1 \%$ va en bicicleta, el $39 \%$ en colectivo (ómnibus), el $5 \%$ en tren, el $1,5 \%$ en vehículo particular, el 1,3\% en vehículo de trabajo, el $1,3 \%$ en moto y el $4,4 \%$ en "van clandestina" (remís "trucho"), con un $5,8 \%$ sin informar. (CRAVINO, 2009b, p. 171)

6 "Durante a década de 1980, a população brasileira cresceu a taxas de 1,9\% e a população moradora de favelas, 7,6\%, segundo o IBGE. Para a década de 1990 esses números são 1,63\% e 4,18\%, respectivamente" (MARICATO, 2012, p. 148).
} 
menos eficientes en cuanto al consumo de energía, aumentan el consumo de combustibles fósiles, y, por tanto, la producción de $\mathrm{CO}_{2}$. La densidad de la población es una cuestión importante, puesto que el transporte público sólo es viable económicamente en ciudades compactas. Los modelos urbanos densos basados en la diversidad de usos del suelo generan una cantidad mucho menor de $\mathrm{CO}_{2}$ que la ciudad suburbana moderna convencional. Esta es la razón por la que la producción per cápita de $\mathrm{CO}_{2}$ varía entre distintos países. La clave se halla en el modelo de vida. (EDWARDS, 2009, p. 6)

Edwards, preocupado por el progresivo grado de contaminación del medio ambiente por causa del excesivo y continuo volumen de descarga de $\mathrm{CO}_{2}$ en la atmosfera, concuerda con que:

Se cree que unos 15 árboles son capaces de transformar las
emisiones de carbono de un coche medio durante un año, mientras
que unos 40 podrían convertir las de toda una casa. Todo depende,
sin embargo, del tamaño y del tipo de árbol, así como de la eficiencia
energética del elemento productor de $\mathrm{CO}_{2}$. Estos resultados se
apoyan en la premisa de que son necesarios $160 \mathrm{~m}^{2}$ de árboles para
compensar cada $1.000 \mathrm{~kW} / \mathrm{h}$ de energía utilizados para calefacción,
$900 \mathrm{~m}^{2}$ por cada $1.000 \mathrm{~kW} / \mathrm{h}$ de electricidad y $1.200 \mathrm{~m}^{2}$ por cada
1.000 I de gasolina consumida. De todo ello se deduce que cada
hogar requiere aproximadamente $8.000 \mathrm{~m}^{2}$ de bosque para
transformar sus emisiones de $\mathrm{CO}_{2}$ en oxígeno. (EDWARDS, 2009, p.
63 ).

Esto indica la gravedad del problema del $\mathrm{CO}_{2}$ en ámbito mundial y se vuelve aún más preocupante cuando se observa el bajo porcentaje del verde en los proyectos de VIS brasileños, lo que es un inequívoco índice del descuido del paisajismo en el proyecto y demuestra además una inexplicable falta de importancia dada a los espacios verdes por gran parte de los profesionales en innumerables proyectos de VIS, como es muy común constatar al no tomarse lo suficientemente en serio algo tan sencillo como que:

La calidad del aire en las zonas urbanas también puede mejorarse plantando árboles, pues depuran el aire, modifican el clima y proporcionan sombra [... y que] pasamos el $80 \%$ de nuestro tiempo dentro de edificios y la mayor parte del resto en zonas urbanas contaminadas. (EDWARDS, 2009, p. 138)

Por otro lado, la política de transporte de cuño automovilístico impuesta por los sucesivos gobiernos brasileños en la esfera federal, cuya política conviene mucho más a la poderosa rama industrial automovilística y a sus segmentos, situación menos presente en Argentina, tiene que ver con que: 
Se há especificação espacial [del modo de transporte] $e$ determinação do modo de gestão, há também diferenciação social, quer dizer distribuição desigual dos meios de transportes entre os grupos sociais (segundo, em última instância, seu lugar nas relações de produção) e distribuição desigual dos meios de transportes no espaço, ele próprio socialmente diferenciado [...] o conhecimento das leis tendenciais para este ou aquele tipo de translado e o estabelecimento dos desvios, dos efeitos em sentido contrário etc. numa dada realidade, permitem distinguir as contradições do sistema de circulação, introduzindo assim à problemática da planificação (que tentará regulá-las) e dos movimentos sociais suscitados pela experiência vivida de tais situações. (CASTELLS, 2000, p. 280)

El cuadro general hasta aquí presentado, mantenidas las debidas proporciones y respectivas particularidades, puede verse en Argentina donde, por ejemplo, en el período de la redemocratización, luego del 83, se intentó promover avances con la flexibilización del rígido Código de Planeamiento de 1977, de frente a los nuevos tiempos, incluyéndose las propuestas de Las 20 Ideas para Buenos Aires, estimuladas por el Consejo de Planificación Urbana (CPU), pero que no provocó satisfactoriamente el efecto deseado. Interesantes ideas y proyectos, pero con insuficiente efectividad, salvo excepciones, según Clichevsky (1996, 45-55).

Basándose en datos de una investigación realizada en 1999 por el Programa de Aprimoramento das Informações de Mortalidade do Município de São Paulo (PRO-AIM), Marcos Drumond (1999) analizó y demostró que se establece una relación directa entre espacialidad y violencia, indicando que es en las áreas más violentas donde existe una confluencia de determinados indicadores sociodemográficos, como "baixa renda, baixa taxa de escolaridade, maior proporção de negros entre os moradores, maior taxa de desemprego, maior número de moradores de favelas, piores condições de moradia e urbanísticas" (MARICATO, 2011, p. 34). En este contexto, esta autora también concluye que "São Paulo, como outras metrópoles latino-americanas, cresce produzindo verdadeiras bombas socioecológicas no seu interior. Nelas não há lei ou qualquer regulação, seja urbanística seja nas relações sociais." (MARICATO, 2011, p. 34.

Además de estos ingredientes básicos para la producción de dichas bombas, la misma autora agrega otros como la:

Concentração territorial homogeneamente pobre (ou segregação espacial), ociosidade e ausência de atividades culturais e esportivas, ausência de regulação social e ambiental, precariedade urbanística, mobilidade restrita ao bairro, e, além dessas características todas, o 
desemprego crescente que, entre outras consequências, tende a desorganizar núcleos familiares. (MARICATO, 2011, p. 36) ${ }^{7}$

Este proceso se ve agravado a partir de la pos-Segunda Guerra Mundial por la progresiva emigración rural-urbana en América Latina, donde uno de los principales motivos, según Castells (2000, p.104), fue "a contradição entre o aumento acelerado da população, consequência da baixa recente taxa de mortalidade, e a manutenção das formas improdutivas da propriedade latifundiária".

En este contexto social adverso no se puede olvidar de que espacios con alta densidad habitacional, de habitaciones diminutas, con escasez o inexistencia de estructuras comunitarias deportivas, de recreación y de educación, asociado a la ociosidad por desempleo o desocupación, son factores propicios para fomentar el comprometimiento de la calidad de vida y de la sociabilidad de las comunidades, así como para propiciar la violencia doméstica y el operar de grupos marginales (ABIKO y ORNSTEIN, 2002, p. 336) $)^{8}$.

Este cuadro social sentó las bases de las preocupaciones a inicios del siglo pasado del discípulo de Robert Ezra Park (1925), Louis Whirth (1938) -sociólogo de la Escuela de Chicago-, para el que las principales relaciones causales entre características y formas culturales de los aglomerados en espacio urbano son dimensión, densidad y heterogeneidad (CASTELLS, 2000, p. 126-138). Fue en este

\footnotetext{
${ }^{7}$ Resultados de IBGE del Censo de 2000 señalan que el número total de 3.905 núcleos "favelados" en Brasil, entre 1991 y aquel año, representa un aumento del $22 \%$ en todo el País en el referido período. Conviene resaltar que en la metodología de este órgano federal no se computa como favela núcleos con menos de cincuenta unidades habitacionales, lo que hace creer, por otras investigaciones, que el problema sea mucho más grave, ya que esta situación no registrada por dicho órgano es muy expresiva de la realidad nacional (MARICATO, 2011, p. 37). Un ejemplo de esta preocupante constatación proviene de los datos que dan cuenta, según Maricato (2012), de que en la década del (19)80 la tasa de crecimiento de la población moradora de favela triplicó con relación a la población urbana en su conjunto y que en la década de los (19)90 esta tasa duplicó: "Perto de 12\% da população de São Paulo e Curitiba moram em favelas. Em Belo Horizonte e Porto Alegre, até $20 \%$. No Rio de Janeiro, 25\%. Em Salvador, Recife, Fortaleza, São Luiz e Belém, mais de 30\% das pessoas vivem em favelas" (MARICATO, 2012, p. 186). En Argentina, según el intendente de la Capital Federal, Saúl Bouer, de las personas que vivían en Buenos Aires, en 1993, cerca del 15\% habitaban en villas miseria, lo que correspondía a 51.821 personas (otras fuentes computaban 58.000). Situación que se agrava cuando se computa el número de personas que residen en inmuebles desocupados, tomados, en alquileres y en pensiones, las que hasta 1990 totalizaban en la capital porteña una parcela que variaba de ciento cincuenta a doscientos mil habitantes, según Clichevsky (1996, p. 19, 143-144). Estudios más recientes constatan que cerca del $12 \%$ de la población de la Región Metropolitana de Buenos Aires vive en habitaciones clasificadas con variado nivel de pobreza, principalmente en villas miseria y asentamientos, y mitad de ese porcentaje se refiere a la CABA (CASTRO, 2010, p. 97), mientras que "Hacia fines de la década del '80, la ciudad presentaba la paradójica coexistencia de un $10,6 \%$ de su población -110.000 hogares, 346.000 personas- en condiciones de demanda crítica con un vasto parque habitacional desocupado", según constata Rodríguez (2009, p. 92).

${ }^{8}$ La Organización Mundial de la Salud (OMS) recomienda $15 \mathrm{~m}^{2}$ construidos por morador (ABIKO y ORNSTEIN, 2002, p. 342).
} 
contexto que surgió el uso de la tipología arquitectónica de construcción en altura que inició con dicha escuela, extendiéndose al Movimiento Moderno, que busca soluciones únicas y válidas para todos los casos, según recuerda Balter (2015, p. 10).

A su vez, Gordilho (2008, p. 158-159) alerta sobre el "déficit cualitativo ampliado", o sea: más que la provisión del número de construcciones de viviendas populares y de la calidad arquitectónica de éstas, hay que tener en cuenta necesariamente los componentes urbanísticos -estructuras públicas y privadas- en el entorno de las mismas, es decir, en el hábitat, que, al fin, responde por la calidad de vida que todo ciudadano, pobre o no, tiene derecho a disfrutar en la ciudad, hábitat que se transforma continuamente.

En un breve período de mejoría en la distribución de renta observada prácticamente en todo Brasil, reflejada en el boom de inmuebles, cuyo ápice se dio en 2008 por cuenta de varias políticas sociales, como por ejemplo el de Bolsa Família, creada por la Ley $10.836 / 2004$, la clase media se vio ampliada por los segmentos sociales más bajos emergentes. Aun así, el tejido urbano de Salvador continuó externando índices de desarrollo socioeconómico muy dispares, a depender del barrio, con situaciones de nivel de calidad de vida comparable al de los más altos de países desarrollados al lado de otras situaciones solo vistas en las regiones más pobres del mundo: "Essas realidades espelhadas, de fato refletem as contradições estruturais [...] na forma desigual segregada, precária e excludente, na construção do espaço urbano [...]' em que cerca de $60 \%$ da população habita em parcelamentos clandestinos" (GORDILHO, apud OLIVEIRA, 2013, p. 199).

Oliveira (2013, p. 199) enfatiza que aquellas contradicciones suceden "ao mesmo tempo em que cresce o mercado imobiliário formal, voltado aos segmentos de alta renda". Quien, en Buenos Aires, transite por las elegantes avenidas del barrio de Recoleta, o de Palermo, por ejemplo, y haga lo mismo en las laberínticas calles de la Villa 31/31Bis, en el barrio de Retiro, centro de la capital porteña, o incluso en el barrio de Barracas, no tendrá dificultad en comprobar la perfecta similitud que existe con relación al tipo de injusticia social que hay en el espacio urbano de Salvador.

Delante de esta situación, hay que defender un desarrollo económico con transformaciones sociales y territoriales, respaldadas en la observación de la función social de la propiedad y en el derecho a la ciudad y a la justicia urbana (MARICATO, 2012, p. 25). 
Argentina, que se ha destacado en el continente como el país que obtuvo mejores resultados de reducción de la pobreza entre 2002 y 2013 según el Banco Mundial a partir de los Indicadores de Desarrollo Mundial (IDH), basados en datos recogidos por la Encuesta Permanente de Hogares (EPH), aunque la metodología haya sido cuestionada (COHEN, CARRIZOSA y GUTMAN, 2016, p. 486-487), presenta la siguiente situación en las dos últimas décadas anteriores a ésta en cuanto: a) al déficit habitacional, b) a la variación relativa de la población, hogares y viviendas ocupadas, c) a viviendas deshabitadas; d) a la evolución de las formas de tenencia y e) a la evolución de la población con cobertura de agua y servicios sanitarios, según se puede apreciar en las Tablas $1.4,1.5,1.6,1.7$ y 1.8 respectivamente:

Tabla 1.4 - Evolución de la situación deficitaria (1991-2001-2010)

\begin{tabular}{|c|c|c|c|c|c|c|}
\hline & \multicolumn{2}{|c|}{1991} & \multicolumn{2}{|c|}{2001} & \multicolumn{2}{|c|}{2010} \\
\hline & Absoluto & $\%$ & Absoluto & $\%$ & Absoluto & $\%$ \\
\hline Total de Hogares & 8927289 & 100 & 10073625 & 100 & 12171675 & 100 \\
\hline I & 752357 & 8,4 & 560477 & 5,6 & 476894 & 3,9 \\
\hline II & 348413 & 3,9 & 346771 & 3,4 & 824010 & 6,8 \\
\hline Déficit cuantitativo & 1100770 & 12,3 & 907248 & 9,0 & 1300904 & 10,7 \\
\hline III & 1662676 & 18,6 & 1646371 & 16,3 & 1668330 & 13,7 \\
\hline IV & 569899 & 6,4 & 456238 & 4,5 & 616767 & 5,1 \\
\hline Déficit cualitativo & 2232575 & 25 & 2102609 & 20,9 & 2285097 & 18,8 \\
\hline $\mathbf{V}$ & 3333345 & 37,3 & 3009857 & 29,9 & 3586001 & 29,5 \\
\hline VI & 5593945 & 62,7 & 7063769 & 70,1 & 8585765 & 70,5 \\
\hline
\end{tabular}

Fuente: adaptado de Cohen, Carrizosa y Gutman (2016, p. 321) a partir de Censos de 1991, 2001 y 2010.

Legenda:

I - Hogares en viviendas irrecuperables ("ranchos", "casillas", locales no construidos para fines habitacionales y viviendas móviles);

II - Hogares en viviendas buenas con hacinamiento (casas "A" y departamentos);

III - Hogares en viviendas recuperables (casas "B" y piezas de inquilinato);

IV - Hogares en viviendas buenas con hacinamiento por cuarto (casas "A" y departamentos que presentan una relación superior a 2,0 personas por cuarto;

$\mathrm{V}$ - Total de hogares deficitarios;

VI - Total de hogares en viviendas aptas y sin hacinamiento. 
Tabla 1.5 - Variación relativa de la población, hogares y viviendas ocupadas (1991-20012010)

\begin{tabular}{|c|c|c|}
\hline \multirow{2}{*}{ Población } & $\begin{array}{c}\text { Variación relativa } \\
\mathbf{1 9 9 1 - 2 0 0 1}\end{array}$ & $\begin{array}{c}\text { Variación relativa } \\
\mathbf{2 0 0 1 - 2 0 1 0}\end{array}$ \\
\hline Hogares & $13,9 \%$ & $9,1 \%$ \\
\hline Viviendas ocupadas & $12,8 \%$ & $20,8 \%$ \\
\hline
\end{tabular}

Fuente: adaptado de Cohen, Carrizosa y Gutman (2016, p. 322), a partir de Censos de 1991, 2001 y 2010.

Tabla 1.6 - Viviendas deshabitadas (1991-2001-2010)

\begin{tabular}{|c|c|c|c|c|c|c|}
\hline \multirow{2}{*}{1991} & \multicolumn{2}{c|}{2001} & \multicolumn{2}{c|}{2010} \\
\hline Viviendas totales & 10062731 & $100 \%$ & 12041584 & $100 \%$ & 13812125 & $100 \%$ \\
\hline Viviendas deshabitadas & 1547290 & $15,4 \%$ & 2328923 & $19,3 \%$ & 2494618 & $18,1 \%$ \\
\hline
\end{tabular}

Fuente: adaptado de Cohen, Carrizosa y Gutman (2016, p. 325), a partir de Censos de 1991, 2001 y 2010.

Tabla 1.7 - Evolución de las formas de tenencia (1991-2001-2010)

\begin{tabular}{|c|c|c|c|c|c|c|}
\hline \multirow{2}{*}{ Censos } & \multicolumn{2}{|c|}{$\begin{array}{c}\text { Propietario de la } \\
\text { vivienda y terreno }\end{array}$} & \multicolumn{2}{c|}{ Inquilino } & \multicolumn{2}{c|}{ Otras situaciones ${ }^{*}$} \\
\cline { 2 - 7 } & Total & $\%$ & Total & $\%$ & Total & $\%$ \\
\hline 1991 & 5486831 & 61,5 & 1101575 & 12,3 & 2338883 & $26,2 \%$ \\
\hline 2001 & 7115508 & 70,6 & 1122208 & 11,1 & 1835909 & $18,2 \%$ \\
\hline 2010 & 7774540 & 68,7 & 1795906 & 15,9 & 1747061 & $15,4 \%$ \\
\hline
\end{tabular}

Fuente: adaptado de Cohen, Carrizosa y Gutman (2016, p. 326), a partir de datos de la Subsecretaría de Desarrollo Urbano y Vivienda (2010) y Censo 2010.

* Forman parte todas las situaciones de tenencia informal y la tenencia por relación de dependencia.

Tabla 1.8 - Evolución de la población atendida con red de agua y servicio sanitario (19912001-2010)

\begin{tabular}{|l|l|l|l|l|l|l|l|}
\hline \multicolumn{2}{|c|}{1991} & 2001 & 2010 & \\
\cline { 2 - 8 } & Absoluto & $\%$ & Absoluto & $\%$ & Absoluto & $\%$ \\
\hline $\begin{array}{l}\text { Total de población en hogares } \\
\text { particulares }\end{array}$ & 32245467 & 100 & 35923907 & 100 & 39672520 & 100 \\
\hline Provisión de agua & & & & & & \\
\hline $\begin{array}{l}\text { Por red pública con cañería dentro } \\
\text { o fuera de la casa, pero dentro del } \\
\text { terreno }\end{array}$ & 21335228 & 66,2 & 27672,749 & 77,0 & 32442606 & 81,8 \\
\hline $\begin{array}{l}\text { Por red pública con cañería fuera } \\
\text { del terreno }\end{array}$ & 682320 & 2,1 & 490355 & 1,4 & 335213 & 0,8 \\
\hline $\begin{array}{l}\text { Otras formas de provisión y } \\
\text { procedencia del agua }\end{array}$ & 10277869 & 31,7 & 7760803 & 21,6 & 6894701 & 17,4 \\
\hline Servicio sanitario & & & & & \\
\hline
\end{tabular}




\begin{tabular}{|l|l|l|l|l|l|l|}
\hline Descarga a red pública & 11065713 & 34,3 & 15268987 & 42,5 & 19381029 & 48,9 \\
\hline Otro servicio sanitario & 21179754 & 65,7 & 20654920 & 57,5 & 20291491 & 51.1 \\
\hline
\end{tabular}

Fuente: adaptado de Cohen, Carrizosa y Gutman (2016, p. 328), a partir de Censos de 1991, 2001 y 2010.

Por lo hasta aquí expuesto se puede ya corroborar, con relación a Brasil, con lo que dice Cravino (2014) sobre el sentido de las favelas y asentamientos populares que van cristalizándose, informalmente, en el tejido urbano de muchos centros latinoamericanos:

\begin{abstract}
Desde la perspectiva de la planificación urbana, las urbanizaciones informales eran vistas, durante muchas décadas, como fenómenos anómalos que sucedían en las ciudades por la falta de acción del Estado (sea ésta directa o indirecta como la regulación), en cierta medida, esta mirada persiste. Sin embargo, en la actualidad, en muchas ciudades de América Latina no constituyen la excepción sino la regla y el crecimiento urbano se dé fundamentalmente vía este tipo de barrios. Claramente, más que un problema de planificación, se trata de un fenómeno que responde a causas estructurales: pobreza extendida y creciente, Estados sin capacidad de cubrir la demanda de vivienda y que no regula el funcionamiento del mercado inmobiliario, en particular el del suelo y un mercado que no atiende a los sectores de menores recursos porque su rentabilidad se realiza en otros submercados. (CRAVINO, 2014, p. 243)
\end{abstract}

Esta percepción de la antropóloga argentina se vuelve de fundamental importancia para entender este estado progresivo y peligroso del modo en que vive una enorme parcela de la población de las grandes ciudades de este continente por culpa del descuido del Estado en enfrentar con determinación dicha cuestión. Su discurso se vuelve preocupante debido a que esta realidad existe desde hace más de un siglo, y cuando se depara con semejantes constataciones, como por ejemplo por parte del médico y secretario Cesario N. de A. Motta Magalhães Júnior, del Ministério dos Assuntos do Interior, del estado de São Paulo, que en su informe presentado el 28 de marzo de 1894 al entonces presidente de aquel estado -cargo que corresponde actualmente al de gobernador-, al abordar el tema sobre el refuerzo de las medidas sanitarias entonces aplicadas para combatir las epidemias de fiebre amarilla y de cólera-morbo, que aterrorizaban a todos, pobres y ricos, sobre el final del siglo XIX e inicio del siglo $\mathrm{XX}$, en todo Brasil y principalmente en las grandes ciudades, refiere:

[...] não bastava, com efeito, melhorar as condições de abastecimento de água e do serviço de esgoto, encetar a drenagem 
profunda e superficial do solo, proceder à regularização e limpeza dos terrenos baldios, retificar o curso dos rios urbanos, efetuar o asseio e limpeza das ruas e quintais, regularizar ou regulamentar as construções novas, arborizar as praças e logradouros públicos, calçar as ruas, tomar enfim todas as medidas para manter em nível elevado a higiene de uma cidade que cresce rapidamente e cuja população triplicou em dez anos; é preciso cuidar da unidade urbana da habitação, não já da habitação privada, mas daquela onde se acumula a classe pobre, a estalagem onde [se aloja] a população operária - o cortiço como vulgarmente se chamaram as casas, construções acanhadas, insalubres, repulsivas algumas, onde as forças vivas do trabalho se ajuntam em desmedida, fustigadas pela dificuldade de viver numa quase promiscuidade a que a economia Ihes impõe mas que a higiene repele. (MOTTA apud BONDUKI (2011, p. 38)

En un ámbito más general, la génesis de esta problemática está inserida en la reflexión que hacía el arquitecto argentino Wladimo Acosta en 1947, en un balance histórico sobre la relación entre habitación y ciudad, en el que señalaba al responsable por el dilema en que se encontraba la ciudad contemporánea:

[...] si, mediante un esfuerzo, nos sobreponemos por un momento a la ceguera mental a que el acostumbramiento al ambiente y a los hechos presentes nos reduce y analizamos el problema en su raíz y escala verdadera, debemos convenir en que no hay en la urbe ningún elemento no hecho por el hombre, nada capaz, por sí mismo, de escapar a su control.

En esencia, la crisis de la ciudad contemporánea es un reflejo de la crisis de la sociedad capitalista. La sociedad actual, que ha aprisionado y se sirve de las energías de la naturaleza, que ha creado la civilización maquinista, se muestra incapaz de gobernar las fuerzas y sistemas, económicos y de convivencia, que ella ha desencadenado. (ACOSTA apud GAITE, 2008, p. 24)

Preocupaciones tan antiguas como actuales, como ejemplo de propuestas aún hoy tan pertinentes como lo fueron a inicio del siglo pasado, cuando técnicos del Departamento Estadual do Trabalho proponían, de forma más pragmática, incisiva, medidas de cuño político-económico como parte de la solución del drama en el cual vivían los paulistas y toda la población brasileña en general con la llegada de las epidemias, entrando, literalmente, por la puerta de sus viviendas:

[...] fica pois bem entendido de que se não preconizarmos um radical socialismo do Estado, contudo não poderemos endossar uma certa opinião que infelizmente corre e fez adeptos, segundo a qual a função do Estado é a de mero espectador dos acontecimentos. É evidente que a iniciativa privada não pode dar uma solução à questão [...]. Sendo as casas operárias, para os capitalistas, uma questão de dinheiro como qualquer outra, qual o meio de conseguir, 
para as classes pobres, casas ao mesmo tempo higiênicas e baratas? A resposta é óbvia: ou o Estado (em nosso caso o município) assume o papel do capitalista, construindo as casas, ou proporciona empréstimo aos operários para que as construam ou concede certas regalias aos indivíduos e associações que se obrigarem a efetuar a construção de tais casas de acordo com um tipo aprovado, bem como alugá-las por preço módico, devidamente fixado (BOLETIM DO DEPARTAMENTO ESTADUAL DO TRABALHO, 1916, apud Bonduki, 2011, p. 40).

Bonduki (2011, p. 41) recuerda que hasta 1930, por cuenta de la concepción liberal vigente, era incompatible al Estado "assumir o papel de capitalista" y, así, durante toda la Primera República -1889/1930- se privilegió el incentivo apenas a los privados, una vez que, según el entendimiento de la época, en el caso de que el Estado tomara para sí el encargo de construir casas, estaría desalentando la inversión privada, conforme fue el parecer, en 1927, de una comisión creada por el intendente de São Paulo, el ingeniero y farmacéutico José Pires do Rio, cuyo parecer recomendaba la opción de incentivos a los privados.

Por lo visto aún hoy esta lógica continúa muy actual entre los gobernantes, considerando la modalidad predominante de las contrataciones de obras en las políticas públicas habitacionales, tanto en Argentina como en Brasil, así como por la extrema afinidad que parece haber entre algunas altas autoridades y representantes de constructoras importantes y poderosas, según harto material divulgado en los últimos años por los medios en general aquí y allá.

\section{2- Tierras concentradas en manos de pocos}

Siendo el suelo un factor indispensable para la producción de vivienda, muchos autores sostienen que, según la etapa del capitalismo periférico, asociado a la postura del Estado en el momento histórico que se analiza, las condiciones de apropiación de este factor reflejaron la mayor o menor capacidad de las camadas sociales más desfavorecidas para resolver sus necesidades de habitación. Históricamente, dicho capitalismo periférico, por cuestiones estructurales, no promueve la remuneración del trabajo de manera suficiente a viabilizar al trabajador la adquisición de su morada a través del mercado formal, transfiriendo esa responsabilidad al Estado, del cual, en contrapartida, espera que le facilite la reproducción del capital (WERNA et al., 2001, p. 280). 
El problema latifundista en Brasil se había vuelto más grave para las poblaciones más pobres a partir de la Ley de Tierras de 1850, cuando, desde entonces, según Raquel Rolnik (1997), sucedió la desvinculación del reconocimiento del derecho de acceso a la tierra mediante su ocupación, lo que esta autora denominó de absolutización de la propiedad, y la "monetización" de la tierra, por la cual ésta pasó a adquirir plenamente el estatuto de mercadería (ROLNIK apud GORDILHO-SOUZA, 2008, p. 39).

Antes de dicha Ley de Tierras, el entonces Estado imperial demostró interés en regular las tierras brasileñas, ya en 1842, intentando establecer las bases de donación de los lotes para el proceso de colonización por los inmigrantes extranjeros, con los cuales se esperaba resolver el problema de mano de obra para las nuevas áreas agrícolas, particularmente la del café. El Consejo de Estado se responsabilizó por tal acción, estableciendo los mecanismos de financiación del transporte, adaptación y estadía, ya que su intención era la de obstaculizar que los inmigrantes se volvieran propietarios de la tierra y que fueran los sustitutos, en las grandes propiedades, de la mano de obra esclava que en aquel período iba hacia su extinción bajo la fuerte presión y vigilancia de los ingleses.

El Consejo de Estado enfrentó varios tipos de dificultades para llegar hasta la Ley de 1850, por ejemplo debido a las concesiones que tuvo que dar a los latifundistas y otros detenedores de tierras por causa de las propuestas iniciales, presentadas por el Ministro de la Marina, Rodrigues Torres, en 1843, que fueron incorporadas en la referida Ley: la devolución al Estado de las tierras ocupadas ilegalmente y no cultivables (por las que hubieran sido cultivadas el Estado cobraría una indemnización), la revalidación, mediante cobro de pago, de las antiguas donaciones de tierras, la limitación de donaciones en zonas de frontera, el no reconocimiento de ocupación por tiempo inferior a veinte años, la obligatoriedad de registrar y medir las tierras hasta entonces ocupadas. Esta obligatoriedad de registro y medición de las tierras tenía la intención clara de facilitar, posteriormente, la aplicación del embrionario impuesto territorial, de iniciativa del político Bernardo Pereira de Vasconcelos.

Es interesante considerar que, más de un siglo y medio después, a pesar de las idas y vueltas del Estado para intentar ordenar la posesión y uso de tierras en Brasil, la mentalidad de aquella época se ve arraigada aún hoy, con artimañas semejantes de parte de quien dispone de poder para retardar, e incluso inviabilizar, cualquier intento en este sentido. Lo que, sin sombra de duda, se explicita en el 
problema estructural latifundista brasileño, ya sea en el campo, con los extensos latifundios, ya sea en los centros urbanos, con la especulación latifundista/inmueble, el cual, desde entonces y hasta hoy, está directamente relacionado al progresivo aumento del déficit habitacional de las grandes ciudades, fenómeno que, por consecuencia, es responsable del agravamiento de las difíciles condiciones de la calidad de vida de millones de brasileños sin techo, y de otros motivos como el de los "elevados padrões mínimos exigidos pelas prefeituras no parcelamento do solo urbano", señalados por Ricardo Farret (apud FERNANDES y SOUZA, 2004, p. 6263).

A mediados del siglo XIX, la aplicación de la Ley de Tierras precisó de cuatro años más para ser aplicada después de su creación porque hubo una intensa discusión sobre aspectos de la misma debido a una fuerte resistencia por parte de los contendientes de las provincias de entonces, de los detenedores de tierras públicas, de forma legal o no, a cualquier control, registro y medición de las mismas por parte del Estado, en una realidad que, hasta entonces, transcurría de acuerdo con las conveniencias de dichos detenedores, en especial de los que disponían de más poder. Así, cuando fue creado, en 1854, el órgano responsable de la aplicación de dicha Ley había sido abandonada ya la intención de permitir que los inmigrantes extranjeros pudieran acceder al loteo de tierras, aunque pequeñas, y, más aún, había sido suprimida la cobranza del impuesto territorial, así como la posibilidad de confiscar las tierras que no fueran registradas por sus propietarios, determinación que había sido sustituida por una multa. A pesar de la aceptación de las concesiones impuestas por aquellos propietarios al Estado para que la polémica Ley fuera instituida, eran comunes, en las décadas siguientes, los reclamos de gobernantes, como por ejemplo del gobernador de Minas Gerais, en 1870, con relación a las dificultades de aplicación de ésta debido a la persistente resistencia de las personas y del creciente número de ocupaciones ilegales (DEVOTO y FAUSTO, 2008, p. 70-72).

Esta situación de fuerte resistencia por parte de importantes sectores de la sociedad se hizo presente también en otros intentos, durante la década del (18)80, durante la decadencia del régimen imperial que intentó la aplicación del impuesto territorial, mirando a la cohibición de la improductividad de las tierras y así obligar al cultivo o a la venta de éstas. El Imperio se fue y la República llegó con la Ley de Tierras ya como "letra muerta", al contrario de la providencial Ley que había sido aprobada en 1879 a favor de los que poseían propiedades, que obligaba a los 
inmigrantes a "que honraran" sus compromisos cuando ingresaban en Brasil, la que establecía, en la práctica, un mecanismo de control por parte de los propietarios sobre aquellos operarios que acababan teniendo que soportar penosas condiciones de trabajo y un costo alto por la supervivencia.

Se constata hoy que, efectivamente, poco efecto surtieron en gran parte de la población brasileña los intentos mencionadas por Bonduki (2011), que tenían la intención de transformar aquella realidad a través de la difusión de la lógica de la pequeña propiedad en favor de los inmigrantes que habían sido estimulados a que vinieran a Brasil desde Europa:

[...] Defrontando-se com uma sociedade de cunho oligárquico e excludente, que desde a Lei de Terras de 1850, dificultara o acesso à propriedade da terra, essas centenas de milhares de imigrantes ainda não haviam tido a oportunidade de, num processo cumulativo ao longo das gerações, alcançar a condição de proprietários. Desse modo, havia uma verdadeira identificação entre os proprietários e os ricos, uma herança do período colonial. Para a ideologia do novo Estado que se formava, era essencial romper essa identificação e promover, sem afetar os interesses das oligarquias, o acesso do povo à propriedade. O Boletim do Ministério do Trabalho, Indústria e Comércio ao longo dos anos 30 e 40 está repleto de artigos onde se defende a difusão da pequena propriedade e da casa própria. (BONDUKI, 2011, p. 84)

Dicho contexto socioeconómico de fin de siglo XIX, entre patrones y empleados, Estado y sociedad, con sus variantes, permanece muy actual hoy en Brasil bajo varios aspectos al considerarse varios tópicos del Estatuto da Cidade, de 2011, que proclama el cumplimiento de la función social de la tierra, o, incluso, las diferentes versiones legales de la Reforma Latifundista, que viene intentando, al menos en teoría, y sin gran éxito, desmontar el gran latifundio improductivo, lo que vuelve válido, para los días republicanos de hoy, lo que dicen Devoto y Fausto (2008) sobre la creación de la polémica Ley de Tierras:

De este modo el Imperio cayó y seguía vigente la incumplida ley de 1850. En lo que a nosotros interesa, esta pequeña historia muestra los límites que tenía el poder imperial para tratar de aplicar disposiciones que, aunque apuntasen beneficiar al Estado o si se prefiere al 'bien común', o simplemente fuesen medidas de sentido común e inherentes a cualquier Estado moderno, contaban con la hostilidad de los poderosos señores de la tierra. (DEVOTO y FAUSTO, 2008, p. 72) 
En cuanto a la cuestión latifundista en Argentina, hay que tener en cuenta sus particularidades, como el régimen político republicano federal posindependencia (1810), así como las intensas rivalidades interprovinciales, como por ejemplo el de las disputas en relación al predominio en el plano administrativo por parte de las élites de Córdoba, que rivalizaban con el poderío económico de Buenos Aires, que con su puerto tenía el control de la mayor parte de las exportaciones e importaciones que se producían a nivel nacional y que, también, a su vez, sufría una fuerte competencia por el control de la centralización por parte de la estratégica provincia de Entre Ríos, ubicada en la región mesopotámica argentina contigua con Uruguay.

A pesar de las rivalidades provinciales, estas provincias tenían mayor autonomía en la conducción de sus negocios, al contrario de lo que ocurría en un Brasil centralizado de forma casi absolutista bajo el régimen imperial. Así, al lado de aquellas rivalidades, los principios capitalistas de compra y venta se fueron gestando de forma más acelerada en el contexto latifundista, a lo largo del siglo XIX, donde la enfiteusis no tenía tanta longevidad como en Brasil, con lo que Argentina mantuvo muchas semejanzas al desarrollar tan bien, en especial durante el período del dictador Rosas, y después también, la política bien conocida del "a los amigos, todo, a los enemigos, el rigor de la ley". Esta práctica generó muchas incertidumbres del punto de vista legal, aunque en aquel siglo ya hubiera sido creado un órgano estatal para la legalización y fiscalización de la propiedad de las tierras. También en aquel mismo siglo fue común la práctica del Estado argentino de lotear tierras de su propiedad para la venta, lo que no impidió la concentración de grandes extensiones en las manos de algunos pocos que ejercitaban la especulación con vistas a la obtención de un mayor lucro.

Además de la desorganización en relación con el control latifundista en Argentina durante todo el siglo XIX, un rasgo, muy diferente de lo que ocurrió en Brasil, fue la lógica de la colonización del interior del continente con la participación del inmigrante extranjero. Menos atraída por el deseo de blanqueamiento del país idea propuesta por Alberdi-, algo muy presente, también, en los objetivos de colonización brasileña, prevaleció la tesis de Sarmiento, para quien los colonos extranjeros deberían ser integrados con la condición de pequeños propietarios de la tierra, idea que fue incorporada y tomada en serio por Argentina, lo que derivó en el respeto de la propiedad por parte de estos nuevos propietarios, incluso en el turbulento período del dictador Rosas, para quien nunca está de más recordar, 
prevaleció la máxima de que "a los amigos, todo, a los enemigos, el rigor de la ley" (DEVOTO y FAUSTO, 2008, p. 73-75).

De esta forma:

\begin{abstract}
Hacia fines del siglo pasado [XIX], el alto costo de la tierra y la ausencia de créditos hicieron que los trabajadores no pudieron comprar lotes en la periferia (solo alcanzaban a adquirirlos grupos excepcionales de trabajadores medios). Pero en 1904 se abre la venta a plazos y entre 1904 y 1906 se venden unos 20.000 lotes con lo cual se van rellenando las zonas intermedias entre el Centro y Flores, Belgrano y Barracas [...] Así los inmigrantes, después de un periodo de estadía en los conventillos del Centro, se mueven hacia la periferia, donde construyen una pequeña vivienda (en general de una sola habitación) y donde el hacinamiento es evidentemente muy elevado. Estos barrios fueron en un comienzo zonas sin servicios ni pavimentos; según el censo municipal de 1909 existían en la Capital 64.605 viviendas sin cloacas sobre 46.530 que las poseían, y 59.660 casas con agua corriente contra 53.303 sin este servicio. (SUMMA, 1974, p. 15)
\end{abstract}

En el arco de situaciones similares que ocurrieron, y preponderaron, en la cuestión de habitación de las personas de más baja renta, prácticamente en el mismo período histórico, tanto en Argentina como en Brasil, está la de las epidemias que costaban inúmeras vidas, aterrorizando toda la población, inclusive a las familias adineradas. Se puede decir que, mantenidas las debidas proporciones, éste ha sido el motivo que forzó por primera vez al Estado de ambos países a intervenir a larga escala, con algún tipo de medida, en las principales ciudades, para revertir el cuadro de crisis social de la precariedad habitacional:

Pero el carácter dramático que asumió su proliferación [inmigrantes europeos que llegaron a Argentina], estuvo en el enorme grado de hacinamiento y absoluta carencia de servicios, generadoras de una insalubre promiscuidad urbana [...].

Recién a principios del siglo veinte aparecen tibias e insuficientes medidas ante la magnitud del déficit de viviendas que resultan de las corrientes de inmigrantes que se radican principalmente en la Capital Federal.

Las medidas que se toman para paliar la alarmante falta de viviendas son en gran parte el producto de temores generalizados ante los problemas de salud de la población que resultan de la citada carencia de elementales condiciones higiénicas. (GAITE, 2008, p. 1417)

Este breve paralelo de la génesis de la especulación latifundista y de la historia de la modalidad de apropiación de las tierras por parte de algunos grupos a lo largo del siglo XIX e inicios del XX, explica en gran medida las persistentes 
contradicciones sociales que aún se ven en la actualidad en ambos países. De aquí, se puede establecer un punto de partida para intentar comprender el mecanismo de formación de aquellas contradicciones que interfieren flagrantemente en la actual forma de habitar, y a partir de ese análisis, proponer acciones que intenten interrumpir este proceso, revertiendo el estado de las cosas. De esto se cuestiona:

\begin{abstract}
¿Qué conclusión se puede sacar de la comparación de las dos políticas de tierra? La primera es que la de la Argentina fue mucho más errática, producto de los sucesivos cambios de gobierno. La segunda es que, pese a que el Estado argentino era más débil, logró imponer mucho más que el brasileño el principio de regular la cuestión de la tierra y finalmente obtuvo muchos más recursos fiscales que éste. De todo ello no necesariamente hay que concluir que en conjunto la capacidad del Estado argentino fuese mayor. En realidad, lo que se busca señalar aquí es que más allá de la legislación, de los aparatos burocráticos, de las formas visibles de un Estado, la cuestión es mucho más compleja. Esa complejidad sugiere que el desorden político y el caos administrativo argentino no estaban abismalmente lejos, en sus acciones concretas, de la envidiada estabilidad y articulación del Estado imperial. (DEVOTO y FAUSTO, 2008, p. 75-76)
\end{abstract}

Para agravar el problema de morada de las personas más pobres en Argentina, ocurrió la huelga general en 1909 debido a la Ley de Residencia de autoría del Ejecutivo, por la cual todo extranjero involucrado en cuestiones de perturbaciones al orden social podría ser extraditado. Recuérdese que dos años antes ocurrió el paro de los inquilinos, los que se recusaron a pagar los alquileres debido al aumento por causa de la transferencia a los inquilinos por parte de los locatarios del aumento de impuestos establecido por el gobierno de la ciudad de Buenos Aires. Ambos hechos tuvieron un reflejo directo en las difíciles condiciones de habitabilidad de la población operaria y de bajos ingresos argentina (DEVOTO y FAUSTO, 2008, p. 165-166). En Brasil, esta camada social va a enfrentar tres décadas más tarde semejante agravamiento en las condiciones de obtenciones de una morada con la entrada en vigor de la Lei do Inquilinato, de 1942, la cual desencadenó una verdadera fuga de una extensa parcela de la población de las principales ciudades, desde los barrios centrales hacia la periferia, en busca de un techo por cuenta propia sin ningún apoyo del Estado. Bonduki (2011), a partir de investigaciones sobre la experiencia de los loteos clandestinos que sucedió en la ciudad de São Paulo en aquel período, refiere que: 
A despeito dos evidentes e conhecidos problemas que esse modelo de ocupação (ilegal, clandestina, antiurbana, insalubre, precária e contrária aos princípios da técnica urbanística) trariam para a cidade no futuro, formou-se uma espécie de conluio branco entre loteadores, compradores, Executivo, Legislativo e Judiciário para não se criar empecilhos ao livre desenvolvimento desse tipo de empreendimento. A liberdade com que se processou, durante décadas, a transformação, sem projeto nem obras, de glebas rurais em lotes teoricamente urbanos, foi decisiva para a difusão do sistema de autoempreendimento. (BONDUKI 2011, p. 286)

El autor entiende que el Estado brasileño tuvo una gran responsabilidad en direccionar la población, y en especial a los más pobres, hacia una:

[...] solução habitacional arcaica e precária, baseada na combinação de loteamentos privados especulativos com o auto-empreendimento da casa própria [...].

Ainda que esta solução não tenha sido elaborada de propósito, em termos técnicos ou políticos, não foi por acaso que surgiram condições tão propícias. A forma como o Executivo e o Legislativo (nos âmbitos municipal, estadual e federal) trataram -ou deixaram de tratar- a expansão dos loteamentos e suas condições de ocupação e comercialização, foi decisiva para a consolidação de produção no auto-empreendimento. BONDUKI (2011, p. 287)

Teniendo en cuenta los datos recolectados para esta tesis, se corrobora el pensamiento de Bonduki (2011), y se prosigue llamando la atención sobre todas las vicisitudes provenientes de aquella "solución" del problema del déficit habitacional en Brasil estimulada desde la década del (19)40 y que, de cierta forma, continúan presentes en la actualidad para nada menos que seis millones de familias que esperan obtener un techo digno y seguro en Brasil -y esta cifra considerando los índices de investigación más optimistas sobre el tema-.

En Salvador, en las primeras ocupaciones colectivas en la década del (19)40 ${ }^{9}$, cuando convenía al segmento propietario de tierras en función de su valorización por la implementación de infraestructura producida por las referidas ocupaciones, éstas eran de cierta manera toleradas por ellos y por el Estado que lo permitía libre de gravamen, en parte como mecanismo de provisión de habitación popular ${ }^{10}$. Nótese

\footnotetext{
${ }^{9}$ La primera gran ocupación informal de la cual se tiene noticia ocurrió en 1946, donde hoy está el barrio Pero Vaz, conocida como Corta-Braço, que inspiró el romance homónimo de autoría del periodista Ariovaldo Matos (1988), que acompañó el mencionado proceso de ocupación.

${ }_{10}$ En este trabajo se están usando los términos vivienda/habitación popular, vivienda/habitación precaria, vivienda/habitación de grupo de personas de bajos ingresos/baja renta, vivienda/habitación informal, como sinónimos porque son los más encontrados en la bibliografía sobre el tema, tanto en Argentina como en Brasil, no obstante en relación a este último término, vivienda/habitación informal, hay divergencias entre algunos autores, por ejemplo del arquitecto argentino Javier Castro (2010), para quien esta expresión es inadecuada, ya que este tipo de vivienda/habitación tiene forma y
} 
que durante el período militar de 1964-1985, cuando el capitalismo industrial estaba más estructurado en Brasil y aquellas conveniencias ya no se correspondían más a los intereses de los grupos dominantes hubo un recrudecimiento contrario a nuevas ocupaciones.

Como se fue preparando ya el terreno para la entrada en vigor de la lógica de "vistas gordas" que se puso en práctica en la década del (19)40 por parte del Estado brasileño en relación con los loteamientos clandestinos y ocupaciones irregulares en las periferias de las grandes ciudades, Vargas impuso el Decreto-Ley 38 en 1937, que se preocupó más de los aspectos jurídicos -registro notarial y seguridad en la posesión de la propiedad- que de los urbanísticos. De esa forma, varios aspectos básicos estructurales de un loteamiento -red de agua, cloaca, energía eléctrica, calles, transportes públicos, etc.- fueron desconsiderados por las autoridades, ya sea en la implementación como en la fiscalización, cobrando a los dueños de loteos lo que era interpretado por éstos como un salvoconducto para que actuaran libremente. Este contexto tenía sentido ya que el Estado estaba "ausente" y los patrones pagaban sueldos bajos a sus empleados, que a duras penas conseguían buscar abrigo bajo un techo de "su propiedad", el que, considerando las difíciles condiciones de sobrevivencia, era un fuerte estímulo en su imaginario como una importante conquista de seguridad. Esta lógica perduró por más de cuatro décadas, hasta que, en 1979, cerca ya del final del período militar, la legislación federal fue modificada al respecto (BONDUKI, 2011, p. 288-313).

Al inicio del período de la redemocratización, a partir de 1985, el Estado no pudo más mantenerse en defensa de los intereses del segmento privado de inmuebles, motivo por el cual hacía la vista gorda con relación a las ocupaciones de tierras por parte de personas de baja renta, pasando a asumir el discurso de su responsabilidad institucional para con aquel grupo desfavorecido y así, a partir de entonces, pasó a rever sus políticas públicas de habitación popular (GORDILHOSOUZA, 2008, p. 133). No por coincidencias históricas, y mantenidas las debidas proporciones entre lo que ocurrió en los países desarrollados y los de periferia, tiene sentido recordar lo que sucedió en la segunda mitad del siglo XIX en el París de Haussmann poco antes y durante la III República, cuando se llevó a cabo la

características específicas, evidentemente diferentes de las de la tipología "oficial", las cuales están más acordes a las normas urbanísticas establecidas. El autor refuerza su divergencia en cuanto al uso inapropiado de esta expresión por el hecho de que este tipo de vivienda/habitación es cuantitativamente predominante en diversos espacios urbanos de América Latina, motivo por el cual el referido tipo de habitación/vivienda representaría el padrón "regular" de esos espacios: de ahí su preferencia por la expresión "hábitat de la pobreza" (CASTRO, 2010, p. 108-109). 
"suburbanización/periferización" (expulsión del centro de la capital) de indigentes y operarios incómodos (migrantes y desempleados) para la burguesía. El fenómeno de "suburbanización/periferización" fue visto como un cambio de la lógica del habitar por la del hábitat (racional/funcional), según entiende Lefebvre (2001, p. 11-28).

En cuanto a la cuestión de la falta de fiscalización por parte del Estado en relación al ordenamiento urbano de la ciudad, la historia muestra que se trata de un trazo cultural, teniendo en cuenta que, mucho antes, en 1715, cuando llegó de Europa a Salvador, enviado por la Corona portuguesa, el ingeniero João Massé, especialista en arquitectura militar, para elaborar un Plan de Fortificación de la Capital de Brasil, este especialista registró su descontento en relación a la población local por su indisciplina y falta de respeto de las normas, por las ocupaciones de espacios reservados al referido Plan y también para con los gobernantes a quienes atribuyó cierta negligencia o connivencia por tales manifestaciones de los habitantes. Es un hecho, también, que ya a mediados del siglo $X X$, estudios del ingeniero civil y profesor Américo Simas (1978) basados en los diseños de lo que fuera proyectado y ejecutado y en relatos de la época, refieren "a falta de cumprimento do Plano de 1715, pela invasão e arrematação de áreas necessárias à sua execução, sem qualquer intervenção das autoridades responsáveis pela implantação do Plano" (SAMPAIO, 1999, p. 56).

En la década del (19)50, período de un nuevo ciclo de industrialización en el estado de Bahía, Salvador, capital del estado, sufre una gran presión en la ocupación espacial urbana a través principalmente del movimiento migratorio que agravó el fenómeno de la segregación socioespacial y creó una fuerte demanda por loteos de tierras populares con ocupaciones informales -verdaderas "invasiones" populares-. Esto llevó a la Intendencia a intentar contener la situación creando el Instituto do Lote Popular con el discurso de que "o problema da habitação popular não era a casa e sim o lote". El área destinada para el inicio de las actividades de este Instituto fue en la periferia norte de la Ciudad, en la Fazenda Periperi y en la Fazenda Itapoan, que se volvieron insuficientes para solucionar el problema habitacional de las clases más pobres, haciendo con que las ocupaciones ilegales de tierra continuaran en las décadas siguientes, así como la segregación espacial entre pobres y ricos (GORDILHO-SOUZA, 2008, p. 110-111) ${ }^{11}$.

${ }^{11}$ Se tenga en consideración que en este período el Estado promovió también una serie de intervenciones en diversos trechos de la ciudad estimulando no sólo la expansión de ocupaciones de la periferia por las camadas sociales más pobres sino también el surgimiento de nuevos loteos que atendían a las expectativas de las clases medias y de los emprendedores privados del sector de 
Estudios de Gordilho-Souza (2008, p. 137) indican que los loteos públicos se originaron al final de la década del (19)60 con los asentamientos de familias sin techo o que fueron removidas de ocupaciones de otras partes de la Ciudad, patrocinados por el poder público que urbanizara los loteamientos ${ }^{12}$.

Hasta hoy el tema de la ocupación del suelo para morada de la mayoría de la población de Salvador continúa siendo una pesadilla si se piensa en términos legales. Esta capital tiene uno de los más bajos índices sociodemográficos en lo que se refiere a distribución de renta y sueldo mensual de la población económicamente activa entre las capitales del País.

En el pasaje de la primera para la segunda mitad del siglo XX "mais de dois terços das novas unidades criadas entre 1950/1980 foram produzidas clandestinamente, ou seja, ao lado da produção 'normal"' (BRANDÃO, 1979, p. 252 apud SANTANA, 1994, p. 27). A este fenómeno se asocia el hecho de que con la progresiva escasez de suelo para fines habitacionales los estratos más bajos de la sociedad, compelidos hacia áreas inhabitables y periféricas de la ciudad, intensificaron el uso de hormigón para la "creación de suelo" en las nuevas construcciones, que se constituyen así en un tipo no capitalista, contradictorio al proceso impositivo de reproducción del mercado latifundista y de vivienda, que es fruto de este mismo proceso excluyente y que, al final, siendo incluso de menor costo que la construcción de planta baja, acabaron por incorporar parte de las influencias mercadológicas del sector de inmuebles -inversiones públicas en infraestructura y privadas- del lugar donde están inseridas (SANTANA, 1994, p. 3740).

Conviene señalar que en una investigación realizada en Salvador los tres principales argumentos justificados por moradores para la construcción de un nuevo pavimento sobre la planta baja han sido: la llegada de familiares $(20 \%)$, crecimiento de la familia $(17,8 \%)$ y la fuga del alquiler como contención de costos $(20 \%)$, siendo de poca importancia para los entrevistados: la proximidad del trabajo $(4,4 \%)$, los servicios ofrecidos en el lugar $(2,2 \%)$ y la intención de venta $(2,2 \%)$ (SANTANA, 1994, p. 85).

inmuebles que habían ya seleccionado el sur de la ciudad y la costa atlántica como espacios privilegiados para su confort (GORDILHO-SOUZA, 2008, p. 111).

${ }_{12}$ Los mismos estudios registran que en 1989 existía un total de 51 núcleos, correspondiendo a 322,62 ha, lo que significaba cerca del 1\% del área del Municipio, con loteos que poseían de 60 a $80 \mathrm{~m}^{2}$, abrigando cerca de 5 personas por unidad. También fue constatado que las primeras ocupaciones, ocurridas entre 1946 y 1950, fueron las más populosas y con mayor índice de densidad, entre 225 a 960 habitantes/ha, mientras que las más recientes indican 200 habitantes/ha. (GORDILHO-SOUZA, 2008, p. 137-140). 
Además de la insuficiencia de medidas institucionales por parte del Estado, para sanar el dilema de vivienda popular en los sucesivos gobiernos, hay que recordar que un marco importante para el agravamiento de esa situación, en Salvador, se encuentra en la Ley Municipal 2.181/68, la de Reforma Urbana del Municipio -que se anticipaba a la extinción de la enfiteusis en Brasil y cuya extinción ha sido impuesta por la Ley Federal 5827/72-. También debe ser mencionado que, a través de la referida Reforma, el intendente de entonces, con el discurso de que pretendía adecuar las tierras del Municipio para la abertura de grandes vías, según proponían los trabajos técnicos de EPUCS de 1948, así como la implementación de loteos y conjuntos habitacionales populares, acabó por privatizar extensas áreas del patrimonio de tierras de la ciudad, pasando éstas a manos de pocas familias involucradas con importantes constructoras locales. De todo esto resultó que a la población más pobre de la ciudad no se le solucionó sus necesidades habitacionales y el Municipio se quedó con un stock de tierras sensiblemente disminuido para administrar el problema de la habitación popular.

Este contexto agravó la cuestión del suelo en Salvador, ya que, con la privatización de las tierras públicas, que favoreció a importantes constructoras, el Municipio pasó de disponer de cerca del $70 \%$ de las tierras de la ciudad a un $30 \%$, con lo que se recrudeció la especulación del suelo en la capital, como referido en Menezes (2002, p. 16-21), Câmara (1996, p. 585), Gordilho-Souza (1990, p. 3, 118), Franco (1983, p. 105, 110-113, 115 y 156) y Mattedi (1979, p. 91-92).

La entrada en vigor del decreto de diciembre de 1968 fue definida por la socióloga Maria Brandão (1981) como el "Último dia da criação", pues significó el marco del inicio de la especulación muy estructurada del sector de inmuebles con todo el cuadro jurídico-institucional elaborado con el aval del Estado para que la iniciativa privada pasara a actuar libremente en el suelo urbano de Salvador:

Em dezembro de 1968, a aprovação, pela Câmara Municipal, da Lei 2.181/1968, abriria à aquisição particular em propriedade plena milhões de metros quadrados de terras municipais [...] Removia-se assim o mais pesado obstáculo ao mercado capitalista do solo. Faltariam ainda, como passo crucial nesse processo, as sucessivas revisões dos códigos municipais [...] e a impaciente realização de obras d'arte, capazes de permitir a remoção ou o estancamento de qualquer forma de ocupação do solo fora do alcance do 'capital' imobiliário. (BRANDÃO apud VALLADARES, 1981, p. 140) 
Con anterioridad a aquella medida privatizadora por parte del gobierno municipal, prácticamente mitad del suelo urbano de Salvador estaba en poder del capital bancario, aún en la década del (19)50, a través de la Companhia de Aliança da Bahia, empresa que promovía el financiamiento del sector de inmuebles en Rio de Janeiro y São Paulo, además de controlar en Bahía excedentes de la industria textil y del azúcar, según Pinto de Aguiar (apud SAMPAIO, 1999, p. 78). Ya posteriormente a la misma Ley Municipal 2.181/68:

Nos meados dos anos 70 , apenas quatro grandes empresas detinham 2/3 das terras nas imediações da Av. Paralela [importante avenida urbana de Salvador que une el centro con el aeropuerto y es vía de salida de la ciudad hacia el Litoral Norte y otras capitales de estado del Nordeste de Brasil]. São elas: a Odebrecht, a Góes Cohabita, a S. Leone e a OAS. (SAMPAIO, 1999, p. 242, Nota al pie de página $n^{\circ} 85$ )

Es sabido que el patrimonialismo, desde varios siglos arraigado en la formación cultural brasileña, ha prácticamente impedido la distribución de tierras, ya sea vía reforma agraria o urbana que por otro mecanismo legal. Conviene recordar el importante papel del Estado en colocar en práctica políticas del suelo y del sector de inmuebles, las que interfieren en la valorización de ambos y cuya valorización adviene, por ejemplo, por las inversiones públicas, expropiaciones e implementación de infraestructura, por lo que debería tener en cuenta la desigual correlación de fuerzas de los sujetos en disputa y sus tácticas de apropiación de los beneficios sobre el espacio (MARICATO, 2011, p. 88).

Esta interferencia del Estado también se manifiesta en la espacialidad territorial, cuando actúa en relación con las ocupaciones informales populares, ya sea promoviendo su manutención, transferencia, reubicación, erradicación, urbanización o incluso manteniéndose omiso. Estas posturas del poder público ya sucedieron en Salvador dependiendo del momento histórico y político-social de la ciudad, como ya se mencionó anteriormente (GORDILHO-SOUZA, 2008, p. 137). Este panorama de permisividad del Estado brasileño según las conveniencias políticas del momento en cuanto a la ocupación y uso del suelo por los más pobres en áreas de protección ambiental y otras inadecuadas -en cuestas y pendientes, terrenos inundables, márgenes de arroyos y de autopistas-, sin importunar a los propietarios de áreas reservadas según las prioridades del mercado, acaba por 
contribuir con la institución de "uma grande baderna" (MARICATO, 2011, p. 156-157, 182-184).

Forma parte de aquel juego de vistas gordas por parte del Estado a los intereses de segmentos de tierras/inmuebles y hasta incluso de moradores de otros estratos elevados de la sociedad, el hecho de que para determinadas áreas de la ciudad sea inaceptable la ocupación informal por parte de las clases populares que quieran allí construir sus asentamientos en contraste con determinados espacios, generalmente inhóspitos, o que no sean del interés de los segmentos más ricos de la sociedad, donde tal construcción no es combatida.

Cravino (2009) ve en este juego de fuerzas políticas y sociales que ocurre en Argentina, de forma muy parecida a lo que ocurre en Brasil, la evidencia de una cuestión social no resuelta y cuya cuestión apunta a la deuda ética del Estado para con los sin-techo, teniendo en cuenta que el Estado no está cumpliendo lo que obliga la Constitución argentina (CRAVINO, 2009a, p. 48 y 49). Tal situación merece un urgente enfrentamiento con soluciones éticas, justas y racionales por parte de toda la sociedad, tanto en Argentina como en Brasil.

Semejante postura en que el Estado actúa mancomunado con la iniciativa privada, volviéndose omiso en determinadas acciones, fuera de las normas urbanísticas, en relación con la población de baja renta, también ocurre en Buenos Aires, conforme constata Cravino (2014):

\footnotetext{
Cada forma de acción colectiva posee una historia que dirige y transforma usos del repertorio conocido y utilizado. La acción colectiva cae dentro de repertorios bien definidos y limitados que son particulares a diversos actores, objetos de acción, tiempos, lugares y circunstancias estratégicas. En este caso, cierta tolerancia por parte del Estado y la sociedad modela los límites de las prácticas de construcción de esta 'ciudad informal'. Esta tolerancia encuentra límites cuando entra en contradicción con el mercado inmobiliario formal, como es el caso de la Villa 31 y la propuesta de un megaproyecto en la zona de Retiro, o cuando pone en conflicto a la 'ciudad formal'. (CRAVINO, 2014, p. 236 y 237)
}

Esta situación dificulta el acceso al terreno urbano por parte de la población en general, y promueve una:

[...] 'produção estratégica da 'escassez' do solo' [... al establecer una] 'redefinição do controle do espaço urbano, controle esse marcado por um processo radical de 'privatização' das áreas desocupadas e pela concentração da propriedade fundiária (...) esgotam-se os vazios -terras devolutas, terras públicas, 
terrenos com donos ausentes, terrenos de posse pouco esclarecida- passados a outras mãos. Solda-se assim toda estrutura de controle privado do solo, sem deixar brechas, exceto escassas áreas ainda sob controle público, com destinação prevista. (BRANDÃO apud SANTANA, 1994, p.35) (La negrita es de SANTANA)

Así, en Brasil y resto de América Latina, a la inversa de lo que ocurre en Europa y Estados Unidos, el Imposto sobre Propriedade Territorial Urbana (IPTU), que es una de las más importantes herramientas fiscales de captación de recursos para el financiamiento de las ciudades, ha sido doblemente desvirtuado como instrumento fiscal de justicia: es de consenso en prácticamente todas las clases sociales la visión distorsionada del derecho de que uno pueda apropiarse privadamente de los beneficios de la valorización del suelo y de los inmuebles a través de sus propiedades aunque dicha valorización provenga exclusivamente de inversiones públicas. Esto pesa sobre la sociedad como un todo, ya que los datos comprueban que, en muchos casos, el alto costo de morada se dé más por cuenta de dicha valorización de la tierra que por la producción de construcción, según afirma el ingeniero Nilton Vargas (1999) (MARICATO, 2011, p. 85-91).

A este análisis sobre la escasez de disponibilidad de suelo urbano que interfiere directamente en la viabilidad de la producción de viviendas para la población de bajos ingresos se agregue que: "Se calcula que en la mayoría de las ciudades occidentales el $20 \%$ del suelo está desocupado e infrautilizado, y a menudo es debido a la contaminación” (EDWARDS, 2009, p. 139).

En este juego de intereses y conveniencias, de acciones estratégicas y puntuales, el paisaje urbano de Salvador fue moldándose en:

[...] um espaço urbano multifacetado que traz as marcas dos tempos históricos e sua organização intra-urbana - da Colônia ao Império e à República- cuja singularidade do sítio não esconde a segregação dos territórios: dos ricos, dos pobres e dos 'arremediados' [... una expresión local identificada con la 'clase media' baja, no necesariamente de asalariados]. Nisto, Salvador não se distingue radicalmente das cidades grandes brasileiras; seu traço diferencial continuará sendo dado pelas peculiaridades do sítio geográfico e menos pela configuração sócio-espacial [...] Das práticas assentadas nas 'atividades capitalistas especulativas' emergirá a cidade moderna, fragmentada, numa ação combinada entre segregação espacial e especulação imobiliária. Eis aí parte da chave do entendimento da lógica dos movimentos que determinarão a nova forma-urbana na etapa seguinte: a da industrialização moderna propriamente dita, alavancada pelo Estado. (SAMPAIO, 1999, p. 100) 
Es interesante observar que, en general, el Estado usa como 'discurso legitimador" y como "discurso competente" la forma-urbana en los mensajes contenidos en sus propagandas en relación a las grandes intervenciones en espacios públicos provenientes del "planeamiento científico", enfatizando el embellecimiento y la modernización de estos espacios como evidencias del progreso material impuesto que no siempre se condice con las reales necesidades y aspiraciones de la mayoría, con la intención de aplacar contradicciones entre los agentes sociales (grosso modo de parte de los excluidos versus los de mayor poder de persuasión y los gobernantes) con la intención de apropiarse de ventajas ya calculadas de las referidas intervenciones promovidas por el "liberalismo estatal" mancomunado con la iniciativa privada (SAMPAIO, 1999, p. 125-138, 149-154; 2009; 2010, p. 70-71, 109-114) $)^{13}$.

Así ha sido en Salvador durante el siglo pasado que, como ocurrió en el resto de Brasil, experimentó intervenciones urbanas pragmáticas, calcadas en un "liberalismo estatal" industrialista del pos-1950, con influencias directas en el sector comercial y de servicios en los grandes centros urbanos, lo que impulsó más aún la especulación del sector de inmuebles que, en esta capital, se evidenció entre 1960 y 1980 por tres componentes:

1) retenção do solo como 'reserva de valor' para investimentos futuros, tornando mais rígida a oferta (inelástica);

2) apropriação dos investimentos feitos pelo poder público em infraestrutura [sic] viária nas áreas de expansão, ou já urbanizadas, incorporando a valorização resultante;

3) interferência na mudança dos parâmetros urbanísticos e, por meio de 'informações privilegiadas', antecipando-se na aquisição de áreas passiveis de valorização. (SAMPAIO, 1999, p. 124)

La especulación del sector de inmuebles en Salvador se exacerbó como consecuencia de las políticas neoliberales implementadas en Brasil principalmente en la década de los (19)90 y en la siguiente, teniendo en cuenta que el referido sector viene siendo favorecido por aquellas políticas desde después de la crisis de la “década perdida”, la del (19)80.

\footnotetext{
${ }^{13}$ Términos entre comillas según figuran en Sampaio (2009); en cuanto al término "liberalismo estatal" se refiere al que fuera importado del período de la Gran Depresión (1929) y posteriormente de la posSegunda Guerra Mundial, de inspiración Keynesiana, en que el Estado Proveedor debería ser el propulsor del Bienestar Social. En Brasil, la inspiración permaneció sólo en el discurso y casi siempre ha sido adaptada a los intereses de la iniciativa privada, esto es, de los grandes capitalistas financieros e industriales, principalmente locales, además de los extranjeros.
} 
Con la reestructuración del Sistema Financeiro Habitacional (SFH) el financiamiento habitacional fue favorecido con la creación de los Fundos de Investimentos Imobiliários (FII), a partir de la Ley № 8.668 de 1993, cuyos fondos estaban formados por recursos captados a través del Sistema de Distribución de Valores Mobiliarios que, transformados en cuotas, eran pasibles de comercialización, como títulos -debentures ${ }^{14}$ - en las Bolsas de Valores y fiscalizados por la Comissão de Valores Mobiliários (CVM).

A partir de 2007, dos años antes del lanzamiento del megaproyecto PMCMV por el Gobierno Federal brasileño, las constructoras pasaron a participar de estas operaciones de los FII, consolidando la lógica de fortalecimiento de los logros e intereses de los agentes del sector de inmuebles. Al lado de los FIl, entre otras importantes medidas, una de las que también incentivó los negocios de los inversionistas de inmuebles -empresas de incorporación y constructoras, principalmente- ha sido la decisión del gobierno de desvincular la exclusiva intermediación bancaria cuando se trata de la captación de recursos en el mercado por inversionistas a través de la inclusión de la alienación fiduciaria, cambio que buscaba estimular el mercado de inmuebles con el fin de favorecer el segmento de clase media y dar más seguridad a los emprendimientos, protegiendo, por lo tanto, el capital, lo que se consolidó con la creación del Sistema de Financiamento Imobiliário (SFI), a través de la Ley № 9.514 del 20 de noviembre de 1997. Con base en esta Ley se establece el instrumento jurídico del patrimonio de "afectación", que, resumidamente, consiste en vincular el patrimonio de la empresa que incorpora/construye el inmueble como garantía de solvencia del emprendimiento (OLIVEIRA, 2013, p. 182-184; AZEVEDO apud FERNANDES y SOUZA, 2004, p. 104-105). Lamentablemente los segmentos sociales populares, que continúan, aún, careciendo de financiación para VIS, no han sido beneficiados proporcionalmente en la misma medida que las clases medias y altas.

Fue muy importante también la promulgación del Estatuto da Cidade, de $2001^{15}$, la aplicación en Salvador del instrumento urbanístico relativo a la Concessão de Uso Especial para fins de Moradia, fundamentado en la Ley Municipal № 6.099/2002, en consonancia con el Estatuto, a partir del que se pasó a conceder título de regularidad territorial de forma colectiva, directamente por el Ejecutivo, lo

\footnotetext{
${ }^{14}$ En portugués proviene del inglés, como aquí referido, mientras que, en español, obligaciones, proviene de la palabra francesa obligation.

${ }^{15}$ Ley No 10.257 promulgada el 10 de julio de 2001.
} 
que, en parte, facilitó la situación de regularización de los loteos ocupados informalmente en áreas de propiedad del Municipio, una vez que, antes de aquella Ley, el trámite jurídico-burocrático era individualizado, a través del instrumento de Concessão de Direito Real de Uso, y demandaba permiso del poder Legislativo (GORDILHO-SOUZA, 2008, p. 424) ${ }^{16}$.

En Brasil, el Estatuto da Cidade posee tres dispositivos que pueden ser considerados muy importantes para que haya más agilidad y se favorezca el Poder Público municipal durante la expropiación del inmueble (lote de tierra): el de la Transferência do Direito de Construir (TRANSCON) a través del cual el Poder Público "ofrece" al propietario un área equivalente en otra parte de la ciudad. Esto se aplica básicamente en tres situaciones: necesidad de implementación de estructuras públicas o comunitarias, regularización de suelo para VIS, o cuando el área o edificio sea considerado de importancia histórica. El segundo dispositivo es el de la Desapropriação com Pagamento em Títulos da Dívida Pública; en cuanto a éste, los propietarios lo evitan o rechazan debido a la demora para que se comercialicen en el mercado los mencionados Títulos, así como debido a su baja cotización en el mercado. El tercer dispositivo es el del Direito de Preempção, el que da la preferencia de compra al gobierno. Sin embargo, es común que la burocracia, por cuenta de los pleitos judiciales planteados casi siempre por los propietarios de los inmuebles/lotes de tierra, haga demorar mucho tiempo (años) para que se aplique de hecho la expropiación. Otra situación común que se presenta para dificultar la expropiación es cuando la Promotoría Pública no se pone de acuerdo con las condiciones de la expropiación presentadas por el Poder Ejecutivo Municipal.

En Argentina la cuestión de la expropiación es regida por la Ley 21.499 de Expropiación de 1977, que enfatiza la fundamentación de la expropiación a través de la utilidad pública, es decir, que la utilidad del bien común sea de naturaleza material o espiritual. Por esta Ley existe la prerrogativa para que actúen como expropiante el Estado Nacional, la Municipalidad de la Ciudad de Buenos Aires, las entidades autárquicas nacionales y las empresas del Estado Nacional desde que estén habilitadas legalmente por sus leyes orgánicas o por leyes especiales. Está incluso permitido por aquella Ley que personas particulares puedan actuar como

\footnotetext{
${ }^{16}$ A partir del nuevo procedimiento fueron emitidos en Salvador entre 2003 y 2004 cerca de 50 mil títulos de regularización de fondos de áreas de propiedad del Municipio, ocupadas por población de baja renta (GORDILHO-SOUZA, 2008, p. 439, Nota al pie de página $\mathrm{n}^{\circ} 15$ ).
} 
expropiante de un bien desde que estén autorizadas por ley o por acto administrativo generado por ley.

Hay que resaltar que esta Ley de Expropiación abarca todo tipo de objeto que sea pasible de atender a las necesidades de utilidad pública, siendo de régimen privado o público, de consistencia material o no, en la mayor parte de sus setenta y cuatro artículos se refiere a casos de inmuebles -edificios 0 construcciones-.

En esta Ley de Expropiación no entrarán en el cómputo para definición del valor del bien a ser pagado por el expropiante los arreglos ejecutados en el inmueble a partir de la fecha de notificación del trámite de expropiación, excepto los reparos que sean hagan necesarios al inmueble, así como no entrarán en el cómputo expectativas personales como valor afectivo, lucros futuros presumidos, valorizaciones del inmueble por cuenta de obras que puedan estar previstas, ni lucro cesante. Una parcela que es pasible de ser incorporada al valor del bien a ser expropiado es la que se refiere a la corrección monetaria del valor estipulado y que será pagada a posteriori a dicha expropiación. La misma Ley de Expropiación establece que el valor del inmueble a ser pagado debe estar refrendado por el Tribunal de Tasaciones de la Nación, el que lo indicará al juez dentro de 90 días cuando requerido por éste hubiera divergencias entre las partes involucradas en la expropiación. La indemnización deberá ser pagada en dinero efectivo, salvo acuerdo en contrario con el expropiado, y sobre dicho valor no se aplicará tasa fiscal o impuesto alguno, y si el pago fuera hecho en cuotas se aplicará una tasa del $6 \%$ anuo.

Un aspecto muy importante de esta Ley es el que establece como control del valor a ser pagado por el inmueble expropiado el límite máximo del 10\% sobre el mismo (ARGENTINA, 1977) cuando el inmueble posea características que justifiquen el aumento del valor inicialmente estimado. Una diferencia que se percibe con relación a Brasil es que los municipios argentinos no tienen un papel preponderante en los trámites de expropiación, al menos no como sucede en los municipios brasileños. Además de la expropiación existen en Brasil los convenios urbanísticos que son aplicados mediante lo que establezcan los códigos y normas de cada municipio (LINCOLN INSTITUTE OF LAND POLICY, 2009).

Pese a la universalidad de las leyes, es sabido que éstas son aplicadas con mayor rigor cuando se trata de un ciudadano común que cuando se trata de un 
importante propietario de inmuebles que tenga algún vínculo con el grupo político de turno. Asociado a esta práctica enraizada en ambos países y en buena parte de América Latina, sucede que, en la estipulación del valor mencionado, es común tomar como referencia el valor constante en los datos catastrales públicos que, excepciones aparte, generalmente está por debajo del valor de mercado. Lo opuesto también es común cuando se trata de alguien importante con determinados contactos con el poder político que, estimulado por el espíritu patrimonialista y clientelista, el Estado acaba pagando valores superiores a lo que el mercado sugiere, práctica poco republicana. Los medios en general han divulgado hartamente este tipo de situación, tanto en Brasil como en Argentina (LINCOLN INSTITUTE OF LAND POLICY, 2009).

Según datos de la intendencia de Salvador, a inicio de la primera década de este siglo, la ciudad poseía una carencia de cerca de 100 mil habitaciones desde el punto de vista cuantitativo, y de más de 400 mil habitaciones existentes desde el punto de vista cualitativo, con algún tipo de problema constructivo en relación con la legislación edilicia. Históricamente esta realidad explica, también, por qué Salvador se mantiene, desde hace décadas, como una de las más críticas capitales brasileñas en varios índices sociodemográficos: tasa de analfabetismo, tasa de natalidad, desempleo, media salarial, entre otros. En este contexto se puede comprender por qué cerca del $60 \%$ de la población adquiere sus habitaciones por autoconstrucción y el $70 \%$ de la población total vive en condiciones precarias, utilizando cerca del $32 \%$ del área de esta capital, según constata Funke (2005, p. 3).

Con relación a la demanda de tierras en Salvador, está muy restricta ya que sólo cuenta con cerca del $15 \%$ del total del área de la ciudad aún sin construcción, y esto considerándose también las áreas de reservas ambientales. Esto se vuelve más preocupante en el centro urbano, donde una gran extensión del parque inmobiliario está compuesto por edificios abandonados o de lotes por los que hay alguna pelea judicial o con alguna construcción antigua y en ruinas, sin uso alguno. Los únicos espacios disponibles para eventuales VIS o pasibles de ser comercializados para habitación tanto en zonas valorizadas como desvalorizadas se encuentran a una distancia de aproximadamente $10 \mathrm{~km}$ del centro urbano histórico de Salvador.

El problema del monopolio de la tierra es muy importante y últimamente debido a la escasez y a un mayor reclamo por parte de los sin-techo los conflictos están agravándose, sea en el campo que en las grandes ciudades. En Brasil, 
después de la creación del Estatuto da Cidade (Ley № 10.257 de 10/07/2001), y de la creación del Ministério das Cidades (2003), están habiendo algunos avances en cuanto a este tema, sin embargo, los movimientos de los Sem-Terra y de los SemTeto reclaman que los cambios en esta cuestión están muy lentos y así promueven ocupaciones de tierras en secuencia, sea en el campo que en las áreas suburbanas. Estudiosos e investigadores brasileños del tema afirman que la cultura colonialista basada en el clientelismo, personalismo, autoritarismo, nepotismo, carismatismo, tan conocida y arraigada en la cultura brasileña y demás culturas latinoamericanas tiende a retardar los avances que el Estatuto pretende dar a los brasileños. Es evidente que gran parte de las élites latifundistas y terratenientes no quieren que la esencia de la propiedad privada de la tierra, bien tan raro y que no se reproduce, esté sometida al principio del uso social y colectivo. Las actuales peleas en el ámbito judicial están confrontándose con este embate que el Estatuto da Cidade trajo para bien de la ciudadanía al afirmar que el derecho privado es secundario en relación con el derecho del social y colectivo.

Recientemente, en el ámbito territorial brasileño, la Ley 11.977/09, originada a través de la Medida Provisoria 459, trajo importantes avances en lo que se refiere a simplificar y acelerar el trámite notarial y de regularización de tierras y con bajo costo para los sectores de más bajos ingresos (MARICATO, 2012, p. 68). Lo que se vuelve preocupante es que en los treinta años de vigencia del Estatuto da Terra (1964-1994), creado a inicios de la dictadura militar en Brasil para resolver el problema de la reforma del suelo agrario, fueron asentadas solamente poco más de 350 mil familias, lo que corresponde a una media anual de 11,7 mil familias. A pesar de que esté lejos de solucionar el mencionado problema, sirve de consuelo saber que el índice subió a 83 mil familias por año en el período de 1995 a 2001, según Devoto y Fausto (2008, p. 465).

En Argentina, con la política de viviendas y lotes populares desarrolladas por el gobierno peronista entre 1946 y 1955 y con la sanción de la Ley de Propiedad Horizontal, la tasa de inquilinos que en la década del (19)40 era del 60\% decreció actualmente al $30 \%$, donde cerca del $70 \%$ de la población es considerada propietaria de sus moradas a pesar de que datos del Sistema de Información Monitoreo y Evaluación de Programas Sociales (SIEMPRO) registren en 1997 una tasa del $17 \%$ de posesión irregular en relación con la morada, involucrando diversas situaciones como: ocupante por préstamo, ocupante de hecho, ocupante solamente del inmueble construido, vivienda desvinculada del lote, entre otros. 
Desafortunadamente los números indican que el problema de morada en los 24 partidos del Gran Buenos Aires que rodean la CABA se ha agravado: la población total creció cerca del $35 \%$ entre 1981 y 2006 , y la población de las villas y asentamientos populares aumentó cerca del 220\% CRAVINO (2009b, p. 89, 105109).

Entre las décadas del (19)40 y (19)50, debido a la falta de trabajo en las provincias, gran parte de la población del interior de Argentina migró para los grandes centros urbanos haciendo fuerte presión por demandas sociales ya existentes, lo que, dadas las circunstancias políticas y económicas, posibilitó, en 1949, la incorporación en la Constitución Federal vigente, entre los derechos sociales, del derecho a la vivienda. Con la suspensión de la referida Constitución, la Convención Constituyente de 1957, volvió a incorporar aquel derecho con base en el "acceso a una vivienda digna" (GAITE, 2008, p. 17-19).

La Ley Federal de Propiedad Horizontal № 13.512 sancionada el 30 de setiembre de 1948 interfirió en la realidad y el paisaje urbano al volverse un marco legal para las construcciones en altura en Argentina, como por ejemplo sucedió en la capital y área metropolitana de Mendoza a partir de la década del (19)50, cuando hasta entonces la tipología urbana era más uniforme, sin superar los $12 \mathrm{~m}$ de altura (BALTER, p. 48).

A inicios del siglo pasado importantes estudiosos de las cuestiones sociales entre ellos muchos de los pioneros de la Arquitectura Moderna- defendían la tesis de que con el avance de las ciencias y la tecnología en general la tendencia sería la de sustituir el trabajo más arduo y las fábricas por los centros de conocimiento (GAITE, 2008, p. 106), y que de esta manera habría más tiempo disponible para el confort y recreo de la Humanidad. En los últimos años el sociólogo Domenico De Masi (2001) actualizó aquella tesis a través del su ya clásico Ócio criativo; infelizmente la gran mayoría de los sectores de más bajos ingresos, por aspectos de su idiosincrasia cotidiana, no alcanzaron esta utopía. Siguiendo esta línea de pensamiento, lo que se ve es una persistente desvalorización cultural del trabajo físico por parte de los intelectuales y un selectivo y pequeño grupo de personas, lo que favoreció aún más la segregación en bolsas de pobreza de la mayoría, sobre todo de los operarios de la construcción -albañiles, carpinteros, ayudantes- los sirvientes. Hasta ahora, los esfuerzos de los intelectuales no fueron suficientes para revertir esta lamentable situación (GAITE, 2008, p. 106-107). Este fenómeno ha sido registrado por Sérgio Buarque de Holanda (2006) en su clásico Raízes do Brasil: 
[...] tenta entender não só os principais elementos formadores do Brasil, como sua herança no Brasil dos anos 1930, em um momento potencial de mudanças, com 'uma população em vias de organizarse politicamente' [...] Imbuído de um ferramental teórico oriundo de diferentes correntes, nesta tarefa procura caracterizar as raízes mentais daqueles que colonizaram estas terras, que teria sido obra de 'aventureiros', em busca da 'riqueza que custa ousadia, não trabalho' [...], os únicos capazes de empreender a tarefa, em contraposição aos 'trabalhadores' [...] Não se trata apenas de uma característica do português, mas uma matriz própria dos povos ibéricos, que, ao contrário dos seus vizinhos europeus, buscam uma vida baseada na invencível repulsa que sempre Ihes inspirou toda moral fundada no culto ao trabalho' [...] própria da herança ibérica [...]. (HOLANDA apud MEDRANO in GOMES, 2009, p. 265)

Mucho antes de Holanda, el misionero católico André João Antonil (16491716), que viniera con el padre Antônio Vieira a Brasil en 1681 y se quedara hasta su muerte en 1716, ya había también percibido esta aversión de los colonos portugueses a las actividades laborales físicas, a tal punto que Antonil afirmó algo como que a éstos "sólo les gustaba ser servidos".

A inicios de la segunda mitad del siglo pasado, asociado al discurso de la importancia del problema de la adquisición de vivienda, crece la preocupación por distribuir racionalmente la población en todo el territorio argentino. Con relación a este discurso surge, en 1952, la Ley $N^{\circ} 14.184$, en cuyo capítulo VII, destinado a la vivienda, define como prioritaria la función social de la misma, y se hace mención, por primera vez, de la necesidad de la "distribución geográfica racional de la población". De esta problemática, adviene, en 1965, la aprobación de la Ley № 16.765, la cual crea la Secretaría de Estado de Vivienda, responsable por la planificación a escala nacional en ámbito urbano y rural, seguida de la Ley nacional que, en 1967, a partir de la Ordenanza de 1961, establece la Comisión Municipal de la Vivienda (CMV), primer órgano técnico estatal con el objetivo de resolver los problemas de desequilibrio habitacional en CABA y adyacencias. Luego surge la Ley № 19.929 que instituyó, en 1972, el primer Fondo Nacional de la Vivienda (FONAVI), reformado en 1976 por la Ley FONAVI No 21.581 (GAITE, 2008, p. 20, 25, 29).

En la década del (19)60 el General Onganía estableció, en 1966, el Programa de Erradicación de Villas de Emergencia (PEVE), dejando de reconocer las instituciones representativas de estas comunidades, lo que produjo la desestabilización de la Federación de Villas y Barrios Marginados de la Ciudad de Buenos Aires (FEDEVI), inviabilizando la actuación de ésta como interlocutora en el 
ámbito de las negociaciones con el Estado. Con el enflaquecimiento de la influencia de la FEDEVI, las comunidades contaron con el apoyo del Sindicato Único de Portuarios Argentinos (SUPA), del Movimiento de Sacerdotes para el Tercer Mundo y de la Confederación General del Trabajo de los Argentinos (CGT) como interlocutores. Cravino (2014) señala que desde 1970 las comunidades reclaman por mejorías en el lugar donde están radicadas y que aún hoy carias de ellas sostienen que no son contrarias a ser removidas para otro lugar desde que sea dentro de la ciudad y las viviendas sean construidas antes de la mudanza. La autora llama la atención sobre esta estrategia de "concordancia" de los moradores con esta política estatal de erradicación, considerando que en las políticas subsecuentes a aquellas iniciadas por PEVE erradicación significaba dirigirse para áreas de la periferia del Gran Buenos Aires, o sea, no dentro de la ciudad (CRAVINO, 2014, p. 84). Se puede concluir que esta estrategia de las comunidades de las villas les da margen a maniobras de negociación en sus reivindicaciones con el Estado.

En Argentina, a partir de la década del (19)80, una conjunción de factores nuevos y antiguos promovió un recrudecimiento en la capacidad de adquirir un techo, cerrándose en la década del (19)70 un ciclo de facilidad de obtención del suelo que se había iniciado en los años (19)40 y que favorecía a los sectores de más bajos ingresos de la sociedad. Entre estos factores están: la sanción del Decreto-Ley de 1977 que colocó en práctica una serie de restricciones en el ordenamiento y uso del suelo en el territorio de la provincia de Buenos Aires, el surgimiento en 1977 del Código de Planeamiento Urbano (CPU) de la CABA -que impulsaba la construcción de autopistas y liberaba el precio de los alquileres-, la desindustrialización, y, por fin, la caída del valor de los presupuestos sociales. La sumatoria de estos factores obligó a los sectores populares a solucionar la necesidad de morada a través de la urbanización informal. Así, en la década del (19)80 se inaugura una "nueva" manera informal de vivir, la del asentamiento, que fue visto también como una forma de contornear el estigma peyorativo que sufrían en las villas, y que, tanto para éstos como para el Estado, representaba una medida provisoria, premisa que los años confirmaron tratarse de un equívoco, dada la fuerza con que proliferó esa "nueva" modalidad de vivir. Aparece también en este período el fenómeno a gran escala de las ocupaciones de casas y fábricas por parte quienes no renuncian a vivir en el centro de la ciudad (CRAVINO, 2014, p. 238).

Cravino (2014) entiende que, básicamente, existen dos formas de expansión de las urbanizaciones informales tanto en el Gran Buenos Aires como en la CABA: 
por el surgimiento de nuevos asentamientos en las áreas periféricas, generalmente de forma no mercantilizada, preponderante en el Gran Buenos Aires, y por la ocupación del suelo o viviendas en barrios ya consolidados a través de la mercantilización, fenómeno observable con mayor intensidad en la CABA. A pesar de haber a una mayor oferta de tierras desocupadas en el Gran Buenos Aires, en los últimos años se dieron dos factores que han interferido en dicha oferta, así como en los valores de las mismas, tanto en el mercado formal como en el informal: en primer lugar el aprovechamiento de esas tierras para la construcción de condominios y "barrios cerrados", inclusive en áreas inundables que hasta entonces no servían para la construcción, pero que debido las nuevas tecnologías de "recuperación" se volvieron aprovechables; en segundo lugar los programas de vivienda, como por ejemplo el del gobierno Federal, que ha absorbido grandes extensiones de tierras, lo que ha contribuido al aumento de precios en el área Metropolitana de Buenos Aires. En cuanto a la CABA, las tierras "desocupadas" han sido más vigiladas por el Estado, por el Poder Judicial y por el Ejecutivo, que ha promovido acciones represivas para inhibir la ocupación en masa; motivo por el cual se ha han comenzado a hacer las ocupaciones en grupos menores y de forma dispersa, con la intención de sustraerse a tal vigilancia, como por ejemplo las ocupaciones realizadas al margen de las vías ferroviarias (CRAVINO, 2014, p. 239). Una situación muy semejante sucede en Salvador y en el resto de Brasil.

Las ocupaciones de tierras en la mayoría de los países en desarrollo se dan básicamente de dos maneras: masiva o gradual, siendo la primera más común en América Latina y la segunda en África y Asia. A pesar de que las de masa sean más raras, se ven más en situaciones políticas específicas, como por ejemplo cuando el gobierno se encuentra débil para promover una expulsión o necesita de apoyo político -como en épocas de elecciones-, tal como ocurrió en Buenos Aires en 1981 con la crisis del gobierno militar (WERNA, 2001, p. 58), o, por ejemplo, como sucedió en Salvador y el resto de Brasil a partir de la redemocratización del país a mediados de esa misma década.

Es cierto que con la regularización de la tierra e inmuebles construidos el morador se siente mejor psicológicamente, reconocido socialmente, y en mejores condiciones de usufructuar de financiamientos legales presentes en el mercado, así como poseedor de una garantía de seguridad con relación a los herederos, sin embargo, para otros, la regularización del lote significa estar al alcance del Estado para ser tributado (CRAVINO, 2009b, p. 208-211, 216). Por otro lado, en un 
ambiente desventajoso, como es América Latina, donde la solución de vivienda para los sectores de más bajos ingresos se da de forma brutal, con todo tipo de gravamen sobre la responsabilidad y los riesgos, la regularización de la posesión informal, ya sea del lote como de la vivienda, es importante para la inclusión en el mercado, y de consecuencia, de la mejoría de la calidad de vida de los que no consiguen salir de la pobreza, algo con lo que, según Hernando De Soto (apud MARICATO, 2009b, p. 39 ), se tendería a reducir o a erradicar dicha pobreza, aunque otros autores no comparten esta idea, como por ejemplo Edesio Fernandes (apud MARICATO, 2009b, p. 40), para quien este trámite de titulación del lote no resolvería necesariamente los obstáculos para la inclusión de estos grupos en el mercado formal urbano.

Según datos del Ministério das Cidades, de 2004:

Entre 1995 e 1999, 70\% da produção de moradia no Brasil estavam fora do mercado formal, pois do total de 4,4 milhões de unidade[s] empreendidas apenas 700 mil foram promovidas pela iniciativa pública e de empresas privadas, sendo o restante produto da iniciativa da própria população. (OLIVEIRA, 2013, p. 173, Nota al pie de página $n^{\circ} 106$ )

Teniendo en cuenta la realidad de Salvador, donde la mayoría de las construcciones populares poseen algún tipo de irregularidad en cuanto a la formalización del lote, la Prefectura Municipal emitió hasta julio de 2016 más de 25 mil títulos de posesión de los 30 mil estipulados para el período de 2013-2016 a través del Programa Municipal de Regularização Fundiária Casa Legal, habiendo beneficiado a más del $80 \%$ de las familias previstas por el programa. El objetivo del programa es promover el acceso legal a la posesión y uso del lote, así como asegurar el derecho a la habitación y al ejercicio de la ciudadanía de los ocupantes.

Para obtener la regularización del lote es necesario cumplir los siguientes criterios:

- Que el lote esté ubicado en área urbana perteneciente al Municipio;

- Que la ocupación sea en un área de terreno de hasta $250 \mathrm{~m}^{2}$;

- Que la utilización del lote sea para fines de morada del poseedor o de su familia;

- No ser propietario o concesionario de otro lote urbano o rural;

- No haber sido ya beneficiado por el programa de regularización de tierras; 
- Poseer un ingreso familiar de hasta seis Salarios Mínimos (SM).

Tanto el trámite de regularización del lote como el de su registro ante el Cartório de Imóveis que sucede a través del Registro de Imóveis de Interesse Social, Ley Federal No 11.481/2004, no tiene costo para el morador. El Programa Casa Legal tiene por objetivo que el morador pase a tener asegurado el derecho a la posesión y también pueda:

- Registrar la construcción de su habitación;

- Acceder a préstamos para mejorías habitacionales;

- Transferir legalmente el lote por venta, con la anuencia de la Prefectura, desde que cumplidos los criterios de participación del programa;

- Transferir legalmente el lote por herencia ${ }^{17}$.

1.3 - Un primer abordaje sobre la legislación edilicia

En Salvador las primeras medidas de regulación de ocupación urbana y parcelación de lotes ocurrieron entre 1920 y 1926, con los respectivos Códigos de Posturas Municipales de aquellos años, del que derivó el primer registro de loteo en la Prefectura en 1925, marco de la privatización oficial del suelo urbano parcelado en lotes, estructurado bajo la concepción del ideario urbanístico moderno, con énfasis en el "plan zonal de funciones", que, a su vez, también sirvió de base al Escritório de Planejamento e Urbanismo da Cidade do Salvador (EPUCS), que originó el Código de Urbanismo de 1948 (GORDILHO-SOUZA, 2008, p. 18, 98-103) ${ }^{18}$.

\footnotetext{
${ }^{17}$ Todas las informaciones referentes al Programa Municipal de Regularização Fundiária Casa Legal fueron dadas por la urbanista Renée Buzahr, Coordinadora de Regularização Fundiária do Município de Salvador, de la Secretaria Municipal de Infraestrutura e Defesa Civil (SINDEC).

${ }^{18}$ EPUCS fue establecido a partir del 1 de enero de 1943, extendiéndose hasta marzo de 1947, mediante contrato entre la Prefeitura de Salvador y el ing. Mário Leal Ferreira, con el objetivo de hacerse un amplio estudio de la espacialidad urbana de la ciudad y ofrecer soluciones para que se realizara una extensa intervención en ese sentido, una vez que Salvador pasaba por una gran expansión en su ocupación territorial, de la que derivaban diversos problemas en aquel momento (GORDILHO-SOUZA, 2008, p. 163, Nota al pie de página $n^{\circ} 32$ ). El referido primer registro de loteo privado de tierras en Salvador, el Vila Bomfim, de 1931, fue realizado en Itapagipe, área destinada a la implantación de industrias y de conjuntos habitacionales para los operarios, por la Companhia Comércio Imóveis e Construção, compuesto por 123 lotes de $200 \mathrm{~m}^{2}$ en un área de $42.391 \mathrm{~m}^{2}$. En la costa atlántica, vector preservado para los sectores sociales adinerados, fue proyectado otro loteamiento privado a pedido de Manoel Dias da Silva en las tierras de su hacienda, en el barrio de Pituba, por el ingeniero Theodoro Sampaio, en 1919, loteo Cidade da Luz, bajo principios de ciudades-jardines que tuvo su registro autorizado en julio de 1932, volviéndose marco para sucesivos emprendimientos de este tipo en aquel período (GORDILHO-SOUZA, 2008, p. 101). Con relación al primer loteo público de Salvador, el conjunto Castro Alves, fue implantado también en Itapagipe, en
} 
Esta reglamentación ocurría ya bajo la máxima de la higienización del espacio urbano de la segunda mitad del siglo XIX, lo que contribuyó no solamente para reforzar la progresiva segregación espacial, empujando a los más pobres para la periferia, sino también para ampliar las posibilidades de ganancias del iniciador segmento privado de inmuebles, todo con cierta connivencia del Estado (GORDILHO-SOUZA, 2008, p. 41).

Asociado a la preocupación por el "higienismo urbano" del siglo XIX, surgen en Salvador, a finales del mismo siglo, los primeros conjuntos habitacionales "villas operarias", en el primer ciclo industrial que se iniciaba en esta capital, inspirados en los moldes europeos de entonces, "villas" que fueron implantadas en la segunda década del siglo pasado, luego de la declinación del primer ciclo (GORDILHOSOUZA, 2008, p. 91 $)^{19}$.

Con el avance tecnológico y del transporte a inicios del siglo XX y la cada vez mayor influencia de los postulados del "plan zonal urbano" -habitación, trabajo, recreo y circulación-, basados en la Carta de Atenas, de 1933, una nueva lógica de segregación socioespacial pasó a ser diseminada en las grandes ciudades: la individualización del habitar en las periferias de los grandes centros urbanos, reforzando una nueva "suburbanización" predominante en aquel siglo, lo que estimuló la fragmentación de la apropiación privada del suelo, fenómeno que se rebate en la expresión popularmente conocida como la da "casa propia" (GORDILHO-SOUZA, 2008, p. 28$)^{20}$.

El aumento de la mercantilización de tierras y de la habitación, fomentado por el avance del capitalismo, con los resultantes problemas sociales a partir de la Segunda Guerra Mundial, llevó al Estado a intervenir en socorro de los sectores sociales de más bajos ingresos, aunque preservando los intereses de los sectores

1943, por el gobernador de Bahia, Pinto Aleixo, mientras que el primer conjunto habitacional, el del Instituto de Aposentadoria e Pensão (IAPI), fue en 1944, en el barrio que llevó el mismo nombre de este Instituto (GORDILHO-SOUZA, 2008, p. 271).

${ }^{19}$ Se diga de paso que las "villas" y "villas operarias" mencionadas no se vinculan al sentido de villa miseria o favela que se tiene hoy. Se trataba de conjuntos habitacionales que en la mayoría de los casos eran similares a los actuales conjuntos de VIS, lo que sugiere que aquéllos se anticipaban a éstos.

${ }^{20}$ Gordilho-Souza $(2008$, p. 46) llama la atención sobre que el vector de migración segregacionista centro urbano-periferia que ocurrió en Brasil se dio en sentido contrario a lo que sucedió en los países centrales. Ya en Argentina, con la recuperación económica a principios de la década de los (19)90, que se reflejó en una mejora en el sector de la construcción y en el resurgimiento de los incorporadores inmobiliarios, con una abertura crediticia para el sector, hubo alteración de tipos de morada entre los grupos de la alta y media alta capa social, que pasaron a migrar de la periferia para el centro urbano de Buenos Aires, fenómeno anteriormente observado desde mediados de la década anterior reforzado también por las mudanzas ocurridas tanto en el Código de Planeamiento como en el Código de Edificación, según relata Clichevsky $(1996,23,145)$. 
adinerados. De ahí surgen en las periferias los inmensos conjuntos habitacionales, generalmente desprovistos de estructuras públicas, que en buena parte eran insuficientes, y que, asociados a la densificación del espacio, terminaban por ofrecer baja calidad de vida a los moradores.

Históricamente, en Brasil, la preocupación por atender en masa a los sectores de más bajos ingresos ocurrió en la década del (18)80 a cargo de agencias gubernamentales y de iniciativa privada que producían unidades habitacionales para sus operarios y de cierta forma atendía también al interés del patronato en mantener un mayor control en el comportamiento del obrero, cuyas residencias eran construidas en las proximidades de las fábricas, generalmente instaladas fuera del centro urbano.

Luego del período de construcción en masa, un nuevo impulso ocurrió en 1920, cuando el presidente de la República de Brasil Epitácio Pessoa implantó un programa de construcción volcado al alquiler, que tuvo versiones regionales como la creación de la Fundação da Casa Operária (FCO) por el Gobierno del Estado de Pernambuco. Este programa ha sido superado por otro, del presidente Arthur Bernardes, cuya piedra fundamental fue lanzada en 1923 y del cual surgieron las Caixas de Aposentadoria, inicialmente para los trabajadores del ferrocarril, $\mathrm{y}$, en seguida, para los de otras categorías profesionales que pasaron a disponer de sus Caixas.

Con el inicio de la política industrial de sustitución de importaciones de 1930, que se extendió hasta 1955, con énfasis de la intervención estatal en la economía, la política de construcción fue fortalecida en todo el país, de manera que en 1933 fueron creados los Institutos de Aposentadoria e Pensão (IAPs) que gradualmente fueron substituyendo a las Caixas y que, más tarde, durante el gobierno del presidente Eurico Gaspar Dutra, dieron origen a la FCP, a través del Decreto-Ley Federal 9.218 del $1^{\circ}$ de mayo de 1946, que fue extinguido en los años (19)60, contabilizando una producción insatisfactoria. La referida Fundação fue sustituida por el Banco Nacional de Habitação (BNH) en 1964, el que, en 1986, también fue extinguido con parcos resultados en la producción de inmuebles para personas de baja renta. Del total de 4,5 millones de unidades financiadas mientras estuvo vigente, solamente cerca del $33 \%$ fue destinado a la población pobre, y de este porcentaje solo 250 mil habitaciones fueron entregadas a los que ganaban entre $1 \mathrm{y}$ 3 SM (GORDILHO-SOUZA, 2008, p. 43-45). 
En 1938 surgieron también las Carteiras Prediais de los IAPs, en 1946 el Departamento de Habitação Popular do Distrito Federal, y en 1942 la Lei do Inquilinato, cada una dentro de su lógica específica, lo que indicaba que la cuestión de la habitación integraba la agenda pública como un tema social a nivel nacional. La Lei do Inquilinato, a su vez, venía para amenizar las dificultades económicas de entonces de la población en general, y de esta Lei resultó la desmotivación de la producción habitacional por parte de la iniciativa privada, lo que, a su vez, inició un progresivo aumento de escasez de este bien esencial, conforme afirma Bonduki (2011, p. 12-14). El autor recuerda que en este período se inaugura la fase en la cual el Estado asume el problema de la habitación, tratándolo como un problema social, y considerándola: "uma mercadoria específica, ou mesmo como uma nãomercadoria, [...] um serviço público [... aunque] como um governo de caráter conservador, que perseguia os comunistas, pôde tomar uma medida radical de suspensão da propriedade privada, como foi a Lei do Inquilinato" (BONDUKI, 2011, p. 14).

La primera vez que el Estado brasileño intervino en esta área, a tan larga escala, a nivel nacional, fue en la segunda mitad del siglo XIX con propósitos higienistas preocupado por la salud pública.

El Estado argentino procedió de forma parecida en el mismo período y también a inicios de este siglo por motivos semejantes, sin embargo, las evidencias comprueban que actuó de manera anticipada y con mayor intensidad que Brasil, vistas las intervenciones estatales ya sea a través de medidas del Poder Legislativo que por intervención directa del Ejecutivo en la producción de conjuntos habitacionales para la población obrera.

Con la extinción del BNH, en 1986, y la tendencia de municipalización establecida por la Constitución brasileña de 1988, el tema de la habitación pasó a ser compartido entre el ente local y el federal, al menos en el ámbito de los reclamos por parte de los ciudadanos demandantes. Así, nuevos programas fueron creados, ya sea con recursos exclusivos de responsabilidad del gobierno federal que del municipal, aunque con el aval del gobierno federal o compartido con él. Pero quedó en evidencia que la intermediación de empresas privadas en la captación de recursos y construcción de las obras restableció una tendencia que ya se notaba incluso desde el $\mathrm{BNH}$, que la clase media era mejor y más rápidamente atendida que los clientes que ganaban entre 1 y $5 \mathrm{SM}$. Para este segmento social medio existían, por ejemplo, recursos del Programa de Habitação Popular (PROHAP), el 
Plano Empresário Popular (PEP), el Construcard, la Poupança de Crédito Imobiliário, la Poupança de Crédito Imobiliário "Poupanção", la Carta de Crédito Individual y la Carta de Crédito Associativa además de financiamientos mediante recursos del FGTS. Ya para las camadas populares fue creado, por ejemplo, el Habitar-Brasil, a fondo perdido, el Plano de Ação Imediata para Habitação (PAIH), mediante financiación, y el Pró-Saneamento, parcialmente a fondo perdido. Aún en este período, fue creada la COHAB municipal de Salvador y la Secretaria de Terras e Habitação (SETHA) para que hicieran frente a las crecientes demandas por un techo (GORDILHO-SOUZA, 2008, p. 325-329). En 1999, fue creado el Programa de Arrendamento Residencial (PAR), con recursos federales, a través de la Caixa Econômica Federal, con vistas a disminuir el déficit habitacional de VIS para familias con presupuesto entre 3 y 6 SM. Bajo el PAR la lógica de las inversiones en los conjuntos habitacionales fue que éstos fueron construidos, en su mayoría, en áreas libres adyacentes a las principales vías de circulación de la periferia, con infraestructura ya existente, en tipología de condominio cerrado, con el máximo de 160 unidades, con área útil en torno a los $37 \mathrm{~m}^{2}$, en bloques de edificaciones en altura, de hasta cinco pisos, incluyendo la planta baja y sin ascensor. En Bahía, este programa fue direccionado en gran parte para atender la necesidad de habitación de los empleados públicos (GORDILHO-SOUZA, 2008, p. 425).

Sea cual fuere el ángulo por el que se quiera analizar la producción habitacional del período del $\mathrm{BNH}$, no hay fundamentos suficientes para argumentar que en este período el Estado tuvo una actuación insignificante, y que la producción se puso a cargo de las especulaciones y ganancias de la iniciativa privada. Bonduki (2011) recuerda que en el período en cuestión la producción estatal ha sido mayor que el $20 \%$ de las unidades construidas, o sea, casi cinco millones de habitaciones, lo que correspondería a aproximadamente 25 millones de personas (BONDUKI, 2011, p. 318).

Gordilho-Souza tuvo otra lectura al contabilizar para el mismo período 19641986 un total de 4,5 millones de unidades habitacionales construidas por el $\mathrm{BNH}$, lo que equivale al $25 \%$ de la producción de inmuebles realizada en Brasil. De esa producción financiada por el BNH "somente 1,5 milhão de unidades $(33,3 \%)$ destinaram-se às camadas populares da população, tendo sido produzidas apenas 250 mil unidades em programas alternativos, ou seja para a renda de 1-3 SM" (GORDILHO-SOUZA, 2008, p. 45, 127; SOUZA apud FERNANDES y SOUZA, 2004, p.188). 
Con relación al mismo periodo en discusión:

O desempenho da política habitacional, nas últimas três décadas, mostrou-se profundamente perverso quando os dados são desagregados, sendo que, das unidades financiadas, somente cerca de 33\% foram destinadas aos setores populares (Azevedo 1988). Além disso, a política habitacional teve, na prática, um caráter 'redistributivo às avessas', pois baseou-se num sistema financeiro abastecido de capitais sub-remunerados, oriundos de pequenos poupadores (cadernetas de poupança) e de recursos dos assalariados (Fundo de Garantia por Tempo de Serviço, FGTS). (AZEVEDO apud FERNANDES y SOUZA, 2004, p. 92-93).

En este contexto, con la presión popular sobre el Estado por la cuestión de la dificultad de adquisición de lote y de habitación, surge la Ley 6766/79 que intenta inhibir la producción de loteos clandestinos que estaban siendo ofrecidos en el mercado, muchas veces sin la infraestructura necesaria, y que por la referida Ley criminalizaba al empresario y daba derecho al comprador de suspender el pago cuando la infraestructura no fuera la debida (GORDILHO-SOUZA, 2008, p. 47).

Una situación parecida se vivía en Argentina en esa misma década de (19)70 por una medida semejante aplicada en la provincia de Buenos Aires a través del Decreto-Ley Nº 8.912 de 1977, que agravó aún más el problema de la morada para los más pobres, pues, con la imposición legal de que también los loteos populares fueran comercializados en el mercado, ya con infraestructura, asociada a la pérdida de renta por la crisis económica de aquel período y de las políticas macroeconómicas, acabó por hacer con que el capital privado se volviera inaccesible a aquel segmento social en dicha provincia (CASTRO, 2010, p. 30).

Ha sido importante la influencia del Plano de Desenvolvimento Urbano de Salvador (PLANDURB), de iniciativa de la Intendencia entre 1976 y 1979, con el cual se intentó, en los años subsiguientes, abarcar en gran sentido el proceso expansionista urbano de la ciudad y su entorno, cuyo proceso fue estimulado por el dinamismo económico industrial en curso y con el objetivo de minimizar el recrudecimiento de los inconvenientes sociales -segregación/exclusión de los más pobres- del mismo dinamismo industrial de aquel entonces.

El referido PLANDURB se estructuró, básicamente, en tres instrumentos: en la Ley do Plano Diretor de Desenvolvimento Urbano (PDDU), en la Ley de Ordenamento do Uso e da Ocupação do Solo (LOUOS) y en la Ley do Processo de Planejamento de Participação Comunitária. Este intento de resolver el problema del tejido urbano de Salvador no fue suficiente en relación con la gravedad del 
problema, ya que, no por el mérito técnico de los planes y sí por ausencia efectiva de acción política, sucedía un alejamiento entre lo que Heliodório Sampaio (1998) llama de "cidade-ideal" y "cidade-real", alejamiento producido históricamente por las relaciones sociales en el espacio (GORDILHO-SOUZA, 2008, p. 117-118). Tal contradicción es señalada por Castro (2010, p. 29-31) en Argentina, con base en el evidente alejamiento entre lo que teóricamente se argumenta y se pretende alcanzar con las medidas gubernamentales en el tejido urbano y los efectos colaterales indeseables de estas medidas que son obligadas a soportar los sectores más pobres.

Otra evidencia del modelo de "liberalismo estatal" practicado en Salvador muy mancomunado con los intereses del sector de inmuebles puede constatarse en lo que Sampaio (1999) dice de la implementación en esta capital del Modelo de Ocupação Físico Territorial a cargo del PLANDURB, así como de la elaboración de tres anteproyectos de Ley, que deberían ser el producto final de la primera etapa del modelo. Las referidas leyes solamente fueron implementadas a mediados de la década siguiente, entre 1983 y 1985, con la singularidad de que "houve uma curiosa inversão: a Lei de Ordenamento do Uso e Ocupação do Solo antecede a Lei do Plano Diretor. Consequentemente, infere-se que as pressões do mercado imobiliário foram negociadas antes mesmo do Plano ser aprovado" (SAMPAIO, 1999, p. 266) ${ }^{21}$.

Esta situación estaba ancorada ya en las propuestas desarrollistas para Salvador desde la pos-Segunda Guerra Mundial en dos proyectos, uno para la implementación del Centro Industrial de Aratu y otro para la del Complexo Petroquímico de Camaçari, en áreas adyacentes a Salvador, bajo la lógica de la "metropolización" con énfasis en la red viaria apuntando a la interconexión de los espacios de forma urbana polinuclear. Así, el capital inmobiliario encontró "o campo fértil necessário aos seus negócios: a malha expandida com extensas áreas de terras vazias próximas às novas vias e a legislação urbanística flexibilizada no sentido horizontal e vertical, implodindo a velha forma-urbana de característica mononuclear herdada do século XIX" (SAMPAIO, 1999, p. 236).

El Estado no está actuando racionalmente y mucho menos cumpliendo con su función social cuando estimula, e incluso cuando financia, la creación de nuevas

\footnotetext{
${ }^{21}$ La Lei No 3.345 del 14 de diciembre de 1983: "Dispõe sobre o processo de planejamento e da participação comunitária no desenvolvimento do Município", la Lei $N^{\circ} 3.377$ del 23 julio de 1984: "Dispõe sobre o ordenamento do uso e ocupação do solo no Município", y la Lei $N^{\circ} 3.525$ del 11 septiembre de 1985: "Dispõe sobre o Plano Diretor de Desenvolvimento Urbano de Salvador para o período até 1992" (SAMPAIO, 1999, p. 266).
} 
centralidades en la ciudad, y, consecuentemente, el surgimiento de nuevos vectores de expansión en consonancia exclusiva con los intereses del capital de tierras y de inmuebles, dejando atrás el centro antiguo y las poblaciones más pobres que ahí viven, o para donde migran, comportándose con negligencia al dejar de aprovechar el ocioso stock infraestructural existente en beneficio de estas poblaciones carenciadas, lo que evidencia la histórica práctica socialmente injusta de intervención y gasto del erario (MARICATO, 2011, p. 138-145).

Asociado a esa realidad se agrega el fenómeno que se volvió conocido como "gentrificación" y que consiste en la expulsión de los moradores nativos más pobres con la valorización de espacios, generalmente en los centros urbanos y áreas portuarias adyacentes a éstos, destinados a intervenciones público-privadas capitaneadas por el Estado con el objetivo de adecuarse a situaciones "al gusto" de los intereses de la iniciativa inmobiliaria, como la implementación de oficinas empresariales y de infraestructura turística y de recreo. Esta lógica se ha intensificado desde los años (19)90 y hasta hoy, aunque con actualizaciones y mantenidas las debidas particularidades, tanto en Brasil como en Argentina, donde, por ejemplo:

En 1994 se modifica el Código Penal, transformando la ocupación en un delito penal y permitiendo el desalojo de los inmuebles antes de la culminación de los juicios. Esto contribuyó a disuadir sobre la realización de nuevas ocupaciones y a acelerar los desalojos en propiedades privadas. (RODRÍGUEZ, 2009, p. 44)

En Salvador, como en todo Brasil, están vigentes los principales instrumentos jurídico-urbanísticos derivados de la Constituição Federal de 1988 y del Estatuto da Cidade de 2001: el PDDU, Outorga Onerosa do Direito de Construir (OODC), TRANSCON, Imposto Predial e Territorial Urbano (IPTU), parcelaciones, edificación o utilizaciones compulsorias, expropiación, incentivos fiscales, la preferencia a favor de la Intendencia para la compra de un bien inmobiliario, y la Ley de LOUOS.

La Carta Orgánica de 1882 fue uno de los primeros instrumentos de regulación urbanística de Buenos Aires, que estableció como responsabilidad de la Municipalidad el trazado de la ciudad y que facultaba al Concejo Deliberante a: la ampliación y abertura de calles, la fijación de alturas de los edificios particulares, la creación de plazas y aceras, además de otras atribuciones afines, facultad que fue poco ejercida. En 1888 fue sancionada la primera Ordenanza que regula la altura de construcciones en función del ancho de las calles (CLICHEVSKY, 1996, p. 29). El 
primer Plan Urbanístico para la ciudad fue elaborado por el arquitecto Bouvard en 1906, inspirado en los principios haussmanianos aplicados en Paris en 1853. El plan no llegó a revertirse en un código que regulara las acciones privadas y que orientara las inversiones públicas en ese sector. En este sentido, en cuanto al planeamiento del trazado de la ciudad tuvieron mayor influencia: el Plan Noel, de 1925, del intendente Carlos M. Noel; el Código de Edificaciones de 1944, el primero de Buenos Aires, durante el gobierno del militar Edelmiro J Farell, que también creó la Caja Nacional de Ahorro Postal con la intención de conceder préstamos a pequeños ahorristas, el Plan Director de 1962 y el Código de Planeamiento de 1977 (CLICHEVSKY, 1996, p. 29; GAITE, p. 93) 22 .

El plan propuesto por Le Corbusier en 1938 junto con Ferrari Hardoy y Juan Kurchan para la ciudad de Buenos Aires no fue implementado, algunos de sus presupuestos, como la necesidad de vincular las área sur y norte, y el de la creación de autopistas, se hicieron presentes en todos los estudios y proyectos sobre la ciudad y su área metropolitana (CLICHEVSKY, 1996, p. 30; GOMES, 2009, p. 102103).

Los postulados urbanísticos de la Arquitectura Moderna vigentes en toda América Latina en el siglo pasado, por ejemplo, el del establecimiento de zonas por funciones, parcelación y uso del suelo, se volvieron característicos en el trazado de muchas ciudades de Argentina, basados en el Código de Edificación de 1944, y aún hoy se perciben en la CABA. Es importante resaltar el hecho de que este Código de Edificación ha sufrido fuertes influencias de las prácticas urbanistas de entonces, como relata la revista argentina Nuestra Arquitectura en su edición de agosto de 1940, presentando el libro Las ciudades de los Estados Unidos: su legislación urbanística, su código de edificación, del ingeniero Luis Vicente Migone (1940, p. $717)^{23}$ : "al mostrarnos la situación anterior de las ciudades americanas y lo que han

\footnotetext{
${ }^{22}$ El Reglamento General de Construcción, de 1928, fue creado a través de la Ordenanza № 2.736 , y había sido propuesto por el Plan de 1925, siendo el mismo Reglamento el antecesor del Código de Edificación, que entró en vigor a partir de 1944 - basado en el Decreto № 9.434 del Gobierno Federal -y que reguló las construcciones particulares, bien como definió, en cierta medida, la configuración morfológica edilicia de la ciudad de Buenos Aires, en especial de las áreas más densificadas, conjuntamente a la Ley de Propiedad Horizontal $\mathrm{N}^{\circ} 13.512$, además de que, el mencionado Código también normativizó, a partir de 1957, la construcción "en torre", a través del Decreto-Ordenanza n ${ }^{\circ}$ 4.110/57. (CLICHEVSKY, 1996, p. 30-31 y 146).

${ }^{23}$ Migone se recibió en Ingeniería en la UBA en 1918 y participó de la investigación sobre el tema de reglamentación de construcciones junto del Concejo Deliberante de la Municipalidad de Buenos Aires, de cuya investigación nace el libro. También realizó proyectos de viviendas económicas basados en los principios de la racionalización y estandarización constructiva (GOMES, 2009, p. 36).
} 
hecho por mejorarle, nos está enseñando el camino que se debe seguir para curar nuestros propios males" (NUESTRA ARQUITECTURA apud GOMES, 2009, p. 26.).

En Brasil la Lei do Inquilinato entró en vigor en 1946, mientras que, en Argentina, su congénere, la Ley $N^{0} 11.156$ del Alquiler, había sido promulgada ya en 1921, durante el primer período del presidente Hipólito Yrigoyen, y reforzada, en el mismo año, por la Ley de Emergencia $N^{0}$ 11.157. Ésta última establecía que a partir de su entrada en vigor los valores de los alquileres de varios tipos de edificación residencial, comercial e industrial- no podrían ser superiores a los valores practicados, respectivamente, al 10 de enero de 1920. Esta medida se debió a que a partir de 1883 los precios venían aumentando progresiva y aceleradamente. Este momento fue muy importante para la discusión de las dos corrientes de opiniones e intereses que rivalizaban entre sí: el que defendía la producción estatal volcada al alquiler o la iniciativa privada, y el que defendía la modalidad de habitación unifamiliar o multifamiliar (UNIVERSIDAD DE BUENOS AIRES, 2000, p. 13). EI congelamiento de los precios de los alquileres se mantuvo oficialmente hasta la entrada en vigor de la Ley Federal № 21.342 de 1976, que los liberó, sin embargo, dada la coyuntura precedente y debido a las dificultades económicas de la población, al contrario de lo que se esperaba con la Ley, "el parque habitacional destinado al alquiler se redujo del $40 \%$ al $25 \%$ del total" (RODRÍGUEZ, 2009, p. 42).

Los antecedentes de VIS en Argentina están vinculados al combate de la fiebre amarilla ocurrida en 1871 a partir de las recomendaciones de los médicos higienistas: Rawson, Wilde y Coni, entre otros. Después de las primeras obras que surgieron durante el gobierno del intendente Torcuato Alvear, en 1886, fue creada la Comisión Nacional de Casas Baratas, la cual actuó por 30 años; en ese período también surgieron varias Cooperativas de Vivienda. Más tarde, con el aumento de la población en las décadas del (19)30 y (19)40, hubo un unánime reclamo por la producción de viviendas, lo que se realizaría durante el gobierno de Juan Domingo Perón (1945-1955), con la producción de VIS a nivel nacional (COSOGLIAD, 2003, p. 62-63).

Si en Brasil la primera fase del problema habitacional de final del siglo XIX e inicio del siglo XX se colocó en la retórica higienista, de cuño cristiano-caritativo, en Argentina, las oligarquías, aunque divididas entre esas dos concepciones, la de la intervención directa o indirecta del Estado, mostraron un carácter más práctico al acatar la construcción de conjuntos de viviendas populares. El primero de éstos, denominado "barrio de vivienda económica" fue proyectado por el arquitecto 
Buschiazzo y construido en 1887 durante el gobierno del intendente Torcuato Alvear, contaba con 58 unidades entre las calles Las Heras, Larrea, Azcuénaga y Melo, conjunto habitacional originariamente destinado para operarios pero que acabó siendo entregado a empleados públicos. Otros dos conjuntos de "barrio de vivienda económica" fueron autorizados por la intendencia de Buenos Aires a través de la Ley 4.824 de 1905: el primero, denominado "Barrio Buteller", disponía de 64 casas entre las calles Cobo, Senillosa, Zelarraián y avenida La Plata, entregadas en 1907, el otro, "Barrio Patricios", compuesto por 116 viviendas entre las calles Cachi, Arena, Aconcagua y San Francisco, entregadas en 1910. Estos fueron los primeros conjuntos construidos directamente por el Estado en la Ciudad de Buenos Aires y enmarcan el inicio de la primera etapa de intervención en masa del Estado, donde se instaura la Ley 4.824/05 de Casas Baratas, también conocida como Ley Irigoyen, etapa que se cierra en 1947 con la ascensión del peronismo y bajo un clima de nuevas demandas y propuestas para el sector habitacional de interés social por parte de la sociedad (SUMMA, 1974, p. 14-16; UNIVERSIDAD DE BUENOS AIRES, 2000, p. 13).

En 1889, el Banco Hipotecario Nacional (BHN), que había sido creado tres años antes con la finalidad de fornecer préstamos bajo hipoteca para propiedades aptas para producir bienes, autorizó un préstamo al propietario de un predio improductivo con la intención de que se construyera en dicho predio. Con esta nueva línea de préstamos, el BHN inauguró la modalidad de financiación de construcción para viviendas en pequeños lotes, destinadas a empleados y obreros, aunque excluía el sector de más bajos ingresos, considerando la exigencia de financiar el equivalente al $60 \%$ del valor total involucrado. De los valores negociados con el BHN para construcciones, algo como $\$ 62.352 .000$ de pesos en todo el país, cerca del 80\% correspondía a la Ciudad de Buenos Aires (SUMMA, 1974, p. 16).

En 1905, por causa de la falta de crédito para la obtención del suelo, se permitió la venta a plazos, lo que hizo aumentar los negocios. Pero, como la población más pobre continuaba a demandar vivienda, en 1915 se sancionó la Ley Nacional № 9.677 de Casas Baratas, de autoría del diputado Juan F. Carrefata, como también se volvió conocida. A partir de la sanción de la Ley, fue creada la Comisión Nacional de Casas Baratas (CNCB), primera institución pública responsable por la solución de vivienda popular en Argentina que, inspirada en las sociedades francesas de Habitation à Bom Marché, produjo 1.012 unidades habitacionales, primera experiencia relevante de producción real hasta entonces, 
hasta 1944, cuando fue cerrada y sustituida por la Administración Nacional de Vivienda. En 1912, bajo un clima de ardua discusión para sancionar o no el proyecto de Ley Carrefata, los ánimos se dividían entre dos corrientes, pro y contra la intervención directa del Estado en la producción de conjuntos habitacionales, si al Estado cabía o no actuar directamente en la financiación de producción de viviendas mediante intereses de la iniciativa privada o si para posterior alquiler social a familias operarias, y si se debería priorizar la habitación individual -unifamiliar- o de tipo colectivo -multifamiliar-. Lo interesante a partir de ese período fue que se promovió una discusión en cuanto a la tipología a ser adoptada, de cuya discusión, al fin y al cabo, se definió que las viviendas de un piso serían direccionadas a áreas despobladas y más alejadas del centro, en el eje este-oeste de la ciudad, mientras que las construcciones en altura, inspiradas en el modelo del hoff europeo, se destinarían a áreas deterioradas del centro y del sector sur de Buenos Aires (SUMMA, 1974, p. 16; UNIVERSIDAD DE BUENOS AIRES, 2000, p. 13). Esta solución suscitó una futura segregación urbana socioespacial que años después e incluso hoy, al menos en lo que se refiere a la zona sur porteña, se convirtió en un refugio para gran parte de la población más pobre.

El fenómeno de segregación socioespacial fue percibido más claramente a partir del final de la década de los (19)60 con los grandes conjuntos habitacionales en altura que pasaron a ser el padrón tipológico arquitectónico más utilizado en Argentina para VIS a gran escala en la expectativa de que fuesen:

[...] pequeñas ciudades auto-suficientes de mayor densidad de población que su entorno, con equipamiento comunitario a gran escala, y de fuerte impacto en la trama y el perfil urbano. Se inspiran en las new towns inglesas, en los grandes ensembles franceses, y en los modelos impulsados por el Team $X$, sustentados en la creación de espacios de encuentro a distinta escala, y en los valores de identidad y vida urbana de los habitantes. En Buenos Aires, se localizaron en el área S/SO de la ciudad, en los barrios de Mataderos, Lugano y Soldati. Las respuestas proyectuales dieron lugar a soluciones formales y funcionales novedosas. El resultado esperado fue el de barrios desvinculados de su entorno, estigmatizados por sus habitantes y vecinos, y prematuramente deteriorados. (UNIVERSIDAD DE BUENOS AIRES, 2000, p. 17)

En la primera mitad del siglo pasado hubo varias medidas en Argentina volcadas a la problemática de la vivienda, por ejemplo el de las referidas Leyes $\mathrm{N}^{\circ}$ 11.156 y 11.157, de financiación por el BHN a partir de 1919 de habitaciones para empleados públicos que poseían diez años o más de trabajo, y de las iniciativas de 
"consorcio" entre el Estado y el sector privado, como ocurrió en dos momentos distintos entre la intendencia de Buenos Aires y la Compañía de Construcciones Modernas en 1913 y 1922 para la construcción de varios conjuntos habitacionales populares por un total de 10 mil unidades, aunque se ejecutara la mitad de lo contratado en un principio. En este contexto también hubo iniciativas exclusivamente privadas, como las de algunas patronales para sus operarios, como en el caso de la cervecería Quilmes y de cooperativas como la de Hogar Obrero, del Partido Socialista, y de la de la Unión/Acción Católica Argentina, todas direccionadas a la construcción de conjuntos habitacionales populares. Dos ejemplos de las primeras construcciones de vivienda colectiva en altura destinadas a sectores de baja renta: la Casa colectiva Valentín Alsina, en Parque Patricios, concluida en 1920, con 70 departamentos, de dos o tres dormitorios, sala, cocina y baño, distribuidos en cuatro pisos, incluyendo la planta baja, proyectada mediante licitación pública, y el "Barrio Chacarita", inaugurado en 1928 entre las calles Leiva, Roney, Concepción Arenal y Gusmán, con 130 departamentos distribuidos en bloques separados, también de cuatro pisos con la planta baja incluida.

Con la creación en 1943 de la Secretaría de Trabajo y Previsión Social de la Nación, Argentina encara cambios que irían a ocurrir en una segunda etapa de sus políticas públicas, con base en la revisión de su legislación de la vivienda (SUMMA, 1974, p. 18; UNIVERSIDAD DE BUENOS AIRES, 2000, p. 13-14).

Como se ha mencionado ya, a inicios del siglo pasado ya se discutía el problema de la vivienda popular, inclusive entre los especialistas del área. En el ámbito de los Congresos Panamericanos de Arquitectos, en su III edición, en Buenos Aires, en 1927, se propone que "se criassem casas individuais ou coletivas, e além, que se vendessem habitações a chefes de família vinculados ao Estado" (GOMES, 2009, p. 78). En el IV Congreso Panamericano, en Rio de Janeiro, en 1930, la discusión avanzó, formando parte de un debate más amplio sobre, entre otras cuestiones, la pertinencia de los rascacielos como forma y estética en las ciudades estadunidenses. A partir de la sugerencia del III Congreso en Buenos Aires, se aprobó, en Rio de Janeiro, una resolución destinada a baratear el costo y la minimización del área urbana para la construcción de VIS: "que se recomende um estudo que permita a edificação cooperativista, ou seja, a divisão das casas por pisos e apartamentos e, sua venda fracionada, como uma das fórmas [sic] para resolver o problema residencial urbano, para operarios [sic] e empregados" (ARQUITETURA E URBANISMO, 1940, p. 82;GOMES, 2009, p. 78). 
Basándose en Nabil Bonduki (1999, p. 303) y Flávia Brito do Nascimento (2004, p. 77), Gomes (2009) llama la atención sobre la afinidad entre las "atitudes da política do período Vargas com as discussões dos dois últimos Congressos PanAmericanos de Arquitetos", considerando que dicho presidente del Brasil ha optado por la casa unifamiliar en lotes de la periferia financiada por el trabajador así como por la autoconstrucción, considerando que en aquel entonces crecía la "penetração da estética e do planejamento urbano segundo os gostos americano e europeu" (GOMES, 2009, p. 78).

Una de las más importantes e impactantes legislaciones urbanísticas en la configuración espacial de Buenos Aires y en el plan social después del Código de Edificación de 1944 fue la del Código de Planeamiento de 1977, originalmente propuesto en 1973, y que promovió alteraciones en las interconexiones de las áreas verdes de la ciudad con su entorno en el área metropolitana -cinturón ecológico- a través de parques regionales, de los cuales algunos fueron privatizados y otros, ya existentes, reutilizados. En cuanto al impacto social fue extremamente radical y elitista: excluyente para los más pobres, compelidos a la periferia urbana si consideramos que "erradicación" había sido la palabra de orden en agosto de 1980 ante la constatación hecha por las autoridades municipales de que cerca del $76 \%$ de la población de las villas de la entonces Capital Federal había sido reubicada y estaba viviendo en "casa propia"24 (CLICHEVSKY, 1996, p. 32-35).

Con el gran éxodo de la mano de obra rural del interior argentino para los grandes centros del país en la década del (19)40, como ocurría en Brasil, también en argentina se dio inicio en aquella década al fenómeno de la "villa miseria", que en Brasil se denomina favela, áreas de las ciudades caracterizadas por poseer un nivel mínimo, o nulo, de infraestructura -redes de agua potable y cloacas, energía eléctrica, pavimentación- además de construcciones habitacionales con materiales de baja calidad y por fuera de la legislación edilicia, inclusive con la ocupación irregular del terreno. En este ambiente urbano, las reivindicaciones por mejorías y soluciones definitivas aumentan y el Estado argentino se ve en la necesidad de intervenir a mayor escala. De esta manera, a partir de 1946, el sector de la vivienda

\footnotetext{
${ }^{24}$ A pesar del tenor radical e impactante en el tejido urbano del referido Código de Planeamiento de 1977 a través del Plan Director de 1962 y del CPU de 1971 y 1972, y de que ya se habían iniciado estudios sobre la plusvalía y la tierra apropiada por privados a causa de las alteraciones de las normas del uso del suelo, este tema no fue tenido en cuenta suficientemente por las autoridades municipales en 1977 (CLICHEVSKY, 1996, p. 146). El Código de Planeamiento de 1977 fue sustituido por otro en 2000, después de haber sufrido innumerables alteraciones para amenizar aspectos de su rigidez, según constata Cravino (2014, p. 26).
} 
consigue que se creen 13 leyes, incluyendo la que prorrogaba el congelamiento de los alquileres y la que suspendía los desalojos, aprobada en 1943. También, ocurrieron crecientes reivindicaciones sociales por la vivienda que se hicieron presentes tanto en el Primer Plan Quinquenal de 1947 como en el Primer Plan de Vivienda de 1952, ambos durante el período en que Perón estuvo al Poder, durante el cual el Estado dio una mayor atención a este tema (UNIVERSIDAD DE BUENOS AIRES, 2000, p. 14).

En aquel período, el arquitecto Hilario Zalba, uno de los fundadores del grupo Austral, pioneros de la diseminación de los postulados de la Arquitectura Moderna en Argentina, actuó como jefe de Urbanización y Vivienda del Ministerio de Obras Públicas de la provincia de Buenos Aires y desenvolvió un trabajo volcado hacia la VIS, por ejemplo el proyecto Barrio Obrero en Ingeniero White, en la zona portuaria de Bahía Blanca, en 1944, y en la playa de La Perla, en Mar del Plata, bien como actuando en 1943 como integrante de la Comisión de Estudios de Vivienda Popular, por designación de la Sociedad Central de Arquitectos, donde participa del proyecto Casa Amarilla, que sería una propuesta para enfrentar el problema de la vivienda en Argentina (COSOGLIAD, 2003, p. 63).

Tal contexto también se dio en el Brasil de Vargas a partir del final de la década del (19)30, en que los IAPs, ya bajo fuerte influencia, como en Argentina, de los presupuestos de la Arquitectura Moderna, a través de la proliferación de ideas provenientes de los Congresos Internacionales de Arquitectura Moderna (CIAMs), de los salones de encuentros de los Congresos Panamericanos de Arquitectos, y similares eventos de Urbanismo y Arquitectura en este continente, de norte a sur, y en Europa (GOMES, 2009).

Entre los significantes cambios que se notaron durante las gestiones de Perón, en 1947, la Administración Nacional de la Vivienda pasó a ser subordinada al $\mathrm{BHN}$, que además de proseguir con su misión inicial de financiación de las viviendas, también se responsabilizaría por la ejecución de éstas. Si entre 1886, año de su fundación, y 1947, este Banco escrituró 101.200 viviendas, entre 1947 y 1957, escrituró 300.000, lo que indica el énfasis dado a las construcciones con las políticas de Perón, conforme recuerda Facciolo (et al. apud UNIVERSIDAD DE BUENOS AIRES, 2000, p. 14).

Dentro de los cambios significativos en el sector de la vivienda que ocurrieron en Argentina bajo el mando de Perón, en 1948 fue sancionada la Ley 13.512 de Propiedad Horizontal, según se anticipó ya, que pasaba a permitir, por primera vez 
en este país, la subdivisión y venta por separado de unidades independientes de un mismo edificio multifamiliar, lo que significó una innovación en el mercado de inmuebles y en la legislación urbana y edilicia, ampliando la posibilidad de que un mayor número de familias, de varias clases sociales, obtuviera su casa propia. En 149 se implementó otra importante medida de cuño social, esta vez interfiriendo directamente en el derecho de la propiedad privada, célula mater del capitalismo, a través de la Ley 13.581 que establece que "la locación de los inmuebles estará subordinada a la función social de la propiedad", mediante la introducción del argumento de la "emergencia", por lo cual los propietarios de inmuebles eran obligados a dejarlos disponibles para alquiler cuando los mismos estuvieran desocupados. Esta realidad sumada a la del congelamiento de los precios de los alquileres y a la prohibición de los despejos promovió un fuerte impacto en las relaciones y producción en el mercado del inmueble y entre sus agentes (UNIVERSIDAD DE BUENOS AIRES, 2000, p. 14). Tal contexto y sus desdoblamientos ocurrieron también en el mercado de Brasil, en la misma década, en condiciones muy semejantes, con las sucesivas intervenciones de Getúlio Vargas a través de sus Decretos-Ley para mediar los precios de los alquileres y la ampliación del parque de inmuebles.

En el período entre 1957-1967 se vio en Argentina un esfuerzo al quererse institucionalizar la actuación estatal en el tema de políticas públicas para la vivienda, por ejemplo, las medidas en el campo jurídico y económico direccionadas a aquel sector. En este sentido, se adoptó el "conjunto habitacional" como la opción urbanoarquitectónica más adecuada para la solución de la vivienda social, basado en el edifico con tipología arquitectónica en altura inspirada en el pabellón y en la torre. En cuanto a la metodología de la elaboración y ejecución de los proyectos, los municipios estimularon la participación de las empresas privadas en los concursos públicos de vivienda, y en cuanto a los aspectos constructivos, incentivaron la promoción de experiencias de sistemas racionales y de nuevas técnicas de producción industrial involucradas sector (UNIVERSIDAD DE BUENOS AIRES, 2000, p. 15).

Con la Ley 17.174, que creó, en 1968, la CMV durante el gobierno de Onganía, se viabilizó la ejecución de conjuntos habitacionales en la ciudad de Buenos Aires y en su región metropolitana, algo que ocurrió en mayor medida durante la década del (19)70, decreciendo en la década siguiente, a través de licitación empresarial, mediante recursos del FONAVI. En la década del (19)80, a 
pesar de que la Ordenanza Municipal 39.753 indicara una mayor tolerancia con el trámite de "radicación" a través de los asentamientos en las villas y en ocupaciones de edificios, dicha indicación no tuvo asignación de presupuesto. Solamente a partir de 1989, con la ascensión del nuevo gobierno y de una nueva orientación política en sintonía con propuestas de instituciones internacionales, es que surge el "Decreto del Poder Ejecutivo Nacional No 1.001 y Programa Arraigo, diseñado para llevar adelante procesos de regularización dominial de villas y asentamientos localizados en tierras de propiedad pública nacional" (RODRÍGUEZ, 2009, p. 56-57).

Sobre el Decreto-Ley $N^{\circ}$ 8.912/1977 de Ordenamiento Territorial y Uso del Suelo sancionado el 24 de octubre de 1977 en la provincia de Buenos Aires, el Instituto de Estudios y Gestión Urbanos, Territoriales y Ambientales del Colegio de Arquitectos de la Provincia de Buenos Aires (I-CAPBA), veinticuatro años después de la sanción, entiende que pretendió provocar importantes avances en el espacio urbano, como, por ejemplo, el de: a) establecer un mecanismo de control y ordenamiento del suelo por parte de las autoridades municipales responsables, b) inserir la práctica de creación de zonas funcionales y así intentar controlar la especulación de tierras y de inmuebles -obtenido en parte por el Colegio, al menos en el ámbito de la "ciudad formal"-, c) establecer como necesaria en los planes del gobierno la provisión de servicios y estructuras, bien como de edificaciones y parcelación del suelo con vistas a la mejoría del ambiente urbano, conforme se entiende como instrumento de gestión, d) estimular la participación de la comunidad en las decisiones de los proyectos urbanos, y e) la necesidad de articular problemas y soluciones entre gestiones públicas de municipios vecinos -actual región metropolitana-. En relación a las loables intenciones expresas en la Ley $N^{\circ}$ 8.912, y al particular pedido de inserción de la participación popular en los destinos de los proyectos urbanos, lamentablemente la sanción de la Ley se dio al inicio de uno de los períodos más aterrorizantes que los argentinos vivieron bajo la opresión de los militares (1976-1983), el Colegio de Arquitectos de la Provincia de Buenos Aires constató que, de lo que se previó, poco de concreto ocurrió, y argumenta como causas principales de "los fracasos, carencias o aspectos obsoletos de la Ley": a) a falta de estructura técnica -profesionales cualificados y estructuras- en varios municipios, b) la excesiva centralización administrativa, la burocracia y la indiferencia dada a la realidad sociocultural de la población, c) el simplismo de concebirse la división conceptual territorial entre rural y urbano, sin tener en consideración las particularidades regionales de la provincia -áreas pampeanas y atlánticas, entre 
otras-, d) la ausencia de mecanismos necesarios para combatir la especulación inmobiliaria estimulada por la apropiación de plusvalía por parte de los agentes inmobiliarios, e) la implementación de un padrón urbanístico que privilegia las bajas densidades urbanas con edificios de perímetro libre, disociándose de la morfología urbana tradicional, de la uniformidad tipológica, y promoviendo serias amenaza a la sustentabilidad económica y ambiental de la ciudad (BUENOS AIRES, 1977) ${ }^{25}$. Situación de prácticas socioeconómicas semejantes que se verifican hasta el día de hoy entre ambos países investigados.

A partir de 1983, con la vuelta a la democracia, surgieron nuevas medidas, las cuales amenizaron las dificultades del sector de la vivienda, como por ejemplo la del proceso de autoevaluación iniciado por la FONAVI, que dieron lugar a las resoluciones 92/86 y 95/87 que fijaron "un cupo del 10\% anual para la realización de programas con cooperativas de vivienda". Otra importante medida de la FONAVI fue la incorporación del Programa de Viviendas Progresivas al Programa 029 a través de la resolución reglamentaria 93/86, lo que significó un cambio que apuntaba a una diversificación de la financiación del fondo, contribuyendo así con diversos sectores, conforme entiende el Centro de Estudios del Hábitat y la Vivienda (apud UNIVERSIDAD DE BUENOS AIRES, 2000, p. 17). Otra medida se dio en 1990 con el Decreto PEN No 1001 que liberaba la venta de los inmuebles y terrenos fiscales ociosos, dando prioridad a los ocupantes ilegales mediante un crédito. Luego, la Presidencia de la Nación argentina creó la Comisión de Tierras Fiscales (Programa Arraigo), que se volvió responsable por la aplicación de Ley Nacional de Tierras (Ley 23.967), para el estudio y puesta en marcha de planes de regularización de dominio. También, con la creación del Sistema Federal de La Vivienda, en 1985, mediante la Ley 24.464, vinculado al FONAVI, los organismos provinciales reforzaron sus atribuciones de administradores y ejecutores de los fondos. Además, aprovechando la buena fase ocurrida a mediados de la década de los (19)90, hubo diversas operaciones financieras direccionadas a la construcción de viviendas y destinadas a las capas sociales más adineradas, las cuales se predisponían a ahorrar, mediante sistemas como el leasing, el fideicomiso, las letras hipotecarias, entre otros, según autorizaba la Ley 24.441/95 (UNIVERSIDAD DE BUENOS AIRES, 2000, p. 17-18).

Poco antes de la emancipación política de la CABA en 1996, durante el gobierno del intendente justicialista Carlos Grosso, fue promulgado el Decreto

\footnotetext{
${ }^{25}$ El Decreto-Ley No $8.912 / 1977$ fue rectificado por el Decreto $3389 / 87$ con las modificaciones del Decreto-Ley $N^{\circ} 10128$ y las Leyes $N^{\circ} 10653,10764,13127,13342$ y 14449.
} 
10982/92 a través del cual se instituyó el Consejo de Enlace entre el Ejecutivo local y las organizaciones villeras, que consistía en la Mesa de Concertación, la cual formaba parte de lo que establecía el Programa de Radicación de Villas de la Capital Federal, programa que obtuvo apoyo del Programa de Naciones Unidas para el Desarrollo (PNUD), y que proponía, sin éxito, volverse la base de las intervenciones urbanísticas para las mejorías de los asentamientos informales y la permanencia de los pobladores en los mismos (CASTRO, 2010, p. 33).

Con la extinción del Programa de Radicación de Villas surge en su lugar en 1991 el Programa Arraigo, de iniciativa federal, que, a pesar de la denominación, se volvió evidente, en el caso de Villa 31, que parte de los grupos políticos, mancomunados con la iniciativa privada, no tenían como objetivo mantener allí a la población de aquel barrio, como era propagado, vistos los mega proyectos previstos hacía mucho tiempo para el barrio de Retiro, y para quienes los proyectos de manutención de la Villa 31, en su totalidad, no eran bien vistos (CASTRO, 2010, p. $38,42)$.

El Plan Director de la Ciudad de Buenos Aires aprobado en 1962 fue víctima de varias alteraciones, a través de las modificaciones pleiteadas entre 1983 y 1988, sin éxito, y con alguna consecuencia en 1989. Según Odilia Suárez, el CPU de 1977: “debe seguir siendo la expresión legal del Plan Director de la ciudad. Toda modificación sustancial en la estructura urbana que se propicie debería afectar, primero, al Plan Director [...] y, luego ser transferida al Código (SUÁREZ apud CLICHEVSKY, 1996, p. 56, 151, Nota n 117), (el itálico está según CLICHEVSKY).

Una particularidad de la Ciudad de Buenos Aires es que, habiendo sido Capital Federal de la Argentina, pasó a tener autonomía institucional sólo a partir de 1996, en que se transformó en la CABA, y que, hasta entonces, su gobernante -el intendente- y sus auxiliares, eran indicados por la presidencia de la República. A partir de la autonomía política de 1996 las comunidades de las villas han sido contempladas con mayor participación en las discusiones sobre la problemática de la vivienda con la entrada en vigor de la Ley 148 de diciembre de 1998, que incluía en la recién creada Comisión Coordinadora de Participación (CCP) representantes de varios segmentos de la sociedad, como moradores y asociaciones de diversos barrios, al lado de responsables del Ejecutivo y Legislativo de la ciudad. Estos cambios pretendían ser exitosos en las discusiones y soluciones de los problemas habitacionales de las capas más pobres, pero una vez más demostraron que la complejidad y los contradictorios intereses, las inoperancias y las omisiones de 
derecho y de hecho, no proporcionaron el avance pretendido (CASTRO, 2010, p. 43). Se constata, otra vez más, que las realidades de ambos países son muy similares.

En la década de los (19)90 la ciudad se insería aún más fuertemente en la lógica de la globalización, como otras ciudades-clave de América Latina destinadas a volverse vitrina de la "modernización del fin de siglo", y para poder ofrecer servicios turísticos y de recre pasaron por intervenciones puntuales en determinados espacios de las mismas -en gran parte los centros históricos y/o áreas portuarias- más afines a esa lógica, volcada a intereses de inversiones de grandes conglomerados nacionales y/o extranjeros-, con la aquiescencia del Estado (RODRÍGUEZ, 2009, p. 25-33; CICCOLELLA, 2000).

Cravino (2014) observó que lo que ocurrió en el espacio urbano de la Ciudad de Buenos Aires en la década de los 19(90) ha sido una "modernización" de la ciudad, oriunda de la conjugación de dos esferas estatales, la Nacional y la Distrital, donde la primera promovió la privatización de servicios públicos con la introducción de la agenda de los megaproyectos en la Ciudad, tal como lo que se hizo en el barrio central de Retiro, y la segunda, a su vez, garantizó la privatización de algunas áreas que convenían al capital privado sin el cuidado de obtener de éste el retorno previsto en compensaciones sociales. Este panorama de realidad consistió en lo que Adrian Gorelik denominó de "ciudad de los negocios", algo como "la ciudad como máquina de crecimiento" (CRAVINO, 2014, p. 27).

Es sabido que en función de las normas edilicias que el Estado establece, como la flexibilización o restricción de parámetros como densidad, tasa de ocupación y de utilización del suelo, hay consecuencias, directas e indirectas, en el precio de suelo. En CABA, por ejemplo, se constató que, entre 2001 y 2005, hubo un aumento diferenciado en los precios por $\mathrm{m}^{2}$ de suelo que dependió de las normas vigentes y de las intervenciones hechas bajo el aval del Estado en determinadas zonas. En Villa Devoto, por ejemplo, donde la legislación no permite la construcción de edificios en altura, se constató que los precios del suelo se mantuvieron estables en los U\$400,00/m² (CRAVINO, 2014, p. 31).

Lo que se constata hasta aquí, es que en Salvador, como en otras ciudades brasileñas, hay una cultura muy conservadora en términos políticos y de poco espíritu de ciudadanía para enfrentar el grave tema de las favelas y de otras irregularidades en relación a la realidad edilicia. Es indudable que, con relación a la legislación edilicia, paradojalmente, Brasil posee algunas de las mejores y más 
modernas leyes, preocupadas por lo social, pero, sin embargo, falta la "voluntad política" de muchos gobernantes y su empeño para imponerlas, así como para vencer las resistencias de fuertes grupos económicos involucrados en el problema de las tierras y del sector inmobiliario. Empeño que se vuelve incluso menor que antes del momento de la creación de dichas leyes, cuando muchas veces los gobernantes actuaban públicamente a favor de éstas: es como si el sistema conspire para que las cosas continúen como están, y, por ende, nunca se consiguen los deseados avances sociales. Queda claro que, sin un cambio profundo a través principalmente de una educación formal que focalice en la ética, en la piscología social y en la sociología y que siga la pedagogía de la autonomía propuesta por Freire $(1996)^{26}$., en la mentalidad de la gran mayoría de los integrantes de la sociedad, mucho se hablará, muevas leyes serán aprobadas, y se continuará todavía a ignorarlas, y lo que es peor, a no respetarlas, según denuncia Pinsky (2017, p. 53). Cuantiosas inversiones del erario, supuestamente destinadas a las mejoras sociales, continuarán haciéndose y muy poco efectivamente se alcanzará, como hasta ahora, por este camino. Quién acaso tenga dudas acerca de lo dicho, haga un recorrido alrededor del paisaje urbano de Salvador, en especial en los barrios populares, que concentran el mayor porcentaje de población, y dé una mirada en las pendientes de los cerros.

\section{4 - Las propuestas de los técnicos: arquitectos, ingenieros y urbanistas}

Actualmente es prácticamente de consenso entre los estudiosos del tema que los programas de rehabilitación de espacios construidos son más indicados para áreas centrales de ciudades brasileñas que en general presenten un alto índice de decadencia (MARICATO, 2011, p. 12). Estos programas podrían estar inseridos en Planes Directores de ciudades, de manera que el ordenamiento de suelo fuera pensado según la lógica zonal, expurgándose, obviamente, los aspectos negativos derivados de su implantación y constatados ya a lo largo del tiempo, desde el inicio del siglo pasado, como por ejemplo la segregación y el aumento de precio del suelo, e incluso el excesivo funcionalismo ya criticado, a su modo, por el grupo de

\footnotetext{
${ }^{26}$ El ilustre pensador de la Educación al ser cuestionado por un estudiante sobre el porqué de su defensa de los sin-tierra, que el estudiante veía como unos "barrabás", creadores de peleas, el profesor le contestó: "'Pode haver baderneiros entre os sem-terra' [...] 'mas sua luta é legítima e ética'. 'Baderneira' é a resistência reacionária de quem se opõe a ferro e a fogo à reforma agrária. A imoralidade e a desordem estão na manutenção de uma 'ordem' injusta” (FREIRE, 1996, p. 71).
} 
arquitectos modernistas del Team X (MARICATO, 2011, p. 114; BARONE, 2002, 4349).

Una provechosa actualización de la lógica zonal es estudiar la mejor manera de incorporarla en los proyectos de intervenciones públicas, especialmente para áreas centrales y degradadas, utilizando la diversidad de usos, de tipologías de edificios, de sectores de renta, de grupos étnicos, de capas sociales, tendiendo a potencializar los efectos positivos de relaciones de vecindad entre las personas que se apropian del espacio urbano (MARICATO, 2011, p. 115). En misma dirección, sigue el arquitecto argentino Juan Pfeifer, autor del proyecto de una de las tres comunidades investigadas en Buenos Aires, según se ve en la entrevista presentada en la pág. 274 adelante. En este sentido, estudios en comunidades populares de Rio de Janeiro y de Diadema/SP, que pasaron por intervención urbana, comprueban que los lazos de amistad, de vecindad, además de los familiares, refuerzan la creación de redes de solidaridad, lo que, asociado a un control de la organización comunitaria, tiende a desestimular la salida de moradores, incluso con la valorización de los inmuebles y áreas después de la intervención (ABIKO y ORNSTEIN, 2002, p. 331-332).

En el pasaje del siglo XIX al XX, con los problemas en el espacio urbano causados por las epidemias -cólera, sarampión, malaria, etc.- lo que provocó la estigmatización de los conventillos y las políticas higienistas, tanto en el plano edilicio como de los espacios, varios profesionales involucrados en la cuestión en Brasil, tal como ocurría en São Paulo, preocupados por la gravedad del problema, proponían una actuación más consistente por parte del Estado con relación a la viabilidad de medios para que la población pudiera obtener una morada más adecuada con lo que la salud pública exige de todos:

[...] fica pois bem entendido de que se não preconizarmos um radical socialismo do Estado, contudo não podemos endossar uma certa opinião que infelizmente corre e faz adeptos, segundo a qual a função do Estado é a de mero espectador dos acontecimentos. É evidente que a iniciativa privada não pode dar uma solução à questão [...] Sendo as casas operárias, para os capitalistas, uma questão de dinheiro como qualquer outra, qual o meio de conseguir, para as classes pobres, casas ao mesmo tempo higiênicas e baratas? A resposta é óbvia: ou o Estado (em nosso caso o município) assume o papel do capitalista, construindo as casas, ou proporciona empréstimos aos operários para que as construam ou concede certas regalias aos indivíduos e associações que se obrigam a efetuar a construção de tais casas de acordo com um tipo aprovado, bem como alugá-las por preço módico, devidamente 
Como se observa en esta propuesta, ya se adelantan varias sugerencias, como la de producción de habitación por parte del Estado para alquiler social, algo que aún hoy es motivo de quejas sobre la ineficiencia de la actuación del poder público en este tema. Bonduki (2011) indica una explicación evidente que aclara porqué en Brasil el Estado se volvió durante décadas inerte a la solución del problema de la adquisición de vivienda por parte de los sectores de bajos ingresos, con el progresivo agravamiento de la cuestión en los centros urbanos a inicios del siglo $\mathrm{XX}$ :

Na República Velha [1889-1930], os setores sociais beneficiados pelo mercado rentista sempre tiveram força para impedir toda ação que prejudicasse o mercado de locação. A despeito dos discursos higienistas contra a precariedade das moradias, associando-as aos surtos epidêmicos, o Estado limitou-se à proposição de medidas de caráter legislativo e, no âmbito da polícia sanitária, a reprimir as situações mais calamitosas.

A preocupação com a precariedade das condições habitacionais resultava quase sempre em medidas favoráveis ao setor rentista, como a isenção de impostos para a construção de moradias, adotadas em todos os níveis de governo. Essas iniciativas só aumentavam os ganhos dos proprietários pois, em um mercado de oferta escassa, regulado pela lei da oferta e da procura, o subsídio sob a forma de isenção fiscal acabava não sendo transferido para o inquilino. (BONDUKI, 2011, p. 77-78)

Delante de esta lógica perversa, que prevaleció por mucho tiempo, se hace evidente la reacción, muy conservadora y corporativista, manifestada en el parecer de la Comisión creada en 1927 por el intendente de la Ciudad de São Paulo, Pires do Rio, con la intención de analizar la problemática de la habitación en esa capital y proponer sugerencias para solucionarla:

A Comissão julga dever aconselhar a máxima circunspeção na ação direta do poder público na construção de casas populares, procurando incentivar por todos os meios possíveis ao seu alcance a iniciativa privada [...] Não haja ilusões. No estado atual de nossa organização social, política e econômica, a construção de habitações populares pelo poder público, diretamente ou por meio de empresas, longe de ser uma solução será causa de agravamento da crise atual. O simples anúncio de que o poder público irá construir alguns milhares de casas que serão oferecidos por preços e aluguéis fixos será o bastante para afastar automaticamente os capitais particulares que anualmente se empregam em construções. (CINTRA apud BONDUKI, 2011, p. 78) 
A la aplicación del argumento de la construcción de vivienda para alquiler financiada por el Estado, se agrega la reacción de los propietarios de inmuebles para alquiler del sector privado y la estructura vigente asociada a las prácticas culturales existentes en América Latina, que no favorecen la sustentación y diseminación de dicho argumento, ya que la adquisición de "casa propia", en sociedades con enormes parcelas de grupos sociales de bajos ingresos, no sólo refuerza el imaginario colectivo de seguridad, que en práctica es una certeza de padecer menos con problemas adversos inherentes a la supervivencia: desempleo, enfermedad y vejez. Además, la lógica capitalista ampliamente estructurada en este continente, basada en la dependencia de la fuerza de mano de obra y en la ambición del lucro sobre los activos económicos, dificulta una reversión hacia otra postura de tenor socialmente más justa, cuadro que involucra a todas las capas de la sociedad (MARICATO, 2011, p. 130-132; MARICATO, 2009b).

A mediados del siglo pasado, entre los profesionales que se destacaron en Salvador por proponer soluciones para los problemas de habitación popular, están Américo Simas Filho y Walter Gordilho, los cuales, inspirados en los presupuestos modernistas defendidos en esta ciudad durante la Semana de Urbanismo de 1935 y en el EPUCS de 1940, proponían la idea de intentar baratear los costos de la construcción a través de tecnologías alternativas y del sistema de cooperación comunitaria 27 ", así como de estimular el espíritu comunal entre moradores mediante la instalación de "unidades de vecindad" en las áreas de habitación, que deberían ser implantadas conforme la "lógica zonal", es decir, funcional, en que las industrias serían estratégicamente ubicadas alejadas del centro y en que, en general, se tomara en consideración el planeamiento demográfico pautado en programas de acción social sustentados por los beneficios del progreso industrial alcanzado en aquel momento (GORDILHO-SOUZA, 2008, p. 131).

A partir de 1939, luego del Primer Congreso Panamericano de la Vivienda Popular en Buenos Aires, las principales revistas del mundo publicaron varios artículos sobre del continente Latinoamericano. Desde entonces, los congresos relacionados con el tema de la vivienda popular en este continente pasaron a ser de interés para los periódicos especializados. Uno de los principales y comunes cuestionamientos en aquellos eventos se debía a la necesidad de que los estados

\footnotetext{
${ }^{27}$ En portugués, "mutirão" se refiere a trabajo comunitario gratuito entre vecinos, una especie de "ayuda mutua".
} 
financiaran las viviendas populares además de promover "uma política liberal da terra" (GOMES, 2009, p. 25).

Sin embargo, no está demás recalcar una común y peligrosa práctica en Brasil y Argentina y por lo visto en otros parajes de este continente, que es la de colocar óptimas intenciones en el papel, pero de dudosa eficacia en las acciones, práctica criticada por Maricato (2011, p. 116) en lo que se refiere a Brasil, y por Clichevsky (1996, p. 50) a Argentina.

Otra práctica no menos peligrosa e injusta para con sectores de más bajos ingresos es la del desconocimiento o exclusión de la cuestión de la morada como aspecto central del tema de tierras y de inmuebles, aspecto despreciado por técnicos y autoridades públicas a la hora de la discusión y elaboración de planes urbanísticos para las ciudades. Es fundamental que se tenga en cuenta, en todo momento de la elaboración de los planes urbanísticos, que los programas habitacionales diversificados tengan como eje la ampliación del mercado legal y la recuperación de áreas degradadas ocupadas irregularmente. En algunas ciudades de Brasil, que no son pocas, el mercado residencial privado legal está restricto a una parcela que no ultrapasa el 30\% (MARICATO, 2011, p. 119).

1.5 - Las intervenciones del Estado en materia de vivienda popular

Las inversiones públicas son el factor más importante de valorización inmobiliaria, la que a su vez está controlada por el mercado, motivo por el cual se explica el sofisticado juego de los lobbies sobre la aplicación de los recursos públicos. Este escenario se relaciona con el modelo de urbanización de Brasil que se dio en el siglo $X X$ y que está arraigado al patrimonialismo, al fisiologismo del "parroquialismo", del clientelismo y de privilegios otorgados que perduran en prácticamente todo Brasil, incluso en espacios más desarrollados como la ciudad de Salvador (MARICATO, 2011, p. 43-45).

La sociedad debe exigir permanentemente la presencia del Estado bajo las tres esferas institucionales en pro de las medidas necesarias en la gestión de la política habitacional para que la inercia de éste en lo que urge ser realizado para los estratos de menor poder adquisitivo, que precisan de un techo, no acabe favoreciendo a los agentes económicos de mayor poder que quieren hacer valer sus intereses, como por ejemplo refiere Castells en sus estudios, vinculando la lucha 
urbana a la lucha política con base en sus investigaciones en Francia, Canadá y Chile (CASTELLS, 2000, p. 459-533).

Para la solución del déficit habitacional hay muchos caminos, pero hay que enfrentar esta arraigada práctica de la sociedad brasileña, práctica que, a su vez, se pone en evidencia cuando el Estado no hace valer suficientemente su derecho y deber constitucional en la captura de parte de las rentas inmobiliarias oriundas de la valorización del suelo proveniente de inversiones públicas que favorecen principalmente a la iniciativa privada (MARICATO, 2011, p. 129). Además, es ingenuo, cuanto inconveniente y falaz, afirmar que el problema del déficit habitacional será resuelto solamente por vía de intervención estatal. Hay que mezclar diferentes sujetos y acciones, sin minimizar el poder de influencia de grupos dominantes sobre las políticas públicas de responsabilidad del Estado, muy frecuentemente en ruta de colisión con las necesidades de amplios sectores sociales más débiles (CASTELLS, 2000, p. 537-545).

Durante el período de 1950 a 1970 los gobiernos pasaron a intervenir macizamente en la producción de vivienda para la población de bajos ingresos, y en este juego de necesidades, intereses y poderes, la motivación subyacente básicamente poseía tres razones: la pacificación de la población desde el punto de vista político, la construcción de la nación, y por fin, la necesidad de demostrar a la sociedad que las medidas estaban siendo tomadas para responder a su demanda (WERNA, 2001, p. 67).

Al final de la Segunda Guerra Mundial y con el alejamiento de Getúlio Vargas del Poder Brasil estuvo cerca de dar un salto de calidad en cuanto a la solución del problema de la habitación popular, ya que disponía de un conjunto de factores favorables, acumulados con las exitosas experiencias desde el final de la década del (19)30 con los conjuntos habitacionales de los IAPs: un plantel de especialistas calificados -ingenieros, arquitectos, asistentes sociales, administradores, economistas, entre otros-, un gran volumen de recursos que provenían de la unificación de los IAPs en el Instituto de Serviços Sociais do Brasil (ISSB), la creación de la FCP en 1946, la discusión a nivel nacional sobre la necesidad apremiante de una solución más arriesgada para el creciente déficit de viviendas, particularmente entre la capa media y los segmentos de operarios, y un empeño mayor de Vargas en los últimos años de su gobierno en el Estado Novo (1937-1945) para el problema de la habitación popular. Todo esto hubiera potencializado un salto de calidad esperado por la mayoría, pero, la fuerza del corporativismo y de los 
intereses económicos privilegiados hicieron postergar hasta 1964 ese ciclo virtuoso del sector de la vivienda, al contrario de lo que ocurrió en Argentina que, bajo Perón, pudo implementar en el período en cuestión una versión del welfare state, al menos, en aquel sector (BONDUKI, 2011, p. 99-101 y 136).

En el Brasil de Getúlio Vargas, desde las primeras implantaciones en masa de conjuntos habitacionales al final de los años (19)30, con los IAPs hasta los años (19)50 y con la FCP, el tema de la habitación era visto por el Estado más como un argumento de refuerzo de ganancias populistas -electorado- por los dirigentes, que justamente políticas públicas consistentes, direccionadas para solucionar de hecho el problema de la falta de techo para la gran mayoría de los brasileños, a la inversa de lo que ocurrió en la Argentina de Juan Domingo Perón, que, en aquella ocasión, apoyado por su esposa, Eva Duarte, supo hábilmente, sin renunciar a su electorado, producir de hecho una significante y arriesgada obra social en el plano de la vivienda popular, según entiende el argentino Oscar Yujnovsky (1984) en su obra Claves políticas del problema habitacional argentino 1955-1981:

En el periodo 1943/1955 cambia la acción del Estado referida a la vivienda. Ello es coherente con las características de la política general del Estado que expresa los intereses del capital nacional industrial. [...] El crédito para vivienda es uno de los instrumentos de la política de redistribución del ingreso y de crecimiento de la demanda interna. El crédito barato del Estado permite entonces que gran parte de la población urbana pueda acceder a mejores servicios habitacionales. [...] La política financiera de vivienda planteaba acentuar la selección crediticia y el estímulo [sic] de la construcción privada de la vivienda, desalentando las construcciones suntuarias de lujo y prohibiendo la edificación de vivienda que no se destinara a la habitación permanente. (YUJNOVSKY apud BONDUKI, 2011, p. 125-126).

El "milagro económico" (1969-1974) proporcionó la expansión de los grandes conjuntos habitacionales con emprendimientos en altura multifamiliares en Salvador, más específicamente en "Seso" de la ciudad, volviendo este segmento inmobiliario, en las décadas siguientes en Brasil, no sólo un importante argumento para la reproducción del capital, bien como una nueva forma de morar que fuera consolidándose y volviéndose parte de la identidad de la urbanización brasileña, particularmente en cuanto a esta tipología arquitectónica se refiere, conforme consta en la disertación de Maestría de Luiz Antonio de Souza (apud OLIVEIRA, 2013, p. 168). 
En Salvador, a partir de 1970, ocurrieron diversas iniciativas, casi siempre sobre el ámbito del SFH, para enfrentar los problemas de la habitación popular que crecían en la ciudad. Con varias de estas iniciativas no se obtuvo el éxito esperado porque las ganancias fueron menores de lo previsto en relación con el capital invertido por insuficiente apoyo político e incluso por problemas técnicoadministrativos. Entre algunas de las experiencias que no han ido adelante están: el Plano Nacional de Habitação Popular (PLANHAP) de 1974, el Programa de Lotes Urbanizados (PROFILURB I) de 1976, el Plano de Ajuda Mútua (PAM) de 1976, la Comunidade Urbana para Recuperação Acelerada (CURA) de 1980, el Núcleo de Apoio à Produção (NAP) de 1985 y João de Barro de 1986 (GORDILHO-SOUZA, 2008 , p. 129). Por otro lado, se puede registrar como experiencias relativamente muy exitosas en esta capital brasileña: la de Avaliação das Ações de Saneamento Ambiental em Áreas Pauperizadas de Salvador (AISAM) de 1994 y el Projeto Ribeira Azul de 1996.

Al final de la primera década de este siglo ocurrió en Salvador la implementación de tres importantes medidas direccionadas a atacar el problema de la habitación popular en el plano social y urbano: el Plano Municipal de Habitação de Salvador, elaborado por la entonces Secretaria Municipal de Habitação (SEHAB), creada en 2001, para el período de 2008-2025, el Conselho Municipal de Habitação y el Fundo Municipal de Habitação. Hay que registrar también avances en la esfera estatal en cuanto a la preocupación de la institucionalización de medidas que fueran continuamente implementadas por el Estado, como la elaboración de una nueva Política Estadual de Habitação de Interesse Social, la creación del Fundo Estadual de Habitação, bien como del Conselho de Habitação, instrumentos que, generalmente en asociación con el Gobierno Federal, dirigen el Plano Estadual de Habitação. La perspectiva, en las tres esferas estatales, es que sus políticas habitacionales en adelante sean sostenidas mediante el apoyo de los recursos provenientes del Fundo Nacional para Habitação de Interesse Social. ${ }^{28}$

\footnotetext{
${ }^{28}$ Por presiones políticas locales la SEHAB de la Prefeitura Municipal de Salvador fue extinta justo cuando entró en vigor el Plano Municipal, en 2008, apropiándose de las atribuciones relacionadas a la VIS y a la regularización de tierras en el ámbito del Municipio. Recientemente, con el apoyo de Brasilia, el Estado da Bahia, como el resto de las demás entidades federativas del país, tuvo una mejora en la producción de VIS con la vigencia del Programa de Aceleração de Crescimento (PAC) a partir de 2007 y que tuvo su tercera etapa anunciada en junio de 2013, como respuesta del presidente de la República en el ápice de las ruidosas manifestaciones que se propagaron por meses por todo el país cuando millones de brasileños salieron a las calles a protestar por una mejoría en la calidad de vida en diversos sectores como Educación, Seguridad, Salud y Habitación, entre otros, en medio a innumerables denuncias de corrupción en los preparativos y obras de las arenas sede, en 12 capitales brasileñas, de las partidas de fútbol de la Copa Mundial de 2014.
} 
En Argentina, a partir de la redemocratización en 1983, después de idas y vueltas con diversos gobiernos forzando la erradicación de las moradas populares informales - ya sea el lote o la construcción o ambos -, algo que venía ya ocurriendo desde los años (19)60 y (19)70, se decide, durante la década de los 19(90), por la implementación de políticas de mantenimiento de las poblaciones en aquellas áreas, teniendo en cuenta los presupuestos de HABITAT I de Vancouver en 1976, y siguiendo el rumbo de los nuevos tiempos que se instalaban bajo el descenso de las dictaduras militares ${ }^{29}$. Como por ejemplo, lo que ocurrió en Brasil con el colapso del Sistema Financeiro de Habitação, administrado por el $\mathrm{BNH}$, después de dos décadas de vigencia, entre los años (19)60 y (19)80, fenómeno que también sucedió en Argentina, con los grandes conjuntos habitacionales construidos en las décadas del 19(60) y (19)70, generalmente alejados del centro, en las periferias, mediante el Programa FONAVI, a partir de cuándo, afectados por la crisis económica, los adquirentes de los inmuebles, endeudados, interrumpieron el ciclo financiero que debían mantener con el pago de las cuotas de la financiación inmobiliaria para la construcción de nuevos emprendimientos (MIGUEL, 2010, p. 95).

A partir del final de la década del (19)80 la presión de las potencias neoliberales impone que el Estado se vuelva mínimo en la administración e inversiones, priorizando la iniciativa privada en la actuación del mercado, dejando a éste el papel de facilitador en lugar de apoyador. Esta lógica, también conocida como enabling role, pasó a direccionar las inversiones donde quiera que estas se hicieran presentes y monitoreadas por los organismos internacionales, tal como el FMI y el Banco Mundial. Ha sido esta determinación que guio, por ejemplo, los trabajos de Habitat II en Istambul en junio de 1996 y en adelante (WERNA, 2001, p. $18-20)^{30}$.

\footnotetext{
${ }^{29}$ Entre los motivos de estas nuevas políticas implementadas por los gobiernos democráticos argentinos volcadas hacia la producción de viviendas populares, Cravino (2009a, p. 46) relaciona: la ocurrencia de nuevas demandas debido al surgimiento de más asentamientos informales, el malogro de la política de "llaves en manos", reformas fiscales -venta de tierras- vía privatizaciones incentivadas por la concepción del Estado mínimo, uno de los pilares del Consenso de Washington, las nuevas lógicas de intervención urbana oriundas de investigaciones académicas y experiencias en países ricos, con incentivos -préstamos- por parte de organismos internacionales, cuyas lógicas pasaron a priorizar la mejoría de aquellos asentamientos, y por fin, los posicionamientos de la ONU (Hábitat) en ese sentido, a partir de Vancouver en 1976, cuyos posicionamientos se tornaran conocidos como "políticas alternativas" en contraposición al de "llaves en manos", y que de forma pionera en América Latina venían siendo aplicados ya en cierta medida en Perú, a través de su Ley de Barrios Marginales de 1961, y en México, mediante el Comité para la Regularización de la Tenencia de la Tierra (CORETT) de 1973 (CASTRO, 2010, p. 26-27; CRAVINO, 2009b, p. 24,123).

30 Desde el comienzo de la década del (19)60 ha crecido la discusión sobre si los gobiernos metropolitanos deben ser orientados por un modelo centralizado o descentralizado, habiendo argumentos favorables y contrarios en cada postura (WERNA, 2001, p. 29).
} 
En medio de esta lógica, y de aplicación de recetas listas, la mayoría de las veces descontextualizadas de las realidades locales, graves inconvenientes se evidenciaron en países en desarrollo como Brasil y Argentina, teniendo en cuenta que con la reducción del aporte financiero del Estado en algunos sectores económicos, por ejemplo el de construcción de vivienda para familias de bajos ingresos, la iniciativa privada no se hizo presente para llenar el vacío dejado por el Estado: el reajuste estructural pretendido llevó en muchos casos al agravamiento de las condiciones sociales, una vez que la pobreza, la caída de la oferta de los servicios públicos y los cortes en la administración pública desencadenaron, a su vez, la desmoralización de estos servicios, la corrupción y al absentismo (WERNA, 2001, p. 20).

Ya en la segunda década del siglo $X X$ se señalaba la inviabilidad de adquisición de vivienda por parte del operario brasileño, subyugado por el patrón a por la baja remuneración con el objetivo de controlar su supervivencia en el trabajo y hasta fuera de él, según constata Bonduki (2011) en el documento del estado de São Paulo, de inicios del siglo XX, lo que era muy común también en el resto de Brasil en aquel período, y también en los días de hoy, y admitiéndose que el Estado tenía por principio por entonces ser bastante liberal al punto de no entrometerse en demasía, reglamentando las prácticas laborales de la iniciativa privada:

$\mathrm{Na}$ classe pobre, especialmente na classe operária, o aluguel da casa absorve uma boa parte dos limitados ganhos do chefe de família. A exiguidade do salário, comum às grandes indústrias [...] põe o operário entre as portas de um angustiante problema: ou comer pouco e mal, ou morar num cortiço. Em nove casos sobre dez, ele opta pela segunda solução. Obedece ao estômago. (BOLETIM DO DEPARTAMENTO ESTADUAL DO TRABALHO, 1916, p. 146 apud BONDUKI, 2011, p. 53)

Décadas después el problema persistía en Brasil, y nadie menos que el presidente de la Federação das Indústrias do Estado de São Paulo (FIESP), Roberto Simonsen, en la apertura de las Jornadas de Habitação Econômica en 1914, declaraba en su discurso que:

Não é possível aguardarmos, por tempo indeterminado, que o padrão de vida média se eleve, por toda parte, a um tal grau, que dentro do regime econômico vigente e sob a ação da oferta e da procura de capitais, possa a iniciativa particular proporcionar casas confortáveis para todos os que delas precisam [...]. Problema de difícil solução por simples iniciativa privada, porque num país onde o capital é escasso 
e caro e o poder aquisitivo médio tão baixo, não podemos esperar que a iniciativa privada venha em escala suficiente ao encontro das necessidades da grande massa proporcionando-lhes habitações econômicas [...] O problema das moradias das grandes massas nas cidades populosas passa a ser questão de urbanismo. Para sua integral solução torna-se indispensável a intervenção decisiva do Estado. (SIMONEN 1942, p. 25, apud BONDUKI, 2011, p. 79).

Cabe recordar que Ubirajara Zogaid (1942), así como Roberto Simonsen em 1914, defendió la propuesta de que los Institutos y Caixas de Aposentadorias e Pensões se volvieran responsables de la producción de casas populares en su artículo Economia popular e habitação, divulgado en la Revista do Arquivo Municipal/82, en 1942, y ha sido categórico, sin medias palabras, al afirmar que "Para resolver o problema de modo racional e de acordo com os princípios da ciência econômica é necessário elevar o padrão de vida, ou seja, aumentar o poder aquisitivo do povo" (BONDUKI, 2011, p. 92).

Como se ve, este nudo gordiano está aún hoy en día involucrado a la pobreza crónica de gran parte de las sociedades latinoamericanas, pobreza que se materializa en el espacio urbano de los grandes centros de este continente, y que ha sido recientemente otra vez objeto de interrogantes por el arquitecto brasileño Heliodorio Sampaio (2010), sobre cómo manejar, en la práctica, el cambio del actual concepto de "desarrollo sostenible", lo cual está fuertemente asociado aún al concepto de "desarrollo estratégico", ambos reminiscencias del "desarrollo urbano integrado" de los años (19)60 y (19)70, que, a su vez, se ha originado en el posSegunda Guerra Mundial, según la lógica del planeamiento "comprensivo" bajo el cual al Estado-proveedor, que tendría el poder de controlar el suelo urbano, cabía promover las grandes intervenciones infraestructurales (SAMPAIO, 2010, p. 25-48).

La mencionada interrogante se refiere a la contradicción de promover la logística operacional del desarrollo sostenible en un medio de subdesarrollo, como ocurre en Brasil y el resto de América Latina, con el discurso del desarrollo integrado para intentar aplicar el planeamiento urbano y regional, como en el caso del Plan Director local municipal.

Sampaio insiste con esta interrogante:

[...] como superar a in-sustentabilidade urbana apenas com pactos territoriais, na medida em que persistem alguns fatores combinados num mesmo espaço, como pobreza aguda, desigualdade social, e inviabilidade de ascensão econômica de muitos? Dito de outra forma: como planejar o desenvolvimento sustentável apoiado tão somente 
numa concepção que pressupõe um desenvolvimento endógeno, em cidades pobres, sem grandes aportes de recursos externos para alterar seu metabolismo interno? A rigor, um ambiente claramente insustentável, como é o das grandes cidades, carece de investimentos longe do horizonte que se vislumbra [...] como elevar a renda e encontrar mecanismos de distribuição da mesma, ainda insuportavelmente concentrada nas mãos de poucos? Isto nenhum Plano Diretor Urbano consegue materializar, embora possa até constar dos seus objetivos, mas só enquanto discurso. (SAMPAIO, 2010, p. 41-43)

Entre un cuestionamiento y otro el autor no contesta de manera directa a sus interrogantes, sin embargo da al lector algunas valiosas pistas para que se empiece a desatar el dicho nudo gordiano, además de que las mismas interrogantes traen ya un rumbo por donde iniciar la reflexión: son presentadas tres antiguas cuestiones estructurales que, sin la superación de las mismas, no se puede pensar en llevar adelante los propósitos de la mencionada logística operacional del desarrollo sostenible: a) el cambio de la estructura de distribución de la renta para que se pueda promover la equidad social; b) reestructuración del padrón tecnológico dominante, base de las tasas de lucro, para que se eliminen o minimicen los factores contaminantes del medio ambiente -efluentes gaseosos, líquidos y sólidos; c) revisión del padrón de consumo de bienes y servicios de todos los grupos sociales, con vistas a bajar los impactos negativos ambientales, y en este sentido, evitar lo superfluo y el desperdicio (SAMPAIO, 2010, p. 42).

En la coyuntura deflagrada a partir del Consenso de Washington de 1989, Argentina establece el Decreto 1001190 que poca importancia dio al tema del lote y de la producción de VIS, postura que no resuelve la cuestión mientras que el Estado solamente facilite la adquisición del lote o de la vivienda. Sin embargo, desconsidera que el bajo poder adquisitivo de la población, casi siempre desempleada o con una irrisoria remuneración, impide el pago de las tasas sobre la vivienda y/o el lote, inviabilizando la permanencia del morador adquirente del inmueble, lo que, según afirma Cravino (2009a, p. 58, 61, 74), es muy común en América Latina.

Con relación a estas preocupaciones sociales -pobreza, desempleo, bajos ingresos, déficit habitacional, etc.-, los arquitectos Admir Basso y Ricardo Martucci (apud ABIKO y ORNSTEIN, 2002, p. 277-278) refutan una argumentación muy corriente en Brasil, que ellos entienden como una falacia, la de que "o setor da construção civil é o fiel da balança dos problemas sociais causados pelo desemprego". Estos arquitectos ven en esa proposición la idea de que cualquier persona con un mínimo de calificación profesional pueda ser incorporada a este 
sector productivo, lo que de cierta manera atiende a la cuestión del empleo de las masas, aunque esta visión contribuya a fortalecer la práctica de mantener el nivel tecnológico de ese sector desfasado. Contra esta realidad, Basso y Martucci (apud ABIKO y ORNSTEIN, 2002, p. 277-278) proponen medidas orientadas a la modernización del proceso de producción mediante la valorización del profesional a través de su calificación, autonomía de decisión en el obrador, participación en la elaboración de los proyectos, mejoría en las condiciones de trabajo -horarios, sueldos, promociones, premiaciones, entre otras-, lo que en la práctica "levariam a uma democratização dos processos produtivos e construtivos empregados por empresas e/ou profissionais que participam do projeto de produto e projeto da produção". Al mismo tiempo: “a introdução de inovações tecnológicas e organizacionais nos projetos do produto e da produção [... tendería] para uma melhoria das condições de trabalho e aumento salarial". Queda claro que con este conjunto de medidas colocadas en práctica habría un aumento de productividad.

Durante la década de los (19)90, en Argentina, diferentes elementos fueron utilizados para la manutención de las familias en las comunidades y los asentamientos populares donde se habían instalado, elementos que no siempre producían resultados exitosos considerando la simultaneidad en tiempo y en espacio de las instancias del gobierno federal, de la provincia de Buenos Aires y de la CABA sobre la misma cuestión: el Programa Arraigo iniciado en 1992, la Ley 23.967/89 que dispone el traspaso de tierras "privadas" del Estado Nacional para las provincias y la Capital Federal con la finalidad de contribuir con los programas de vivienda y de lotes de tierras para las familias de bajos ingresos, el Decreto 1.001/90 que permite la transferencia de tierras a los ocupantes de las mismas o a organizaciones asociativas, la aplicación de la Ley 24.374 (“Ley Pierri”) del 7 de setiembre de 1994 en ámbito nacional con el objetivo de la regularización inmobiliaria -tierras e inmuebles- para estas poblaciones, así como las ordenanzas municipales, con menor alcance, como por ejemplo las del Programa de Radicación, creado por el gobierno de la Ciudad de Buenos Aires y que en poco tiempo pasó por alteraciones en su formato (CRAVINO, 2009b, p. 124 y 125).

Relacionados a la problemática de la vivienda, en Argentina hay básicamente cuatro tipos de situaciones que demandan solución: la primera se refiere a las villas surgidas en la década del (19)30, la segunda a las viviendas ocupadas por los sintecho, modalidad de vivienda surgida en la década de los (19)80 en un municipio al sur de la región metropolitana de Buenos Aires, expandiéndose luego a otros 
distritos de la región, la tercera, los que viven en hoteles-pensión, en gran parte por iniciativa del Estado y mantenidos por éste, y, por fin, el grupo de los moradores de la calle. Una de las críticas que se hace es que con lo que gastó el Estado en la manutención de los alquileres de la población que vive en los hoteles-pensión, que, en el caso de Brasil, corresponde al "aluguel social", hubiera sido posible construir viviendas definitivas. Debido a las varias críticas de ese tipo, el gobierno resolvió disminuir el alcance de dicho método como vía de solución para la emergencia habitacional. En cuanto a los moradores de la calle, fueron creados albergues, pero sin atender a la demanda real.

Datos controvertidos apuntan que, estimativamente, en la mitad de la primera década de este siglo, cerca de cien mil personas constituían la población de cada uno de aquellos tres primeros tipos mencionados. Ya para la población de los moradores de la calle, la Dirección General de Estadísticas y Censos de la Ciudad de Buenos Aires computaba 9.501 personas en 2003. De modo general, se estima que cerca del $10 \%$ y $15 \%$ de la población total de la CABA y de su región metropolitana, respectivamente, vivan informalmente, ya sea en villas, asentamientos o casas y edificios tomados. Cifras preocupantes, en especial para esta capital, que tiene su población en estadio de decrecimiento en contrapartida al aumento de la población de vivienda informal. Según la EPH, mientras que en 2003 la media de personas por familia era de 2,7 en la CABA, la de las familias en las villas era de 4,6 (CRAVINO, 2014, p. 35, 46-48).

El surgimiento del fenómeno de ocupación de casas y predios en el Gran Buenos Aires coincide con las erradicaciones promovidas por los gobiernos militares en diecisiete villas miseria de la Capital entre 1976 y 1983, período en que la población de aquellas comunidades sufrió una reducción de 94\%, pasando de 213.823 habitantes en 1976 para 12.593 a inicio de los años (19)80, según Cuenya (apud CRAVINO, 2014, p. 49).

A mediados de los (19)90 se implanta a nivel nacional el Programa de Mejoramiento de Barrios (PROMEBA), de mayor envergadura, considerándose las amplias variables que lo constituyen -infraestructura, estructuras comunitarias, componentes ambientales, participativos, productivos y capacitaciones diversas-, con financiación del BID y presupuestos similares al programa brasileño FavelaBairro, de Rio de Janeiro. En 1997, el Programa Gran Buenos Aires fue incorporado al PROMEBA, pero con la exclusión de la CABA debido a los criterios focalizados por éste (CRAVINO, 2009b, p. 125-126). 
Entre tantos programas y tentativas, lo cierto es que, en Argentina, los resultados hasta hoy son muy insignificantes, admitiéndose la creciente necesidad del problema, y cuando se trata de las regularizaciones de los asentamientos, los resultados son más satisfactorios si los inmuebles en cuestión pertenecen al Estado, principalmente si están en el ámbito de la municipalidad. En resumen, mucho hay que hacerse todavía con relación al tema de la vivienda popular en este país (CRAVINO, 2009b, p. 127-130).

Es pertinente retomar la discusión del "dualismo estructural" muy discutido en América Latina a partir de mediados del siglo pasado, en especial en la PosSecunda Guerra Mundial, que fundamentó el surgimiento de CEPAL y que subyace al reciente recrudecido fenómeno de la globalización mediante la dependencia de países de este continente de las tradicionales potencias con el empeño de las elites dominantes locales. Dualismo estructural no olvidado por Castells (2000, p. 9-51) a lo largo de su clásico trabajo, cuando se refiere a la estructuración de la cuestión urbana de este lado del Atlántico.

1.6- Transformaciones visuales de la tipología arquitectónica en el tejido urbano

En rigor se puede afirmar que la construcción en altura para habitación en Brasil tuvo inicio en la década del (19)40 en Copacabana, Rio de Janeiro, para la clase media. Sin embargo, fue a partir de 1964, a inicios de la dictadura militar (1964-1984), que el perfil de las grandes ciudades brasileñas cambió en virtud de la construcción en altura de habitaciones para la clase media, que recibió una enorme inversión de recursos financieros como jamás ocurriera en este país a través del BNH, integrado al Sistema Financeiro de Habitação (SFH) (MARICATO, 2011, p. 20).

En Salvador, desde inicios de la década pasada, se observa el recrudecimiento de fenómenos urbanos que caracterizan el espacio de la ciudad: densificación y construcción en altura de las antiguas habitaciones construidas en ocupaciones informales, tanto en la periferia como en especial en el centro urbano, disminución de la cantidad y tamaño de los lotes en áreas ocupadas informalmente, bien como la disminución del número de ocupaciones de modalidad colectiva, como también, una relativa disminución de la oferta de loteos públicos populares, el aumento del número de condominios privados en altura, habitacionales o no, de la clase media, y construcción de VIS en bloques en altura de hasta 5 pisos, 
incluyendo la planta baja, sin ascensor. También hubo en ese período ocupaciones lideradas por el Movimento dos Sem Teto de Salvador (MSTS) en forma de campamentos colectivos conflictivos, donde intervino no solo la policía sino también la Justicia, muy ágil cuando se trata de juzgar pleitos de expropiación en favor de los grandes propietarios y muy lenta cuando se trata de demandas de los ciudadanos comunes (GORDILHO-SOUZA, 2008, p. 424-431).

Maricato (2012) constata grandes semejanzas en la lógica del modelo constructivo adoptado en Brasil con el aval del Estado en los años 1996 y 1997 con lo que se vio a partir del 2003: emprendimientos habitacionales direccionados a la clase media y media baja, con presupuesto familiar de entre 3 y $10 \mathrm{SM}$, en amplios terrenos en la periferia cercanos a las fuentes de transportes, igual modelo tecnológico y gerencial de construcción con aumento del número de unidades por emprendimiento, algo inusual hasta el momento en el sector de construcción residencial brasileño que apostó en la innovación tratándose de las clases bajas en lo que la autora llama de simulacro de condominio-club: torres altas o bajas con sectores y estructuras de servicios y de recreo incluso para las capas entre 0 y $3 \mathrm{SM}$ para VIS, con la diferencia de que en el primer período la negociación ocurría predominantemente por autofinanciación (MARICATO 2012, p. 61-64). Al realizar la comparación de estos dos períodos la autora debe haber considerado que están incluidos en mandatos presidenciales de ideología político-partidarias y de gobierno antagónicas: el primer período bajo prácticas de matiz neoliberal -privatizaciones y fuerte ajuste presupuestario-, y el segundo cargado de un discurso de contenido populista-socialista que con el paso del tiempo se identificó también por acciones muy al gusto de los intereses conservadores mega empresariales de Brasil en varios aspectos.

Otra importante semejanza constatada por Maricato (2012) cuando analiza la modalidad de las financiaciones públicas para VIS en Brasil es la que ocurrió tanto en el período del extinto BNH en los años 1960-1980 como en el período a partir del 2003 , en los que hubo una inversión de prioridades ante el volumen de demanda, priorizando la clase media en detrimento de la baja. En otras palabras, en el período más reciente, la demanda de habitación del sector de entre 0 y 3 SM corresponde al $90 \%$ del déficit habitacional del país y está contemplado por el PMCMV con cerca del $40 \%$ de las unidades totales previstas, mientras que la demanda del sector de 
entre 6 y 10 SM, que ocupa el 2,4\% del déficit, está contemplado en un $25 \%{ }^{31}$ de las unidades totales previstas (MARICATO, 2012, p. 72).

En 2007 hubo una alteración que favoreció al sector de clase baja y que fue la incorporación por parte del Gobierno Federal brasileño de los proyectos de urbanización de favelas en PAC, lo que aportó recursos del presupuesto del Gobierno Federal y promovió un aumento de las intervenciones al sumarse valores aportados anteriormente por BIRD y BID. (MARICATO, 2012, p. 109).

1.7 - Repasando el concepto e importancia de la tipología en Arquitectura ${ }^{32}$

El concepto de tipología que se utiliza actualmente en la arquitectura se relaciona directamente al proceso de clasificación de los seres vivos elaborada por el biólogo sueco Carl Linnaeaus ([17--]) en el siglo XVIII y que se basa esencialmente en las funciones de las partes de un todo. Las categorías asociadas a la clasificación tipológica en el campo de la arquitectura son principalmente: la escala, la estructura funcional, la distribución espacial y el elemento constructivo (TAVARES FILHO, 2005, p. 6). A partir de entonces se toma en arquitectura la idea de tipo, no como algo estático que se toma como modelo y sí como un instrumento específico que respalda el proceso del proyecto constructivo y en el cual permite la agrupación de objetos arquitectónicos desde sus similitudes de estructuración constitutiva, los que se caracterizan fundamentalmente en términos de composición geométrica (TAVARES FILHO, 2005, p. 7).

En el siglo XIX, con J. L. Durán y su discípulo Julien Gadet, el concepto de tipo se fortalece como una unidad de significación sobre el de estilo arquitectónico, que vinculaba fuertemente la construcción al contexto histórico en que se había creado y a sus influencias locales, mientras que el tipo se volvía en un elemento "no contextualizable", pudiendo separarse de la forma. En este sentido, el concepto de modelo se une directamente a la forma y a los estilos arquitectónicos, implicando la objetividad, la precisión y la formulación de juicio de valor, mientras que el tipo, por el contrario, admite la subjetividad, la generalización, la esquematización e indistinción de la obra arquitectónica, liberando el artista-arquitecto de la influencia

\footnotetext{
${ }^{31}$ En el texto original (MARICATO, 2011, p. 72) parece haber un error para los estratos sociales mencionados: los números de unidades habitacionales son 400 mil y 200 mil y los porcentajes $40 \%$ y $25 \%$, cuando debería corresponder al $20 \%$.

${ }^{32}$ Esta sección consiste esencialmente en una adaptación de trechos relevantes extraídos del trabajo final de Maestría de Tavares Filho (2005).
} 
de un factor condicional de una determinada forma histórica particular y de la formación de juicio de valor. También Quatremère de Quincy, para quién el modelo es un objeto que debe repetirse como es mientras que el tipo parte de un principio por el cual se permite gobernar la creación de varios objetos diferentes, entiende que "en el modelo, todo es preciso y determinado. En el tipo, todo es vago" (TAVARES FILHO, 2005, p. 9).

Se entiende el tipo, de manera conceptual, como una reducción del edificio, un método de organizar el espacio y una prefiguración de la forma, es decir, una unidad significante deducida de una serie de otras unidades y de cuyo tipo puede surgir obras que no se parezcan (TAVARES FILHO, 2005, p. 10-11). El tipo original, cuando se trasforma en modelo, volviéndose repetitivo inadvertidamente, pierde su carácter de historicidad, resultando en la dilución de su valor estético. Cuando se habla de la noción de tipo como generalizaciones esquemáticas poseedoras de valores simbólicos ideológicos, el tipo funcional no parece existir por si propio, y representa en sí las funciones, las prácticas y las necesidades sociales. Las características de los tipos funcionales permiten comprender en qué medida la arquitectura proporciona soluciones a los diferentes y efímeros modos de vida (TAVARES FILHO, 2005, p. 42).

Para el estudio del tema de las series de tipologías formales, se entiende que la propia constitución formal sufre influencia directa de cómo se perciben las relaciones forma/función o forma/contenido. La creación de formas puede asimilarse por tres modos distintos: como algo interno para el desarrollo del propio mundo interior de formas, como también el resultado de actos fuera de este mundo o como una interacción compleja de múltiples factores internos y externos (TAVARES FILHO, 2005, p. 29).

Para la teoría funcionalista, cuya representación de valores proviene de la eficiencia, la estética se logra desde el estricto cumplimiento de la función, que en este caso es la adecuación a una necesidad práctica de uso o a una función estructural. La arquitectura funcionalista, que se originó al final del siglo XIX, considera que cada objeto arquitectónico tiene una sola función, específicamente definida, desde la finalidad según la cual se construye. Este concepto fundamentó todas las corrientes funcionalistas desde la Antigüedad Clásica y se ha constituido en el núcleo del Movimiento Moderno de la arquitectura del siglo XX (TAVARES FILHO, 2005, p. 36). 
La arquitectura, al apropiarse del concepto del término función, lo hizo asimilando por analogía lo que se entiende de este término en los campos del conocimiento de la Matemática, Biología y Psicología. Y esta apropiación ocurrió según la máxima ampliamente conocida de Louis Sullivan ([¿19--?]), para quien "la forma sigue la función", a pesar de que esto se concibió en una concepción metafísica de esencia orgánica. Uno de los ejemplos clásicos de la aplicación de esta máxima se encuentra en el siglo XVIII, en el proyecto penitenciario panóptico de Jeremy Bentham, de 1791. Configuraciones espaciales utilizadas comúnmente en otras áreas funcionales, tales como edificios militares, hospitales, escuelas, espacios religiosos, centros de rehabilitación, etc., también aplican el principio de la visión espacial panóptica como estrategia de vigilancia. Los patios internos de la escuela generalmente les permiten a los profesores y a los inspectores tener el control visual del espacio y de las actividades estudiantiles (TAVARES FILHO, 2005, p. 36-54; BONDUKI, 2008, p. 149).

Conviene resaltar la importancia que se dio en Arquitectura, con mayor énfasis en determinados momentos históricos, a la opción por una determinada tipología como mecanismo de control social por parte del Estado, vinculado al contexto político, cultural y económico vigente en aquel momento. En Brasil, principalmente a partir del final de la década del (19)30, con la implantación de millares de unidades habitacionales por los IAPs, ocurría que:

A preferência pela casa isolada, com recuos laterais e frontal, nesses primeiros empreendimentos, reflete ainda a influência dos higienistas que, no início do século, haviam privilegiado tal solução. Na década de 1930, portanto, ainda predominava uma concepção que defendia, para o operário, um modelo de moradia que reproduzia em miniatura o palacete pequeno-burguês, em oposição à promiscuidade do cortiço e à aglomeração apenas tolerada da casa geminada de vila.

A revisão deste modelo, com a difusão das propostas modernas, mostra a importância da intervenção do Estado. Somente um decisivo apoio do Estado, no caso através dos Institutos, poderia ter sido capaz de, em tão pouco tempo, revisar de modo tão radical o modelo de habitação adequada para o trabalhador. Nesse sentido, o novo modelo era, simbólica e concretamente, a expressão desse momento em que o Estado se fortalecia na condição de protetor dos trabalhadores e de responsável pelo atendimento de todas suas necessidades.

Os objetivos de ordem, controle, subordinação, reeducação, massificação etc., tão característicos da visão estado-novista [19371945] encontraram nesses núcleos habitacionais de inspiração moderna o espaço propício para sua difusão. As soluções arquitetônicas e urbanísticas adotadas não podem, portanto, ser consideradas neutras: eram parte integrante de um projeto- 
ideológico, no qual as novas concepções formais e espaciais se adequavam à estratégia mais ampla no nacionaldesenvolvimentismo. (BONDUKI, 2011, p. 164)

Durante la década del (19)40 surgen en Brasil, en medio a la proliferación de la producción de los IAPs, los proyectos más innovadores bajo las más diversas inspiraciones tipológicas predominantes en Occidente, como la de unité d'habitation de Le Corbusier, de las Siedlungen alemanas, de los Höfes vienenses, del "racionalismo" de la habitación social, tan en boga en la pos-Segunda Guerra Mundial, y de las ciudades-jardines de Howard (BONDUKI, 2011, p. 164).

Admitiéndose un análisis funcional, se proyecta un edificio, en rigor, desde un programa de necesidades en el que se requiere la vinculación de funciones afines, contemplando las formas, las dimensiones, los mobiliarios, los equipos y determinadas condiciones ambientales de confort para una determinada finalidad (TAVARES FILHO, 2005, p. 48). Actualmente, resulta que la tipología se clasifica de manera predominante basada en la función: hospitales, aeropuertos, centros comerciales, centros culturales. De acuerdo con esta lógica, se puede traer aquí lo que piensa Horacio Baliero (1983) que, según Gaite: "En la película Del Conventillo al Conjunto Habitacional [...] reflexiona acerca de la notable similitud entre la planta característica del conventillo y la de un barco negrero. El programa era el mismo: máximo rendimiento para ubicar camas" (GAITE, 2008, p. 14).

En la primera fase de la Arquitectura Moderna, de pleno aliento vanguardista, puede decirse que al mismo tiempo en que se rompe con el academicismo ocurre un rechazo del concepto de tipo como una herramienta para comprender el objeto arquitectónico desde su historicidad, destacando, por lo tanto, la desviación con relación al tradicionalismo de arquitectura de estilos historicistas. Resulta que los contratipos creados en esta primera fase asumieron el status de tipos de formas arquitectónicas para las generaciones posteriores. Los mismos enmarcan la teoría de la Arquitectura Moderna y los prototipos originales de ésta, recomendados por Le Corbusier -estructura independiente, planta libre, uso de pilastras en serie, terrazasjardín y fachada libre-, fueron legitimados socialmente (TAVARES FILHO, 2005; BONDUKI, 2011, p. 148-149).

El uso de nuevos materiales y tecnologías fueron apropiados por la Arquitectura Moderna y por los tipos en medio a las estructuras y formas antiguas, en cierta medida, lo que justifica la aceptación/asimilación de estos nuevos valores. Por lo tanto, las series de tipos funcionales pueden adquirir diversas características, 
de manera que, entre estas, las continuidades, los rompimientos y las coincidencias puedan sucederse incesantemente: nuevas exigencias sociales no necesariamente producen tipologías nuevas, funciones existentes pueden transformarse en nuevas tipologías, tipologías viejas pueden ocultar situaciones nuevas, viejas y nuevas tipologías pueden existir en una misma obra (TAVARES FILHO, 2005, p. 45). En general, se puede establecer un ejemplo práctico de esta "metamorfosis" basado en la inspiración de valorización de la historia colonial luso-brasileña en los enlaces continentales y en las tradiciones locales, donde el estilo neocolonial o mission style surgió en contra de los est ilos clásicos y ecléticos de líneas europeas que predominaban durante el siglo XIX, agregando formas hispánicas a la arquitectura neocolonial brasileña, como por ejemplo los rasgos del estilo neocolonial español con las arcadas en arco pleno macizas, columnas "torsas"33, revoque grueso en relievo con diseños informales que se asemejan vagamente a la decoración árabe (TAVARES FILHO, 2005, p. 111).

Además de la clasificación básica de los tipos considerados, bajo aspectos de morfología y función, conviene mencionar la visión de Giulio Argan (2000), para quien los tipos se clasifican en tres categorías, basadas: en la configuración general de los edificios -la planta central o longitudinal-, en los grandes elementos constructivos -coberturas planas o cúpulas-, y en los elementos ornamentales órdenes de columnas, elementos decorativos-. Para dicho autor, que rescató la ejecución de las nociones de tipo para el proceso de proyecto en la década del (19)60, reinterpretando los conceptos de Quatremére de Quincy de modo más pragmático, la concepción arquitectónica puede dividirse en dos etapas: el momento tipológico y el momento de establecer la forma. La noción de tipo permite al arquitecto ejecutar una caracterización del componente tradicional al asociar las conexiones culturales al contexto, así como le permite desarrollar su capacidad de invención, dada la versatilidad y gran potencial para la variación formal del concepto mencionado. (TAVARES FILHO, 2005, p. 12-20).

Por otro lado, un hito importante en el campo de la arquitectura en cuanto al desarrollo del concepto de función y su relación con la forma también se produce en la década del (19)60 con la influencia de Aldo Rossi (1966), el cual, en la ruta de su crítica al Modernismo arquitectónico publica La Arquitectura de la Ciudad, que

\footnotetext{
${ }^{33}$ En Portugués se refiere a columna entorchada o salomónica, que tiene el fuste contorneado en espiral.
} 
sintetiza y reinterpreta las discusiones dispersas y variadas hasta el momento en relación con el Modernismo (TAVARES FILHO, 2005, p. 39).

En arquitectura las funciones prácticas y estéticas son pasibles de relaciones dialécticas puesto que cuando la función estética se maximiza al extremo en el proyecto puede representar la antítesis de la funcionalidad (TAVARES FILHO, 2005, p. 40-41), algo que, en general, no ocurre con la Arquitectura Moderna, donde las funciones prácticas tienden a preponderar sobre las demás. Ya según Argan (2000), los principios de la organización espacial son seleccionados por el arquitecto durante el momento tipológico del proyecto, teniendo en cuenta las necesidades del programa, como las relaciones de proximidad y escala de dimensión entre los recintos, condiciones de la jerarquía espacial, acceso a la edificación, potencial de expansión de esta, ventilación y luz natural, así como la intención de aprovechar las vistas panorámicas. La Geometría, la topografía y las características generales del predio son restricciones locales que pueden desalentar o aumentar la elección de un tipo particular de organización espacial. Diferentemente de las relaciones geométricas, las relaciones topológicas no se basan en ángulos fijos, áreas o distancias que pueden medirse o definirse, sino en los principios de proximidad, separación, sucesión, continuidad y cierre (dentro/fuera). (TAVARES FILHO, 2005, p. 57).

La Topología, que es la rama de la Geometría que se basa en la noción de un espacio en el aspecto cuantitativo y en el que se aplican sólo las relaciones de posición de los elementos, es un instrumento teórico-metodológico más apropiado para el estudio de manifestaciones de agrupaciones urbanas espontáneas como las villas miserias y ciudades no planificadas, mientras que la Geometría sería la más adecuada para el estudio de los principios organizacionales de tejidos urbanos diseñados de modo planeado y, en escala arquitectónica, de los edificios según un proyecto geométricamente organizado (TAVARES FILHO, 2005, p. 58). Aunque a menudo el partido arquitectónico se origine de la combinación de estos principios de organización espacial, el arreglo sencillo de las relaciones geométricas no implica la existencia de unidades entre las partes constituyentes de un edificio. El concepto de unidad arquitectónica proviene de la analogía entre estas partes, obtenidas con el uso de materiales, detalles, proporciones y formas similares, y en ese sentido, se entiende que un conjunto sea tan destacado por sus partes cuanto más éstas sean similares entre sí. Si las partes arquitectónicas demuestran un alto grado de diferencias entre unas y otras, ni siquiera el uso de principios geométricos de 
composición claramente perceptibles transmitirá la idea de plenitud al objeto arquitectónico, que en este caso se parecerá a un conjunto de todos menores (TAVARES FILHO, 2005, p. 69).

A su vez, Bruno Zevi (1969), siguiendo el ejemplo de otros autores, discrepa sobre la importancia del uso del concepto de tipología con el argumento de que existe una gran variedad de factores que forman parte de la construcción de este concepto. En este sentido, teniendo en cuenta el énfasis en los procesos de comunicación y en la significación de la Arquitectura Postmoderna, el concepto, en su sentido tradicional, ha sido minimizado, como en Robert Venturi (apud MONEO, 1978), que reduce el tipo a la idea de imágenes de las cuales se establece la comunicación (TAVARES FILHO, 2005, p. 12-15).

Un ejemplo de tipología formal y funcional es el patio. A pesar de que el Movimiento Moderno en Arquitectura, oficializado en 1933 por la Carta de Atenas, se caracterice por la ruptura con modelos y tradiciones arquitectónicas que reconocen a la Historia como una valiosa fuente de inspiración, el patio, como un elemento del proyecto arquitectónico, se mantiene asimilado a los nuevos conceptos modernistas (TAVARES FILHO, 2005, p. 80). En términos generales, la mayoría de las casas con patio de la segunda mitad del siglo XX en la cultura occidental son el producto de adaptaciones circunstanciales de las antiguas casas con patios a las necesidades y limitaciones domésticas contemporáneas. El patio jardín comúnmente usado en la antigüedad se convierte en lo que hoy se llama "patio interno" o "jardín de Invierno". Sin embargo, nuevos experimentos se llevan a cabo en programas amplios de urbanización en países como Estados Unidos, Alemania, Suecia e Italia, donde las habitaciones están diseñadas en forma de " $\mathrm{L}$ " $\mathrm{O}$ en bloques cuadrangulares desarrollados alrededor de un patio (TAVARES FILHO, 2005, p. 81). En las zonas urbanas de alta densidad ocupacional, el patio puede contribuir en favor de una mejor calidad de vida ya que, en el centro de la residencia, se vuelve un espacio abierto y de carácter intimista: en días de clima agradable, es habitado como un área para sentar, en días fríos sirve como un elemento de relación entre el Hombre y la naturaleza y, durante todo el año, permite percibir los cambios de las estaciones, ofreciendo a los usuarios protección de intemperie, de ruidos externos y de curiosidad ajena (TAVARES FILHO, 2005, p. 84). En el centro histórico de la ciudad de Rio de Janeiro, el programa Novas Alternativas promueve desde 1997 la rehabilitación de edificios de patrimonio cultural considerados aptos para vivienda en un tejido urbano dañado por la falta de inversiones inmobiliarias. Las unidades de 
vivienda suelen ser más pequeñas y se adecuan mejor a los solteros y parejas sin hijos. El empleo de patios internos en estos casos, además de facilitar las condiciones básicas de habitabilidad, de ventilación e iluminación natural, contribuye a la viabilidad económica de las obras, ya que los costos de construcción se reducen considerablemente por la construcción de espacios descubiertos (TAVARES FILHO, 2005, p. 82).

Por fin, conviene recordar que, en un programa arquitectónico como el de una escuela, hay relaciones de correspondencia entre sus conjuntos funcionales y el nivel de compartimentación de sus partes, habiendo una relación directa con la naturaleza de las actividades realizadas en cada conjunto funcional en general y específicamente en cada parte. Tal correlación, a su vez, es independiente del tipo de organización espacial en la que se distribuye el programa (patio o tira) (TAVARES FILHO, 2005, p. 181).

Los usos de tipologías arquitectónicas en muchos de los proyectos de VIS, tanto en Brasil como en Argentina, suelen utilizarse masivamente sin ninguna preocupación con estos conceptos básicos y se vuelven modelos repetitivos sin cualquier vinculación con el contexto -cultural, climático o geográfico- en el que son inseridos. En Brasil, el caso más actual donde se puede verificar esto es en el PMCMV, donde ocurrió algo muy similar con lo ocurrido entre los años 1960 y 1980 con los proyectos de conjuntos habitacionales a cargo del BNH (BONDUKI, 2011, p. 158); y en Argentina, con los del FONAVI (GAITE, 2008, p. 39).

En Brasil, a pesar del alto nivel técnico alcanzado y de las herramientas disponibles principalmente a partir de los años (19)30 con los proyectos arquitectónicos aplicados en los conjuntos habitacionales de los IAPs, las ambigüedades y contradicciones en el contexto de las políticas públicas no permitieron que se alcanzara una producción significativa a larga escala para hacer frente a las progresivas demandas. Así, desde entonces y hasta hoy, el acervo inmobiliario de VIS producido en Brasil por el Estado fue siempre insuficiente en relación con el déficit habitacional. Sin embargo, gran parte de los equipos de profesionales involucrados con el tema abogaran sacar partido a larga escala de las premisas básicas propaladas por los portavoces de la Arquitectura Moderna, los cuales tuvieron en los CIAMs y eventos nacionales congéneres un fértil campo de discusión y diseminación "buscando compatibilizar 'economia, prática, técnica e estética' [...con el objetivo de...] viabilizar financeiramente o atendimento de 
trabalhadores de baixa renda, garantindo dignidade e qualidade arqutietônica" (BONDUKI, 2011, p. 134).

La búsqueda del lucro incesante, en especial por parte de las constructoras, desde entonces y hasta hoy, hizo prevalecer la vertiente económica sobre el atendimiento pleno de las demandas sociales. Predominan, con raras excepciones, proyectos arquitectónicos de calidad dudosa -monotonía- descontextualizados culturalmente del espacio urbano y físico donde fueron inseridos, los cuales, por causa de la masificación en serie y del empobrecimiento de la calidad de materiales utilizados, asociado al ínfimo esmero en la época de la ejecución de los referidos proyectos, hacen sobrar las quejas por gran parte de la población adquiriente de los inmuebles en cuestión.

\subsection{CONCLUSIONES}

Con la implantación de la Ley de Tierras en la segunda mitad del siglo XIX tanto en Brasil como en Argentina las elites buscaron resguardar para sí el monopolio de la propiedad del suelo, lo que se hizo evidente en Brasil durante la erradicación de los aglomerados y precarias habitaciones de los grandes centros urbanos a raíz de las epidemias. A causa del gran número de inmigrantes que llegaron a Brasil y Argentina a finales del siglo XIX así como por la cantidad de familias que a lo largo del siglo XX migraron desde el interior hacia las capitales en busca de una mejor oportunidad de vida impelidas por el proceso de industrialización, el Estado tuvo que movilizarse para responder a las reivindicaciones de estos grupos mejorando la asistencia sanitaria, interviniendo durante la carestía y el aumento de precios de los ítems básicos, controlando los valores de los alquileres incompatibles con los bajos salarios, etc., sin descuidar los intereses y privilegios de las clases medias y altas. En este contexto se crearon leyes e instituciones para reordenar el espacio urbano ejecutando campañas de vacunación, la erradicación de inmuebles que acarreaban riesgos a la salud pública, la apertura de calles, la implantación de sistemas de agua potable y cloacas, la financiación y construcción de conjuntos habitacionales para las clases medias y bajas, el congelamiento de los precios de los alquileres por más de una década y ejecutando inúmeros proyectos de grandes conjuntos habitacionales para operarios y empleados públicos, principalmente a partir de la década del (19)30, con el objetivo de achicar la brecha entre los beneficios sociales que el capitalismo 
industrial prometía y el persistente retraso de su llegada a los sectores de más bajos ingresos así como el restricto alcance del Estado de bienestar social que estratégicamente solo alcanzaba a una minoría apareada a las elites políticas y económicas.

Estos grandes proyectos de conjuntos habitacionales fueron implantados con sus tipologías arquitectónicas inspiradas en los presupuestos de la Arquitectura Moderna que rápidamente se instaló en este continente a través de los Congresos Panamericanos, cuyos anfitriones reproducían los postulados modernistas CIAMs además de enriquecedoras adaptaciones en las producciones locales.

En pleno siglo XXI el ideario modernista para democratizar la vivienda y promover el confort con las nuevas tecnologías arquitectónicas no se concretó en dimensión satisfactoria pese al interesante y promisor acervo técnico producido en aquellos Congresos, de relativa aplicación en la sociedad en general.

Mucho menos se consolidó el discurso del Estado de Bienestar Social, atropellado por el neoliberalismo que a partir de 1989 evidenció un capitalismo cada vez más globalizado que no perdió sino que exacerbó su esencia de espoliar a la sociedad, teniendo como artífices y cómplices en este perverso proceso a muchas de las elites económicas locales mancomunadas con los representantes políticos de turno en el poder y en sintonía con poderosas instituciones privadas y públicas de las tradicionales y emergentes potencias mundiales. Sin olvidar también la criminal distribución de renta que desde hace siglos se mantiene incólume en este continente y que vuelve a los ricos cada vez más ricos y a los pobres cada vez más pobres.

Para superar este estado inicuo se espera que las sociedades consigan promover una transformación profunda en la mentalidad de la gran mayoría de sus ciudadanos a través principalmente de la educación escolar con especial foco en la ética, la psicología social y la sociología en base a la pedagogía de la autonomía propuesta por Paulo Freire, para que, finalmente, a través del respeto y cumplimiento de las leyes en provecho de la sociedad como un todo y no sólo de aquellos pocos relacionados al poder y a la política, cesen sus malas creencias y prácticas que condenaba Max Weber (WEBER, 1966; SAINT-PIERRE, 2004).

En el contexto expuesto en este primer Capítulo y derivado de una herencia cultural colonial de espoliación de los más pobres por parte de las elites económicas mancomunadas con los agentes políticos bajo leyes y políticas públicas de dudosa eficacia para resolver el problema de vivienda de los sectores más pobres, tan arraigado en Brasil como en Argentina, se empiezan a elucidar las semejanzas y 
diferencias de los principales factores facilitadores y restrictivos para la aplicación de políticas públicas de VIS a través de la tipología de construcción en altura, así como se empieza a corroborar ya parte de la hipótesis de esta tesis sobre la influencia negativa de dicha herencia cultural en la aplicación de dichas políticas públicas.

Indudablemente por lo que se pudo traer de informaciones en este Capítulo 1 ha sido hartamente comprobado que entre el desarrollo del proceso histórico, cultural y socioeconómico de Brasil y Argentina hay muchas semejanzas que explican prácticas similares, ya sea por el aspecto positivo o negativo, según se constató en la aplicación de políticas públicas de VIS, conforme se preveía inicialmente en la hpótesis de esta tesis. Por el aspecto positivo en común a ambos países en esta área se comprobó, por ejemplo la diseminación de padrones constructivos basados en la arquitectura moderna así como de movimientos de expansión del estado de bienestar social en dirección a los sectores de bajos ingresos. Por otro lado, también se encontró en la documentación y bibliografía investigados tanto en uno como otro país que estas buenas intenciones estuvieron por largo tiempo del periodo estudiado bajo fuertes controles restrictivos -leyes, inaccesibilidad al suelo, prácticas discriminatorias y distribución de renta, principalmente- de grupos más poderosos y elitistas, lo que evidentemente significó en realidad el agravamiento del problema del déficit habitacional tanto en Argentina como Brasil. 


\section{CAPÍTULO 2}

\section{LAS ESTRATEGIAS APLICADAS EN BRASIL, ARGENTINA Y URUGUAY PARA}

VIS

\section{1 - Las cooperativas entran en acción}

El arquitecto Sebastián Miguel (2010) defiende la idea de autoconstrucción por los propios moradores bajo orientación técnica y administrativa del Estado y de las asociaciones comunitarias como una forma de gestión en que el ciudadano se ve protagonista de la solución de un tema crucial para su existencia y la de su familia: el techo (MIGUEL, 2010, p. 102-103).

La institución social de la cooperativa surge como un mecanismo de enfrentamiento de los inconvenientes del capitalismo -explotación, precios extorsivos y desempleo, entre otros-. Un ejemplo pionero fue una asociación de consumo, la Sociedad de los Probos Pioneros de Rochdale, creada en 1844 por 28 operarios, entre ellos algunos tejedores, en Manchester, Lancashire, Inglaterra. A pesar de que iniciativas parecidas ya habían aparecido antes, esta sociedad se destacó por lanzar los principios fundamentales que dieron origen a las cooperativas de todo el mundo, inspirados en los presupuestos socialistas de Robert Owen, Charles Fourier, JeanBaptiste Godim y Ferdinand Lasalle, entre otros. (FERREIRA y MORAES apud FERNANDES y SOUZA, 2004, p. 283). En Brasil, una de las primeras experiencias de la que se tiene noticia fue la del francés Jean Maurice Faivre, el cual lideró un grupo de inmigrantes europeos en la fundación de la colonia Tereza Cristina en el estado de Paraná, en 1847, de bases cooperativistas que, a pesar de haber durado solo 11 años, tuvo la importancia de haber divulgado el movimiento cooperativista en el país (ANTONELLI, 2013). La participación de las cooperativas fue fundamental en la solución del déficit habitacional en Europa con anterioridad al período de welfare state, y para esto fue esencial la presencia de sindicatos y asociaciones populares (MARICATO, 2011, p. 120).

Representantes de importantes sectores financieros y de la construcción, entre otros, no manifestaron interés en la maduración y expansión del movimiento cooperativista. A lo largo del tiempo fueron interpuestos varios obstáculos por estos representantes en la producción edilicia para restringir el avance de las cooperativas de los sectores sociales populares, lo que explica, entre otros factores, la poca expresividad de estas cooperativas en los indicadores económicos hasta hace poco 
tiempo, aunque ha habido mejoras en ese sentido últimamente, conforme constatan Ferreira y Morais (apud FERNANDES y SOUZA, 2004, p. 284-286):

Quanto ao estágio de desenvolvimento do cooperativismo no Brasil, comparando com o de outros países, os dados da Aliança Cooperativa Internacional - $\mathrm{ACl}$, referentes à participação da população, mostram a baixa adesão ao sistema. Enquanto, na França, 25\% da população é cooperativada, o que significa o envolvimento de 10 milhões de pessoas, nos Estados Unidos 22\% (50 milhões), na índia 10\% (70 milhões) e na Argentina 20\% (6 milhões), no Brasil, menos de $5 \%$ do total da população faz parte do sistema cooperativista.

No entanto, vários são os indícios de que a tendência é de reversão deste quadro. Atualmente [ano 2000], o cooperativismo brasileiro vem se fortalecendo e ganhando espaço na economia nacional. São mais de seis mil cooperativas, com um número superior a seis milhões de cooperados, responsáveis por 5\% do PIB [Produto Interno Bruto] Nacional. (FERREIRA y MORAIS apud FERNANDES y SOUZA, 2004, p. 284-285)

Según datos divulgados por la Organização das Cooperativas Brasileiras (OCB) y por la Organização das Cooperativas do Estado de São Paulo (OCESP), se constata que el número de afiliados en Brasil prácticamente duplicó en los últimos dieciséis años, pasando de más de seis millones en 2000 a 12.721.177 en 2016, mientras que, en el mismo período, el número de cooperativas brasileñas ascendió apenas de 6.000 a 6.751 (Tabla 2.1); de este universo, según la OCESP, las de viviendas no llegan a 300 en todo Brasil. En Argentina (Tabla 2.2), según datos del Instituto Nacional de Asociativismo y Economía Social (INAES), de las 16.059 cooperativas existentes en 2001, el 19\%, unas 3.060, corresponden a las de tipo Vivienda y construcción, número que se ve reducido en 2014 a 1.787 sobre un total de las 28.853 cooperativas, lo que representa un 6,2\% (VUOTTO, 2014).

Tanto en Brasil como en Argentina y otras partes del continente es extremamente difícil pensar en rever, flexibilizar o romper el intocable conceptodogma de la propiedad privada absoluta del suelo y del inmueble construido, principalmente cuando para validar dicho concepto "a fuego y hierro" se desconsideren las más fundamentales necesidades de la ciudadanía: el techo y el cultivo. La legislación es muy refractaria a facilitar el permiso de construcción colectiva, asegurando así el derecho de la propiedad individual del inmueble, excepto mediante la propiedad colectiva que convalide el concepto de producción social sin perjuicio del usufructo individual de la vivienda de quien haya contribuido con la misma. Ya que, en la óptica cooperativista, la unidad habitacional en cuestión 
deja de ser vista como "un objeto-mercancía que se pueda negociar libremente en forma individual” (RODRÍGUEZ, 2009). Esta lógica de la propiedad colectiva admite la existencia del mercado, y las cooperativas actuarán junto a éste como un submercado, aunque con sus reglas específicas; Rodríguez (2009) entiende que esta sencilla problematización de las formas de propiedad implica un cambio cultural, pues:

\begin{abstract}
Al proponer determinados arreglos institucionales, cualitativamente se genera un campo de tensión con aquellos otros arreglos que son hegemónicos. En este sentido el IVC le ha planteado a las cooperativas del MOI que: i) la Ley Federal de Vivienda de 1994 no permite la propiedad cooperativa; ii) el estatuto del IVC sólo contempla como destinatarios a las personas. iii) el Código Civil es un obstáculo insalvable porque ser usuario no es suficiente garantía para resguardar la inscripción del derecho individual... Sin embargo la Ley Nacional de Cooperativas y el Estatuto Tipo de Cooperativas de Vivienda plantean como una opción el sistema de usuarios. También han existido en la historia argentina, cooperativas de usuarios, como Cooperativa de Vivienda Rosario (1957), sustentadas en operatorias del Banco Hipotecario Nacional, como la resolución 66 del 7 de noviembre de 1958. El debate así generado expresa las dificultades político-ideológicas para abrir opciones ante un hito estructurante y arraigado de nuestras creencias y valores más profundos, como es la propiedad privada individual. (RODRÍGUEZ, 2009, p. 178).
\end{abstract}

De esta forma, en Argentina, entre los participantes del MOI:

[...] se fue constituyendo la noción de que la propiedad colectiva es la expresión jurídica que se corresponde con el proceso colectivamente desarrollado por las cooperativas autogestionarias para acceder a la vivienda y consolidar el derecho a la ciudad. No hay ganancia individual sino apropiación colectiva, uso y goce de un producto habitacional urbano, al cual no se habría podido acceder individualmente a través del mercado. (RODRÍGUEZ, 2009, p. 178), (El itálico está según Rodríguez).

Un importante avance para sobrellevar este problema de la cuestión de la propiedad del suelo se dio en las discusiones de moradores de la Villa 31 al implantarse un régimen de copropiedad de los lotes ocupados por varias familias. Esta experiencia puede servir de estímulo a la legislatura edilicia de la ciudad para resolver una realidad tan frecuente en comunidades de VIS (CASTRO, 2010, p. 154).

En este ámbito de discusión acerca de la regularización de la propiedad, la arquitecta Nirce Saffer Medvedovski (apud, ABIKO e ORNSTEIN, 2002, p. 148-149), 
basada en su experiencia de trabajo relacionada a la regularización del suelo de 1.788 unidades habitacionales del Conjunto Habitacional Lindóia de la ciudad de Pelotas/RS, con cerca de cinco mil habitantes, sugiere que la regularización de VIS se realice respaldada por la figura jurídica de Condominio debido al desfasaje entre los postulados de esta figura y la realidad de tierras existente. Inherente al Derecho Privado y reglamentado por el Derecho Civil, este instrumento jurídico no se adecua a la "delineación" del Derecho Urbanístico, que se fundamenta en el Derecho Público.

Tabla 2.1 - Tipos de cooperativas registradas en Brasil en 2016

\begin{tabular}{|c||c||c|}
\hline \multicolumn{1}{|c||}{ Ramo } & Cooperativas & Cooperados \\
\hline \hline Agropecuario & 1.557 & 938.610 \\
\hline \hline Consumo & 169 & 2.940 .622 \\
\hline \hline Crédito & 927 & 7.151 .306 \\
\hline \hline Educacional & 270 & 58.983 \\
\hline \hline Especial & 6 & 284 \\
\hline \hline Habitacional & 293 & 111.227 \\
\hline \hline Infraestructura & 131 & 997.748 \\
\hline \hline Mineral & 83 & 8.483 \\
\hline \hline Producción & 237 & 5.837 \\
\hline \hline Salud & 819 & 219.661 \\
\hline \hline Trabajo & 942 & 169.102 \\
\hline \hline Transporte & 1.294 & 117.724 \\
\hline \hline Turismo y Recreo & 23 & 1.590 \\
\hline Total & $\mathbf{6 . 7 5 1}$ & $\mathbf{1 2 . 7 2 1 . 1 7 7}$ \\
\hline
\end{tabular}

Fuente: OCESP/OCB, 2017.

Tabla 2.2 - Tipos de cooperativas registradas en Argentina en 2001 y 2014

\begin{tabular}{|c|c|c|c|c|}
\hline Cooperativas/Años & \multicolumn{2}{|c|}{2001} & \multicolumn{2}{c|}{2014} \\
\hline & $N^{\circ}$ & $\%$ & $N^{\circ}$ & $\%$ \\
\hline Agropecuarias & 2236 & 14 & 1297 & 4,5 \\
\hline Consumo & 252 & 1 & 195 & 0,1 \\
\hline Crédito & 341 & 2 & 290 & 1 \\
\hline Provisión & 1544 & 10 & 1582 & 5,5 \\
\hline Seguros & 51 & 0 & 19 & 0,7 \\
\hline Servicios públicos & 1889 & 12 & 1167 & 4 \\
\hline Trabajo & 6686 & 42 & 22516 & 78 \\
\hline Vivenda y construcción & 3060 & 19 & 1787 & 6,2 \\
\hline Total & 16059 & 100 & 28853 & 100 \\
\hline
\end{tabular}

Fuente: adaptación a partir de Vuotto (2014). 
Estudios demuestran que, mundialmente, la tasa de producción habitacional por cooperativa es de alrededor del $6 \%$ y el $13 \%$ del total construido. En Latinoamérica, Uruguay, desde la década del (19)60, se destacó bajo varios aspectos de este proceso de cooperativas de viviendas destinadas a los sectores de bajos ingresos, llegando a exportar know-how entre sus vecinos continentales, demostrando el éxito de su experiencia en este tipo de proceso constructivo.

A pesar de que las cooperativas de habitación tienen que sobrevivir en un medio capitalista muy hostil donde el lucro a corto plazo es el objetivo principal de los accionistas, y de que tienen que enfrentar reglas financieras muy duras -altos intereses para préstamos monetarios y diversos tipos de impuestos-, un tratamiento, en Brasil, equivalente al aplicado a las constructoras, aun así, las cooperativas consiguen construir inmuebles con valores "considerados baixos, preservando-se o preço de custo, o que representa $20 \%$ a $30 \%$ abaixo do valor de mercado [... sin olvidarse de que] há questionamentos quanto à qualidade do produto final" conforme constataron en Natal, capital de Rio Grande do Norte, Ferreira y Morais (apud FERNANDES y SOUZA, 2004, p. 296).

\section{2 - La participación de las constructoras privadas}

Basados en estudios de caso, autores como Davey (1992) argumentan que son aspectos positivos de la construcción de iniciativa privada: la capacidad de crear y deshacer la concentración de poder, la capacidad de movilizar recursos extras de capital y de know-how, una mayor eficiencia por cuenta de la competencia de mercado, una mejor versatilidad y propensión a reducir perdidas y trabajo improductivo; promover recompensas por performance, la libertad para poder actuar sin rígidos procedimientos burocráticos, la habilidad para actuar con producción a larga escala, todo esto debido a estar presentes en varias jurisdicciones. Estos argumentos refuerzan el imaginario de que los servicios privatizados son eficientes por que poseen una administración rigurosa, una flexibilidad para satisfacer la demanda, calidad de productos y servicios, bien como un estricto control de costos (WERNA, 2001, p. 32-33).

Sin embargo, es sabido que las empresas de iniciativa privada se encuentran con dificultades para obtener incentivos e inversiones a largo plazo, así como para cobrar luego tales inversiones, lo que depende de conseguir establecer niveles de 
precio adecuados al mercado y de alcanzar la demanda necesaria para justificar tales inversiones.

Además, otros autores señalan el problema del control de los servicios por parte de la iniciativa privada, como refiere el argentino Pedro Pirez (1994), que sostiene que en su país la privatización trajo consigo el grave inconveniente de la concentración de la riqueza en manos de cuatro o cinco importantes grupos, algunos de los cuales vinculados a empresas extranjeras, lo que produjo la exclusión de los sectores de bajos ingresos de la participación de los bienes producidos (WERNA, 2001, p. 33).

También, desde el punto de vista político, la privatización de servicios tiende a acarrear la reducción de la transparencia, la pérdida de activos cuando la privatización se realiza a precios por debajo del mercado, el riesgo de que las empresas no den la infraestructura ni ofrezcan los servicios en áreas de baja renta, motivo por el cual los gobiernos tienen que mantenerse competentes y eficaces en vigilar y constatar que las empresas privadas actúen con responsabilidad y calidad en la provisión de los servicios (WERNA, 2001, p. 34-35).

\section{3 - Redes institucionales (Estado, ONGs, Asociaciones, Academia)}

Las Organizaciones no Gubernamentales (ONGs) pasaron a tener una actuación mayor en Latinoamérica a partir de los años (19)60 y (19)70 ya que los países desarrollados y organizaciones internacionales evitaban establecer contacto directo con los gobiernos autoritarios y antidemocráticos. Estas organizaciones, también conocidas como del tercer sector, generalmente están direccionadas a los sectores de baja renta ya que, con raras excepciones, los gobiernos tienden a ocuparse más de los sectores de mayor poder adquisitivo (WERNA, 2001, p. 37-38).

Desde Chile, en 1997, se expande a otros países latinoamericanos -Uruguay, Argentina, México, Perú, El Salvador y Colombia- la interesante idea de jóvenes universitarios preocupados por las familias de bajos ingresos en materia de construcción de viviendas de emergencia a través de la ONG Un techo para Chile, que se expandió por el continente bajo el slogan "Un techo para mi país" (MIGUEL, 2010, p. 106).

Generalmente las ONGs son criticadas aludiendo que la tasa de administración tiende a ser más costosa que los servicios que prestan, lo que no se sustenta según los números analizados, que comprueban que las tasas cobradas 
por el $76 \%$ de ellas están por debajo del 15\%, mientras que en el mercado están por debajo del $20 \%$, y atacando el nivel de legitimidad y credibilidad de las mismas, una vez que, en su gran mayoría, dependen de recursos exteriores, no siendo capaces de sustentarse dentro del propio país. Entre críticas y aciertos su número es cada vez mayor en Latinoamérica y una de las razones señaladas para su aumento se debe a la predisposición de las instituciones no gubernamentales a atraer recursos externos (WERNA, 2001, p. 38-39). Se debe considerar también dos importantes aspectos que se han evidenciado actualmente en Latinoamérica: la baja productividad frente a la demanda en lo que se refiere a cantidad de unidades habitacionales en áreas de baja renta, así como el comprobado desinterés en dar respuesta a este problema, una vez que muchas de estas instituciones incurren en prácticas ética y legalmente condenables.

En cuanto a la participación de la comunidad en la propia construcción de sus habitaciones (autoconstrucción y autogestión) hay dos posicionamientos que dirigen la discusión: los que consideran importante y motivan la participación ya que la consideran positiva en la mejoría de la calidad del producto final y en la reducción de costos, así como en la sociabilización de la familia y la vecindad, y los que ven una sobreexplotación por parte del Estado y del sistema capitalista que no favorecen la adquisición de la propia habitación a través de precios accesibles de los inmuebles obligando a los sectores de más bajos ingresos a invertir tiempo y energías de descanso y de recreo además de sus propios escasos recursos para asumir los costos sin ninguna contrapartida del Estado ni de los sectores patronales. Situación que se vuelve más preocupante cuando es bien sabido que en países en vías de desarrollo -con excepción de Singapur, China y Vietnam además de otros estados socialistas-, el Estado ha participado, en media, con solo un $10 \%$ del stock de viviendas construidas (WERNA, 2001, p. 40-42).

Los investigadores sostienen que además del tan bajo índice de actuación del Estado se manifiestan otros factores negativos como la incompatibilidad del proyecto con las condiciones geográficas y culturales, la inadecuada localización, la baja calidad de construcción, la falta de cumplimiento de metas y los altos costos, lo que, en conjunto, acaba por obligar a los sectores de más bajos ingresos a improvisar una vivienda incluso por vía ilegal (WERNA, 2001, p. 69).

Esta lógica mercadológica está subyacente al presupuesto de que: 
[...] em qualquer época a forma da estrutura e sua relação com os agentes é determinada pelo equilíbrio entre a necessidade de o Estado de salvaguardar os interesses estratégicos do modo dominante de produção como um todo, e as necessidades dos agentes individuais envolvidos nesse setor da economia. (WERNA, 2001, p. 49)

Esta lógica mercadológica se puede observar en las tres comunidades investigadas en Salvador bajo la concepción del fenómeno de las "redes de solidaridad", también constatada por la antropóloga Cravino (2014) en varias villas de Buenos Aires, por Pedro Abramo (2003 y 2004) en las favelas de Rio de Janeiro, y por Nelson Baltrusis (2004 y 2005) en las de São Paulo, como por ejemplo la existencia de parentesco entre las familias de un mismo conjunto habitacional, lo que sugiere que dichos vínculos ya existían en la comunidad precedente. Hay relatos de moradores de que las informaciones y apoyos mutuos entre algunos de ellos fueron fundamentales para la obtención de la vivienda en el complejo habitacional. Estas redes se constituyen como uno de los principales factores de lo que Abramo (2003) denomina de "capital locacional", también existente en las tratativas realizadas en la población que circula en el mercado informal inmobiliario (CRAVINO, 2014, p. 135-178). A pesar de que no haya sido éste el objeto de esta investigación, esta situación se hizo evidente en algunos momentos en las tres comunidades analizadas en Salvador, cuando algún encuestado, al inicio o durante el transcurso de la encuesta, informaba que vivía en el departamento con el cónyuge y sus hijos pero que la titularidad del inmueble era de uno de los padres que lo había cedido temporaria o definitivamente en préstamo. Sin embargo, el fenómeno del "préstamo" dentro del círculo de la familia fue mucho menos respondido en las encuestas de las comunidades de Brasil.

\section{4 - Revisión de la Legislación (Estatuto da Cidade, PDDU, ZEIS, LOOUS) ${ }^{34}$}

La inflexibilidad de la legislación edilicia en la mayoría de las ciudades de Brasil, influenciadas por la lógica del planeamiento urbano funcionalista, constante en el Estatuto da Cidade, impide que las construcciones financiadas por el Estado y destinadas a la habitación puedan incluir espacios destinados a otros usos, y que

\footnotetext{
${ }^{34}$ En este apartado y en lo que toca a la realidad de la propiedad de tierras en América Latina, en especial de Argentina, muchas informaciones fueron aportadas por las profesoras y estudiantes de varios países de este continente y de España en la plataforma de los fórums del curso EAD "Gestión de los Mercados de Suelo Urbano" realizado entre el 5 de octubre y el 29 de noviembre del 2009 por el Programa para Latinoamérica y el Caribe del Lincoln Institute of Land Polifcy.
} 
sólo pueda considerarse pasible de uso para función social de la propiedad las áreas del inmueble no edificadas (MARICATO, 2011, p.147, 189). Semejantes inconvenientes de tenor legislativo que contrastan con los intereses de los sectores de más bajos ingresos también pueden encontrarse en Argentina, como por ejemplo el que surge a partir de la Ley 962 de $2002^{35}$, que impone el uso de ascensor en toda construcción con más de dos pisos además de la planta baja, aunque la mayoría de los 225 moradores argentinos encuestados (ver sección 5.3.1: Perfil sociodemográfico de las comunidades de CABA) apruebe la promulgación de la ley. La cuestión que hay que analizar es que, más allá del confort en relación con la accesibilidad, la Ley restringe la oferta de un mayor número de viviendas para los sectores de más bajos ingresos una vez que encarece no solo los costos de los proyectos habitacionales sino también los de pos-ocupación, donde está comprobado que el mantenimiento de tales estructuras se vuelve permanente foco de problemas para los moradores. Problema que los moradores no llevaron en consideración o sobre el que no quisieron posicionarse cuando se manifestaron sobre el tema; cuestión que merece un estudio más profundo en el futuro.

Desde la implantación en Brasil de los primeros conjuntos en altura al final de la década del (19)30 por los IAPs, la VIS viene siendo entorpecida por los sectores que elaboran y fiscalizan las normas edilicias -loteos, tasas límites para FOS y FOT, cielorraso mínimo, disposición de las vías de circulación etc.-, cuando lo que hubieran debido hacer para este tipo particular de construcción era flexibilizar las exigencias legales referentes a estos tópicos con el objetivo de viabilizar su construcción (BONDUKI, 2011, p. 159), en los casos en que esto sea viable, sin comprometer, por supuesto, la seguridad, la asequibilidad y el confort principalmente. No bastaron las exigencias de la legislación que restringían la capacidad de construir habitaciones para la población más pobre, la clientela de los IAPs también tuvo que enfrentar una discusión tan antigua como actual en Brasil, de la cual, como se sabe, Argentina no está exenta, discusión que se vio reforzada con lo que admitió el ingeniero Ulysses Hellmeister (2011), uno de los profesionales más actuantes del departamento técnico de ingeniería de IAPC:

\footnotetext{
${ }^{35}$ Ver en la pág. 398 de DA el extracto de la Ley 962 de accesibilidad sancionada el 05 diciembre 2002 y promulgada el 2 de enero de 2003, publicada en Diario Oficial de la Ciudad de Buenos Aires $\mathrm{N}^{\circ} 1607$ del 13 de enero de 2003, la cual se encuentra en vigencia en la CABA desde el 23 mayo 2003 y que actualizó la Sección 4 del Código de Edificación de la CABA.
} 
O preço elevado dos terrenos e sua urbanização, somados aos altos custos da mão-de-obra e materiais de construção tornam a habitação praticamente inacessivel aos trabalhadores em geral. Para contornar essa situação é necessária a redução do custo das obras, o que só é possível com a padronização dos materiais de construção em série, industrialização e o provimento de indústrias próprias (dos institutos). (HELLMEISTER apud BONDUKI, 2011, p. 160)

Este embrollo aún no resuelto es muy importante en la actualidad, por lo que merece ser destacado. Según Celso Furtado, uno de los pioneros del CEPAL y de la teoría del subdesarrollo económico, el proceso de habilitación ya sea a través de títulos de propiedad o por inserción calificada en los procesos productivos, se encuentra bloqueado. $\mathrm{Y}$ explicita que:

[...] isto é evidente com respeito a populações rurais sem acesso à terra para trabalhar ou devendo pagar rendas escorchantes para ter acesso. O mesmo se pode dizer das populações urbanas que não estão habilitadas para ter acesso à moradia. As instituições que permitem a concentração em poucas mãos da formidável valorização das terras urbanas respondem pela miserabilidade de grandes massas da população. A pobreza em massa, característica do subdesenvolvimento, tem com frequência origem numa situação de privação original do acesso à terra e moradia. Essa situação estrutural não encontra solução através dos mecanismos de mercado. (FURTADO apud ARANTES, VAINER y MARICATO, 2013, p. 33)

A finales de la segunda década del siglo XXI da vergüenza en un Brasil con tantas potencialidades, materiales e intelectuales, tener que enfrentar todavía esa vieja discusión:

Hoje, em termos tecnológicos, pode-se recorrer à chamada teoria do desenvolvimento endógeno - e não mais às categorias albertianas. Do ponto de vista econômico, o que diz a teoria? Que endogenizar a criação de tecnologias tem sido, historicamente, um dos fatores mais importantes de desenvolvimento econômico das nações. Para tanto, o desenvolvimento tecnológico requer pesquisas de processos, materiais e produtos que acelerem a economia. Também é sabido que a decisão de investir em pesquisa tecnológica é, sobretudo, uma decisão política, pois a mão invisível do mercado, isoladamente, nunca se dispõe a fazê-lo.

No caso da arquitetura e do urbanismo, voltados para as necessidades sociais, é insensato pensar na evolução tecnológica da construção como uma simples resposta do mercado. Sobretudo quando se sabe que o acesso à moradia de qualidade nas cidades, por parte da população pobre e desassistida, encontra no mercado imobiliário urbano formal um fator de impedimento e nunca um meio para viabilizas suas demandas. Cumpre ainda hoje ao Estado, e não ao mercado, atuar diretamente na questão do acesso à terra e na 
promoção de pesquisa tecnológica, bem como na distribuição da renda. Temas em franco desuso na era pós-modernista, mais afeita ao prazer dos mais aquinhoados. (SAMPAIO, 2010, p. 240)

Con relación al nudo gordiano de la problemática habitacional, Sampaio (2010, p. 242) vaticina, yendo directo al punto de la cuestión, reproduciendo las palabras del profesor Paulo Bruna (1976), para quien aún no se encontró, o no se quiso encontrar, el camino para la salida del problema de la falta de vivienda para los sectores de más bajos ingresos de Brasil y de Latinoamérica:

[...] que os maiores obstáculos da industrialização da construção não são de ordem técnica, na elaboração dos projetos, fabricação e montagem dos organismos arquitetônicos, mas de caráter econômico, administrativo e político. Estes somente poderão ser superados pela compreensão das vantagens sociais que a industrialização traria ao conjunto do desenvolvimento brasileiro. (SAMPAIO, 2010, p. 242)

A su vez, en Argentina, esta preocupación también continua en el medio académico con la misma intensidad, según constata Felix Bombarolo (2004):

Desde mediados del siglo XX, los pueblos de América Latina se enfrentan cotidianamente con dos preguntas..., medulares, e íntimamente relacionadas...: ¿cómo evitar el sufrimiento de cerca de 250 millones de personas pobres, que viven en el continente en condiciones de miseria y exclusión?, y paralelamente...: ¿cómo hacer para que una región tan rica en recursos humanos y naturales como en cultura, pueda crecer y avanzar por un camino que implique bienestar para todos? (BOMBAROLO apud LOMBARDI, 2004, p. 23) (La negrita es de Bombarolo)

Inspirado en lo que se había hecho en Argentina por motivos análogos, una de las primeras importantes medidas por parte del Estado brasileño para afrontar el creciente aumento de alquileres y de la reducción de la oferta a inicios del siglo pasado por causa de la Primera Guerra Mundial y las agitaciones sociales fue la promulgación en 1921 de la primera Ley del Inquilinato mediante el Decreto 4403/21, que duró hasta diciembre de 1928, cuando se revocó la Ley con el restablecimiento del Código Civil. El código permitía que el propietario usase como bien entendiera su propiedad, incluso no alquilándola cuando no le fuera conveniente (BONDUKI, 2011, p. 211-212).

Tras la persistencia del problema, tanto de los inquilinos como de los propietarios de las habitaciones, incluida la clase media, el gobierno federal 
brasileño pasó a intervenir más firmemente a partir de la década del (19)40 con una serie de Decretos-Ley, iniciando por el $N^{0} 4.598 / 42$, que, en teoría, intentaban proteger a los inquilinos de las constantes amenazas de desalojo por parte de los propietarios, que eran ingeniosos en crear estratagemas para que les fueran devueltos los inmuebles de inmediato cada vez que el lucro no fuera conveniente. Bonduki (2011) se pregunta si la ambigüedad de acciones del gobierno de Vargas no encerraba una estrategia de doble sentido: por un lado, la de mantener su lógica populista y desarrollista iniciada en 1930, protegiendo a los inquilinos con el congelamiento de los alquileres y así, en el plano político, ganar el apoyo de las masas, y, por el otro, en el aspecto económico, induciendo a los propietarios capitalistas a que invirtieran sus recursos en los sectores vitales de la industria dada la escasa rentabilidad de alquiler de los inmuebles (BONDUKI, 2011, p. 213-218). Sagaz como era Vargas, es muy probable que ambas estrategias hayan sido puestas en curso, como supone Bonduki (2011, p. 220-221; 227; 234, 242; 244-245). Táctica que continuó vigente hasta recientemente en Brasil de la mano de otros gobernantes al querer ganar el apoyo político de todas las clases. En Argentina, Perón procedió de forma muy parecida; con relación a Vargas, tuvo más éxito con las masas urbanas, motivo por lo cual, muy probablemente, aún hoy es más recordado por sus discípulos que su coetáneo brasileño.

La prevalencia de la Ley del Inquilinato en Brasil por más de una década, con el inconveniente corolario social, a partir de la década del (19)40, en especial para los sectores de más bajos ingresos, cuyo problema de vivienda aumentaba, sin sombra de duda fue uno de los motivos de la proliferación de las favelas en los centros urbanos del país, única solución para las familias de bajos ingresos forzadas a la autoconstrucción en condiciones muy adversas de calidad de vida bajo varios aspectos: salud, educación, alimentación, recreo, etc. (BONDUKI, 2011, p. 264).

En Brasil, después del surgimiento del proceso de "tugurización" de los principales centros urbanos a inicios del siglo XX, fue con la Ley del Inquilinato, a partir de la década del (19)40, que el fenómeno tomó proporciones como nunca se había visto. Con el agravamiento de las dificultades para obtener un techo, buena parte de la población puso en práctica lo que Bonduki (2011) denominó auto emprendimiento de la morada popular:

[...] uma série de expedientes de construção de casas à margem do mercado formal e do Estado [...] baseado no trinômio loteamento periférico, casa própria e autoconstrução [...] predominando em São 
Paulo e em grande parte das cidades brasileiras, tornando-se a forma mais comum de moradia dos setores populares. (BONDUKI, 2011, p. 281)

Hasta hoy este ha sido el mecanismo más utilizado en lo que se refiere a la solución habitacional, incluso para la clase media, pese a las políticas públicas que a lo largo de las últimas décadas se vienen implementando.

En contra de lo que establece el Estatuto da Cidade en cuanto a que las medidas de intervención pública abran espacio para consultas y para la atención del interés social, a finales de diciembre de 2007 se aprobó la Ley No. 7400/2008 en la Câmara de Vereadores de Salvador, que vino a ser el nuevo Plano Diretor de Desenvolvimento Urbano, revisión del anterior PDDU de 2004, pieza clave en las propuestas de configuración territorial de la Ciudad. Este nuevo plano aprobó el aumento de los FOT y FOS en trechos de la costa marítima de Salvador a favor de la especulación inmobiliaria volcada a los sectores de clase media y media alta ignorándose la argumentación técnica en contrario presentada por diferentes entidades afines a la ingeniería, arquitectura, urbanismo y otras, relacionadas a la infraestructura urbana, la creación de áreas públicas y los estudios de impacto en áreas de protección cultural, ambiental y paisajística. Con la sanción del intendente en febrero de 2008, bajo fuerte presión en los medios de comunicación por las denuncias de dichas entidades, el polémico PDDU llegó al Supremo Tribunal Federal y pasó por revisiones. ${ }^{36}$ Sin embargo, hubo un aspecto positivo en el nuevo PPDU: la transformación de las 33 Áreas de Proteção Sócio-Ecológica (APSE) creadas por la Ley 3.592 del 16 de noviembre de 1985 en 116 Zonas Especiais de Interesse Social (ZEIS), transformación que se ratificó por la Lei de LOUOS de 2012, según lo que determinaba el Estatuto da Cidade de 2001, Lei 10.257/2001 (OLIVEIRA, 2013, p. 165-166).

En Salvador, como en el resto de Brasil y Latinoamérica, por razones culturales y de diferentes intereses en juego, no es nada fácil para un investigador llegar al fondo de la cuestión del suelo y otros problemas vinculados a las VIS.

Para combatir la especulación inmobiliaria instigada por las elites del sector y las grandes constructoras el Estatuto da Cidade establece el mecanismo jurídicofiscal de la OODC, Solo Criado, y el de la Transferência do Direito de Construir,

\footnotetext{
${ }^{36}$ Ver Postigo (2008): Salvador, escândalo da votação na Câmara de Vereadores.
} 
entre otros ${ }^{37}$, además de los ya citados anteriormente. Estos dos mecanismos de control de la retención/producción del suelo urbano, sumados a los otros y bien administrados, pueden ser capaces de inhibir la especulación de la tierra urbana bien como ampliar el stock de suelo urbano destinado a la producción de loteos populares y de construcción de estructuras públicas que atiendan a un mayor número de habitantes y menor costo para la sociedad.

Un importante mecanismo que, si puesto en práctica, contribuiría mucho bajo varios aspectos para el tema de VIS, es el de la Cota de Interés Social, que establece que grandes emprendimientos privados inmobiliarios, como condominios, sean obligados a colaborar con la construcción de VIS mediante alguna de las siguientes opciones:

[...] produção de unidades de habitação popular no mesmo terreno do empreendimento em questão; transferência não onerosa em favor do município de imóvel próximo ao empreendimento para fins exclusivos de habitação de interesse social; ou depósito ao Fundo Municipal de Habitação de Interesse Social (FMHIS). (ABDALLA, 2015)

Con este mecanismo se espera también la convivencia entre personas de segmentos sociales diferentes, lo que se supone positivo según algunos entienden, como por ejemplo Marco Aurélio Becker, director de programas especiales de la Companhia de Habitação (COHAB) de Curitiba (ABDALLA, 2015).

Un ejemplo muy característico y que elucida el fenómeno de "las buenas intenciones en crearse modernas e interesantes leyes de alcance social pero de dudosa eficacia de aplicabilidad en favor de los sectores de más bajos ingresos" proviene de una ciudad que hace décadas se volvió referencia nacional en planeamiento y ordenamiento urbanos: Curitiba, capital de la provincia de Paraná, con relación a la revisión entre 2014 y 2015 de su PDDU del 2004, donde el IPTU Progressivo, la Cota de Habitação Interesse Social y la diversificación de tipologías de ZEIS, que son tres de los más importantes puntos de interés para los sectores de más bajos ingresos, fueron dejados sin efecto:

O Plano [de 2014] continua a ser genérico, esvaziado de aplicabilidade. Ele leva, novamente, para fora do Plano, a decisão

\footnotetext{
${ }^{37}$ Por ejemplo, el Parcelamento, Edificação e Utilização Compulsórios, la Desapropriação com Pagamento em Títulos da Dívida Pública, el Direito de Preempção, y el Estudo de Impacto de Vizinhança, que son temas estructurales del Estatuto.
} 
sobre a conformação do território, sobre a política urbana e sobre a tão sonhada justiça sócio-espacial. A minuta do projeto de lei faz previsão de elaboração de 16 leis especificas para regulamentar os institutos que dispõe. Ou seja, exatamente nos temas que podemos dizer que o Plano avança, pois aborda de forma mais extensa estas temáticas, ele deixa a decisão dos critérios de sua aplicação para lei específica, deixando esvaziado de conteúdo político e de força diretiva o texto proposto. (COELHO, 2015)

La abogada Luana Xavier P. Coelho (2015), que forma parte del Setor Jurídico da Terra dos Direitos, organización de Derechos Humanos que actúa nacional e internacionalmente a partir de las oficinas en Paraná, Curitiba y Santarém, y en Brasília, crítica fuertemente la revisión del mencionado PPDU de 2004:

[...] o Plano dá um salto qualitativo na abordagem do IPTU progressivo, com contornos mais diretivos para sua futura aplicação. É um dos instrumentos que mais sofreu alterações se comparado à lei vigente. Na mesma linha, contudo, faz menção a lei especifica para definir as etapas de aplicação, critérios, localização e tamanhos dos lotes (art. 98). Avançamos e retrocedemos na mesma medida. $O$ instrumento já era previsto e nunca foi amplamente aplicado, visando gerar os efeitos que propõe. Mais uma vez, deixa definições importantes para depois. [...] a proposta trazida à análise pública nos deixa o desafio: quando este Plano pretende ser executado? Temos uma pista no art. 153, que em seu $\S 2^{\circ}$ dá o prazo de 1 (um) ano ao município para instituir comissão com a finalidade de propor as adequações na legislação vigente. Não há prazo, contudo, para elaboração das legislações regulamentadoras ausentes no compêndio vigente. (COELHO, 2015)

Esta situación de retroceso se vio también en Argentina según Catennazzi y Reese (apud COHEN, CARRIZOSA, y GUTMAN, 2016, p. 303-304) con relación a la aplicación del Plan Urbano Ambiental (PUA) y del CPU de la CABA y otras localidades.

A pesar del intento a partir de 1983 de crear condiciones institucionales para la participación popular en las decisiones en materia de construcción con la creación de diferentes grupos de trabajo, llamados Talleres de Planeamiento y Gestión, en diferentes barrios, lo que se vio fue un cruce de intereses conflictivos por la obtención de privilegios para algunos sectores y la falta de consenso por las propuestas discutidas y aprobadas que acabaron por hacer con que el intento perdiera aliento hasta desaparecer en 1990. En junio de 1991 se creó en su lugar, mediante el Decreto No. 2.709, el Consejo para la participación Ciudadana en el ámbito de la Secretaría de Gobierno de la Municipalidad que, a su vez, tuvo la 
misma suerte de los talleres, no cumplió sus objetivos y se extinguió en 1992 (CLICHEVSKY, 1996, p. 118-124) ${ }^{38}$.

En el pos-1983 mediante el Decreto N. ${ }^{\circ} 1.279 / 89$ firmado por el presidente Menen y la creación de la Corporación Puerto Madero con participación del Gobierno Nacional y de la Municipalidad de Buenos Aires se inició en tiempo récord la reforma de Puerto Madero sin las suficientes consultas populares: 77 estratégicas hectáreas desde siempre codiciadas por la iniciativa privada fueron rápidamente revitalizadas para la creación del más caro y elitista complejo habitacional y empresarial de la Argentina con el valor por metro cuadrado más alto del país ${ }^{39}$.

No tuvo la misma suerte con relación a la celeridad la puesta en marcha del Plan de Villas (Decreto $N^{\circ}$ 653/84, Ordenanza $N^{\circ} 39.753$, promulgada el 13 de febrero de 1984) también con decretos firmados en mayo y septiembre de 1990 por el Gobierno Nacional y la Municipalidad de Buenos Aires (Decretos de N. ${ }^{\circ}$ 1001/90 y 17137/90), con el que se pretendía regularizar la permanencia de los ocupantes de las villas de la ciudad y realizar la manutención de la estructura de servicios. Además de estas importantes medidas se creó el Programa de Radicación de Villas de la Capital en junio de 1991. Frustrante y lamentable es la constatación de que, a pesar de la buena voluntad y supuesto empeño de los promotores gubernamentales, los resultados en los discursos fueron nuevamente mayores que las acciones concretas (CLICHEVSKY, 1996, p. 124-130).

Como Argentina no posee una Ley de Ordenamiento Territorial Nacional, al contrario de Brasil, que tiene el Estatuto da Cidade, es común que este tema esté a cargo de cada provincia y municipio. Así, la Ley 8912/77 de Ordenamiento Urbano Territorial de la Provincia de Buenos Aires contempla en su Artículo 52 el control de los instrumentos que promueven la flexibilización de la normativa urbanística en la provincia, y al establecer las medidas mínimas para una parcelación en loteos de

\footnotetext{
${ }^{38}$ Los Talleres de Planeamiento fueron lanzados en un Seminario denominado "Perspectivas del CPU de cara a la Ciudad" promovido conjuntamente por el Ejecutivo Municipal y los Consejos Vecinales entre el 31 de julio y el 4 de agosto de 1989, donde fueron abordados temas como: Descentralización, Zonas Especiales de Urbanización y CPU. Los Talleres se propusieron discutir la producción del tejido urbano con sus problemas y proponer soluciones, tomando como base las contribuciones del Congreso Urbanístico de Barracas, desarrollado entre 1983 y 1986, bien como la experiencia del proyecto "Las 20 Ideas para Buenos Aires", de cuya iniciativa surgió en 1990 el programa PROSURBARRACAS, del cual se creó la Unidad de Gestión Urbana (UGU) que fue financiada por el Programa de las Naciones Unidas para el Desarrollo (PNUD) (CLICHEVSKY, 1996, p. 121-122).

${ }^{39}$ La referida área de Puerto Madero era codiciada desde décadas por la iniciativa privada: en 1930 se dio la primera tentativa de hacer una remodelación urbanística, sin éxito, lo que también sucedió en 1940, 1969, 1971 y 1982, hasta concretizarse en 1990 (CLICHEVSKY, 1996, p. 124-125).
} 
área de hasta 200 habitantes/ha, con 12 metros de frente y $300 \mathrm{~m}^{2}$, expresa lo siguiente:

Dichas dimensiones mínimas no serán de aplicación cuando se trate de proyectos urbanísticos integrales que signifiquen la construcción de la totalidad de las edificaciones, dotación de infraestructura y equipamiento comunitario para los cuales la municipalidad mantenga la densidad establecida y fije normas específicas sobre F.O.S., F.O.T., aspectos constructivos, ubicación de áreas verdes y libres públicas y otras de aplicación para el caso. El dictado de disposiciones reglamentarias o la aprobación de proyectos exigirá el previo dictamen del Ministerio de Obras Públicas. (BUENOS AIRES, 1977)

El tipo de proyecto de carácter social se denomina Distritos de Urbanización Especial (DUE), los que mantienen alguna semejanza con las Zonas de Interesse Social brasileñas, y donde se permiten superficies más pequeñas de hasta $250 \mathrm{~m} 2$ con $10 \mathrm{~m}$ de frente, obteniéndose así más lotes, o sea, un mayor número de viviendas. Este tipo de instrumento se utiliza sólo para asentamientos formales promovidos por el Estado. No hay dentro de esta Ley otras herramientas que propongan normas especiales para asentamientos irregulares o informales. En general los DUE son creados en su gran mayoría en predios de la periferia y muy raramente en el interior de la ciudad, en terrenos fiscales ya que no se pretende pleitear con el propietario privado. Una importante diferencia entre los DUE argentinos y las ZEIS brasileñas es que, al contrario de éstas, no son creados para proteger los espacios de los sectores de más bajos ingresos de la especulación del mercado inmobiliario frente a un posible desalojo y sí para autorizar la flexibilización edilicia permitiendo la reducción de los indicadores arquitectónicos y urbanísticos en estos casos. El hecho de que los DUE sean propuestos por el Estado garantiza la seguridad jurídica de la tierra, ya que una vez que las familias inician a abonan las cuotas del terreno y vivienda se procede a la escrituración. El valor de la vivienda destinada a los sectores de más bajos ingresos es mucho más bajo que los del mercado. En general, los conjuntos habitacionales de esta naturaleza no cuentan con una gran oferta de servicios públicos, además de que su tipología, empleada repetitivamente desde hace 30 años, carece de renovación y perfeccionamiento.

También se promulgó la Ley 148 en diciembre de 1998 durante el gobierno del intendente radical Fernando De La Rúa, que, de acuerdo con la Constitución de 1996 de la CABA, imponía el plazo de cinco años para regularizar la situación de las ocupaciones informales, como la Villa 31, y obligaba a la creación de una comisión 
coordinadora participativa en que estuvieran presentes representantes de todas las partes involucradas en la cuestión.

Con el agravamiento de la crisis económica del país durante el pasaje de siglo y ante las agitaciones sociales, se implementaron durante el gobierno del intendente Aníbal Ibarra, entre agosto de 2000 y diciembre de 2003, una serie de medidas con el objetivo de minimizar el caótico cuadro social: el Programa Autogestión para la Vivienda, conocido más popularmente como Ley 341, a través del cual un morador de bajos ingresos, individual o colectivamente a través de cooperativas, asociación mutual o alguna asociación civil sin fines de lucro podría solicitar al gobierno un crédito de hasta $\$ 48.300$ pesos por grupo familiar para comprar, reformar o construir una unidad habitacional, pudiendo inclusive, con el crédito concedido, negociar directamente con alguna de las constructoras autorizadas. Otras medidas gubernamentales en este sentido fueron: el Programa de Recuperación de la traza ex AU3 y el Programa de Rehabilitación del hábitat del barrio de La Boca: a) el Programa de Rehabilitación y Mantenimiento de Conjuntos y Barrios y, b) Programa de Regularización Dominial (CRAVINO, 2009, p. 211).

La Ley de Emergencia Habitacional de julio de 2004 de la Municipalidad de Buenos Aires ampliaba los recursos para este fin en el ámbito de VIS y establecía el plazo de tres años de vigencia de la situación de emergencia de los sin-techo en la capital argentina.

Asociado a los programas de vivienda popular, el gobierno de la CABA, a través de la Secretaría de Promoción, instituyó el Vale Ciudad, en dinero, por cada niño, semejante a la Bolsa-Familia brasileña para las familias de baja renta, y ofreció también materiales de construcción a las familias que se responsabilizaron por la producción de la propia vivienda, lo que generó críticas: que fue insuficiente para atender el gran número de familias postulantes y que se concedió privilegios a través de injerencias político-partidarias con relación a algunos moradores y delegados de las comunidades. Para los moradores de Villa 31 hubo además otra disconformidad debida a la angustia de una posible remoción por la inminente implantación de los millonarios proyectos inmobiliarios del barrio de Retiro, teniendo en cuenta los complejos intereses y sus protagonistas: gobierno nacional, gobierno de la CABA, elites de los elegantes barrios vecinos, los poderosos conglomerados e inversionistas de capital privado (CASTRO, 2010, p. 57 y 58). 


\section{5 - Tecnología y técnicas constructivas disponibles}

En la ciudad de Salvador, a mediados del siglo pasado, en pleno dinamismo del proceso de industrialización, fenómeno presente en todos los grandes centros urbanos brasileños durante el pos-Segunda Guerra Mundial, recrudecía la segregación espacial. La solución vino de dicho proceso, propuesta por los técnicos de entonces -ingenieros, arquitectos y urbanistas-, como por ejemplo el arquitecto Américo Furtado de Simas Filho, que propuso la producción en serie de conjuntos habitacionales populares mediante el apoyo mutuo de los ocupantes informales de la periferia a través de la utilización de la técnica del suelo-cemento en la producción de casas, técnica que estaba siendo experimentada en la Escola Politécnica de la UFBA (Poli-UFBA) en asociación con el Instituto Tecnológico da Bahia bajo la coordinación del profesor arquitecto Walter Gordilho (GORDILHO-SOUZA, 2008, p. 142).

En Salvador, los intentos implementados hasta el momento en el campo de VIS, ya sea en la participación comunitaria en la elaboración/ejecución de los proyectos como en la producción/aplicación de tecnologías innovadoras, alcanzaron resultados bien por debajo de lo pretendido, según Gordilho-Souza (2008, p. 341).

Son poquísimos los raros casos de participación comunitaria con la aquiescencia previa de los autores de los proyectos de intervención ocurridos en el período de la redemocratización, cuando el vector social se volvió condición sine qua non a través de la Constitución de 1988. Entre estos casos se pueden mencionar algunos ejemplos: el proyecto Ações Integradas de Saneamento Ambiental (AISAM), de iniciativa de la Poli-UFBA, en la Baixa do Camurujipe, que incluía construcción de unidades habitacionales; el proyecto de macro drenaje e infraestructura en el Vale do Paraguari, asesorado por la Associação Nacional do Solo Urbano (ANSUR); el proyecto Novos Alagados, con la participación de la ONG italiana de cuño socioreligioso Associação Voluntários para o Serviço Internacional (AVSI) que movilizó la participación de la comunidad e intermedió en las discusiones de ésta con CONDER y con URBIS; el proyecto de ocupación Yolanda Pires, que por injerencias políticas modificó el nombre para Vila Viver Melhor, el proyecto de intervención de la comunidad Gamboa de Baixo, que también movilizó diversas entidades, además de la prensa; el proyecto de la comunidad de Candeal Pequeno, implantada en un área noble de la ciudad, que presentó una singularidad al tener como portavoz de sus reivindicaciones a un ilustre morador renombrado cantante de ámbito internacional; y 
uno de los proyectos de URBIS, en la Baixa do Caranguejo, para el que constaba entre los requisitos del concurso público la exigencia de la participación de la comunidad en su elaboración (GORDILHO-SOUZA, 2008, p. 340-345).

En ámbito nacional, se puede citar: el Programa FUNAPS, de São Paulo, entre 1989/1992, que revindicó el "direito à arquitetura"; el Plano Diretor de Ipatinga, de Minas Gerais, que creó el concepto de "unidades espaciales de vida urbana"; el Programa Favela-Bairro, iniciado en 1994 en Rio de Janeiro, que mediante concurso de ideas busca nuevas estrategias de integración entre áreas de favelas y la estructura urbana; y las prácticas bien sucedidas que fueron premiadas en el Hábitat II (GORDILHO-SOUZA, 2008, p. 353).

Estas experiencias, en mayor o menor grado, responden a lo que estableció el Hábitat de Vancouver sobre la necesidad de priorizar la historia de vivencia de los moradores -unidades de vecindad- en estos espacios, donde las comunidades pasan por intervenciones urbanísticas y no se puede trabajar como si fueran tablas rasas y donde lo nuevo debe ser sinónimo de regreso al punto de partida (CASTRO, 2010, p. 112).

Gordilho-Souza (2008) entiende que pese al avance ocurrido en la lógica predominante de los programas/proyectos y en la cantidad y calidad de los mismos en las intervenciones urbanísticas implantadas por el poder público, particularmente en el período de 1997-1998, la ciudad aún se resiente de la falta de inclusión de los espacios precarios que existen sea en la periferia como en las áreas elitistas, haciendo con que todos los que viven en esta urbe pertenezcan de hecho y de derecho, con habitaciones de calidad, confort y seguridad, al hábitat mayor que es Salvador, sin segregación de ningún tipo, ya sea de renta, etnia, espacial u otra (GORDILHO-SOUZA, 2008, p. 354-358).

Un momento muy rico en la industrialización de prefabricados en Bahia ocurrió con la creación de la Fábrica da Companhia de Renovação Urbana de Salvador (RENURB) en 1979 durante la gestión del intendente Mário Kertész con la intención de implantar el proyecto de Transportes Urbanos de Salvador (TRANSCOL), financiado por BIRD, y que involucraba toda orden de construcción de estructuras públicas direccionadas al sector viario. Dada la compleja topografía de la ciudad, muy accidentada, asociada a la ocupación informal y desordenada en sus pendientes y áreas alagadizas, se hizo necesario un estudio más profundo de la tecnología de industrialización de piezas premoldeadas en hormigón y argamasa armada para hacer frente a los desafíos de los servicios de micro y macro drenaje, 
bien como de saneamiento básico. Para apoyar el equipo técnico que actuaba en la RENURB, que tenía al frente al arquitecto João Filgueiras "Lelé" Lima, se invitó al ingeniero Frederico Schieel, que en aquel periodo desarrollaba un proyecto de argamasa armada en la USP de São Carlos. De la asociación de estos dos profesionales resultaron las escaleras "con drenaje" que además de proporcionar una mejoría en la calidad de vida de los pobladores de terrenos con pendiente dio partida a la experimentación de una tecnología pionera en la industrialización de la construcción, abriendo espacio para su aplicación en construcciones de edificios ${ }^{40}$.

Otra importante contribución a la construcción del renombrado arquitecto "Lelé", además de su participación en el equipo de Oscar Niemeyer durante la construcción de la ciudad de Brasília, fue el acervo dejado a través de la producción de piezas estructurales livianas para la creación del Centro de Tecnologia da Rede Sarah (CTRS) -hospitales especializados en ortopedia de varias capitales de Brasil que atiende a toda la población, independientemente del estrato social-, utilizando la lógica comprobada en investigaciones científicas, según la cual:

[...] estudios sugieren que los empleados de edificios de oficinas que trabajan más cerca de las ventanas sufren menos estrés y, como consecuencia, están más sanos y son más productivos que aquellos situados más apartados de ellas. Estudios similares realizados en hospitales establecen una correlación parecida entre la posibilidad de los pacientes de controlar personalmente la luz y la ventilación y la tasa de tensiones, comportamiento antisocial y recuperación [...] En las viviendas donde se desarrolla la mayor parte de nuestra vida, es importante evitar sistemas, materiales, productos y procesos nocivos para salud. (EDWARDS, 2009, p. 146)

Infelizmente, con el despido del citado intendente en 1981 por el gobernador Antonio Carlos Magalhães se interrumpió una de las más importantes contribuciones de "Lelé" ${ }^{41}$, pues el dinamismo original de aquel proyecto decreció durante la nueva administración municipal de Salvador del intendente Manoel Castro hasta que se transfirió a la iniciativa privada y por consiguiente disminuyó sensiblemente su calidad en la ejecución de las obras (LIMA, 2000, p. 98). Esta situación estimuló el

\footnotetext{
${ }^{40}$ Formó parte de este equipo, en el sector de cerrajería, el técnico Osmar, artista renombrado del Carnaval baiano, que en asociación con su amigo "Dodô" crearon el trio elétrico -vehículo adaptado con equipamientos de música- donde se presentan los artistas hasta hoy en varias ciudades de Brasil durante el carnaval.

${ }^{41}$ Para "Lelé", a pesar de que en las últimas décadas del siglo XX Brasil haya conseguido un importante destaque en el ramo de la tecnología de hormigón armado en la construcción de puentes y grandes estructuras, esto poco influenció en la solución de problemas de infraestructura de áreas de baja renta de la periferia de los grandes centros urbanos (LIMA, 2000, p.105; 2009; 2012). Ver Acervo del arquitecto João Filgueiras "Lelé" Lima en pág. 386 en DA.
} 
empobrecimiento del nivel tecnológico industrial de la construcción, pensado para alcanzar la producción a gran escala, con calidad y largo alcance social, conforme la visión de "Lelé", incorporando la VIS a algo que, paulatinamente, se quedó en el olvido, así como el rico acervo de este ícono de la Arquitectura Moderna brasileña, en parte por la fuerte presión del neoliberalismo y también por los "puristas" de estética a los que no interesaba este tipo de producción en masa (SAMPAIO, 2010, p. 222-223, 230).

Maricato (2012) observa con relación al modo de producir habitación de las constructoras brasileñas que, si hasta ahora se registran avances notables en la gestión y control de metas, lo que significa una mejoría en la producción, lo mismo no se puede decir de la base técnica, que continúa atrasada y compuesta por operarios tercerizados, aunque haya una tendencia hacia la formalización, al igual que el personal del sector de marketing y de arquitectura, que tiende a adecuar en terrenos diferentes modelos arquitectónicos previamente adoptados en otras situaciones. Aunque en la producción de habitaciones en masa los prefabricados o premoldeados estén presentes, la mayoría de las empresas, por miedo de correr riesgos con tecnologías nuevas, prefieren mantenerse fieles a las tecnologías tradicionales, ya de su dominio, como la de albañilería armada (MARICATO, 2012, 64-65 $)^{42}$

En tiempos en que la industria de construcción brasileña se concentra más en los avances tecnológicos de última generación para el consumo de lujo y de emprendimientos de alta valorización comercial con lucros cada vez mayores, es forzoso recordar a los profesionales y dirigentes que en la primera mitad del siglo XX se ocuparon de construir miles de habitaciones para los sectores de más bajos ingresos, preocupados con: "projetos arquitetônicos e urbanísticos, procedimentos construtivos -sempre voltados para a racionalização e a redução de custos-, busca de materiais alternativos e aspectos sociais e administrativos" (BONDUKI, 2011, p. 156). En este sentido, fue muy importante la actuación, entre otros profesionales, del arquitecto Carlos Frederico Ferreira, jefe del sector de arquitectura y diseño de la Divisão de Engenharia del Instituto de Aposentadoria e Pensões dos Industriários (IAPI), que se empeñó en la aplicación de innovaciones tecnológicas en la industria de la construcción, como ocurrió en la implantación del primer conjunto habitacional de grandes proporciones en Brasil, del proyecto Realengo, entre 1939 y 1943, en

\footnotetext{
${ }^{42}$ La preocupación por la escasez de uso de nuevas tecnologías en las políticas públicas urbanas de Brasil se puede ver en Sampaio (2010, p. 226, 233-234, 239).
} 
Rio de Janeiro, con 2.344 habitaciones de aproximadamente $30 \mathrm{~m}^{2}$. Este proyecto piloto, de autoría de Carlos Ferreira, fue el primero en Brasil en combinar bloques de plantas residenciales unifamiliares con tipología de casas gemelas y tipología multifamiliar en altura de cuatro pisos, lo que sirvió de punto de partida para que se replicara de allí en adelante por todo Brasil y de modo general los bloques en altura en los grandes centros urbanos y las casas unifamiliares aisladas y gemelas en el interior de las provincias (BONDUKI, 2011, p. 157-159, 164, 180-181).

Ferreira relató al arquitecto Nabil Bonduki en una entrevista de 1994, pocos meses antes de su fallecimiento, cómo se dio a mediados del siglo pasado la implantación de una de las primeras usinas de pre-fabricación de materiales para la construcción en Brasil:

\begin{abstract}
A pesquisa de custo mínimo levou-me a considerar alguns materiais pouco usados até agora entre nós. Quero me referir principalmente ao emprego de blocos prensados de concreto usados em substituição aos tijolos comuns de cerâmica e as placas compensadas e revestidas para divisões internas. As vantagens econômicas são consideráveis e quanto às qualidades técnicas dos materiais em apreço, a construção de um grupo experimental confirmou inteiramente as previsões feitas [...]

Duas mil habitações você não faz em um dia. Nós tivemos um período de adaptação e de estudo para organizar o projeto e a obra. Neste período, o presidente do IAPI, engenheiro Plínio Castanhede, fez uma viagem aos EUA e lá descobriu uma máquina que eles tinham inventado, de fazer blocos de concreto grandes, bem maiores do que destes de $30 \mathrm{~cm} \times 20 \mathrm{~cm}$, destes que se fazem hoje a três por dois [...] e não precisava revestir nem nada. Nós fizemos os blocos, esta máquina fez o maior sucesso em Realengo; tinha um engenheiro lá que ficou muito interessado e queria fazer blocos menores e realmente fez e produziu uma máquina para fazer blocos de cimentos menores e fez direitinho.

A máquina fez um sucesso relativo, porque na hora de você confeccionar, verificava que tinha detalhes que criavam problemas malucos, principalmente nos encontros de paredes. Era um problema, mas eu resolvi todos os problemas e esta máquina ficou falada, fez o maior sucesso. Hoje tem essa máquina em todo canto, mas naquela época ninguém conhecia. (FERREIRA apud BONDUKI, 2011, p. 156). (El itálico es de BONDUKI)
\end{abstract}

La tipología de bloques con habitaciones en altura que proliferó en Brasil a partir del fin de la década del (19)30 sirvió como propuesta para la solución del crecente déficit de los sectores de bajos ingresos, generalmente tenía de 3 a 4 pisos, con un máximo de 5 , incluyendo la planta baja, y sin ascensor. Algunos proyectos, en casos excepcionales, comportaban edificios con más de 5 pisos, como el Conjunto Residencial da Várzea do Carmo, en el centro de la ciudad de São 
Paulo, proyectado por el equipo del arquitecto Attílio Corrêa Lima, que preveía algunas torres con 12 pisos paralelas a los bloques de 4 pisos, pero sólo éstos fueron ejecutados. La propuesta original fue la de maximizar la racionalización del espacio considerando los costos y la densidad dentro de las premisas "corbuseanas". Dicho arquitecto, que con este proyecto trajo en aquella época el ambicioso plan de abrigar 22 mil personas en el centro de la capital paulista, defendiendo la propuesta de "utilização de prédios altos, apesar do elevador, que ele propõe com paradas a cada três pavimentos, de modo a garantir uma densidade de 1250 habitantes/ha, sem um impacto significativo no custo final" (BONDUKI, 2011, p. 166-169).

Acerca de la densidad en unión al confort en el interior del departamento y en función del mejor uso de la luz diurna y de la ventilación natural, no hay que olvidar que:

[...] los edificios sostenibles evitan plantas demasiado profundas, la altura excesiva o la irregularidad en las formas. Su profundidad máxima debería estar entre 12 y $15 \mathrm{~m}$, y no sobrepasar las 4-6 plantas de altura. La combinación de forjados poco profundos y atrios puede aumentar la incidencia de la luz diurna y maximizar el uso de energías renovables mediante la ventilación por efecto chimenea [...] Para maximizar la explotación de la energía renovable, los edificios deberían estar correctamente orientados (con la fachada principal a sur), tener inclinación adecuada $\left(30-40^{\circ}\right.$ la cubierta y $60-70^{\circ}$ la fachada) y estar lo suficientemente espaciados para permitir la incidencia de luz solar (en especial en invierno, cuando los rayos de sol inciden bajo un ángulo de unos $18^{\circ}$ [...] en Reino Unido, el $20 \%$ de la energía consumida en los edificios se malgasta debido a fallos de diseño y a una mala comprensión del funcionamiento de los sistemas. (EDWARDS, 2009, p. 164-180)

Ya con relación al consumo de energía involucrado a la densidad urbana y al uso de transporte, Edwards (2009) recuerda que:

[...] un barrio denso y de uso mixto consume mucha menos energía primaria que uno disperso y de baja densidad. Además, el transporte público sólo resulta viable en áreas de densidad media o alta, con los consiguientes beneficios energéticos y sociales. Con una densidad relativamente alta, de unas 200 unid./ha distribuidas en edificios de cuatro plantas, el consumo de la energía procedente de combustibles fósiles representa un tercio del de unas viviendas suburbanas con una densidad de 20 unid./ha. Si se tiene en cuenta el transporte a comercios, centros escolares y lugares de trabajo, el balance energético ( $y$, por tanto, la diferencia de emisiones de carbono) es aún más favorable para las viviendas compactas [...] Sin embargo, a medida que aumenta la densidad, también aumentan otros 
problemas, como la inseguridad, la delincuencia, el aislamiento y la pérdida del sentimiento de comunidad. (EDWARDS, 2009, p. 197198)

Sugiere como características sostenibles de una vivienda urbana: una profundidad máxima de la planta entre 10 y 12 metros, la orientación del edificio entre sureste y suroeste, un máximo de $30^{\circ}$ del ángulo de obstrucción solar, una densidad teórica de 200 viviendas por hectárea y los edificios con un máximo de tres o cuatro plantas de altura. $Y$ advierte que hay un aumento correlativo de un $1 \%$ en el consumo de energía para cada punto porcentual que exceda el $30 \%$ de obstrucción solar (EDWARDS, 2009, p. 198).

Otra estrategia para alcanzar una alta densidad sin aumentar los costos con números mayores a 5 pisos, descartando la necesidad de uso de ascensor, fue la del aprovechamiento de la topología accidentada, implantándose la lámina sobre la pendiente de manera a obtener accesos independientes a partir de un nivel intermediario para cada grupo de 3 pisos, tanto para el grupo de la parte más alta, como para el grupo de la parte más baja. Se utilizó una variante de este recurso arquitectónico en el Conjunto Residencial da Lagoinha, conocido como Cidade Industriária, de Belo Horizonte, con 928 unidades habitacionales construidas por el IAPI entre las décadas del (19)40 y (19)50, y, en el mismo período, el Pedregulhos, de Rio Janeiro, el ícono de Brasil, con 328 unidades de las 478 originalmente previstas, ejecutado por el arquitecto Affonso Eduardo Reidy con el apoyo de la ingeniera Carmen Portinho, directora del Departamento de Habitação Popular (BONDUKI, 2011, p. 174-175, 194-195, 200-201).

Sampaio (2010) también argumenta a favor de la construcción en altura en los siguientes términos:

É claro que as pesquisas empíricas mostram correlações significativas entre as densidades residenciais (hab./ha) e os custos de implantação das infraestruturas: água, esgotos, energia, drenagem, sistema viário etc. Vide os trabalhos de Urdaneta (1974), Mascaró (1987), Campos Filho (1989) entre outros.

Entretanto, se os custos das infraestruturas obedecem a uma curva que decresce à medida que se aumentam as densidades, é também aceita a existência de um limite ou patamar - entre 900 e 1.000 hab./ha - que, se ultrapassado, resulta em deseconomias, onerando os custos de urbanização, ao invés de rebaixá-los.

Logo, as altas densidades só são vantajosas do ponto de vista econômico quando associadas a um conhecimento do impacto sobre a implantação elou substituição das infraestruturas, mas sempre respeitando um certo 'limite inferior' na curva decrescente do custo 
per capta, pois esta curva volta a crescer, de modo acentuado, se o 'umbral' - ou patamar - de densidade for ultrapassado. (SAMPAIO, 2010, p. 138)

La Figura 2.1 explicita mejor la relación entre costo de urbanización y densidad (habitantes/ha), mencionada anteriormente:

Figura 2.1 - Relación entre costo de urbanización y densidad de habitantes

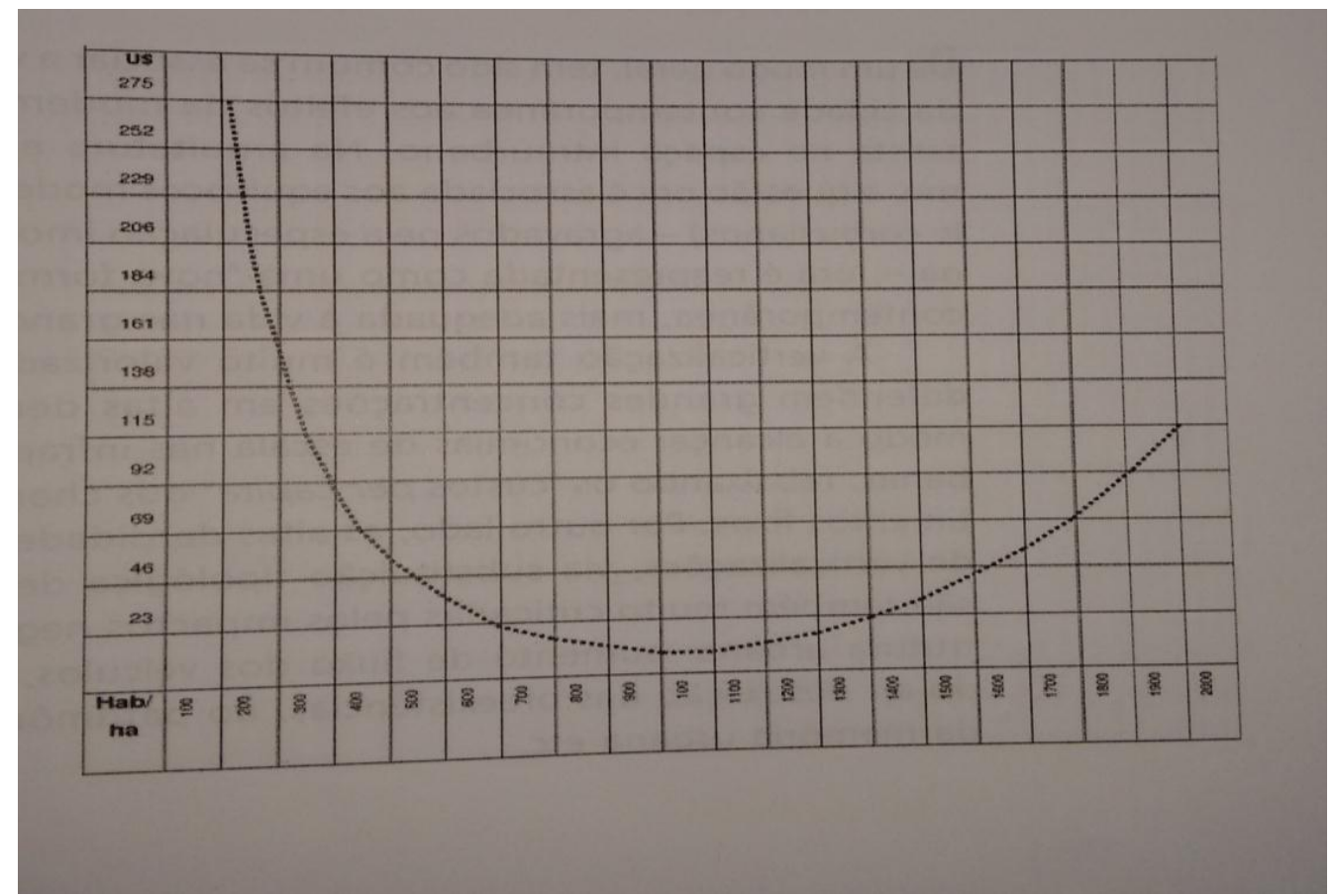

Fuente: adaptación a partir de Urdaneta (apud SAMPAIO, 2010, p. 138) (Habitante/hectárea) Donde en el original se digitó 100 después de 900 debe leerse 1000).

En la misma dirección, que ya se volvió de consenso entre gran parte de los especialistas en el tema, siguen las recomendaciones de la Comisión Asesora de la Dirección Nacional de Viviendas, de Uruguay, de finales de la década pasada, según la cual:

Debe procurarse la densificación habitacional de la ciudad consolidada, para aprovechar mejor las inversiones ya realizadas, así como la utilización plena del suelo vacante urbano.

Ello implica maximizar la capacidad de carga habitacional en las áreas centrales e intermedias en sus más variados modos de actuación: [...] Reciclaje de fincas: aumento de unidades según normativa específica y de volumen con tope de normativa urbana. [...] Densificación del lote: operaciones de pequeña escala en $\mathrm{PH}$ [construcción en altura] [...] Suelo vacante baldío en cota cero o elevado (azoteas), o edificado (estructuras industriales, otras), la 
vivienda existente como activo físico, social y financiero. [...] Asimismo deben estudiarse y ensayarse nuevas normas de fraccionamiento de lotes y modalidades de propiedad que faciliten la densificación. [...] La creación y desarrollo de Carteras de Tierras a nivel nacional y municipal debe ser un componente fundamental del Plan Quinquenal. Para ello debe preverse los recursos requeridos y aprobarse las herramientas jurídicas necesarias para facilitar la adquisición de tierras por el Estado (revisión de normas referentes a expropiaciones, régimen de prescripción, dación en pago, etc.). (VIVIENDA POPULAR, 2010, p. 82-83)

Sin embargo, la aplicación de esta sugestiva medida de uso de la tipología arquitectónica en altura para VIS destinada a los sectores de más bajos ingresos se ve dificultada, tanto en Brasil como en Argentina y en otras partes de este continente, también por causa de políticas públicas de vivienda según los intereses de ciertas elites, como constatan Catenazzi y Reese:

Así, durante los 20 años del periodo [1996-2016] en análisis, las
políticas habitacionales dirigidas a los sectores de menores ingresos
se centraron, en términos generales, en dos grandes líneas de
actuación: la construcción de unidades de vivienda nueva y la
regularización urbana y dominial de la urbanización popular.
Siguiendo este esquema, la respuesta en Argentina ha segmentado
los campos de acción. Mientras la construcción de viviendas
contribuye principalmente a la mejora del nivel de actividad
económica y a la creación de empleo a través del sector de la
construcción, las políticas de regularización contribuyen a la
supuesta integración social y urbana mediante el otorgamiento de
títulos de propiedad. Ahora bien, ambas líneas de actuación tienden
a reforzar la urbanización de baja densidad alejada de las áreas de
centralidad en ciudades que tienen una gran cantidad de lotes
urbanos ociosos, con una excelente localización en términos de
acceso a bienes y servicios urbanos y por lo tanto, con altas
expectativas de valorización. (COHEN, CARRIZOSA, y GUTMAN,
2016, p. 370-371)

Los ingenieros Renata de Faria Rocha, Celso Santos Carvalho y Ricardo de Sousa Moretti concuerdan en que, para un abordaje inicial del área de una comunidad pasible de intervención urbana se debe hacer un diagnóstico de los riesgos a la seguridad de la ocupación, la circulación de personas y de vehículos, la densidad y las limitaciones en cuanto a la regularización del suelo frente a la legislación. Además, proponen dos mecanismos urbanísticos para evaluar preliminarmente la densidad urbana de una comunidad, el primero, a través del "lote equivalente medio", el cual consiste en determinar la razón entre el área construida y el número de moradas, despreciando los espacios vacíos internos que haya en el área, definida por los contornos de las construcciones observadas, y el segundo, 
mediante la tasa del sistema viario, que se determina por el cociente del área total de vías por el número de familias residentes. Para la evaluación por lote equivalente se tiene una escala con tres intervalos caracterizados por: a) sector en que el lote equivalente medio es mayor que $70 \mathrm{~m}^{2}$, siendo aceptable, sin necesidad de intervención; b) sector en que el lote equivalente medio está entre $45 \mathrm{~m}^{2}$ y $70 \mathrm{~m}^{2}$, siendo aceptable, desde que se proceda con mejorías en el sistema viario; c) sector en que el lote equivalente medio está por debajo de $45 \mathrm{~m}^{2}$, considerado inaceptable al indicar una elevada densidad de viviendas. Con relación al criterio de evaluación por la tasa de sistema viario, hay dos categorías de realidad: a) Adecuado -en que el ancho de las vías es mayor de 4 metros, o entre 2 y 4 metros desde que la distancia hasta una vía de vehículos sea inferior a 60 metros-, b) Inadecuado -en el caso en que no se atiende ninguno de los requisitos de a)-. Cuando se dan los dos mecanismos urbanísticos, los ingenieros recomiendan dos niveles de padrón urbanístico: a) Nivel 1, padrón intermedio o alto -en que el lote equivalente es superior a $60 \mathrm{~m}^{2}$ o la tasa del sistema viario es mayor que $20 \mathrm{~m}^{2} /$ familia, o, incluso, cuando ambos son mayores que dichos valores-, b) Nivel 2, padrón bajo -cuando el lote equivalente presenta un valor por debajo de $60 \mathrm{~m} 2$ y la tasa del sistema viario corresponde a menos de $20 \mathrm{~m}^{2} /$ familia- (ABIKO y ORNSTEIN, 2002, p. 296-304, 315).

Se sabe que la mayor parte del consumo energético de una edificación se da por cuenta del sistema de calentamiento de agua, iluminación, acondicionamiento de aire y calefacción. Los proyectos habitacionales deben considerar la racionalización del consumo y la sustentabilidad, motivo por el cual los resultados de las investigaciones sobre la cuestión son una valiosa fuente a la hora de la elaboración de los proyectos habitacionales.

Hay expectativa en Brasil, en tono de alerta, sobre la decisión política de observar un escenario virtuoso proveniente de las buenas prácticas en el ámbito de la construcción de VIS, considerando la

[...] melhoria da qualidade na cadeia produtiva e para o incremento da produtividade através do desenvolvimento de planos organizacionais e inovações tecnológicas, tais como a revisão e a produção de normas técnicas, a redução do desperdício em canteiros de obras, a utilização de sistemas industrializados e a formação de um sistema nacional de certificado. (ABIKO y ORNSTEIN, 2002, p. 5) 
Con relación a la mejora de la producción de VIS, los ingenieros Edmundo Werna, Alex Abiko y Leandro Coelho, proponen, entre otras cosas, para solucionar el déficit habitacional en Brasil de los sectores de más bajos ingresos:

[...] a implantação de uma política de subsídio de aluguel através da concessão de vouchers, com valor correspondente a um percentual do valor total do aluguel, tal como no modelo americano [... y] outros modos de provisão que envolvam a parceira 'público-privado'. Uma delas poderia ser o estímulo aos programas de Mutirão parcial vertical, no qual as empreiteiras privadas executam a estrutura das edificações, enquanto as Associações [de moradores, cooperativas, profesionales: sindicatos] fazem a gestão do processo de conclusão. (WERNA, ABIKO y COELHO apud ABIKO y ORNSTEIN, 2002, p. 5253)

Lo que hasta aquí se ha presentado en cuanto al uso de tecnologías de construcción para VIS ratifica lo que piensan muchos expertos en el tema en cuanto a la mayor dificultad que hay para la adquisición del techo por los sectores de más bajos ingresos, según la arquitecta Angela Gordilho Souza (2004):

Já no início do século [XX], o padrão suburbano de ocupação será possibilitado pelo desenvolvimento tecnológico dos meios de transporte e pela abertura de grandes loteamentos nas periferias das cidades. No entanto, como já amplamente demonstrado, o problema de habitação não representa uma questão técnica; a insuficiência de renda é o grande empecilho para a aquisição dessa mercadoria especial. (SOUZA apud FERNANDES y SOUZA, 2004, p.187)

A pesar de los avances en el tema de VIS hay que empeñar más esfuerzos para que los resultados de los innúmeros centros de investigación universitarios alcancen las empresas del mercado, pues es incontestable el desfasaje que existe hasta hoy en la falta de un nexo fuerte entre estos dos polos. Problema que tiene que ser abordado por la sociedad como un todo para que los que más lo necesitan puedan usufructuar de forma racional y en mayor provecho los éxitos de los investigadores, como alertó el economista Alberto Padilla (2010) en una entrevista ${ }^{43}$.

En este sentido, en Argentina, la FAU-UNLP continúa haciendo su parte a través del desarrollo de tecnologías direccionadas al ámbito social junto con otras universidades de América y de Europa en el Programa iberoamericano de Ciencia y Tecnología para el Desarrollo (CYTED), creado en 1984 a través del Acuerdo de

\footnotetext{
${ }^{43}$ Durante el programa de Televisión Economía y Finanzas de la cadena TV CNN en español, transmitido a las 07:30 del 30 diciembre de 2010 (horario de Salvador, Bahia), en el que se analizaba el desempeño económico de América Latina y del mundo.
} 
Ámbito Interinstitucional firmado por diecinueve países de Latinoamérica, España y Portugal, entre cuyos objetivos se encuentran acciones para la mejoría de VIS.

En los nueve conjuntos habitacionales con edificios de VIS investigados en Montevideo, Uruguay, por el grupo de investigación Evaluación de Tecnologías para VIS del Instituto de la Construcción (IC) de la Facultad de Arquitectura de la Universidad de La República (UdelaR), una de las patologías detectadas fue la de fisuras en las paredes, algo que, si bien no evidenció agravamiento directo en las construcciones, se volvió importante con relación al riesgo de corrosión de las armaduras de las estructuras por posible infiltración de agua en las mismas. Esta patología fue más común en los sistemas constructivos tipo "FC2" utilizado en dos de las nueve comunidades y en la de "Beno", en las que el recubrimiento de las armaduras fue relativamente poco espeso. Las restantes, que se construyeron con sistemas tradicionales, no presentaron este problema. En cuanto a la durabilidad de las construcciones, el sistema constructivo tradicional fue el que demostró un mejor desempeño. Las que utilizaron elementos metálicos en sus estructuras o en las terminaciones se vieron expuestas a una disminución de su vida útil sin el adecuado mantenimiento del elemento metálico. El fenómeno del surgimiento de microgrietas en las estructuras fue algo comúnmente observado en construcciones con divisorias de ambientes de paneles preformados tipo "FC2", fenómeno que depende en gran medida de la inexperiencia de los operarios no especializados en el proceso de cooperación comunitaria, de las dosis de preparación de argamasas y del proceso de "secado" de éstas, del revestimiento de las placas y del nivel de mantenimiento durante la post ocupación. El análisis de los aspectos constructivos indicó que, en cuanto a las ampliaciones espaciales de las unidades habitacionales realizadas por los moradores, estas resultaron más eficientes en los casos en que las obras estuvieron bajo responsabilidad de las cooperativas "tradicionales" en comparación con las que fueron ejecutadas por empresas, lo mismo ocurrió en relación con el mantenimiento y la seguridad de las viviendas. Otro aspecto importante fue que se confirmó la lógica ya conocida de que los proyectos habitacionales implantados en áreas bien servidas de infraestructura básica son menos onerosos y tienden a dar un mayor nivel de satisfacción a los moradores, mientras que los que son implantados en terrenos con insuficientes disponibilidades de servicios públicos tienden a encarecer las inversiones. También se comprobó lo que ya se suponía sobre las familias en que predomina un bajo nivel de escolaridad, un número mayor de dependientes y el desempleo: que tienden a tener serias dificultades de 
mantenimiento del inmueble durante la post ocupación, lo que genera una mayor degradación de las unidades habitacionales y, por consiguiente, una disminución de la calidad de vida, por lo que se recomienda una mayor preocupación en los proyectos de VIS para sectores de bajos ingresos en relación con el tipo de materiales y costos de manutención de las construcciones. Lo que fue también señalado por Cravino (2009b, p. 188-189) en sus estudios sobre algunas comunidades de Buenos Aires. Se verificó que en las construcciones donde se utilizó mano de obra de tipo ayuda mutua/cooperativa el costo total aumentó entre el 12 y el $18 \%$ si se computa el costo de la cuota correspondiente a dicha mano de obra y a las respectivas exenciones sociales obtenidas por las cooperativas. En líneas generales, en la investigación se consideraron el aspecto económico, físico y social de los proyectos habitacionales, así como la disponibilidad/facilidad o no de los terrenos donde fueron implantados y la infraestructura urbana del local (UNIVERSIDAD DE LA REPÚBLICA, 2008, p. 27-32, 36-38, 42, 64, 82-84, 90-92).

Resultados similares a los observados en Uruguay también se observaron en Brasil. Los arquitectos Marcelo de Andrade Roméro y Nelson Solano Vianna sugieren, para la producción en serie de VIS, a partir de sus investigaciones en la ciudad de São Paulo: a) que se analicen las experiencias de los sistemas cooperativos europeos con el objetivo de incorporar a las familias moradoras en todas las etapas de proyecto, incluso con la participación del Estado promoviendo la diseminación de esta modalidad constructiva, b) que se realice una reducción en la escala de los conjuntos habitacionales en los cuales haya una capacidad máxima de cien unidades residenciales, insertándolos en el tejido urbano con tipologías diferentes -sugerencia más viable si se replica en las áreas centrales disponibles de la ciudad y con dimensiones reducidas-, c) que los taludes no tengan un declive mayor de 1:2, lo que facilita, inclusive, el tratamiento paisajístico de los mismos ${ }^{44}, \mathrm{~d}$ ) que en la fase de proyecto no se ignore que muchas familias utilizan sus viviendas también como local de trabajo, por lo que además de las dimensiones espaciales se considere la necesidad de cableado y enchufes apropiados al uso de equipos eléctricos profesionales, como por ejemplo máquina de coser, e) que la dimensión mínima de la vivienda para un mínimo confort es de entre 50 y $60 \mathrm{~m}^{2}$ (ABIKO y ORNSTEIN, 2002, p. 222). Esta última recomendación coincide con la de otros

\footnotetext{
${ }^{44}$ Hay quien sugiere que el declive del terreno compatíble para la implantación de VIS deba ser entre el 20 y el 60\% (ABIKO y ORNSTEIN, 2002, p. 61).
} 
autores y se corroboró a través de los resultados de la Encuesta tipo 1 para moradores aplicada en las comunidades investigadas en esta tesis.

Según la investigación realizada en Uruguay, el costo de mantenimiento anual, en media, por metro cuadrado construido, es entre el 2 y el $5 \%$ del valor invertido, lo que indica que, en media, el costo de la manutención de una unidad habitacional corresponde al cabo de treinta años al valor de una unidad habitacional nueva. EI IC también constató que, en general, según los resultados obtenidos de las evaluaciones realizadas en los programas habitacionales, no hubo diferencia significativa entre los que utilizaron tecnologías innovadoras o tradicionales, de lo que se deduce que un factor muy importante para la calificación de un proyecto es que el mismo pueda tener resultados positivos diseminados equilibradamente, en diversos ítems, y no en uno u otro ítem que se distancie mucho de los demás. (VIVIENDA POPULAR, 2013, p. 28-31).

En Egipto, un estudio comparativo entre tres sistemas constructivos -el tradicional autoportante, el de estructura de hormigón y sellado con ladrillos, y el de grandes paneles prefabricados- concluyó que el costo del sistema de construcción del totalmente industrializado y el del semi industrializado fueron respectivamente del $30 \%$ y del $10 \%$ más caros que el tradicional autoportante, sin considerar el costo de la inversión inicial para la implantación del "parque industrial" (WERNA et al., 2001, p. 68).

Considerando todo esto, conviene mezclar sistemas constructivos industrializados y tradicionales, incluso de manera experimental a lo largo del tiempo con prototipos en tamaño real en el propio proyecto habitacional en ejecución, como sugiere el arquitecto argentino Gaite (2008, p. 43 y 72-74), para quien, según su experiencia, es común que se rechace el ladrillo aparente bajo el argumento de que tal material no sería adecuado en una construcción de vivienda económica, lo que no es cierto. También, citando Vivienda y Clima de Waldimiro Acosta (1976), critica a aquellos que en nombre de una "tecnología de vanguardia o de punta" desprecian la sabiduría y riqueza cultural de la construcción tradicional, por ejemplo, con adobe y paja, utilizada satisfactoriamente desde hace siglos por los incas en Cuzco:

[...] parecería de elemental sabiduría y sensatez recoger y aprovechar las enseñanzas que indudablemente encierran las construcciones autóctonas. Ello casi seguramente permitirá llevar a cabo con rapidez planes más amplios y generosos, económicamente realizables y que tendrían al mismo tiempo la inapreciable ventaja de 
mantener un tipo de vivienda enraizada en el paisaje, el clima y el modo de vivir del hombre de la región.

Es preciso entender que no se trataría, en este caso, de mantener una tradición ni un estilo 'criollista' - un formulismo - sino de promover una simbiosis armónica de la técnica constructiva y sanitaria moderna con el uso de los materiales y las formas tradicionales, funcionalmente útiles, de los primitivos habitantes del lugar. (ACOSTA apud GAITE, 2008, p. 74)

Al compararse estas recomendaciones con la realidad de que los proyectos de VIS, salvo excepciones, son elaborados y ejecutados sin la debida participación de las personas para quienes son construidas, se tiene una pista del grave error que se viene cometiendo y del origen de las inúmeras críticas que reciben, principalmente en la fase de post ocupación. Dentro de esta óptica es oportuno recordar que la teoría del "Conflicto Arquitectónico", según presupuestos fenomenológicos de M. Heidegger (1962), es un instrumento muy importante para la elaboración del proyecto arquitectónico una vez que es condición básica evitar toda incompatibilidad entre lo que se pretende ofrecer y quien desea usufructuar adecuadamente el espacio ofrecido, ya sea por la ausencia de un elemento fundamental en ese espacio como por la indeseable materialización de ese elemento. En estos términos, admitiéndose que un rasgo característico cultural del brasileño es el hábito de preparar las comidas en la cocina, surge un "conflicto arquitectónico" en los proyectos de VIS que generalmente ofrecen espacios reducidos en este ambiente, induciendo al morador a encontrar una solución no siempre adecuada para esta práctica cultural. Situación semejante se da en los proyectos en que en el lavadero sólo se provee lugar para la máquina/tanque de lavar y una pileta, sin mesada o estructura para refregar y enjuagar la ropa. Los corolarios de la teoría del "conflicto arquitectónico" desarrollada por M. L. Malard (apud ABIKO y ORNSTEIN, 2002, p. 250-266) fueron percibidos en diferentes situaciones en las comunidades investigadas para esta tesis, ya sea por los moradores como por los profesionales que participaron en la ejecución de los proyectos. Se constatan así cuatro situaciones que comúnmente generan "conflictos arquitectónicos" en las VIS en Brasil y que son motivo de reclamación por los moradores en relación con el aspecto externo de la vivienda: 1) estandarización de los cerramientos; 2) estandarización de la volumetría; 3) uniformidad de colores; 4) falta de elementos decorativos en las fachadas (ABIKO y ORNSTEIN, 2002, p. 264).

Con relación al aspecto tecnológico en la ejecución del proyecto se debe mencionar un producto relativamente nuevo: el concreto flexible llamado Engineered 
Cement Composite (ECC) que, al contrario del concreto tradicional, éste que tiene características de cerámica, rígido y quebradizo con un estiramiento máximo del 0,01\%, alcanza una recuperación total cuando estirado hasta el 3\% a más de su extensión original, no obstante soporte un estiramiento de hasta el $5 \%$ sin romperse. Este nuevo producto, desarrollado por un equipo de investigadores de la Universidad de Michigan, Estados Unidos, a partir de un cemento extra seco, es capaz de "auto restaurarse" solamente con la adición de agua y dióxido de carbono (CO2), lo que le da al concreto mayor resistencia, y al incorporar fibras sintéticas alrededor del acero lo protege de la corrosión, el cual, por minúsculas que sean las fisuras, acaba siendo damnificado por la presencia de líquidos (MATERIAIS, 2009).

En Mendoza se realizaron pruebas en diferentes alturas de edificios utilizando materiales aislantes en las fachadas; por los índices de los ensayos de aislamiento térmico se recomienda el poliestireno expandido de $0,075 \mathrm{~m}$ de espesor, la lana mineral de $0,075 \mathrm{~m}$, la fibra de vidrio de $0,1 \mathrm{~m}$ y las placas de corteza de $0,1 \mathrm{~m}$ que responden a los tres niveles de transmitancia térmica establecidos por las normas de la serie 11600 de IRAM, en toda Argentina. Existe un cuarto nivel propuesto por Mercado y Esteves (2004), que utiliza el poliuretano expandido de 0,05m, atendiendo conjuntamente los requisitos da transmitancia, practicidad y economía (BALTER, 2015, p. 181-183). Mendoza es considerada una ciudad-oasis, con clima templado continental árido y una humedad relativa del $54,7 \%$, un nivel de precipitación anual que no ultrapasa los $218 \mathrm{~mm}$ y una radiación solar media anual de 18.4 MJ $/ \mathrm{m}^{2}$ día, típica de zonas semidesérticas, posee, en verano, la temperatura máxima absoluta de $37,4 \mathrm{C}^{\circ}$, y en inverno la mínima absoluta de $-5,7 \mathrm{C}^{\circ}$, las medias de máximas y mínimas en verano de $30,1 \mathrm{C}^{\circ}$ y $18,4 \mathrm{C}^{\circ}$, y en invierno de, respectivamente, $14,7 \mathrm{C}^{\circ}$ y $3,4 \mathrm{C}^{\circ}$, y vientos suaves, que en invierno provienen del sur a una velocidad máxima de $8 \mathrm{Km} / \mathrm{h}$, y en verano, del suroeste, a $15 \mathrm{Km} / \mathrm{h}$. (BALTER, 2015, p. 18).

También, con experiencia comprobada de aislante térmico, se puede mencionar el producto DURLOCK, utilizado satisfactoriamente en la construcción de 240 unidades de VIS en la ciudad de San Pedro, provincia de Jujuy, Argentina, en ladrillo hueco según la Revista Summa (1979, p. 63).

Estudios de inercia de energía con simulaciones en rascacielos públicos residenciales construidos en Hong Kong, en hormigón con paredes revestidas con poliestireno de $5 \mathrm{~cm}$ como aislante térmico, indicaron diferentes resultados en 
función de la orientación y ubicación de las paredes revestidas: de reducción del $38 \%$ de energía a un aumento de consumo energético del $7 \%$. De ahí la necesidad de evaluar caso por caso la relación costo/beneficio (BALTER, 2015, p. 13).

Con relación al control de la temperatura en el interior del departamento, una sencilla y económica solución constructiva es la de las torres de ventilación:

Se ha calculado que el uso de las torres puede reducir la carga energética del sistema de ventilación en un $40 \%$, con unos costes de capital iniciales un $15 \%$ inferiores que los de las soluciones convencionales. También se requiere menos espacio para la maquinaria y, dado que la tecnología es tan sencilla, los costes de mantenimiento son considerablemente más baratos. (EDWARDS, 2009, p. 150)

El sistema constructivo Drywall, recomendado como divisor/cerramiento entre ambientes, que básicamente consiste en placas a base de yeso (gibbsita), es una herramienta tecnológica relativamente nueva en el mercado y que puede utlizarse en los proyectos de VIS. Su practicidad en la instalación en obra, asociada a las características técnicas, como espesor reducido, peso ligero, resistencia, aislación acústica y térmica, nivel de toxicidad despreciable y bajo índice de residuos en obra: del $5 \%$ contra el $30 \%$ de los productos tradicionales, se adecúa a la norma técnica Norma Brasileira NBR 15.758, de la Associação Brasileira de Normas Técnicas (ABNT), así como a la Norma de Desempenho de Edificações NBR 15.575 (DINIZ, RODRIGUES y KOVACS, 2014).

Investigaciones realizadas en casas y departamentos en Florianópolis/SC indicaron que la tipología en altura con cuatro pisos presenta una inercia térmica más elevada que las casas aisladas, una vez que la amplitud térmica en los departamentos es menor. Asociado a este resultado se constató que la ventilación cruzada es menos favorable en los departamentos que en las casas, lo que también colabora con la sensación de incomodidad térmica, tanto en invierno como en verano. Por lo tanto, se sugiere que para una mejor calidad del confort térmico en el interior de las residencias y con un mejor aprovechamiento de la ventilación y del aumento o disminución de las temperaturas, el proyecto arquitectónico haga uso de balcones, aleros, brises, persianas, saledizos, y que las áreas mayores se ubiquen en orientaciones favorables, con espacios internos menos compartimentados, paredes a media altura, que en la parte alta de paredes y/o de puertas se coloquen elementos vacíos o basculantes, y que haya variedad en la implantación de los 
bloques de departamentos en el terreno, lo que quiebra la excesiva estandarización de las unidades (ABIKO y ORNSTEIN, 2002, p. 199-203).

2.6 - El problema de los organismos públicos

Una primera gran experiencia de cuño interdisciplinar en Argentina que involucró arquitectos y sociólogos en la elaboración de proyectos de VIS se originó con los trabajos de campo entre 1957 y 1958 en la Isla Maciel, entre el Riachuelo y el antiguo arroyo Maciel, en el sur de la CABA, del sociólogo Gino Germani a través del Departamento de Extensión Universitaria de la UBA, la que sirvió de base en la década siguiente para que el arquitecto Vladimiro Acosta pudiera crear un proyecto de conjunto habitacional, bajo encomienda de la UBA, para los moradores de la isla, los cuales, mediante una cooperativa creada por Germani, actuaron como mano de obra en la construcción de sus propias viviendas (MIGUEL, 2010, p. 97-101).

Cuando en 1956 la UBA buscaba disociarse del predominio del "esquematismo" académico y del modelo parisiense de Bellas Artes, el arquitecto Wladimiro Acosta propuso el Taller Vertical, estructurado en sus pioneras concepciones de teoría y práctica trabajadas en el ámbito académico en 1937, las que fueron aplicadas en la incipiente experiencia de la Cooperativa de Villa Maciel junto al sociólogo Gino Germani, lo que sirvió de parámetro para muchos cursos universitarios de arquitectura y sociología en todo el país (GAITE, 2008, p. 21). Pero el 29 de julio de 1966, en la conocida "noche de los bastones largos" experiencias exitosas, como aquellas de Germani y Acosta, fueron reprimidas por los militares de la Policía Federal, que por orden del general golpista Juan Carlos Onganía, invadieron varias facultades de Buenos Aires, lo que produjo el exilio masivo de profesores y estudiantes, como ocurrió en Brasil con pensadores del más alto nivel, como el sociólogo Fernando Henrique Cardoso, el geógrafo Milton Santos, el antropólogo indigenista Darcy Ribeiro, además de la muerte del ilustre educador baiano Anísio Teixeira, durante la dictadura militar (1964-1985).

Dos ejemplos clásicos de referencia en cuanto al pleno éxito de una intervención urbana con vivienda popular de alta calidad bajo diversos aspectos arquitectónico, estructural, de inserción en el medio en que fueron implantados, etc.-, son el proyecto La Casa Colectiva de Parque Los Andes (1926-1928), Chacarita, CABA, del arquitecto Fermín Bereterbide, y el Conjunto Residencial Prefeito Mendes 
de Moraes (1946-1958), "Pedregulho", Rio de Janeiro, del arquitecto Affonso Eduardo Reidy (MIGUEL, 2010, p. 26).

Para un resultado exitoso es imprescindible el trabajo conjunto de los órganos responsables por pensar la espacialidad de la ciudad en la esfera local, provincial o federal, con los profesionales del servicio social, ingeniería, arquitectura y abogacía, actuando interdisciplinarmente, cada uno en su especialidad, así como de los representantes de las asociaciones de futuros moradores, para que el proyecto habitacional se desarrolle en función de éstos (MARICATO, 2011, 145-151). A los profesionales de la entidad pública que sea responsable por las intervenciones urbanas, cabe la responsabilidad de minimizar costos y coordinar la actuación de los grupos de adquirientes que se predispongan y tengan condiciones de participar en la ejecución del proyecto, teniendo en cuenta lo que ya decía el argentino Hilario Zalba en los años (19)50, cuando asumió la presidencia del Instituto de la Vivienda de la Provincia de Buenos Aires: cooperación comunitaria "se hace con quien se puede y no con quien se quiere", y que la selección de los materiales utilizados debe hacerse con base en los costos y en el tipo de la mano de obra que va a manosearlos, la que en este caso no sería especializada y por lo tanto debería ser orientada por los profesionales de los organismos públicos sin que se les diera informaciones anticipadas y específicas de cuál sería su propia futura vivienda, lo que permite que se empeñen indiscriminadamente (COSOGLIAD, 2003, p. 66-67) ${ }^{45}$.

Tomando como base las experiencias en la capital del estado de São Paulo a fines de la década pasada en relación con el mejor aprovechamiento de los proyectos de VIS, se sugiere que se podría tener cierta flexibilidad en cuanto al tipo de material de las terminaciones a la hora de la entrega, lo que permitiría a las familias que no tengan condiciones de realizar ulteriores mejorías acceder a mejores terminaciones que podrían ser compensadas con cuotas de financiación más baja, y también que la entidad responsable por la ejecución pueda ofrecer propuestas de futuras intervenciones por parte de los moradores adecuadas a los proyectos originales. El tiempo de entrega medio admitido en base al análisis de seis tipos

\footnotetext{
${ }^{45}$ Es de ese período, de cuando Zalba dirigía su equipo, la experiencia piloto de un monobloqueprototipo en altura compuesto por 3 plantas arquitectónicas diferentes en un mismo monobloque de 3 a 4 pisos además de la planta baja, sobre una densidad de 250Habitntes/ha, para solucionar el problema habitacional de 35.500 personas. Entre 1963 y 1964 habían sido construidos ya 38 de estos monobloques alrededor de la CABA -y en la ciudad de La Plata y otras ciudades de la provincia de Buenos Aires, como por ejemplo de la construcción de 55 unidades en Bahía Blanca, con financiación del Plan Federal de Vivienda del BHN. La concepción proyectual de este monobloque es una adecuación local de la experiencia implementada por Le Corbusier (1946-1952) y con alguna crítica a la Unidad de Habitación de Marsella (COSOGLIAD, 2003, p. 67-68, 80-100).
} 
diferentes de modalidad constructivas en la última década del siglo pasado en la capital de São Paulo fue de dos años y medio (WERNA et al., 2001, p. 182-222).

La aprobación del Proyecto de Ley $N^{\circ}$ 6.981/06, de autoría del diputado federal y arquitecto Zezéu Ribeiro, que asegura a las familias de bajos ingresos acceso a la asistencia técnica pública y gratuita para el proyecto y construcción de VIS, fue de extrema importancia en Brasil. También representó un gran avance social la sanción de la alteración de la Ley $N^{0} 11.124$ por el presidente Luiz Inácio Lula da Silva en 2007 durante la $3^{a}$ Conferência Nacional das Cidades, ocurrida en Brasilia, alteración que reglamenta el Sistema Nacional de Habitação de Interesse Social (SNHIS), concediendo el acceso directo de asociaciones y cooperativas habitacionales al Fundo Nacional de Habitação de Interesse Social (FNHIS), creado, junto con el SNHIS, por la Ley N $N^{\circ} 11.124$ del 16 de junio de 2005. Dicha alteración tiene por finalidad permitir obtener recursos a través del programa de Produção Social a Moradia, situación que desde la década del (19)80 estaban revindicando los movimientos populares de vivienda desde el histórico éxito de experiencias de autogestión (mutirón) (GORDILHO-SOUZA, 2008, p. 38-39, 436, 437, 441).

La Ley No 11.888, Lei de Assistência Técnica Pública e Gratuita, promulgada el 24 de diciembre de 2008 y originada del Proyecto de Ley $N^{\circ}$ 6.981/06, promovió otra alteración en la Ley N N 11.124, determinando que el Conselho Gestor do FNHIS atienda, según su dotación presupuestaria y financiera, las demandas de asistencia técnica pública y gratuita en áreas de arquitectura, urbanismo e ingeniería (BRASIL, 2008). Con anterioridad a la Ley $N^{\circ} 11.888$, estaba en vigor en la ciudad de Rio de Janeiro el Decreto N 16.269 del 14 de noviembre de 1996, el cual creó el Posto de Orientação Urbanística e Social (POUSO), al que cabe la fiscalización del mantenimiento de los espacios públicos construidos, como plazas, calles y escaleras, entre otros, bien como prohibir las construcciones en áreas de riesgo y controlar la expansión de las edificaciones. El equipo técnico de POUSO, bajo la coordinación de la Secretaria Municipal de Habitação, se encuentra formada por 1 arquitecto o ingeniero, 1 profesional de nivel superior del área de servicio social y agentes comunitarios (ABIKO y ORNSTEIN, 2002, p. 344). Lamentablemente, la materialización de los resultados de ambas leyes está muy por debajo de los presupuestos de la ley y de las expectativas de las familias de bajos ingresos en la gran mayoría de los 5.570 municipios brasileños. 


\section{7 - La oferta de tierras y la especulación del suelo}

Según estudios realizados en varios países en vías de desarrollo basados en los 25 años de implantación de proyectos gubernamentales de lote urbanizado y de políticas de autoayuda en general, se detectaron seis motivos para el fracaso:

a) Un enorme desfasaje entre la producción y la necesidad de demandada: entre 1972 y 1981 cerca de nueve millones de personas fueron atendidas por los referidos proyectos y políticas, mientras que la demanda sería de ocho millones setecientas mil unidades habitacionales por año;

b) El aparato burocrático administrativo, financiero y de personal especializado es muy costoso y demanda tiempo además de complejos operativos de negociación y formalización entre los involucrados, lo que acaba por encarecer los proyectos haciéndolos inalcanzables para los sectores de más bajos ingresos;

c) La inadecuación de los inmuebles en regiones lejanas y de difícil acceso que incurre en dificultades de traslado de la población;

d) La ausencia de apoyo técnico y financiero para que los moradores promuevan mejorías en sus viviendas;

e) El estímulo a la especulación en los predios circunvecinos por causa de las expectativas de implantación de infraestructura en el área de las intervenciones

f) El quiebre del nivel inicial de convivencia -homogeneidad y espíritu colaborativo de las personas de las áreas de origen por causa de los nuevos moradores llegados aleatoriamente por medio de subastas (WERNA et al., 2001, p. 71-72).

Además de esto, existen otros dos factores relacionados a los ítems $c$ y e: la falta de mejoría de los inmuebles alquilados y el aumento de los alquileres debido a las mejoras de la infraestructura realizadas por el Estado (WERNA et al., 2001, p. 73).

Estas dificultades justifican el consenso entre los estudiosos de que el problema del acceso a la vivienda por parte de los sectores de más bajos ingresos está más vinculado a la "tierra urbana" que a la unidad habitacional en sí, lo que, en definitiva, es responsabilidad del Estado, que debería fiscalizar y cohibir la especulación inmobiliaria privada en detrimento de los sectores más vulnerables (WERNA et al., 2001, p. 200). En este sentido, urge que el Proyecto de Ley $N^{\circ}$ 3.057 del 18 de mayo de 2000 del diputado federal Bispo Wanderval no 
sea postergado todavía por más tiempo, proyecto que trata sobre la revisión de la ley de parcelación del suelo urbano, estableciendo normas generales disciplinarias referentes al tema, el cual está regido por la Ley Federal $n^{\circ} 6766 / 79$ y desde hace muchos años sin definición para entrar en vigencia.

Argentina, que carece de parámetros nacionales urbanísticos para VIS, como por ejemplo los del Estatuto da Cidade, sobre el que establece la Constitución de Brasil la función social de la propiedad de la tierra deja este tema a cargo del municipio, el cual, por diversos motivos, no consigue manejar adecuadamente la creación de un banco de tierras para sus operativos urbanísticos y así poder atender la demanda de vivienda de los sectores de más bajos ingresos. Por ende, en la mayoría de las ciudades argentinas no se establece una política eficaz de captura de plusvalías sobre las tierras privadas, lo que provoca que el recaudo de esta naturaleza sea diminuto y compuesto básicamente de multas advenidas por faltas a la construcción. En resumen, las ordenanzas sobre este tema generalmente se encierran en ámbito jurídico entre los interesados. Se agregue a este contexto que culturalmente el valor del impuesto predial es insignificante y no se corresponde con la realidad de mercado entre lo que se cobra basado en los datos catastrales y lo que se practica en las operaciones de compra y venta. Lo que lleva a la necesidad de reflexión sobre este importante tema de justicia social y de economía nacional. Debido al vacío que se vive en Argentina a nivel nacional de una legislación edilicia sobre el uso y ordenamiento del suelo urbano, en especial para VIS, que hace con que las provincias y municipios establezcan sus propias leyes, existe una incertidumbre jurídica en cuanto a las circunstancias para la aplicación de la captura de plusvalías sobre las tierras urbanas, motivo por el cual muchos gobernantes municipales desistan de actuar en consecuencia. Rosario se destaca como uno de los municipios que promovieron varias intervenciones y sin duda es visto como progresista en este tema.

En Argentina, con relación al tema de la Usucapión y Prescripción Adquisitiva de Dominio, la Ley 24.374/94 intenta resolver las ocupaciones de inmuebles y solucionar una problemática social que vive una gran parcela de la población del país, particularmente las que se encuentran en los cinturones urbanos que rodean las grandes ciudades como por ejemplo CABA, Rosario, Córdoba, Mendoza y Santa Fe. Por el régimen de regularización de dominio predial establecido por esta ley, se asegura la posesión al ocupante de un inmueble público que lo ocupara de forma pacífica y continua durante tres años con anterioridad al 1 de enero del 1992 (este 
artículo se modificó el 1 de enero de 2008). Esta ley permitió al Estado no sólo ejercer una efectiva regulación y control de los inmuebles en sus aspectos impositivos, de salubridad, seguridad y de ordenamiento urbano y territorial, sino también sanear la informalidad de una gran cantidad de títulos. Todo poseedor individual de un bien inmueble público que esté actuando como su propietario y que así permanezca durante un tiempo determinado puede adquirir la propiedad de éste, siempre que la posesión haya ocurrido según los requisitos. Son previstas dos modalidades: la prescripción corta, cuyos requisitos son diez años de posesión, justo título y buena fe, y la prescripción larga, cuyo único requisito es el transcurso de 20 años de posesión.

El artículo $2^{\circ}$ de la Ley 24.374/94 establece que pueden usufructuar de los beneficios y obligaciones que forman parte de la misma: a) las personas físicas ocupantes originarias del inmueble, b) el cónyuge supérstite y los sucesores hereditarios del ocupante originario que hayan continuado con la ocupación del inmueble, c) las personas que, sin que sean sucesores, hubiesen convivido con el ocupante originario, recibiendo trato familiar, por un lapso no menor a dos años anteriores a la fecha establecida por el artículo $1^{\circ}$, y que hayan continuado con la ocupación del inmueble; d) los que, mediante acto legítimo, fuesen continuadores de dicha posesión.

La Ley 11418/93, del 27 de julio de 1993 referente al régimen de donación de inmuebles para vivienda familiar dice en su artículo $1^{\circ}$ que al Poder Ejecutivo está autorizado a donar a los municipios de los partidos en donde se encontraren ubicados los inmuebles de dominio privativo del Estado Provincial cuando estos estuvieren siendo usufructuados por ocupantes, según las siguientes condiciones: a) estar ocupando el inmueble exclusivamente con finalidad de vivienda propia y la de su grupo familiar, b) haber construido en el mismo su vivienda y/o haber introducido mejoras de carácter permanente al momento de la verificación de las condiciones requeridas en la Ley, conforme establezca la Reglamentación, c) que el titular de la ocupación y/o alguno de los miembros de su grupo familiar no sea propietario de bienes inmuebles, d) que el monto del canon anual de ocupación, determinado para el último período que debieren abonar, no supere el de diez salarios básicos mensuales correspondientes a la Categoría 4, del Escalafón establecido para los agentes de la Administración Pública Provincial.

A pesar de que en Argentina sea posible la usucapión de tierras de dominio privativo del Estado, este mecanismo no es válido para las villas y asentamientos ya 
que la ley no permite una petición colectiva y el trámite judicial sería muy costoso. Quien se beneficia de este mecanismo generalmente son las personas de mayor poder adquisitivo y en el ámbito rural, donde el proceso es común. En el caso de los inmuebles públicos el trámite se debe realizar ante un Juzgado de injerencia administrativa: no alcanza la prueba de testigos, la presentación de comprobantes de pagos de impuestos y tasas es muy relevante y se deben presentar los planos de mensura.

En cuanto a los casos de usurpación colectiva y asentamientos irregulares, la entonces diputada nacional por la provincia de Santa Fe, Silvia Augsburger, presentó un Proyecto de Ley para que se apruebe la "declaración de usucapión especial colectiva de inmueble urbano" a través de una sentencia que serviría de título para su registro en la repartición de catastro. El referido Proyecto de Ley pretendía contemplar las ocupaciones de los sectores de más bajos ingresos con fines de vivienda por un periodo de cinco años ininterrumpidos mientras que los ocupantes no fueran propietarios de otro inmueble urbano o rural. En la sentencia, el juez atribuiría igual fracción ideal de terreno a cada ocupante, independientemente del tamaño del terreno que cada uno utilice, exceptuadas las fracciones ideales diferenciadas que hubiesen sido consensuadas por escrito entre los condóminos. Desafortunadamente se volvió "letra muerta", pues el referido proyecto no siguió adelante. En Argentina, de manera muy similar a lo que sucede en Brasil, hay una cultura instalada: la de que se tengan títulos plenos sobre la propiedad, y tal vez por este motivo sea tan difícil incorporar en la legislación la usucapión colectiva.

Junto a la regularización de propiedad de la tierra, están previstos en el Capítulo IV de la Ley 9533/80 las condiciones para la concesión de uso o cualquier otra modalidad administrativa referente a la tenencia de bienes de dominio privativo del Estado, a saber: a) la tenencia será siempre precaria y como consecuencia el acto revocable en cualquier momento por decisión de la autoridad competente, b) el tiempo de la tenencia no podrá exceder los cinco años; c) el canon anual a cuyo pago estará obligado el tenedor se fijará en el acto administrativo respectivo y no podrá ser inferior al diez por ciento de la valuación fiscal vigente en cada uno de los años de concesión, d) toda ocupación ilegítima, sin perjuicio de otras acciones que correspondan al Estado, queda sometida en las disposiciones de esta Ley. El artículo 29 aclara que los incisos b) y c) no serán aplicados cuando la tenencia se dé mediante licitación o cuando se trate de inmuebles que por su naturaleza especial o uso al que se destinarán se justifique exceptuarlos de tales disposiciones o tengan 
destino de vivienda familiar única y de ocupación permanente y cuya valuación fiscal no supere el monto establecido por la Ley Impositiva para la exención del impuesto inmobiliario prevista en el inciso n) del artículo 137 del Código Fiscal. El artículo 32 describe los motivos pasibles para la cancelación de la concesión: a) cumplimiento del plazo, b) muerte del concesionario, c) Imposibilidad de cumplimiento del objeto, d) revocación y e) caducidad por causas imputables al concesionario, tales como: falta de pago, cambio de domicilio, cesión, pérdida material de la tenencia por la acción de intrusos, abandono, daño deliberado del bien por acción u omisión del beneficiario, y hechos que en forma potencial o efectiva tiendan a disminuir su valor.

En cuanto a la transferencia de la tenencia y administración de los inmuebles fiscales provinciales del Poder Ejecutivo a las Municipalidades, el artículo 38 de la misma Ley 9533/80 establece que la transferencia ocurrirá cuando la ubicación y característica de los mismos inmuebles aconsejen la medida. En tales casos la respectiva Municipalidad podrá a su vez conceder el uso de los inmuebles a terceros con sujeción a las disposiciones de la referida Ley. El canon que se perciba en estos casos ingresará al patrimonio municipal en compensación por la gestión administrativa. La transferencia a cada municipalidad y la consecuente concesión de uso de que dispone cesará de inmediato cuando la Provincia requiera los inmuebles. La delegación de la administración implicará además de por parte de la Municipalidad la obligación de asumir el cuidado y conservación del bien incluyendo las cargas consiguientes.

\section{8 - El difícil sueño de la casa propia}

Una de las principales críticas que se hacen al PMCMV, que en su inicio estableció la meta de construcción de 3,4 millones de unidades habitacionales en seis años, es la de que sea fuertemente subsidiado por el Estado, el que dispensa al programa un tratamiento muy vinculado al mercado al dejar que las constructoras elaboren los proyectos y administren su ejecución, dejando a las entidades sociales, cooperativas y otras instituciones sin fines lucros de autogestión de la vivienda, toda la burocracia e impuestos, como si se tratara de una empresa privada. Esta postura del Estado, que sigue la misma lógica mercadológica aplicada a las empresas, incluye el mecanismo de alienación de la propiedad en caso de falta de pago. Incluso cuando está probado desde hace mucho tiempo y por diferentes experiencias, tanto en Brasil como en Argentina, Uruguay y otras partes de 
Latinoamérica, que las viviendas construidas mediante autogestión por cooperativas y otras asociaciones compuestas por los propios futuros moradores alcanzaron mejores resultados, desde el punto de vista de los proyectos y de la calidad, que las viviendas producidas por privados y sin la participación de los moradores (VIVIENDA POPULAR, 2013, p. 91-93).

En Brasil la situación se agrava con la constatación de que, a lo largo de la historia, el Estado no se preocupó en implantar un sistema de uso del suelo compatible con las necesidades de producción habitacional, y en especial de Interés Social, lo que fatalmente aumenta el costo de la vivienda en general para todas las capas sociales, pero obviamente aún más para los sectores de más bajos ingresos, confinándolos a las periferías donde el costo de la tierra es en un primer momento menor, pero que "acaba saliendo más caro" por la falta de infraestructura. Además del hecho de que, aún hoy, el reconocimiento del valor social de la tierra, así como los mecanismos de control y ordenamiento del suelo, impuestos por la Constitución de 1988 son poco recordados en Brasil, por no decir olvidados. Otro de los motivos es la escasez de oficinas públicas previstas por la constitución para ocuparse del problema, los parcos recursos para su operatividad, el cuadro funcional desfasado de profesionales especialistas, la estructura logística operacional desgastada, además del complicado enmarañado jurídico en especial con relación a la cuestión de regularización del suelo, entre otros, lo que lleva a favorecer el predominio de las grandes empresas privadas que se fortalecen con los créditos del erario.

\section{9 - CONCLUSIONES}

En este Capítulo 2 al exponerse con más detalles lo que ya se anticipó en el primer capítulo, se corrobora, según estas Conclusiones, con todos los tópicos enunciados en la Presentación de esta tesis (la pregunta guía de ésta (saber cuáles fueron los principales elementos facilitadores y restrictivos en la adopción de políticas públicas de VIS a través de la tipología arquitectónica en altura durante el período de 1937 a 2017), las dos hipótesis y los objetivos (general y específicos propuestos)). Así este doctorando cree que pudo comprobar satisfactoriamente bajo aspectos teóricos y prácticos la importancia y viabilidad del uso de la tipología arquitectónica en altura, como un expediente para solución, del grave problema social del déficit habitacional, a través de políticas de VIS, cuya solución para este problema indudablemente justifica el avance y profundización de esta investigación 
más adelante en otras oportunidades. Se llama la atención que los detalles mencionados hace poco se presentan intercalados entre los seis ejes metodológicos propuestos, éstos que están mezclados a lo largo de gran parte de toda esta tesis, como se puede percibir hasta entonces y adelante, a saber:

Para intentar enfrentar los graves problemas sociales, entre éstos el del déficit de vivienda, se han constituido cooperativas sin fines de lucro que, desde su surgimiento a finales del siglo XIX, se han mostrado hasta hoy una importante opción eficaz y de bajo costo. Sin embargo, los representantes de los sectores financiero e inmobiliario -de vivienda y tierra -, entre otros, no sólo nunca manifestaron interés en la madurez y expansión de las cooperativas, sino que incluso obstaculizaron la creación y reglamentación de leyes que favorecieran el ejercicio de las actividades cooperativistas.

Argentina ha estado mejor posicionada que Brasil en lo que toca al tema de las cooperativas, al menos numéricamente en cuanto a la participación de estas asociaciones en varios sectores del mercado además del de la construcción. Sin embargo, en ambos países y en otras partes del continente, la obstaculización proviene del cultural e intocable concepto-dogma de la propiedad privada absoluta de la tierra y del inmueble, incluso ante las más fundamentales necesidades públicas de abastecimiento de vivienda y de tierras de cultivo para los sectores de más bajos ingresos. Concepción que urgentemente debería ser extinta en función del concepto de propiedad colectiva, convalidando, de esta manera, el concepto de producción social. Tanto en Argentina como en Brasil, las políticas neoliberales y las privatizaciones masivas han traído consigo graves consecuencias para la sociedad en general, como por ejemplo el de la concentración de la riqueza en manos de pocos con exclusión de los sectores de baja renta. Política que se puede apreciar incluso en el PMCMV, que a pesar de que presente una gran preocupación por los sectores de bajos ingresos y que esté fuertemente subsidiado por el Estado, mantiene un alto grado de "financierización" dado el espacio que da a las expectativas e intereses de la iniciativa privada pese a la importancia de su participación en la sociedad como un todo en la construcción de la riqueza económica (PIB) de cualquier país.

En cuanto a las ONGs, surgidas en el siglo pasado, importante herramienta de políticas públicas, reciben generalmente dos críticas: la de que tienden a ser más costosas con relación a la tasa de administración que cobran por los servicios que prestan, crítica que carece de fundamentación, como se ha expuesto, y sobre su 
legitimidad y credibilidad, una vez que en su gran mayoría dependen de recursos externos ya que no les son suficientes los ingresos internos del propio país.

En lo que se refiere a la utilización de las leyes como estrategia de intervención en el campo del urbanismo, en especial en el sector de la vivienda, la realidad demuestra que, aunque los sectores de más bajos ingresos consigan ver sus expectativas atendidas, dichas leyes no siempre están exentas de subterfugios que en práctica acaban por dificultar, y a veces inviabilizar, lo que originariamente se pretendía alcanzar, muchas veces por ser creadas de manera inconexa con la realidad de los segmentos que deberían beneficiar, como por ejemplo el caso expuesto de la Lei No 11.888, Lei de Assistência Técnica Pública e Gratuita, de 2008, originada a partir del Projeto de Lei $N^{\circ}$ 6.981/06, del arquitecto Zezéu Ribeiro, que por diversos motivos no se corresponde con la expectativa de millones de brasileños que podrían ser asistidos mediante la autoconstrucción de sus viviendas a través de la creación y funcionamiento de las oficinas públicas previstas por la ley pero que en la práctica son insuficientes e incluso incompetentes. En este sentido conviene recordar las recomendaciones de la Comisión Asesora de la Dirección Nacional de Viviendas de Uruguay en cuanto al cuidado que se debe tener en el buen uso del mecanismo de densificación de áreas centrales e intermedias de las grandes ciudades, así como de la política de creación de una Cartera de Tierras, entre otras medidas, por parte del Estado, para el buen éxito de las políticas públicas de VIS. Y para esto, tiene que haber más decisión política y menos propaganda, es decir, más efectividad en las acciones públicas.

Un antiguo obstáculo en las políticas públicas de vivienda continúa bien actual: el precio elevado de los terrenos y de su urbanización, sumado a los altos costos de la mano de obra y de los materiales de construcción, que vuelven la adquisición del techo prácticamente inaccesible a los trabajadores en general. Para resolver esta situación es necesaria la reducción del costo de las obras, lo que podría solucionarse mediante la estandarización de los materiales, la facilitación al acceso de la tierra, la revisión de las leyes edilicias controvertidas, la promoción de la investigación tecnológica, la actuación de las oficinas públicas, así como a través de algo absolutamente imprescindible y urgente: políticas eficaces de distribución de renta. Temas que se arrastran desde hace décadas, sino siglos, al compás de los intereses de grupos conservadores y reaccionarios que ven sus privilegios amenazados, como, por ejemplo, durante la vigencia de la Ley del Alquiler en Brasil y en Argentina. 
En la CABA, en 1987, fueron vanos los esfuerzos de la Secretaría de Obras Públicas para aprobar una tasación fiscal del 15\% sobre el excedente en altura permitido por el Código de Planeamiento de 1977. De igual forma ocurrió con el primer intento de alterar el código a fines de la década del (19)80 para que el Municipio pudiera aplicar una tasa diferencial sobre el ulterior aumento del valor de los lotes proveniente de las potenciales intervenciones urbanísticas.

Una importante medida favorable a los sectores de bajos ingresos fue la que ocurrió en la CABA con la creación del Programa de Radicación de Villas de la Capital en junio de 1991. Frustrante y lamentable es la constatación de que, a pesar de la buena voluntad y supuesto empeño de los promotores gubernamentales de estas medidas, los resultados en los discursos hayan sido mayores que las acciones realizadas hasta hoy en pro de dicha población.

En el campo de la legislación edilicia y en especial para VIS, Argentina carece de parámetros urbanísticos nacionales, como por ejemplo el Estatuto da Cidade, basado en lo que establece la constitución de Brasil al respecto de la función social de la propiedad de la tierra, cuyo tema en Argentina está a cargo del municipio o de la provincia, generando, algunas veces, distorsiones o superposiciones en la aplicación de los parámetros.

Con relación a la Usurpación y Prescripción Adquisitiva de Dominio en Argentina, la Ley 9533/80 y la 24.374/94 intentan resolver los casos de ocupación de terrenos e inmuebles de propiedad del Estado por personas o familias de bajos ingresos y así solucionar una significativa problemática social. En vano la diputada Silvia Augsburger presentó un proyecto de ley para que se apruebe la "declaración de usucapión especial colectiva de inmueble urbano" que a través de una sentencia judicial hubiera servido como título de propiedad para su registro en la dirección de catastro, lo que hubiera atendido numerosos casos de asentamientos irregulares colectivos.

Diferentes estudios comprueban la conveniencia económica y de mejor calidad de vida del uso de la tipología en altura multifamiliar en áreas urbanas centrales de alta densidad e infraestructura, al contrario de las habitaciones unifamiliares aisladas del centro, en espacios de baja densidad o sin infraestructura. Dicha conveniencia económica se da cuando el proyecto considera el impacto de la implantación y/o sustitución de la infraestructura y siempre que respete el 'límite inferior' de la curva decreciente del costo "per capita", pues la curva vuelve a crecer. 
También la falta de una voluntad política en lo que se refiere a la falta de leyes adecuadas para las políticas de vivienda de los sectores de más bajos ingresos hace que un parque inmobiliario utilizable y desocupado desde tiempo en las ciudades no sea aprovechado para resolver el problema de la vivienda, situación para nada razonable.

Al analizarse la producción social colectiva en América Latina no se puede olvidar del acervo técnico producido desde los (19)60 por las cooperativas de vivienda de Uruguay, lo que refuerza la convicción de que cuando se quiere y hay determinación política la sociedad consigue resolver de la mejor manera sus problemas y aspiraciones, utilizando tanto las herramientas materiales -tecnología-, como inmateriales -leyes e investigaciones cualificadas-, disponibles. Así, al pensarse la elaboración y ejecución de proyectos de VIS, hay que sacar el mejor provecho del fenómeno de las redes de solidaridad, que están asociadas a otro fenómeno no menos importante, el del "capital local", tan común en este continente, actúe o no en el mercado formal inmobiliario. Por lo tanto, no está demás enfatizar que los mayores obstáculos a la industrialización de la construcción no son de orden técnico -elaboración de los proyectos, fabricación y montaje de los elementos arquitectónicos-, sino de carácter económico, administrativo y político. Un ejemplo ilustrativo del despilfarro por parte del Estado al ignorar la útil e inteligente aplicación del acervo técnico producido por profesionales de varios campos disciplinares de todo el continente, es el abandono en que se encuentra la producción intelectual y material del arquitecto João Filgueiras "Lelé" Lima, reconocido internacionalmente, sobre el que no se habla y mucho menos se aplica en los espacios urbanos brasileños. Lamentablemente así ocurre en Brasil y por lo visto también en Argentina, a ejemplo del arquitecto Fermín Bereterbide..

Otros tantos autores, con sus incesantes contribuciones intelectuales, en sus respectivas áreas de conocimiento, a lo largo de todo el siglo XX, tanto en Argentina como en Brasil, comprobaron hartamente, no sólo en teoría sino también en la práctica, que técnica y económicamente, la tipología arquitectónica en altura es la más conveniente considerando la escasez del suelo y el encarecimiento de la implantación de redes de servicios públicos en las grandes ciudades del continente, Ante lo hasta aquí expuesto y la necesidad insatisfecha de solucionar el problema del déficit habitacional, en especial de sectores de más bajos ingresos, se hace evidente la falta de voluntad política y de sentido cívico colectivo de gran parte de los grandes sectores de la iniciativa privada. 


\section{CAPÍTULO 3}

\section{LOS COSTOS DIRECTOS E INDIRECTOS}

No se puede ignorar que, desde el punto de vista financiero, una vivienda económica no necesariamente tiene que ser la más barata. El arquitecto Jorge Czajkowski y el ingeniero Carlos Discoli refieren que es preciso calcular los diferentes costos de una construcción, como la mano de obra, los materiales, el mantenimiento, el factor ambiental, las normas y la organización espacial de los elementos constructivos utilizados; todo esto debe asociarse a la localización geográfica de la vivienda, la que condiciona el mejor aprovechamiento y adecuación al medio ambiente (LOMBARDI, CREMASHI y MARSILLI, 2004, p. 161).

Como se mencionó anteriormente, se sabe que el uso de baja densidad en la VIS requiere de más suelo, lo que tiende a encarecer el proyecto. Un motivo por el cual generalmente se direccionan los conjuntos habitacionales para la periferia de los grandes centros, es el costo potencialmente más bajo de la tierra en un primer momento, pero que, por otro lado, requiere de implantación de infraestructura, y así, lo que inicialmente parecía ser lo más barato, tiende a convertirse en un problema más complejo, pasible de comprometer la sustentabilidad ambiental en el futuro para el morador. En el caso de optarse por proyectos de mayor densidad, con construcciones en altura, es fundamental que se entienda que el proyecto debe hacer el mejor uso posible de los avances tecnológicos, conforme alerta el arquitecto uruguayo Raúl Vallés (2013), para quien no se debe incurrir en la simplificación arriesgada de "ver el árbol y no el bosque" (VIVIENDA POPULAR, 2013, p. 21-23).

Criticando la manera en que FONAVI promueve la distribución de los recursos destinados a los programas habitacionales en Argentina, Gaite (2008) refiere que actúa bajo una "abstracción de normas fundadas en 'universalidad y vanguardia' [...] Utopía convertida en realidad para operar que produce costosos resultados", y que a inicios de 1984 una casa de FONAVI costaba cerca de U\$20.000 (GAITE, 2008, p. 83). Señala también que:

No escapa a nuestra consideración que el problema se asienta en una característica propia del conflicto que afronta la civilización: la desigual distribución de la riqueza y de los medios disponibles para generarla. Es claro que si las posibilidades de trabajo y remuneración adecuada tuvieran vigencia, la "vivienda digna" entraría naturalmente en el campo de los posible (sic), y en definitiva esto constituye la aspiración madre de nuestros desvelos. 
Pero nos preguntamos: mientras la sociedad lucha detrás de este ideal, nuestra preocupación por el hábitat, la calidad de vida del ser humano ¿debe llamarse a sosiego, sentarnos a esperar que en el mundo aparezca la justicia y se den las condiciones adecuadas de operar? [...] Como profesionales dedicados por vocación a la creación de habitabilidad (así entendemos la arquitectura) creemos firmemente que no. Que nuestra misión esencial consiste en actuar HOY Y AQUí [...]

No estamos solos en esta tesitura. La población necesitada de vivienda, sin tantas normas, sin tantas líneas de justificación y análisis de la situación de su derecho a habitar dignamente, se la procura. Pone en acción eses instinto biológico, ancestral.

A veces como el gorrión, instalándose en viviendas desocupadas. Las más de las veces como el hornero, haciendo un esfuerzo más consciente en procura del techo. (GAITE, 2008, p. 84)

\section{1 - El medio ambiente se resiente}

Se sabe que la industria de la construcción es una de las menos sostenibles del mundo ya que consume cerca de $50 \%$ de los recursos disponibles, según Edwards (2009, p. 3). Según Baron (apud BALTER, 2015, p. 12), resultados de investigaciones realizadas por la Universidad Nacional de Cuyo, indican que la energía consumida para la construcción y uso de edificios es de alrededor del 43,5\% del total utilizado en Argentina.

Por otra parte, en Brasil, un grave problema que se observa en los proyectos urbanísticos de VIS es la pobreza del aspecto paisajístico, evidenciada por la aridez, salvo raras excepciones. De las tres comunidades investigadas en Salvador, donde esto menos se ve, aunque esté, es en el Condomínio Perseverança. Este cuadro desfavorable acaba interfiriendo, también, en el entorno de las comunidades y en el nivel de calidad de vida de los moradores.

Además de las incuestionables contribuciones de tenor estético, de control del microclima y de la salud física y espiritual del Hombre, entre otras, que el verde promueve donde esté implantado, en el caso de las VIS, a través de las huertas colectivas, también se puede sacar partido de la generación de trabajo y renta mediante emprendimientos comunitarios como el propuesto por el arquitecto argentino Miguel (2010, p. 25), basado en los resultados provenientes de las huertas cooperativas en pleno centro de Caracas.

El Rocky Mountain Institute, renombrado equipo de profesionales expertos en medio ambiente defiende la teoría del "factor cuatro", que consiste en: a) crear tecnologías más eficientes, b) promover un mayor uso del reciclaje, c) mejorar la 
gestión y d) elaborar proyectos más eficaces, de donde la sociedad podría pensar en crecer sin causar más daños ecológicos (EDWARDS, 2009, p. 7).

Durante el siglo XIX, asociado a la preocupación higienista -limpieza y salubridad-, el tema de la implantación y preservación de áreas verdes en las ciudades se volvió evidente, ya que hubo también un cambio en la percepción del uso de estas áreas, que hasta entonces tenían un carácter privativo y estético, convirtiéndose así en una función social, pública y cívica. Este cambio empezó con más aliento en Inglaterra y luego se expandió por Europa y el resto del mundo, fuertemente vinculado a la noción de orden y desarrollo -técnico-industrial-, difundida por el positivismo. De la propuesta del belt -anillos concéntricos alternándose entre ocupaciones urbanas y rurales- defendida por John Loudon para los espacios verdes de Londres, se pasa a la de Paxton y Repton, incorporando lagos, prados y belts en sus parques, hasta llegar a la propuesta más difundida en el exterior, la de Ebenezer Howard, con sus ciudades-jardín, sin que la noción de cooperativa necesaria para viabilizar el emprendimiento se haya sustentado, como por ejemplo los actuales suburbios-jardín, reminiscencias de lo que planeara Howard (MIGUEL, 2010, p. 122124; HOWARD, 1996).

Destinados a la supervivencia de los operarios y de la pequeña burguesía alemana a través de la producción de alimentos durante el siglo XIX, se hicieron muy conocidos los huertos individuales alemanes schrebergärten, en los cuales las familias, con el aval del Estado, cultivaban sus propias plantaciones -hortalizas y frutas-, mientras desarrollaban, principalmente entre los más jóvenes, la enseñanza y contacto con la naturaleza. Propuesta bien vista por el arquitecto Sebastián Miguel para que se estudie y aproveche en los contextos de proyectos urbanísticos en áreas de construcciones precarias, en busca de una nueva relación ciudad/naturaleza a través de los jardines, lo que fundamenta la "arquitectura sostenible" (MIGUEL, 2010, p. 126-231).

Aún en el siglo XIX, como propuesta política para mejorar las interrelaciones de grupos sociales diferentes, surge el proyecto del agricultor Frederick Law Olmsted, inspirado en el garden movement (movimientos de los cementerios rurales) estadounidense, para la creación del Central Park de New York, proyecto que, a su vez, sirvió de inspiración en la implantación del Parque Palermo en Buenos Aires (MIGUEL, 2010, p. 128), tal como ocurrió en São Paulo, en la construcción del Parque Ibirapuera, por el arquitecto Oscar Niemeyer y el paisajista Roberto Burle Marx. 
Considerando el alto grado de contaminación de los ríos y lagunas, que se volvieron verdaderas redes de desechos residenciales e industriales a cielo abierto en las grandes y pequeñas ciudades, la preocupación por el medio ambiente actualmente en Brasil permanece sólo en el papel, como por ejemplo la bacía de Alto Tietê, a la cual pertenece la represa de agua Billings que abastece la ciudad de São Paulo, que contrasta radicalmente con lo que establecen las leyes de preservación ambiental, como la Ley Federal brasileña $N^{0} 6.766 / 70$, que regula la parcelación del suelo urbano y establece que es área no edificable la que está comprendida en una franja de $15 \mathrm{~m}$ a cada lado de un arroyo, y la Ley Federal $\mathrm{N}^{\circ}$ 4.771/65, conocida como Código Florestal, que establece como área de preservación permanente de florestas y demás formas de vegetación natural a lo largo de ríos y de cualquier curso de agua una franja de $30 \mathrm{~m}$ a cada lado, y 50 en torno de las nacientes (ABIKO y ORNSTEIN, p. 305).

A partir del primer Congreso Internacional de Vivienda, ocurrido durante la Exposición Internacional de Paris, en 1889, surge el concepto de "casas baratas" de construcción económica para atender a los operarios vinculados a la industria y que es el antecedente del actual concepto de VIS. Con la valorización de la creación de espacios verdes, ya sea en ámbito público que privado, surge un cambio en el tradicional trazado en ajedrez de las cuadras de Buenos Aires, como ocurrió en el Barrio Butteler, construido en 1907, el Barrio Cafferata, en 1921, y en La Casa Colectiva Patricios, en 1938. Utilizando una escala de mayor densidad y mezclando torres de diez pisos con viviendas en planta barra unifamiliares entre espacios verdes, recordando propuestas de los modernistas del Team $X$, surge el proyecto Barrio Catalinas Sur, construido en 1963, y que aún hoy atiende satisfactoriamente sus presupuestos (MIGUEL, 2010, p. 87-92).

En la segunda mitad del siglo pasado, en otras partes del mundo, muchos proyectos fueron elaborados, como por ejemplo el de Emilio Ambasz, en 1976, en California, que utilizó sofisticadas tecnologías para el racionamiento de la energía y la explotación de recursos naturales en una cooperativa de viñedos mexicanonorteamericanos. Otro proyecto fue el de los Centros Comunitario-Educacionales y Agrícolas, en las laderas de los Andes peruanos, en Lima en la década del (19)60, donde el gobierno en asociación con el PNDU promovió, a partir del Proyecto Piloto 1-PREVI, intervenciones urbanas en áreas degradadas y de asentamientos espontáneos. Otro en el sur de Francia en 1996, donde se inició un proyecto de 50 VIS bajo responsabilidad del arquitecto Valicourt, del Instituto Mediterráneo de 
Edificación y de Medio Ambiente, muy atento a los temas ecológicos, tanto en el espacio privado como en el público. También el programa Green City de la fundación Planet Drum, surgido en 1990, orientado a la problemática de las ciudades sostenibles, que incluía aspectos de gobernanza comunitaria -cooperativas-. En Alemania, la Universidade de Karlsruhe, apoyó la fundación, en 1989, de la asociación Initiativkreis Ökologisches, para la promoción de métodos de construcción ecológicos donde se da relieve a la participación comunitaria y a la metodología de sistemas constructivos abiertos y flexibles en proyectos interdisciplinares. En Canadá existen los jardines comunitarios, generalmente instalados en áreas de fábricas desactivadas, donde las VIS colectivas para la tercera edad poseen huertas cultivadas por los propios moradores. En Argentina, un interesante ejemplo de proyecto de huerta comunitaria viene de la ciudad de Rosario, Santa Fe, desde 2001, a través del Programa de Agricultura Urbana (PAU), con la participación de la Secretaría de Promoción Social y del CEPAR, programa que promueve la actividad cooperativa y la participación comunitaria en la explotación de productos y alimentos provenientes del cultivo de las huertas.

Se puede considerar también entre éstos el Proyecto para un Jardín Productivo -recalificación de espacios públicos- Complexo do Alemão, de 2009, fruto del trabajo conjunto del arquitecto argentino radicado en Brasil Jorge Mario Jáuregui con un grupo de investigadores dirigidos por el arquitecto argentino Sebastián Miguel de la Facultad de Arquitectura y Urbanismo de la UBA (FADU-UBA) en el ámbito de las macro intervenciones urbanísticas realizadas en Brasil por el PAC en el Complexo do Alemão, Rio de Janeiro, a partir de 2008. También, este mismo grupo de investigadores realizó, en el mismo período y bajo un concepto urbanístico semejante, otro importante proyecto de gran porte en una extensa área de alta vulnerabilidad social y de degradación: el Corredor Productivo, en el Complexo de Manguinho, Rio de Janeiro, también a través del PAC (MIGUEL, 2010, p. 140- 151; 179-195, 197-202).

Según Echechuri et al. (1996), a través de un levantamiento realizado entre 1990 y 2004, presentado en el Informe final Los espacios verdes de la Capital Federal, la CABA disponía de solamente el $5 \%$ del total de su superficie con espacios verdes (ECHECHURI et al., apud CLICHEVSKY, 1996, p. 21, 144). Situación preocupante de la cual Salvador, con su poco más del diez por ciento, no está exenta, al igual que tantas otras ciudades de este continente, por lo que no hay que olvidarse que: 
[...] la construcción en altura mediante un diseño ambientalmente consiente, es prácticamente la única alternativa posible en términos de sustentabilidad, a partir de la concentración de la construcción y de la utilización de edificios de pequeña huella que reduzcan al máximo el uso del suelo disponible.

Las posibilidades de conseguir un programa global para un futuro sostenible, se decidirá, probablemente en las ciudades. Si las previsiones de campo-ciudad resultan correctas el tipo de edificio clave podría muy bien ser el edificio urbano de alta densidad. La evidente consecuencia de semejante comprensión de personas en espacio pequeños es construir hacia arriba, para acomodar a la oleada de habitantes urbanos. (...) independientemente de si estamos a favor o en contra del rascacielos. (YEANG apud BALTER, 2015, p. 14-15).

3.2 - Los moradores de bajos ingresos levantan sus techos

Estudios sostienen que en Salvador, entre 1969 y 1989, en las ocupaciones colectivas más precarias, predominantemente de planta baja, se presentan las mayores tasas de densidad, de alrededor de 400 habitantes/ha -variando de 56 habitantes/ha a 1600 habitantes/ha para lotes de $15 \mathrm{~m}^{2}$ a $250 \mathrm{~m}^{2-}$. En estas ocupaciones las habitaciones fueron construidas con bloques de cerámica, sin revestimiento, con techo prefabricado, teja de amianto y un baño, con un área media de $30 \mathrm{~m}^{2}$ en lotes de alrededor de $60 \mathrm{~m}^{2}$. Con estas características, el costo estimado de la construcción, incluyendo la mano de obra, estaría alrededor de U\$ 6.000 (U\$ 200 por $\mathrm{m}^{2}$ ), contando el valor del lote, a depender de la ubicación, totalizaría entre U\$8.000 y U\$ 10.000 por unidad habitacional (GORDILHO-SOUZA, 2008, p. 273).

Cuando Bonduki (2004, p. 250) critica el modelo de gestión de la ciudad, al que denomina de "central-desenvolvimentista", y que tuvo origen durante el gobierno de Getúlio Vargas, en el periodo del Estado Novo (1937-1945), lo caracteriza como un modelo autoritario, centralizador, sin la participación popular, que privilegiaba el transporte individual e implantaba muchas veces obras innecesarias además de que no tuviera respeto por el medio ambiente y el patrimonio cultural:

[...] quando o BNH (a partir de 1986, a Caixa Econômica Federal), ou as Cohab's, buscaram reduzir o custo da moradia para atender à população que vinha empobrecendo, em vez de alterar o processo de gestão e produção, que encarece o produto final, optaram por rebaixar a qualidade da construção e o tamanho da unidade, construíram moradias cada vez menores, precárias e distantes. 
(BONDUKI apud PERES y LIMA apud FERNANDES y SOUZA, 2004, p. 251)

No es necesario reforzar la argumentación para saber quién es que continúa siendo más perjudicado con esta postura, la cual se adoptó en aquel momento y que permanece vigente en mayor o menor grado hasta hoy.

El equipo de arquitectos uruguayos Casa Concepto propone proyectos racionales, mínimos, diversificados -huyendo de los prototipos en serie- con base operacional simple y concreta, vinculando aspectos del hábitat, densidad e infraestructura, ofreciendo al usuario la posibilidad de participar en el desarrollo del proyecto, incluso de la ampliación de su vivienda en futuro. En ese sentido es importante considerar el aspecto del alto costo del suelo en áreas centrales de la ciudad y que el ítem de infraestructura urbana generalmente consume la mitad del costo de una vivienda, por lo que sugieren utilizar el ancho mínimo de las dimensiones del terreno para optimizar costos (VIVIENDA POPULAR, 2013, p. 3449).

En Uruguay, el programa Plan Lote permite al ciudadano de baja renta financiar la compra de lotes infra estructurados en áreas consolidadas y de materiales para la autoconstrucción de la unidad habitacional unifamiliar. EI adquiriente amortiza el préstamo a partir de 24 meses y el valor de la cuota mensual se reajusta anualmente, sin que exceda el $20 \%$ del valor del presupuesto declarado en el catastro del programa. El plazo máximo de la financiación es de 20 años, y la tasa de amortización es del $2 \%$ anual del valor financiado. El plan es administrado por la Intendencia de Montevideo en convenio con el Ministerio de Vivienda, Ordenamiento y Medio Ambiente (MVOTMA) a partir de 2008 y en coordinación con los municipios y Centros Comunales Zonales que hacen parte del Programa. El valor de la financiación es dividido en seis veces: la primera cuota se destina a la compra del terreno -lotes entre $200 \mathrm{~m}^{2}$ y $350 \mathrm{~m}^{2}$ - y la escrituración, las cinco siguientes son para la compra de materiales y parte de la mano de obra, mediante comprobación del avance de las obras. Conforme preestablecido contractualmente, el adquiriente tiene hasta 18 meses a partir de la firma de la "escritura de compraventa", para construir la vivienda (VIVIENDA POPULAR, 2013, p. 68-75). El Plan Lote fue aceptado satisfactoriamente por la población, pero el número de familias interesadas superó significativamente la oferta disponible. De las viviendas construidas, el $65 \%$ posee 3 habitaciones, el $14 \%$ posee 4 y el $21 \%$ posee 2 . Hubo dos constataciones importantes en esta experiencia: la primera, que el proceso de autoconstrucción de 
las viviendas tuvo mayor éxito entre las familias que poseían algún conocimiento o práctica de construcción y que tuvieron una mayor disponibilidad de tiempo y capacidad de administrar la obra, lo que se vio potencializado por el trabajo de orientación de los profesionales del Programa que dieron asesoramiento personalizado, la segunda, que todavía hay que afrontar una mejor estrategia de mezclar personas de realidades y clases sociales diferentes en espacios vecinos (VIVIENDA POPULAR, 2013, p. 73-75). Con relación a los controles para evitar problemas en la financiación de las VIS con recursos estatales, hay que tener en cuenta que:

[...] para fortalecer el sistema, las viviendas subsidiadas deben sustraerse del mercado, para lo cual su comercialización debe ser controlada por el MVOTMA, especialmente aquellas que se otorgan en régimen de propiedad individual. Para ello, el subsidio otorgado, en el caso que se mantenga en propiedad del destinatario si abandona la vivienda, debe ser entregado en forma de certificado no negociable, como una forma de garantizar su uso para vivienda. (VIVIENDA POPULAR, 2010, p. 81)

Las recomendaciones de la Comisión Asesora de la Dirección Nacional de Viviendas sirvieron como propuesta para la actualización de la Ley Nacional de Vivienda $\mathrm{n}^{\circ} 13.728$ de 1968, que fue una referencia muy importante en Latinoamérica, y fundamentaron el Plan Quinquenal de Vivienda 2011-2015 aprobado por el Parlamento. La Ley Nacional de Vivienda de 1968, en su artículo 142, define a las cooperativas de vivienda como:

[...] "sociedades regidas por el principio cooperativo (...) cuyo objetivo principal es proveer de alojamiento adecuado y estable a sus asociados, mediante la construcción de vivienda por esfuerzo propio, ayuda mutua, administración directa o contratos con terceros y proporcionar servicios complementarios a la vivienda." [y en su artículo 142 continúa] "son unidades cooperativas de vivienda las constituidas con un mínimo de 10 socios y un máximo de 200, tienen por finalidad proporcionar vivienda y servicios complementarios a los mismos, construyendo con ese objetivo un inmueble o un conjunto habitacional. [...] Las cooperativas adoptan dos sistemas: el de ahorro previo y el de ayuda mutua. En ambos el grupo tiene que aportar al menos un $15 \%$ del valor de las obras, el primero con un ahorro grupal y el segundo con su mano de obra en la construcción. [...] La ley también prevé, a los efectos de evitar la especulación, que en las cooperativas de usuarios, al dejar la casa el socio debe renunciar, pagándole la cooperativa los aportes hechos en mano de obra o ahorro, así como las cuotas pagas como amortización, cobrándosele el mismo monto al socio entrante, seleccionado por la cooperativa, siendo una forma de control social grupal sobre la 
mercantilización del bien. (VIVIENDA POPULAR, 2012, p. 27-29). (las comillas y el itálico están según el original).

\section{3 - El Estado y el retardo de inversiones en viviendas populares}

Hay que considerar que a pesar del importante avance de las tecnologías las dos últimas décadas del siglo XX demuestran que la globalización impidió la apropiación de éstas por parte de la mayoría de la humanidad, como Francisco Silva (apud MARICATO, 2011, p. 62-68) alertaba sobre las llamadas "ilhas de primeiro mundo", espacios privilegiados donde se desarrollan y apropian las ventajas de los procesos globales productivos y financieros. $Y$ esto se refiere también al campo de la construcción, donde la producción de VIS se insiere, fenómeno que se presenta de forma cruda en las regiones periféricas de América.

Carlos Lobo (apud LOMBARDI, 2004, p. 23, 196), arquitecto mexicano, propone una tecnología para VIS que puede ser aplicada por los futuros moradores durante su ejecución y mantenimiento, haciendo los procesos de construcción más rápidos y baratos: que la planta de los baños sea de triple función, es decir, espacio para ducha, lavatorio e inodoro simultáneamente, considerando que esta parte de la construcción comúnmente representa cerca del $27 \%$ del costo de la vivienda.

El arquitecto argentino Hilario Zalba, que dominó profundamente el tema de la reducción de costos en la construcción de vivienda, defendía la tesis de racionalización y prefabricación como herramientas a las que no se puede renunciar. Zalba, integrante del grupo argentino Austral, como se dijo, fue uno de los pioneros en diseminar en Argentina los postulados modernos propuestos por Le Corbusier. Para Zalba, la construcción en altura ofrecía mejores habitaciones y de más bajo costo en comparación con las "viviendas aisladas" -casas unifamiliares- que demostraron ser más caras (ZALBA apud COSOGLIAD, 2003, p. 65-80).

En cuanto al aprovechamiento de las construcciones deterioradas, muy numerosas en los centros antiguos de las grandes ciudades, se deberían utilizar nuevas tecnologías para racionalizar los costos y los plazos, produciendo habitaciones populares más confortables, seguras y económicas. Para esto es indispensable la actualización de los catastros inmobiliarios de la ciudad, de donde se puede evaluar el stock y situación real de los inmuebles, bien como analizar la tendencia del mercado local, y, también, actualizar la legislación edilicia y del suelo para enfrentar la demanda de VIS en este sentido (MARICATO, 2011, p. 145-146). 
En el mencionado proyecto AISAM en la Baixa do Camurujipe, Salvador, donde se construyeron 124 casas con el sistema de cooperación comunitaria de moradores locales, la participación del equipo técnico de la UFBA y el ingeniero Marcos Jorge de A. Santana, el costo por $\mathrm{m}^{2}$ fue de alrededor de $\mathrm{R} \$ 289 / \mathrm{m}^{2}$ (durante el período en que hubo un retraso en la entrega de materiales de 23 meses además de los 12 meses previstos originariamente para la finalización; costo cerca de un $20 \%$ por encima del de mercado) y de alrededor de $\mathrm{R} \$ 176 / \mathrm{m}^{2}$ durante la etapa regular de la obra en que no hubo retraso alguno. En este proceso de colaboración mutua participaron 236 personas de las 628 pertenecientes a las familias beneficiadas por el Proyecto entre 1993 y 1997 (ABIKO y ORNSTEIN, 2002, p. 105107).

El campus experimental de Narandiba, Salvador, para empleados públicos activos y jubilados-, construido por el BNH en 1978 en unión con constructoras privadas fue un muy importante emprendimiento técnico-constructivo, intencionado en abaratar el costo de la habitación popular, donde se aplicaron: "novas tecnologias habitacionais, tecnologias de construção industrializadas e tecnologias alternativas ou apropriadas, como eram denominadas na época" (MALARD et al., apud ABIKO y ORNSTEIN, 2002, p. 244). Lamentablemente, durante los sucesivos gobiernos federales, estatales y municipales, no hubo voluntad política de promover la diseminación, ni siquiera entre los profesionales del área de la construcción.

Experiencias en Uruguay indican que, con la flexibilización de los presupuestos básicos de la Ley de Vivienda ( $n^{\circ} 13.728$, de 1968) en 1992 para atenderse a situaciones de emergencia, fuera permitida la construcción de la vivienda -"Vivienda Mínima" o "Núcleo Básico Evolutivo"/NBE-, con 30,00m², con sólo una habitación, sala y baño, para posterior ampliación por el morador, en lotes de $100,00 \mathrm{~m}^{2}$. Esta excepción pasó a ser regla y con el tiempo trajo graves inconvenencias no sólo del punto de visto de la estructura de la vivienda como también de lo económico, social y urbanístico debido a las adaptaciones deficitarias adoptadas por los vecinos así como a los costos imprevistos, e inclusive una ausencia de optimización del uso adecuado del suelo y del aprovechamiento de la infraestrucutura y servicios existentes. su origen, con todos sus posibles variantes bajo la óptica del costo/beneficio (UNIVERSIDAD DE LA REPÚBLICA, 2012, p. 7179). Asociado a este tema, hay que tenerse en cuenta el hecho de que al implantar un conjunto habitacional, el valor de la infraestructura adicional necesaria en áreas alejadas y desprovistas de servicios, con lotes aparentemente más baratos, acaba 
tornando el proyecto más caro. Investigaciones indican también que, con relación a la productividad en función de la eficacia de las inversiones por metro cuadrado construido, es más importante la modalidad de gestión a ser aplicada en la implantación del proyecto que el tipo del sistema constructivo adoptado, pues, evaluaciones post-ocupación comprobaron que las cooperativas fueron más productivas que las empresas privadas, aunque se computen las ventajas adquiridas -incentivos o exenciones de tasas-, vía leyes sociales (UNIVERSIDAD DE LA REPÚBLICA, 2011 y UNIVERSIDAD DE LA REPÚBLICA, 2012).

Por otro lado, se constató también que, aunque se analicen proyectos con modalidades constructivas semejantes, comparando sus productividades, se pueden detectar diferencias considerables entre estos por causa de sus realidades específicas, como factores externos, como por ejemplo una provisión constante de recursos o de dificultades físicas y geográficas. Tal situación ocurrió en los análisis comparativos entre los seis proyectos de la capital de São Paulo en la última década del siglo $\mathrm{XX}$, lo que indica que no hay que atribuir la eficiencia o la eficacia de un proyecto de forma aislada, solamente por su modalidad de construcción, privada, cooperativa, etc. (WERNA et al., 2001, p. 248) ${ }^{46}$. En la capital de São Paulo, según la Assessoria Técnica Ambiente, cuando se realiza la gestión de proyectos habitacionales bajo responsabilidad de los propios mutualistas por cooperación comunitaria, en el proceso de compra de materiales, contratación de empresas para ejecutar etapas de las obras, fiscalización financiera, etc., se obtiene una reducción en el costo total de la obra de alrededor del $30 \%$ o $40 \%$, y del $10 \%$ en la mano de obra, por lo que se puede concluir que en los procesos constructivos en los cuales se emplea el sistema de cooperación comunitaria la economía obtenida en el costo total final es mayor por causa de la autogestión que de la autoconstrucción (WERNA et al., 2001, p. 198). Incluso, con relación al factor costo/beneficio en función de los procesos constructivos adoptados en los proyectos investigados, se constató que la unión Estado/iniciativa privada mostró resultados más eficaces en función del número de unidades habitacionales construidas, por otro lado, la unión Estado/ciudadano mostró ser más eficiente financieramente ya que fue la que

\footnotetext{
${ }^{46}$ Se usan los conceptos de eficiencia y eficacia establecidos por Francisco Cardoso (2001), que entiende que: "Eficiência [... es la] Capacidade de rendimento de um sistema avaliado, qualitativamente ou quantitativamente, face um certo nível de recursos de base (equipamento; homem; capital; trabalho)". Ya "Eficácia [... es la] Capacidade de alcançar certos objetivos fixados." Así, un sistema puede ser o no eficaz al conseguir o no su objetivo, como, también, puede ser más o menos eficiente, ya que se puede graduar su nivel de eficiencia, lo que, por consecuencia, hace posible comparar dos o más sistemas, organizaciones, procedimientos, etc., en cuanto a sus niveles de eficiencia (CARDOSO apud WERNA et al., 2001, p. 253-254).
} 
produjo unidades habitacionales de forma más económica (WERNA et al., 2001, p. 203-204). Resultados que sugieren que, respetadas las particularidades de los países-objeto de esta tesis, se averigüe la viabilidad, siempre que posible, de la elaboración de proyectos para VIS intentando conjugar estas dos modalidades de asociación con el objetivo de alcanzar proyectos tan eficaces como eficientes, sobre una base ética, racional -técnica y económica- y social, obviamente sin vicios de cualquier especie.

Es necesario que todo proyecto de VIS tenga sus objetivos, metodologías, plazos y costos previstos, permanentemente evaluados bajo los diversos aspectos que se vinculan entre sí, incluso en la post-ocupación, en especial entre los usuarios de los inmuebles que son el público seleccionado de cualquier proyecto de esta naturaleza. Se puede, a título de optimización de análisis, elaborar las informaciones bajo tres grandes aspectos: físico, económico y social, como por ejemplo sugiere el Equipo de Evaluación de Tecnologías y Programas de VIS del IC de la UdelaR (VIVIENDA POPULAR, 2013, p. 25).

El costo de las actividades operacionales que varía de acuerdo con la realidad y el perfil de cada obra y que corresponde a inversiones con el "projeto executivo, gerenciamento e manutenção das obras, consultoria técnica e assistência social" (ABIKO y ORNSTEIN, 2002, p. 312), puede estimarse basado en una porcentual sobre la suma de los costos de infraestructura y superestructura. En el caso de la intervención urbana de 1995 en la comunidad Parque Amélia/Santa Margarida, en el área del manantial de la represa de Guarapiranga, en São Paulo, con la adopción de la tipología en altura de 4 pisos, se estimó la tasa de costo con las actividades operacionales en cerca del $30 \%$ de la suma. Véase la comparación de precios de construcción popular por metro cuadrado de residencias unifamiliares -casas en planta baja- y multifamiliares -edificios colectivos- de la Tabla $3.1^{47}$.

\footnotetext{
47 Se aclara que: "Os valores abaixo referem-se aos Custos Unitários Básicos de Construção $\left(C U B / m^{2}\right)$, calculados de acordo com a Lei Fed. No. 4.591, de 16/12/64 e com a Norma Técnica NBR 12.721:2006 da Associação Brasileira de Normas Técnicas (ABNT) e são correspondentes ao mês de janeiro/2008. 'Estes custos unitários foram calculados conforme disposto na ABNT NBR 12.721:2006, com base em novos projetos, novos memoriais descritivos e novos critérios de orçamentação e, portanto, constituem nova série histórica de custos unitários, não comparáveis com a anterior, com a designação de CUB/2006' [...] 'Na formação destes custos unitários básicos não foram considerados os seguintes itens, que devem ser levados em conta na determinação dos preços por metro quadrado de construção, de acordo com o estabelecido no projeto e especificações correspondentes a cada caso particular: fundações, submuramentos, paredes-diafragma, tirantes, rebaixamento de lençol freático; elevador(es); equipamentos e instalações, tais como: fogões, aquecedores, bombas de recalque, incineração, ar-condicionado, calefação, ventilação e exaustão, outros; playground (quando não classificado como área construída); obras e serviços complementares; urbanização, recreação (piscinas, campos de esporte), ajardinamento, instalação e regulamentação do condomínio; e outros
} 
Una medida que puede ser estimulante para el aumento de la producción de VIS y para romper con el crónico problema de la falta de recursos para tal fin o de la incertidumbre permanente sobre su viabilidad económica, es la de hacer efectiva la destinación regular, bajo criterios técnicos, de una porcentual por parte de las tres esferas de gobierno -municipal, estatal y federal-, con reglamentación específica, considerándose los eventuales contratiempos de caja por causa de una disminución en la recaudación u otro contratiempo, y así evitar desvíos indebidos que dependan del humor del gobernante de turno, por lo que se hace necesaria la permanente vigilancia de todos los sujetos involucrados.

Tabla 3.1 - Evolución de CUB de 2008 a 2017 en el estado de Bahia

\begin{tabular}{|c|c|c|c|c|c|c|c|}
\hline $\begin{array}{c}\text { Mes/ } \\
\text { Variación\%*1 }\end{array}$ & R-1 & PP-4 & R-8 & PIS & $\begin{array}{l}\text { USD\$ } \\
/ R^{* 2}\end{array}$ & $\underset{2}{A R S} \mathbf{R} / \mathbf{R}^{*}$ & $\underset{2}{\text { USD }} \underset{2}{\text { IARS }}$ \$ \\
\hline Enero 08 & 787,77 & 722,43 & 686,59 & 506,81 & 1,76 & 0,56 & 3,16 \\
\hline Variac. \% & $0,72 \%$ & $0,33 \%$ & $0,31 \%$ & $-0,41 \%$ & & & \\
\hline Dic. 08 & 859,51 & 787,60 & 753,35 & 552,79 & 2,34 & 0,68 & 3,45 \\
\hline Variac. \% & $0,63 \%$ & $0,27 \%$ & $0,50 \%$ & $-0,08 \%$ & & & \\
\hline Enero 09 & 864,40 & 799,71 & 764,52 & 559,75 & 2,32 & 0,66 & 3,48 \\
\hline Variac. \% & $0,57 \%$ & $1,54 \%$ & $1,48 \%$ & $1,26 \%$ & & & \\
\hline Dic. 09 & 905,23 & 810,76 & 772,89 & 575,11 & 1,74 & 0,46 & 3,80 \\
\hline Variac. \% & $-0,13 \%$ & $-0,30 \%$ & $-0,45 \%$ & $-0,24 \%$ & & & \\
\hline Enero 10 & 900,63 & 812,47 & 774,82 & 575,05 & 1,87 & 0,49 & 3,82 \\
\hline Variac. \% & $-0,51 \%$ & $0,21 \%$ & $0,25 \%$ & $-0,01 \%$ & & & \\
\hline Dic. 10 & 942,45 & 833,83 & 789,93 & 599,43 & 1,66 & 0,42 & 3,97 \\
\hline Variac. \% & $0,07 \%$ & $0,08 \%$ & $0,02 \%$ & $0,21 \%$ & & & \\
\hline Enero 11 & 952,03 & 843,14 & 798,91 & 603,84 & 1,67 & 0,42 & 4,00 \\
\hline Variac. \% & $1,02 \%$ & $1,12 \%$ & $1,14 \%$ & $0,74 \%$ & & & \\
\hline Dic. 11 & $1.009,87$ & 887,15 & 840,06 & 638,14 & 1,88 & 0,44 & 4,30 \\
\hline Variac. \% & $0,01 \%$ & $0,09 \%$ & $0,08 \%$ & $0,10 \%$ & & & \\
\hline Enero 12 & $1.013,27$ & 889,55 & 842,35 & 639,56 & 1,74 & 0,40 & 4,33 \\
\hline Variac. \% & $0,34 \%$ & $0,27 \%$ & $0,27 \%$ & $0,22 \%$ & & & \\
\hline Dic. 12 & $1.078,01$ & 940,09 & 891,92 & 681,97 & 2,04 & 0,42 & 4,91 \\
\hline Variac. \% & $-0,40 \%$ & $-0,27 \%$ & $-0,24 \%$ & $-0,12 \%$ & & & \\
\hline Enero 13 & $1.078,62$ & 945,49 & 896,82 & 686,06 & 1,99 & 0,40 & 4,98 \\
\hline Variac. \% & $0,06 \%$ & $0,57 \%$ & $0,55 \%$ & $0,60 \%$ & & & \\
\hline Dic. 13 & $1.177,22$ & $1.012,89$ & 961,40 & 745,27 & 2,34 & 0,36 & 6,52 \\
\hline Variac. \% & $0,22 \%$ & $0,26 \%$ & $0,28 \%$ & $0,16 \%$ & & & \\
\hline Enero 14 & $1.179,02$ & $1.015,09$ & 963,36 & 747,08 & 2,43 & 0,30 & 8,01 \\
\hline Variac. \% & $0,15 \%$ & $0,22 \%$ & $0,20 \%$ & $0,24 \%$ & & & \\
\hline Dic. 14 & $1.228,18$ & $1.055,89$ & $1.002,20$ & 777,67 & 2,66 & 0,31 & 8,37 \\
\hline Variac. \% & $0,12 \%$ & $0,18 \%$ & $0,18 \%$ & $0,15 \%$ & & & \\
\hline Enero 15 & $1.228,53$ & $1.056,27$ & $1.002,39$ & 777,63 & 2,66 & 0,31 & 8,63 \\
\hline Variac. \% & $0,03 \%$ & $0,04 \%$ & $0,02 \%$ & $-0,01 \%$ & & & \\
\hline
\end{tabular}

serviços (que devem ser discriminados no Anexo A - quadro III); impostos, taxas e emolumentos cartoriais, projetos: projetos arquitetônicos, projeto estrutural, projeto de instalação, projetos especiais; remuneração do construtor; remuneração do incorporador" (SINDUSCON-BA, [s/f]). 


\begin{tabular}{|cccccccc|}
\hline Dic. 15 & $1.311,60$ & $1.116,07$ & $1.056,12$ & 823,22 & 3,90 & 0,30 & 12,94 \\
\hline Variac. \% & $0,16 \%$ & $0,07 \%$ & $0,07 \%$ & $0,11 \%$ & & & \\
\hline Enero 16 & $1.317,97$ & $1.124,57$ & $1.064,30$ & 830,64 & 4,04 & 0,29 & 13,89 \\
\hline Variac. \% & $0,49 \%$ & $0,76 \%$ & $0,77 \%$ & $0,90 \%$ & & & \\
\hline Dic. 16 & $1.406,19$ & $1.194,88$ & $1.130,33$ & 887,43 & 3,26 & 0,21 & 15,86 \\
\hline Variac. \% & $0,08 \%$ & $0,10 \%$ & $0,10 \%$ & $0,08 \%$ & & & \\
\hline Enero 17 & $1.410,31$ & $1.198,80$ & $1.133,99$ & 890,00 & 3,13 & 0,20 & 15,91 \\
\hline Variac. \% & $0,29 \%$ & $0,33 \%$ & $0,32 \%$ & $0,30 \%$ & & & \\
\hline
\end{tabular}

Fuente: basado en SINDUSCON-BA (s/f). Custo Unitário Básico-CUB/ $\mathrm{m}^{2}$ y SINDUSCONMG (2007).

Leyenda (Proyectos-Padrón Residencial Bajo): R-1: Residencial/1 piso (casa/planta baja); PIS: Proyecto de Interés Social; PP-4: Edificio Popular/4 pisos; R-8: Residencial /8 Pisos. Precios en Real $(R \$)$.

${ }^{* 1}$ Variación porcentual ocurrida en el mes.

*2 Cotización cambial (entre Real, Dólar estadunidense y Peso Argentino del último día útil del mes (BANCO CENTRAL DO BRASIL, 2007).

3.4 - Una burocracia que no se agota

Castells (2000, p. 229) sostiene que en Francia cerca del $20 \%$ corresponde al valor del terreno. Para Julián Salas ([19--]) el costo de una vivienda en Latinoamérica se compone básicamente por: el 50\% referente al crédito bancario, el $30 \%$ al terreno y el $20 \%$ a la construcción. Carlos Lobo (apud LOMBARDI, CREMASHI y MARSILLI, 2004, p. 205) refiere que el costo del lote se asocia intrínsecamente a su ubicación espacial, así como a los servicios de infraestructura de que dispone y a qué distancia de éstos se encuentra., lo que sirve de alerta para la importancia del Estado como regulador de la función social de la tierra mediante leyes de ordenamiento y tasación, ya que, en un sistema capitalista, la especulación privada es una poderosa arma de segregación y de expulsión de los que no poseen tierra. Desafortunadamente, la Historia muestra que, excepciones aparte, los gobiernos latinoamericanos no han hecho valer su poder en este sentido, no han definido una política pública de "cartera de tierras" para lotes populares y no han aplicado la legislación del suelo y edilicia existentes en pro de la función social de la tierra.

Para la elaboración del Plano Municipal de Habitação de Salvador la entonces Secretaria de Habitação tomó como parámetro para una proyección de los costos medios por unidad habitacional los valores medios presentados en la Tabla 3.2, excluyéndose el ítem referente al terreno, con base en las inversiones realizadas en las intervenciones urbanísticas de 2007. 
Tabla 3.2 - Proyección 2007 de costos medios por unidad habitacional en Salvador

\begin{tabular}{|c|c|c|c|c|}
\hline Ítem & Servicios & $\mathbf{R \$ ( R e a l / B r )}$ & U\$ (Dolar) & \$ (Peso/Arg.) \\
\hline $\mathbf{0 1}$ & Urbanización por lote & $7.660,71$ & 4324,91 & $13.619,14$ \\
\hline $\mathbf{0 2}$ & Regularización de tierras & 80,00 & 45,16 & 142,22 \\
\hline $\mathbf{0 3}$ & Construcción de unidad habitacional & $23.500,00$ & $13.267,09$ & $41.778,07$ \\
\hline $\mathbf{0 4}$ & Urbanización completa del área & $7.660,71$ & 4324,91 & $13.619,14$ \\
\hline $\mathbf{0 5}$ & Urbanización parcial & $4.000,00$ & 2258,23 & $7.111,16$ \\
\hline
\end{tabular}

Fuente: a partir de Gordilho-Souza (2008, p. 432, 441 (Nota a pie de página $\left.\left.n^{0} 29\right)\right)^{48}$

Dada la exigua realidad espacial de Salvador, que en 2008 poseía un déficit habitacional de 100 mil unidades, se estimaba necesaria un área mínima de $20 \mathrm{~km}^{2}$ para resolverse el problema habitacional, por lo que se previó trabajar con una densidad media de 150habitantes/ha. y con un área media de $200 \mathrm{~m}^{2} /$ unidad, incluyendo áreas comunes, de circulación interna, áreas verdes y de recreo, excepto las destinadas para estructuras (GORDILHO-SOUZA, 2008, p. 435-436, 441).

De la bibliografía vinculada al tema de vivienda se desprende que el exceso de burocratización al lado de la baja renta, o ninguna, de las familias humildes, está entre los principales motivos para la incapacidad de obtener un techo o mejorar el que poseen a través de los programas privados o estatales. Además de estos obstáculos, están la falta de divulgación de los criterios de accesos a los programas habitacionales existentes, el clientelismo/paternalismo, el partidarismo del gobierno de turno, que tiende a beneficiar a quien posee algún tipo de vinculación con los responsables de los programas.

Una importante herramienta en lo que concierne al control de la oferta y uso del suelo urbano y de refuerzo del erario municipal es el IPTU progresivo en el tiempo, mediante el cual los terrenos sin construcción y los inmuebles desocupados serían progresivamente tasados para forzar a los propietarios a no olvidar la función social que la Constitución brasileña establece para el uso de éstos. Desafortunadamente, por diferentes motivos, entre los cuales los intereses de los privados vinculados a la política -representantes del Ejecutivo, Legislativo y Judiciario-, este mecanismo no es racionalmente accionado ni divulgado como importante para la sociedad en general. Asociada a la dificultad y a la falta de voluntad política para la aplicación de estos instrumentos jurídicos por parte de los

\footnotetext{
${ }^{48}$ Las conversiones cambiarias han sido hechas a partir de Banco Central Do Brasil (2008).
} 
administradores públicos en general, está la resistencia de los empresarios del sector inmobiliario, que históricamente presionan y corrompen administradores y políticos para limitar todo intento del Estado para tasar la plusvalía proveniente de la valorización de las propiedades a causa de alteraciones en las normas edilicias e inversiones públicas, directas o no, en el espacio urbano de la ciudad.

En Buenos Aires fueron vanos los esfuerzos de la Secretaría de Obras Públicas en el Concejo Deliberante de 1987 para que aprobaran una ordenanza fiscal con la que se pretendía tasar con el $15 \%$ el excedente en altura de lo que permite el Código de Planeamiento de 1977. De igual forma ocurrió con el primer intento a fines de la década del (19)80, cuando se pretendía alterar el código para que el Municipio pudiera aplicar una tasa diferencial sobre los valores de lotes de tierras valorizadas con la plusvalía proveniente de las modificaciones que estaban siendo propuestas para la flexibilización del código, como por ejemplo la de la ampliación del FOT. La resistencia de los poderosos grupos económicos privados interesados en la cuestión inmobiliaria resultó suficiente para que se abortara el intento (CLICHEVSKY, 1996, p. 59). Las pretendidas alteraciones al Código de Planeamiento de 1977, conocidas como Plano de Cambios, según los intereses de los sectores de la industria de la construcción y en especial de los propietarios de tierras y constructoras, fueron aprobadas finalmente bajo el gobierno del intendente justicialista Carlos Grosso a través de las Ordenanzas 44.092/89, 44.094/89 y 44.095/89 promulgadas por el Decreto 3.517 del 20 de diciembre de 1989 (CLICHEVSKY, 1996, p. 56-82). ${ }^{49}$

Propuesta en 1988 y promulgada el 12 de abril de 1991 la Ordenanza No 43.226/98 autorizaba al CPU a promover, dentro de ciento ochenta días, algunos cambios con normas especiales de construcción para los Distritos de Arquitectura Especial (DAE) e incorporarlos en el Art. 5.4.7 del CPU con la idea de favorecer al sector industrial. Sin embargo, en los años siguientes, al contrario de lo que ocurrió con las alteraciones del código con relación al sector de la construcción residencial, los referentes a la actividad industrial acabaron por promover una baja de los precios de las tierras del sector (CLICHEVSKY, 1996, p. 84-87) ${ }^{50}$.

\footnotetext{
${ }^{49}$ Las modificaciones al Código de Planeamiento de 1977, también vinculadas al que se denominó Plano de 2008, suscitaron enormes conflictos entre las partes involucradas, así como durante su aplicación, pues ocurrieron supuestas desapariciones de parte de la documentación, extravíos a lo largo de los trámites, supuestas adulteraciones, digitaciones de palabras y expresiones que alteraban la interpretación, conflictos con la prensa y hasta con la Justicia (CLICHEVSKY, 1996, p. 75-82).

50 En función de las excepciones concedidas, informaciones extraoficiales del ámbito del Concejo Deliberante refieren que de $U \$ 40$ a $\cup \$ 50$ por metro cuadrado acrecido y autorizado por tal
} 
Lamentablemente, en el sector de las construcciones residenciales y comerciales, las reglas de excepción en relación a lo que determinaba el CPU de Buenos Aires se volvieron tan comunes que acabaron desvirtuándolo con el agravante de una serie de irregularidades asociadas a las mismas, como el anonimato de quien las pleiteaba, extravío u ocultación de parte o de toda la documentación protocolada en el trámite, la clasificación del tipo de construcción incompatible con el distrito donde sería instalada, además de que se hizo común sobre el final del mandato de los concejales una miríada de pedidos de excepción, como ocurrió entre fines de noviembre y diciembre de 1989, 1990 y 1991. Para intentar revertir la situación, con la sanción de la Ley Nacional No 24.111/92, se volvió obligatorio al CPU llevar en consideración en el análisis de los pedidos de excepciones el parecer por escrito y firmado de SCA, CAI, de los Consejos Directivos de FADU y de la Facultad de Ingeniería de la UBA, así como del Consejo Vecinal correspondiente a la jurisdicción de la pretendida excepción de construcción (CLICHEVSKY, 1996, p. 93-106).

\section{5 - CONCLUSIONES}

En este Capítulo 3, otra vez más como hasta entonces, se presentaron las informaciones metodológicamente de manera transversal a los seis ejes propuestos -a) el proyecto arquitectónico; b) el presupuestario (costos); c) el suelo (para la construcción); d) el tecnológico; e) el gerenciamiento gubernamental (políticas públicas); y f) la legislación edilicia- enfatizándose en especial los ítems b, c, d, e y f. Los aportes provenientes de experiencias de las cooperativas en Uruguay así como de implantaciones de proyectos de VIS en São Paulo fueron muy sustantivos para comprobar los presupuestos teóricos -hipótesis- de esta tesis cuanto a la importancia y viabilidad del uso de la tipología arquitectónica en altura, mediante determinadas condiciones, como un expediente válido para solucionar el grave problema social del déficit habitacional, a través de políticas de VIS, Asimismo en otras situaciones presentadas a lo largo del mencionado Capítulo se mostraron más comprobaciones sobre las principales semejanzas y diferencias en relación con los elementos facilitadores y restrictivos en la adopción de aquella tipología arquitectónica durante el período de 1937 a 2017 entre Salvador y Buenos Aires.

mecanismo fueron la recompensa al concejal responsable por la concesión (CLICHEVSKY, 1996, p. 105-106). 
Con el avance de la práctica de las cooperativas habitacionales en las políticas de VIS, Uruguay se volvió una importante referencia en América Latina. Esta modalidad constructiva presenta mayores ventajas bajo varios aspectos mediante el uso del equipo técnico, ofreciendo asesoría, al contrario de cuando sólo se usa la modalidad de autoconstrucción. De la misma manera, la experiencia demuestra que un proyecto tiende a ser más eficiente, independientemente de que sea de iniciativa privada o pública y de si se utiliza tecnología tradicional o de pre-fabricación, cuando posee un mejor gerenciamiento durante la implementación del mismo. En función de la optimización de los recursos invertidos en dichas políticas, la experiencia sugiere cautela si se opta por la tipología arquitectónica que privilegia unidades habitacionales básicas de área total construida mínima de alrededor de $30 \mathrm{~m}^{2}$, con solamente una habitación, sala y baño, y posterior ampliación por el morador, en función de los altos costos de la infraestructura/urbanización, así como por causa de los demás índices que componen las inversiones en la construcción de esta unidad habitacional, ya que es cuestionable económica y socialmente, pues, en viviendas de mayor número de habitaciones, dichos costos tienden a ser relativamente más bajos, atendiendo a un mayor número de personas, algo que, utilizándose la tipología arquitectónica en altura, al contrario de la de planta baja unidomiciliar, los resultados tienden a ser mayores, aunque hay autores que no compartan con esta recomendación porque no perciban ganancias relevantes en esta comparación, motivo por lo cual débase admitir que cada caso es un caso y por ahí conviene evaluarse un proyecto, desde su origen, con todos sus posibles variantes bajo la óptica del costo/beneficio.

En la misma línea de pensamiento, hay que tener cuidado del lugar donde se quiere implantar un conjunto habitacional por el valor de la infraestructura adicional que se tendrá que agregar en áreas periféricas y desprovistas de servicios públicos, donde generalmente el precio del lote es más bajo, pero que se vuelve inconveniente. Utilizándose la tipología arquitectónica en altura multifamiliar se obtiene una doble ventaja: por un lado, en la relación costo/beneficio, ya que se tiende a economizar donde ya existan los servicios públicos, como en áreas centrales, y, por el otro, considerando que en estas áreas los terrenos son de menores dimensiones, siendo más favorable al uso en zonas de mayor densidad urbana, al contrario de la tipología arquitectónica de viviendas unifamiliares de planta baja, ya que se podrá atender a más personas, a menor costo por unidad habitacional, reduciéndose así satisfactoriamente el déficit en este sector público. 
Un aspecto positivo relevante observado en la capital de São Paulo que puede ser considerado para aplicarse en otras localidades, es la modalidad de gestión de políticas de VIS basada en el binomio Estado/iniciativa privada, el cual mostró resultados más eficaces con relación al número de unidades habitacionales producidas. Así como la del binomio Estado/ciudadano -cooperativas/asociaciones comunitarias-, que probó ser el más eficiente financieramente, es decir, el que produjo unidades habitacionales de forma más económica. Estas dos modalidades en conjunto, entre otras análogas, siendo lo suficientemente investigadas por los agentes responsables por la elaboración y ejecución de dichas políticas públicas, y conjugadas en sus variadas combinaciones, pueden generar proyectos tan eficaces como eficientes, de base ética, racional -técnica y económica- y social, sin vicios de cualquier especie ni interferencias externas. En este sentido, es fundamental que toda la sociedad presione al Estado para que valorice cada vez más el empoderamiento de asociaciones de moradores, cooperativas y congéneres, como legítimas representantes en las demandas locales por la mejoría de calidad de la vivienda, entre otras cosas.

De la bibliografía sobre el tema de la vivienda en América Latina se constata que, en mayor o menor grado en este continente, el exceso de burocratización, muchas veces tendencioso, y el bajo o nulo presupuesto de las familias humildes, están entre los principales motivos para la incapacidad de obtener un techo o mejorar el que ya se posee a través de programas privados o incluso estatales. A estos obstáculos se suma la insuficiente o inexistente política pública de "cartera de tierras" para lotes populares, la deficiente aplicación de la legislación del suelo y edilicia existentes en pro de la función social esbozada en dicha legislación, la falta de divulgación de los criterios de accesos a los programas habitacionales existentes, lo que puede ser entendido, también, como falta de transparencia, clientelismo, paternalismo y excesiva presencia del partidarismo político del gobierno de turno, que tienden a beneficiar un público próximo al gobierno en detrimento de la sociedad en general. Para quien aún pueda tener alguna duda al respecto, la historia de Brasil y Argentina desde sus inicios y hasta la actualidad, ofrecen innumerables ejemplos de esta lamentable realidad, tan común en estas dos naciones. 


\section{CAPÍTULO 4}

\section{PRÁCTICAS E INTERVENCIONES RECIENTES DE VIS EN ALTURA EN 6 COMUNIDADES}

Dos experiencias que se hicieron icónicas tanto en Brasil como Argentina (ver Figura 4.1) de proyecto de VIS bien exitosos bajo varios aspectos, entre ellos el nivel de excelencia de la calidad y la originalidad, son el proyecto del arquitecto Fermín Bereterbide, El Barrio de Los Andes, también conocido como Casa Colectiva Parque Los Andes, inaugurado en 1927 en la ciudad de Buenos Aires, y el del arquitecto Affonso Eduardo Reidy, el Conjunto Pedregulho -Conjunto Residencial Prefeito Mendes de Moraes, concluido en 1952 en la capital de Rio de Janeiro (MIGUEL, 2010, p. 26).

Con relación a las propuestas que se han desarrollado en Latinoamérica en intervenciones públicas de VIS, una importante referencia es el Programa FavelaBairro en áreas de favela de la ciudad de Rio de Janeiro, Brasil, a partir de 1993, con la intención de valorizar el acervo construido a lo largo del tiempo por las poblaciones de aquellas áreas como algo importante a ser potencializado en los proyectos urbanísticos sobre las prácticas y las configuraciones preexistentes (CASTRO, 2010, p. 120-121)

De acuerdo a la metodología establecida en esta tesis para la investigación de la realidad de los proyectos, una de las etapas de campo se desarrolló mediante consultas a los moradores de las tres comunidades investigadas -Paraíso Azul/Recanto Feliz, 27 de Abril/SINDOMÉSTICO y Perseverança/Luiz Inácio Lula da Silva- en tres barrios populares de Salvador -Costa Azul, Dorón/Saramandaia y Pernambues-, respectivamente, que adquirieron una vivienda después de catastrados en proyectos de VIS bajo la responsabilidad de la CONDER. La investigación realizada constató una serie de contratiempos ocurridos durante el proceso de implantación de las VIS: retrasos de obra, exceso de burocracia -demora en la regularización del lote/titularidad del inmueble residencial-, materiales de baja cualidad, pisos de habitaciones entregadas sin revestimiento -solo contrapiso- y

\footnotetext{
${ }^{51}$ Esta experiencia brasileña fue objeto de un estudio más profundo a partir de un trabajo conjunto de investigación que fue premiado en la III Bienal Ibero-americana de Arquitectura y Urbanismo realizada en Santiago de Chile en 2002, desarrollado por Jorge Mario Jáuregui, Javier Fernández Castro y Pedro Cunca Bocayuva que, con el apoyo del subsidio obtenido con el premio, pudieron continuar las investigaciones sobre los presupuestos del Programa Favela-Bairro, reelaborarlos y adecuarlos, así como sobre otras propuestas similares en diferentes ciudades de este continente (CASTRO, 2010, p. 121).
} 
ruidos transmitidos a través de los cerramientos laterales de albañilería entre unidades próximas; estos fueron algunos de los reclamos más observados en las encuestas de EPO utilizadas para esta tesis.

Figura 4.1 - Mapa de América de Sur

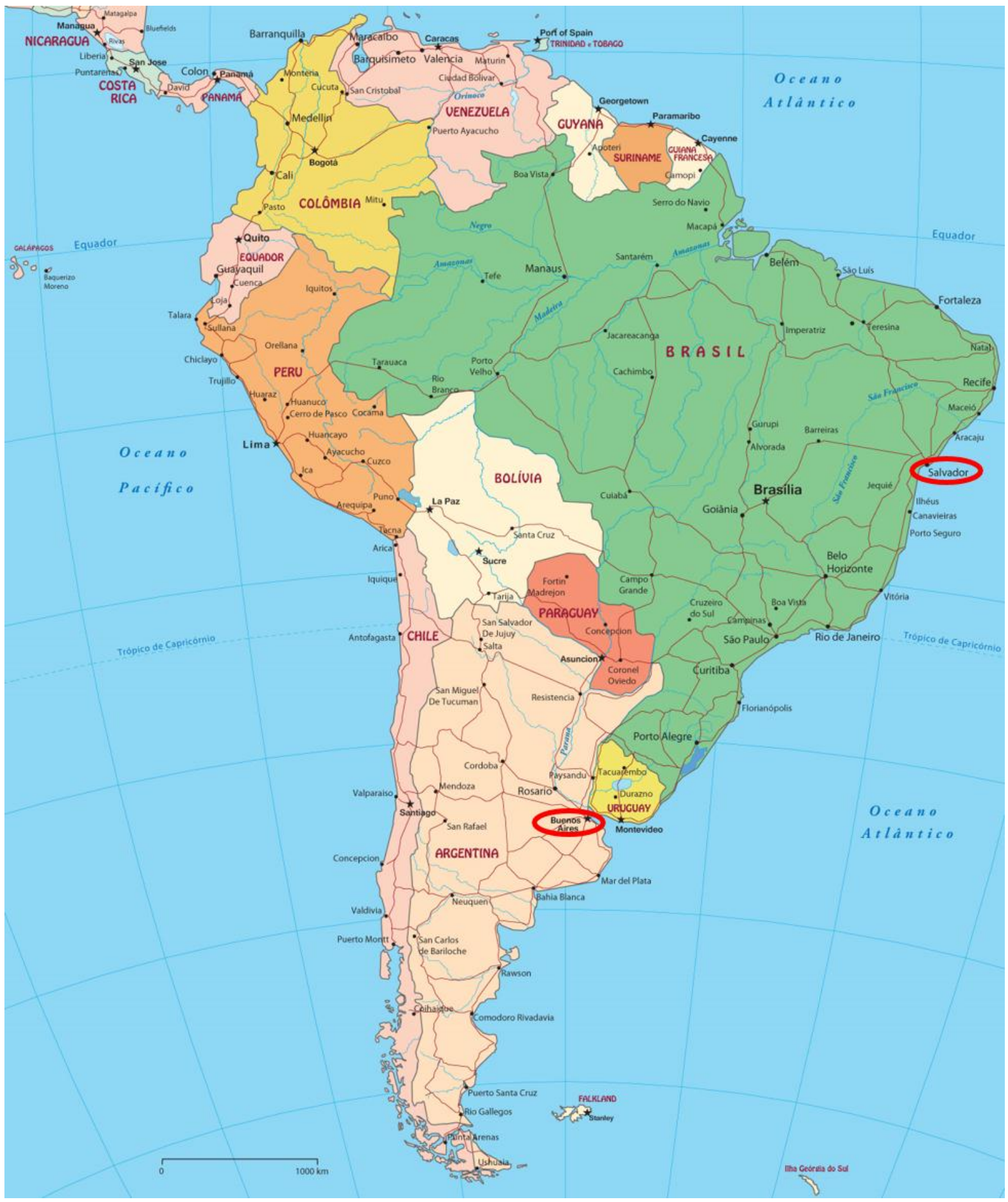

Fuente: Ramon Cotinguiba (2018) a partir de la Guia Geográfico: Mapas da América ([s/f]). 
Como ya se adelantó en la introducción de esta tesis, el objetivo principal es averiguar lo que piensan los moradores de inmuebles construidos a través de políticas públicas de VIS con tipología arquitectónica en altura -con tres/cuatro pisos además de la planta baja y sin ascensor- a través del estudio comparado de caso entre las tres comunidades mencionadas en Salvador, Brasil y entre las tres en la CABA, Argentina -Complejo Luzuriaga (Barracas); Complejo Padre Mugica (Villa Lugano) y Complejo Monteagudo (Parque de los Patricios). La investigación se justifica por el hecho de que se partió del principio de que esta tipología arquitectónica tiende a ser un importante instrumento para solucionar el problema de vivienda popular tanto en Brasil como en Argentina y otros países de este continente desde que se atiendan determinados presupuestos esenciales básicos, como por ejemplo: dimensiones, confort -térmico y acústico-, privacidad, estética e infraestructura de servicios públicos en la localidad -sistema de energía eléctrica, agua y cloacas, telefonía, colecta de residuos, transportes públicos, etc.

Hasta hace poco tiempo, como se ha dicho, la referida tipología fue dejada en segundo plano en Brasil, considerando el gran número de proyectos de VIS implantados en las mayores ciudades brasileñas en décadas recientes que utilizaron la tipología arquitectónica de planta baja unifamiliar.

Es de fundamental importancia destacar que, por lo que se averiguó entre los moradores, líderes comunitarios y profesionales, y que será mejor explicitado más adelante, las inúmeras irregularidades señaladas, sea por la deficiencia de los proyectos, sea por la ejecución constructiva o, incluso, por el gerenciamiento gubernamental, asociados a la dificilísima realidad enfrentada por los ciudadanos que se ven imposibilitados de adquirir un techo mínimamente digno, se puede explicar la aparente paradoja de lo que contestaron los moradores de Argentina, donde cerca del 73\% admitió que estaba "insatisfecho" (pregunta 5 de la Encuesta Tipo 1) de habitar en viviendas en altura y, al mismo tiempo, alrededor del $76 \%$ informó que no tiene "ninguna intención" (pregunta 33 de la Encuesta Tipo 1 e ítem 39 de la Planilla de Tabulación) de deshacerse del departamento. En Brasil, por el contrario, se obtuvo que aproximadamente el $20 \%$ de los moradores estaban insatisfechos (pregunta 5), y que cerca del $73 \%$ no pretende deshacerse del inmueble (pregunta 33), de lo que se extrae, al menos en Brasil, que la tipología defendida es un importante instrumento de solución en políticas públicas para el déficit habitacional de los sectores de más bajos ingresos. Sin embargo habría que profundizar más los estudios en Argentina. Tal vez, una de las explicaciones para la 
gran diferencia entre argentinos y brasileños pueda estar en la misma diferencia que existe entre los relieves de las ciudades investigadas: Salvador se encuentra muy accidentada topográficamente por cerros y valles, mientras que la CABA es relativamente plana en la mayoría de su superficie.

Esta solución constructiva para viviendas multifamiliares se vuelve cada vez más interesante y, de cierta manera, más factible, dada la escasez de tierras en los grandes centros urbanos, lo que hace prohibitivo el acceso a la vivienda a los sectores de más bajos ingresos, y dada la conveniencia para el erario mediante la relación costo/beneficio de la implantación de núcleos de vivienda de tipología en altura en áreas de la ciudad que ya poseen algún tipo de infraestructura básica (BONDUKI, 2011, p.157), así como por la tendencia del mercado privado por la construcción en altura. Como sostiene Sampaio (2010):

\begin{abstract}
Ademais, na mudança de habitat do interior para a capital, mesmo para um bairro popular, está implícita uma decisão que admite o 'risco' da troca por um outro [sic] modo de vida, ou seja: quem muda de lugar não busca uma mera repetição do modo de vida anterior. $A$ pessoa expulsa do campo ou da pequena cidade tem como opção ou na falta dela- o ônus que uma mudança de habitat implica, sempre ligado à sua estratégia de sobrevivência [...] Defende-se aqui o ponto de vista de que ao pobre interessa mais é uma localização próxima -mesmo mais densa-, que uma localização amena e bucólica, porém distante, onerada pelos gastos e desgaste com os transportes. (SAMPAIO, 2010, p. 147-148).
\end{abstract}

Sampaio (2010) va en la misma dirección que Castro (2010), que es contrario a los que critican el hecho de que las poblaciones más pobres, en particular aquellas oriundas del medio rural, consigan vivir en construcciones en altura sin sentirse inaptas para ello. Castro (2010) argumenta que generalmente estas poblaciones están ya inseridas en las condiciones de este tipo de vivienda predominante en el medio urbano, incluso en muchos casos debido a los lugares donde trabajan, además de que, como viene ocurriendo en las ciudades más habitadas de este continente, la propia habitación informal autoconstruida se vuelve progresivamente horizontal, incluso en la periferia (CASTRO, 2010, p. 174). En la Tabla 4.1 se presenta una muestra de la realidad inmobiliaria según el número de inmuebles ocupados y no ocupados en EEUU, Brasil, y Argentina.

Se constató que en las comunidades investigadas ocurrieron fallas en el proceso de elaboración/ejecución de los proyectos debido a que no siempre se consideró que las políticas públicas mantuvieran el necesario tenor "sistémico", 
integrador con tecnologías más adecuadas a la VIS de bajo costo y practicidad en la ejecución/mantenimiento de las estructuras. Además, ocurrieron también otras fallas cuando no fueron suficientemente llevadas en consideración cuestiones vinculadas a las prácticas culturales de las comunidades involucradas y a sus relaciones de vecindad.

Tabla 4.1 - Datos comparativos de familias/domicilios entre EEUU, Brasil y Argentina

\begin{tabular}{|c|c|c|c|c|c|c|c|}
\hline & & \multicolumn{2}{|c|}{ EEUU (2000) } & \multicolumn{2}{|c|}{ Brasil (2000) } & \multicolumn{2}{|c|}{ Argentina (2001) } \\
\hline It. & $\begin{array}{c}\text { Tipos de } \\
\text { domicilio/población }\end{array}$ & Número & $\%$ & Número & $\%$ & Número & $\%$ \\
\hline \multirow{4}{*}{1.0} & Domicilio no ocupado & 10.424 .540 & 100,0 & 9.244 .140 & 100,00 & 2.328.923 & 100,00 \\
\hline & Para venta o alquiler & 4.500 .000 & 43,2 & No dimen. & - & 314.980 & 13,5 \\
\hline & $\begin{array}{c}\text { Uso ocasional, vacaciones o } \\
\text { fin de semana }\end{array}$ & 3.600 .000 & 34,5 & 2.685 .701 & 29,1 & 324.576 & 13,9 \\
\hline & Vacíos por otro motivo & 2.324 .540 & 22,3 & 6.558 .439 & 70,9 & 1.689 .367 & 72,5 \\
\hline \multirow{5}{*}{2.0} & Domicilios ocupados & 105.480 .101 & 100,0 & 44.795 .101 & 100,0 & 10.073 .625 & 100,0 \\
\hline & Con arreglos familiares & 71.787 .347 & 68,1 & 40.630 .487 & 90,7 & 8.455 .021 & 82,7 \\
\hline & Con arreglos no familiares & 33.692 .754 & 31,9 & 4.164 .614 & 9,3 & 1.618 .604 & 17,3 \\
\hline & Persona sola & 27.230 .075 & 25,8 & 4.021 .987 & 9,0 & 1.512 .788 & 15,0 \\
\hline & Multipersonal no familiar & 6.462 .679 & 6,1 & 142.627 & 0,3 & 105.816 & 2,2 \\
\hline
\end{tabular}

Fuente: adaptación a partir de ALVES y CAVENAGHI (2006).

\section{1 - En Brasil}

Desde el punto de vista geológico, Salvador (ver Figura 4.2) se encuentra sobre una falla que divide la ciudad en dos partes, la Cidade Alta y la Cidade Baixa, separadas entre sí por un desnivel que llega a alcanzar alrededor de 70m. Como ya se mencionó anteriormente, Salvador posee una topografía muy accidentada, formada por una serie de pequeños cerros recortados por varios valles distribuidos a lo largo y ancho de toda su superficie.

Las tres comunidades investigadas -Paraíso Azul/Recanto Feliz, 27 de Abril ISINDOMÉSTICO y Perseverança/Luiz Inácio Lula da Silva- se encuentran en la Cidade Alta, en barrios relativamente próximos a la costa atlántica: a $1 \mathrm{~km}$ la comunidad de Recanto Feliz/Paraíso Azul -Costa Azul- y las otras dos comunidades, 27 de Abril/SINDOMÉSTICO y Perseverança a unos 6 y 8 km -Dorón/Saramandaia y Pernambues- (ver Figura 4.3). 
Figura 4.2 - Mapa de Salvador/BA

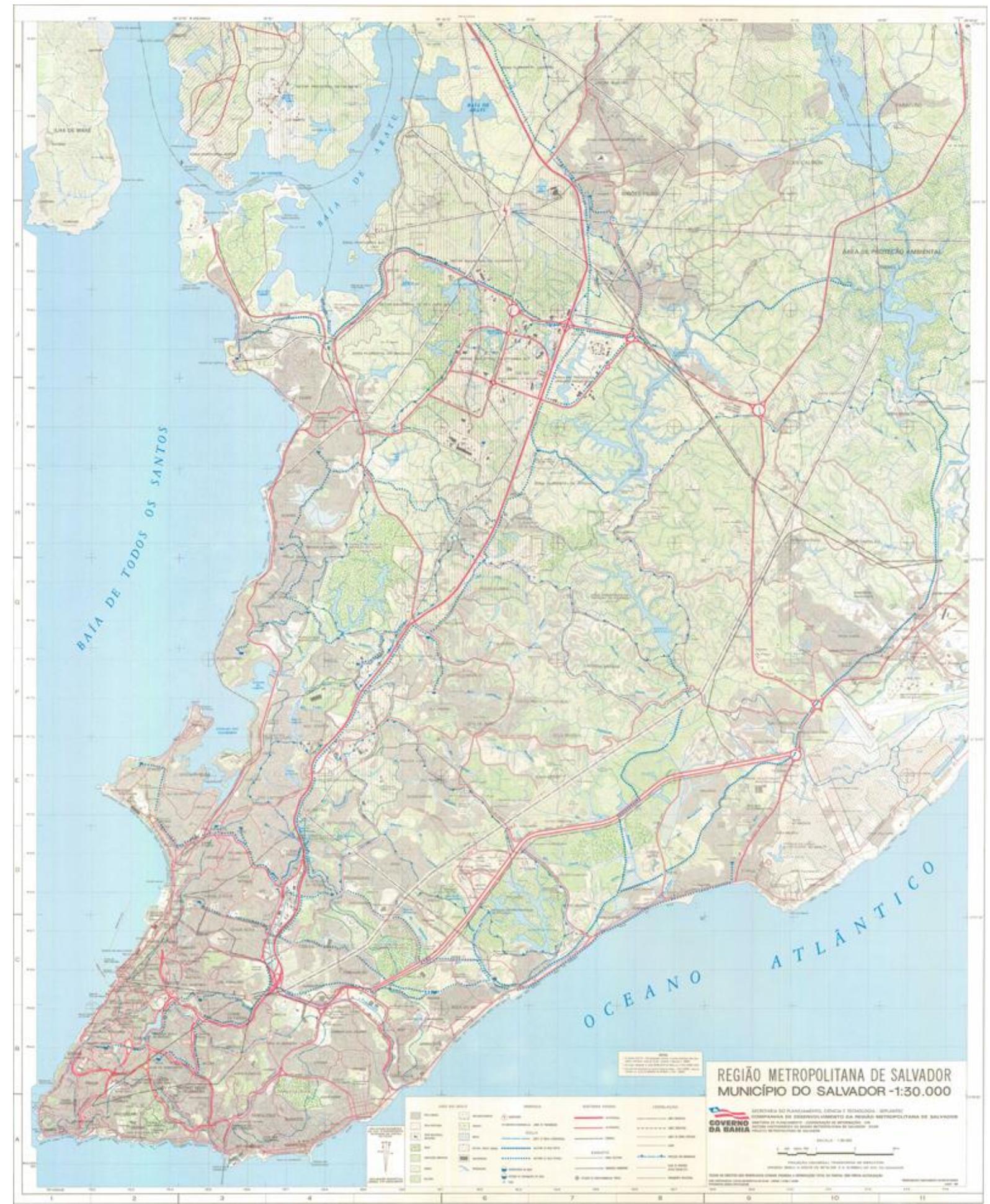

Fuente: CONDER (1992). Escala 1:30.000.

Los datos cuantitativos -unidades, superficie, distribución, costos y plazos de inicio y conclusión de las obras- de las tres comunidades brasileñas pueden verse en la Tabla 4.2. 
Figura 4.3 - Localización de las 3 comunidades investigadas de Salvador

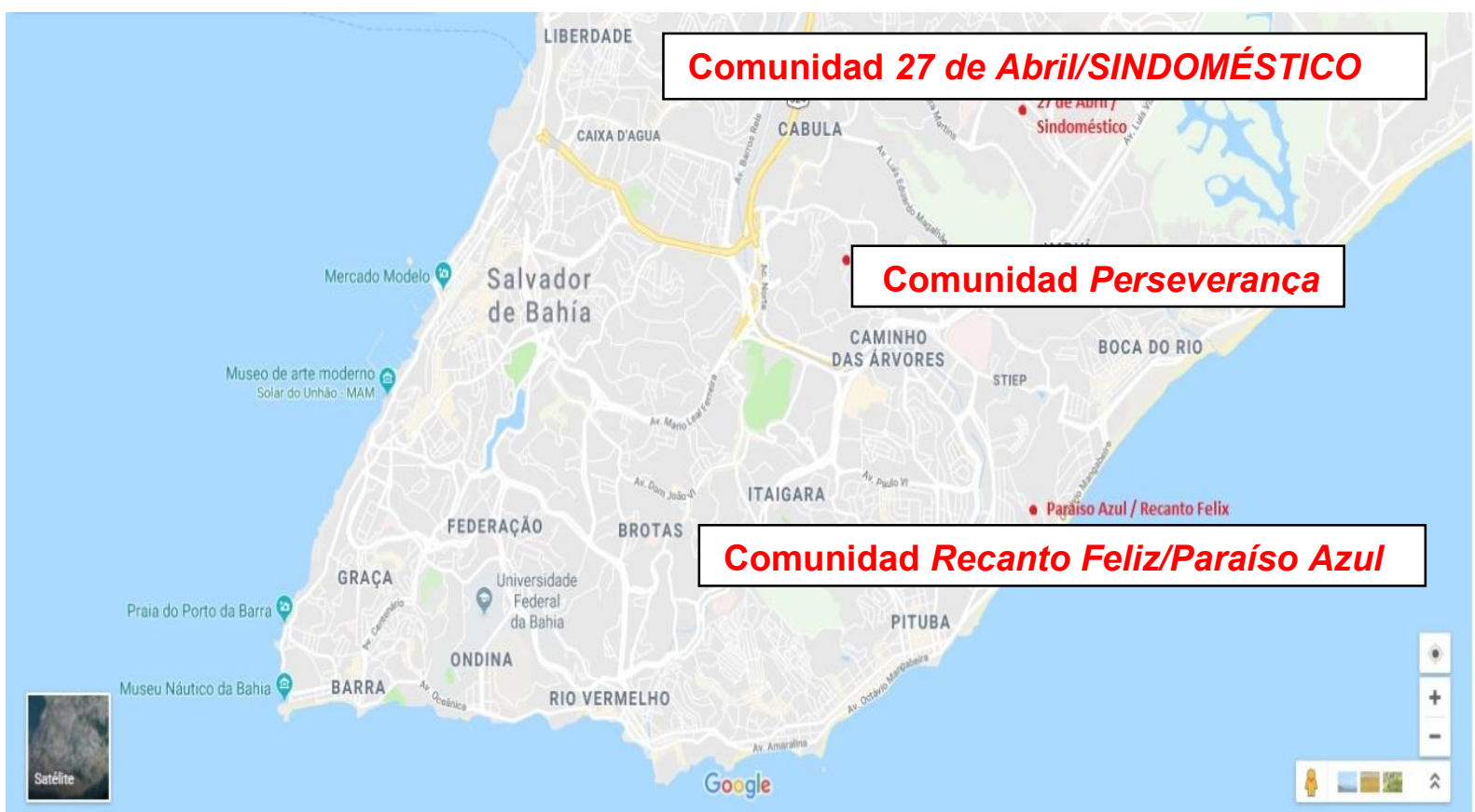

Fuente: Ramon Cotinguiba (2018) a partir de adaptación de GOOGLE Maps ([s/f]).

Tabla 4.2 - Datos cuantitativos y de costos de los 3 proyectos brasileños

\begin{tabular}{|c|c|c|c|c|}
\hline \multicolumn{2}{|c|}{ Ítems/Comunidades } & $\begin{array}{c}\text { Recanto } \\
\text { Feliz/Paraíso } \\
\text { Azul } \\
\text { (Costa Azul) }\end{array}$ & $\begin{array}{c}27 \text { de Abril/ } \\
\text { SINDOMÉSTICO } \\
\text { (Doron) }\end{array}$ & $\begin{array}{c}\text { Perseverança/ } \\
\text { "Lula" } \\
\text { (Pernambues) }\end{array}$ \\
\hline \multicolumn{2}{|c|}{ Discriminación } & $\mathrm{S}, \mathrm{C}, 2 \mathrm{H}^{* 2}, \mathrm{~B}, \mathrm{AS}$ & $\mathrm{S}, \mathrm{C}, 2 \mathrm{H}, \mathrm{B}, \mathrm{AS}$ & $\mathrm{S}, \mathrm{C}, 2 \mathrm{H}, \mathrm{B}, \mathrm{AS}$ \\
\hline \multicolumn{2}{|c|}{ Cantidad (Unid.) } & $336^{* 3}$ & 80 apt. & 60 apt. \\
\hline \multirow{3}{*}{ Área $\left(m^{2}\right)$} & Predio & $14.363,32$ & $3.486,87$ & $3.431,90$ \\
\hline & $\begin{array}{l}\text { Privativa } \\
\text { (dep) }\end{array}$ & $38,60^{* 4}$ & 38,16 & 40,00 \\
\hline & Paisajismo & $2.114,00$ & 548,94 & 693,83 \\
\hline \multirow{6}{*}{$\begin{array}{l}\text { Costos en } \\
(\mathrm{R} \$)^{* 1} / \text { Brasil }\end{array}$} & Total & $13.209 .190,32$ & $3.321 .000,94$ & $2.624 .632,30$ \\
\hline & Predio & & & \\
\hline & Unidad $/$ dept $^{\circ}$ & $39.313,07^{* 3}$ & $41.512,51$ & $43.743,87$ \\
\hline & $\$ / m^{2}$ & $1.018,47^{4}$ & $1.087,85$ & $1.093,60$ \\
\hline & Proyecto soc. & & & \\
\hline & Paisajismo & $\begin{array}{l}28.166,35 \\
(0,21 \%)^{* 7}\end{array}$ & $\begin{array}{l}7.335,20 \\
(0,23 \%)^{* 7}\end{array}$ & $\begin{array}{l}6.654,53 \\
(0,25 \%)^{* 7}\end{array}$ \\
\hline \multicolumn{2}{|c|}{$\begin{array}{l}\text { Plazos de obra: } \\
\text { inicio/conclusión }\end{array}$} & $\begin{array}{l}\text { Enero } 2005 / \text { dic. } \\
2007\end{array}$ & $\begin{array}{c}\text { Jun. 2010/agosto } \\
2012\end{array}$ & $\begin{array}{c}\text { Feb. 2010/sep. } \\
2013\end{array}$ \\
\hline
\end{tabular}

Fuente: adaptación a partir de documentos disponibilizados por CONDER (2018).

${ }^{* 1}$ Valores en Real conforme el período de conclusión de la obra (cambio oficial en 28 de diciembre 2007: U\$1,00 = R\$1,77; en 30 de agosto 2012: U\$ $1,00=R \$ 2,05$; en 30 de 
septiembre 2013: U\$ 1,00 = R 2,23 Conforme BANCO CENTRAL DO BRASIL (23 abril de2017);

${ }^{*}$ En cada uno de los departamentos hay: 1 sala $(\mathrm{S}), 1$ cocina $(\mathrm{C}), 2$ habitaciones $(\mathrm{H}), 1$ baño (B) y lavadero (AS). En cada una de las 112 casas hay 1 habitación;

${ }^{*}$ Incluyen 224 departamentos de cerca de $40,00 \mathrm{~m}^{2}$ y 112 casas unifamiliares de $35,00 \mathrm{~m}^{2}$;

${ }^{*} 4$ Área aproximada, por media ponderada, entre la de los 224 departamentos de cerca de $40,00 \mathrm{~m}^{2}$ y la de las 112 casas unifamiliares de $35,00 \mathrm{~m}^{2}$

${ }^{*}$ De propiedad del gobierno del Estado (valor de mercado no informado y no computado en los costos);

${ }^{*} 6$ Proyecto social: valor no discriminado, parcialmente tercerizado, incluye también personal del cuadro efectivo de CONDER;

${ }^{7}$ Porcentual de valor de paisajismo sobre el valor total del proyecto.

\subsection{1 - Conjunto Recanto Feliz/Paraíso Azul (Costa Azul)}

Esta comunidad se sitúa en el barrio Costa Azul (ver Figura 4.4) y comprende dos zonas contiguas, Recanto Feliz y Paraíso Azul, ocupadas informalmente hace décadas. Allí CONDER implantó en la primera fase 336 unidades (224 departamentos en bloques de tres pisos además de la planta baja entregados en 2008 y 112 viviendas unifamiliares), y en la segunda fase 155 unidades (130 departamentos, de los cuales 30 fueron entregados en 2014, y 25 viviendas unifamiliares), encontrándose el resto aún en construcción durante la aplicación de las encuestas. Los bloques de departamentos de la segunda etapa son básicamente similares a los de la primera etapa, siendo la principal diferencia que en esta nueva etapa cada bloque posee 4 pisos además de la planta baja y los adquirentes estarán exentos de cualquier tasa por resarcimiento, como sucedió en la primera etapa, en la que se pagó mensualmente entre $R \$ 50$ y $R \$ 70$ por unidad habitacional. Básicamente el contexto general de ambas etapas es muy similar entre sí bajo varios aspectos, sin cambios significativos en sus realidades. 
Figura 4.4 - Localización de la Comunidad Recanto Feliz/Paraíso Azul, Salvador

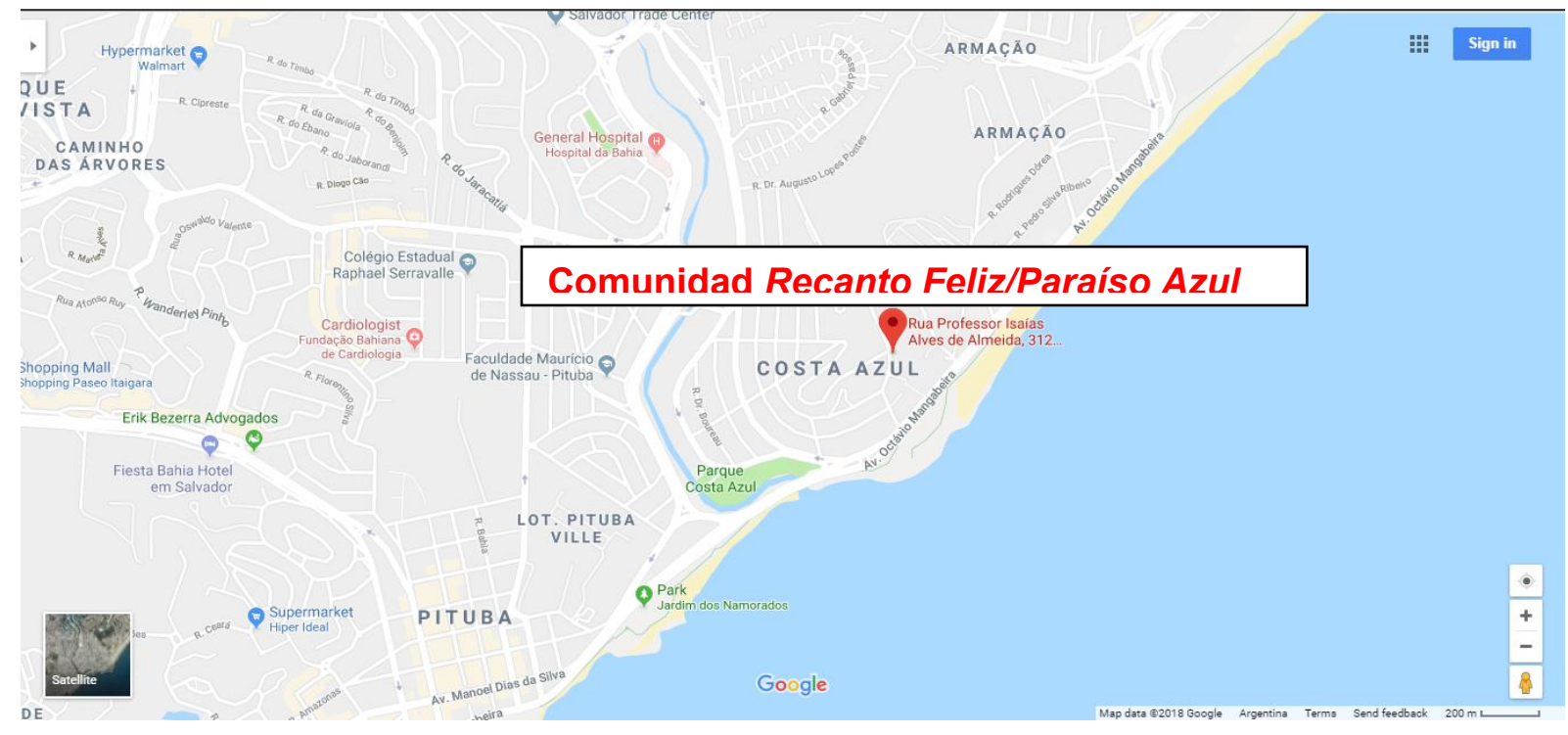

Fuente: Ramon Cotinguiba (2018) a partir de adaptación de GOOGLE Maps ([s/f]).

El Proyecto Recanto Feliz/Paraíso Azul I y II tuvo apoyo del Programa PróMoradia a través de la Caixa Econômica Federal. Antes del proyecto, destinado a las familias que estaban allí instaladas informalmente próximo al área de dunas en pésimas condiciones de habitabilidad (ver Figura 4.5). La primera etapa se inició en mayo de 2005 y consistió en la implantación de servicios de drenaje, red de cloaca y de estructura en general, incluyendo la construcción de 80 unidades sanitarias ${ }^{52}$, favoreciendo directamente cerca de dos mil personas. Tuvo un costo originalmente previsto de $\mathrm{R} \$ 10.729 .882,87$, alcanzando al final mediante aditivos de obras el valor de $R \$ 13.209 .190,32$ (ver Figura 4.6). La segunda etapa se inició en octubre de 2013, con plazo de ejecución programado para febrero de 2015, pero postergado para mayo de 2007, con un costo originalmente previsto de $R \$ 11.720 .902,20$, alcanzando al final mediante aditivos de obras el valor de $\mathrm{R} \$ 13.209 .190,32$. Para esta segunda etapa, el gobierno federal fue responsable por el 91,37\% del costo, y el resto fue responsabilidad del gobierno del estado de Bahia.

\footnotetext{
${ }^{52}$ Se llama de unidad sanitaria el conjunto de inodoro, ducha y lavatorio que se instala en una vivienda existente en la comunidad donde se ejecuta el proyecto de intervención urbana y cuya vivienda no disponga de aquéllos.
} 
Figura 4.5 - Comunidad de Recanto Feliz/Paraíso Azul, Salvador - Fase inicial

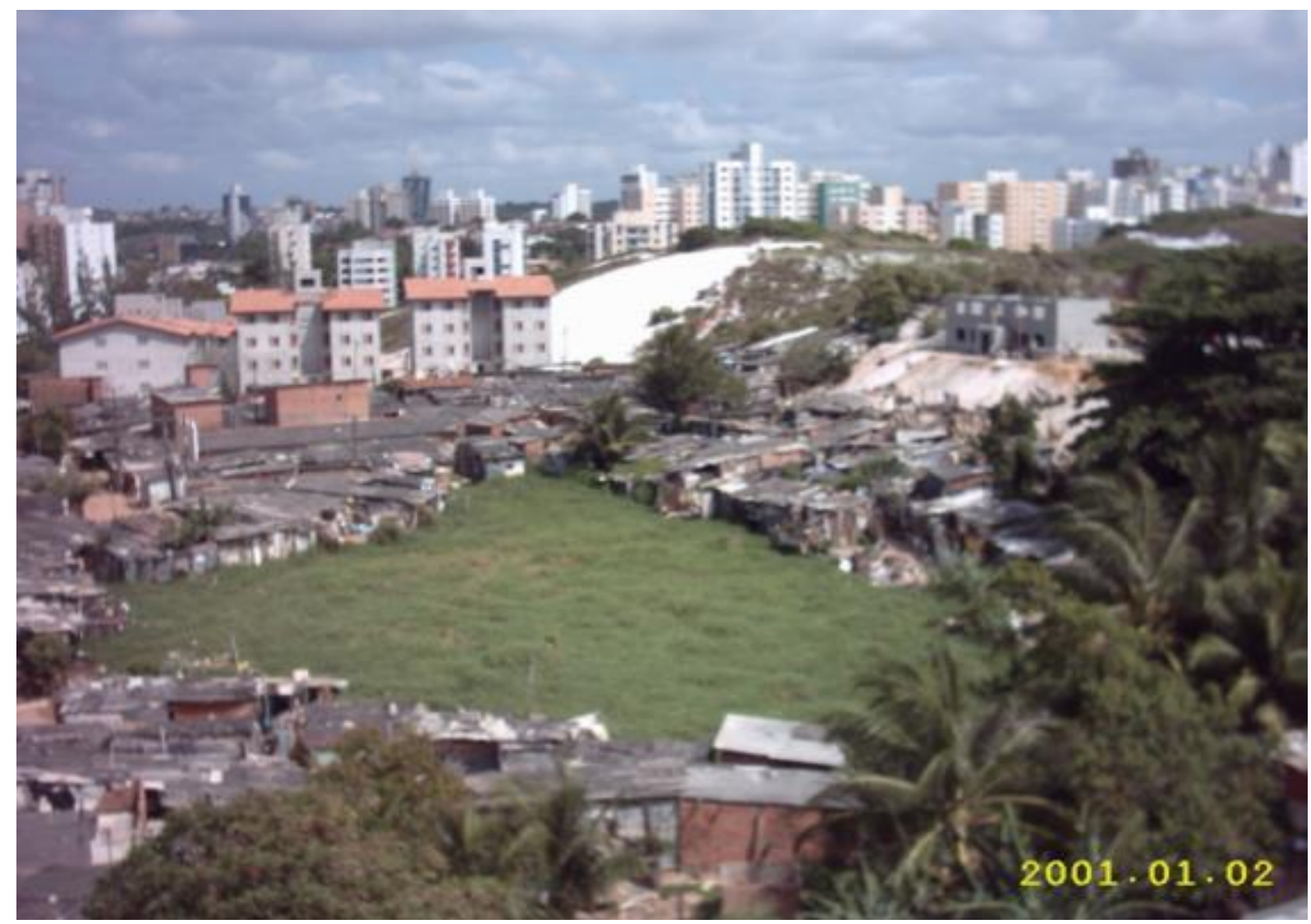

Fuente: CONDER (2001).

En esta comunidad se realizaron 84 evaluaciones EPO entre enero de 2014 y agosto de 2015, en su gran mayoría entre las familias de la primera etapa. 


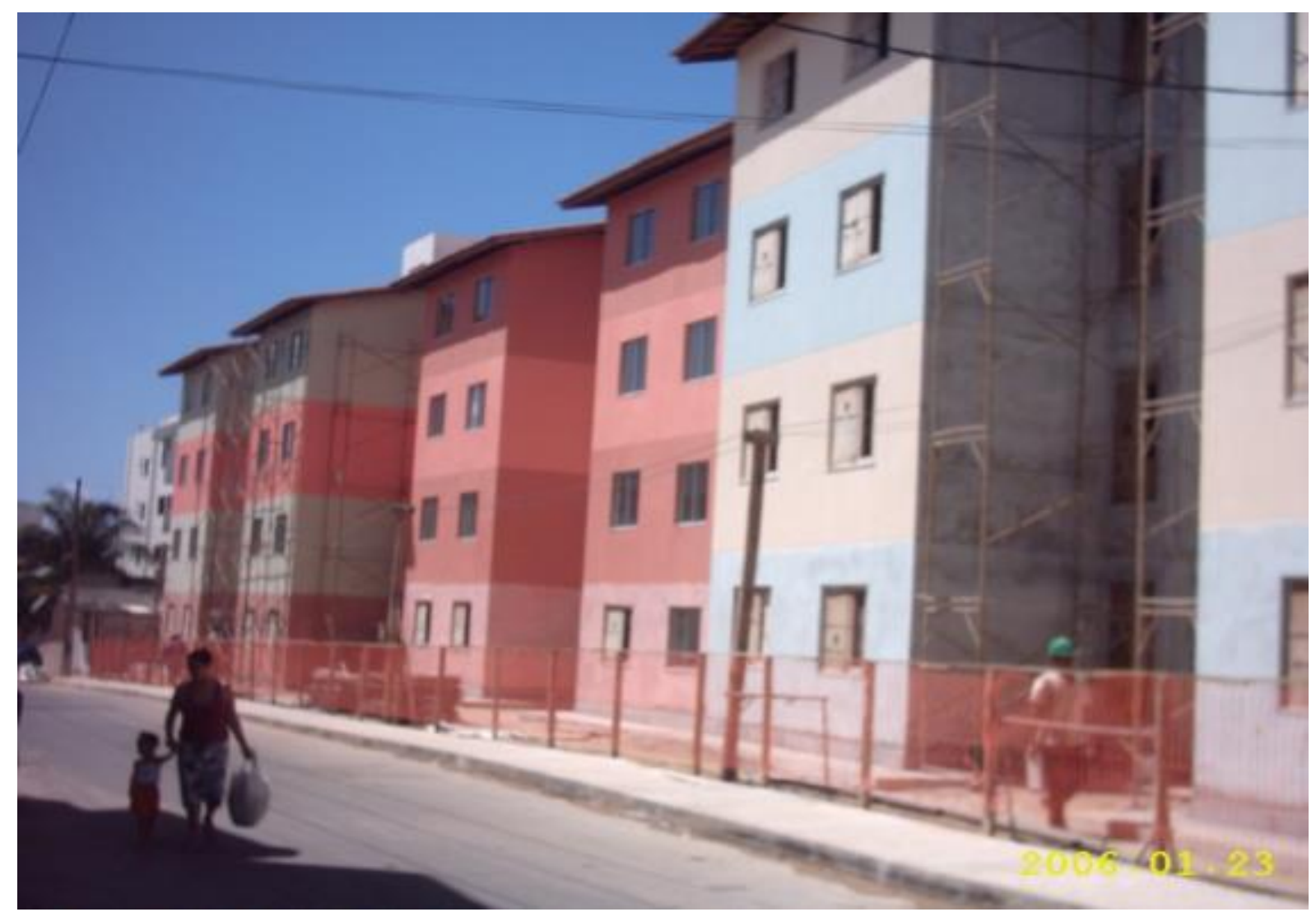

Fuente: Luiz Menezes (2014)

Tanto en la implantación de este proyecto como en el argentino de Parque Patricios, CABA, la prensa registró manifestaciones de protesta por parte de vecinos de mayor poder adquisitivo que intentaron evitar la construcción de las VIS, situación que en Brasil se manifiesta desde la segunda mitad del siglo XIX,: "um antigo desejo da elite: eliminar os cortiços do centro da cidade e segregar o trabalhador na periferia, reduzindo assim o custo das moradias e ampliando a distância física entre as classes sociais" (BONDUKI, 2011, p. 77). Fenómeno de repulsa que también registró Castells (2000) en su estudio de estratificación espacial:

[..] a estratificação e a segregação urbanas não são a projeção direta sobre o espaço do sistema de estratificação social, mas efeito da distribuição do produto entre os sujeitos, e do produto-moradia no espaço, bem como da correspondência entre estes dois sistemas de distribuição. Esta abordagem exige que se deduza a composição do espaço social a partir do estudo do seu processo de produção, tanto a nível das formas urbanas, quanto da distribuição dos indivíduos entre elas. (CASTELLS, 2000, p. 252-253.) 
Castells (2000, p. 517 y 518) refiere también que esta situación "confirma também o atraso dos progressos culturais em relação às reivindicações econômicas e aos processos de mobilização política", como sucedió en Chile cuando ciudadanos de movimientos sociales que reivindicaban viviendas populares tuvieron la oportunidad de participar con sugerencias en el proyecto arquitectónico y rechazaron propuestas de conjuntos habitacionales que no incluían una unidad domiciliar individualizada como anhelaban, aislada de los vecino a través de muros alrededor del bloque residencial donde fueron a vivir colectivamente con otras familias de la misma situación social.

\subsection{2 - Conjunto 27 de Abril/SINDOMÉSTICO (Dorón)}

El Conjunto 27 de Abril/SINDOMÉSTICO fue construido en el barrio Dorón (ver Figura 4.7) y está constituido por 4 torres de 5 pisos con 4 departamentos de $40 \mathrm{~m}^{2}$ por piso, con 2 habitaciones, cocina, baño y lavadero.

Figura 4.7 - Localización de la Comunidad 27 de Abril/SINDOMÉSTICO, Salvador

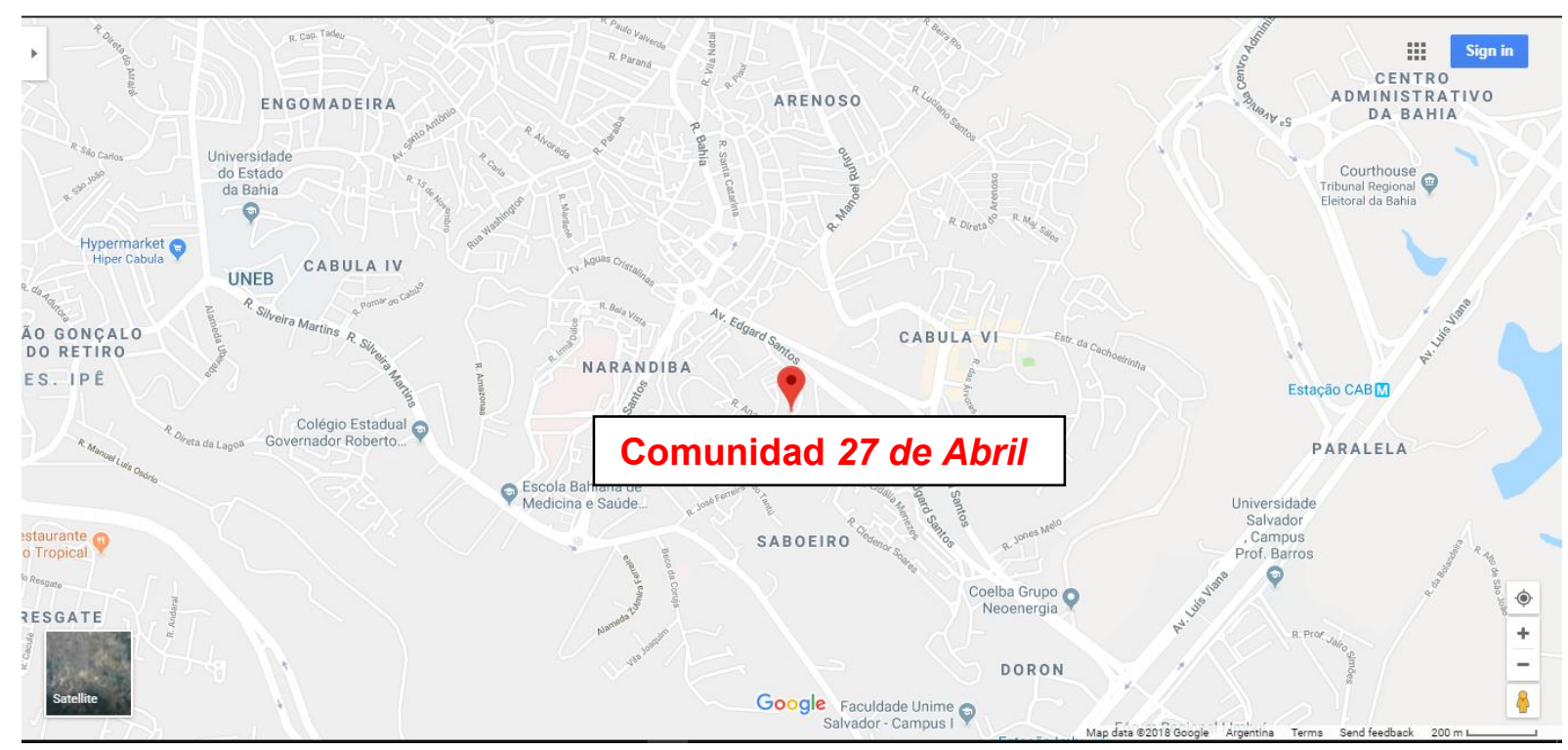

Fuente: Ramon Cotinguiba (2018) a partir de adaptación de GOOGLE Maps ([s/f]).

Una singularidad de este complejo residencial es que fue el primer conjunto habitacional en Brasil intermediado por un sindicato de trabajadoras de mucamas, SINDOMÉSTICO y por el gobierno de un estado, en este caso el estado de Bahia, el 
cual eximió a las 80 familias de mucamas contempladas del $100 \%$ de los costos de financiación de las construcciones de los inmuebles (ver Figura 4.8).

Las evaluaciones EPO en esta comunidad se realizaron entre el mes de abril de 2014 y el mes de septiembre de 2015, contabilizando un total de 52 domicilios evaluados.

Figura 4.8 - Condominio 27 de Abril/SINDOMÉSTICO, Salvador

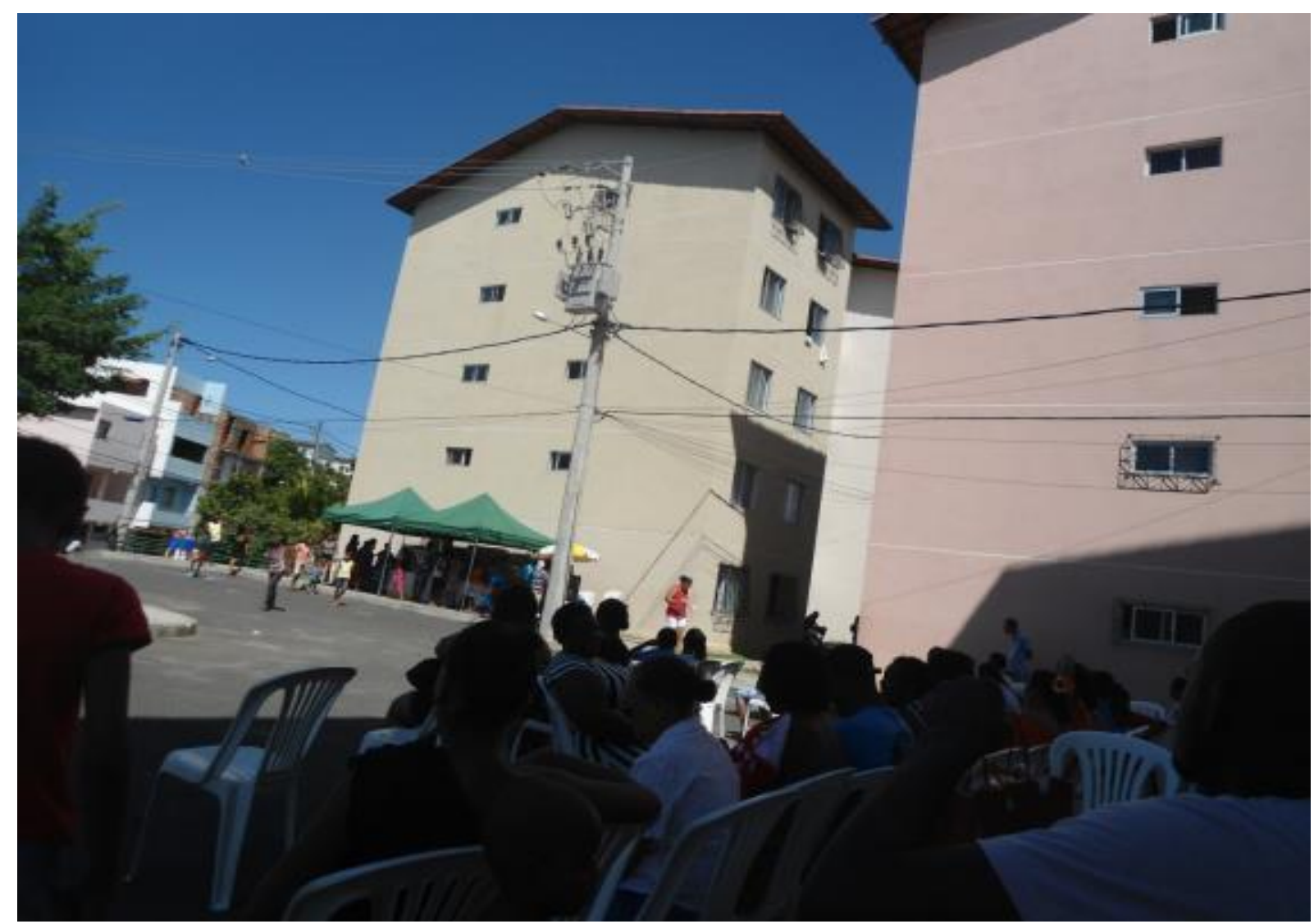

Fuente: Luiz Menezes (2014).

\subsection{3 - Conjunto Perseverança (Pernambues)}

La tercera comunidad que se investigó en Brasil es la de Perseverança, que fue inaugurada oficialmente como Residencial Luiz Inácio Lula da Silva, en el barrio de Pernambues (ver Figura 4.9), en un área de propiedad de la Prefeitura Municipal de Salvador. Posee una tipología arquitectónica alargada (en tiras) con 2 torres horizontales de 30 departamentos de $40 \mathrm{~m}^{2}$ cada una distribuidos en 5 pisos, con 2 habitaciones, cocina, baño y lavadero (ver Figura 4.10). 
Figura 4.9 - Localización de la Comunidad Perseverança, Salvador

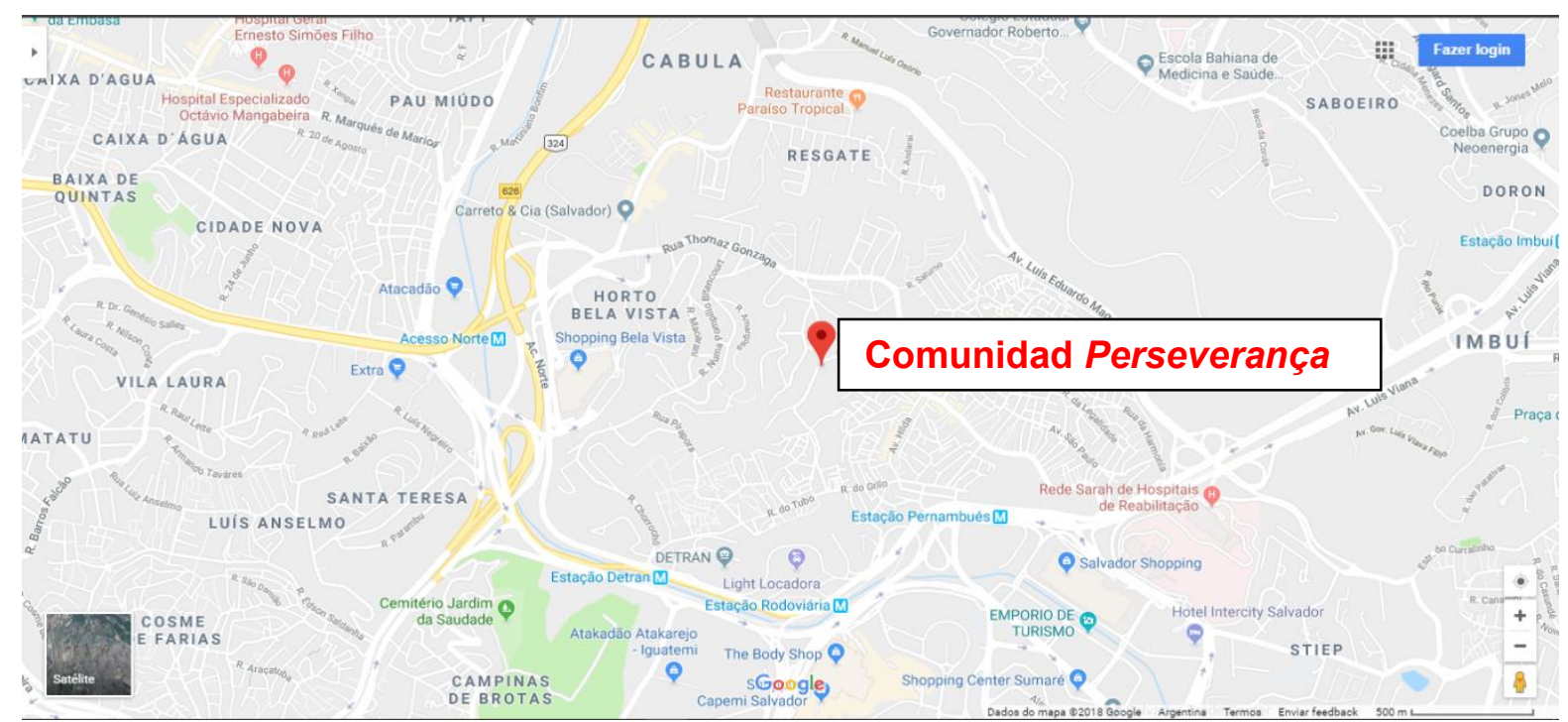

Fuente: Ramon Cotinguiba (2018) a partir de adaptación de GOOGLE Maps ([s/f]).

Figura 4.10 - Conjunto Luiz Inácio Lula da Silva/PERSEVERANÇA, Salvador

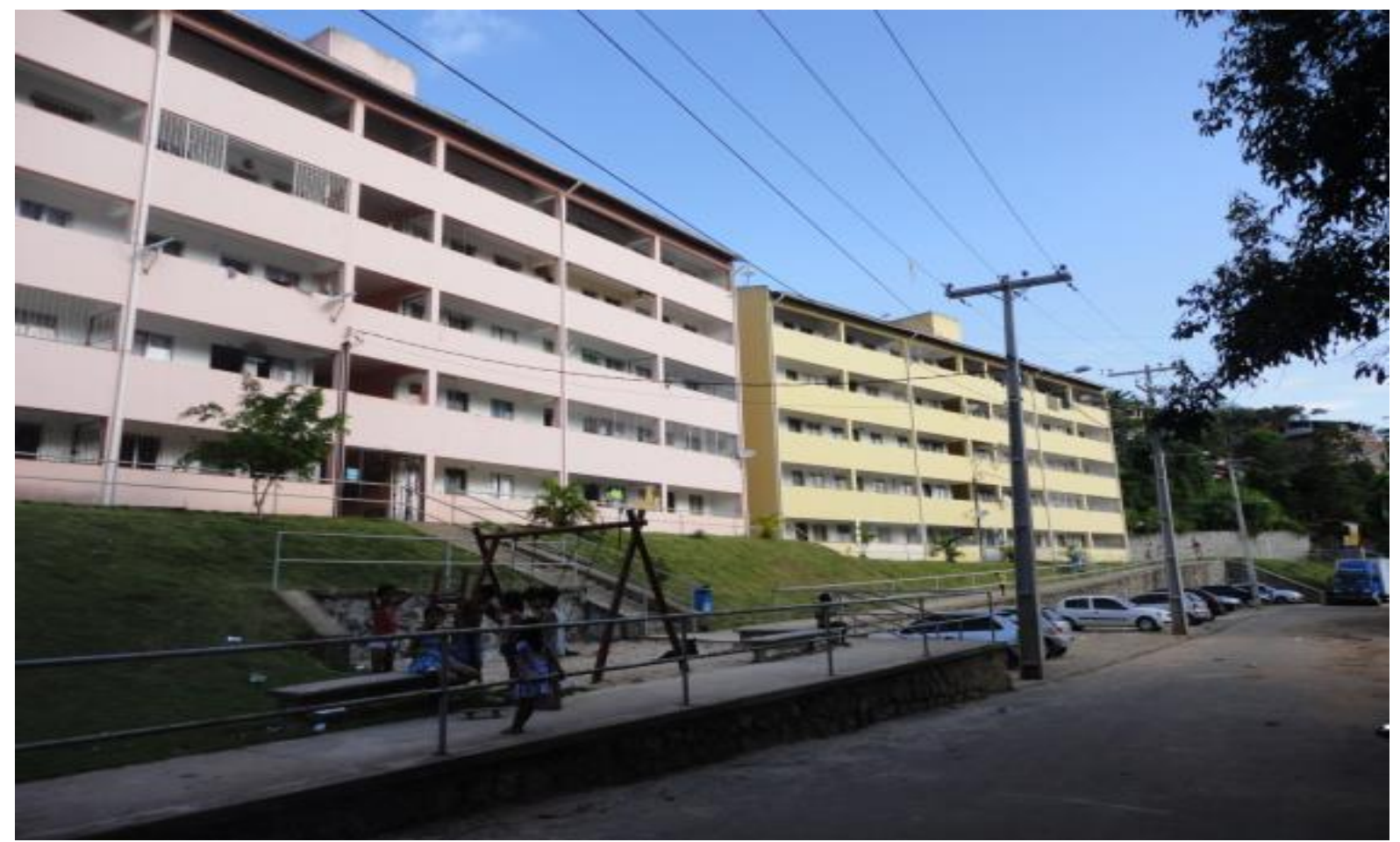

Fuente: Luiz Menezes (2014).

Fue construido mediante un acuerdo entre el gobierno del estado de Bahia y la municipalidad de Salvador por medio del cual al estado quedó la responsabilidad de la elaboración de los proyectos y de la construcción de las unidades habitacionales, así como de las estructuras y de la infraestructura, y a la 
municipalidad quedó la regularización del terreno y la titularidad de las unidades habitacionales construidas.

Se planeó el Projeto Perseverança mediante una intermediación del Movimento dos Sem Teto de Salvador y el gobierno del estado de Bahia, el cual eximió a los adquirentes de las unidades habitacionales del pago de los costos de financiación de las construcciones de los inmuebles, beneficiando, así, las sesenta familias de baja renta contempladas.

La evaluación EPO fue realizada entre junio de 2014 y abril de 2015 con un total de sólo 39 encuestados debido a la resistencia de una parte de los moradores a responder a la encuesta.

\section{2 - En Argentina}

Las 3 comunidades investigadas en la CABA son Parque Patricios/Monteagudo, ubicada en el barrio de Parque Patricios, Luzuriaga, en el barrio de Barracas y Padre Mujica, en el barrio de Villa Lugano (ver Figura 4.11).

Figura 4.11 - Ubicación de las 3 comunidades investigadas en CABA

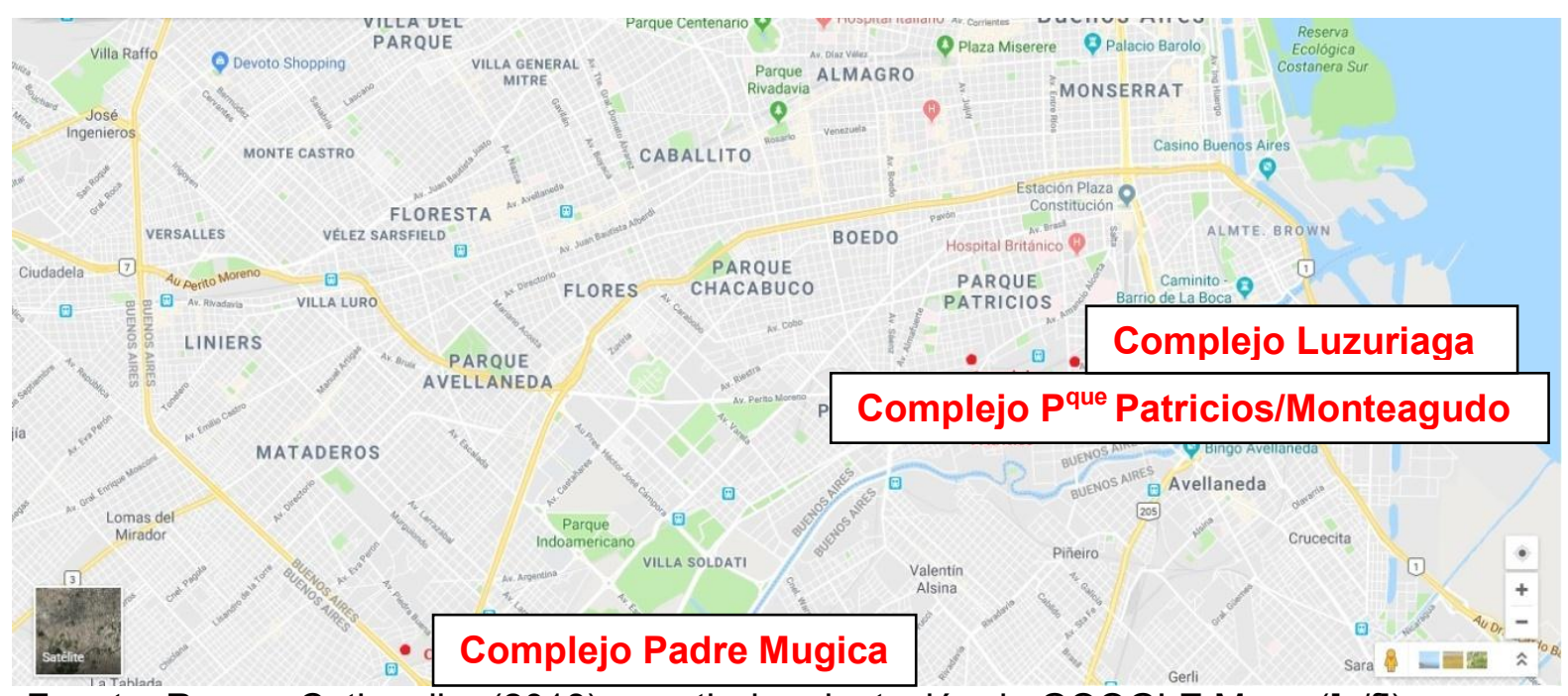

Fuente: Ramon Cotinguiba (2018) a partir de adaptación de GOOGLE Maps ([s/f]).

Los datos cuantitativos de las tres comunidades argentinas pueden verse en la Tabla 4.3. 
Tabla 4.3 - Datos cuantitativos y de costos de los 3 proyectos argentinos

\begin{tabular}{|c|c|c|c|c|}
\hline \multicolumn{2}{|c|}{ Ítems/Comunidades } & $\begin{array}{c}\text { Pque. } \\
\text { Patricios/MTL } \\
\text { (Monteagudo) }\end{array}$ & $\begin{array}{l}\text { Padre Mugica } \\
\text { (Villa Lugano) }\end{array}$ & $\begin{array}{l}\text { Luzuriaga } \\
\text { (Barracas) }\end{array}$ \\
\hline \multicolumn{2}{|c|}{ Discriminación } & $*_{2}^{2}$ & S, C, 3 ó $4 \mathrm{H}, \mathrm{AS}$ & \\
\hline \multicolumn{2}{|c|}{ Cantidad (Unid.) } & 326 & $300^{* 4}$ & 125 \\
\hline \multirow{3}{*}{ Área $\left(m^{2}\right)$} & Predio & 14400,00 & $66500,00^{5}$ & 3825,85 \\
\hline & $\begin{array}{l}\text { Privativa } \\
\text { (dep) }\end{array}$ & $*_{2}$ & 74,00 & $51,78^{* 7}$ \\
\hline & Paisajismo & No informado & No informado & No informado \\
\hline \multirow{6}{*}{$\begin{array}{c}\text { Costos en } \\
(\$)^{* 1} / \text { Argentina }\end{array}$} & Total & $13691327,00^{* 3}$ & $193000000,00^{6}$ & $62644387,00^{* 8}$ \\
\hline & Predio & $1400000,00^{* 3}$ & No informado & No informado \\
\hline & Unidad/dept ${ }^{\circ}$ & & $247435,90^{* 6}$ & No informado \\
\hline & $\$ / m^{2}$ & *2 & $3343,73^{* 6}$ & No informado \\
\hline & $\begin{array}{l}\text { Proyecto } \\
\text { soc. }\end{array}$ & No informado & No informado & No informado \\
\hline & Paisajismo & No informado & No informado & No informado \\
\hline \multicolumn{2}{|c|}{$\begin{array}{l}\text { Plazos de obra: } \\
\text { inicio/conclusión }\end{array}$} & $\begin{array}{l}2,5 \text { años (sept. } 2004 \\
\quad \text { a marzo 2007) }\end{array}$ & $\begin{array}{c}\text { Cerca de } 3 \text { años } \\
\text { (2008 a febrero } \\
2011)\end{array}$ & $\begin{array}{l}\text { (final de obra } \\
\text { marzo 2015) }\end{array}$ \\
\hline
\end{tabular}

Fuente: encuestas, entrevistas y planillas aplicadas entre 2014 y 2015.

${ }^{* 1}$ Valores en Pesos (de Argentina);

${ }^{*}$ Variable: ver Tabla 4.5;

${ }^{*}$ Valores estimados para marzo de 2007, fecha de la inauguración del Proyecto;

${ }^{*} 4$ Entregados el 10 de febrero de 2011 formando parte del total de 780 departamentos (S: sala, C: cocina, H: habitación, AS: área de servicio;

${ }^{*}$ Estimado, a partir de la planta de situación "Plano según mensura con fraccionamiento";

${ }^{*} 6$ Valores estimados para febrero de 2011, fecha de la inauguración de la primera etapa del Proyecto;

${ }^{*}$ Media ponderada $(\mathrm{Mp})$ a partir del número de departamentos con sus respectivas áreas, entre el total de las 125 unidades: ver Tabla 4.6.

${ }^{* 8} \$$ (Peso, de Argentina) en valores divulgados en enero de 2015, dos meses antes de la inauguración del Proyecto, según el artículo RELOCALIZACIÓN a vecinos de la Villa 26, ubicada a orillas del Riachuelo (2015).

\subsection{1 - Un caso muy singular en Argentina: la Villa 31}

La Villa 31 ocupa un área trapezoidal de 39 hectáreas en el barrio de Retiro, CABA, zona central y estratégica de la ciudad en cuanto a trabajo y transporte público. Su origen se remonta a la década del (19)30, cuando ocurrieron las primeras ocupaciones en el barrio, debido, principalmente, a la grave crisis económica mundial que acentuó la desocupación y la llegada de inmigrantes provenientes de Europa, incluyendo excombatientes de la primera Guerra Mundial. Durante este período hubo tolerancia de parte de las autoridades, que también 
distribuyó materiales básicos como chapas de zinc y adoquines para la construcción de las rústicas viviendas, sin ninguna orientación (CRAVINO, 2009, p. 17).

Tras la continua expansión que iba ocupando áreas contiguas con los nuevos asentamientos, surgieron los primeros intentos de desocupación por parte del estado en los años (19)50 e inicio de los 60. La resistencia por parte de los moradores no sólo les permitió permanecer allí sino también conseguir mejoras en la infraestructura, algo que no estaba en los planes de los gobernantes que, no habiendo logrado erradicarlos, pretendieron por lo menos contener la expansión. En 1962 la CMV realizó un censo en los cinco barrios que componían la ocupación Saldías, YPF, Comunicaciones, Güemes e Inmigrantes-, en el que se totalizó 1.856 viviendas para 6.731 moradores, de los cuales el $37 \%$ eran extranjeros, y en su mayoría de países limítrofes. Estos casi siete mil moradores representaban cerca del $15 \%$ de los que vivían en similares condiciones en la CABA (CRAVINO, 2009, p. $20)^{53}$

El término villa pasó a ser utilizado en Buenos Aires a partir de 1931 en la expresión "villa desocupación" para referirse a las casas simples de los operarios portuarios despedidos con la crisis de 1929 cerca de Puerto Nuevo. Luego, la expresión "villa miseria" se refería al conjunto de casas construidas con materiales precarios, en terrenos baldíos urbanos generalmente ocupados de forma ilegal por inmigrantes del interior de Argentina que a partir de mediados del siglo pasado pasaron a instalarse masivamente en la CABA, según Alicia Novik (apud MIGUEL, 2010 , p. $76-77$ ). Con el tiempo, el término "miseria", que inicialmente se refería a la precariedad de los materiales utilizados, abarcó también peyorativamente al contexto social de la población que moraba en dichas viviendas.

\footnotetext{
${ }^{53}$ En 1971, con un barrio más, el Laprida, "creado" por estrategias estatales en 1964, la comunidad de la Villa de Retiro, que a partir de la nueva clasificación numérica implantada durante la dictadura militar -1976/1983- pasó a llamarse Villa 31, contaba con 4.900 viviendas y una población de 24.385 personas, algo como el $25 \%$ de la población "villera" de Buenos Aires (CRAVINO, 2009, p. 21). En una investigación de 2003 encomendada por el consultor estadístico Hugo Maia a causa de la diatriba entre mantener los moradores en la Villa 31 o retirarlos de allí debido a la presión de diferentes grupos interesados en los terrenos, Clarín (2004) publicó que el $54 \%$ de la comunidad tenía trabajo estable, el $39 \%$ trabajo regular, el $2 \%$ estaba desempleado y el $4 \%$ restante eran jubilados y amas de casa. La investigación constató que el $69 \%$ de los moradores eran argentinos, que de los extranjeros el $21 \%$ poseía ya vivienda regularizada y que el $10 \%$ restante tenía pendencias con relación a la morada (CRAVINO, 2009, p. 110). La Dirección de Estadística y Censos del GCBA en 2009 estimaba que a fines de 2010 la población total de Villa 31 estaría en torno de los 30 mil habitantes (CASTRO, 2010 , p. 100). En 2003, la CMV, debido a críticas recibidas sobre sus mecanismos operativos y productividad, sufrió un rediseño institucional, a partir del cual sus atribuciones fueron transferidas al entonces Instituto de la Vivienda del Gobierno de la Ciudad (IVC) a través de la Ley 1.251 del 4 de diciembre de 2003 (CASTRO, 2010, p. 43, 52).
} 
Con la progresiva expansión de la Villa 31, durante la dictadura militar del general Onganía, iniciada en 1966, se intentó su erradicación, así como también la de otras villas emergentes en la entonces Ciudad de Buenos Aires a través del Decreto-Ley 17.605, Ley de Erradicación. Varias organizaciones sociales se rebelaron a esta medida, incluyendo a los religiosos católicos, entre ellos al cura Carlos Mugica, que vivía en la Villa 31 desde los años 60, donde era párroco. Mugica fue asesinado el 31 de mayo de 1974 después de una misa por un supuesto miembro de la Triple A -Alianza Anticomunista Argentina- (CASTRO, 2010, p. 86-88).

El período entre la década del (19)60 e inicio de la de los (19)80, entre dictaduras militares y gobiernos constitucionales, sufrió sucesivos cambios de rumbo en las políticas públicas y entre éstas las vinculadas al sector de la VIS. Con la creación de la CMV por el Decreto-Ley 17.174/67, la Ciudad de Buenos Aires pasó a promover acciones de VIS también en áreas de la periferia junto al Gobierno Federal (UNIVERSIDAD DE BUENOS AIRES, 2000, p. 16).

Fue a partir de la década de los (19)80 que más estudios académicos propusieron soluciones urbanísticas de mayor amplitud para el barrio de Retiro. Anteriormente, experiencias basadas en sistemas tecnológicos de premoldeado, como, por ejemplo, la que se implantó en la escuela Bandera Argentina de Mataderos en 1966, ya eran aplicadas por jóvenes universitarios que prestaban servicios con actividades de extensión en la comunidad de Retiro. La dictadura militar restringió este tipo de experiencias político-tecnológicas, en boga en los años (19)60 y (19)70, pero sirvieron de base para las nuevas experiencias a partir de la redemocratización a inicio de los años (19)80, como las desarrolladas en los talleres académicos por los arquitectos Osvaldo Bidinost y Daniel Beti, que fue diputado de la Ciudad de Buenos Aires años después y fue impulsor de la propuesta de aprobación por el Poder Legislativo de la Capital Federal de la primera versión del anteproyecto que sirvió de base para la Ley de Urbanización № 3.343 de 2009 , iniciativa del diputado Facundo de Filipo. También en ámbito académico sobre producción de VIS se puede mencionar, en la especialidad de fundamentación teórica y de investigación proyectual, la colaboración del Laboratorio de Morfología de la FADU/UBA, actualmente incorporado al Instituto de la Espacialidad Humana y del Centro de Poiesis, dirigido por el profesor Jorge Sarquis (CASTRO, 2010, p. 118120).

En el clima de libertad democrática pos-1983 surge, también, el Programa Arraigo, de alcance nacional, que pretendía resolver el problema de la ocupación 
irregular de tierras federales en Argentina y que por diversos motivos acabó por no volverse realidad, como, por ejemplo, en la Villa 31, donde se había previsto la construcción a partir de 1991 de ochocientas viviendas por un total de \$ 25.597.579 \$ 436 por metro cuadrado- ${ }^{54}$ (CRAVINO, 2009, p. 102-103). Los moradores que aceptaron la propuesta del gobierno de la ciudad para ser removidos de la Villa 31 habrían recibido un valor de indemnización de $\$ 25.000$, poco más del doble de los $\$$ 12.000 ofrecidos por el Estado (CRAVINO, 2009, p 142-163). Contrariamente al espíritu del Programa Arraigo, cuando se decidió la construcción de la autopista que corta la Villa 31, bajo el gobierno del intendente Carlos Grosso se publicó la Ordenanza 44873/91 sobre las intervenciones en las villas -apertura/ampliación de calles- que trajo la polémica dimensión mínima de $72 \mathrm{~m}^{2}$ necesaria para que un lote pudiera recibir aportes del Estado, índice que fue cuestionado tanto desde el punto de vista técnico como político (CRAVINO, 2009, p. 88-89). ${ }^{55}$

Tanto los moradores de la Villa 31 como los del resto de las ocupaciones informales de la ciudad sufren constantemente presión y discriminación por parte de varios sectores, como por ejemplo a través de campañas mediáticas en las que se los acusa de especuladores -de tierra e inmuebles-, de pertenecer a grupos que fomentan actividades de narcotráfico, de ser extranjeros, y de evasión fiscal -por causa de los subsidios de políticas sociales- (CASTRO, 2010, p. 61-62). En los casos de los DUE, la situación se agrava, ya que no siempre las viviendas son de buena calidad ni son entregadas con los muros medianeros construidos, lo que influyen mucho en la visual y genera problemas con los vecinos. Todo esto provoca que la existencia de conjuntos habitacionales populares generalmente influya bajando los precios de los terrenos linderos, lo que hace que se agrave la discriminación y segregación socioespacial de los moradores de estos "barrios pobres" y que termina por promover un vacío en estas áreas producido por la fuga de los vecinos. Lo más grave es que esta cultura discriminatoria en Argentina ocurre

\footnotetext{
${ }^{54}$ Se estimaba que viviendas de habitaciones: $1\left(59,51 \mathrm{~m}^{2}\right), 2\left(70,77 \mathrm{~m}^{2}\right), 3\left(89,97 \mathrm{~m}^{2}\right)$ y $4\left(99,86 \mathrm{~m}^{2}\right)$ serían vendidas respectivamente por $\$ 25.946, \$ 30.856, \$ 39.227$ y $\$ 43.539$. En un segundo momento se habló de 2.110 unidades que, sin embargo, tampoco fueron construidas (CRAVINO, 2009, p.103). Por otro lado, como indicador para el análisis del costo del suelo para implantación de proyectos de VIS, se tiene que, en un área cercana de donde se instaló el Proyecto Celina, donde habrían sido transferidas las familias que estaban en el trazado de la autopista que pasa por la Villa 31 , un lote de $300 \mathrm{~m}^{2}$ saldría $\$ 600$, o sea, $\$ 2 / \mathrm{m}^{2}$ (CRAVINO, 2009, p. 161). Sobre los costos de vivienda, el arquitecto mexicano Carlos Gonzalez Lobo (LOMBARDI, CREMASHI y MARSILLI, 2004, p. 205) refiere en el Seminario de Tecnología y Gestión para el Hábitat Social Latinoamericano en FAU-UNLP con relación a lo que Julián Salas ([19--]) constata para América Latina, que cerca del $50 \%$ corresponde al crédito bancario, $30 \%$ al lote y $20 \%$ a la vivienda propiamente dicha.

${ }^{55}$ La Ordenanza 44873/91 continuó válida durante la vigencia del Programa Arraigo (CASTRO, 2010, p. 44-45).
} 
en áreas donde los conjuntos habitacionales son de buena calidad, además de contribuir para la mejora de los servicios públicos que acompañan las inversiones de recursos que el Estado aporta. Un ejemplo de esto se vio durante la implantación del proyecto Parque Patricios/Monteagudo, como se verá más adelante.

Una experiencia interesante es la de la participación de un mayor número de moradores en las obras de construcción de sus propias VIS. El arquitecto argentino Javier Castro (2010) llama la atención sobre el hecho de que, a pesar de la poca escolaridad de gran parte de los moradores de las comunidades de VIS, no procede el prejuicio que muchos profesionales vinculados a las intervenciones urbanísticas nutren al suponer que no tendrían condiciones de discernimiento ni capacidad de opinión sobre soluciones de aspectos técnicos de los proyectos, lo que sería factible bajando el nivel de lenguaje de las discusiones. Castro (2010) argumenta que tal procedimiento se vuelve innecesario una vez que, por ejemplo, él y su equipo no necesitaron utilizar dicho artificio en momento alguno durante las varias reuniones que tuvieron con los moradores de la Villa 31, y que no tuvieron ninguna disminución de calidad por la participación de los moradores para presentar o definir algún problema y/o solución en el decurso de la elaboración del proyecto de forma participativa (CASTRO, 2010, p. 130).

Castro (2010) agrega también que otra ventaja para las intervenciones urbanísticas de VIS es la de contar con construcciones preexistentes producidas por los moradores de las comunidades, de las que se puede obtener un ahorro al promover mejoras y adaptaciones, al contrario de siempre querer partir de cero, situación más problemática y costosa. Basado en el caso de la Villa 31, por ejemplo, sostiene que cerca del $70 \%$ de las viviendas existentes podrían recuperarse y ser mejoradas, lo que, en comparación a la opción de erradicar una comunidad para otra localidad, teniendo en cuenta la inversión en infraestructura necesaria, significaría un substancial ahorro (ver Tabla 4.3), al que se puede agregar los beneficios sociales que traería a través del mantenimiento de los vínculos de vecindad desarrollados por la población (CASTRO, 2010, p.190). Premisa corroborada por estudios realizados en Brasil que demuestran que:

Os custos de infraestrutura não implicam em grandes acréscimos no valor total da intervenção, mesmo quando se trata de percentuais altos de sistema viário [... y] Considerando-se que os custos de relocação representam praticamente $50 \%$ do valor de reassentamento, as alternativas que disponibilizam maiores áreas de 
relocação promovem soluções mais econômicas. (ABIKO y ORNSTEIN, 2002, p. 314) ${ }^{56}$

Tabla 4.4 - Parámetros urbanísticos para recolocación

\begin{tabular}{|c|c|c|c|c|}
\hline & Área de parcelación & $\begin{array}{l}\text { Área de } \\
\text { sistema } \\
\text { viario }\end{array}$ & $\begin{array}{l}\text { Tipología de } \\
\text { parcelación }\end{array}$ & $\begin{array}{c}\text { Densidad de } \\
\text { ocupación } \\
\text { (unidades/ha) }\end{array}$ \\
\hline \multirow{3}{*}{ Áreas > 1ha } & \multirow{3}{*}{50 a $60 \%$} & \multirow{3}{*}{20 a $30 \%$} & Lote $125 \mathrm{~m}^{2}$ & 40 a 48 \\
\hline & & & $\begin{array}{l}\text { Condominio en } \\
\text { planta baja }\end{array}$ & 60 a 70 \\
\hline & & & $\begin{array}{l}\text { Edificio popular } \\
\text { de } 4 \text { pisos }\end{array}$ & 100 a 120 \\
\hline \multirow{3}{*}{$\begin{array}{c}\text { Áreas entre } 0,3 \\
\text { a 1ha }\end{array}$} & \multirow{3}{*}{70 a $80 \%$} & \multirow{3}{*}{20 a $30 \%$} & Lote $125 \mathrm{~m}^{2}$ & 64 \\
\hline & & & $\begin{array}{l}\text { Condominio en } \\
\text { planta baja }\end{array}$ & 96 a 112 \\
\hline & & & $\begin{array}{l}\text { Edificio popular } \\
\text { de } 4 \text { pisos }\end{array}$ & 160 a 192 \\
\hline \multirow{3}{*}{ Áreas $<0,3 \mathrm{ha}$} & \multirow{3}{*}{$100 \%$} & \multirow{3}{*}{0} & Lote $125 \mathrm{~m}^{2}$ & 80 \\
\hline & & & $\begin{array}{l}\text { Condominio en } \\
\text { planta baja }\end{array}$ & 120 a 140 \\
\hline & & & $\begin{array}{l}\text { Edificio popular } \\
\text { de } 4 \text { pisos }\end{array}$ & 200 a 240 \\
\hline
\end{tabular}

Fuente: ABIKO y ORNSTEIN (2002, p. 311).

Además de los interesantes aprendizajes provenientes de las intervenciones urbanísticas con proyectos de VIS, otras dos enseñanzas básicas que no pueden ser ignoradas en la solución habitacional son: la primera, la falta de adecuación compatibilidad- de todos los proyectos, incluso los constructivos, destinados a una determinada comunidad, como ocurrió en Buenos Aires entre 1991 y 1992, con la inviabilidad de implantación de infraestructuras; la segunda tiene que ver con la cuestión de pretender la participación unánime de los potenciales moradores beneficiados, sin que se tengan la mínima capacitación y condiciones necesarias (CRAVINO, 2009, p. 86, 87-100).

\subsection{2 - Complejo Parque Patricios/Monteagudo (Parque Patricios)}

El Proyecto Parque Patricios/Monteagudo fue destinado a "piqueteros" sin techo, muchos de los cuales desempleados (ver Figura 4.12), y fue desarrollado por el estudio Pfeifer y Zurdo arquitectos, reconocido en Argentina por especializarse en

${ }^{56}$ Abiko y Ornstein (2002, p. 311) están aplicando aquí el concepto de "reasentamiento" como remoción de familias para fuera de la comunidad, y el de "recolocación" como remoción de familias de dentro de la comunidad original. 
proyectos de grandes dimensiones como shopping centers de alto estilo. Fue implantado en una superficie cubierta total de $22.000 \mathrm{~m}^{2}$; en un terreno de $14.400 \mathrm{~m}^{2}$ que era de una antigua fábrica desactivada. Totaliza 326 unidades, 152 viviendas de 1 habitación, 138 viviendas de 2 habitaciones y 36 viviendas de 3 habitaciones, y fue concluido en $2007^{57}$.

Figura 4.12 - Localización de la Comunidad Parque Patricios/Monteagudo, CABA

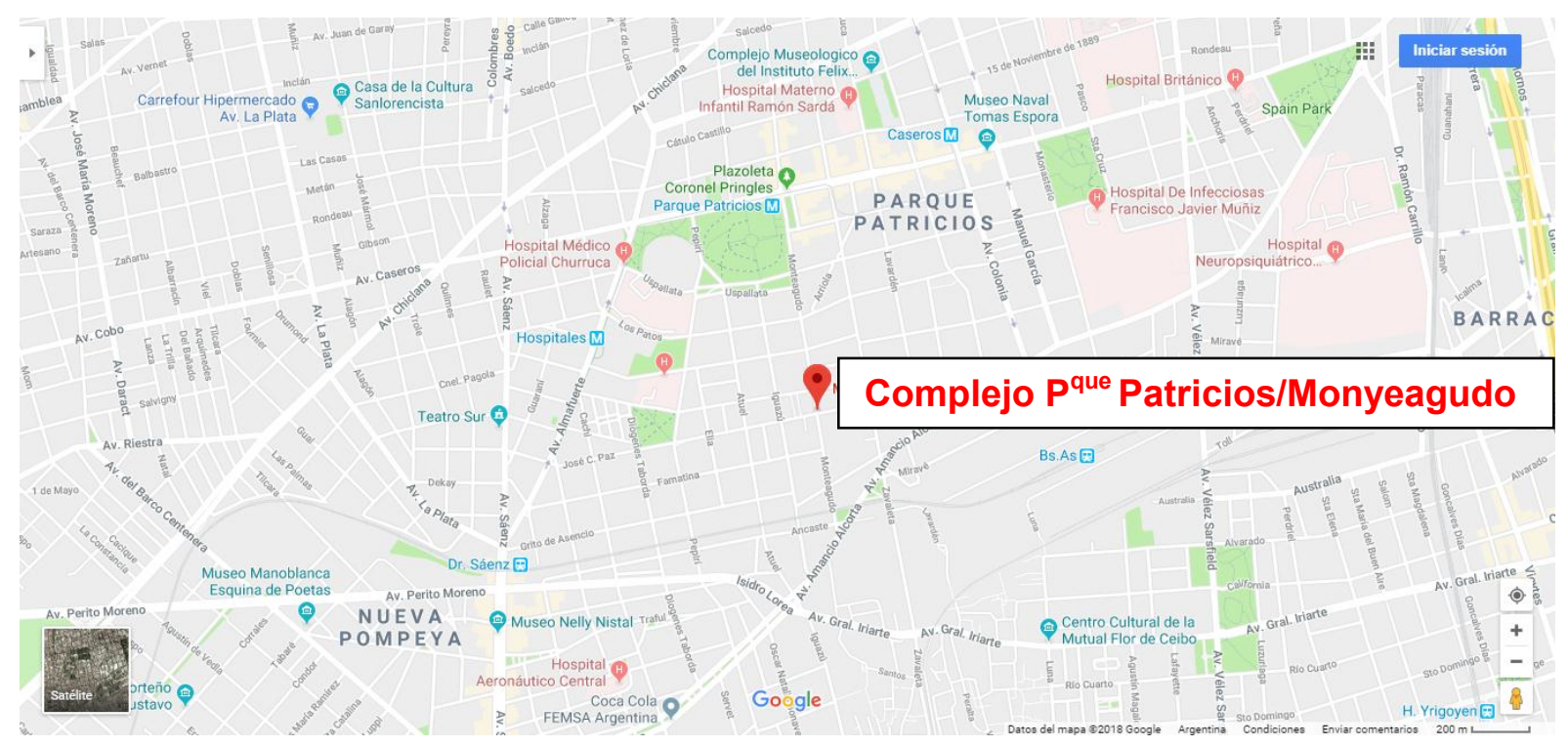

Fuente: Ramon Cotinguiba (2018) a partir de adaptación de GOOGLE Maps ([s/f]).

El estudio Pfeifer-Zurdo realizó una propuesta arquitectónica que procuró respetar la historia del barrio y que dialoga con el entorno construido a su alrededor: fachadas con ladrillo -cerámico- a la vista y alineadas con el límite del predio de la fábrica en relación a la vía pública para evitar desperdicio de espacio, utilización de la antigua fachada de uno de los módulos de la planta arquitectónica y paisajismo con abundante distribución de árboles nativos favoreciendo el micro clima del área (ver Figuras 4.13 y 4.14 ). La implantación de los edificios en "tiras" de cuatro pisos, incluyendo la planta baja, sin ascensor, dispuestos en el eje longitudinal de Este a Oeste favoreció la luminosidad en todas las unidades habitacionales por mayor tiempo. El financiamiento es a 30 años, con cero intereses (ver Tabla 4.4).

\footnotetext{
${ }^{57}$ La población objeto de este Proyecto es en su mayoría originaria del asentamiento de la Villa 21, también conocida como Zabaleta, formada por "piqueteros", desempleados o "changarines" e inmigrantes de países próximos -bolivianos, chilenos, paraguayos y peruanos-.
} 
Figura 4.13 - Condominio Parque Patricios/Monteagudo, CABA

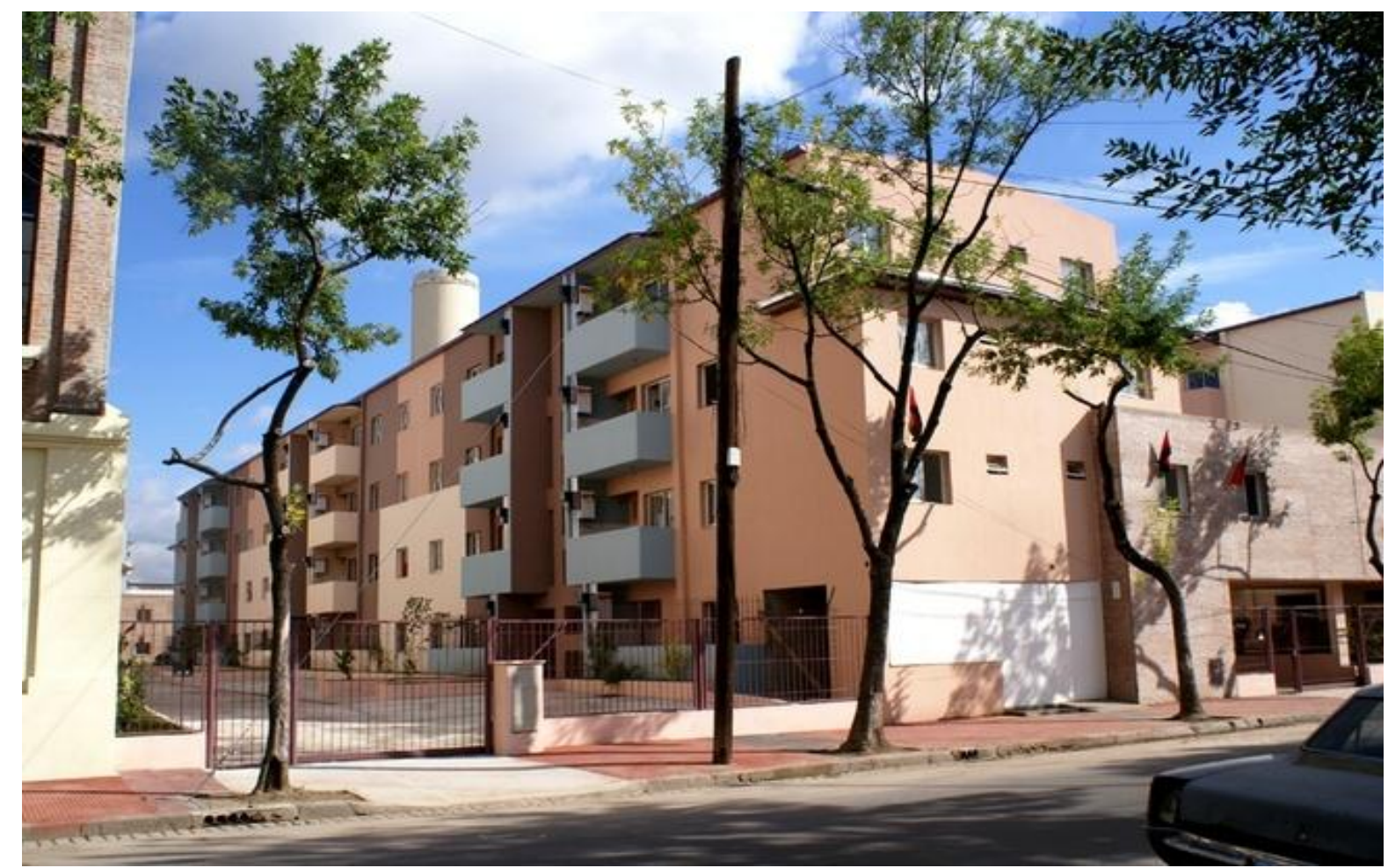

Fuente: PfZ Arquitectos (2007).

Figura 4.14 - Condominio Parque Patricios/Monteagudo, CABA

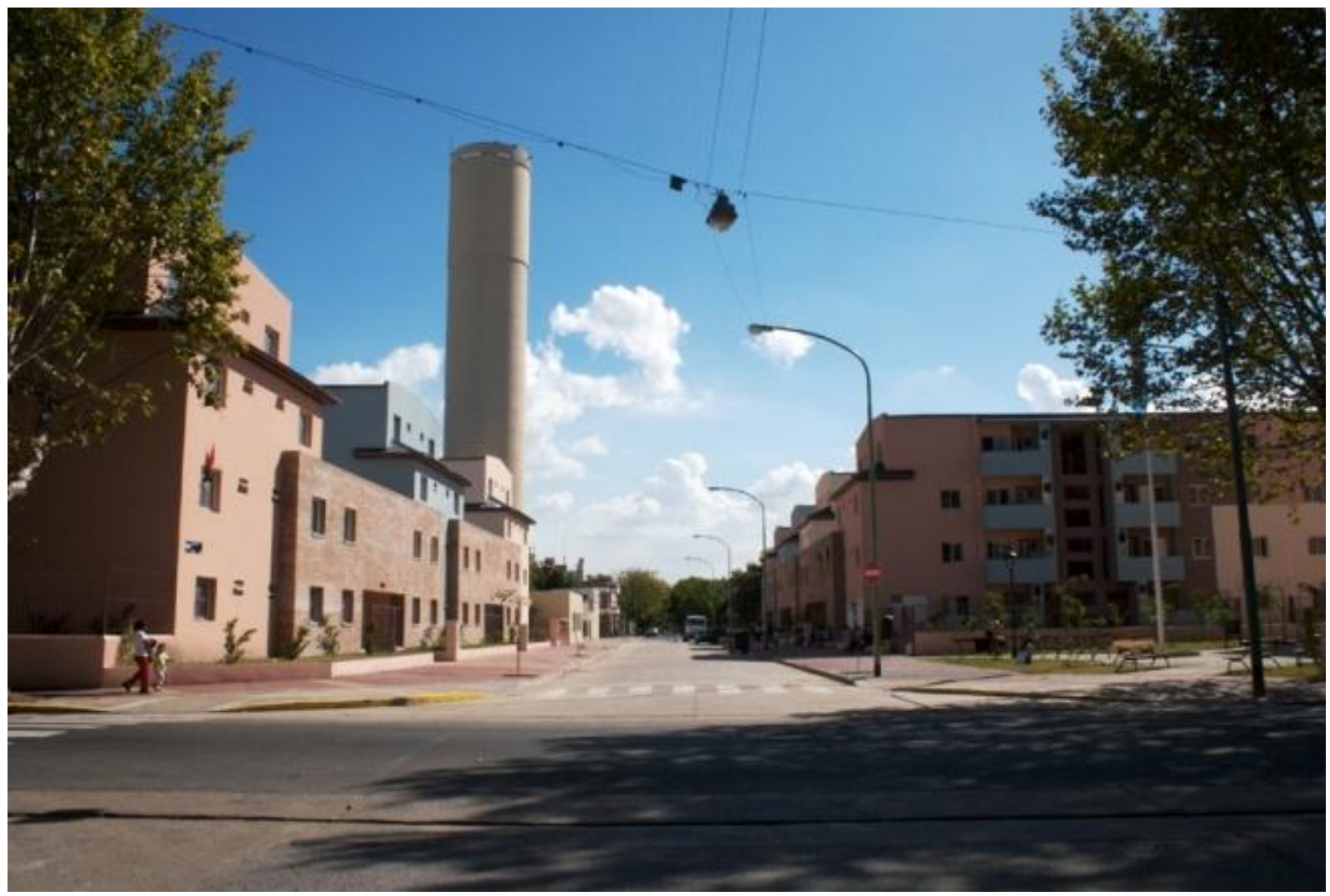

Fuente: PfZ Arquitectos (2007). 
Tabla 4.5 - Habitaciones y valores monetarios del Complejo Parque Patricios-Monteagudo, por tipo de planta de departamento

\begin{tabular}{|c|c|c|c|c|}
\hline $\begin{array}{l}\text { Ítem/Modelo de } \\
\text { planta arquitect. }\end{array}$ & Discriminación & $\begin{array}{l}\text { Área/dept } \\
\left(\mathrm{m}^{2}\right)\end{array}$ & $\begin{array}{l}\text { Cuota mensual } \\
\qquad(\$)^{*^{1}}\end{array}$ & $\begin{array}{l}\text { Valor total } \\
(\$)^{* 1} / \text { dept }^{\circ}\end{array}$ \\
\hline A & $\begin{array}{l}1 \text { dormit., sala/estar, } \\
\text { cocina, baño,balcón }\end{array}$ & 38,00 & 165,00 & 59400,00 \\
\hline B & $\begin{array}{c}1 \text { dormit., sala/estar, } \\
\text { cocina, baño, lavabo, } \\
\text { "ampliación" }\end{array}$ & 43,00 & 182,00 & 65520,00 \\
\hline C & $\begin{array}{l}2 \text { dormit., sala/estar, } \\
\text { cocina, baño,balcón }\end{array}$ & 50,00 & 220,00 & 79200,00 \\
\hline D & $\begin{array}{l}2 \text { dormit., sala/estar, } \\
\text { cocina, } 2 \text { baños,balcón }\end{array}$ & 56,00 & 240,00 & 86400,00 \\
\hline E & $\begin{array}{c}2 \text { dormit., sala/estar, } \\
\text { cocina, } 2 \text { baños,balcón }\end{array}$ & 63,00 & 280,00 & 100800,00 \\
\hline $\mathbf{F}$ & $\begin{array}{l}3 \text { dormit, sala/estar, } \\
\text { cocina, } 2 \text { baños,balcón }\end{array}$ & 75,00 & 354,00 & 127440,00 \\
\hline G & $\begin{array}{c}3 \text { dormit, sala/estar, } \\
\text { cocina, } 2 \text { baño, } \\
\text { balcones, "ampliação" }\end{array}$ & 93,00 & 420,00 & 151200,00 \\
\hline
\end{tabular}

Fuente: a partir de informaciones fornecidas por la Cooperativa de MTL/CTA (2010). *1: Valores estimados en marzo de 2007, fecha de la inauguración del Proyecto. Cambio: $1 \mathrm{R} \$=$ $\$ 2,30$ Pesos argentinos, y 1 U $\$$ Dólar de EEUU $=3,98$ Pesos argentinos (BANCO CENTRAL DE LA REPÚBLICA ARGENTINA. (2010)).

Para la concepción del proyecto el estudio Pfeifer-Zurdo contó con profesionales de sociología, considerando la diversidad cultural entre los futuros moradores. También buscó inspiración y referencias importantes dentro del segmento de construcción de VIS en Argentina, como el arquitecto Fermín Beretervide, que diseñó el Parque de Los Andes en 1928 en el barrio de operarios de Chacarita, CABA; y trabajó en la propuesta de revitalización de una antigua zona industrial degradada, área de conflicto social, en Bobigny, en los alrededores de Paris, habitada por personas de diversas nacionalidades, donde la propuesta era la de pasar a usos mixtos -viviendas/comercio/recreo/hotel/oficinas, y también el arquitecto Álvaro Siza, de la Cidade de Porto: la implantación del edificio en conjunto con la municipalidad impidió áreas libres vulnerables y maximizó la cantidad de viviendas ${ }^{58}$.

\footnotetext{
${ }^{58}$ Proyectar viviendas colectivas para familias pobres de diferentes nacionalidades fue común entre algunos arquitectos modernistas como Le Corbusier (1989; 2006), principalmente en el pos-Segunda Guerra Mundial, como el Team 10: Giancarlo de Carlo, Ralph Erskine, Alison y Peter Smithson, en los años (19)50 y (19)60, preocupados en producir una "arquitectura social" (BARONE, 2002). Anteriormente, a fines del siglo XIX, también se preocuparon con la habitabilidad de los más pobres:
} 
Una importante medida realizada por el MTL, vinculado a la CTA, fue la fundación, con base en la Ley 341 de 2000, de una cooperativa, y, a través de ésta, de una constructora. Así, la cooperativa pudo generar trabajo para sus asociados y gestionar las obras de forma participativa, incluyendo en el cuadro de operarios la fuerza laboral femenina con cerca del $25 \%$ de las 300 personas que actuaron en la construcción, y, también, promover la inclusión de estudiantes de nivel secundario de familias de bajos ingresos, a los que se les enseñaba un oficio y posteriormente se los agregaba a la propia cooperativa para que desempeñaran el oficio aprendido $^{59}$.

Un hecho lamentable que desafortunadamente es común y conocido en situaciones de implantación de VIS fue el de la resistencia manifestada por parte de la población del barrio. Consciente de este fenómeno socio-reactivo, el MTL realizó con mucha discreción la compra del predio de la antigua fábrica, manteniéndose en anonimato y solamente revelándose como compradora a los propietarios ya en la fase conclusiva de las negociaciones. De igual manera, cuando fue implantado el Proyecto de MTL, los futuros moradores sufrieron una fuerte resistencia por parte de los vecinos del barrio Parque Patricios, los que alegaban que la presencia de ellos aumentaría el clima de inseguridad pública en el barrio.

Dicho fenómeno socio-reactivo ante la implantación de proyectos de VIS en barrios residenciales de clase media o en sus cercanías, e incluso en barrios "populares", es muy común y no es ninguna novedad en otras partes de Latinoamérica, como ocurrió en Chile, y en Salvador de Bahía durante la implantación de los dos proyectos contiguos, Paraíso Azul y Recanto Feliz en el barrio de Costa Azul, en el que las familias de clase media reaccionaron de manera semejante a los argentinos. Otro hecho semejante ocurrió también en Salvador durante la implantación del Projeto SINDOMÉSTICO y también durante la postocupación por parte de la población vecina de estrato social "popular", que exteriorizó una cierta hostilidad por la presencia de las moradoras domésticas, población-objeto del proyecto. Uno de los motivos alegados fue que el terreno del proyecto servía de cancha de futbol desde hacía tiempo. Esta realidad refuerza la

Ebenezer Howard con sus ciudades-jardines (HOWARD, 1996) y los socialistas utópicos: Charles Fourier e Jean-Baptiste Godin, practicante del principio de los falansterios, como es sabido.

${ }_{59}$ Un ejemplo de participación de trabajadores en decisiones sobre el andamiento de las obras fue la implementación de una variedad de opciones en el menú del comedor de la obra, teniendo en cuenta los gustos y culturas diferentes que actuaban allí, lo que aumentó la autoestima de los operarios y se reflejó en una mayor productividad y mejor convivencia entre ellos (aunque inicialmente hubo una cierta resistencia). 
necesidad de que se deba dar mayor relieve en los proyectos de VIS al papel de los profesionales del sector social, como pedagogos y psicólogos, pues, como se viene enfatizando en este trabajo, es fundamental la colaboración de los mismos en la tarea de minimizar los conflictos entre y dentro de los grupos sociales de diferentes estratos, así como calificar mejor el perfil de participación de los moradores en las cuestiones que les atañen, en especial las vinculadas a la convivencia colectiva en viviendas multifamiliares ${ }^{60}$. Hechos semejantes también fueron observados en los proyectos implantados en la capital de São Paulo (WERNA, 2001, p. 154).

Es de resaltar como algo relevante sobre la implantación de proyectos de VIS que desde el inicio, durante los primeros encuentros de los profesionales del sector social de la institución pública responsable con los futuros moradores, y también a la hora de la entrega las viviendas, sean respetadas las reglas decididas en asamblea sobre los criterios de prioridades, como el número de componentes del núcleo familiar, la presencia de ancianos en las familias, de personas con algún tipo de enfermedad o discapacidad que exijan un mayor cuidado, e, incluso, el compromiso demostrado a lo largo del tiempo de filiación al proyecto y su contribución en la solución de los reveses cotidianamente enfrentados por el colectivo en la lucha por alcanzar sus metas, procedimientos que fueron observados en el desarrollo del Proyecto Parque Patricios/Monteagudo ${ }^{61}$.

\subsection{3 - Complejo Luzuriaga (Barracas)}

El conjunto habitacional Luzuriaga está ubicado en Luzuriaga $N^{\circ} 837$, en el Barrio de Barracas, y está compuesto por 125 unidades funcionales distribuidas en seis edificios independientes dentro de un predio que totaliza $3825,85 \mathrm{~m}^{2}$, correspondiente a la $15^{\mathrm{a}}$ parcela de la manzana 13 (sección18 y circunscripción 3 ), comprendida entre la calle Olavarría y la calle Luzuriaga (ver Figura 4.15). La concepción constructiva utilizada es tradicional con tipología arquitectónica en altura de 4 y 5 pisos además de la planta baja y con ascensor (ver Figura 4.16), con una media ponderada (Mp) de $51,78 \mathrm{~m}^{2}$ por departamento (ver Tabla 4.5). El costo total del proyecto ha sido de $\$ 62.644 .387$, compartido en un $65 \%$ por el gobierno de la

\footnotetext{
${ }^{60}$ Inclusive durante el período de aplicación de las encuestas en 2014, y en otras ocasiones en 2015 , era común escuchar relatos de las moradoras del SINDOMÉSTICO sobre escaramuzas con los vecinos con relación al uso indebido del espacio del condominio utilizado por éstos para estacionar vehículos y otros problemas de convivencia comunitaria.

${ }^{61}$ Complejo de Vivienda Monteagudo -Finalista 2008/Argentina (¿2008?).
} 
CABA y en un $35 \%$ por el gobierno nacional. El gobierno porteño lo inauguró en 2015.

Figura 4.15 - Localización de la Comunidad Luzuriaga, CABA

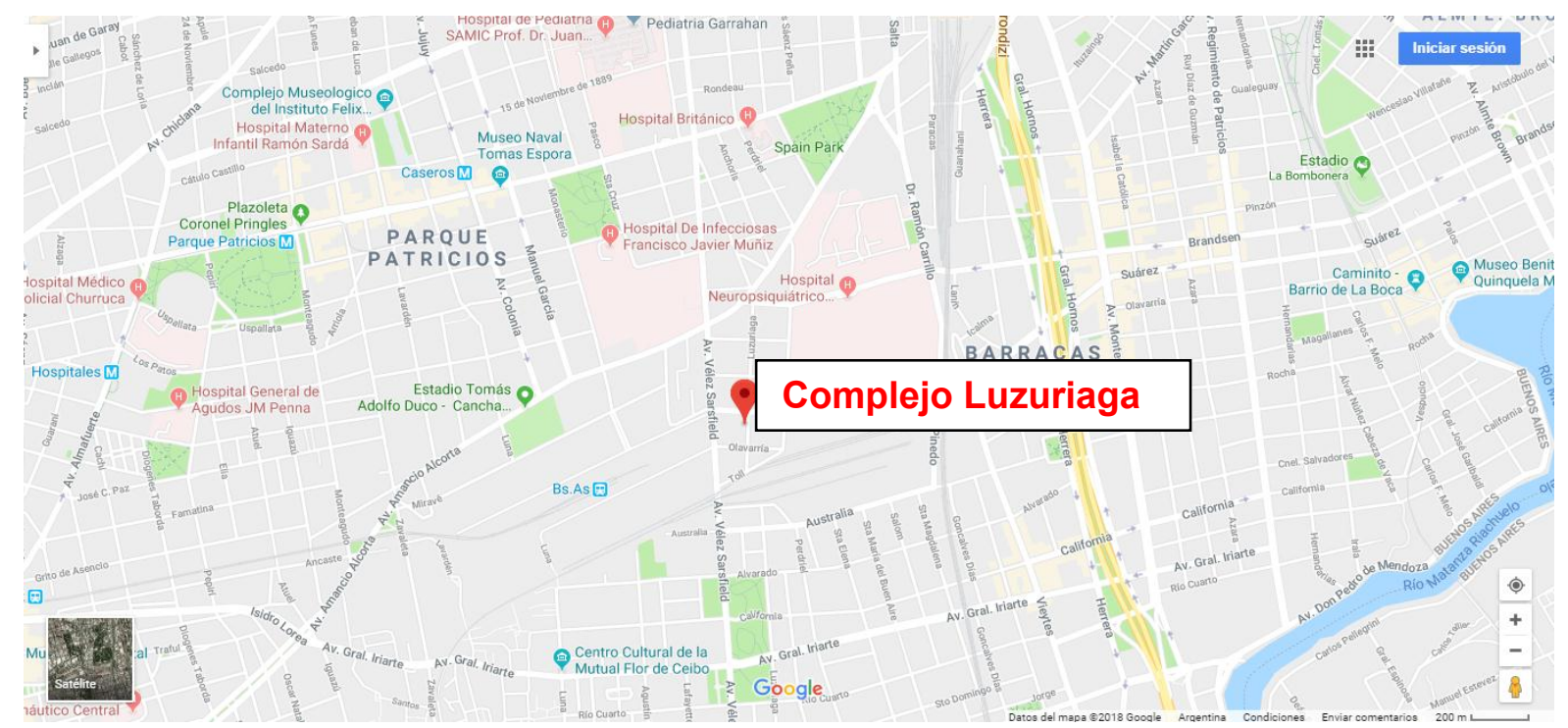

Fuente: Ramon Cotinguiba (2018) a partir de adaptación de GOOGLE Maps ([s/f]).

Figura 4.16 - Complejo Habitacional Luzuriaga/Barracas, CABA

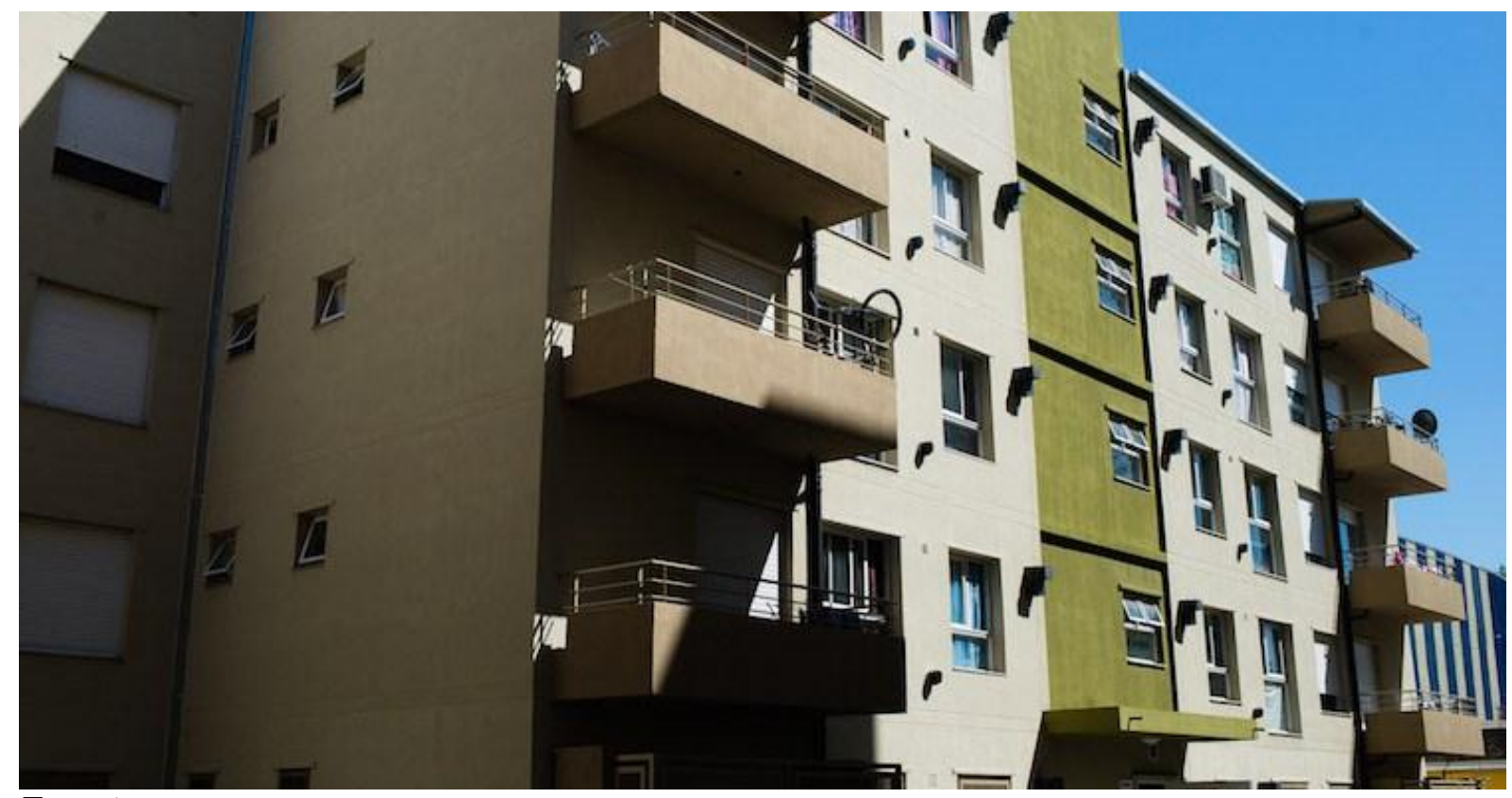

Fuente: Pura Ciudad - Buenos Aires Noticias (2015)

Fue creado para familias provenientes de la Villa 26, del mismo barrio, y hace referencia a viejas tipologías de conjuntos de vivienda social para ofrecer a los 
vecinos la posibilidad de disfrutar de un entorno seguro y confortable mediante un marco consorcial y ambiente sostenible, buscando mantener el sentido de comunidad ya construido por estas familias durante años.

Las familias se mudaron para sus nuevas residencias ya con la escritura del departamento firmada en diciembre de 2014, algo hasta entonces no común en Argentina, lo que dio más seguridad a las familias que se sienten de hecho, y de derecho, propietarias de sus inmuebles, usufructuando por completo los derechos advenidos

Tabla 4.6 - Habitaciones y valores monetarios del Complejo Luzuriaga, por tipo de planta de departamento

\begin{tabular}{|c|c|c|c|c|}
\hline Tipo & Discriminación & Área/dept ${ }^{\circ}\left(m^{2}\right)$ & $\begin{array}{c}\mathbf{N}^{\circ} \\
\text { Unidades }\end{array}$ & $\begin{array}{l}\text { Valor total } \\
(\$)^{* 1} / \text { dept }^{\circ}\end{array}$ \\
\hline A & $1 \mathrm{~d}, \mathrm{~cm}, \mathrm{cc} / \mathrm{bñ} / \mathrm{M} . \mathrm{C}$. & 34,62 & 1 & $\mathrm{NI}$ \\
\hline B & $1 \mathrm{~d}, \mathrm{~cm}, \mathrm{cc} / \mathrm{bñ} / \mathrm{bc}$ & 34,62 & 4 & $\mathrm{NI}$ \\
\hline C & $1 \mathrm{~d} / \mathrm{e}, \mathrm{cm}, \mathrm{cc}, \mathrm{Iv} / \mathrm{b} \tilde{\mathrm{n}} / \mathrm{bc}$ & 42,93 & 4 & $\mathrm{NI}$ \\
\hline D & $1 \mathrm{~d} / \mathrm{e}, \mathrm{cm}, \mathrm{cc}, \mathrm{Iv} / \mathrm{b} \tilde{\mathrm{n}} / \mathrm{bc}$ & 43,35 & 10 & $\mathrm{NI}$ \\
\hline E & $1 \mathrm{~d} / \mathrm{e}, \mathrm{cm}, \mathrm{cc}, \mathrm{Iv} / \mathrm{b} \tilde{\mathrm{n}} / \mathrm{M} . \mathrm{C}$. & 43,49 & 4 & $\mathrm{NI}$ \\
\hline $\mathbf{F}$ & $1 \mathrm{~d} / \mathrm{e}, \mathrm{cm}, \mathrm{cc}, \mathrm{Iv} / \mathrm{b} \tilde{\mathrm{n}} / \mathrm{M} . \mathrm{C}$. & 43,57 & 1 & $\mathrm{NI}$ \\
\hline G & $1 \mathrm{~d} / \mathrm{e}, \mathrm{cm}, \mathrm{cc}, \mathrm{Iv} / \mathrm{b} \tilde{\mathrm{b}} / \mathrm{M} . \mathrm{C}$. & 43,75 & 1 & $\mathrm{NI}$ \\
\hline $\mathbf{H}$ & $1 \mathrm{~d} / \mathrm{e}, \mathrm{cm}, \mathrm{cc}, \mathrm{Iv} / \mathrm{bn} / \mathrm{bc}$ & 43,75 & 4 & $\mathrm{NI}$ \\
\hline I & $1 \mathrm{~d} / \mathrm{e}, \mathrm{cm}, \mathrm{cc}, \mathrm{Iv} / \mathrm{b} \tilde{\mathrm{n}} / \mathrm{M} . \mathrm{C}$. & 43,83 & 1 & $\mathrm{NI}$ \\
\hline $\mathbf{J}$ & $1 \mathrm{~d} / \mathrm{e}, \mathrm{cm}, \mathrm{cc}, \mathrm{Iv} / \mathrm{b} \tilde{\mathrm{n}} / \mathrm{M} . \mathrm{C}$. & 44,23 & 1 & $\mathrm{NI}$ \\
\hline K & $1 \mathrm{~d} / \mathrm{e}, \mathrm{cm}, \mathrm{cc}, \mathrm{Iv} / \mathrm{b} \tilde{\mathrm{n}} / \mathrm{M} . \mathrm{C}$. & 44,24 & 2 & $\mathrm{NI}$ \\
\hline $\mathbf{L}$ & $1 \mathrm{~d} / \mathrm{e}, \mathrm{cm}, \mathrm{cc}, \mathrm{Iv} / \mathrm{b} \tilde{\mathrm{n}} / \mathrm{M} . \mathrm{C}$. & 44,28 & 4 & $\mathrm{NI}$ \\
\hline M & $1 \mathrm{~d} / \mathrm{e}, \mathrm{cm}, \mathrm{cc}, \mathrm{Iv} / \mathrm{bñ} / \mathrm{M} . \mathrm{C}$. & 44,30 & 1 & $\mathrm{NI}$ \\
\hline $\mathbf{N}$ & $1 \mathrm{~d} / \mathrm{e}, \mathrm{cm}, \mathrm{cc}, \mathrm{Iv} / \mathrm{bñ} / \mathrm{bc}$ & 44,35 & 10 & $\mathrm{NI}$ \\
\hline 0 & $1 \mathrm{~d} / \mathrm{e}, \mathrm{cm}, \mathrm{cc}, \mathrm{Iv} / \mathrm{b} \tilde{\mathrm{n}} / \mathrm{M} . \mathrm{C}$. & 44,47 & 1 & $\mathrm{NI}$ \\
\hline $\mathbf{P}$ & $1 \mathrm{~d} / \mathrm{e}, \mathrm{cm}, \mathrm{cc}, \mathrm{Iv} / \mathrm{b} \tilde{\mathrm{n}} / \mathrm{M} . \mathrm{C}$. & 50,54 & 1 & $\mathrm{NI}$ \\
\hline $\mathbf{Q}$ & $1 \mathrm{~d} / \mathrm{e}, \mathrm{cm}, \mathrm{cc}, \mathrm{Iv} / \mathrm{bn \tilde {n }} / \mathrm{bc}$ & 50,58 & 5 & $\mathrm{NI}$ \\
\hline
\end{tabular}




\begin{tabular}{|c|c|c|c|c|}
\hline $\mathbf{R}$ & $2 \mathrm{~d} / \mathrm{e}, \mathrm{cm}, \mathrm{cc}, \mathrm{Iv} / \mathrm{bn \tilde {h }} / \mathrm{bc}$ & 51,66 & 1 & $\mathrm{NI}$ \\
\hline $\mathbf{S}$ & $2 \mathrm{~d} / \mathrm{e}, \mathrm{cm}, \mathrm{cc}, \mathrm{Iv} / \mathrm{bn} / \mathrm{bc}$ & 55,24 & 4 & $\mathrm{NI}$ \\
\hline $\mathbf{T}$ & $2 \mathrm{~d} / \mathrm{e}, \mathrm{cm}, \mathrm{cc}, \mathrm{Iv} / \mathrm{bn} / \mathrm{bc}$ & 55,62 & 18 & $\mathrm{NI}$ \\
\hline $\mathbf{U}$ & $2 \mathrm{~d} / \mathrm{e}, \mathrm{cm}, \mathrm{cc}, \mathrm{Iv} / \mathrm{bn} / \mathrm{bc}$ & 55,66 & 17 & $\mathrm{NI}$ \\
\hline $\mathbf{v}$ & $2 \mathrm{~d} / \mathrm{e}, \mathrm{cm}, \mathrm{cc}, \mathrm{Iv} / \mathrm{b} \tilde{\mathrm{n}} / \mathrm{M} . \mathrm{C}$. & 55,83 & 1 & $\mathrm{NI}$ \\
\hline w & $2 \mathrm{~d} / \mathrm{e}, \mathrm{cm}, \mathrm{cc}, \mathrm{Iv} / \mathrm{b} \tilde{\mathrm{b}} / \mathrm{M} . \mathrm{C}$. & 55,85 & 1 & $\mathrm{NI}$ \\
\hline$x$ & $2 \mathrm{~d} / \mathrm{e}, \mathrm{cm}, \mathrm{cc}, \mathrm{Iv} / \mathrm{bn} / \mathrm{bc}$ & 55,85 & 4 & $\mathrm{NI}$ \\
\hline $\mathbf{Y}$ & $2 \mathrm{~d} / \mathrm{e}, \mathrm{cm}, \mathrm{cc}, \mathrm{Iv} / \mathrm{bñ} / \mathrm{bc}$ & 55,87 & 5 & $\mathrm{NI}$ \\
\hline $\mathbf{z}$ & $2 \mathrm{~d} / \mathrm{e}, \mathrm{cm}, \mathrm{cc}, \mathrm{Iv} / \mathrm{b} \tilde{\mathrm{n}} / \mathrm{M} . \mathrm{C}$. & 56,05 & 1 & $\mathrm{NI}$ \\
\hline $\mathrm{Z1}$ & $2 \mathrm{~d} / \mathrm{e}, \mathrm{cm}, \mathrm{cc}, \mathrm{Iv} / \mathrm{b} \tilde{\mathrm{n}} / \mathrm{bc}$ & 56,05 & 2 & $\mathrm{NI}$ \\
\hline $\mathbf{Z 2}$ & $2 \mathrm{~d} / \mathrm{e}, \mathrm{cm}, \mathrm{cc}, \mathrm{Iv} / \mathrm{b} \tilde{\mathrm{n}} / \mathrm{bc}$ & 56,06 & 6 & $\mathrm{NI}$ \\
\hline $\mathbf{Z 3}$ & $2 \mathrm{~d} / \mathrm{e}, \mathrm{cm}, \mathrm{cc}, \mathrm{Iv} / \mathrm{bñ} / \mathrm{bc}$ & 63,65 & 1 & $\mathrm{NI}$ \\
\hline $\mathbf{Z 4}$ & $2 \mathrm{~d} / \mathrm{e}, \mathrm{cm}, \mathrm{cc}, \mathrm{Iv} / \mathrm{bñ} / \mathrm{bc}$ & 63,83 & 1 & $\mathrm{NI}$ \\
\hline $\mathbf{Z 5}$ & $3 \mathrm{~d} / \mathrm{e}, \mathrm{cm}, \mathrm{cc}, \mathrm{Iv} / \mathrm{bñ} / \mathrm{bc}$ & 75,17 & 4 & $\mathrm{NI}$ \\
\hline $\mathbf{Z 6}$ & $3 \mathrm{~d} / \mathrm{e}, \mathrm{cm}, \mathrm{cc}, \mathrm{Iv} / \mathrm{b} \tilde{n} / \mathrm{bc}$ & 75,35 & 4 & $\mathrm{NI}$ \\
\hline Tot. & - & 6474,65 & 125 & $62644387,00^{* 1}$ \\
\hline
\end{tabular}

Fuente: adaptación a partir de la compilación de datos obtenidos en las plantas arquitectónicas del Complejo Luzuriaga (2017).

Leyenda: d (dormitorio); e (sala de estar); cm (comedoro); cc (cocina); IV (lavadora); bñ (baños); bc (balcón); M. C. (Muro Común); NI: No Informado.

${ }^{* 1} \$$ (Peso argentino) en valores de enero de 2015 , dos meses antes de la inauguración del Proyecto.

\subsection{4 - Complejo Padre Mugica (Villa Lugano)}

El Complejo Padre Mugica fue implantado en un predio de aproximadamente $66.500 \mathrm{~m}^{2}$ entre la avenida Castañares, la avenida General Paz y las vías del F.N.G.B (ver Figura 4.17), y consta de 5 pisos, además la planta baja, con ascensor. De la suma total de familias beneficiadas, 540 provenían de otros barrios, lo que, dada la diversidad de origen, dificulta la convivencia colectiva: 340 provenientes de la Villa Cartón (módulos 4, 5, 6, 7, 8 y 9 - Ley 1987), 120 de la Villa 21/24 (60 en módulo 2 y 60 en el 10), 60 de Magaldi (en el módulo 3), 20 del Barrio INTA/Villa 17 (módulo 8) y del Barrio Bermejo. 
Figura 4.17 - Localización de la Comunidad Padre Mugica, CABA

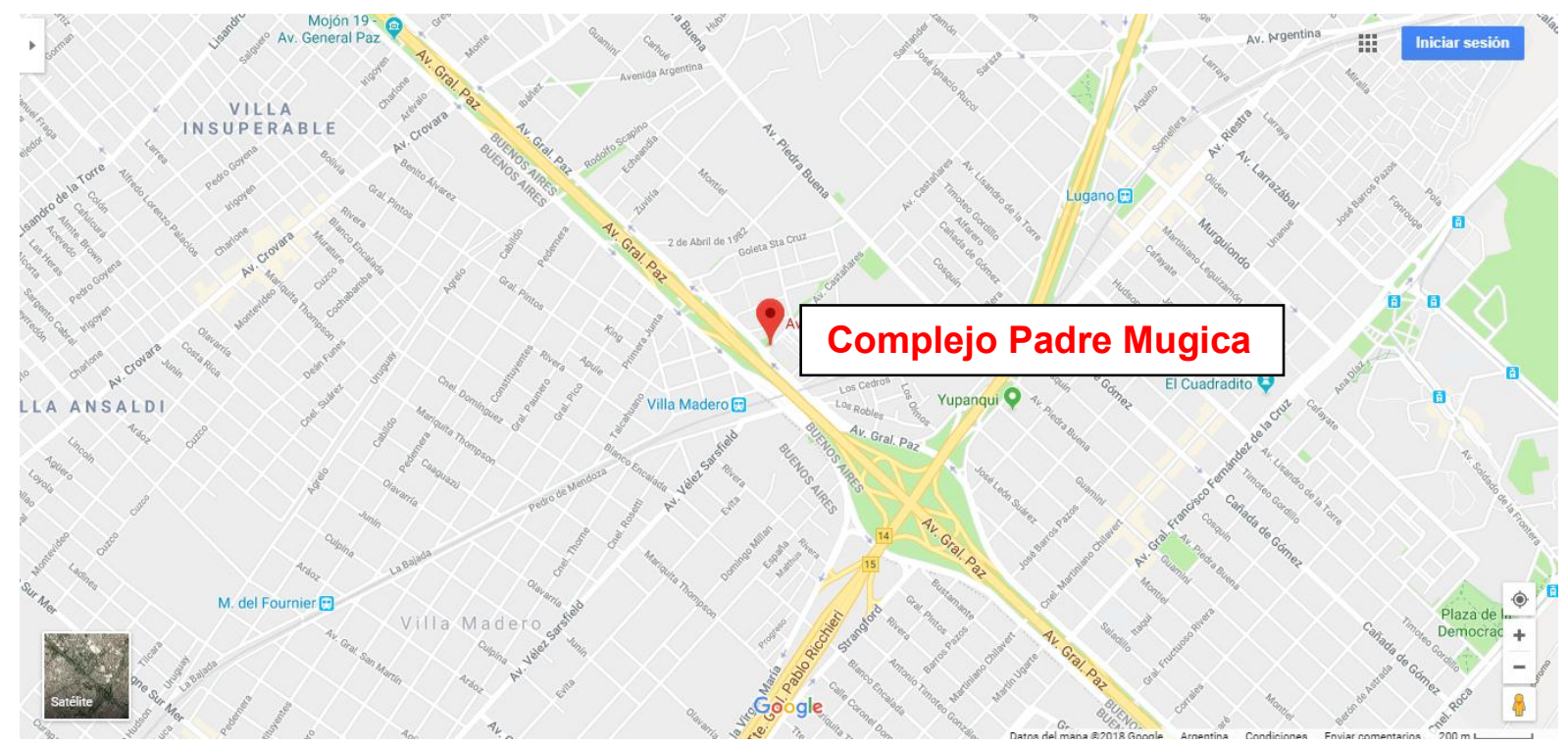

Fuente: Ramon Cotinguiba (2018) a partir de adaptación de GOOGLE Maps ([s/f]).

En la primera etapa se entregaron cinco módulos de 60 habitaciones cada uno en la avenida Castañares al 6.800, esquina General Paz. Las viviendas cuentan con 3 y 4 dormitorios y están equipadas con cocina, termotanque, mobiliario, calefacción, bajo mesada, baño completo con bañera y artefactos de iluminación, aunque algunos módulos carecieron de terminaciones. Algo que generalmente se critica en este tipo de proyecto arquitectónico, al igual que en Brasil, es que el diseño seriado, repetitivo y homogéneo no refleja la complejidad de los modos de habitar y disminuye las posibilidades de adaptación al nuevo contexto urbano, es decir, una relación nula con el contexto, mala disposición de los bloques de vivienda, indefinición del espacio común, programa urbano homogéneo -solo viviendas sin usos comunitarios, comercios y estructuras-, contrariamente a lo que se recomienda últimamente en ámbito internacional como prácticas recomendables para VIS. Con relación al aspecto constructivo, se observa que el sistema racionalizado denominado Emmedue (M2) de la empresa italiana Cassaforma conllevó graves fallas en el proceso de ejecución por la mala capacitación de la mano de obra y fallas en los controles, por lo que los edificios presentan vicios ocultos de construcción y varias filtraciones que aparecieron aún antes de que las obras concluyeran.

Al contrario de lo que ocurrió en el Complejo Luzuriaga, la adjudicación de viviendas IVC tuvo problemas durante los trámites burocráticos: a pesar de haber 
entregados los boletos de compra y venta hasta la fecha ningún departamento se escrituró por diversas razones, como por ejemplo la falta de final de obra, así como de los planes de subdivisión parcelaria, además del tema jurídico relacionado a la propiedad horizontal colectiva. Sin embargo, uno de los problemas más preocupantes ocurrió por la gestión mixta Nación-CABA y la ejecución a través de la institución Sueños Compartidos, pues hubo fallas en la coordinación del proyecto y falta de controles cruzados, según se cuestiona, con la participación de Fundación Madres de Plaza de Mayo. Desafortunadamente, desde el 2010, existe una causa judicial por desvío de fondos en la que están imputados exfuncionarios públicos y miembros de esta fundación. Recientemente el gobierno de la CABA, a través del IVC, hizo un llamado a licitación pública por el valor de \$142.403.676 para reparaciones debido a los "vicios de construcción" según Pura Ciudad - Buenos Aires Noticias (2018).

Las unidades habitacionales del Complejo Padre Mugica forman parte de un plano de 780 viviendas con un costo originalmente calculado en $\$ 152$ millones pero que actualmente llega a los \$ 193 millones, iniciado en 2008. La presidente Cristina Fernández entregó el 10 de febrero de 2011 las primeras 300 viviendas construidas con aportes del Gobierno Nacional a través de la Fundación Madres Plaza de Mayo, cuya política habitacional prevé más de 800 mil nuevos hogares en todo el país (ver Figura 4.18). En la ocasión estuvo acompañada por Hebe Bonafini, titular de la asociación Madres de Plaza de Mayo, y ministros del Poder Ejecutivo.

Figura 4.18 - Complejo Padre Mugica, CABA

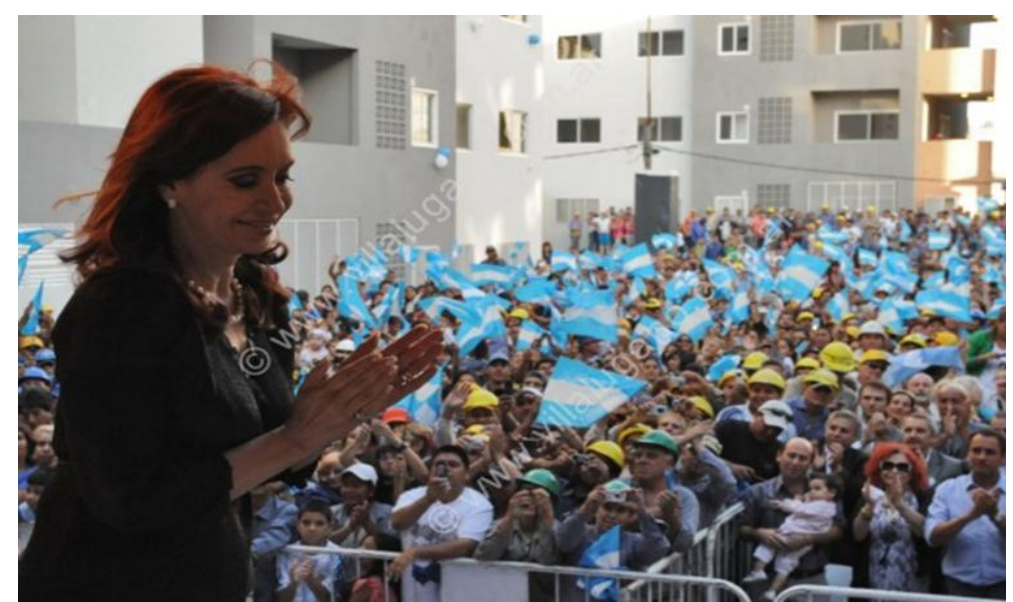

Fuente: Pura Ciudad - Buenos Aires Noticias (2018). 


\section{3 - CONCLUSIONES}

Llama la atención la diferencia en la calidad del estándar de los proyectos arquitectónicos, tanto en su elaboración como en su ejecución, implementados en Argentina y Brasil a mediados del siglo pasado, como en el caso de El Barrio de Los Andes, en Buenos Aires, de Fermín Bereterbide y del Conjunto Pedregulho, en Rio de Janeiro, de Affonso Eduardo Reidy, si comparados entre muchos de los proyectos de VIS implementados actualmente en ambos países.

En Brasil hay aún mucho que avanzar en las evaluaciones de todas las etapas del proceso de construcción de VIS, teniendo en cuenta la recurrencia que se constata, aún en los días de hoy, de reclamos de moradores por causa de atrasos de obra, exceso de burocracia -demora en la regularización del lote/titularidad del inmueble-, materiales de baja calidad, pisos de las habitaciones con el contra piso y sin revestimiento definitivo y ruidos transmitidos a través de los cerramientos laterales de albañilería entre departamentos vecinos. Éstas fueron las primeras quejas de los moradores registradas en las encuestas de EPO utilizadas para esta tesis. Teniendo en cuenta lo que históricamente ocurre en el seguimiento del servicio público en Brasil, en especial cuando se trata de políticas públicas de VIS, es indudable que hay muchas cosas incumplidas que hacer todavía, y por mejorar también, aunque sólo se enfaticen los avances obtenidos en los años más recientes en este segmento. En el caso de Argentina, varias de estas quejas también fueron presentadas por los adquirentes de las VIS investigadas.

Un cuestionamiento muy antiguo pero que perdura cuando se trata del tema de VIS con tipología arquitectónica en altura multifamiliar se refiere a los problemas para atender a las familias más pobres, en particular a las de zona rural, de forma que éstas se sientan satisfechas con la vivienda, ya que el objetivo principal es poder disfrutar de un techo, con seguridad, dignidad, relativo confort, estética de "buen gusto" $y$, preferencialmente, de fácil acceso al trabajo y a la infraestructura pública. De modo general, estas personas conviven ya diariamente, sea en el trabajo e incluso en la residencia, en un centro urbano o en la periferia, y en muchos casos, en condiciones muy adversas, con la idea de una residencia multifamiliar; algo muy común en los grandes núcleos urbanos de este continente. Esta solución constructiva se vuelve cada vez más interesante, y de cierta forma más factible, entre otras ya diseminadas, una vez que es incuestionable que, principalmente en los grandes centros urbanos, la escasez de tierras hace prohibitivo el acceso a éstas 
por parte de los sectores de más bajos ingresos. La conveniencia para el erario, mediante la relación costo/beneficio, al adoptar dicha tipología arquitectónica en las políticas públicas de VIS en áreas infra estructuradas de grandes ciudades, además de una cada vez más progresiva "verticalización" autoconstructiva por parte de las poblaciones de más bajos ingresos, tiende a reforzar la viabilidad de estas políticas públicas a través de la solución constructiva defendida en esta tesis.

Estas premisas iniciales, que subsidiaran desde el comienzo la decisión de enfrentar el desafío de investigar, y comprobar, la fundamentación del objeto de esta tesis, fueron suficientemente verificadas bajo diferentes ángulos y niveles a través de los mencionados seis ejes privilegiados metodológicamente como guía de trabajo en la referida investigación: a) Proyecto arquitectónico, b) Presupuestario (costos), c) Suelo (terreno), d) Tecnológico, e) Gerenciamiento gubernamental (políticas públicas) y f) Legislación edilicia. Dichas verificaciones fueron constatadas a través de hartos registros bibliográficos, no sólo en el marco del período de este estudio 1937 a 2017-, sino anteriormente también, a través de relatos orales y escritos encuestas aplicadas- entre profesionales vinculados al tema, moradores y líderes de las comunidades consultadas. Se resalta que estos resultados fueron comprobados tanto en Argentina como en Brasil, aunque con diferencias de intensidad en algunos ítems de las encuestas.

En este contexto, se hace necesario que los equipos técnicos responsables de llevar adelante proyectos de esta naturaleza no pierdan de vista, además de los aspectos ya abordados, que las políticas públicas mantengan un tenor "sistémico", integrador, con tecnologías más adecuadas a las VIS, de bajo costo y practicidad en la ejecución/mantenimiento de la infraestructura, y que no solamente los aspectos técnicos sean trabajados en el más alto nivel, sino también los aspectos relacionados a las prácticas culturales de las comunidades involucradas, así como lo referente a sus relaciones de vecindad y a las inevitables inconveniencias surgidas en el proceso. $Y$, en ese sentido, es fundamental que se pueda dar mayor relieve en dichos proyectos de VIS al papel de los profesionales de la asistencia social, pedagogos y psicólogos sociales, pues, como se viene enfatizando en este trabajo, es fundamental la colaboración de los mismos en la tarea de minimizar conflictos entre y dentro de los grupos sociales de diferentes estratos, así como en la tarea de cualificar mejor el perfil de articulación de los moradores en las cuestiones que los involucran, en especial las vinculadas a la convivencia colectiva, desde el inicio mismo de la implementación de los proyectos de VIS, desde los primeros encuentros 
del sector social, de la institución pública responsable de los mismos, así como en el momento de la entrega de las viviendas, sin olvidar que al finalizar las obras sean respetadas las reglas decididas en asamblea sobre los criterios establecidos para las prioridades, como el número de componentes del núcleo familiar, y para los aspectos excepcionales, como la existencia de personas de edad avanzada en las familias o con algún tipo de discapacidad/enfermedad.

Una de las tareas de mayor importancia que también involucra a los profesionales del sector social está relacionada al aumento de la autoestima de los moradores que sufren diariamente discriminación, como en Argentina y Brasil, por ejemplo, a través de campañas mediáticas que los acusan de especulación inmobiliaria -tierras e inmuebles-, de pertenecer a grupos que fomentan actividades de narcotráfico, de xenofobia, de ser evasores fiscales por causa de los subsidios estatales recibidos, y que, de este modo, sufren también otro tipo de violencia, la segregación, que hace con que sean compelidos a vivir en pésimas condiciones en las áreas más inhóspitas e inseguras de la ciudad. Otra forma subrepticia de estos dos males sociales que las personas de baja renta enfrentan es que sean consideradas inaptas debido al bajo nivel de educación formal para que participen en las discusiones y decisiones de los proyectos de VIS junto con las autoridades y profesionales expertos en el tema. Hay registros de casos muy exitosos que contradicen este prejuicio. De hecho, no siempre es necesario partir de cero, al final, muchas de estas personas tienen un rico acervo en sus trayectorias de vida que no puede ser desconsiderado y que seguramente va a contribuir para el pleno éxito de dichos proyectos de VIS. Un ejemplo de esto se puede observar en el proyecto 27 de Abril/SINDOMÉSTICO que, de forma solidaria, viene promoviendo, en la posocupación, pequeñas e importantes soluciones para la mejoría de la rutina de habitabilidad de la nueva comunidad en que viven.

Al hablar de solidaridad entre moradores de comunidades de proyectos de VIS, es imperioso recordar el espíritu de cohesión entre los cooperativistas que, con organización y determinación, tuvieron competencia para seguir adelante en la implementación del Complejo Parque Patricios/Monteagudo, algo que, sin sombra de duda, hubiera sido probablemente inviable sin la existencia de una cooperativa, como lo fue la del MTL/CTA, al abrigo de la Ley 341/00, con innegable tenor de justicia social. En esta coyuntura, la Cooperativa del MTL/CTA no dejó de dar oportunidad en el cantero de obras a la fuerza laboral femenina, que fue cerca del $25 \%$ del total, ni de estimular el sueño de jóvenes aprendices, estudiantes de nivel 
medio, provenientes de familias de bajos ingresos, y que ejercían un oficio profesional.

También es fundamental que en los proyectos de VIS la burocracia sea reducida a fin de que las familias puedan ingresar con seguridad en sus inmuebles, ya con la posesión de titularidad, como por ejemplo sucedió en el Complejo Luzuriaga, algo que, desafortunadamente, no es común en estos casos, ni en Argentina ni en Brasil. Algo todavía común en estos dos países en el campo de las VIS es la desvinculación que existe entre los diversos sectores responsables de la elaboración y ejecución de los proyectos arquitectónicos y demás, generando ruido en la comunicación entre los sectores, lo que en la práctica significa atrasos, desperdicios, redundancias y, en fin, muchas molestias y frustraciones por el tiempo perdido y los varios perjuicios. Esto debe ser enfrentado con determinación y competencia por todos los sujetos involucrados en los proyectos para que se reduzcan los plazos de finalización de las obras y se abrevie la entrega de la morada.

En cuanto a los aspectos no exitosos de los proyectos arquitectónicos, es muy común la señalización de moradores y profesionales, tanto en Brasil como en Argentina, de vicios de construcción -fisuras/rajaduras, infiltraciones, desniveles en la fundación estructural del inmueble, etc.- y del uso de planta en serie, repetitiva, homogénea, sin tener en cuenta suficientemente las diferencias culturales de los moradores ni el diálogo con el contexto urbano donde están inseridas, desprovistas de identidad, falta de espacios comunes y ausencia de usos mixtos -comunitarios, residenciales y comerciales-, además de la implantación inadecuada de los bloques residenciales. Varias de estas críticas vienen siendo recurrentemente encontradas, por ejemplo, en la producción del PMCMV, del Gobierno Federal brasileño, y en el Complexo Padre Mugica, en el barrio de Villa Lugano, CABA.

Así, este Capítulo 4 trae la gran contribución de presentar las condiciones más generales de cada uno de los seis proyectos investigados y reitera las evidencias de situaciones prácticas de semejanzas y diferencias más importantes entre ambos países cuanto al uso de la tipología en cuestión, durante el espacio temporal de los ochenta años (1937/2017), según se propusiera en esta tesis.

En el Capítulo 5 se presentan más detalladamente no sólo estas evidencias prácticas sino también las quejas y sugerencias que expresaron los vecinos, los líderes comunitarios y los profesionales de las comunidades investigadas, tanto en Argentina como en Brasil, para que los futuros proyectos de VIS sean mejorados. 


\section{CAPÍTULO 5 \\ DESDE EL DESARROLLO DE LOS PROYECTOS Y HASTA LA EPO: ANÁLISIS DE LOS RESULTADOS.}

Más allá de lo investigado y volcado en los capítulos 1 a 4 se trabajó en este Capítulo 5 sobre las realidades presentes en las comunidades/proyectos, de manera de superar el aspecto teórico y académico, considerando a esto como una originalidad de esta tesis.

Como ya se anticipó en la Introducción, la investigación fue estructurada siguiendo seis ejes de trabajo: a) el proyecto arquitectónico; b) el presupuestario (costos); c) el suelo (terreno para la construcción); d) el tecnológico; e) el gerenciamiento gubernamental (políticas públicas); y f) la legislación edilicia. Se utilizaron los siguientes recursos metodológicos: bibliografía especializada y entrevistas sobre la cuestión urbana, en especial sobre las condiciones de habitabilidad de los sectores de bajos ingresos desde diferentes ópticas: histórica, política, cultural y socioeconómica, privilegiando principalmente autores oriundos de los países investigados y de trayectoria consolidada en relación con el tema abordado. Adicionalmente, fueron usadas obras literarias, material fílmico, documental, y programas de televisión. El recorte temporal adoptado ha sido el de los últimos 80 años (1937 - 2017) ya que fue a partir de entonces que por primera vez en Brasil el Estado tomara la decisión de producir a nivel nacional y a larga escala conjuntos habitacionales en altura -de 3 a 4 pisos, predominantemente, además de la planta baja- a través de los IAPs y de la FCP, para afrontar el problema de la falta de habitación de los sectores de más bajos ingresos.

Los datos obtenidos durante esta investigación provienen de seis estudios de caso comparados realizados en Brasil y Argentina a partir de seis proyectos, tres en Salvador y tres en la CABA, construidos mediante programas públicos de VIS con la tipología arquitectónica en altura. De éstos, uno fue implantado en la década pasada y los dos demás a inicio de ésta tanto en uno como otro país. Los estudios de caso consistieron en visitas de campo y entrevistas a moradores de las comunidades investigadas a través de la EPO:

En la CABA: excepto el Conjunto Parque Patricios/Monteagudo, donde fue posible el contacto con responsables por el liderazgo del MTL/CTA, así como con el estudio arquitectónico PfZ Arquitectos, que lo ha proyectado; el Complejo Luzuriaga y el Complejo Padre Mujica que, por la ya mencionada restricción legal de la CABA, 
locus principal de esta investigación en Argentina, poseen ascensores en el interior de sus estructuras.

En Salvador, de igual modo, se han hecho consultas a los moradores y a los profesionales del CONDER, responsable de la implementación de los tres proyectos habitacionales: Paraíso Azul/Recanto Feliz, 27 de Abril/SINDOMÉSTICO y Perseverança/Luiz Inácio Lula da Silva.

En las seis comunidades investigadas se han analizado y evaluado las unidades habitacionales mediante EPO a través de la aplicación de encuestas a los moradores, a los representantes comunitarios y a los profesionales -ingenieros, arquitectos, urbanistas, asistentes sociales y abogados- involucrados con el tema de la VIS, participantes directos o no de los proyectos analizados. También se han realizado entrevistas parcialmente estructuradas a algunos colaboradores de estos segmentos consultados en ambos países.

La Encuesta de Tipo 1 fue direccionada a los moradores de los proyectos; la Tipo 2 a los profesionales en general, involucrados o no a los mencionados proyectos; la Tipo 3 a los profesionales del área técnica -arquitectos, urbanistas e ingenieros- que participaron de los proyectos; la Tipo 4 al equipo de asistentes sociales participaron de los proyectos; las Tipo 5,6 y 7 a la coordinación del área técnica, de la administración jurídica y del equipo de asistentes sociales, respectivamente. Desafortunadamente, por motivos ya mencionados, las Tipo 5, 6 y 7 no fueron lo suficientemente respondidas por los profesionales responsables.

Con relación a los resultados obtenidos se hacen dos observaciones: la primera es que el gran volumen de información recabada fue obtenido directamente de los propios interesados -moradores y profesionales- y refleja sus percepciones y opiniones a partir de sus experiencias directas con los trámites relacionados al tema, la segunda observación deriva del mencionado volumen de información y refleja una gran carga de insatisfacción, no propiamente por causa de la tipología arquitectónica propuesta y sí debido a las inúmeras imperfecciones detectadas, ya sea por errores de los proyectos o durante su ejecución -vicios de construcción- tanto en Argentina como en Brasil, donde los moradores abundaron en críticas con relación a diferentes e importantes ítems de análisis. 


\section{1 - Metodología de la EPO}

En total, como se mencionó anteriormente, han sido elaboradas siete tipos de encuestas, tanto para Argentina como para Brasil, destinadas a los moradores de las comunidades de los proyectos estudiados y sus líderes comunitarios, así como a los profesionales que trabajan con la temática de VIS con la tipología arquitectónica en altura, habiendo participado o no en los referidos proyectos. La Encuesta de Tipo 1 fue respondida por 225 moradores en Argentina y 173 en Brasil. La Encuesta de Tipo 7 fue respondida por tres líderes comunitarios brasileños y un líder comunitario argentino. Las Encuestas de Tipo 2, 3, 4, 5 y 6 fueron respondidas por 23 profesionales brasileños: 6 arquitectos, 9 ingenieros, 4 asistentes sociales, 2 urbanistas, 1 pedagogo y 1 sociólogo, y 8 profesionales argentinos: 5 arquitectos, 1 abogado, 1 geógrafo y 1 asistente social.

Seis de los siete tipos de encuestas fueron elaboradas con el propósito de averiguar las percepciones de los encuestados, así como el grado de satisfacción de los mismos, en cuanto a principalmente aspectos cuali-cuantitativos del proceso y del producto como: número y dimensiones de las habitaciones de los departamentos, calidad de los materiales utilizados en las estructuras y revestimientos, además del desempeño, confort ambiental -soleamiento, frío, ventilación y luminosidad-, privacidad y reacción acústica, instalaciones hidrosanitarias y eléctricas intradomiciliarias, infraestructura -plaza, cancha deportiva-, servicios públicos -salud, escuela, guardería, seguridad, comercio y transportes-, todos asociados, también, a eventuales vicios de construcción. Además de éstos, fueron investigados, también, aspectos referentes a los plazos de las etapas de los proyectos, burocracia, situación de titularidad del lote y del inmueble construido y participación de las familias-objetivo, así como sobre la realidad sociodemográfica de las familias.

La EPO está constituida, entonces, por un conjunto de 7 tipos de encuestas:

- Encuesta Tipo 162: "Consuta a moradores de la Comunidad" (ver pág. 399 en DA). Dirigida a un porcentaje de moradores en función de la cantidad de

\footnotetext{
${ }^{62}$ Basado en lo que recomienda Ornstein (1992, p. 74-86), la cantidad prevista de aplicación de esta encuesta fue la siguiente: Recanto Feliz/Paraíso Azul: 78, Condomínio 27 de Abril: 50 y Perseverança: 50. Por motivos explicados más adelante no fue posible alcanzar las 50 encuestas sugeridas para la comunidad Perseverança, pero fue respetado el número mínimo de 30 encuestas recomendado. Con relación al porcentaje de encuestas aplicadas en las tres comunidades argentinas
} 
unidades componentes del proyecto. Posee 33 preguntas, 2 con subdivisión, incluyendo varios tópicos sobre la vivienda y su entorno. Fueron aplicadas en las tres comunidades brasileñas, al total, 173 encuestas y, en las tres argentinas, 225.

- Encuesta Tipo 2: "Consulta a profesionales que actúan con VIS" (ver pág. 403 en DA). Dirigida a profesionales que de alguna manera actúan (o actuaron recientemente) con proyecto, ejecución y fiscalización de obras de VIS que utilicen la tipología arquitectónica en altura. Aborda categorías estructurales del desarrollo de VIS, así como la percepción de aspectos favorables/avances e impeditivos/retrocesos de dicho desarrollo.

- Encuesta Tipo 3: "Sobre proyecto/ejecución de VIS (al equipo técnico: arquitectos, ingenieros, urbanistas...)" (ver pág. 405 en DA). Dirigida a quien actuó directamente en el sector técnico -arquitecto, ingeniero urbanista, abogado, administrador $u$ otro-, en al menos una de las seis comunidades-objetivo de esta investigación.

- Encueta Tipo 4: "Sobre proyecto/ejecución de VIS (al equipo de asistencia social)" (ver pág. 408 en DA). Dirigida a profesionales que actuaron directamente en el sector social -asistentes sociales, pedagogos, sociólogos-, en al menos una de las seis comunidades-objetivo de esta investigación.

- Encuesta Tipo 5: "Tópicos para la caracterización del Proyecto de las VIS" (ver pág. 412 en DA). Dirigida a profesionales responsables del gerenciamiento de cada uno de los proyectos, con el objetivo de obtener datos de identificación institucional y cuantitativos técnicos del proyecto como: plazos y costos previstos/ejecutados-, dimensiones, plantas arquitectónicas, planillas, informes, etc. En el caso de Brasil los tres proyectos fueron construidos bajo responsabilidad de CONDER. En Argentina, dos proyectos, el Conjunto Parque Patricios y el Complejo Luzuriaga, fueron construidos por el Instituto de Vivienda de la Ciudad, y el tercero, el Complejo Padre Mugica, por el Ministerio de la Vivienda del Gobierno Federal. Desafortunadamente no se obtuvo la información suficientemente satisfactoria esperada de ninguno de estos órganos responsables argentinos.

investigadas el atendimiento superó lo recomendado. La Encuesta Tipo 1 aplicada en Argentina tiene 1 pregunta más que la aplicada en Brasil, la $n^{\circ} 34$, debido a que la ley edilicia de la CABA obliga al uso de ascensor. 
- Encuesta Tipo 6: "Factores intervinientes en la cuestión de la tierra para VIS" (ver pág. 415 en DA). Dirigida al sector público responsable de esta parte operacional de los proyectos. En el caso de Brasil, el sector de tierra de CONDER, infelizmente, no cumplió las expectativas en cuanto a la provisión de informaciones al respecto de los tres proyectos investigados. Tampoco se tuvo éxito en Argentina.

- Encuesta Tipo 7: "Empadronamiento y atendimientos de familias en el Proyecto de VIS" (ver pág. 417 en DA). Dirigida a representantes comunitarios con vínculo de liderazgo entre los moradores de las comunidades investigadas y que actuaron también como tales frente a los órganos responsables de los proyectos.

A partir de los datos concernientes a la realidad constructiva brasileña y argentina, con base en las tres comunidades investigadas de Salvador y las tres comunidades de la CABA, se compararon sus realidades, similares bajo varios aspectos, en cuanto a sus dinámicas constructivas, y se identificaron los puntos fuertes y vulnerables de cada una bajo el punto de vista de los propios moradores de las viviendas producidas así como de los profesionales que actuaron o no en uno o más de los seis proyectos analizados.

Conviene recordar una vez más que por los motivos informados, ya sea en Brasil como en Argentina, el volumen de información recabada resultó un tanto menor al esperado.

Para esta investigación de campo a través de EPO del ambiente construido se adoptaron las recomendaciones estadísticas de la arquitecta brasileña Sheila Ornstein (1992, p. 69-113), tomándose como parámetros generales: el Nivel de Confianza (n) del 95,5\%, el Margen de Error (e) igual al 10\%, la "proporción de elementos con característica estudiada" (Hipótesis: p) igual al 50\%, lo que condiciona que el "complemento de p" (q) sea del 50\%. A partir de estos datos la autora presenta una "Tabla de muestras casuales simple" de la que se obtuvo el número de muestras (unidades de viviendas) investigadas con base en el universo cuantitativo total del parque inmobiliario construido, para cada una de las seis comunidades, tanto en Argentina como en Brasil.

En Brasil, la aplicación de las Encuestas de Tipo 1 en las tres comunidades elegidas ocurrió en el período comprendido entre enero de 2014 y septiembre de 2015: la primera comunidad investigada, desde enero hasta agosto de 2015, fue la de Paraíso Azul/Recanto Feliz, con 83 consultas, la segunda, la de 27 de 
Abril/SINDOMÉSTICO, con 51 consultas desde abril de 2014 hasta septiembre de 2015 y, por último, la de Perseverança, con 39 consultas, desde junio de 2014 hasta abril de 2015.

En general cada una de las 33 preguntas propuestas ofreció cinco opciones en orden creciente en una escala de menor a mayor: a) "ni un poco" / "no existe"; b) "muy poco"; c) "poco" / "tal vez"; d) "aceptable" / "regularmente" / "probablemente" / "mucho" y e) "muchísimo". En la Encuesta de Tipo 1 aplicada a los moradores argentinos hubo una pregunta más, la número 34 , en función de un tema específico de CABA, debido a que la Ley municipal de $\mathrm{N}^{\circ} 962$ del 5 de diciembre de 2002 obliga al uso de ascensor en cualquier edificio construido en la ciudad a partir de la entrada en vigor de la ley que tenga más de dos pisos además de la planta baja. Sin embargo, no se ha constatado una reacción suficientemente explicativa vinculada al tema sobre la fundamentación del propósito de esta ley.

Las tres comunidades argentinas fueron visitadas simultáneamente por el equipo de aplicadores compuesto por tres personas en prácticamente dos meses, entre mediados de junio y agosto de 2015.

Tanto en Argentina como en Brasil, una de las mayores dificultades enfrentadas por los aplicadores de las encuestas durante todo el período, desde el inicio, en especial en Brasil, en Salvador, fue una gran resistencia por parte de los moradores, que obstaculizaban, de cierta forma, la programación de los encuentros para la referida aplicación de las encuestas, lo que significó para el autor de esta tesis sucesivas idas y venidas, en las tres comunidades, a veces sin ningún éxito después de varios intentos. Dificultades también presentes, de cierta forma, por diferentes motivos, entre los profesionales consultados de los órganos responsables de la implantación de los proyectos y entre las constructoras ejecutantes de las obras de las viviendas. Dificultades que no estuvieron ausentes, en varios casos, durante la búsqueda de información en las instituciones públicas, más específicamente la estatal CONDER, la Secretaria de Saúde y a Secretaria de Infraestructura, ambas de la Prefeitura Municipal de Salvador, aunque hubo un gran empeño por parte de una limitada porción de profesionales de estos órganos públicos, que colaboraron en la concreción de esta tesis. 
5.2 - Análisis de los resultados de la Encuesta Tipo 1 en las comunidades de Salvador

Este tópico presenta esencialmente, basado en diversos cuadros y tablas, los resultados de las respuestas de los moradores y los líderes de las tres comunidades investigadas en Brasil, así como sus opiniones, generalidades, críticas y sugerencias al respecto de los proyectos, según lo propuesto en la Encuesta Tipo1.

5.2.1 - Perfil sociodemográfico de los moradores de las comunidades de Salvador

Ha sido construido un cuadro para cada una de las tres comunidades investigadas en Brasil, abordando los aspectos sociodemográficos -edad, género, nivel de escolaridad, ocupación profesional, cantidad de ocupantes de la morada, presupuesto mensual familiar-, tiempo de ocupación del inmueble, piso del departamento, disposición de vivir en construcción en altura y pretensión de deshacerse de la propiedad. Los datos se observan en los Cuadros 5.1, 5.2 y 5.3.

Cuadro 5.1 - Perfil sociodemográfico de la comunidad Paraíso Azul/Recanto Feliz

\begin{tabular}{|c|c|c|c|c|c|c|c|c|c|c|}
\hline It. & A & B & C & D & $\mathbf{E}$ & $\mathbf{F}$ & $\mathbf{G}$ & H (SM) & I & $\mathbf{J}$ \\
\hline 01 & $F$ & $\mathrm{Ni}$ & $\mathrm{Ni}$ & $\mathrm{Ni}$ & $\mathrm{Ni}$ & $\mathrm{Ni}$ & $\mathrm{Ni}$ & $\mathrm{Ni}$ & $d$ & $d$ \\
\hline 02 & $F$ & 36 & Fundamental 1 & $\mathrm{Ni}$ & 5 & $\mathrm{Ni}$ & $\mathrm{Ni}$ & $1,51 \mathrm{SM}$ & $d$ & $a$ \\
\hline 03 & $\mathrm{M}$ & $\mathrm{Ni}$ & Fundamental 1 & Albañil & 4 & $\mathrm{Ni}$ & $C$ & $\mathrm{Ni}$ & $\mathrm{e}$ & $\mathrm{b}$ \\
\hline 04 & $F$ & 53 & $\mathrm{Ni}$ & Ama de casa & 4 & $\mathrm{e}$ & $b$ & $\mathrm{Ni}$ & $\mathrm{d}$ & $a$ \\
\hline 05 & $F$ & 46 & Fundamental 1 & Vendedora & 5 & $\mathrm{e}$ & $d$ & $1,0 \mathrm{SM}$ & $d$ & $a$ \\
\hline & $F$ & $\mathrm{Ni}$ & $\mathrm{Ni}$ & $\mathrm{Ni}$ & 4 & $\mathrm{Ni}$ & $\mathrm{Ni}$ & $\mathrm{Ni}$ & $d$ & $a$ \\
\hline 07 & $F$ & 38 & $\mathrm{Ni}$ & Mucama & 4 & $\mathrm{e}$ & $C$ & $0,70 \mathrm{SM}$ & $\mathrm{d}$ & $a$ \\
\hline & $F$ & 53 & $\mathrm{Ni}$ & Ama de casa & 2 & $\mathrm{e}$ & $C$ & $\mathrm{Ni}$ & $\mathrm{d}$ & $d$ \\
\hline 09 & $F$ & 38 & Fundamental 1 & Mucama & 3 & $a$ & $d$ & $1,00 \mathrm{SM}$ & $\mathrm{d}$ & $a$ \\
\hline & $\mathrm{M}$ & 53 & Fundamental 1 & Electricista & 2 & $a$ & $d$ & $1,00 \mathrm{SM}$ & $d$ & $\mathrm{~b}$ \\
\hline 11 & $\mathrm{~F}$ & 32 & $\overline{\mathrm{Ni}}$ & $\mathrm{Ni}$ & $\mathrm{Ni}$ & $\mathrm{Ni}$ & $\mathrm{Ni}$ & $\mathrm{Ni}$ & $\mathrm{Ni}$ & $\mathrm{Ni}$ \\
\hline 12 & $\mathrm{Ni}$ & $\mathrm{Ni}$ & Tercer grado & $\mathrm{Ni}$ & 1 & $a$ & e & $1,15 \mathrm{SM}$ & $\mathrm{b}$ & $d$ \\
\hline 13 & $\mathrm{~F}$ & 36 & Secundario & Ama de casa & 3 & $a$ & $\mathrm{a}$ & $0,28 \mathrm{SM}$ & $d$ & $a$ \\
\hline 14 & $\mathrm{~F}$ & 50 & Fundamental & Limpieza & 2 & $a$ & e & $1,00 \mathrm{SM}$ & $d$ & $a$ \\
\hline & $\mathrm{M}$ & 68 & Fundamental & Limpieza & 2 & $a$ & $\mathrm{~b}$ & $1,00 \mathrm{SM}$ & $d$ & $a$ \\
\hline & $\mathrm{F}$ & 56 & Fundamental & Ama de casa & 3 & $a$ & $\mathrm{~b}$ & $1,00 \mathrm{SM}$ & $d$ & $\mathrm{~b}$ \\
\hline
\end{tabular}




\begin{tabular}{|c|c|c|c|c|c|c|c|c|c|c|}
\hline 17 & $\mathrm{~F}$ & 58 & Fundamental & Limpieza & 3 & $a$ & $\mathrm{~b}$ & $1,00 \mathrm{SM}$ & d & d \\
\hline 18 & $\mathrm{~F}$ & 48 & Analfabeto & Recicla basura & 5 & e & $\mathrm{C}$ & $1,00 \mathrm{SM}$ & $\mathrm{b}$ & $\mathrm{d}$ \\
\hline 19 & $\mathrm{~F}$ & 44 & Secundario & Desocupado & 4 & e & $\mathrm{C}$ & SR & d & a \\
\hline 20 & $\mathrm{~F}$ & 24 & Secundario & Estudiante & 3 & $a$ & $\mathrm{C}$ & SR & a & a \\
\hline 21 & $\mathrm{~F}$ & 30 & Secundario & Agente de negocio & 3 & $a$ & $d$ & $1,00 \mathrm{SM}$ & $\mathrm{C}$ & $a$ \\
\hline 22 & $\mathrm{~F}$ & 20 & Secundario & Ama de casa & 3 & $\mathrm{C}$ & $\mathrm{b}$ & $4,00 \mathrm{SM}$ & d & $\mathrm{C}$ \\
\hline 23 & $\mathrm{~F}$ & 52 & Fundamental 1 & Ama de casa & 3 & $\mathrm{C}$ & $a$ & $2,00 \mathrm{SM}$ & $\mathrm{d}$ & $\mathrm{e}$ \\
\hline 24 & $\mathrm{~F}$ & 44 & Fundamental 1 & Ayudante de camión & 5 & e & $a$ & $0,50 \mathrm{SM}$ & $\mathrm{e}$ & a \\
\hline 25 & $\mathrm{M}$ & 31 & Secundario & Seguridad & 2 & $d$ & $\mathrm{C}$ & $2,00 \mathrm{SM}$ & $\mathrm{b}$ & $a$ \\
\hline 26 & $\mathrm{~F}$ & 60 & Fundamental 1 & Mucama & 5 & $d$ & $\mathrm{C}$ & $1,00 \mathrm{SM}$ & d & a \\
\hline 27 & $\mathrm{~F}$ & 68 & Analfabeta & Ama de casa & 2 & $\mathrm{e}$ & $\mathrm{b}$ & SR & $\mathrm{d}$ & $a$ \\
\hline & $\mathrm{F}$ & 42 & Fundamental 1 & Mucama & 4 & $\mathrm{e}$ & $\mathrm{b}$ & $1,00 \mathrm{SM}$ & $\mathrm{a}$ & $a$ \\
\hline 29 & $\mathrm{~F}$ & 49 & $\mathrm{Ni}$ & Diarista (Mucama) & 2 & $a$ & $\mathrm{C}$ & $1,00 \mathrm{SM}$ & $\mathrm{d}$ & $\mathrm{C}$ \\
\hline & $\mathrm{F}$ & 22 & Universitario & Estudiante & 2 & $a$ & $a$ & $3,00 \mathrm{SM}$ & $\mathrm{d}$ & $\mathrm{b}$ \\
\hline & $\mathrm{F}$ & 42 & Fundamental 1 & Mucama & 4 & $\mathrm{e}$ & $\mathrm{b}$ & $1,00 \mathrm{SM}$ & $\bar{e}$ & $\bar{C}$ \\
\hline & $\mathrm{M}$ & 40 & Fundamental 1 & Tc. en informática & 4 & $\mathrm{e}$ & $a$ & $2,07 \mathrm{SM}$ & $\mathrm{d}$ & $\bar{a}$ \\
\hline & $\mathrm{M}$ & 36 & Fundamental 2 & Cocinero (pastel) & 3 & $\mathrm{e}$ & $a$ & $2,00 \mathrm{SM}$ & e & a \\
\hline 34 & $\mathrm{~F}$ & 60 & Secundario & Empleado públ/jubil & 3 & e & $a$ & $4,00 \mathrm{SM}$ & $\mathrm{d}$ & $\mathrm{C}$ \\
\hline 35 & $\mathrm{~F}$ & 49 & $\mathrm{Ni}$ & $\mathrm{Ni}$ & $\mathrm{Ni}$ & $\mathrm{e}$ & $a$ & $\mathrm{Ni}$ & $\mathrm{C}$ & a \\
\hline & $\mathrm{Ni}$ & $\mathrm{Ni}$ & $\mathrm{Ni}$ & $\mathrm{Ni}$ & $\mathrm{Ni}$ & $\mathrm{C}$ & $a$ & $\mathrm{Ni}$ & $\mathrm{d}$ & $\mathrm{e}$ \\
\hline & $\mathrm{Ni}$ & $\mathrm{Ni}$ & $\overline{\mathrm{Ni}}$ & $\mathrm{Ni}$ & $\mathrm{Ni}$ & $\mathrm{e}$ & $\mathrm{b}$ & $\overline{\mathrm{Ni}}$ & $\mathrm{d}$ & $\mathrm{a}$ \\
\hline & $\mathrm{Ni}$ & $\mathrm{Ni}$ & $\mathrm{Ni}$ & $\mathrm{Ni}$ & $\mathrm{Ni}$ & e & $\mathrm{b}$ & $\mathrm{Ni}$ & $\mathrm{C}$ & $\mathrm{ni}$ \\
\hline & $\mathrm{M}$ & 33 & $\mathrm{Ni}$ & Herrero (constr.civil) & 3 & $\mathrm{e}$ & $\mathrm{b}$ & $\mathrm{Ni}$ & C & $\mathrm{a}$ \\
\hline & $\mathrm{F}$ & 43 & Analfabeta & Mucama & 7 & e & $\mathrm{b}$ & SR & $\mathrm{d}$ & $\bar{a}$ \\
\hline & $\mathrm{M}$ & 38 & Fundamental 1 & Ate. de albañilería & 7 & $\mathrm{e}$ & $\mathrm{d}$ & $1,00 \mathrm{SM}$ & $\mathrm{b}$ & $\bar{a}$ \\
\hline & $\mathrm{F}$ & 22 & Secundario & Estudiante & 3 & $\mathrm{e}$ & $d$ & $1,00 \mathrm{SM}$ & $\mathrm{e}$ & $\mathrm{a}$ \\
\hline 43 & $\mathrm{~F}$ & 41 & Fundamental 1 & Mucama & 3 & $\mathrm{e}$ & $\mathrm{C}$ & $1,00 \mathrm{SM}$ & $\overline{\mathrm{e}}$ & a \\
\hline & $\mathrm{M}$ & 43 & Secundario & Adm. de condominio & 3 & e & $\mathrm{C}$ & $3,50 \mathrm{SM}$ & $\mathrm{d}$ & $\bar{a}$ \\
\hline 45 & $\mathrm{M}$ & 34 & Universitario & Administrador & 3 & $\mathrm{e}$ & $\mathrm{C}$ & $3,00 \mathrm{SM}$ & $\mathrm{d}$ & $\mathrm{C}$ \\
\hline & $\mathrm{F}$ & 35 & Secundario & Mucama & 2 & e & $\mathrm{d}$ & $1,50 \mathrm{SM}$ & $\mathrm{d}$ & $\bar{a}$ \\
\hline 47 & $\mathrm{~F}$ & 48 & Fundamental 1 & Mucama & 2 & $\mathrm{e}$ & $\mathrm{b}$ & $1,00 \mathrm{SM}$ & $a$ & $\mathrm{C}$ \\
\hline & $\mathrm{M}$ & 66 & Secundaria & Emplead. públ/jubil & 2 & e & $\mathrm{b}$ & $2,00 \mathrm{SM}$ & d & $\bar{a}$ \\
\hline 49 & $\mathrm{M}$ & 41 & Técnico (Secun.) & Albañil (Autónomo) & 3 & $\mathrm{e}$ & $\mathrm{a}$ & $4,50 S M$ & $\bar{d}$ & $\bar{a}$ \\
\hline 50 & $\mathrm{~F}$ & 31 & Secundario & Costurero & 3 & e & $\mathrm{b}$ & $2,50 \mathrm{SM}$ & $\bar{a}$ & $\mathrm{C}$ \\
\hline 51 & $\mathrm{~F}$ & 56 & Fundamental & Autónomo & 4 & $\mathrm{e}$ & $\mathrm{C}$ & $\overline{\mathrm{Ni}}$ & $\bar{d}$ & $\bar{e}$ \\
\hline 52 & $\mathrm{~F}$ & 38 & Fundamental & Ama de casa & 4 & e & $\mathrm{Ni}$ & 050SM & e & $\mathrm{C}$ \\
\hline 53 & $\mathrm{~F}$ & 26 & Secundario & Designer/depilador. & 2 & e & $\mathrm{C}$ & $2,00 \mathrm{SM}$ & $\mathrm{e}$ & a \\
\hline 54 & $\mathrm{~F}$ & 25 & Secundario & Estudiante & 8 & $\mathrm{e}$ & $\mathrm{b}$ & $1,00 S M$ & $d$ & $\mathrm{C}$ \\
\hline
\end{tabular}




\begin{tabular}{|c|c|c|c|c|c|c|c|c|c|c|}
\hline 55 & - & - & DESCARTADO & DESCARTADO & - & - & - & - & - & - \\
\hline 56 & $\mathrm{~F}$ & 32 & Universitario & Estudiante & 3 & $\mathrm{e}$ & $\mathrm{C}$ & $2,50 \mathrm{SM}$ & $\mathrm{d}$ & $\mathrm{e}$ \\
\hline 57 & $\mathrm{M}$ & 39 & Fundamental & Celador (de edificio) & 5 & $\mathrm{e}$ & $\mathrm{d}$ & $1,00 S M$ & $\mathrm{~d}$ & $\mathrm{a}$ \\
\hline 58 & $\mathrm{~F}$ & 45 & Fundamental & Diarista & 5 & $\mathrm{e}$ & $\mathrm{C}$ & $2,50 \mathrm{SM}$ & $d$ & $\mathrm{a}$ \\
\hline 59 & $\mathrm{~F}$ & 26 & Fundamental 1 & Mucama & 6 & $a$ & $a$ & $1,00 \mathrm{SM}$ & $\mathrm{C}$ & $a$ \\
\hline 60 & $\mathrm{~F}$ & 41 & Fundamental 1 & Diarista & 6 & $\mathrm{e}$ & $\mathrm{b}$ & $1,00 \mathrm{SM}$ & $d$ & $\mathrm{C}$ \\
\hline 61 & $\mathrm{~F}$ & 18 & Secundario & Estudiante & 3 & $\mathrm{e}$ & $\mathrm{b}$ & $1,00 \mathrm{SM}$ & $d$ & $\mathrm{e}$ \\
\hline 62 & $\mathrm{M}$ & 39 & Fundamental & Repartidor en moto & 4 & $\mathrm{e}$ & $\mathrm{C}$ & $1,00 \mathrm{SM}$ & $\mathrm{d}$ & $a$ \\
\hline 63 & $\mathrm{~F}$ & 26 & Secundario & Ama de casa & 5 & $\mathrm{e}$ & $a$ & $1,00 S M$ & $\mathrm{~d}$ & $a$ \\
\hline 64 & $\mathrm{~F}$ & 35 & Secundario & Adm. de empresas & 2 & $\mathrm{C}$ & $a$ & $2,00 S M$ & $\mathrm{~d}$ & $d$ \\
\hline 65 & $\mathrm{~F}$ & 28 & Tercer grado & Pedagoga & 2 & $\mathrm{a}$ & $\mathrm{b}$ & $3,0 \mathrm{SM}$ & $d$ & $\mathrm{e}$ \\
\hline 66 & $\mathrm{~F}$ & 49 & Fundamental 2 & Mucama & 3 & $\mathrm{e}$ & $\mathrm{b}$ & $2,50 \mathrm{SM}$ & $\mathrm{a}$ & $a$ \\
\hline 67 & $\mathrm{M}$ & 20 & Secundario & Estudiante & 4 & $\mathrm{e}$ & $\mathrm{c}$ & $2,0 \mathrm{SM}$ & $\mathrm{d}$ & C \\
\hline 68 & $\mathrm{~F}$ & 19 & Secundario & Aux. administrativo & 4 & $\mathrm{e}$ & $\mathrm{C}$ & $1,00 \mathrm{SM}$ & $d$ & $a$ \\
\hline 69 & $\mathrm{M}$ & 82 & Fundamental 1 & Chofer/celador & 3 & $a$ & $\mathrm{C}$ & $3,50 \mathrm{SM}$ & $d$ & $\mathrm{C}$ \\
\hline 70 & $\mathrm{M}$ & 35 & Fundamental 1 & Casero & 3 & $\mathrm{a}$ & $\mathrm{d}$ & $0,50 \mathrm{SM}$ & $\mathrm{e}$ & $a$ \\
\hline 71 & $\mathrm{~F}$ & 53 & Fundamental 1 & Mucama & 3 & $a$ & $d$ & $0,50 \mathrm{SM}$ & $\mathrm{e}$ & $a$ \\
\hline 72 & $\mathrm{~F}$ & 59 & Fundamental 2 & Mucama & 2 & $a$ & $d$ & $1,00 \mathrm{SM}$ & $d$ & $a$ \\
\hline 73 & $\mathrm{M}$ & 42 & Fundamental 1 & Autónomo & 4 & $a$ & $\mathrm{~b}$ & $1,00 \mathrm{SM}$ & $\mathrm{e}$ & $\mathrm{C}$ \\
\hline 74 & $\mathrm{~F}$ & 52 & Fundamental 1 & Mucama & 2 & $\mathrm{a}$ & $\mathrm{d}$ & $1,00 \mathrm{SM}$ & $\mathrm{e}$ & $a$ \\
\hline 75 & $\mathrm{~F}$ & 38 & Fundamental 1 & Mucama & 2 & $a$ & $\mathrm{~b}$ & $1,00 S M$ & $\mathrm{e}$ & $a$ \\
\hline 76 & $\mathrm{~F}$ & 35 & Secundario & Diarista & 2 & $a$ & $a$ & $\mathrm{Ni}$ & $\mathrm{b}$ & $a$ \\
\hline 77 & $\mathrm{M}$ & 33 & Secundario & Celador & 2 & $a$ & $\mathrm{~b}$ & $1,50 \mathrm{SM}$ & $\mathrm{e}$ & $a$ \\
\hline 78 & $\mathrm{M}$ & 76 & Tercer Grado & Médico Veterinario & 3 & $\mathrm{a}$ & $\mathrm{b}$ & $\mathrm{Ni}$ & $\mathrm{d}$ & $\mathrm{C}$ \\
\hline 79 & $\mathrm{M}$ & 29 & Secundario & Ate. de Albañilería & 3 & $\mathrm{a}$ & $\mathrm{b}$ & $2,00 \mathrm{SM}$ & $\mathrm{e}$ & $\mathrm{b}$ \\
\hline 80 & $\mathrm{M}$ & 41 & Fundamental 1 & Albañil & 3 & $a$ & $\mathrm{e}$ & $1,00 \mathrm{SM}$ & $\mathrm{e}$ & $a$ \\
\hline 81 & $\mathrm{M}$ & 26 & Fundamental 1 & Sirviente & 3 & $d$ & $\mathrm{~b}$ & $1,00 \mathrm{SM}$ & C & $a$ \\
\hline 82 & $\bar{M}$ & 52 & Secundario & Albañil & 4 & $\mathrm{e}$ & $\mathrm{b}$ & $\mathrm{Ni}$ & $d$ & $a$ \\
\hline 83 & $\mathrm{M}$ & 39 & Secundario & Portero & 2 & $\mathrm{C}$ & $d$ & $\mathrm{Ni}$ & $d$ & $\mathrm{a}$ \\
\hline 84 & $\mathrm{M}$ & 49 & Fundamental 2 & Carpintero & 4 & $d$ & $\mathrm{C}$ & $\mathrm{Ni}$ & C & $a$ \\
\hline
\end{tabular}

Fecha: julio de 2017. Legenda: It.: Ítem, A: Sexo (M: Masculino, F: Femenino), B: Edad, C: Grado de escolaridad. Se aclara que, a título de mejorar la comprensión y facilitar la comparación, se usó la designación de Enseñanza de Brasil, donde el Nivel Fundamental, lo cual corresponde al Primario en Argentina, es subdividido en el Fundamental 1, comprendiendo del $1^{\mathrm{er}}$ al $5^{\text {to }}$ año, y el Fundamental 2 (del $6^{\text {to }}$ al $9^{\circ}$ año). El Nivel Medio, en Brasil, regularmente posee 3 años (ó 4, en algunos casos, si es de formación técnica) y equivale al Secundario, de Argentina. D: Ocupación profesional, E: Cantidad de ocupante(s) en la habitación, F: Tiempo en años en que vive en la vivienda (a: +- 1 año, b: +- 2 años, c: +- 3 años, d: +- 4 años, e: +- 5 años o más), G: Piso en que la vivienda se ubica (a: planta baja, b: $1^{\text {er }}$ piso, c: $2^{\circ}$ piso, d: $3^{\text {er }}$ piso, e: $4^{\circ}$ piso, $e^{*}$ : $5^{\circ}$ piso o piso más arriba), $\mathrm{H}$ : Presupuesto mensual familiar (SM en Brasil), I: Satisfacción de vivir en edificio en altura (a: definitivamente no, b: muy poco, c: poco, d: 
mucho, e: muchísimo), J: Pretensión de alquilar/vender la vivienda (a: definitivamente no, b: muy poco, c: tal vez, d: probablemente, e: sí, Ni: No Informado, SR: Sin Rendimiento. Observaciones: El SM en Brasil desde el 1 de enero al 31 de diciembre de 2014 ha sido de $R \$ 724,00$, equivalente a $\$ 2.411,73$ (Peso argentino) y a U\$ 282,80 (Dólar de EEUU) según cambio de 28 nov. 2014 conforme BANCO CENTRAL DO BRASIL ([S/f]).

Cuadro 5.2 - Perfil sociodemográfico de la comunidad 27 DE Abril/SINDOMÉSTICO

\begin{tabular}{|c|c|c|c|c|c|c|c|c|c|c|}
\hline Ít. & A & B & C & D & $\mathbf{E}$ & $\mathbf{F}$ & G & H (SM) & I & $\mathbf{J}$ \\
\hline 01 & $\mathrm{~F}$ & 42 & Fundamental & Mucama & 3 & $\mathrm{~b}$ & $\mathrm{e}$ & 0,5 & d & a \\
\hline 02 & $\mathrm{~F}$ & 62 & Medio (incompleto) & Mucama & 3 & a & $\mathrm{b}$ & 1,0 & d & a \\
\hline 03 & $\mathrm{~F}$ & 55 & Medio & Mucama & 3 & $\mathrm{~b}$ & $\mathrm{~d}$ & 2,0 & $\bar{d}$ & $\bar{a}$ \\
\hline 04 & $\mathrm{~F}$ & 55 & No informado & Mucama & 2 & $\mathrm{~b}$ & $\mathrm{~b}$ & 1,0 & $\bar{d}$ & $\bar{a}$ \\
\hline 05 & $\mathrm{~F}$ & 30 & Medio & Asis. de soporte & 3 & $\mathrm{~b}$ & $\mathrm{~d}$ & 2,0 & $\bar{d}$ & $\bar{a}$ \\
\hline 06 & $\mathrm{~F}$ & 32 & Fundamental & Mucama & 3 & $\mathrm{~b}$ & $d$ & 1,0 & $\mathrm{~d}$ & $\bar{a}$ \\
\hline 07 & $\mathrm{~F}$ & 43 & No informado & Limpieza & 7 & $a$ & $a$ & 1,0 & $\mathrm{~d}$ & $\bar{a}$ \\
\hline 08 & $\mathrm{~F}$ & 56 & Fundamental 2 & Mucama & 4 & $\mathrm{~b}$ & $a$ & 1,0 & $\overline{\mathrm{e}}$ & $\bar{a}$ \\
\hline 09 & $\mathrm{~F}$ & 52 & Medio (incompleto) & Mucama & 2 & $\mathrm{~b}$ & $\mathrm{~b}$ & 1,5 & $\mathrm{e}$ & $\bar{a}$ \\
\hline 10 & $\mathrm{~F}$ & 46 & Medio (incompleto) & Mucama & 3 & $\mathrm{~b}$ & $\mathrm{C}$ & 1,0 & $\mathrm{e}$ & $\mathrm{b}$ \\
\hline 11 & $\mathrm{~F}$ & 63 & No informado & No informado & 2 & $a$ & $a$ & $\mathrm{Ni}$ & $\mathrm{e}$ & $\bar{a}$ \\
\hline 12 & $\bar{M}$ & 25 & No informado & No informado & $\mathrm{Ni}$ & $\mathrm{b}$ & $\mathrm{d}$ & $\mathrm{Ni}$ & $\bar{c}$ & $\bar{a}$ \\
\hline 13 & $\mathrm{~F}$ & 56 & Fundamental 1 & Mucama & 2 & $\mathrm{~b}$ & $a$ & 2,2 & $\mathrm{~d}$ & $a$ \\
\hline 14 & $\mathrm{~F}$ & 48 & Fundamental 1 & Mucama & 3 & $\mathrm{~b}$ & $d$ & 1,0 & $\bar{d}$ & $a$ \\
\hline 15 & $\mathrm{~F}$ & 54 & Fundamental & Mucama & 2 & $a$ & $a$ & 2,0 & $\bar{a}$ & $\bar{a}$ \\
\hline 16 & $\mathrm{~F}$ & 40 & Fundamental & Peluquera/Mucama & 2 & $\mathrm{~b}$ & $\mathrm{~b}$ & 0,6 & $\mathrm{~d}$ & $a$ \\
\hline 17 & $\mathrm{~F}$ & 57 & Fundamental 1 & Mucama & 2 & $\mathrm{~b}$ & $\mathrm{~b}$ & 1,0 & $\bar{d}$ & $\bar{a}$ \\
\hline 18 & $\mathrm{~F}$ & 47 & Fundamental 2 & Mucama & 2 & $a$ & $\mathrm{C}$ & 1,0 & $\mathrm{~d}$ & $a$ \\
\hline 19 & $\mathrm{~F}$ & 39 & No informado & Mucama & 5 & $\mathrm{~b}$ & $\mathrm{a}$ & 1,0 & $\bar{d}$ & $\bar{C}$ \\
\hline 20 & $\mathrm{~F}$ & 45 & Medio & Mucama & 1 & a & $\mathrm{C}$ & 1,0 & $\mathrm{~d}$ & a \\
\hline 21 & $\mathrm{~F}$ & 39 & Medio & Limpieza & 4 & $\mathrm{~b}$ & $\mathrm{e}$ & 1,0 & $\overline{\mathrm{e}}$ & $\bar{a}$ \\
\hline 22 & $\mathrm{~F}$ & $\mathrm{Ni}$ & Fundamental 1 & Ama de casa & 2 & $\mathrm{~b}$ & $d$ & $\mathrm{Ni}$ & $\mathrm{d}$ & a \\
\hline 23 & $\mathrm{~F}$ & 41 & Medio & Mucama & 4 & $\mathrm{~b}$ & $\mathrm{~b}$ & $\mathrm{Ni}$ & $\bar{d}$ & $\bar{a}$ \\
\hline 24 & $\mathrm{~F}$ & 32 & Medio & Ama de casa & 3 & $\mathrm{~b}$ & $\mathrm{~d}$ & $\mathrm{Ni}$ & $\mathrm{d}$ & a \\
\hline 25 & $\mathrm{~F}$ & 53 & Medio & Mucama & 1 & $\mathrm{~b}$ & $\mathrm{a}$ & 1,0 & $\mathrm{~d}$ & a \\
\hline 26 & $\mathrm{~F}$ & 49 & Fundamental 1 & Mucama & 2 & $a$ & $\mathrm{~d}$ & 1,0 & $\mathrm{e}$ & a \\
\hline 27 & - & - & DESCARTADO & DESCARTADO & - & - & - & - & - & - \\
\hline 28 & $\mathrm{~F}$ & 43 & Fundamental 1 & Mucama & 2 & $a$ & $\mathrm{~d}$ & 1,0 & $\mathrm{e}$ & $\bar{a}$ \\
\hline 29 & $\mathrm{~F}$ & 54 & Fundamental & Mucama & 1 & $a$ & $\mathrm{~b}$ & 1,0 & $\bar{d}$ & $\mathrm{C}$ \\
\hline 30 & $\mathrm{~F}$ & 31 & Medio (incompleto) & Manicura/Mucama & 4 & $a$ & $\mathrm{e}$ & 2,1 & $d$ & a \\
\hline
\end{tabular}




\begin{tabular}{|c|c|c|c|c|c|c|c|c|c|c|}
\hline 31 & $\mathrm{~F}$ & 28 & Medio & Tec. de enfermería & 1 & a & c & $\mathrm{Ni}$ & d & a \\
\hline 32 & $\mathrm{~F}$ & 31 & Medio & Mucama & 3 & $\mathrm{~b}$ & $\mathrm{~b}$ & 1,0 & $\mathrm{e}$ & $a$ \\
\hline 33 & $\mathrm{~F}$ & 56 & Fundamental 1 & Mucama & 1 & $\mathrm{~b}$ & $\mathrm{~b}$ & 1,0 & $\mathrm{e}$ & $\mathrm{a}$ \\
\hline 34 & $\mathrm{~F}$ & 55 & Medio & Mucama & 1 & $\mathrm{~b}$ & $\mathrm{~b}$ & 1,0 & $\mathrm{e}$ & C \\
\hline 35 & $\mathrm{~F}$ & 27 & Universitario & Operadora de caja & 3 & $a$ & C & 2,2 & $\mathrm{C}$ & a \\
\hline 36 & $\mathrm{~F}$ & 23 & Universitario & Estudiante & 3 & $\mathrm{~b}$ & $\mathrm{e}$ & 1,9 & $\mathrm{e}$ & a \\
\hline 37 & $\mathrm{~F}$ & 35 & Medio & Mucama & 2 & $\mathrm{~b}$ & C & 1,0 & $\mathrm{~d}$ & $a$ \\
\hline 38 & $\mathrm{~F}$ & 50 & Fundamental 1 & Mucama & 3 & $\mathrm{~b}$ & $a$ & 1,0 & $a$ & $\mathrm{~b}$ \\
\hline 39 & $\mathrm{~F}$ & 45 & Medio & Mucama & 6 & $a$ & c & 2,0 & $\mathrm{C}$ & a \\
\hline 40 & $F$ & 43 & Medio & Diarista & 3 & $a$ & $d$ & $\mathrm{Ni}$ & $d$ & $a$ \\
\hline 41 & $\mathrm{Ni}$ & 40 & Fundamental 2 & No informado & 2 & $\mathrm{~b}$ & $\mathrm{e}$ & 1,0 & $\mathrm{~d}$ & $a$ \\
\hline 42 & $\mathrm{~F}$ & 50 & Medio (incompleto) & Cocinera & 1 & $a$ & $\mathrm{~b}$ & 1,0 & $\mathrm{e}$ & 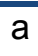 \\
\hline 43 & $\mathrm{~F}$ & 42 & No informado & Mucama & $\mathrm{Ni}$ & $a$ & $\mathrm{~b}$ & 1,0 & $\mathrm{~d}$ & $a$ \\
\hline 44 & $\mathrm{~F}$ & No & Medio & Secretaria & $\mathrm{Ni}$ & $a$ & $a$ & 1,0 & $\mathrm{e}$ & $a$ \\
\hline 45 & $\mathrm{~F}$ & 57 & Fundamental & Mucama & 2 & $\mathrm{~b}$ & C & 0,8 & $\mathrm{~d}$ & $\mathrm{~b}$ \\
\hline 46 & $\mathrm{~F}$ & 41 & Medio & Tec. Administrativo & 5 & $\mathrm{~b}$ & $\mathrm{~b}$ & 2,0 & $\mathrm{~d}$ & $a$ \\
\hline 47 & $\mathrm{~F}$ & 58 & Fundamental 1 & Mucama & 1 & $\mathrm{a}$ & $\mathrm{d}$ & SR & $\mathrm{d}$ & $a$ \\
\hline 48 & $\mathrm{~F}$ & 46 & Fundamental 2 & Mucama & 4 & $\mathrm{~b}$ & $\mathrm{~b}$ & 1,5 & $\mathrm{e}$ & a \\
\hline 49 & - & - & DESCARTADO & DESCARTADO & - & - & - & - & - & - \\
\hline 50 & $\mathrm{~F}$ & 32 & Universitario & Niñera/Mucama & 1 & $\mathrm{~b}$ & $d$ & 1,5 & $\mathrm{e}$ & $\bar{a}$ \\
\hline 51 & $\mathrm{~F}$ & 48 & Universitario & Adm. de empresa & 1 & $\mathrm{~b}$ & $a$ & 2,5 & $\mathrm{a}$ & $a$ \\
\hline 52 & $\mathrm{~F}$ & 46 & No informado & Mucama & 3 & $\mathrm{~b}$ & $\mathrm{e}$ & $\mathrm{Ni}$ & $\mathrm{e}$ & $\bar{a}$ \\
\hline 53 & $\mathrm{Ni}$ & $\mathrm{Ni}$ & $\mathrm{Ni}$ & $\mathrm{Ni}$ & $\mathrm{Ni}$ & $a$ & c & $\mathrm{Ni}$ & $\mathrm{d}$ & $\mathrm{a}$ \\
\hline
\end{tabular}

Fecha: julio de 2017. Legenda: It:: Ítem, A: Sexo (M: Masculino, F: Femenino), B: Edad, C: Grado de escolaridad, D: Ocupación profesional, E: Cantidad de ocupante(s) en la habitación, F: Tiempo en años en que vive en la vivienda (a: +- 1 año, b: +- 2 años, c: +- 3 años, d: +- 4 años, e: +- 5 años o más), G: Piso en que la vivienda se ubica (a: planta baja, b: $1^{\text {er }}$ piso, c: $2^{\circ}$ piso, d: $3^{\text {er }}$ piso, e: $4^{\circ}$ piso, $\mathrm{e}^{*}: 5^{\circ}$ piso o piso más arriba), $\mathrm{H}$ : Presupuesto mensual familiar (SM en Brasil), I: Satisfacción de vivir en edificio en altura (a: definitivamente no, b: muy poco, c: poco, d: mucho, e: muchísimo), J: Pretensión de alquilar/vender la vivienda (a: definitivamente no, b: muy poco, c: tal vez, d: probablemente, e: sí, Ni: No Informado, SR: Sin Rendimiento. Observaciones: EI SM en Brasil desde el 1 de enero al 31 de diciembre de 2014 ha sido de $R \$ 724,00$, equivalente a \$ 2.411,73 (Peso argentino) y a U\$ 282,80 (Dólar de EEUU) según cambio de 28 nov. 2014 conforme BANCO CENTRAL DO BRASIL ([s/f]). 
Cuadro 5.3 - Perfil sociodemográfico de la comunidad Luiz Inácio Lula da Silva/Perseverança

\begin{tabular}{|c|c|c|c|c|c|c|c|c|c|c|}
\hline It. & A & B & C & D & $\mathbf{E}$ & $\mathbf{F}$ & G & H (SM) & I & $J$ \\
\hline 01 & $\mathrm{M}$ & 51 & Medio & Sindicalista/pintor & 3 & $\mathrm{a}$ & $b$ & $1,50 \mathrm{SM}$ & $\mathrm{d}$ & $a$ \\
\hline 02 & $\mathrm{~F}$ & 50 & Medio & Atención & 2 & $a$ & C & $1,00 \mathrm{SM}$ & $b$ & $a$ \\
\hline 03 & $\mathrm{~F}$ & 40 & $\mathrm{Ni}$ & Sirvienta & 3 & $a$ & $d$ & $\mathrm{Ni}$ & $\mathrm{e}$ & $\mathrm{e}$ \\
\hline 04 & $\mathrm{M}$ & 35 & $\mathrm{Ni}$ & Pintor & 6 & a & $\mathrm{C}$ & $1,00 S M$ & $b$ & a \\
\hline 05 & $\mathrm{~F}$ & $\mathrm{Ni}$ & $\mathrm{Ni}$ & $\mathrm{Ni}$ & 3 & a & $\mathrm{C}$ & $\mathrm{Ni}$ & $d$ & a \\
\hline 06 & $\mathrm{~F}$ & 27 & $\mathrm{Ni}$ & Cuidadora & 4 & a & $\mathrm{e}$ & $1,00 S M$ & d & a \\
\hline 07 & $\mathrm{~F}$ & $\mathrm{Ni}$ & $\mathrm{Ni}$ & $\mathrm{Ni}$ & 3 & a & $\mathrm{e}$ & $\mathrm{Ni}$ & $d$ & a \\
\hline 08 & $\mathrm{M}$ & $\mathrm{Ni}$ & $\mathrm{Ni}$ & $\mathrm{Ni}$ & $\mathrm{Ni}$ & $a$ & $b$ & $\mathrm{Ni}$ & $\mathrm{e}$ & a \\
\hline 09 & $\mathrm{~F}$ & 21 & Medio & Vendedora & 2 & a & $\mathrm{C}$ & $1,50 \mathrm{SM}$ & $d$ & a \\
\hline 10 & $\mathrm{M}$ & 44 & Medio & Cocinero & 2 & $a$ & $\mathrm{C}$ & $2,00 S M$ & $d$ & a \\
\hline 11 & $\mathrm{~F}$ & 54 & Fundamental 2 & Autónomo/cocinero & 3 & $a$ & $a$ & $1,00 \mathrm{SM}$ & a & a \\
\hline 12 & $\mathrm{~F}$ & 23 & Universitario & Estudiante & 4 & $a$ & $a$ & $1,38 \mathrm{SM}$ & $d$ & $a$ \\
\hline 13 & $\mathrm{M}$ & 32 & Medio & Vendedor & 3 & $a$ & $\mathrm{C}$ & $1,66 \mathrm{SM}$ & $\mathrm{e}$ & a \\
\hline 14 & $\mathrm{~F}$ & 30 & Medio (incompleto) & Mucama & 3 & $a$ & $\mathrm{e}$ & $1,00 \mathrm{SM}$ & $\mathrm{e}$ & $d$ \\
\hline 15 & $\mathrm{~F}$ & 71 & Analfabeta & "Cajonera" (vended.) & 2 & $a$ & $a$ & $1,00 \mathrm{SM}$ & a & C \\
\hline 16 & $\mathrm{~F}$ & 55 & Fundamental (inic.) & Mucama & 3 & $a$ & $a$ & $<0,5 \mathrm{SM}$ & $a$ & $a$ \\
\hline 17 & $\mathrm{~F}$ & 28 & Tercer grado & Profesora/licenciada & 2 & $a$ & $\mathrm{C}$ & $\mathrm{Ni}$ & $d$ & a \\
\hline 18 & $F$ & 34 & Medio & Aux. administrativa & 5 & $a$ & $a$ & $1,00 \mathrm{SM}$ & $a$ & $a$ \\
\hline 19 & $\mathrm{M}$ & $\mathrm{Ni}$ & $\mathrm{Ni}$ & $\mathrm{Ni}$ & $\mathrm{Ni}$ & $a$ & $a$ & $\mathrm{Ni}$ & $a$ & $\mathrm{C}$ \\
\hline 20 & $\mathrm{M}$ & $\mathrm{Ni}$ & $\mathrm{Ni}$ & $\mathrm{Ni}$ & $\mathrm{Ni}$ & $a$ & $\mathrm{~d}$ & $\mathrm{Ni}$ & $d$ & $a$ \\
\hline 21 & $\mathrm{M}$ & $\mathrm{Ni}$ & $\mathrm{Ni}$ & $\mathrm{Ni}$ & $\mathrm{Ni}$ & $\mathrm{a}$ & $\mathrm{e}$ & $\mathrm{Ni}$ & $\mathrm{b}$ & $b$ \\
\hline 22 & $\mathrm{M}$ & $\mathrm{Ni}$ & $\mathrm{Ni}$ & $\mathrm{Ni}$ & $\mathrm{Ni}$ & $\mathrm{a}$ & $\mathrm{e}$ & $\mathrm{Ni}$ & $d$ & $\mathrm{a}$ \\
\hline 23 & $F$ & $\mathrm{Ni}$ & $\mathrm{Ni}$ & $\mathrm{Ni}$ & $\mathrm{Ni}$ & $\mathrm{a}$ & $\mathrm{e}$ & $\mathrm{Ni}$ & $d$ & $b$ \\
\hline 24 & $F$ & 36 & Fundamental 1 & Mucama & 6 & $\mathrm{a}$ & $\mathrm{e}$ & $1,00 \mathrm{SM}$ & $d$ & $a$ \\
\hline 25 & $\mathrm{~F}$ & 37 & Tercer grado & Secretaria & 5 & $a$ & $\mathrm{e}$ & $2,50 S M$ & $\mathrm{~d}$ & $\mathrm{a}$ \\
\hline 26 & $\mathrm{M}$ & 41 & Medio & Instalador hidráulico & 2 & $a$ & $\mathrm{C}$ & $2,00 \mathrm{SM}$ & $\mathrm{d}$ & $\bar{a}$ \\
\hline 27 & $\mathrm{~F}$ & 34 & Medio & Auxiliar administra. & 5 & $\mathrm{a}$ & $\mathrm{a}$ & $1,00 \mathrm{SM}$ & $d$ & $\bar{a}$ \\
\hline 28 & $\mathrm{M}$ & $\mathrm{Ni}$ & Fundamental 1 & Metalúrgico/desoc. & $\mathrm{Ni}$ & $a$ & $a$ & $\mathrm{Ni}$ & $d$ & $\bar{a}$ \\
\hline 29 & $\mathrm{M}$ & 21 & Universitario & Estudiante & 4 & $a$ & $\mathrm{e}$ & $2,00 \mathrm{SM}$ & $d$ & $\bar{a}$ \\
\hline 30 & $F$ & 60 & Fundamental 2 & Peluquera & 2 & $a$ & $\mathrm{~b}$ & $1,50 \mathrm{SM}$ & $d$ & $\bar{d}$ \\
\hline 31 & $\mathrm{~F}$ & 38 & Universitario & Ama de casa & 3 & $a$ & $\mathrm{C}$ & $1,00 \mathrm{SM}$ & $d$ & $\bar{a}$ \\
\hline 32 & $\mathrm{~F}$ & 55 & Medio & Ama de casa & 2 & $a$ & $\mathrm{~d}$ & $1,00 \mathrm{SM}$ & $\mathrm{e}$ & $\bar{a}$ \\
\hline 33 & $\mathrm{~F}$ & 42 & Medio & Vendedor/calzados & 2 & $\mathrm{a}$ & $\mathrm{d}$ & $1,00 S M$ & $\mathrm{e}$ & $\mathrm{a}$ \\
\hline 34 & $\mathrm{M}$ & 34 & Medio (inicio) & Vigilante & 2 & $a$ & $\mathrm{C}$ & $2,00 S M$ & $a$ & $\mathrm{e}$ \\
\hline
\end{tabular}




\begin{tabular}{|c|c|c|c|c|c|c|c|c|c|c|}
\hline 35 & $\mathrm{~F}$ & 66 & Analfabeta & Mucama & 1 & a & $b$ & $1,00 S M$ & $d$ & a \\
\hline 36 & $\mathrm{~F}$ & 35 & Medio & Cuidadora/anciano & 5 & $\mathrm{a}$ & $\mathrm{b}$ & $1,00 \mathrm{SM}$ & $\mathrm{d}$ & $a$ \\
\hline 37 & $\bar{F}$ & ‘50’ & Fundamental & Ama de casa & 3 & $\mathrm{a}$ & $\mathrm{b}$ & $\mathrm{Ni}$ & $\mathrm{e}$ & $a$ \\
\hline 38 & $\mathrm{~F}$ & 29 & Universitario & Ama de casa & 2 & $\mathrm{a}$ & $\mathrm{C}$ & $1,50 \mathrm{SM}$ & $\mathrm{d}$ & $\mathrm{b}$ \\
\hline 39 & $\bar{M}$ & 59 & Fundamental 1 & Chofer & 2 & $\mathrm{a}$ & $d$ & $1,50 S M$ & $d$ & $\mathrm{a}$ \\
\hline
\end{tabular}

Fecha: julio de 2017. Legenda: It.: Ítem, A: Sexo (M: Masculino, F: Femenino), B: Edad, C: Grado de escolaridad, D: Ocupación profesional, E: Cantidad de ocupante(s) en la habitación, F: Tiempo en años en que vive en la vivienda (a: +- 1 año, b: +- 2 años, c: +- 3 años, d: +- 4 años, e: +- 5 años o más), G: Piso en que la vivienda se ubica (a: planta baja, b: $1^{\mathrm{er}}$ piso, c: $2^{\circ}$ piso, d: $3^{\mathrm{er}}$ piso, e: $4^{\circ}$ piso, $\mathrm{e}^{*}: 5^{\circ}$ piso o piso más arriba), $\mathrm{H}$ : Presupuesto mensual familiar (SM en Brasil), I: Satisfacción de vivir en edificio en altura (a: definitivamente no, b: muy poco, c: poco, d: mucho, e: muchísimo), J: Pretensión de alquilar/vender la vivienda (a: definitivamente no, b: muy poco, c: tal vez, d: probablemente, e: sí, Ni: No Informado, SR: Sin Rendimiento. Observaciones: EI SM en Brasil desde el 1 de enero al 31 de diciembre de 2014 ha sido de $R \$ 724,00$, equivalente a $\$$ 2.411,73 (Peso argentino) y a U\$ 282,80 (Dólar de EEUU) según cambio de 28 nov. 2014 conforme BANCO CENTRAL DO BRASIL ([s/f]).

\subsection{2 - Respuestas de la Encuesta Tipo 1 de las comunidades de Salvador}

Las respuestas de la Encuesta Tipo 1 se presentan en dos tablas. En la Tabla 5.1 para cada interrogante se explicitan los cinco niveles de grado propuestos y las cantidades registradas se refieren al total de las 3 comunidades investigadas en Brasil. La Tabla 5.2 registra el total de las respuestas para cada interrogante según cada comunidad investigada. 
Tabla 5.1 - Respuestas de la Encuesta Tipo 1 de las 3 comunidades de Salvador (Paraíso Azul/Recanto Feliz; 27 de Abril/SINDOMÉSTICO y Perseverança)

\begin{tabular}{|c|c|c|c|c|c|c|}
\hline Preguntas (excepto las $1^{\mathrm{ra}}, 2^{\mathrm{nda}}, 3^{\mathrm{ra}}, 4^{\mathrm{ta}}, 13^{\mathrm{ra}}, 14^{\mathrm{ta}}$ y $15^{\mathrm{ta}}$ ) & $\begin{array}{c}\text { Total } \\
\text { (1) }\end{array}$ & A & B & C & D & $\mathbf{E}$ \\
\hline \multicolumn{7}{|l|}{ (1) Tiempo de morada } \\
\hline \multicolumn{7}{|l|}{ (2) Piso en que vive } \\
\hline \multicolumn{7}{|l|}{ (3) Cantidad de cuartos } \\
\hline \multicolumn{7}{|l|}{ (4) Área residencial } \\
\hline (5) Satisfacción en vivir en el edificio de hasta 5 pisos & 164 & 13 & 8 & 11 & 91 & 41 \\
\hline (6) Participación en el proyecto o construcción & 164 & 73 & 23 & 30 & 16 & 22 \\
\hline (7) La burocracia para entrega de las llaves & 164 & 24 & 21 & 25 & 41 & 53 \\
\hline (8) La cantidad de cuartos es suficiente & 164 & 9 & 14 & 25 & 81 & 35 \\
\hline (9) El tamaño de los cuartos es suficiente & 164 & 15 & 18 & 41 & 69 & 21 \\
\hline (10) Los ambientes fueron distribuidos conforme necesidad & 164 & 12 & 11 & 29 & 73 & 39 \\
\hline (11) Es satisfactorio el suministro de agua & 164 & 5 & 3 & 10 & 56 & 90 \\
\hline (12) La fachada del edificio es agradable & 164 & 19 & 11 & 24 & 76 & 34 \\
\hline \multicolumn{7}{|l|}{ (13) Sistema de portero eléctrico (tipo) } \\
\hline \multicolumn{7}{|l|}{ (14) Sistema de gas de cocina (tipo) } \\
\hline \multicolumn{7}{|l|}{ (15) Área de lavado (tipo) } \\
\hline (16.1) Acceso a la entrada y salida del departamento & 164 & 32 & 23 & 21 & 68 & 20 \\
\hline (16.2) Los equipamientos de combate a incendios & 164 & 14 & 18 & 41 & 68 & 23 \\
\hline (16.3) Entrenamiento de Combate a incendios & 164 & 126 & 5 & 6 & 13 & 14 \\
\hline (17) Facilidad de transporte público & 164 & 27 & 14 & 20 & 52 & 51 \\
\hline (18.1) El revestimiento del piso & 164 & 85 & 24 & 30 & 24 & 1 \\
\hline (18.2) Revestimiento de paredes habitaciones, sala y corredor & 164 & 46 & 25 & 29 & 58 & 6 \\
\hline (18.3) Revestimientos en la cocina, baño y área de servicio & 164 & 41 & 32 & 44 & 42 & 5 \\
\hline (18.4) Revestimiento del techo & 164 & 37 & 16 & 23 & 76 & 12 \\
\hline (18.5) El herraje (cerraduras, bisagras, cerrojos) & 164 & 36 & 21 & 29 & 63 & 15 \\
\hline (19) Los cerramientos: puertas, ventanas y basculantes & 164 & 16 & 21 & 22 & 64 & 41 \\
\hline (20) La mensualidad de la financiación es adecuada & 149 & 13 & 6 & 3 & 40 & 87 \\
\hline (21) El valor de las expensas para mantenimiento del edificio & 146 & 13 & 1 & 9 & 80 & 43 \\
\hline (22) El clima en verano en el interior del departamento & 164 & 23 & 12 & 31 & 73 & 25 \\
\hline (23) El clima en invierno en el interior del departamento & 174 & 7 & 4 & 9 & 104 & 50 \\
\hline (24) El revestimiento de las paredes permiten escuchar ruidos & 164 & 11 & 12 & 37 & 32 & 72 \\
\hline (25) La iluminación natural en el interior es adecuada & 164 & 1 & 4 & 6 & 54 & 99 \\
\hline (26) La ventilación es adecuada & 164 & 12 & 13 & 23 & 51 & 65 \\
\hline (27) Las instalaciones de agua y cloaca son adecuadas & 164 & 14 & 19 & 25 & 52 & 54 \\
\hline (28) Las instalaciones eléctricas son adecuadas & 164 & 11 & 7 & 11 & 68 & 67 \\
\hline (29) En el período de lluvia hay inconvenientes & 164 & 114 & 11 & 17 & 15 & 7 \\
\hline (30) Las áreas de esparcimiento son usadas por moradores & 164 & 93 & 30 & 16 & 13 & 12 \\
\hline (31) Los vanos de acceso ofrecen alguna dificultad & 164 & 109 & 16 & 14 & 15 & 10 \\
\hline (32) Hay escuelas públicas, guarderías, puesto de salud & 164 & 17 & 26 & 46 & 53 & 22 \\
\hline (33) Hay intención de pasar las llaves en los próximos 5 años & 164 & 120 & 8 & 23 & 6 & 7 \\
\hline (34) Concordancia con la Ley porteña 962, del 2002: ascensor & - & - & - & - & - & - \\
\hline
\end{tabular}

Fecha: 2017. 1) El total puede no corresponder rigurosamente al número de personas encuestadas para representación de cada comunidad debido al descarte de muestras y/o haber habido respuesta con más de una opción (letra) en una determinada pregunta. Encuestas aplicadas durante el período de enero de 2014 a septiembre de 2015. 2) Leyenda: A: Ni un poco/No existe, B: Muy poco, C: Poco/Tal vez, D: Aceptable/ Regularmente/ Probablemente, E: Muchísimo. 
Tabla 5.2 - Respuestas de la Encuesta Tipo 1 por comunidad de Salvador

\begin{tabular}{|c|c|c|c|c|}
\hline Ítems & $\begin{array}{c}\text { A } \\
(51)\end{array}$ & $\begin{array}{c}B \\
(39)\end{array}$ & $\begin{array}{c}\mathrm{C} \\
(83)\end{array}$ & Total \\
\hline $\begin{array}{l}\text { (1) Cuánto tiempo hace que vive en el } \\
\text { inmueble }\end{array}$ & 51 & 39 & 74 & 164 \\
\hline Hace 1 año o menos & 19 & 39 & 28 & 86 \\
\hline Hace más o menos 2 años & 32 & 0 & 0 & 32 \\
\hline Hace más o menos 3 años & 0 & 0 & 5 & 5 \\
\hline Hace más o menos 4 años & 0 & 0 & 4 & 4 \\
\hline Hace 5 años o más & 0 & 0 & 37 & 37 \\
\hline (2) En qué piso vive & 51 & 39 & 74 & 164 \\
\hline Planta baja & 10 & 8 & 15 & 33 \\
\hline $1^{\mathrm{er}}$ piso & 14 & 5 & 29 & 48 \\
\hline $2^{\text {ndo }}$ piso & 10 & 10 & 16 & 36 \\
\hline $3^{\mathrm{er}}$ piso & 11 & 5 & 11 & 27 \\
\hline $4^{\circ}$ piso o más & 6 & 11 & 3 & 20 \\
\hline $\begin{array}{l}\text { (3) Cuántas habitaciones el departamento } \\
\text { posee }\end{array}$ & 51 & 39 & 74 & 164 \\
\hline Ninguna habitación & 0 & 0 & 0 & 0 \\
\hline 1 habitación & 10 & 4 & 6 & 20 \\
\hline 2 habitaciones & 41 & 34 & 68 & 143 \\
\hline 3 habitaciones & 0 & 1 & 0 & 1 \\
\hline 4 o más habitaciones & 0 & 0 & 0 & 0 \\
\hline (4) Cuántos metros cuadrados & 51 & 39 & 74 & 164 \\
\hline $20 \mathrm{~m}^{2}$ o menos & 3 & 0 & 1 & 4 \\
\hline Más o menos $40 \mathrm{~m}^{2}$ & 47 & 39 & 68 & 154 \\
\hline Más o menos $60 \mathrm{~m}^{2}$ & 0 & 0 & 4 & 4 \\
\hline Más o menos 80 m² & 0 & 0 & 1 & 1 \\
\hline Más o menos $100 \mathrm{~m}^{2}$, o más & 1 & 0 & 0 & 1 \\
\hline $\begin{array}{l}\text { (5) Vivir en edificio con } 3 \text { a } 4 \text { pisos o más, es } \\
\text { satisfactorio }\end{array}$ & 51 & 39 & 74 & 164 \\
\hline Ni un poco & 3 & 6 & 4 & 13 \\
\hline Muy poco & 0 & 3 & 5 & 8 \\
\hline Poco & 3 & 0 & 8 & 11 \\
\hline Aceptable & 28 & 23 & 40 & 91 \\
\hline Muchísimo & 17 & 7 & 17 & 41 \\
\hline $\begin{array}{l}\text { (6) Participó del proyecto o construcción de la } \\
\text { vivienda }\end{array}$ & 51 & 39 & 74 & 164 \\
\hline Ni un poco & 26 & 15 & 32 & 73 \\
\hline Muy poco & 9 & 3 & 11 & 23 \\
\hline
\end{tabular}




\begin{tabular}{|c|c|c|c|c|}
\hline Poco & 9 & 8 & 13 & 30 \\
\hline Aceptable & 4 & 7 & 5 & 16 \\
\hline Muchísimo & 3 & 6 & 13 & 22 \\
\hline $\begin{array}{l}\text { (7) La burocracia para entregar las llaves ha } \\
\text { demorado }\end{array}$ & 51 & 39 & 74 & 164 \\
\hline Ni un poco & 12 & 1 & 11 & 24 \\
\hline Muy poco & 7 & 2 & 12 & 21 \\
\hline Poco & 7 & 6 & 12 & 25 \\
\hline Aceptable & 13 & 16 & 12 & 41 \\
\hline Muchísimo & 12 & 14 & 27 & 53 \\
\hline $\begin{array}{l}\text { (8) La cantidad de cuartos de su vivienda es } \\
\text { suficiente }\end{array}$ & 51 & 39 & 74 & 164 \\
\hline Ni un poco & 1 & 3 & 5 & 9 \\
\hline Muy poco & 4 & 3 & 7 & 14 \\
\hline Poco & 6 & 6 & 13 & 25 \\
\hline Aceptable & 21 & 20 & 40 & 81 \\
\hline Muchísimo & 19 & 7 & 9 & 35 \\
\hline (9) El tamaño de los cuartos es suficiente & 51 & 39 & 74 & 164 \\
\hline Ni un poco & 0 & 7 & 8 & 15 \\
\hline Muy poco & 4 & 4 & 10 & 18 \\
\hline Poco & 11 & 7 & 23 & 41 \\
\hline Aceptable & 21 & 20 & 28 & 69 \\
\hline Muchísimo & 15 & 1 & 5 & 21 \\
\hline (10) Los cuartos están bien distribuidos & 51 & 39 & 74 & 164 \\
\hline Ni un poco & 0 & 6 & 6 & 12 \\
\hline Muy poco & 2 & 1 & 8 & 11 \\
\hline Poco & 6 & 9 & 14 & 29 \\
\hline Aceptable & 15 & 18 & 40 & 73 \\
\hline Muchísimo & 28 & 5 & 6 & 39 \\
\hline $\begin{array}{l}\text { (11) Están contentos con el abastecimiento de } \\
\text { agua del departamento }\end{array}$ & 51 & 39 & 74 & 164 \\
\hline Ni un poco & 2 & 3 & 0 & 5 \\
\hline Muy poco & 1 & 0 & 2 & 3 \\
\hline Poco & 2 & 7 & 1 & 10 \\
\hline Aceptable & 11 & 14 & 31 & 56 \\
\hline Muchísimo & 35 & 15 & 40 & 90 \\
\hline (12) La fachada del edificio es agradable & 51 & 39 & 74 & 164 \\
\hline Ni un poco & 3 & 3 & 13 & 19 \\
\hline Muy poco & 5 & 2 & 4 & 11 \\
\hline
\end{tabular}




\begin{tabular}{|c|c|c|c|c|}
\hline Poco & 6 & 6 & 12 & 24 \\
\hline Aceptable & 21 & 21 & 34 & 76 \\
\hline Muchísimo & 16 & 7 & 11 & 34 \\
\hline $\begin{array}{l}\text { (13) El sistema de portero eléctrico en su } \\
\text { edificio }\end{array}$ & 76 & 39 & 113 & 228 \\
\hline No existe & 32 & 38 & 71 & 141 \\
\hline Sólo permite escuchar la llamada & 3 & 0 & 1 & 4 \\
\hline Permite abrir el portón & 8 & 0 & 0 & 8 \\
\hline Permite comunicar con los vecinos & 6 & 0 & 0 & 6 \\
\hline Parece bien que se deba instalar uno & 27 & 1 & 41 & 69 \\
\hline (14) Cuánto al gas de cocina utilizado & 52 & 39 & 74 & 165 \\
\hline Garrafa de $10 \mathrm{Kg}$ & 50 & 38 & 71 & 159 \\
\hline Colectivo con central fuera del departamento & 0 & 0 & 0 & 0 \\
\hline Cocina colectiva fuera del departamento & 2 & 0 & 1 & 3 \\
\hline Hay otro tipo & 0 & 0 & 0 & 0 \\
\hline No hay nada existente & 0 & 1 & 2 & 3 \\
\hline (15) Área de Lavado de ropas & 81 & 66 & 114 & 261 \\
\hline Lavadero dentro del departamento & 46 & 37 & 52 & 135 \\
\hline Lavadero colectivo & 1 & 0 & 2 & 3 \\
\hline Lavarropa eléctrico dentro del departamento & 34 & 29 & 57 & 120 \\
\hline Lavarropa eléctrico comunitario & 0 & 0 & 1 & 1 \\
\hline No hay ninguna área prevista & 0 & 0 & 2 & 2 \\
\hline $\begin{array}{l}\text { (16.1) Los materiales son confiables (contra } \\
\text { incendio) }\end{array}$ & 51 & 39 & 74 & 164 \\
\hline $\mathrm{Ni}$ un poco & 2 & 7 & 23 & 32 \\
\hline Muy poco & 10 & 4 & 9 & 23 \\
\hline Poco & 8 & 4 & 9 & 21 \\
\hline Aceptable & 22 & 21 & 25 & 68 \\
\hline Muchísimo & 9 & 3 & 8 & 20 \\
\hline $\begin{array}{l}\text { (16.2) Los equipos de combate a incendios son } \\
\text { confiables }\end{array}$ & 51 & 39 & 74 & 164 \\
\hline Ni un poco & 0 & 1 & 13 & 14 \\
\hline Muy poco & 3 & 4 & 11 & 18 \\
\hline Poco & 16 & 11 & 14 & 41 \\
\hline Aceptable & 25 & 18 & 25 & 68 \\
\hline Muchísimo & 7 & 5 & 11 & 23 \\
\hline $\begin{array}{l}\text { (16.3) Hubo entrenamiento de combate a } \\
\text { incendios }\end{array}$ & 51 & 39 & 74 & 164 \\
\hline Ni un poco & 29 & 32 & 65 & 126 \\
\hline Muy poco & 1 & 0 & 4 & 5 \\
\hline
\end{tabular}




\begin{tabular}{|c|c|c|c|c|}
\hline Poco & 4 & 1 & 1 & 6 \\
\hline Aceptable & 6 & 4 & 3 & 13 \\
\hline Muchísimo & 11 & 2 & 1 & 14 \\
\hline (17) Hay facilidad de transporte público & 51 & 39 & 74 & 164 \\
\hline Ni un poco & 2 & 17 & 8 & 27 \\
\hline Muy poco & 6 & 4 & 4 & 14 \\
\hline Poco & 6 & 6 & 8 & 20 \\
\hline Aceptable & 11 & 12 & 29 & 52 \\
\hline Muchísimo & 26 & 0 & 25 & 51 \\
\hline $\begin{array}{l}\text { (18.1) Satisfacción con la calidad de los } \\
\text { materiales de revestimiento de pisos }\end{array}$ & 51 & 39 & 74 & 164 \\
\hline Ni un poco & 22 & 18 & 45 & 85 \\
\hline Muy poco & 7 & 12 & 5 & 24 \\
\hline Poco & 15 & 2 & 13 & 30 \\
\hline Aceptable & 7 & 7 & 10 & 24 \\
\hline Muchísimo & 0 & 0 & 1 & 1 \\
\hline $\begin{array}{l}\text { (18.2) Satisfacción con los revestimientos de } \\
\text { las paredes de las habitaciones/salas }\end{array}$ & 51 & 39 & 74 & 164 \\
\hline Ni un poco & 18 & 9 & 19 & 46 \\
\hline Muy poco & 7 & 7 & 11 & 25 \\
\hline Poco & 10 & 9 & 10 & 29 \\
\hline Aceptable & 13 & 13 & 32 & 58 \\
\hline Muchísimo & 3 & 1 & 2 & 6 \\
\hline $\begin{array}{l}\text { (18.3) Satisfacción con revestimientos de la } \\
\text { cocina/área servicio y baños }\end{array}$ & 51 & 39 & 74 & 164 \\
\hline $\mathrm{Ni}$ un poco & 10 & 7 & 24 & 41 \\
\hline Muy poco & 6 & 9 & 17 & 32 \\
\hline Poco & 16 & 13 & 15 & 44 \\
\hline Aceptable & 17 & 9 & 16 & 42 \\
\hline Muchísimo & 2 & 1 & 2 & 5 \\
\hline $\begin{array}{l}\text { (18.4) Satisfacción con el revestimiento del } \\
\text { techo }\end{array}$ & 51 & 39 & 74 & 164 \\
\hline Ni un poco & 12 & 8 & 17 & 37 \\
\hline Muy poco & 4 & 6 & 6 & 16 \\
\hline Poco & 10 & 6 & 7 & 23 \\
\hline Aceptable & 22 & 16 & 38 & 76 \\
\hline Muchísimo & 3 & 3 & 6 & 12 \\
\hline $\begin{array}{l}\text { (18.5) Satisfacción con los herrajes } \\
\text { (cerraduras, bisagras, cerrojos) }\end{array}$ & 51 & 39 & 74 & 164 \\
\hline Ni un poco & 11 & 5 & 20 & 36 \\
\hline Muy poco & 5 & 7 & 9 & 21 \\
\hline
\end{tabular}




\begin{tabular}{|c|c|c|c|c|}
\hline Poco & 12 & 7 & 10 & 29 \\
\hline Aceptable & 21 & 16 & 26 & 63 \\
\hline Muchísimo & 2 & 4 & 9 & 15 \\
\hline $\begin{array}{l}\text { (19) Satisfacción con los cerramientos } \\
\text { (puertas, ventanas, basculantes) }\end{array}$ & 51 & 39 & 74 & 164 \\
\hline Ni un poco & 4 & 4 & 8 & 16 \\
\hline Muy poco & 7 & 6 & 8 & 21 \\
\hline Poco & 5 & 6 & 11 & 22 \\
\hline Aceptable & 16 & 16 & 32 & 64 \\
\hline Muchísimo & 19 & 7 & 15 & 41 \\
\hline $\begin{array}{l}\text { (20) Satisfacción con la mensualidad de la } \\
\text { financiación del departamento }\end{array}$ & 51 & 39 & 59 & 149 \\
\hline Ni un poco & 5 & 1 & 7 & 13 \\
\hline Muy poco & 0 & 0 & 6 & 6 \\
\hline Poco & 0 & 2 & 1 & 3 \\
\hline Aceptable & 2 & 7 & 31 & 40 \\
\hline Muchísimo & 44 & 29 & 14 & 87 \\
\hline $\begin{array}{l}\text { (21) Satisfacción con el valor da las expensas } \\
\text { de mantenimiento del edificio }\end{array}$ & 51 & 39 & 56 & 146 \\
\hline Ni un poco & 3 & 5 & 5 & 13 \\
\hline Muy poco & 0 & 0 & 1 & 1 \\
\hline Poco & 2 & 3 & 4 & 9 \\
\hline Aceptable & 29 & 23 & 28 & 80 \\
\hline Muchísimo & 17 & 8 & 18 & 43 \\
\hline $\begin{array}{l}\text { (22) El clima en el interior del departamento es } \\
\text { aceptable en verano }\end{array}$ & 51 & 39 & 74 & 164 \\
\hline Ni un poco & 2 & 5 & 16 & 23 \\
\hline Muy poco & 2 & 1 & 9 & 12 \\
\hline Poco & 14 & 3 & 14 & 31 \\
\hline Aceptable & 19 & 26 & 28 & 73 \\
\hline Muchísimo & 14 & 4 & 7 & 25 \\
\hline $\begin{array}{l}\text { (23) El clima en el interior del departamento es } \\
\text { aceptable en invierno }\end{array}$ & 51 & 39 & 74 & 164 \\
\hline Ni un poco & 3 & 0 & 4 & 7 \\
\hline Muy poco & 0 & 0 & 4 & 4 \\
\hline Poco & 4 & 3 & 2 & 9 \\
\hline Aceptable & 25 & 23 & 46 & 94 \\
\hline Muchísimo & 19 & 13 & 18 & 50 \\
\hline $\begin{array}{l}\text { (24) Satisfacción con el revestimiento de las } \\
\text { paredes (ruidos) }\end{array}$ & 51 & 39 & 74 & 164 \\
\hline Ni un poco & 3 & 2 & 6 & 11 \\
\hline
\end{tabular}




\begin{tabular}{|c|c|c|c|c|}
\hline Muy poco & 5 & 1 & 6 & 12 \\
\hline Poco & 8 & 10 & 19 & 37 \\
\hline Aceptable & 11 & 8 & 13 & 32 \\
\hline Muchísimo & 24 & 18 & 30 & 72 \\
\hline $\begin{array}{l}\text { (25) La iluminación natural de día en el } \\
\text { departamento es satisfactoria }\end{array}$ & 51 & 39 & 74 & 164 \\
\hline Ni un poco & 1 & 0 & 0 & 1 \\
\hline Muy poco & 0 & 0 & 4 & 4 \\
\hline Poco & 2 & 2 & 2 & 6 \\
\hline Aceptable & 8 & 16 & 30 & 54 \\
\hline Muchísimo & 40 & 21 & 38 & 99 \\
\hline $\begin{array}{l}\text { (26) Están contentos con la ventilación en el } \\
\text { interior del departamento }\end{array}$ & 51 & 39 & 74 & 164 \\
\hline $\mathrm{Ni}$ un poco & 4 & 2 & 6 & 12 \\
\hline Muy poco & 2 & 2 & 9 & 13 \\
\hline Poco & 9 & 2 & 12 & 23 \\
\hline Aceptable & 12 & 14 & 25 & 51 \\
\hline Muchísimo & 24 & 19 & 22 & 65 \\
\hline $\begin{array}{l}\text { (27) Las instalaciones de agua y cloaca del } \\
\text { departamento atienden bien }\end{array}$ & 51 & 39 & 74 & 164 \\
\hline $\mathrm{Ni}$ un poco & 4 & 4 & 6 & 14 \\
\hline Muy poco & 8 & 4 & 7 & 19 \\
\hline Poco & 7 & 6 & 12 & 25 \\
\hline Aceptable & 16 & 13 & 23 & 52 \\
\hline Muchísimo & 16 & 12 & 26 & 54 \\
\hline $\begin{array}{l}\text { (28) Están contentos con las instalaciones } \\
\text { eléctricas del departamento }\end{array}$ & 51 & 39 & 74 & 164 \\
\hline Ni un poco & 5 & 2 & 4 & 11 \\
\hline Muy poco & 2 & 1 & 4 & 7 \\
\hline Poco & 1 & 6 & 4 & 11 \\
\hline Aceptable & 18 & 13 & 37 & 68 \\
\hline Muchísimo & 25 & 17 & 25 & 67 \\
\hline $\begin{array}{l}\text { (29) Hay problemas en interior del } \\
\text { departamento en período de lluvia }\end{array}$ & 51 & 39 & 74 & 164 \\
\hline Ni un poco & 25 & 30 & 59 & 114 \\
\hline Muy poco & 6 & 3 & 2 & 11 \\
\hline Poco & 8 & 2 & 7 & 17 \\
\hline Aceptable & 6 & 4 & 5 & 15 \\
\hline Muchísimo & 6 & 0 & 1 & 7 \\
\hline $\begin{array}{l}\text { (30) Las áreas de esparcimiento son usadas } \\
\text { por los moradores }\end{array}$ & 51 & 39 & 74 & 164 \\
\hline
\end{tabular}




\begin{tabular}{|c|c|c|c|c|}
\hline Ni un poco & 22 & 14 & 57 & 93 \\
\hline Muy poco & 18 & 7 & 5 & 30 \\
\hline Poco & 5 & 7 & 4 & 16 \\
\hline Aceptable & 2 & 8 & 3 & 13 \\
\hline Muchísimo & 4 & 3 & 5 & 12 \\
\hline $\begin{array}{l}\text { (31) Hay dificultad de acceso/circulación en } \\
\text { hall, pasillo, escalera }\end{array}$ & 51 & 39 & 74 & 164 \\
\hline Ni un poco & 34 & 24 & 51 & 109 \\
\hline Muy poco & 5 & 2 & 9 & 16 \\
\hline Poco & 6 & 3 & 5 & 14 \\
\hline Aceptable & 3 & 4 & 8 & 15 \\
\hline Muchísimo & 3 & 6 & 1 & 10 \\
\hline $\begin{array}{l}\text { (32) Hay disponibilidad de estructuras públicas } \\
\text { básicas (escuela) }\end{array}$ & 51 & 39 & 74 & 164 \\
\hline Ni un poco & 1 & 9 & 7 & 17 \\
\hline Muy poco & 9 & 4 & 13 & 26 \\
\hline Poco & 9 & 9 & 28 & 46 \\
\hline Aceptable & 20 & 13 & 20 & 53 \\
\hline Muchísimo & 12 & 4 & 6 & 22 \\
\hline $\begin{array}{l}\text { (33) Pretende vender su departamento en los } \\
\text { próximos } 5 \text { años }\end{array}$ & 51 & 39 & 74 & 164 \\
\hline Ni un poco & 45 & 28 & 47 & 120 \\
\hline Muy poco & 2 & 3 & 3 & 8 \\
\hline Poco & 3 & 4 & 16 & 23 \\
\hline Aceptable & 1 & 2 & 3 & 6 \\
\hline Muchísimo & 0 & 2 & 5 & 7 \\
\hline
\end{tabular}

Fecha: julio de 2017. 1) El total puede no corresponder rigurosamente al número de personas encuestadas para representación de cada comunidad debido al descarte de muestras y/o haber habido respuestas con más de una opción (letra) en una determinada pregunta. Encuestas aplicadas durante el período de enero de 2014 a septiembre de 2015. 2) Leyenda: A: Cond. 27 de Abril (Doron), B: Perseverança (Pernambues), C: Paraíso Azul/Recanto Feliz (Costa Azul).

\subsection{3 - Opinión de los moradores de las comunidades de Salvador}

Fue de fundamental importancia para esta tesis la contribución de los moradores, tanto de Brasil como de Argentina, al traer sus comentarios generalidades, críticas y sugerencias- sobre como perciben la vida en la comunidad a partir de la calidad constructiva de las habitaciones donde viven. Así, los cuadros siguientes (Cuadros 5.4 - 5.9) fueron elaborados manteniendo lo más fidedigno posible la terminología utilizada por los moradores. 


\section{Generalidades}

- "Não há praça e jardim" (Moradora de aproximadamente 32 años);

- "A luz da cozinha não acende está com algum problema" (Moradora 36 años)

- "O meu comentario o sobre isso e que não tem uma area de lazer para as crianças brincare" [sic] (Moradora 38 años);

- "É muito importante que houvesse um posto policial e 1 creche na comunidade" (Moradora 38 años);

- "Difícil conviver num ambiente com muito lixo, existe muita sujeira proveniente da falta de educação de alguns moradores. Regras de convivência não são respeitadas é quase nula. Tráfico de drogas e bandidagem a luz do dia. Efetivo policial insuficiente. Som alto" (Trecho en sic según escrito anónimamente en una de las encuestas).

- "Não existe ralo na área de serviço, quando joga água para lavar o piso da área de serviço, há dificuldade de secar o piso" (Morador 42 años);

- "A área de serviço não tem ralo, a maioria das pias com defeito, a água é coletiva [no hay hidrómetro individualizado por departamento]" (Moradora 52 años);

- "A demora para definir o valor mensal do financiamento e o valor da taxa de condôminio [sic] não tem ralo no chão da área de serviço" (Moradora 38 años);

- "Escada sem piso - cozinha sem ralo" (Moradora 35 años);

- "A porta de entrada do prédio é fragil [sic] e falta ralo na cozinha, a pia do banheiro pequena" (Morador 76 años);

- "Falta de ralo no piso da área de serviço as torneiras e a descarga do banheiro são de péssima qualidade" (Morador 29 años);

- "Não existe ralo na cozinha, as pias são de pessimo [sic] material, as torneiras sempre dão defeito" (Morador 41 años);

- "A conta da água que vem, e quem paga por enquanto é a CONDER, e as pessoas reclamam do desperdício da água" (Morador 49 años).

- No les agrada la fachada del bloque;

- La falta de pago de la tasa de expensas para el mantenimiento del bloque por algunos moradores hace que el valor recaudado sea insuficiente, generando trastornos para los demás;

- Mientras se aguarda una definición del valor mensual regular para la tasa de expensas para el mantenimiento del bloque los moradores juntan a cada mes el valor de los costos esenciales -energía eléctrica, material de limpieza, etc.;

- Es poquísimo el número de moradores que usan la plazoleta en el interior del conjunto de bloques;

- Los condóminos no están cargando anualmente los extintores como es obligatorio, lo que provoca inseguridad entre algunos moradores;

- No hubo definición del valor de la tasa de expensas para el mantenimiento del bloque durante el periodo de las encuestas de esta tesis;

- Falta espíritu de convivencia colectiva por parte de varios moradores;

- Hubo quien reclamara que en el centro de salud no hay sustituto del médico de vacaciones por lo que el centro no sirve en caso de emergencia;

- Hay quien afirma que CONDER lo invitó a participar con sugerencias durante la elaboración del proyecto, pero no pudo comparecer al encuentro;

- Hubo quien afirmó que en el Conjunto habitacional sólo hay escuela y centro de salud;

- Hay quien, viviendo hace ocho años, dijo que la financiación del departamento está totalmente paga;

- Se sugiere que se utilice el área próxima al bloque para implantación de 
parque para infantes;

- Hubo alteración informal en el bloque por parte del morador para la implantación de garaje individual, algo que no es permitido legalmente;

- Se afirmó que hubo encuentros por tres días con profesionales en relación con el tema de prevención y combate de incendios;

- Se sugiere que la red de agua sea implantada con la individualización del consumo, medición y pago;

- Se sugiere que haya guardia de infantes, lugar de pagos y farmacia en el Conjunto de VIS;

Fecha: julio de 2017.

Cuadro 5.5 - Críticas de la comunidad Paraíso Azul/Recanto Feliz

\section{Críticas}

- No hay espacios viables para esparcimiento/recreo -plaza, parque, jardín etc. y la pequeña plazoleta que hay carece de equipamiento -mobiliario urbano- y paisajismo;

- La cocina es muy pequeña y no tiene rejilla y en el área de servicio no cabe una lavadora eléctrica de ropa;

- El sistema de sifón es deficiente ya que se percibe mal olor en cocina y baños;

- Si hubiera jardín en la plazoleta, ésta sería más receptiva y visitada por los vecinos;

- Hay problemas pendientes de instalación del hidrómetro para lectura de consumo de agua en departamentos de un bloque;

- No hay cañería en las paredes para instalaciones de equipamiento de portero eléctrico en el bloque de departamentos;

- Los pisos de la sala y de los cuartos deberían ser revestidos pues fueron entregados en cemento;

- El área del hall de los departamentos y la de los cuartos es muy pequeña;

- El revestimiento de las paredes de la cocina se limita a tres tiras de azulejos ancha como la pileta;

- Sólo se entregó el baño con puerta, además de la de la entrada del departamento, y son frágiles;

- Los extintores fueron entregados vacíos;

- Los materiales utilizados para la construcción de los departamentos fueron de bajísima calidad;

- Hay departamentos que están orientados totalmente hacia la puesta del sol, lo que produce gran malestar por exceso de calor en verano, pero hubo quien expresara lo contrario, pues su departamento se encuentra orientado hacia el este;

- El hecho de que el baño esté ubicado en frente de la habitación provoca, según el morador, que disminuya el área de la cocina, además de que sólo el baño, entre los demás cuartos internos del departamento, vino con la puerta;

- Falta guardería, comisaría y lugar de pagos;

- Faltó una rejilla en el área de servicio;

- Hay departamentos donde incluso en invierno el clima en el interior de éste es cálido;

- En junio de 2014 se pagaban R\$ 450/mes por el alquiler informal de un departamento en el condominio, según la moradora que es inquilina, argumentando que hace tratamiento médico -hemodiálisis- y espera obtener alguna habitación de VIS. Hay otra negociación informal en negro cuyo alquiler mensual es de $R \$ 110$ sin contar la tasa de expensas que es de $R \$ 10,00 /$ mes 
(los valores mensuales de la tasa de expensas encontrados en los bloques del conjunto durante esta investigación variaban entre $R \$ 40$ y $R \$ 70)$. En octubre de 2014 hubo quien pagaba de alquiler R $\$ 760$ mensualmente;

- Hay quien reclama por ruidos provenientes del departamento vecino e incluso del interior del departamento del propio reclamante;

- La fachada del bloque debería tener un "portoncito" y un mejor revestimiento en azulejo;

- No hubo ninguna información pasada a los moradores sobre prevención y combate de incendios según la mayoría de los contestadores;

- Hay obstrucción en la red de cloacas en el interior de los departamentos además de que hay bloques donde los hidrómetros que miden el consumo de agua de cada departamento no funcionan;

- Hay quien admite que el número de extintores distribuidos en el interior de los bloques en áreas comunes es insuficiente;

- Se reclamó que hubo revestimiento de paredes en azulejo en el baño hasta la mitad altura, pero no hay en la cocina;

- Incluso de día es necesario mantener encendida la lámpara de la cocina para que haya claridad suficiente;

- Hay departamentos en que se mueven bien las ventanas, pero las puertas no;

- Hubo dificultad para transportar la heladera, el sofá etc. en el área de circulación común como las escaleras;

- El área de los baños es muy pequeña, generando dificultades para la cañería de cloacas;

- El box comunitario para pequeños comercios es muy pequeño, mientras que hay áreas libres poco aprovechadas;

- Hay áreas libres dentro del conjunto habitacional subutilizadas;

- Hubo quien reprobara el revestimiento de la cocina, baños y área de servicio definiéndolo como "grotesco";

- El herraje de las puertas es vulnerable: algunas llaves abren varias puertas inclusive de otros departamentos;

- Se reclamó de la cantidad insuficiente de enchufes en el interior del departamento;

- Debido al frecuente inconveniente de los jóvenes que fuman marihuana cerca de los departamentos, principalmente de los que están ubicados en planta baja, muy vulnerables al acceso de extraños, se sugiere que se construyan muros entre los bloques del Conjunto, mejorando la privacidad de los moradores;

- Hay problemas de moho en el interior del departamento, así como goteras por la boca de la lámpara del techo de la habitación;

- Hay quien ha afirmado que "tal vez" quiera vender su departamento en el futuro pues sueña con poseer una casa de planta baja de tipo unifamiliar;

- Hubo departamento en los que surgió infiltración y moho en las paredes de las habitaciones;

- La ubicación del baño es inadecuada pues está muy cerca de la cocina;

- Ante lluvias fuertes el terreo de algún bloque forma lagunas de agua inclusive cerca del portón principal de entrada; en otro bloque el agua de la lluvia entra por el cobogo de la escalera;

- Se sugiere que la cantidad de dormitorios sea compatible con el tamaño de la familia;

- El área de la cocina/servicio es muy pequeña;

- Se sugiere que las fachadas sean revestidas con cerámica para evitar la aparición muy común de manchas y mohos;

- Se reciente que los bloques no estén delimitados por muros;

- Se critica la existencia de muchas callecitas entre los bloques de departamentos;

- Se reclama que los vicios de construcción no fueron resueltos a lo largo de 
cinco años, ni por CONDER, ni por la constructora;

- Se critica que en la cocina no haya ninguna rejilla, ya que en los baños hay dos;

- Hay obstrucción en la red de cloacas en el trecho de la cocina;

- Hay una excesiva quema generalizada de lámparas, lo que sugiere se trate de una subestimación de cálculo de la capacidad del cableado eléctrico;

- Surgió moho en la habitación e inundación en la entrada del departamento;

- Falta seguridad pública en la comunidad;

- Los moradores se resienten de la falta de asistencia social para la administración de conflictos debidos a la convivencia colectiva en el bloque;

- Durante la entrega de llaves de los departamentos por CONDER, se notó que la red de cableado eléctrico se encontraba parcialmente expuesta en el cuadro general de electricidad de un bloque de departamentos;

- La cocina es el lugar más desagradable debido a su pequeño tamaño y a la falta de una rejilla;

- Se reclama que la puerta principal del departamento es de baja calidad -muy delgada y hueca-, el picaporte, suelto, cayó al ser manoseado la primera vez;

- Hay baja presión de salida de agua en algunos terminales del interior del departamento;

- El revestimiento del peldaño de la escalera fue entregado crudo en argamasa de cemento;

Fecha: julio de 2017.

Cuadro 5.6 - Generalidades de la comunidad 27 de Abril/SINDOMÉSTICO

\section{Generalidades}

- "A [há] falta de segurança no conjunto por falta de mura[r] e convivensia com a comunidade" [sic] (Moradora 32 años);

- "Minha observasão [sic] em questão é que foi estalado pouço ponto de telefone so tem um (1) para todo os comudos e minha insatisfação é a respeito do muro que devia ser entregue feito e na SUCON consta como construido" [sic] (Moradora 54 años). Se aclara que la mencionada SUCON es la Superintendência de Controle e Ordenamento do Uso do Solo do Município, institución relacionada con la Intendencia de Salvador/BA;

- $\quad$ "Onde eu moro há muitas dificuldades de transportes apesar de tên várias linhas [de bus] mas tam pouco ônimbus circulando no horário de pico. os carro passa muito cheio que não para em alguns pontos" [sic] (Moradora 45 años);

- "Existe muitos problemas de ruídos em todos os apartamentos vendo [viniendo] do teto qualque[r] barulho por mas [mais] simples que seja passa para o andar inferior [.] esse é um grande problema de e[i]ntriga entre os vizinhos. Só para ter uma idéia do problema: minha vizinha do andar inferior sempre reclama que tenha barulho de minha casa a vezes eu estava fora ou dormi[n]do o ruído ve[i]nha do andar [piso] superior ao meu" [sic] (Moradora 45 años);

- "Os materiais usados nas construções dos edificil, as casas populares deveriam ser mais seguras. Pois muitos apartamentos ou casas com pouco tempo aparecem defeitos, como: vasamentos, rachaduras, entre outros" [sic] (Moradora 28 años);

- "(OBS: Banheiro vazandos todos). Tubulação com mal cheiro) (Antena que não passa o fil com as graganta quebradas) (Não foi murado) trasmissão quebrada) (Portas de mal qualidade com gubim [cupim] (Pisso do Banheiro não colocado) (canos quebrados de Mal qualidade)" [sic] (Moradora 49 años);

- "O bom seria uma assitencia melhor sobre administração do condomínio" [sic] (Moradora 54 años);

- "Sim, eu gostaria, que podecímos fechar quer dizer, colocar muro para que 
tenhamos mais privacidade" [sic] (Moradora 50 años);

- "Banheiro de umidade com vazamento no teto" [sic] (alguien anónimo que contestó la encuesta de esta tesis);

- "OBS: Os imoves já devera ser construidos com rampa para asseso as pessoas caderantes" [sic] (Doméstica 46 años);

- "A Fachada ficou virada para traz" [sic] (Moradora 32 años);

- Se admite que la tasa de expensas para el mantenimiento del bloque es de R\$ 30 (abril 2014), es insuficiente para cubrir los costos efectivos de la manutención del bloque compuesto por veinte departamentos;

- Hubo un momento de charla con un profesional especializado sobre la prevención y combate de incendios, el cual fue contratado por los propios moradores;

- Había red interna y terminal de portero eléctrico en el interior de los departamentos, pero sin el equipamiento;

- Se sugiere un mayor número de líneas de colectivos e incluso de la frecuencia, que es de cerca de una hora o más, principalmente los fines de semana, cuando empeora la situación;

- Se critica que el cielo raso del departamento sea de yeso;

- Se exteriorizó la preocupación de la capacidad futura de los moradores de bajos ingresos, los que ganan, en media, 2 o 3 SM mensuales, para hacer frente al necesario mantenimiento de los edificios -materiales y servicios-;

- Se comentó que el puesto policial más cercano al condominio no registra quejas, encaminándolos para otro lugar más lejano.

Fecha: julio de 2017.

Cuadro 5.7 - Críticas de la comunidad 27 de Abril/SINDOMÉSTICO

\section{Críticas}

- Los materiales utilizados en la construcción de los departamentos son de pésima calidad;

- Los servicios aplicados en la construcción de los departamentos fueron deficientes;

- La administración de las obras del proyecto debería ser más eficiente;

- CONDER ha entregado los departamentos sin portero eléctrico en los bloques;

- Se entregó el conjunto habitacional sin el muro de perímetro para mejor protección contra extraños;

- No hubo ninguna información dada a los moradores sobre la prevención y combate de incendios según gran parte de los contestadores;

- Se escuchan ruidos del departamento de arriba, como cuando caen cubiertos, por ejemplo, y/o del departamento lateral;

- Con el uso del departamento de arriba empezaron a surgir deformaciones en el cielo raso del departamento de abajo;

- Hay problemas en el sistema de sifón de cocina y baños generando olores;

- La obstrucción existente en la red de cloaca del departamento de arriba hace que los vestigios sigan inadecuadamente hacia al departamento de abajo;

- Hubo quien sugiriera que hubo cambios en las fachadas de frente y fondo para compatibilizar la entrada principal de acuerdo al proyecto arquitectónico y para facilitar el uso que se hace rutinariamente al acceder a la vía pública;

- Hubo demora en la burocracia entre el periodo de la conclusión del trámite del catastro y la entrega de la obra, cuyo periodo ha sido de 2006 a 2012;

- Ocurrió vaciamiento en los baños de varios departamentos;

- En el periodo de lluvias hay bloques de departamentos cuya planta baja se 
inunda;

- Se critica que el área de la guardería así como del puesto de salud no corresponde a la (gran) demanda de los vecinos;

- El dispositivo de apertura/cierre de la red general de agua del departamento fue entregado incompleto e inutilizable;

- Se entregó departamento con vaciamiento de agua y obstrucción en la red de cloacas;

- Las puertas del departamento son de pésima calidad presentando insectos en su interior y por eso se las cambió;

- Hubo departamentos cuyas ventanas o puertas presentaron deformaciones;

- El herraje de puertas y ventanas es de baja calidad y el de la puerta es poco seguro;

- Hubo un morador que estaba pagando $\mathrm{R} \$ 150$ (mayo de 2014) mensuales por el "consumo" de agua y percibió que el alto valor se debía a la infiltración en el departamento;

- Hubo revestimiento sólo en el piso de la cocina/área de servicio y baño;

- Hubo ventanas con dificultad para abrir y cerrar;

- Hay departamentos en que en verano hace mucho calor en su interior;

- Hay departamentos en los que, en invierno, durante el periodo de lluvia, el agua pasa por debajo de la puerta y/o por las ventanas;

- Hubo infiltración de agua potable en la red general del bloque;

- Las paredes interiores del departamento fueron entregadas sin pintura, con una aplicación sobre las mismas, de algo similar a la cal blanca;

- Se reclama del horario de atendimiento del puesto de salud, así como de la falta de una comisaría cerca del conjunto habitacional;

- Se critica el reducido número de enchufes en el interior del departamento, algo incompatible con la necesidad de equipamientos electro-electrónicos;

- Se percibe humedad -moho- en las paredes del interior del departamento;

- Hubo quien admitiera que los peldaños de las escaleras del bloque son estrechos;

- Hubo quien a pesar de admitir que los estructuras públicas como escuela, guardería, puesto de salud, comisaría y lugar de pagos, fueran accesibles a la comunidad, reclamó que no funcionan tan adecuadamente;

- La obstrucción existente en la red de cloaca del departamento provoca que el agua no fluya, y además de que el agua residual del vecino transborde en el departamento;

- Se critica que las cañerías eléctricas no fueron bien dimensionadas e instaladas, presentando obstrucciones;

- Se critica que las cañerías hidráulicas y sanitarias fueron mal instaladas generando vaciamientos de origen "desconocida";

- El espacio de esparcimiento fue depredado por extraños al condominio (se supone que la inexistencia del muro facilitó el problema);

- Hubo asaltos luego de la post ocupación del condominio;

- Los moradores reclaman de la falta de asistencia social para la administración de conflictos de convivencia colectiva en el bloque de departamentos;

- Hay algún equívoco en el proyecto hidráulico, o en su ejecución, pues hay baja presión en la circulación (se aclara que el departamento en cuestión se ubica en el tercer piso, es decir, dos pisos arriba de la planta baja);

- Se sintió la falta de enchufes en algunos puntos de algunos departamentos;

- Hay departamento donde surgieron fisuras en el cielo raso;

- Hubo departamento donde se sintió falta de un terminal de teléfono -para interconexión con un potencial portero electrónico- en la pared, así como ubicación inadecuada de enchufes eléctricos.

Fecha: julio de 2017. 


\section{Generalidades}

- El líder comunitario visitó la obra durante la ejecución del proyecto cerca de 4 o 5 veces;

- El tiempo de espera, después del catastro, de confirmación del nombre como futuro morador fue estimado por el líder comunitario en tres años;

- El líder comunitario sólo no evaluó con puntuación máxima su agrado para con la fachada debido al color rosa de la misma;

- El valor mensual de la tasa de expensas para el mantenimiento de los dos bloques es de cerca de $\mathrm{R} \$ 30$ (junio de 2014);

- Los moradores aguardaban la legalización del registro del régimen de condominio de las dos torres para los próximos meses después de junio de 2014 para entonces empezar a construir por cuenta propia un salón cubierto para fiestas;

- El revestimiento con azulejos en las paredes del baño y de la cocina es hasta media altura del cielo raso;

- Se entregaron los departamentos con el revoque de las paredes sin terminación;

- "Achei ótimo esse comentário [encuesta] espero que venha trazer benefício para todos nós que essas questão [sic] não sejam em vão" (Morador 35 años).

- "Eu achei estas perguntas bem ilustradas e bom para nosso desenvolvido no dia a dia e como conviver em conjunto" (Moradora 27 años);

- "O apartamento deveria ser entregue com revestimento nos pisos para haver menos gastos [para la moradora, y] somente o banheiro é muito pequeno, os demais são satisfatórios" (Moradora 30 años);

- "Foi uma benção na minha vida minha casa propria, é tudo que eu precisava, o que eu não gosto aqui e que alguns moradores vendem os apartamentos, e estão vindo moradores estranhos para a area, e agora a policia vive aque nossos filhos não podem mas estarem sozinhos brincando no cond. $E$ os síndicos que escolhemos estão envolvidos a passar os ap. então não temos com quem falar. é até perigoso" [Trecho en sic según escrito en una de las encuestas].

- "A área da lavanderia não cabe uma máquina de lavar [lavadora eléctrica].". (Moradora 36 años);

Fecha: julio de 2017.

Cuadro 5.9 - Críticas de la comunidad Perseverança

\section{Críticas}

- Los pisos de la sala y cuartos deberían ser revestidos;

- En varios departamentos sucede que dos terminales de agua no pueden ser utilizados simultáneamente, pues faltaría agua en uno de ellos, cuando el reservatorio superior no esté suficientemente lleno: baja presión de agua en cañería general y sub-ramales;

- El área del parque infantil es pequeña y las estructuras de recreo son numéricamente insuficientes y son usados por personas extrañas al condominio promoviendo temor con relación a la seguridad;

- Hay dificultad de accesibilidad para quien posee una deficiencia locomotora, tanto en el interior del departamento como en su entorno;

- Algún equívoco en el proyecto hidráulico genera dificultad de uso de los 
terminales en los departamentos: baja presión en la circulación;

- Desde el inicio de la post-ocupación una de las dos torres presenta problemas en la red general de agua debido a un defecto con la bomba;

- Algunos departamentos presentaron obstrucción en la red de cloacas, la cual se desobstruyó posteriormente;

- Varios encuestados reclamaran de los vicios de construcción en las instalaciones hidráulicas/cloacas y de la red de energía eléctrica del interior de los departamentos y en áreas comunes del condominio;

- Hubo departamentos que presentaron vicio de construcción en el cableado eléctrico y el cuadro de energía;

- Se entregaron departamentos en los que la energía eléctrica no pasaba en la cocina ni en los baños (los propios moradores costearon el arreglo);

- Hubo departamentos en que el enchufe de la lavadora de ropa era inadecuado;

- Hubo departamentos con la puerta fuera de plomo y hecha con material de baja calidad, inutilizándola;

- La loza del techo no impide el pasaje de ruidos provenientes del departamento superior, así como a través de las paredes laterales (se escucha el ruido proveniente del vecino, incluso de matrimonios);

- Debería existir iluminación en la entrada de las torres -en la rampa y escalera que conducen del paseo público a la puerta principal del edificio-;

- La pintura de la fachada de las torres es de baja calidad;

- No hubo ninguna información sobre la prevención y combate de incendios según la mayoría de los encuestados, sin embargo, hubo quien afirmara que recibió material informativo impreso, con instrucciones al respecto, de CONDER;

- Las cerraduras de las puertas son vulnerables: las llaves abren varias puertas, inclusive de otros departamentos;

- Algunos extintores fueron entregados vacíos;

- Los departamentos fueron entregados con la vía pública frente al condominio sin las protecciones laterales;

- La falta de protección sobre un arroyo que pasa en frente al condominio trae inconvenientes con la presencia de mosquitos;

- La accesibilidad con la vecindad del condominio es precaria;

- La comunidad no cuenta con correo postal;

- Es muy difícil la accesibilidad al transporte público -lejano- especialmente para quien posee deficiencia física/locomotora;

- La fachada principal de todos los departamentos no tiene ninguna protección visual y está muy a la vista de la vía pública, lo que facilita la falta de privacidad;

- El área de cocina/lavadora de ropa y la de baño son muy pequeñas;

- El largo pasillo que existe en frente a la puerta de entrada de los departamentos facilita el quiebre de privacidad visual/acústica y molesta a quien se encuentra en el interior de los mismos;

- Hubo reclamación de que el largo pasillo-balcón es estrecho para el pasaje de dos personas en sentido contrario;

- Hubo quien reclamara del flujo de circulación de personas y ruido en las áreas comunes (el largo pasillo-balcón de cada piso pasa en frente de la puerta y ventana de todos los departamentos del mismo piso);

- Hubo departamentos que presentaron fisuras en las paredes y vigas;

- En los departamentos del último piso el tejado en cerámica facilita el pasaje de humedad por enfriamiento en periodo de lluvias y crea goteras, así como el malestar en verano debido al exceso de calor: se sugiere un sistema de aislamiento térmico;

- Se entregaron los departamentos sin terminal para enchufe en el baño 
necesitando adaptación para el uso;

- El piso de área común externa en el interior del condominio presentó fisuras y rajaduras;

- El pasamano en algunos trechos de la escalera estaba casi suelto;

- El piso del área común -pasillo y escaleras- debería tener protección para que evitar resbalar principalmente cuando mojado;

- No hay guardería en las proximidades del condominio;

- Sería importante que las torres fuesen entregadas con algún sistema de portero eléctrico o un portón electrónico en la entrada principal;

- Los materiales utilizados en las instalaciones de agua y cloacas de los departamentos son de baja calidad;

- Algunos afirman que hay un exceso de consumo de energía eléctrica debido a algún problema no conocido en las instalaciones del edificio; existe una excesiva quema generalizada de lámparas incandescentes motivo por el cual los moradores las cambiaron por otras fluorescentes;

- Hay problemas en el sistema de sifón de baño que libera olores, así como en la cañería de inodoro, dificultando el desagüe de las excreciones;

- No hay alguna caja de desagüe de aguas de lavado o pluvial en ningún piso, ni en el piso de los pasillos-balcón comunes;

- No hay enchufe eléctrico en ningún piso, ni en los pasillos-balcón comunes;

- Se sugirió que el sector social debería envolver las personas en el proyecto desde el inicio;

- Hubo quien reclamara del calor en el interior del departamento;

- Se entregó departamentos con daño en la cañería de cloaca de la lavadora;

- Desde el inicio hubo infiltración en el baño en algunos departamentos que se origina del piso de arriba, también en una pared cerca del pasillo- balcón y cerca de área semivacío/cobogó de la cocina;

- Se sugirió que el área y número de dormitorios fuesen más grandes;

- Se reclamó que falta una tienda de comestibles cerca y de transporte público que atiendan a la comunidad;

- En noviembre de 2014 se pagaban $\mathrm{R} \$ 400 /$ mes por el alquiler informal de un departamento en el condominio, mientras se aguarda una oportunidad de conseguir un inmoble propio en otro proyecto de VIS;

- La fijación de rejas en el inicio del largo pasillo-balcón está siendo motivo de contiendas entre los vecinos que se sienten molestos con la continua entra y salida de personas;

- Se entregó un departamento con una canilla que gotea agua en algunos periodos;

- La pintura de las paredes es descuidada, hay manchas de pintura en la puerta principal, que está hecha con material de baja calidad;

- Se entregaron algunas paredes con arañazos;

Fecha: julio de 2017. 
5.2.4 - Síntesis y consideraciones sobre las opiniones de los moradores de Salvador

Con base en las informaciones recolectadas a partir de las respuestas obtenidas a través de la Encuesta de Tipo 1 de los moradores de las tres comunidades brasileñas se produjeron las Tabla 5.1 y 5.2 y los Cuadros 5.1 - 5.9 expuestos anteriormente y cuya información analizaremos a continuación:

En relación a la parte arquitectónica se deduce que hay una aprobación en las tres comunidades evaluadas, pues, en los ítems: fachada del edificio (pregunta 5), confianza en relación a los materiales utilizados en la construcción en situación de incendio (pregunta 16.1), satisfacción en clima de verano e invierno (pregunta 22 y 23), iluminación natural en el interior de la vivienda (pregunta 25), ventilación (pregunta 26), inconvenientes en períodos de lluvia (pregunta 29) y accesos comunes al interior del inmueble (pregunta 31), las respuestas fueron satisfactorias. Con relación a la cantidad (pregunta 8), tamaño (pregunta 9) y disposición de las habitaciones (pregunta 10) los resultados estadísticos contabilizados fueron de aprobación satisfactoria. Sin embargo, los materiales utilizados en general, y en particular los de los revestimientos de los pisos (pregunta 18.1), de las paredes de habitaciones y salas (pregunta 18.2), fueron considerados de baja calidad. En lo que se refiere a la privacidad, frente a inconvenientes acústicos originados de día y de noche entre viviendas contiguas, tanto lateral como verticalmente, e incluso entre ambientes internos de la propia vivienda (pregunta 24), llevó a una queja general en las tres comunidades investigadas, lo que se hizo evidente tanto por las críticas verbalizadas como por las registradas en la encuesta.

Tanto en el tópico referente a los inconvenientes acústicos como en los otros abordados en esta investigación, se reclamó una mayor atención del sector social que acompaña a las familias adquirentes de VIS, problema que fue indicado por varios encuestados en las tres comunidades como no resuelto suficientemente desde el inicio de la elaboración de los proyectos, ni durante su ejecución, lo que generó algunos problemas de convivencia teniendo en cuenta la proximidad física entre los vecinos. La pregunta 16.3, referente a este tema, explicitó uno de los más grandes índices de rechazo por parte de los encuestados, con lo que se constató en los resultados un elevado índice de desconocimiento al respecto.

Otro problema fue en relación con la falta de terminación adecuada de las paredes y pisos sin revestimiento de las viviendas, que en general fueron entregadas a los moradores de esta forma rústica para que ellos las concluyan, 
situación presente en las tres comunidades brasileras investigadas, y también constatada por otros autores en varias ciudades de Brasil, según Abiko y Ornstein (2002, p. 264) constataron también.

Otra cuestión muy criticada fue en relación con la atención prestada por el sector social al entrenamiento de los moradores en materia de combate de incendios, ya que el rechazo a la forma en que fue conducido este tema fue del orden del $80 \%$ de los moradores que se manifestaron, quienes aseguraron que desconocían los principios básicos de cómo proceder en situaciones de riesgo de esta naturaleza, como por ejemplo la utilización de un extintor. De modo general, otra crítica fue la falta de una necesaria y mayor participación de los potenciales moradores vinculados al proyecto y su ausencia durante la ejecución, lo que se confirmó con un porcentaje muy insatisfactorio en las tres comunidades (pregunta $6)^{63}$.

Es interesante mencionar algo constatado durante la investigación realizada en las tres comunidades de Brasil, donde algunos moradores beneficiados por el proyecto consideraron que por participar de las asambleas para discutir y deliberar sobre temas pertinentes a ellos deberían ser recompensados de alguna forma, ya que entendían que, siendo carenciados, no era de su obligación hacerlo y sí del Estado, y argumentaron que los técnicos que participaban eran remunerados. Esta concepción es una de las explicaciones de la baja participación de la mayoría de las familias en varios momentos del proyecto y del avance de éste en etapas sucesivas. Tal postura refleja la percepción de cómo se insertan y son vistos en y por la sociedad: sin reconocimiento y sin motivación para actuar de forma activa, y casi siempre vistos como un sector predispuesto a ser "ayudado" e incluido en la cuota de gastos del Estado. Tal hecho es muy semejante al observado por Abiko y Ornstein (2002, p. 122-123) en el citado Projeto AISAM, también de Salvador.

Algo que llamó la atención en los resultados encontrados en las tres comunidades fue también el alto índice de reprobación de los proyectos por parte de los moradores en lo que se refiere a la ausencia de espacios de esparcimiento/recreo (pregunta 30).

\footnotetext{
63 En contrapartida, una observación positiva se constató en la Comunidad 27 de Abril, predominantemente formada por mucamas, en la gran motivación de varias de ellas para participar de la capacitación desarrollada por el sector social de CONDER, destinada a la comisión del condominio, que ha sido institucionalizada, y de demás representantes de la comunidad. Por lo que se vio, esta práctica tiende a reforzar la calidad de vida de todos.
} 
El retraso en la entrega de las viviendas (pregunta 7), incluyendo la burocracia, fue objeto de insatisfacción en la mayoría de los encuestados de las tres comunidades. En menor escala, surgieron quejas por olor desagradable, debido a problemas con el sistema del sifón de las instalaciones sanitarias (pregunta 27), así como por obstrucción de éstas al inicio del uso de las viviendas.

Con relación a los servicios públicos, el del sistema de electricidad (pregunta 28) fue uno de los que obtuvo el más alto porcentaje de aprobación, semejante al ítem referente al fornecimiento de agua en el departamento (pregunta 11), lo que sugiere el acierto en la implantación de los sistemas construidos por CONDER y las concesionarias públicas, de las cuales no se obtuvo ningún reclamo.

En cuanto al servicio de transportes (pregunta 17), las comunidades no se posicionaron uniformemente, pues, la de 27 de Abril, que posee una estación de autobús próxima (cerca de 200 metros), aprobó satisfactoriamente este servicio, al igual que la de Costa Azul, mientras que la de Perseverança, que está ubicada en la parte baja de un cerro, por donde no transitan autobuses, resultó en desaprobación. Una situación semejante ocurrió en relación con el ítem que trata sobre los servicios comunitarios, como escuela, guardería, salud, policía y lugares de pago, (pregunta 32).

Sobre dispendios monetarios por parte de los moradores por causa de resarcimientos relacionados a la financiación del inmueble, se constató que en la primera etapa de la comunidad del barrio Costa Azul, cuyo proyecto es el más antiguo, dadas las circunstancias políticas de la década pasada, los adquirentes no obtuvieron la actual exención de pago que los nuevos proyectos extienden a los moradores de VIS. Aun así, fue muy bajo el índice de respuestas de esa primera etapa que reclamaron de los cerca de $\mathrm{R} \$ 60$ pagados mensualmente por la financiación del inmueble (pregunta 20).

También se observó que el sistema de comunicación por portero eléctrico entre departamentos de un mismo bloque residencial fue insatisfactorio, ya que carece de él por no contar en el proyecto original, lo que explica que 141 encuestados hayan informado que no poseían ningún tipo de portero eléctrico, motivo por lo cual muchos de ellos argumentaron sobre la necesidad de que el dispositivo hubiera debido ser implantado antes de la entrega de los departamentos.

Si en la última pregunta, la número 33, se obtienen índices bajísimos en las respuestas en relación a la pretensión de venta del inmueble, tal ítem trae subyacente un fenómeno no suficientemente discutido y que se debe al "contrato de 
cajón", el que, a pesar de que huya del objetivo propuesto para esta investigación, no deja de ser importante y necesario en la reflexión de todos los entes e instituciones que trabajan con el tema de VIS, cabiendo al Estado brasileño hacer cumplir lo que establecen los artículos 182 y 183 de la Constitución vigente desde 1988. El tema del "contrato de cajón" es uno de los conocidos problemas verificados comúnmente en varios proyectos habitacionales de VIS en Brasil, y es muy recurrente: el fenómeno del "se pasa una casa", fenómeno en el que, por motivos diferentes -distancia de la residencia de los lugares de oportunidades, expansión de la familia y poco espacio, entre otras insatisfacciones-, la familia negocia informalmente el inmueble adquirido. Este problema, muy común en toda América Latina, tiene que ver, también, con la lógica de la "vivienda mínima", que debe ser repensada, considerando que la misma sufrió desvíos en su aplicación y gerencia, acabando por contribuir con la expansión de las construcciones informales desordenadas. Otro problema importante es el de la ocupación y uso indebido de espacios colectivos de forma privada. Algunos autores argumentan como justificativa para esta práctica el hecho de que, de modo general, las personas tienden a empeñarse a cuidar lo mejor posible espacios "claramente delineados e identificables como de su propiedad", volviéndose omisas en relación con los que son colectivos. Esta constatación ha sido también percibida por este doctorando en el desarrollo de esta tesis, así como lo hicieron en su investigación Abiko y Ornstein (2001, 215-216).

5.3 - Análisis de los resultados de la Encuesta Tipo 1 en las comunidades de CABA

Al igual como ocurrió con el tratamiento de las informaciones producidas en Brasil, este tópico presenta esencialmente, basado en diversos cuadros y tablas, los resultados de las respuestas de los moradores y líderes de las tres comunidades investigadas en Argentina, así como sus opiniones, generalidades, críticas y sugerencias al respecto de los proyectos, según lo propuesto en la Encuesta Tipo1.

\subsection{1 - Perfil sociodemográfico de las comunidades de CABA}

Se construyó un cuadro para cada una de las tres comunidades investigadas en Argentina, abordando los aspectos sociodemográficos -edad, género, nivel de escolaridad, ocupación profesional, cantidad de ocupantes de la morada, 
presupuesto mensual familiar-, tiempo de ocupación en el inmueble, piso del departamento, disposición de vivir en construcción en altura y pretensión de deshacerse de la propiedad. Los datos están en los Cuadros 5.10, 5.11 y 5.12.

Cuadro 5.10 - Perfil de la Comunidad Parque Patricios/Monteagudo

\begin{tabular}{|c|c|c|c|c|c|c|c|c|c|c|c|}
\hline It. & $\mathbf{A}$ & B & C & $\mathbf{D}$ & $\mathbf{E}$ & $\mathbf{F}$ & $\mathbf{G}$ & H (SM) & I & $J$ & $\mathbf{K}$ \\
\hline 01 & $\mathrm{Ni}$ & $\mathrm{Ni}$ & $\mathrm{Ni}$ & $\mathrm{Ni}$ & $\mathrm{Ni}$ & e & $d$ & $\mathrm{Ni}$ & $\mathrm{C}$ & a & e \\
\hline 02 & $\mathrm{Ni}$ & $\mathrm{Ni}$ & $\mathrm{Ni}$ & $\mathrm{Ni}$ & $\mathrm{Ni}$ & $\mathrm{e}$ & $d$ & $\mathrm{Ni}$ & $a$ & $\bar{a}$ & $\bar{d}$ \\
\hline 03 & $\mathrm{Ni}$ & $\mathrm{Ni}$ & $\mathrm{Ni}$ & $\mathrm{Ni}$ & $\mathrm{Ni}$ & e & $d$ & $\mathrm{Ni}$ & $a$ & a & e \\
\hline 04 & $\mathrm{~F}$ & 37 & $7^{\circ}$ (Primario) & Ama de casa & 5 & $\mathrm{e}$ & $\mathrm{b}$ & $0,58 \mathrm{SM}$ & $\mathrm{d}$ & a & $\mathrm{d}$ \\
\hline 05 & $F$ & 65 & Secundario & Jubilada & 2 & $\mathrm{e}$ & $a$ & $0,72 \mathrm{SM}$ & $\mathrm{e}$ & $\bar{a}$ & $\bar{e}$ \\
\hline 06 & $F$ & 61 & Primario & Autónoma & 2 & $\mathrm{e}$ & $\mathrm{b}$ & $0,78 \mathrm{SM}$ & $a$ & $\bar{a}$ & $\bar{e}$ \\
\hline 07 & $F$ & 59 & Primario & Ama de casa & 3 & $\mathrm{e}$ & $a$ & $0,78 \mathrm{SM}$ & $d$ & $\bar{a}$ & $\bar{a}$ \\
\hline 08 & $F$ & 43 & Primario & Ama de casa & 8 & $\mathrm{e}$ & $\mathrm{d}$ & $1,16 \mathrm{SM}$ & $a$ & $\bar{a}$ & $\bar{d}$ \\
\hline 09 & $\mathrm{M}$ & 67 & Primario & Jubilado & 2 & $\mathrm{e}$ & $a$ & $0,72 \mathrm{SM}$ & $a$ & a & $\bar{d}$ \\
\hline 10 & $\mathrm{M}$ & 58 & Secundario & Autónomo & 4 & $\mathrm{e}$ & $\mathrm{a}$ & $0,58 \mathrm{SM}$ & $\mathrm{C}$ & a & $\mathrm{a}$ \\
\hline 11 & $\mathrm{M}$ & 42 & Secundario & Comerciante & 4 & $\mathrm{e}$ & $d$ & $1,36 \mathrm{SM}$ & $a$ & $\bar{a}$ & $\overline{\mathrm{e}}$ \\
\hline 12 & $\mathrm{~F}$ & 40 & Tercer grado & Empleado adm. & 3 & $\mathrm{e}$ & $\mathrm{C}$ & $2,91 \mathrm{SM}$ & $\mathrm{a}$ & a & $\mathrm{e}$ \\
\hline 13 & $\mathrm{M}$ & 37 & Primario & Autónomo & 4 & $\mathrm{e}$ & $\mathrm{C}$ & $1,16 \mathrm{SM}$ & $a$ & a & $\mathrm{C}$ \\
\hline 14 & $\mathrm{~F}$ & 38 & $7^{\circ}$ (Primario) & Operaria de limpieza & 8 & $\mathrm{e}$ & $\mathrm{b}$ & $0,62 \mathrm{SM}$ & $\mathrm{b}$ & $d$ & $\mathrm{~b}$ \\
\hline 15 & $\mathrm{M}$ & 68 & Secundario & Jubilado & 5 & $\mathrm{e}$ & $\mathrm{b}$ & $0,71 \mathrm{SM}$ & $\mathrm{d}$ & a & $\mathrm{d}$ \\
\hline 16 & $\mathrm{~F}$ & 47 & $\mathrm{Ni}$ & Portera & 8 & $\mathrm{e}$ & $\mathrm{C}$ & $1,55 \mathrm{SM}$ & $a$ & a & $\mathrm{e}$ \\
\hline 17 & $\mathrm{M}$ & 47 & Tercer grado & Camionero & 4 & $\mathrm{e}$ & $\mathrm{C}$ & $2,33 \mathrm{SM}$ & $a$ & $a$ & a \\
\hline 18 & $\mathrm{~F}$ & 70 & Sin estudio & Ama de casa & 3 & 3 & $\mathrm{~b}$ & $0,58 \mathrm{SM}$ & $d$ & a & $\mathrm{e}$ \\
\hline 19 & $\mathrm{~F}$ & 21 & Secundario & Ama de casa & 8 & $\mathrm{e}$ & $\mathrm{C}$ & $1,36 \mathrm{SM}$ & $a$ & $a$ & $\mathrm{e}$ \\
\hline 20 & $\mathrm{~F}$ & 36 & Secundario & Ama de casa & 4 & $a$ & $\mathrm{e}$ & $0,89 S M$ & $d$ & a & $\mathrm{d}$ \\
\hline 21 & $\mathrm{~F}$ & 45 & Tercer grado & Ama de casa & 5 & e & $a$ & $0,78 \mathrm{SM}$ & $a$ & a & $\bar{d}$ \\
\hline 22 & $\mathrm{~F}$ & 44 & Tercer grado & Ama de casa & 4 & e & $d$ & $0,78 \mathrm{SM}$ & e & a & $\mathrm{e}$ \\
\hline 23 & $\mathrm{Ni}$ & $\mathrm{Ni}$ & $\mathrm{Ni}$ & $\mathrm{Ni}$ & $\mathrm{Ni}$ & $\mathrm{e}$ & $d$ & $\mathrm{Ni}$ & $a$ & $a$ & $\mathrm{~d}$ \\
\hline 24 & $\mathrm{~F}$ & 42 & Secundario & Empleada & 2 & e & $d$ & $1,36 \mathrm{SM}$ & $d$ & a & $\mathrm{e}$ \\
\hline 25 & $\mathrm{Ni}$ & $\mathrm{Ni}$ & $\mathrm{Ni}$ & $\mathrm{Ni}$ & $\mathrm{Ni}$ & $\mathrm{e}$ & $\mathrm{C}$ & $\mathrm{Ni}$ & $\mathrm{b}$ & $a$ & $\mathrm{C}$ \\
\hline 26 & $\mathrm{Ni}$ & $\mathrm{Ni}$ & $\mathrm{Ni}$ & $\mathrm{Ni}$ & $\mathrm{Ni}$ & e & $\mathrm{C}$ & $\mathrm{Ni}$ & $\mathrm{C}$ & $\mathrm{a}$ & $\mathrm{d}$ \\
\hline 27 & $\mathrm{Ni}$ & $\mathrm{Ni}$ & $\mathrm{Ni}$ & $\mathrm{Ni}$ & $\mathrm{Ni}$ & $\mathrm{e}$ & $\mathrm{C}$ & $\mathrm{Ni}$ & $a$ & a & $\mathrm{a}$ \\
\hline 28 & $\mathrm{Ni}$ & $\mathrm{Ni}$ & $\mathrm{Ni}$ & $\mathrm{Ni}$ & $\mathrm{Ni}$ & $\mathrm{e}$ & $\mathrm{C}$ & $\mathrm{Ni}$ & $a$ & $\mathrm{a}$ & $\mathrm{e}$ \\
\hline 29 & $\mathrm{Ni}$ & $\mathrm{Ni}$ & $\mathrm{Ni}$ & $\mathrm{Ni}$ & $\mathrm{Ni}$ & $\mathrm{e}$ & $\mathrm{d}$ & $\mathrm{Ni}$ & $\mathrm{b}$ & a & $\mathrm{C}$ \\
\hline 30 & $\mathrm{Ni}$ & $\mathrm{Ni}$ & $\mathrm{Ni}$ & $\mathrm{Ni}$ & $\mathrm{Ni}$ & $\mathrm{e}$ & $\mathrm{C}$ & $\mathrm{Ni}$ & $a$ & $a$ & $\mathrm{e}$ \\
\hline
\end{tabular}




\begin{tabular}{|c|c|c|c|c|c|c|c|c|c|c|c|}
\hline 31 & $\mathrm{Ni}$ & $\mathrm{Ni}$ & $\mathrm{Ni}$ & $\mathrm{Ni}$ & $\mathrm{Ni}$ & e & $b$ & $\mathrm{Ni}$ & $\mathrm{b}$ & a & d \\
\hline 32 & $\mathrm{Ni}$ & $\mathrm{Ni}$ & $\mathrm{Ni}$ & $\mathrm{Ni}$ & $\mathrm{Ni}$ & e & $\mathrm{C}$ & $\mathrm{Ni}$ & $a$ & a & d \\
\hline 33 & $\mathrm{Ni}$ & $\mathrm{Ni}$ & $\mathrm{Ni}$ & $\mathrm{Ni}$ & $\mathrm{Ni}$ & e & $\mathrm{d}$ & $\mathrm{Ni}$ & $\mathrm{b}$ & a & $\mathrm{e}$ \\
\hline 34 & $\mathrm{Ni}$ & $\mathrm{Ni}$ & $\mathrm{Ni}$ & $\mathrm{Ni}$ & $\mathrm{Ni}$ & e & $d$ & $\mathrm{Ni}$ & $\mathrm{C}$ & a & d \\
\hline 35 & $\mathrm{Ni}$ & $\mathrm{Ni}$ & $\mathrm{Ni}$ & $\mathrm{Ni}$ & $\mathrm{Ni}$ & $\mathrm{e}$ & $\mathrm{d}$ & $\mathrm{Ni}$ & $a$ & $\bar{a}$ & $\bar{d}$ \\
\hline 36 & $\mathrm{Ni}$ & $\mathrm{Ni}$ & $\mathrm{Ni}$ & $\mathrm{Ni}$ & $\mathrm{Ni}$ & e & $a$ & $\mathrm{Ni}$ & $d$ & a & d \\
\hline 37 & $\mathrm{~F}$ & 52 & Secundario & Vendedora & 5 & $\bar{e}$ & $\mathrm{a}$ & $1,55 \mathrm{SM}$ & C & $\bar{a}$ & $\bar{a}$ \\
\hline 38 & $\mathrm{Ni}$ & $\mathrm{Ni}$ & $\mathrm{Ni}$ & $\mathrm{Ni}$ & $\mathrm{Ni}$ & $\mathrm{e}$ & $\mathrm{d}$ & $\mathrm{Ni}$ & $a$ & $\bar{a}$ & $\bar{d}$ \\
\hline 39 & $\mathrm{Ni}$ & $\mathrm{Ni}$ & $\mathrm{Ni}$ & $\mathrm{Ni}$ & $\mathrm{Ni}$ & e & $\mathrm{d}$ & $\mathrm{Ni}$ & $\mathrm{b}$ & $\bar{a}$ & $\bar{C}$ \\
\hline 40 & $\mathrm{Ni}$ & $\mathrm{Ni}$ & $\mathrm{Ni}$ & $\mathrm{Ni}$ & $\mathrm{Ni}$ & e & $\mathrm{d}$ & $\mathrm{Ni}$ & $d$ & $\bar{a}$ & $\bar{d}$ \\
\hline 41 & $\mathrm{Ni}$ & $\mathrm{Ni}$ & $\mathrm{Ni}$ & $\mathrm{Ni}$ & $\mathrm{Ni}$ & $\mathrm{e}$ & $\mathrm{d}$ & $\mathrm{Ni}$ & $a$ & $\bar{a}$ & $\bar{C}$ \\
\hline 42 & $\mathrm{Ni}$ & $\mathrm{Ni}$ & $\mathrm{Ni}$ & $\mathrm{Ni}$ & $\mathrm{Ni}$ & e & $\mathrm{d}$ & $\mathrm{Ni}$ & $a$ & $a$ & $\mathrm{C}$ \\
\hline 43 & $\mathrm{Ni}$ & $\mathrm{Ni}$ & $\mathrm{Ni}$ & $\mathrm{Ni}$ & $\mathrm{Ni}$ & $\mathrm{e}$ & $\mathrm{d}$ & $\mathrm{Ni}$ & $a$ & $a$ & $\mathrm{e}$ \\
\hline 44 & $\mathrm{Ni}$ & $\mathrm{Ni}$ & $\mathrm{Ni}$ & $\mathrm{Ni}$ & $\mathrm{Ni}$ & e & $\mathrm{d}$ & $\mathrm{Ni}$ & $a$ & $\bar{a}$ & $\bar{e}$ \\
\hline 45 & $\mathrm{Ni}$ & $\mathrm{Ni}$ & $\mathrm{Ni}$ & $\mathrm{Ni}$ & $\mathrm{Ni}$ & $\mathrm{e}$ & $\mathrm{b}$ & $\mathrm{Ni}$ & $b$ & a & $\mathrm{d}$ \\
\hline 46 & $\mathrm{Ni}$ & $\mathrm{Ni}$ & $\mathrm{Ni}$ & $\mathrm{Ni}$ & $\mathrm{Ni}$ & e & $\mathrm{C}$ & $\mathrm{Ni}$ & $\mathrm{C}$ & $\bar{a}$ & $\bar{e}$ \\
\hline 47 & $\mathrm{Ni}$ & $\mathrm{Ni}$ & $\mathrm{Ni}$ & $\mathrm{Ni}$ & $\mathrm{Ni}$ & $\mathrm{e}$ & $b$ & $\mathrm{Ni}$ & $b$ & a & $\mathrm{C}$ \\
\hline 48 & $\mathrm{Ni}$ & $\mathrm{Ni}$ & $\mathrm{Ni}$ & $\mathrm{Ni}$ & $\mathrm{Ni}$ & $\mathrm{e}$ & $\mathrm{d}$ & $\mathrm{Ni}$ & $\mathrm{C}$ & a & $\mathrm{d}$ \\
\hline 49 & $\mathrm{Ni}$ & $\mathrm{Ni}$ & $\mathrm{Ni}$ & $\mathrm{Ni}$ & $\mathrm{Ni}$ & $\mathrm{e}$ & $\mathrm{C}$ & $\mathrm{Ni}$ & $a$ & a & $\mathrm{d}$ \\
\hline 50 & $\mathrm{Ni}$ & $\mathrm{Ni}$ & $\mathrm{Ni}$ & $\mathrm{Ni}$ & $\mathrm{Ni}$ & e & $\mathrm{b}$ & $\mathrm{Ni}$ & $\mathrm{b}$ & a & $\mathrm{e}$ \\
\hline 51 & $\mathrm{Ni}$ & $\mathrm{Ni}$ & $\mathrm{Ni}$ & $\mathrm{Ni}$ & $\mathrm{Ni}$ & $\mathrm{e}$ & $\mathrm{d}$ & $\mathrm{Ni}$ & $\mathrm{C}$ & $a$ & $\mathrm{e}$ \\
\hline 52 & $\mathrm{Ni}$ & $\mathrm{Ni}$ & $\mathrm{Ni}$ & $\mathrm{Ni}$ & $\mathrm{Ni}$ & $\mathrm{e}$ & $\mathrm{d}$ & $\mathrm{Ni}$ & $\mathrm{b}$ & a & $\mathrm{e}$ \\
\hline 53 & $\mathrm{Ni}$ & $\mathrm{Ni}$ & $\mathrm{Ni}$ & $\mathrm{Ni}$ & $\mathrm{Ni}$ & $\mathrm{e}$ & $\mathrm{d}$ & $\mathrm{Ni}$ & $a$ & a & $\mathrm{e}$ \\
\hline 54 & $F$ & 46 & Ate de enfermería & $\mathrm{Ni}$ & 4 & e & $\mathrm{C}$ & $1,16 \mathrm{SM}$ & $\mathrm{d}$ & a & a \\
\hline 55 & $\mathrm{~F}$ & 38 & Secundario & Empleada doméstica & 4 & $\mathrm{e}$ & $\mathrm{C}$ & 1,36 & $\mathrm{~d}$ & $a$ & $\mathrm{a}$ \\
\hline 56 & $\mathrm{Ni}$ & $\mathrm{Ni}$ & $\mathrm{Ni}$ & $\mathrm{Ni}$ & $\mathrm{Ni}$ & e & $\mathrm{d}$ & $\mathrm{Ni}$ & $a$ & a & $\mathrm{e}$ \\
\hline 57 & $\mathrm{Ni}$ & $\mathrm{Ni}$ & $\mathrm{Ni}$ & $\mathrm{Ni}$ & $\mathrm{Ni}$ & e & $\mathrm{C}$ & $\mathrm{Ni}$ & $\mathrm{C}$ & $a$ & $\mathrm{a}$ \\
\hline 58 & $\mathrm{~F}$ & 40 & $7^{\circ}$ (Primario) & Ama de casa & 4 & e & $\mathrm{a}$ & $0,97 \mathrm{SM}$ & $\mathrm{d}$ & a & $\mathrm{d}$ \\
\hline 59 & $\mathrm{Ni}$ & $\mathrm{Ni}$ & Secundario & $\mathrm{Ni}$ & $\mathrm{Ni}$ & $\mathrm{e}$ & $\mathrm{d}$ & $\mathrm{Ni}$ & $\mathrm{a}$ & $a$ & $\mathrm{e}$ \\
\hline 60 & $\mathrm{Ni}$ & $\mathrm{Ni}$ & $\mathrm{Ni}$ & $\mathrm{Ni}$ & $\mathrm{Ni}$ & $\mathrm{e}$ & $\mathrm{d}$ & $\mathrm{Ni}$ & $\mathrm{d}$ & a & a \\
\hline 61 & $\mathrm{Ni}$ & $\mathrm{Ni}$ & $\mathrm{Ni}$ & $\mathrm{Ni}$ & $\mathrm{Ni}$ & $\mathrm{e}$ & $\mathrm{Ni}$ & $\mathrm{Ni}$ & $b$ & $a$ & $\mathrm{a}$ \\
\hline 62 & $\mathrm{Ni}$ & $\mathrm{Ni}$ & $\mathrm{Ni}$ & $\mathrm{Ni}$ & $\mathrm{Ni}$ & $\mathrm{e}$ & $\mathrm{d}$ & $\mathrm{Ni}$ & $a$ & a & e \\
\hline 63 & $\mathrm{Ni}$ & $\mathrm{Ni}$ & $\mathrm{Ni}$ & $\mathrm{Ni}$ & $\mathrm{Ni}$ & $\mathrm{e}$ & $\mathrm{d}$ & $\mathrm{Ni}$ & $b$ & a & $\bar{d}$ \\
\hline 64 & $\mathrm{Ni}$ & $\mathrm{Ni}$ & $\mathrm{Ni}$ & $\mathrm{Ni}$ & $\mathrm{Ni}$ & $\mathrm{e}$ & $\mathrm{d}$ & $\mathrm{Ni}$ & $\mathrm{d}$ & a & $\mathrm{e}$ \\
\hline 65 & $\mathrm{Ni}$ & $\mathrm{Ni}$ & $\mathrm{Ni}$ & $\mathrm{Ni}$ & $\mathrm{Ni}$ & e & $a$ & $\mathrm{Ni}$ & $\mathrm{d}$ & $a$ & $\mathrm{e}$ \\
\hline 66 & $\mathrm{Ni}$ & $\mathrm{Ni}$ & $\mathrm{Ni}$ & $\mathrm{Ni}$ & $\mathrm{Ni}$ & $\mathrm{e}$ & $a$ & $\mathrm{Ni}$ & $a$ & a & $\mathrm{e}$ \\
\hline 67 & $\mathrm{M}$ & 44 & $2^{\circ}$ (Secundario) & "Cajonero"/Vendedor & 8 & $\mathrm{e}$ & $\mathrm{d}$ & $1,36 \mathrm{SM}$ & $\mathrm{d}$ & $a$ & $\mathrm{e}$ \\
\hline 68 & $\mathrm{M}$ & 68 & $2^{\circ}$ (Secundario) & Albañil & 2 & e & $a$ & $0,97 \mathrm{SM}$ & $a$ & $a$ & $\mathrm{e}$ \\
\hline
\end{tabular}




\begin{tabular}{|cccccccccccc|}
\hline 69 & $\mathrm{~F}$ & $\mathrm{Ni}$ & $3^{\circ}$ (Secundario) & Ama de casa & 4 & $\mathrm{e}$ & $\mathrm{d}$ & $0,29 \mathrm{SM}$ & $\mathrm{d}$ & $\mathrm{a}$ & $\mathrm{e}$ \\
\hline 70 & $\mathrm{~F}$ & 42 & $3^{\circ}$ (Secundario) & Trabajo doméstico & 6 & $\mathrm{e}$ & $\mathrm{b}$ & $0,97 \mathrm{SM}$ & $\mathrm{d}$ & $\mathrm{a}$ & $\mathrm{a}$ \\
\hline 71 & $\mathrm{~F}$ & 46 & Secundario & Ama de casa & $\mathrm{Ni}$ & $\mathrm{e}$ & $\mathrm{c}$ & $\mathrm{Ni}$ & $\mathrm{b}$ & $\mathrm{a}$ & $\mathrm{a}$ \\
\hline 72 & $\mathrm{Ni}$ & $\mathrm{Ni}$ & $\mathrm{Ni}$ & $\mathrm{Ni}$ & $\mathrm{Ni}$ & $\mathrm{e}$ & $\mathrm{a}$ & $\mathrm{Ni}$ & $\mathrm{b}$ & $\mathrm{a}$ & $\mathrm{c}$ \\
\hline 73 & $\mathrm{M}$ & 50 & Universitario & Construcción & 3 & $\mathrm{e}$ & $\mathrm{c}$ & $1,36 \mathrm{SM}$ & $\mathrm{e}$ & $\mathrm{a}$ & $\mathrm{a}$ \\
\hline 74 & $\mathrm{Ni}$ & $\mathrm{Ni}$ & $\mathrm{Ni}$ & $\mathrm{Ni}$ & $\mathrm{Ni}$ & $\mathrm{e}$ & $\mathrm{a}$ & $\mathrm{Ni}$ & $\mathrm{a}$ & $\mathrm{a}$ & $\mathrm{d}$ \\
\hline 75 & $\mathrm{Ni}$ & $\mathrm{Ni}$ & $\mathrm{Ni}$ & $\mathrm{Ni}$ & $\mathrm{Ni}$ & $\mathrm{e}$ & $\mathrm{Ni}$ & $\mathrm{Ni}$ & $\mathrm{a}$ & $\mathrm{a}$ & $\mathrm{e}$ \\
\hline
\end{tabular}

Fecha: julio de 2017. Leyenda: It.: Ítem; A: Sexo (M: Masculino, F: Femenino), B: Edad del encuestado, C: Grado de escolaridad, D: Ocupación profesional, E: Cantidad de ocupantes de la vivienda, $\mathrm{F}$ : Tiempo en años en que vive en la vivienda (a: +- 1 año, b: +- 2 años, c: +3 años, d: +- 4 años, e: +- 5 años o más), G: Piso en que la vivienda está ubicada (a: planta baja, b: $1^{\circ}$ piso, c: $2^{\circ}$ piso, d: $3^{\circ}$ piso, e: $4^{\circ}$ piso, $\mathrm{e}^{*}: 5^{\circ}$ piso o más arriba), $\mathrm{H}$ : Presupuesto mensual familiar (SM R\$; \$ (peso argentino); U\$), I: Satisfacción de vivir en edificio en altura (a: definitivamente no, b: muy poco, c: poco, d: mucho, e: muchísimo), J: Pretensión de comercializar (alquilar/vender) la vivienda (a: definitivamente no, b: muy poco, c: tal vez, d: probablemente, e: con certeza, K: Concordancia con la validad de la Ley 962 de 2002 de CABA, la cual obliga la implantación de ascensor en edificios con más de 3 pisos (a: definitivamente no, b: muy poco, c: poco, d: mucho, e: muchísimo), Ni: No Informado por el encuestado, SR: Sin Rendimiento. El valor de SM en Argentina vigente en los periodos entre enero a julio y agosto a diciembre de 2015 fue de $\$ 4.716$ y \$ ARS 5.588 respectivamente, motivo por el cual en esta tabla se registra la media aritmética de ambos períodos: \$ 5.152. Correspondían en Dólares EEUU a U\$ 546 y U\$ 601, respectivamente, según cambio conforme BANCO CENTRAL DE LA REPÚBLICA ARGENTINA ([s/f]).

\section{Cuadro 5.11 - Perfil de la Comunidad del Complejo Luzuriaga}

\begin{tabular}{|cccccccccccc}
\hline Ít. & $\mathbf{A}$ & $\mathbf{B}$ & $\mathbf{C}$ & $\mathbf{D}$ & $\mathbf{E}$ & $\mathbf{F}$ & $\mathbf{G}$ & $\mathbf{H}(\mathbf{S M})$ & $\mathbf{I}$ & $\mathbf{K}$ \\
\hline 01 & $\mathrm{M}$ & 27 & Secundario & Cocinero & 4 & $\mathrm{a}$ & $\mathrm{c}$ & $1,36 \mathrm{SM}$ & $\mathrm{c}$ & $\mathrm{a}$ & $\mathrm{d}$ \\
\hline 02 & $\mathrm{~F}$ & 48 & Secundario & Empleada doméstica & 11 & $\mathrm{c}$ & $\mathrm{c}$ & $0,68 \mathrm{SM}$ & $\mathrm{a}$ & $\mathrm{a}$ & $\mathrm{d}$ \\
\hline 03 & $\mathrm{M}$ & 65 & $7^{\circ}$ (Primario) & $\mathrm{Ni}$ & 3 & $\mathrm{a}$ & $\mathrm{a}$ & $\mathrm{Ni}$ & $\mathrm{c}$ & $\mathrm{a}$ & $\mathrm{e}$ \\
\hline 04 & $\mathrm{~F}$ & 37 & Tercer grado & Docente & 2 & $\mathrm{a}$ & $\mathrm{b}$ & $\mathrm{Ni}$ & $\mathrm{a}$ & $\mathrm{e}$ & $\mathrm{d}$ \\
\hline 05 & $\mathrm{~F}$ & 43 & Primario & Comerciante & 3 & $\mathrm{a}$ & $\mathrm{a}$ & $0,97 \mathrm{SM}$ & $\mathrm{a}$ & $\mathrm{c}$ & $\mathrm{e}$ \\
\hline 06 & $\mathrm{~F}$ & 24 & $4^{\circ}$ (Secundario) & Desocupada & 3 & $\mathrm{a}$ & $\mathrm{b}$ & $\mathrm{Ni}$ & $\mathrm{a}$ & $\mathrm{a}$ & $\mathrm{e}$ \\
\hline 07 & $\mathrm{Ni}$ & $\mathrm{Ni}$ & $\mathrm{Ni}$ & $\mathrm{Ni}$ & $\mathrm{a}$ & $\mathrm{c}$ & $\mathrm{Ni}$ & $\mathrm{d}$ & $\mathrm{a}$ & $\mathrm{e}$ \\
\hline 08 & $\mathrm{M}$ & 23 & $2^{\circ}$ (Secundario) & Desocupado & 3 & $\mathrm{a}$ & $\mathrm{d}$ & $\mathrm{Ni}$ & $\mathrm{d}$ & $\mathrm{a}$ & $\mathrm{e}$ \\
\hline 09 & $\mathrm{~F}$ & 40 & Secundario & Empleada & $\mathrm{Ni}$ & $\mathrm{a}$ & $\mathrm{e}$ & $0,97 \mathrm{SM}$ & $\mathrm{d}$ & $\mathrm{a}$ & $\mathrm{e}$ \\
\hline 10 & $\mathrm{Ni}$ & $\mathrm{Ni}$ & $\mathrm{Ni}$ & $\mathrm{Ni}$ & $\mathrm{a}$ & $\mathrm{c}$ & $\mathrm{Ni}$ & $\mathrm{c}$ & $\mathrm{c}$ & $\mathrm{d}$ \\
\hline 11 & $\mathrm{Ni}$ & $\mathrm{Ni}$ & $\mathrm{Ni}$ & $\mathrm{Ni}$ & $\mathrm{a}$ & $\mathrm{d}$ & $\mathrm{Ni}$ & $\mathrm{d}$ & $\mathrm{a}$ & $\mathrm{a}$ \\
\hline 12 & $\mathrm{Ni}$ & $\mathrm{Ni}$ & $\mathrm{Ni}$ & $\mathrm{Ni}$ & $\mathrm{Ni}$ & $\mathrm{a}$ & $\mathrm{d}$ & $\mathrm{Ni}$ & $\mathrm{b}$ & $\mathrm{c}$ & $\mathrm{d}$ \\
\hline 13 & $\mathrm{~F}$ & 63 & $2^{\circ}$ (Primario) & Ama de casa & $\mathrm{Ni}$ & $\mathrm{a}$ & $\mathrm{a}$ & $0,49 S M$ & $\mathrm{a}$ & $\mathrm{d}$ & $\mathrm{e}$ \\
\hline 14 & $\mathrm{~F}$ & 57 & $7^{\circ}$ (Primario) & Ama de casa & 2 & $\mathrm{a}$ & $\mathrm{c}$ & $0,58 S M$ & $\mathrm{a}$ & $\mathrm{c}$ & $\mathrm{e}$ \\
\hline 15 & $\mathrm{M}$ & 47 & Secundario & Operario & 4 & $\mathrm{a}$ & $\mathrm{d}$ & $0,19 S M$ & $\mathrm{~d}$ & $\mathrm{a}$ & $\mathrm{a}$ \\
\hline
\end{tabular}




\begin{tabular}{|c|c|c|c|c|c|c|c|c|c|c|c|}
\hline 16 & $\mathrm{Ni}$ & $\mathrm{Ni}$ & $\mathrm{Ni}$ & $\mathrm{Ni}$ & $\mathrm{Ni}$ & $a$ & $d$ & $\mathrm{Ni}$ & C & $a$ & $d$ \\
\hline 17 & $\mathrm{Ni}$ & $\mathrm{Ni}$ & $\mathrm{Ni}$ & $\mathrm{Ni}$ & $\mathrm{Ni}$ & $a$ & $\mathrm{e}$ & $\mathrm{Ni}$ & $\mathrm{c}$ & $a$ & $\mathrm{e}$ \\
\hline 18 & $\mathrm{Ni}$ & $\mathrm{Ni}$ & $\mathrm{Ni}$ & $\mathrm{Ni}$ & $\mathrm{Ni}$ & $a$ & $d$ & $\mathrm{Ni}$ & $\mathrm{a}$ & $a$ & $d$ \\
\hline 19 & $\mathrm{Ni}$ & $\mathrm{Ni}$ & $\mathrm{Ni}$ & $\mathrm{Ni}$ & $\mathrm{Ni}$ & $a$ & $\mathrm{e}$ & $\mathrm{Ni}$ & $\mathrm{d}$ & $a$ & $d$ \\
\hline 20 & $\mathrm{Ni}$ & $\mathrm{Ni}$ & $\mathrm{Ni}$ & $\mathrm{Ni}$ & $\mathrm{Ni}$ & $a$ & c & $\mathrm{Ni}$ & $\mathrm{b}$ & $a$ & $d$ \\
\hline 21 & $F$ & 39 & Universitario & Empleada pública & 2 & $a$ & $\mathrm{~b}$ & $1,46 \mathrm{SM}$ & $\mathrm{d}$ & C & $d$ \\
\hline 22 & $\mathrm{M}$ & 18 & $1^{\circ}$ (Primario) & Seguridad & 3 & $a$ & c & $0,97 \mathrm{SM}$ & $\mathrm{d}$ & $a$ & $\mathrm{e}$ \\
\hline 23 & $F$ & 24 & $2^{\circ}$ (Primario) & Ama de casa & 4 & $a$ & c & 0,87 & $\mathrm{~d}$ & $a$ & $\mathrm{e}$ \\
\hline 24 & $\mathrm{M}$ & 50 & $1^{\circ}$ (Secundario) & $\mathrm{Ni}$ & 3 & $a$ & $\mathrm{e}$ & $0,23 S M$ & $\mathrm{c}$ & c & $\mathrm{e}$ \\
\hline 25 & $\mathrm{~F}$ & 46 & Secundario & Limpieza & $\mathrm{Ni}$ & $\mathrm{a}$ & $\mathrm{b}$ & $1,55 \mathrm{SM}$ & $\mathrm{c}$ & $\mathrm{a}$ & $\mathrm{e}$ \\
\hline 26 & $\mathrm{Ni}$ & $\mathrm{Ni}$ & $\mathrm{Ni}$ & $\mathrm{Ni}$ & $\mathrm{Ni}$ & $a$ & $\mathrm{~b}$ & $\mathrm{Ni}$ & $\mathrm{d}$ & $\mathrm{a}$ & $\mathrm{e}$ \\
\hline 27 & $M$ & 36 & Primario & Operario & 2 & $a$ & $\mathrm{e}$ & $2,30 \mathrm{SM}$ & c & $\mathrm{d}$ & $\mathrm{a}$ \\
\hline 28 & $\mathrm{Ni}$ & $\mathrm{Ni}$ & $\mathrm{Ni}$ & $\mathrm{Ni}$ & $\mathrm{Ni}$ & $a$ & C & $\mathrm{Ni}$ & $\mathrm{c}$ & $a$ & $\mathrm{e}$ \\
\hline 29 & $\mathrm{Ni}$ & $\mathrm{Ni}$ & $\mathrm{Ni}$ & $\mathrm{Ni}$ & $\mathrm{Ni}$ & $a$ & C & $\mathrm{Ni}$ & $\bar{c}$ & $a$ & $\mathrm{e}$ \\
\hline 30 & $F$ & 22 & $1^{\circ}$ (Secundario) & Ama de casa & 2 & $a$ & $a$ & $0,68 \mathrm{SM}$ & $\mathrm{d}$ & $a$ & $\mathrm{e}$ \\
\hline 31 & $M$ & 43 & $7^{\circ}$ (Técnico) & Tco. aire acondicion. & 5 & $a$ & $\mathrm{e}$ & $1,55 \mathrm{SM}$ & $\mathrm{a}$ & $\mathrm{a}$ & $\mathrm{e}$ \\
\hline 32 & $M$ & 48 & Primario & Chofer & 4 & $a$ & $\mathrm{e}$ & $1,51 \mathrm{SM}$ & $\mathrm{c}$ & $\mathrm{a}$ & $\mathrm{e}$ \\
\hline 33 & $\mathrm{~F}$ & 52 & Universitario & $\mathrm{Ni}$ & 3 & $a$ & d & $1,55 \mathrm{SM}$ & $\mathrm{c}$ & $\mathrm{a}$ & $\mathrm{e}$ \\
\hline 34 & $M$ & 58 & Tercer grado & Desocupado & 2 & $a$ & $a$ & $0,49 S M$ & c & $\mathrm{a}$ & $\mathrm{e}$ \\
\hline 35 & $M$ & 42 & Secundario & Empleado & 3 & $a$ & $\mathrm{~b}$ & $1,16 \mathrm{SM}$ & $\mathrm{b}$ & $a$ & $\mathrm{~d}$ \\
\hline 36 & $\mathrm{~F}$ & 18 & $4^{\circ}$ (Secundario) & Niñera & 5 & $a$ & $\mathrm{~b}$ & $1,55 \mathrm{SM}$ & $\mathrm{d}$ & $\bar{a}$ & $\mathrm{~d}$ \\
\hline 37 & $F$ & 33 & Secundario & Ama de casa & 4 & $a$ & $d$ & $1,75 S M$ & $\mathrm{~d}$ & $\bar{a}$ & $\mathrm{e}$ \\
\hline 38 & $\mathrm{~F}$ & 27 & Secundario & Empleada & 2 & $a$ & $\mathrm{e}$ & $1,94 \mathrm{SM}$ & $\mathrm{d}$ & $\mathrm{c}$ & $\mathrm{e}$ \\
\hline 39 & $\mathrm{Ni}$ & $\mathrm{Ni}$ & $\mathrm{Ni}$ & $\mathrm{Ni}$ & $\mathrm{Ni}$ & $a$ & $\mathrm{e}$ & $\mathrm{Ni}$ & $\mathrm{d}$ & $\mathrm{a}$ & $\mathrm{d}$ \\
\hline 40 & $\mathrm{Ni}$ & $\mathrm{Ni}$ & $\mathrm{Ni}$ & $\mathrm{Ni}$ & $\mathrm{Ni}$ & $a$ & C & $\mathrm{Ni}$ & $\mathrm{a}$ & $a$ & $\mathrm{~d}$ \\
\hline 41 & $\mathrm{Ni}$ & $\mathrm{Ni}$ & $\mathrm{Ni}$ & $\mathrm{Ni}$ & $\mathrm{Ni}$ & $a$ & C & $\mathrm{Ni}$ & $\mathrm{b}$ & $\mathrm{c}$ & $d$ \\
\hline 42 & $\mathrm{Ni}$ & $\mathrm{Ni}$ & $\mathrm{Ni}$ & $\mathrm{Ni}$ & $\mathrm{Ni}$ & $a$ & C & $\mathrm{Ni}$ & $a$ & $\bar{c}$ & $\mathrm{e}$ \\
\hline 43 & $\mathrm{Ni}$ & $\mathrm{Ni}$ & $\mathrm{Ni}$ & $\mathrm{Ni}$ & $\mathrm{Ni}$ & $a$ & C & $\mathrm{Ni}$ & $\bar{a}$ & $\mathrm{c}$ & $d$ \\
\hline 44 & $F$ & 42 & $3^{\circ}$ (Secundario) & Desocupada & 1 & $a$ & $a$ & $0,50 \mathrm{SM}$ & $a$ & $a$ & $\overline{\mathrm{e}}$ \\
\hline 45 & $F$ & 46 & Secundario & Ama de casa & 2 & $a$ & $\mathrm{a}$ & $\mathrm{Ni}$ & $\mathrm{a}$ & $a$ & $\mathrm{~d}$ \\
\hline 46 & $M$ & 37 & Primario & Operario & 2 & $\mathrm{a}$ & $\mathrm{e}$ & $1,55 \mathrm{SM}$ & $\mathrm{b}$ & $a$ & $\mathrm{~d}$ \\
\hline 47 & $F$ & 36 & Tercer grado & Empleada & 4 & $\mathrm{a}$ & $\bar{c}$ & $1,01 \mathrm{SM}$ & $\mathrm{a}$ & $a$ & $\mathrm{a}$ \\
\hline 48 & $\mathrm{M}$ & 54 & Secundario & $\mathrm{Ni}$ & 2 & $\mathrm{a}$ & $\mathrm{C}$ & $2,14 \mathrm{SM}$ & $\mathrm{d}$ & $a$ & $d$ \\
\hline 49 & $F$ & 38 & Primario & Ama de casa & 2 & $a$ & $d$ & $1,94 \mathrm{SM}$ & $\mathrm{d}$ & $a$ & $d$ \\
\hline 50 & $F$ & 23 & Secundario & Ama de casa & 5 & $a$ & $\mathrm{e}$ & Plan S. & $\mathrm{d}$ & $a$ & $d$ \\
\hline 51 & $M$ & 36 & Primario & Operario & 3 & $\mathrm{a}$ & $\mathrm{e}$ & $2,33 \mathrm{SM}$ & c & $\mathrm{e}$ & $\mathrm{a}$ \\
\hline 52 & $M$ & 46 & $2^{\circ}$ (Secundario) & Sin trabajo & 2 & $\mathrm{a}$ & c & Pensión & $\mathrm{a}$ & $a$ & $\mathrm{~d}$ \\
\hline 53 & $F$ & 22 & Universitaria & Empleada & 3 & $a$ & C & $\mathrm{Ni}$ & $\mathrm{d}$ & $a$ & $\mathrm{~d}$ \\
\hline
\end{tabular}




\begin{tabular}{|c|c|c|c|c|c|c|c|c|c|c|c|}
\hline 54 & M & 23 & $4^{\circ}$ (Secundario) & Trabajos eventuales & 4 & a & c & $0,97 S M$ & a & a & $d$ \\
\hline 55 & $\mathrm{~F}$ & 63 & Primario & Cajonera & 6 & $a$ & $a$ & $\mathrm{Ni}$ & $\mathrm{a}$ & $a$ & $\mathrm{~d}$ \\
\hline 56 & $\mathrm{~F}$ & 61 & Primario & Ama de casa & 2 & $a$ & $a$ & Pensión & $a$ & $a$ & $\mathrm{~d}$ \\
\hline 57 & $\mathrm{~F}$ & 24 & Secundario & Peluquera & 3 & $\mathrm{a}$ & d & $1,55 \mathrm{SM}$ & $\mathrm{c}$ & $\mathrm{a}$ & $\mathrm{d}$ \\
\hline 58 & $\mathrm{~F}$ & 18 & Secundario & Estudia y trabaja & 4 & $a$ & $\mathrm{e}^{*}$ & $2,14 \mathrm{SM}$ & C & $a$ & $a$ \\
\hline 59 & $\mathrm{~F}$ & 46 & Primario & $\mathrm{Ni}$ & 2 & $a$ & $\bar{a}$ & $1,75 \mathrm{SM}$ & $\mathrm{a}$ & $\bar{a}$ & C \\
\hline 60 & $\mathrm{~F}$ & 34 & Secundario & Empleada & 5 & $\mathrm{a}$ & $\mathrm{b}$ & $1,16 \mathrm{SM}$ & $\mathrm{a}$ & $\mathrm{a}$ & $\mathrm{d}$ \\
\hline 61 & $\mathrm{~F}$ & 33 & Secundario & Ama de casa & 5 & $\mathrm{a}$ & $\bar{c}$ & $1,36 \mathrm{SM}$ & $\mathrm{a}$ & $\bar{a}$ & $\mathrm{~d}$ \\
\hline 62 & $\mathrm{~F}$ & 38 & Primairo & Ama de casa & 4 & $a$ & $\mathrm{e}$ & $1,55 \mathrm{SM}$ & $a$ & $\bar{a}$ & $\mathrm{~d}$ \\
\hline 63 & $\mathrm{~F}$ & 23 & Secundario & Ama de casa & 3 & $\mathrm{a}$ & $e^{*}$ & $1,55 \mathrm{SM}$ & $\mathrm{a}$ & $\bar{c}$ & $\mathrm{~d}$ \\
\hline 64 & $\mathrm{M}$ & 38 & $6^{\circ}$ (Primario) & Albañil. & 2 & $a$ & $\mathrm{e}^{*}$ & $1,16 \mathrm{SM}$ & $\mathrm{d}$ & $a$ & $a$ \\
\hline 65 & $\mathrm{~F}$ & 34 & Secundario & Ama de casa & 6 & $\mathrm{a}$ & $\mathrm{e}$ & $0,97 \mathrm{SM}$ & $\mathrm{a}$ & $\mathrm{c}$ & $\mathrm{e}$ \\
\hline 66 & $\mathrm{M}$ & 25 & Secundario, inic. & Desocupado & 3 & $a$ & $a$ & $\mathrm{Ni}$ & $\mathrm{d}$ & $\mathrm{c}$ & $\mathrm{e}$ \\
\hline 67 & $\mathrm{M}$ & 55 & Primario & Negocio & 2 & $a$ & $a$ & $0,78 \mathrm{SM}$ & $a$ & $\bar{a}$ & $\mathrm{e}$ \\
\hline 68 & $\mathrm{Ni}$ & $\mathrm{Ni}$ & $\mathrm{Ni}$ & $\mathrm{Ni}$ & $\mathrm{Ni}$ & $\mathrm{a}$ & $\mathrm{b}$ & $\mathrm{Ni}$ & c & $\mathrm{a}$ & $\mathrm{d}$ \\
\hline 69 & $\mathrm{Ni}$ & $\mathrm{Ni}$ & $\mathrm{Ni}$ & $\mathrm{Ni}$ & $\mathrm{Ni}$ & $\mathrm{a}$ & $\mathrm{d}$ & $\mathrm{Ni}$ & $\mathrm{c}$ & $\mathrm{a}$ & $\mathrm{d}$ \\
\hline 70 & $\mathrm{~F}$ & 18 & Universitario & Estudiante & 2 & $\bar{a}$ & $\mathrm{e}$ & $\mathrm{Ni}$ & $\bar{d}$ & $a$ & $\bar{d}$ \\
\hline 71 & $\mathrm{~F}$ & 19 & Tercer grado & Ama de casa & 3 & $a$ & $d$ & $2,32 \mathrm{SM}$ & $\mathrm{d}$ & $a$ & $\mathrm{~d}$ \\
\hline 72 & $\mathrm{Ni}$ & $\mathrm{Ni}$ & $\mathrm{Ni}$ & $\mathrm{Ni}$ & $\mathrm{Ni}$ & $\mathrm{a}$ & $\mathrm{d}$ & $\mathrm{Ni}$ & $\mathrm{d}$ & $\mathrm{d}$ & $\mathrm{e}$ \\
\hline 73 & $\mathrm{~F}$ & 55 & $1^{\circ}$ (Primario) & Ama de casa & 2 & $\mathrm{a}$ & $\mathrm{b}$ & $1,75 \mathrm{SM}$ & $\mathrm{d}$ & $a$ & $\mathrm{e}$ \\
\hline 74 & $\mathrm{Ni}$ & $\mathrm{Ni}$ & $\mathrm{Ni}$ & $\mathrm{Ni}$ & $\mathrm{Ni}$ & $\mathrm{a}$ & $\mathrm{b}$ & $\mathrm{Ni}$ & $\mathrm{a}$ & $a$ & $\mathrm{~d}$ \\
\hline 75 & $\mathrm{Ni}$ & $\mathrm{Ni}$ & $\mathrm{Ni}$ & $\mathrm{Ni}$ & $\mathrm{Ni}$ & $\mathrm{a}$ & $\mathrm{b}$ & $\mathrm{Ni}$ & $\mathrm{b}$ & $a$ & $\mathrm{~d}$ \\
\hline
\end{tabular}

Fecha: julio de 2017. Leyenda: It.: Ítem; A: Sexo (M: Masculino, F: Femenino), B: Edad del encuestado, C: Grado de escolaridad, D: Ocupación profesional, E: Cantidad de ocupantes de la vivienda, F: Tiempo en años en que vive en la vivienda (a: +- 1 año, b: +- 2 años, c: +3 años, d: +- 4 años, e: +- 5 años o más), G: Piso en que la vivienda está ubicada (a: planta baja, b: $1^{\circ}$ piso, c: $2^{\circ}$ piso, d: $3^{\circ}$ piso, e: $4^{\circ}$ piso, $\mathrm{e}^{*}$ : $5^{\circ}$ piso o más arriba), $\mathrm{H}$ : Presupuesto mensual familiar (SM R\$; \$ (peso argentino); U\$), I: Satisfacción de vivir en edificio en altura (a: definitivamente no, b: muy poco, c: poco, d: mucho, e: muchísimo), J: Pretensión de comercializar (alquilar/vender) la vivienda (a: definitivamente no, b: muy poco, c: tal vez, d: probablemente, e: con certeza, K: Concordancia con la validad de la Ley 962 de 2002 de CABA, la cual obliga la implantación de ascensor en edificios con más de 3 pisos (a: definitivamente no, b: muy poco, c: poco, d: mucho, e: muchísimo), Ni: No Informado por el encuestado, SR: Sin Rendimiento. El valor de SM en Argentina vigente en los periodos entre enero a julio y agosto a diciembre de 2015 fue de $\$ 4.716$ y \$ ARS 5.588 respectivamente, motivo por el cual en esta tabla se registra la media aritmética de ambos períodos: \$ 5.152. Correspondían en Dólares EEUU a U\$ 546 y U\$ 601, respectivamente, según cambio conforme BANCO CENTRAL DE LA REPÚBLICA ARGENTINA ([s/f]). 
Cuadro 5.12 - Perfil de la Comunidad del Complejo de Padre Mugica

\begin{tabular}{|c|c|c|c|c|c|c|c|c|c|c|c|}
\hline Ít. & A & B & C & D & $\mathbf{E}$ & $\mathbf{F}$ & $\mathbf{G}$ & H (SM) & I & $J$ & K \\
\hline 01 & $\mathrm{M}$ & 34 & $\mathrm{Ni}$ & Cartonero & 4 & $\mathrm{~b}$ & $\mathrm{C}$ & $0,39 \mathrm{SM}$ & d & a & $\mathrm{e}$ \\
\hline 02 & $\mathrm{~F}$ & 40 & $5^{\circ}$ (Secundario) & Vendedora & 6 & $\mathrm{~b}$ & $a$ & $1,55 \mathrm{SM}$ & d & a & d \\
\hline 03 & $\mathrm{M}$ & 50 & Primario & Construcción & 3 & $\mathrm{~b}$ & $\mathrm{C}$ & $0,58 \mathrm{SM}$ & $b$ & $c$ & $\mathrm{e}$ \\
\hline 04 & $\mathrm{M}$ & 38 & $1^{\circ}$ (Primario) & Empleado & 5 & a & e & $0,78 \mathrm{SM}$ & a & e & $\mathrm{e}$ \\
\hline 05 & $\mathrm{~F}$ & 44 & $7^{\circ}$ (Primario) & Ama de casa & 4 & a & $\mathrm{C}$ & $0,06 \mathrm{SM}$ & d & $c$ & $\mathrm{e}$ \\
\hline 06 & $\mathrm{M}$ & 53 & Secundario & Construcción & 4 & $\mathrm{~b}$ & $d$ & $\mathrm{Ni}$ & d & a & d \\
\hline 07 & $\mathrm{Ni}$ & $\mathrm{Ni}$ & $\mathrm{Ni}$ & $\mathrm{Ni}$ & $\mathrm{Ni}$ & $\mathrm{b}$ & $\mathrm{b}$ & $\mathrm{Ni}$ & $a$ & a & $\bar{C}$ \\
\hline 08 & $\mathrm{Ni}$ & $\mathrm{Ni}$ & $\mathrm{Ni}$ & $\mathrm{Ni}$ & $\mathrm{Ni}$ & $\mathrm{b}$ & $a$ & $\mathrm{Ni}$ & a & $c$ & $\mathrm{e}$ \\
\hline 09 & $\mathrm{~F}$ & 29 & $7^{\circ}$ (Primario) & Ama de casa & 6 & a & e & $0,23 S M$ & a & a & $\mathrm{e}$ \\
\hline 10 & $\mathrm{M}$ & 24 & Secundario & Cooperativista & 4 & $\mathrm{~b}$ & $\mathrm{~b}$ & $0,46 \mathrm{SM}$ & a & a & $\mathrm{e}$ \\
\hline 11 & $\mathrm{M}$ & 29 & $7^{\circ}$ (Primario) & $\mathrm{Ni}$ & 8 & $\mathrm{~b}$ & $d$ & $0,39 S M$ & b & d & $\mathrm{e}$ \\
\hline 12 & $\mathrm{M}$ & 41 & Secundario & Oficial albañil & 3 & $\mathrm{~b}$ & $d$ & $0,78 \mathrm{SM}$ & d & d & e \\
\hline 13 & $\mathrm{~F}$ & 21 & $5^{\circ}$ (Primario) & Ama de casa & 3 & $\mathrm{~b}$ & $\mathrm{~b}$ & $0,39 S M$ & a & $c$ & $\mathrm{e}$ \\
\hline 14 & $\mathrm{M}$ & 45 & Secundaria & Obrero & 6 & $\mathrm{C}$ & $\mathrm{C}$ & $0,97 \mathrm{SM}$ & a & a & $\mathrm{C}$ \\
\hline 15 & $\mathrm{Ni}$ & $\mathrm{Ni}$ & $\mathrm{Ni}$ & $\mathrm{Ni}$ & $\mathrm{Ni}$ & $\mathrm{C}$ & $a$ & $\mathrm{Ni}$ & a & e & a \\
\hline 16 & $\mathrm{M}$ & 56 & $4^{\circ}$ (Primario) & Ama de casa & 6 & a & $d$ & $0,58 \mathrm{SM}$ & a & a & $\mathrm{e}$ \\
\hline 17 & $\mathrm{~F}$ & 50 & $7^{\circ}$ (Primario) & Ama de casa & 1 & a & $a$ & $0,12 \mathrm{SM}$ & d & a & a \\
\hline 18 & $\mathrm{~F}$ & 34 & Secundario & $\mathrm{Ni}$ & 8 & $\mathrm{~b}$ & e & $\mathrm{Ni}$ & a & a & $\mathrm{e}$ \\
\hline 19 & $\mathrm{~F}$ & 22 & $1^{\circ}$ (Secundario) & Estudiante & 5 & $\mathrm{~b}$ & $\mathrm{~b}$ & $0,58 \mathrm{SM}$ & $\mathrm{C}$ & a & a \\
\hline 20 & $\mathrm{M}$ & 56 & $4^{\circ}$ (Primario) & Albañil & 4 & a & $\mathrm{C}$ & $0,29 S M$ & a & a & d \\
\hline 21 & $\mathrm{~F}$ & 27 & $1^{\circ}$ (Secundario) & Ama de casa & 4 & $\mathrm{~b}$ & $a$ & $0,58 \mathrm{SM}$ & d & a & $\mathrm{e}$ \\
\hline 22 & $\mathrm{~F}$ & 32 & $4^{\circ}$ (Secundario) & Ama de casa & 6 & a & e & $1,16 \mathrm{SM}$ & a & d & $\mathrm{e}$ \\
\hline 23 & $\mathrm{~F}$ & 50 & Primario & Ama de casa & 2 & $\mathrm{C}$ & $\mathrm{C}$ & $0,58 \mathrm{SM}$ & a & c & $\mathrm{e}$ \\
\hline 24 & & 39 & $2^{\circ}$ (Secundario) & Ama de casa & 6 & $\mathrm{C}$ & $\mathrm{C}$ & $0,78 \mathrm{SM}$ & d & $c$ & $\mathrm{C}$ \\
\hline 25 & $\mathrm{~F}$ & 41 & Secundario & Autónomo & 7 & $\mathrm{C}$ & $d$ & $1,13 \mathrm{SM}$ & a & a & $\mathrm{C}$ \\
\hline 26 & & 29 & $1^{\circ}$ (Primario) & "Trabaja" & 4 & a & $d$ & $0,58 \mathrm{SM}$ & a & e & a \\
\hline 27 & $\mathrm{~F}$ & 37 & $7^{\circ}$ (Primario) & $\mathrm{Ni}$ & 5 & $\mathrm{C}$ & $d$ & $1,75 \mathrm{SM}$ & a & d & a \\
\hline 28 & $\mathrm{~F}$ & 27 & $6^{\circ}$ (Primario) & Niñera & 4 & a & $d$ & $0,78 \mathrm{SM}$ & a & e & $\mathrm{d}$ \\
\hline 29 & $\mathrm{~F}$ & 26 & $2^{\circ}$ (Secundario) & Ama de casa & 7 & $\mathrm{C}$ & a & $0,87 \mathrm{SM}$ & C & e & a \\
\hline 30 & $F$ & 25 & $1^{\circ}$ (Primario) & Ama de casa & 3 & $\mathrm{~b}$ & e & $0,39 S M$ & $\mathrm{~b}$ & a & $\mathrm{e}$ \\
\hline 31 & $F$ & 39 & $4^{\circ}$ (Primario) & $\mathrm{Ni}$ & $\mathrm{Ni}$ & $\mathrm{b}$ & a & $0,29 S M$ & a & $\mathrm{b}$ & a \\
\hline 32 & $\mathrm{~F}$ & 43 & $3^{\circ}$ (Primario) & Ama de casa & 5 & $\mathrm{~b}$ & $d$ & $0,77 \mathrm{SM}$ & a & e & $\mathrm{e}$ \\
\hline 33 & $F$ & 26 & Secundaria & Ama de casa & 3 & $\mathrm{C}$ & a & 155SM & a & $c$ & $\mathrm{e}$ \\
\hline 34 & $\mathrm{~F}$ & 31 & $2^{\circ}$ (Primario) & Ama de casa & $\mathrm{Ni}$ & $\mathrm{b}$ & $a$ & $0,58 \mathrm{SM}$ & a & $c$ & $\mathrm{e}$ \\
\hline 35 & $\mathrm{~F}$ & 24 & $6^{\circ}$ (Primario) & Ama de casa & 3 & $\mathrm{~b}$ & $\mathrm{~b}$ & $0,97 \mathrm{SM}$ & $a$ & a & e \\
\hline
\end{tabular}




\begin{tabular}{|c|c|c|c|c|c|c|c|c|c|c|c|}
\hline 36 & $\mathrm{~F}$ & 45 & $2^{\circ}$ (Primario) & $\mathrm{Ni}$ & 1 & $\mathrm{~b}$ & e & $0,78 \mathrm{SM}$ & $\mathrm{e}$ & C & $\mathrm{e}$ \\
\hline 37 & $\mathrm{~F}$ & 38 & $2^{\circ}$ (Primario) & $\mathrm{Ni}$ & 5 & $\mathrm{~b}$ & $\mathrm{Ni}$ & $0,50 \mathrm{SM}$ & $a$ & $d$ & $\mathrm{e}$ \\
\hline 38 & $\mathrm{~F}$ & 59 & $6^{\circ}$ (Primario) & Trabajo doméstico & 3 & $\mathrm{~b}$ & a & $0,97 \mathrm{SM}$ & $a$ & $a$ & a \\
\hline 39 & $\mathrm{M}$ & 43 & Secundario & Pintor & $\mathrm{Ni}$ & $\mathrm{b}$ & a & $1,36 \mathrm{SM}$ & $d$ & $a$ & $\mathrm{e}$ \\
\hline 40 & $\mathrm{~F}$ & 63 & $2^{\circ}$ (Primario) & Ama de casa & 4 & $\mathrm{C}$ & $a$ & $0,97 \mathrm{SM}$ & $a$ & $\mathrm{C}$ & $\mathrm{e}$ \\
\hline 41 & $\mathrm{M}$ & 42 & $2^{\circ}$ (Primario) & Obrero & 3 & $\mathrm{~b}$ & $a$ & $1,55 \mathrm{SM}$ & $a$ & $d$ & $\mathrm{e}$ \\
\hline 42 & $\mathrm{~F}$ & 33 & $7^{\circ}$ (Primario) & Docente & 3 & $\mathrm{~b}$ & $b$ & $0,52 \mathrm{SM}$ & $d$ & $\mathrm{C}$ & $\mathrm{d}$ \\
\hline 43 & $\mathrm{~F}$ & 36 & Secundario & Empleada & 6 & $a$ & $b$ & $1,16 \mathrm{SM}$ & $a$ & $\mathrm{e}$ & $\mathrm{d}$ \\
\hline 44 & $\mathrm{~F}$ & 22 & $1^{\circ}$ (Secundario) & Trabaja & 3 & $a$ & e & $0,58 \mathrm{SM}$ & $d$ & $a$ & $\mathrm{e}$ \\
\hline 45 & $\mathrm{Ni}$ & $\mathrm{Ni}$ & $\mathrm{Ni}$ & $\mathrm{Ni}$ & $\mathrm{Ni}$ & $\mathrm{b}$ & $d$ & $\mathrm{Ni}$ & $a$ & $a$ & $a$ \\
\hline 46 & $\mathrm{~F}$ & 25 & Secundario (inc.) & Ama de casa & 8 & $a$ & $d$ & $0,49 S M$ & $a$ & $d$ & $\mathrm{~d}$ \\
\hline 47 & $\mathrm{~F}$ & 22 & $1^{\circ}$ (Secundario) & Trabaja & 5 & $\mathrm{~b}$ & C & $0,97 \mathrm{SM}$ & $a$ & $\mathrm{e}$ & $a$ \\
\hline 48 & $\mathrm{Ni}$ & $\mathrm{Ni}$ & $\mathrm{Ni}$ & $\mathrm{Ni}$ & $\mathrm{Ni}$ & $\mathrm{b}$ & $\mathrm{C}$ & $\mathrm{Ni}$ & $a$ & $\mathrm{~d}$ & $a$ \\
\hline 49 & $\mathrm{~F}$ & 28 & Secundario (inc.) & Desocupada & 3 & $\mathrm{C}$ & $d$ & $1,36 \mathrm{SM}$ & $\mathrm{C}$ & $\mathrm{e}$ & $\bar{d}$ \\
\hline 50 & $\mathrm{~F}$ & 23 & $7^{\circ}$ (Primario) & Coordinad. Telefonía & 7 & $\mathrm{a}$ & $\mathrm{C}$ & $0,97 \mathrm{SM}$ & $\mathrm{d}$ & $\mathrm{C}$ & $\mathrm{d}$ \\
\hline 51 & $\mathrm{~F}$ & 45 & $3^{\circ}$ (Secundario) & Taxista & 5 & $\mathrm{C}$ & $\mathrm{C}$ & $1,75 \mathrm{SM}$ & $\mathrm{a}$ & $\mathrm{d}$ & $\overline{\mathrm{e}}$ \\
\hline 52 & $\mathrm{~F}$ & 36 & $7^{\circ}$ (Primario) & Ama de casa & 4 & $\mathrm{C}$ & $a$ & $1,36 \mathrm{SM}$ & $\mathrm{a}$ & $\mathrm{C}$ & $\overline{\mathrm{e}}$ \\
\hline 53 & $\mathrm{M}$ & 54 & $2^{\circ}$ (Primario) & Albañil & $\mathrm{Ni}$ & $\mathrm{C}$ & $\mathrm{C}$ & $1,16 \mathrm{SM}$ & $\mathrm{a}$ & $\mathrm{C}$ & $\overline{\mathrm{e}}$ \\
\hline 54 & $\mathrm{M}$ & 68 & $7^{\circ}$ (Primario) & Cartonero & 3 & $\mathrm{a}$ & $a$ & $0,49 S M$ & $\mathrm{a}$ & $\mathrm{C}$ & $\overline{\mathrm{e}}$ \\
\hline 55 & $\mathrm{~F}$ & 50 & $5^{\circ}$ (Primario) & Cuidadora & 4 & $d$ & $b$ & $0,23 \mathrm{SM}$ & $a$ & $a$ & $\overline{\mathrm{e}}$ \\
\hline 56 & $\mathrm{~F}$ & 33 & $4^{\circ}$ (Primario) & Cooperativista & 5 & $\mathrm{a}$ & C & $0,39 \mathrm{SM}$ & $\mathrm{d}$ & $\mathrm{C}$ & e \\
\hline 57 & $\mathrm{~F}$ & 42 & $4^{\circ}$ (Primario) & $\mathrm{Ni}$ & $\mathrm{Ni}$ & $\mathrm{b}$ & $d$ & $0,78 \mathrm{SM}$ & $a$ & $a$ & $\bar{e}$ \\
\hline 58 & $\mathrm{Ni}$ & $\mathrm{Ni}$ & $\mathrm{Ni}$ & $\mathrm{Ni}$ & $\mathrm{Ni}$ & $\mathrm{a}$ & $\mathrm{b}$ & $\mathrm{Ni}$ & $\mathrm{b}$ & $a$ & $\mathrm{C}$ \\
\hline 59 & $\mathrm{~F}$ & 46 & $2^{\circ}$ (Primario) & Ama de casa & 4 & $a$ & e & $1,03 \mathrm{SM}$ & $a$ & $a$ & $\overline{\mathrm{e}}$ \\
\hline 60 & $\mathrm{Ni}$ & $\mathrm{Ni}$ & $\mathrm{Ni}$ & $\mathrm{Ni}$ & $\mathrm{Ni}$ & $\mathrm{b}$ & $a$ & $\mathrm{Ni}$ & $a$ & $a$ & e \\
\hline 61 & $\mathrm{M}$ & 53 & $2^{\circ}$ (Primario) & Desocupada & 7 & $\mathrm{~b}$ & $d$ & 058SM & $a$ & $\mathrm{a}$ & $\bar{e}$ \\
\hline 62 & $\mathrm{M}$ & 33 & $7^{\circ}$ (Primario) & Albañil & $\mathrm{Ni}$ & $\mathrm{b}$ & C & $1,16 \mathrm{SM}$ & $a$ & $\mathrm{C}$ & $\mathrm{e}$ \\
\hline 63 & $\mathrm{M}$ & 32 & $7^{\circ}$ (Primario) & Changarín & 6 & $\mathrm{C}$ & $\mathrm{C}$ & $0,35 \mathrm{SM}$ & $a$ & $\mathrm{~d}$ & $\bar{a}$ \\
\hline 64 & $\mathrm{~F}$ & 58 & $4^{\circ}$ (Primario) & Ama de casa/discap. & 7 & $\mathrm{~b}$ & $\mathrm{~b}$ & Pensión & $a$ & $\mathrm{a}$ & a \\
\hline 65 & $\mathrm{~F}$ & 28 & Tercer grado & Estudiante & 4 & $\mathrm{~b}$ & $a$ & $0,83 \mathrm{SM}$ & $a$ & $a$ & $\mathrm{~d}$ \\
\hline 66 & $\mathrm{Ni}$ & $\mathrm{Ni}$ & $\mathrm{Ni}$ & $\mathrm{Ni}$ & $\mathrm{Ni}$ & $\mathrm{C}$ & C & $\mathrm{Ni}$ & $a$ & $\mathrm{a}$ & $\mathrm{d}$ \\
\hline 67 & $\mathrm{~F}$ & 40 & (Primario) & Ama de casa & 6 & $\mathrm{~b}$ & $\mathrm{C}$ & $0,68 \mathrm{SM}$ & $a$ & $a$ & $\mathrm{~d}$ \\
\hline 68 & $\mathrm{~F}$ & 21 & $3^{\circ}$ (Secundario) & Trabaja & 6 & $\mathrm{~b}$ & $a$ & $\mathrm{Ni}$ & $\mathrm{d}$ & $a$ & $\mathrm{~d}$ \\
\hline 69 & $\mathrm{~F}$ & 25 & (Primario) & Ama de casa & 6 & $\mathrm{~b}$ & $\mathrm{a}$ & $0,78 \mathrm{SM}$ & $\mathrm{e}$ & $a$ & $\mathrm{~d}$ \\
\hline 70 & $\mathrm{~F}$ & 22 & Tercer grado & Ama de casa & 5 & $\mathrm{~b}$ & $\mathrm{C}$ & $\mathrm{Ni}$ & $\mathrm{d}$ & $\mathrm{C}$ & $\mathrm{d}$ \\
\hline 71 & $\mathrm{~F}$ & 54 & Primario (inicio) & Ama de casa & 5 & a & $a$ & $\mathrm{Ni}$ & e & $a$ & $\mathrm{~d}$ \\
\hline 72 & $\mathrm{M}$ & 38 & Secundario & Albañil & 5 & $\mathrm{~b}$ & $\mathrm{~b}$ & $0,97 \mathrm{SM}$ & $a$ & $a$ & $\bar{c}$ \\
\hline 73 & $\mathrm{Ni}$ & $\mathrm{Ni}$ & $\mathrm{Ni}$ & $\mathrm{Ni}$ & $\mathrm{Ni}$ & $a$ & $\mathrm{C}$ & $\mathrm{Ni}$ & $a$ & $\mathrm{Ni}$ & $\mathrm{Ni}$ \\
\hline
\end{tabular}




\begin{tabular}{|cccccccccccc|}
\hline 74 & $\mathrm{M}$ & 42 & $\mathrm{Ni}$ & Albañil & 8 & $\mathrm{~b}$ & $\mathrm{~b}$ & $0,58 \mathrm{SM}$ & $\mathrm{a}$ & $\mathrm{a}$ & $\mathrm{a}$ \\
\hline 75 & $\mathrm{~F}$ & 41 & (Primario) & Ama de casa/discap. & 3 & $\mathrm{~b}$ & $\mathrm{~b}$ & Pensión & $\mathrm{d}$ & $\mathrm{a}$ & $\mathrm{a}$ \\
\hline
\end{tabular}

Fecha: julio de 2017. Leyenda: It.: Ítem; A: Sexo (M: Masculino, F: Femenino), B: Edad del encuestado, C: Grado de escolaridad, D: Ocupación profesional, E: Cantidad de ocupantes de la vivienda, F: Tiempo en años en que vive en la vivienda (a: +- 1 año, b: +- 2 años, c: +3 años, d: +- 4 años, e: +- 5 años o más), G: Piso en que la vivienda está ubicada (a: planta baja, b: $1^{\circ}$ piso, c: $2^{\circ}$ piso, d: $3^{\circ}$ piso, e: $4^{\circ}$ piso, $\mathrm{e}^{*}: 5^{\circ}$ piso o más arriba), $\mathrm{H}$ : Presupuesto mensual familiar (SM R\$; \$ (peso argentino); U\$), I: Satisfacción de vivir en edificio en altura (a: definitivamente no, b: muy poco, c: poco, d: mucho, e: muchísimo), J: Pretensión de comercializar (alquilar/vender) la vivienda (a: definitivamente no, b: muy poco, c: tal vez, d: probablemente, e: con certeza, K: Concordancia con la validad de la Ley 962 de 2002 de CABA, la cual obliga la implantación de ascensor en edificios con más de 3 pisos (a: definitivamente no, b: muy poco, c: poco, d: mucho, e: muchísimo), Ni: No Informado por el encuestado, SR: Sin Rendimiento. El valor de SM en Argentina vigente en los periodos entre enero a julio y agosto a diciembre de 2015 fue de $\$ 4.716$ y \$ ARS 5.588 respectivamente, motivo por el cual en esta tabla se registra la media aritmética de ambos períodos: \$ 5.152. Correspondían en Dólares EEUU a U\$ 546 y U\$ 601, respectivamente, según cambio conforme BANCO CENTRAL DE LA REPÚBLICA ARGENTINA ([s/f]).

\subsection{2 - Respuestas de la Encuesta Tipo 1 de las comunidades de CABA}

Las Tablas 5.3 y 5.4 reúnen las respuestas de los moradores de la Encuesta Tipo 1. En la Tabla 5.1, para cada interrogante se explicitan los cinco niveles de

grado propuestos y las cantidades registradas se refieren al total de las 3 comunidades investigadas en Argentina. La Tabla 5.4 trae el total de las respuestas para cada interrogante según cada comunidad investigada. 
Tabla 5.3 - Respuestas de la Encuesta Tipo 1 de las comunidades de CABA (Parque Patricios/Monteagudo; Luzuriaga y Padre Mugica, conjuntamente)

\begin{tabular}{|c|c|c|c|c|c|c|}
\hline Preguntas (excepto las $1^{\text {ra }}, 2^{\text {nda }}, 3^{\text {ra }}, 4^{\text {ta }}, 13^{\text {ra }}, 14^{\text {ta }}$ y $15^{\text {ta }}$ ) & $\begin{array}{c}\text { Total } \\
\text { (1) }\end{array}$ & A & B & C & D & $E$ \\
\hline \multicolumn{7}{|l|}{ (1) Tiempo de morada } \\
\hline \multicolumn{7}{|l|}{ (2) Piso en que vive } \\
\hline \multicolumn{7}{|l|}{ (3) Cantidad de cuartos } \\
\hline \multicolumn{7}{|l|}{ (4) Área residencial } \\
\hline (5) Satisfacción en vivir en el edificio de hasta 5 pisos & 234 & 113 & 24 & 34 & 58 & 5 \\
\hline (6) Participación en el proyecto o construcción & 232 & 165 & 15 & 13 & 25 & 14 \\
\hline (7) La burocracia para la entrega de las llaves & 231 & 38 & 23 & 37 & 55 & 78 \\
\hline (8) La cantidad de cuartos es suficiente & 228 & 72 & 28 & 35 & 92 & 1 \\
\hline (9) El tamaño de los cuartos es suficiente & 227 & 71 & 35 & 37 & 82 & 2 \\
\hline (10) Los ambientes fueron distribuidos conforme necesidad & 214 & 22 & 9 & 32 & 149 & 2 \\
\hline (11) Es satisfactorio el suministro de agua & 223 & 23 & 33 & 33 & 131 & 3 \\
\hline (12) La fachada del edificio es agradable & 225 & 39 & 17 & 33 & 127 & 9 \\
\hline \multicolumn{7}{|l|}{ (13) Sistema de portero eléctrico (tipo) } \\
\hline \multicolumn{7}{|l|}{ (14) Sistema de gas de cocina (tipo) } \\
\hline \multicolumn{7}{|l|}{ (15) Área de lavado (tipo) } \\
\hline (16.1) Acceso a la entrada y salida del departamento & 224 & 103 & 10 & 20 & 90 & 1 \\
\hline (16.2) Los equipamientos de combate a incendios & 224 & 108 & 21 & 19 & 75 & 1 \\
\hline (16.3) Entrenamiento de Combate a incendios & 220 & 156 & 26 & 19 & 19 & 0 \\
\hline (17) Facilidad de transporte público & 223 & 13 & 27 & 53 & 119 & 11 \\
\hline (18.1) El revestimiento del piso & 224 & 89 & 18 & 21 & 94 & 2 \\
\hline (18.2) Revestimiento de paredes habitaciones, sala y corredor & 231 & 104 & 14 & 23 & 83 & 7 \\
\hline (18.3) Revestimientos en la cocina, baño y área de servicio & 225 & 104 & 13 & 21 & 83 & 4 \\
\hline (18.4) Revestimiento del techo & 33 & 112 & 16 & 26 & 74 & 5 \\
\hline (18.5) El herraje (cerraduras, bisagras, cerrojos) & 228 & 109 & 27 & 33 & 57 & 2 \\
\hline (19) Los cerramientos: portas, ventanas y basculantes & 233 & 111 & 24 & 36 & 61 & 1 \\
\hline (20) La mensualidad de la financiación es adecuada & 157 & 9 & 10 & 62 & 67 & 9 \\
\hline (21) El valor de las expensas para mantenimiento del edificio & 155 & 6 & 6 & 20 & 110 & 13 \\
\hline (22) El clima en verano en el interior del departamento & 225 & 74 & 23 & 28 & 95 & 5 \\
\hline (23) El clima en invierno en el interior del departamento & 232 & 37 & 34 & 46 & 111 & 4 \\
\hline (24) El revestimiento de las paredes permiten escuchar ruidos & 224 & 18 & 13 & 27 & 58 & 108 \\
\hline (25) La iluminación natural en el interior es adecuada & 222 & 6 & 1 & 14 & 179 & 22 \\
\hline (26) La ventilación es adecuada & 223 & 1 & 5 & 5 & 183 & 29 \\
\hline (27) Las instalaciones de agua y cloaca son adecuadas & 218 & 64 & 24 & 58 & 71 & 1 \\
\hline (28) Las instalaciones eléctricas son adecuadas & 220 & 65 & 9 & 23 & 115 & 8 \\
\hline (29) En el período de lluvia hay inconvenientes & 214 & 112 & 12 & 26 & 27 & 37 \\
\hline (30) Las áreas de esparcimiento son usadas por moradores & 221 & 109 & 44 & 44 & 20 & 4 \\
\hline (31) Los vanos de acceso ofrecen alguna dificultad & 219 & 160 & 11 & 10 & 25 & 13 \\
\hline (32) Hay escuelas públicas, guarderías, puesto de salud & 221 & 80 & 59 & 42 & 38 & 2 \\
\hline (33) Hay intención de pasar las llaves en los próximos 5 años & 218 & 166 & 1 & 27 & 17 & 7 \\
\hline (34) Concordancia con la Ley porteña 962, del 2002: ascensor & 221 & 34 & 1 & 14 & 79 & 93 \\
\hline
\end{tabular}

Fecha: 2017. 1) El total puede no corresponder rigurosamente al número de personas encuestadas para representación de cada comunidad debido al descarte de muestras y/o haber habido respuesta con más de una opción (letra) en una determinada pregunta. Encuestas aplicadas durante el período de enero de 2014 a septiembre de 2015. 2) Leyenda: A: Ni un poco/No existe, B: Muy poco, C: Poco/Tal vez, D: Aceptable/ Regularmente/ Probablemente, E: Muchísimo. 
Tabla 5.4 - Respuestas de la Encuesta Tipo 1 por comunidad de CABA

\begin{tabular}{|c|c|c|c|c|}
\hline Ítems & $\begin{array}{c}A \\
(75)\end{array}$ & $\begin{array}{c}\text { B } \\
(75)\end{array}$ & $\begin{array}{c}C \\
(75)\end{array}$ & Total* $^{*}$ \\
\hline (1) Cuánto tiempo hace que vive en el inmueble & 75 & 75 & 82 & 232 \\
\hline Hace 1 año o menos & 1 & 75 & 23 & 99 \\
\hline Hace más o menos 2 años & 0 & 0 & 42 & 42 \\
\hline Hace más o menos 3 años & 0 & 0 & 15 & 15 \\
\hline Hace más o menos 4 años & 74 & 0 & 2 & 76 \\
\hline Hace 5 años o más & 0 & 0 & 0 & 0 \\
\hline (2) En qué piso vive & 74 & 73 & 75 & 222 \\
\hline Planta baja & 13 & 12 & 20 & 45 \\
\hline $1^{\text {er }}$ piso & 11 & 12 & 15 & 38 \\
\hline $2^{\text {ndo }}$ piso & 17 & 20 & 22 & 59 \\
\hline $3^{\text {er }}$ piso & 32 & 14 & 13 & 59 \\
\hline $4^{\circ}$ piso o más & 1 & 15 & 5 & 21 \\
\hline (3) Cuántas habitaciones el departamento posee & 73 & 75 & 78 & 226 \\
\hline Ninguna habitación & 0 & 5 & 0 & 5 \\
\hline 1 habitación & 17 & 26 & 0 & 43 \\
\hline 2 habitaciones & 30 & 37 & 36 & 103 \\
\hline 3 habitaciones & 26 & 7 & 42 & 75 \\
\hline 4 o más habitaciones & 0 & 0 & 0 & 0 \\
\hline (4) Cuántos metros cuadrados & 68 & 81 & 71 & 220 \\
\hline $20 \mathrm{~m}^{2}$ o menos & 2 & 17 & 0 & 19 \\
\hline Más o menos $40 \mathrm{~m}^{2}$ & 21 & 48 & 0 & 69 \\
\hline Más o menos $60 \mathrm{~m}^{2}$ & 19 & 14 & 31 & 64 \\
\hline Más o menos $80 \mathrm{~m}^{2}$ & 25 & 2 & 40 & 67 \\
\hline Más o menos $100 \mathrm{~m}^{2}$, o más & 1 & 0 & 0 & 1 \\
\hline (5) Vivir en edificio con 3 a 4 piso o más es satisfactorio & 76 & 82 & 76 & 234 \\
\hline Ni un poco & 33 & 28 & 52 & 113 \\
\hline Muy poco & 13 & 7 & 4 & 24 \\
\hline Poco & 10 & 21 & 3 & 34 \\
\hline Aceptable & 17 & 26 & 15 & 58 \\
\hline Muchísimo & 3 & 0 & 2 & 5 \\
\hline (6) Participó del proyecto o construcción de la vivienda & 74 & 80 & 78 & 232 \\
\hline Ni un poco & 21 & 68 & 76 & 165 \\
\hline Muy poco & 8 & 7 & 0 & 15 \\
\hline Poco & 8 & 4 & 1 & 13 \\
\hline Aceptable & 24 & 1 & 0 & 25 \\
\hline Muchísimo & 13 & 0 & 1 & 14 \\
\hline
\end{tabular}




\begin{tabular}{|c|c|c|c|c|}
\hline (7) La burocracia para entregar las llaves ha demorado & 73 & 81 & 77 & 231 \\
\hline Ni un poco & 31 & 4 & 3 & 38 \\
\hline Muy poco & 16 & 1 & 6 & 23 \\
\hline Poco & 15 & 7 & 15 & 37 \\
\hline Aceptable & 11 & 31 & 13 & 55 \\
\hline Muchísimo & 0 & 38 & 40 & 78 \\
\hline (8) La cantidad de cuartos de su vivienda es suficiente & 71 & 80 & 77 & 228 \\
\hline Ni un poco & 18 & 29 & 25 & 72 \\
\hline Muy poco & 11 & 8 & 9 & 28 \\
\hline Poco & 12 & 10 & 13 & 35 \\
\hline Aceptable & 30 & 33 & 29 & 92 \\
\hline Muchísimo & 0 & 0 & 1 & 1 \\
\hline (9) El tamaño de los cuartos es suficiente & 75 & 77 & 75 & 227 \\
\hline Ni un poco & 9 & 35 & 27 & 71 \\
\hline Muy poco & 11 & 5 & 19 & 35 \\
\hline Poco & 13 & 16 & 8 & 37 \\
\hline Aceptable & 40 & 21 & 21 & 82 \\
\hline Muchísimo & 2 & 0 & 0 & 2 \\
\hline (10) Los cuartos están bien distribuidos & 69 & 75 & 70 & 214 \\
\hline Ni un poco & 2 & 11 & 9 & 22 \\
\hline Muy poco & 1 & 1 & 7 & 9 \\
\hline Poco & 11 & 8 & 13 & 32 \\
\hline Aceptable & 53 & 55 & 41 & 149 \\
\hline Muchísimo & 2 & 0 & 0 & 2 \\
\hline $\begin{array}{l}\text { (11) Están contentos con el abastecimiento de agua del } \\
\text { departamento }\end{array}$ & 75 & 74 & 74 & 223 \\
\hline Ni un poco & 3 & 1 & 19 & 23 \\
\hline Muy poco & 15 & 1 & 17 & 33 \\
\hline Poco & 23 & 0 & 10 & 33 \\
\hline Aceptable & 33 & 72 & 26 & 131 \\
\hline Muchísimo & 1 & 0 & 2 & 3 \\
\hline (12) La fachada del edificio es agradable & 75 & 76 & 74 & 225 \\
\hline Ni un poco & 1 & 3 & 35 & 39 \\
\hline Muy poco & 6 & 3 & 8 & 17 \\
\hline Poco & 7 & 14 & 12 & 33 \\
\hline Aceptable & 55 & 55 & 17 & 127 \\
\hline Muchísimo & 6 & 1 & 2 & 9 \\
\hline (13) El sistema de portero eléctrico en su edificio & 62 & 75 & 74 & 211 \\
\hline No existe & 31 & 0 & 54 & 85 \\
\hline Sólo permite escuchar la llamada & 28 & 75 & 20 & 123 \\
\hline
\end{tabular}




\begin{tabular}{|c|c|c|c|c|}
\hline Permite abrir el portón & 2 & 0 & 0 & 2 \\
\hline Permite comunicar con los vecinos & 1 & 0 & 0 & 1 \\
\hline Parece bien que se deba instalar uno & 0 & 0 & 0 & 0 \\
\hline (14) Cuánto al gas de cocina utilizado & 75 & 75 & 75 & 225 \\
\hline Garrafa de $10 \mathrm{Kg}$ & 74 & 0 & 0 & 74 \\
\hline Colectivo con central fuera del departamento & 1 & 75 & 75 & 156 \\
\hline Cocina colectiva fuera del departamento & 0 & 0 & 0 & 0 \\
\hline Hay otro tipo & 0 & 0 & 0 & 0 \\
\hline No hay nada existente & 0 & 0 & 0 & 0 \\
\hline (15) Área de Lavado de ropas & 73 & 134 & 134 & 341 \\
\hline Lavadero dentro del departamento & 73 & 74 & 67 & 214 \\
\hline Lavadero colectivo & 0 & 0 & 0 & 0 \\
\hline Lavarropa eléctrico dentro del departamento & 0 & 60 & 67 & 127 \\
\hline Lavarropa eléctrico comunitario & 0 & 0 & 0 & 0 \\
\hline No hay ninguna área prevista & 0 & 0 & 0 & 0 \\
\hline (16.1) Los materiales son confiables (contra incendio) & 77 & 74 & 73 & 224 \\
\hline Ni un poco & 29 & 7 & 67 & 103 \\
\hline Muy poco & 4 & 2 & 4 & 10 \\
\hline Poco & 6 & 13 & 1 & 20 \\
\hline Aceptable & 37 & 52 & 1 & 90 \\
\hline Muchísimo & 1 & 0 & 0 & 1 \\
\hline $\begin{array}{l}\text { (16.2) Los equipos de combate a incendio son } \\
\text { confiables }\end{array}$ & 75 & 76 & 73 & 224 \\
\hline Ni un poco & 35 & 6 & 67 & 108 \\
\hline Muy poco & 14 & 3 & 4 & 21 \\
\hline Poco & 11 & 7 & 1 & 19 \\
\hline Aceptable & 15 & 59 & 1 & 75 \\
\hline Muchísimo & 0 & 1 & 0 & 1 \\
\hline (16.3) Hubo entrenamiento de combate a incendios & 73 & 73 & 74 & 220 \\
\hline Ni un poco & 43 & 61 & 52 & 156 \\
\hline Muy poco & 12 & 7 & 7 & 26 \\
\hline Poco & 8 & 1 & 10 & 19 \\
\hline Aceptable & 10 & 4 & 5 & 19 \\
\hline Muchísimo & 0 & 0 & 0 & 0 \\
\hline (17) Hay facilidad de transporte público & 72 & 74 & 77 & 223 \\
\hline Ni un poco & 0 & 7 & 6 & 13 \\
\hline Muy poco & 0 & 9 & 18 & 27 \\
\hline Poco & 2 & 31 & 20 & 53 \\
\hline Aceptable & 60 & 27 & 32 & 119 \\
\hline Muchísimo & 10 & 0 & 1 & 11 \\
\hline
\end{tabular}




\begin{tabular}{|c|c|c|c|c|}
\hline $\begin{array}{l}\text { (18.1) Satisfacción con la calidad de los materiales de } \\
\text { revestimiento de pisos }\end{array}$ & 70 & 79 & 75 & 224 \\
\hline Ni un poco & 3 & 44 & 42 & 89 \\
\hline Muy poco & 3 & 6 & 9 & 18 \\
\hline Poco & 6 & 7 & 8 & 21 \\
\hline Aceptable & 56 & 22 & 16 & 94 \\
\hline Muchísimo & 2 & 0 & 0 & 2 \\
\hline $\begin{array}{l}\text { (18.2) Satisfacción con los revestimientos de las } \\
\text { paredes de las habitaciones/salas }\end{array}$ & 77 & 78 & 76 & 231 \\
\hline Ni un poco & 3 & 46 & 55 & 104 \\
\hline Muy poco & 3 & 6 & 5 & 14 \\
\hline Poco & 6 & 12 & 5 & 23 \\
\hline Aceptable & 58 & 14 & 11 & 83 \\
\hline Muchísimo & 7 & 0 & 0 & 7 \\
\hline $\begin{array}{l}\text { (18.3) Satisfacción con revestimientos de la cocinalárea } \\
\text { servicio y baños }\end{array}$ & 72 & 78 & 75 & 225 \\
\hline Ni un poco & 5 & 40 & 59 & 104 \\
\hline Muy poco & 3 & 8 & 2 & 13 \\
\hline Poco & 5 & 11 & 5 & 21 \\
\hline Aceptable & 55 & 19 & 9 & 83 \\
\hline Muchísimo & 4 & 0 & 0 & 4 \\
\hline (18.4) Satisfacción con el revestimiento en techo & 78 & 78 & 77 & 233 \\
\hline Ni un poco & 9 & 37 & 66 & 112 \\
\hline Muy poco & 7 & 7 & 2 & 16 \\
\hline Poco & 11 & 13 & 2 & 26 \\
\hline Aceptable & 46 & 21 & 7 & 74 \\
\hline Muchísimo & 5 & 0 & 0 & 5 \\
\hline $\begin{array}{l}\text { (18.5) Satisfacción con el herraje (cerraduras, bisagras, } \\
\text { cerrojos) }\end{array}$ & 75 & 78 & 75 & 228 \\
\hline Ni un poco & 12 & 33 & 64 & 109 \\
\hline Muy poco & 19 & 4 & 4 & 27 \\
\hline Poco & 13 & 19 & 1 & 33 \\
\hline Aceptable & 29 & 22 & 6 & 57 \\
\hline Muchísimo & 2 & 0 & 0 & 2 \\
\hline $\begin{array}{l}\text { (19) Satisfacc. con los cerramientos (puertas, ventanas } \\
\text { etc) }\end{array}$ & 75 & 76 & 82 & 233 \\
\hline Ni un poco & 9 & 36 & 66 & 111 \\
\hline Muy poco & 15 & 4 & 5 & 24 \\
\hline Poco & 19 & 13 & 4 & 36 \\
\hline Aceptable & 32 & 23 & 6 & 61 \\
\hline Muchísimo & 0 & 0 & 1 & 1 \\
\hline
\end{tabular}




\begin{tabular}{|c|c|c|c|c|}
\hline $\begin{array}{l}\text { (20) Satisfacción con los cerramientos (puertas, } \\
\text { ventanas, basculantes) }\end{array}$ & 80 & 75 & 2 & 157 \\
\hline $\mathrm{Ni}$ un poco & 2 & 7 & 0 & 9 \\
\hline Muy poco & 9 & 1 & 0 & 10 \\
\hline Poco & 52 & 9 & 1 & 62 \\
\hline Aceptable & 8 & 58 & 1 & 67 \\
\hline Muchísimo & 9 & 0 & 0 & 9 \\
\hline $\begin{array}{l}\text { (21) Satisfacción con el valor de las expensas de } \\
\text { mantenimiento del edificio }\end{array}$ & 74 & 76 & 5 & 155 \\
\hline Ni un poco & 2 & 3 & 1 & 6 \\
\hline Muy poco & 4 & 2 & 0 & 6 \\
\hline Poco & 10 & 8 & 2 & 20 \\
\hline Aceptable & 51 & 58 & 1 & 110 \\
\hline Muchísimo & 7 & 5 & 1 & 13 \\
\hline $\begin{array}{l}\text { (22) El clima en el interior del departamento es } \\
\text { aceptable en verano }\end{array}$ & 74 & 77 & 74 & 225 \\
\hline $\mathrm{Ni}$ un poco & 15 & 32 & 27 & 74 \\
\hline Muy poco & 12 & 5 & 6 & 23 \\
\hline Poco & 4 & 7 & 17 & 28 \\
\hline Aceptable & 39 & 33 & 23 & 95 \\
\hline Muchísimo & 4 & 0 & 1 & 5 \\
\hline $\begin{array}{l}\text { (23) El clima en el interior del departamento es } \\
\text { aceptable en invierno }\end{array}$ & 79 & 75 & 78 & 232 \\
\hline Ni un poco & 12 & 8 & 17 & 37 \\
\hline Muy poco & 14 & 6 & 14 & 34 \\
\hline Poco & 19 & 10 & 17 & 46 \\
\hline Aceptable & 30 & 51 & 30 & 111 \\
\hline Muchísimo & 4 & 0 & 0 & 4 \\
\hline $\begin{array}{l}\text { (24) Satisfacción con el revestimiento de las paredes } \\
\text { (ruidos) }\end{array}$ & 74 & 72 & 78 & 224 \\
\hline $\mathrm{Ni}$ un poco & 12 & 5 & 1 & 18 \\
\hline Muy poco & 7 & 4 & 2 & 13 \\
\hline Poco & 14 & 9 & 4 & 27 \\
\hline Aceptable & 25 & 25 & 8 & 58 \\
\hline Muchísimo & 16 & 29 & 63 & 108 \\
\hline $\begin{array}{l}\text { (25) La iluminación natural de día en el departamento es } \\
\text { satisfactoria }\end{array}$ & 73 & 74 & 74 & 221 \\
\hline $\mathrm{Ni}$ un poco & 1 & 2 & 3 & 6 \\
\hline Muy poco & 1 & 0 & 0 & 1 \\
\hline Poco & 1 & 3 & 10 & 14 \\
\hline Aceptable & 58 & 67 & 54 & 179 \\
\hline Muchísimo & 12 & 2 & 7 & 21 \\
\hline
\end{tabular}




\begin{tabular}{|c|c|c|c|c|}
\hline $\begin{array}{l}\text { (26) Están contentos con la ventilación en el interior del } \\
\text { departamento }\end{array}$ & 73 & 76 & 74 & 223 \\
\hline Ni un poco & 0 & 1 & 0 & 1 \\
\hline Muy poco & 0 & 1 & 4 & 5 \\
\hline Poco & 1 & 2 & 2 & 5 \\
\hline Aceptable & 54 & 69 & 60 & 183 \\
\hline Muchísimo & 18 & 3 & 8 & 29 \\
\hline $\begin{array}{l}\text { (27) Las instalaciones de agua y cloaca del } \\
\text { departamento atienden bien }\end{array}$ & 69 & 74 & 75 & 218 \\
\hline Ni un poco & 14 & 9 & 41 & 64 \\
\hline Muy poco & 7 & 5 & 12 & 24 \\
\hline Poco & 37 & 14 & 7 & 58 \\
\hline Aceptable & 11 & 46 & 14 & 71 \\
\hline Muchísimo & 0 & 0 & 1 & 1 \\
\hline $\begin{array}{l}\text { (28) Están contentos con las instalaciones eléctricas del } \\
\text { departamento }\end{array}$ & 77 & 69 & 74 & 220 \\
\hline $\mathrm{Ni}$ un poco & 4 & 14 & 47 & 65 \\
\hline Muy poco & 0 & 4 & 5 & 9 \\
\hline Poco & 11 & 7 & 5 & 23 \\
\hline Aceptable & 55 & 44 & 16 & 115 \\
\hline Muchísimo & 7 & 0 & 1 & 8 \\
\hline $\begin{array}{l}\text { (29) Hay problemas en el interior del departamento en } \\
\text { período de lluvia }\end{array}$ & 72 & 69 & 73 & 214 \\
\hline $\mathrm{Ni}$ un poco & 49 & 48 & 15 & 112 \\
\hline Muy poco & 8 & 1 & 3 & 12 \\
\hline Poco & 6 & 13 & 7 & 26 \\
\hline Aceptable & 6 & 4 & 17 & 27 \\
\hline Muchísimo & 3 & 3 & 31 & 37 \\
\hline $\begin{array}{l}\text { (30) Las áreas de esparcimiento son usadas por los } \\
\text { moradores }\end{array}$ & 75 & 72 & 74 & 221 \\
\hline Ni un poco & 36 & 41 & 32 & 109 \\
\hline Muy poco & 13 & 9 & 22 & 44 \\
\hline Poco & 16 & 16 & 12 & 44 \\
\hline Aceptable & 8 & 6 & 6 & 20 \\
\hline Muchísimo & 2 & 0 & 2 & 4 \\
\hline $\begin{array}{l}\text { (31) Hay dificultad de acceso/circulación en hall, } \\
\text { corredor, escalera }\end{array}$ & 77 & 72 & 70 & 219 \\
\hline $\mathrm{Ni}$ un poco & 69 & 67 & 24 & 160 \\
\hline Muy poco & 5 & 0 & 6 & 11 \\
\hline Poco & 2 & 5 & 3 & 10 \\
\hline Aceptable & 1 & 0 & 24 & 25 \\
\hline Muchísimo & 0 & 0 & 13 & 13 \\
\hline
\end{tabular}




\begin{tabular}{|l|c|c|c|c|}
\begin{tabular}{|l|c|} 
(32) Hay disponibilidad de estructuras públicas básicas \\
(escuela)
\end{tabular} & $\mathbf{7 7}$ & $\mathbf{7 2}$ & $\mathbf{7 2}$ & $\mathbf{2 2 1}$ \\
\hline Ni un poco & 69 & 5 & 6 & 80 \\
\hline Muy poco & 5 & 26 & 28 & 59 \\
\hline Poco & 2 & 23 & 17 & 42 \\
\hline Aceptable & 1 & 18 & 19 & 38 \\
\hline Muchísimo & 0 & 0 & 2 & 2 \\
\hline $\begin{array}{l}\text { (33) Pretende vender su departamento en los próximos } \\
\text { 5 años }\end{array}$ & $\mathbf{7 6}$ & $\mathbf{7 2}$ & $\mathbf{7 0}$ & $\mathbf{2 1 8}$ \\
\hline Ni un poco & 75 & 56 & 35 & 166 \\
\hline Muy poco & 0 & 0 & 1 & 1 \\
\hline Poco & 0 & 11 & 16 & 27 \\
\hline Aceptable & 1 & 3 & 13 & 17 \\
\hline Muchísimo & 0 & 2 & 5 & 7 \\
\hline $\begin{array}{l}\text { (34) Concordancia con la validad de la Ley 962/00 } \\
\text { (ascensor) }\end{array}$ & $\mathbf{7 6}$ & $\mathbf{7 2}$ & $\mathbf{7 3}$ & $\mathbf{2 2 1}$ \\
\hline Ni un poco & 14 & 7 & 13 & 34 \\
\hline Muy poco & 1 & 0 & 0 & 1 \\
\hline Poco & 7 & 1 & 6 & 14 \\
\hline Aceptable & 23 & 39 & 17 & 79 \\
\hline Muchísimo & 31 & 25 & 37 & 93 \\
\hline Fecha: 2017)
\end{tabular}

Fecha: 2017. 1) El total puede no corresponder rigurosamente al número de personas encuestadas para representación de cada comunidad debido al descarte de muestras y/o haber habido respuestas con más de una opción (letra) en una determinada pregunta. Encuestas aplicadas durante el período de jun. 2015 a agosto de 2015. 2) Legenda: A: Parque Patricios/Monteagudo, B: Complejo Luzuriaga, C: Complejo Padre Mugica.

\subsection{3 - Opinión de los moradores de las comunidades de CABA}

Si los moradores de Brasil fueron muy generosos con sus contribuciones en las encuestas, lo mismo no ocurrió, desafortunadamente, con los argentinos, lo que no impidió que se alcanzaran suficientes informaciones sobre sus percepciones y evaluaciones con relación a vivir en una construcción en altura. Sus opiniones están registradas en los Cuadro 5.13 - 5.14. 
Cuadro 5.13 - Generalidades y críticas de la comunidad Parque Patricios/Monteagudo

\section{Generalidades/críticas}

- "- que tengan cuidado con la ejecución de la obra, porque no hubo gente especializada." [sic] (Morador de 68 años);

- "Que se siente Identificado con la construcción por que el participo de la construcción de este proyecto y está agradecido por eso" [sic] (Morador de 47 años);

- “-Prestar más atención a la ejecución de la mano de obra. Así no tuvieran problemas con las terminaciones" [sic] (Morador de 68 años);

- Se advierte sobre la falta de profesionales en la ejecución de las obras del proyecto para evitar, por ejemplo, problemas con la ejecución de las terminaciones.

Fecha: julio de 2017.

Cuadro 5.14 - Generalidades y críticas de la comunidad Complejo Luzuriaga

\begin{tabular}{l} 
Generalidades/críticas \\
\hline De los 75 consultados del proyecto del Complejo Luzuriaga, \\
desafortunadamente, muchos no quisieron informar datos sobre su identidad, \\
prefiriendo mantenerse totalmente anónimos y nadie quiso hacer comentario \\
alguno sobre el Proyecto, ya sea al respecto de la fase de elaboración, del \\
Proyecto, o de la ejecución de las obras e incluso de la post-ocupación, al \\
contrario de lo que sucedió entre los moradores de los tres proyectos \\
investigados en Brasil, donde hubo una gran participación con comentarios \\
críticos y sugestivos así como varios datos socio-demográficos sobre su \\
realidad personal y profesional.
\end{tabular}

Fecha: julio de 2017.

Cuadro 5.15 - Generalidades/críticas de la comunidad Complejo Padre Mugica

\section{Generalidades/críticas}

- "Está cansada de los caballos y que nadie toma interés en ayudarlos" [sic] (Moradora de 40 años);

- "Quiero vender por falta de seguridad y higiene en la convivencia" [sic] (Morador de 50 años);

- "No le gusta los departamentos porque todo está mal construido" [sic] (Morador de 38 años);

- "No me gusta vivir acá" [sic] (Morador de 24 años);

- "problemas estructurales y la convivencia" [sic] (Morador de 41 años);

- "Tienen problemas de convivencia" [sic] (Moradora de 22 años);

- "No se puede convivir" [sic] (Morador de 56 años);

- "No me gusta nada" [sic] (Moradora de 26 años);

- "mala construcion no sirbe nada se nos cae al departamento ensima" [sic] (Moradora de 39 años);

- "muchos problemas de convivencia. inseguridad malisima construción" [sic] (Moradora de 43 años);

- "aparte de todo los problemas las caballerisas no se puede vivir así" [sic] 
(Moradora de 26 años);

- "muy malo todo" [sic] (Moradora de 31 años);

- "mucha inseguridad. muy mala construcción y mucho olor por las caballerisas" [sic] (Moradora de 45 años);

- "vivimos muy mal" [sic] (Moradora de 59 años);

- "Por qué me sacaron de la Villa estaba mejor no tenía problemas" [sic] (Moradora de 33 años);

- "Hay muchos olores y mucha inseguridad" [sic] (no quiso identificarse con dato personal alguno);

- "Falta de Seguridad y los departamentos Se están cayendo a pedazos" [sic] (Moradora de 25 años);

- "y es inseguro vivir en este lugar" [sic] (no quiso identificarse con dato personal alguno);

- "muy mala construcción" [sic] (Morador de 54 años);

- "mala contrucion mucha inseguridad" [sic] (Morador de 68 años);

- "Quisiera Seguir Viviendo en la Villa" [sic] (no quiso identificarse con dato personal alguno);

- "Falta de seguridad" [sic] (Morador de 25 años);

- "No le gusta vivir en ese lugar porque el olor de los caballos es deseperante y la convivencia no es Buena" [sic] (Moradora de 22 años);

- "Hay Muchos Robos dentro del mismo complejo no se Respeta la convivencia" [sic] (Morador de 42 años);

- Hubo quienes no quisieron informar ninguno de sus datos;

- Hubo quien no quiso informar sus datos personales y está disconforme con la vivienda.

Fecha: julio de 2017.

5.3.4 - Síntesis y consideraciones sobre las opiniones de los moradores de CABA

Se percibe que hay una asimetría cuantitativa del volumen de informaciones presentadas por los moradores argentinos con relación a los brasileños, pero, aun así, también se nota una convergencia en las principales quejas entre los dos países al analizarse la contribución prestada por los moradores del Complejo Padre Mugica. Una singularidad entre los argentinos es la total ausencia de comentarios por parte de una comunidad, la del Complejo Luzuriaga, cuyos moradores se limitaron a contestar las 34 preguntas de la Encuesta Tipo1. Al fin y al cabo, incluso con estas limitaciones encontradas entre los moradores argentinos, lo que se obtuvo a partir de esta encuesta ha sido importante y suficiente para el análisis de la realidad argentina investigada.

5.4 - Opinión de los profesionales y líderes comunitarios involucrados en la VIS

Con base en seis preguntas propuestas a los profesionales del área de VIS correspondientes a los seis ejes estructurales que fundamentan el núcleo de esta 
tesis y que direccionaron metodológicamente el rumbo de esta investigación, según se anticipó: a) el proyecto arquitectónico, b) el presupuestario (costos), c) el suelo (para la construcción), d) el tecnológico (conforme la tipología arquitectónica en altura), e) el gerenciamiento gubernamental (políticas públicas), y f) la legislación edilicia, se obtuvo la opinión de estos profesionales sobre los aspectos más positivos y más negativos, según la óptica de cada uno, además de sus impresiones relatadas a partir de las opiniones de los moradores y de los líderes comunitarios también expuestas a ellos durante el trámite de la ejecución de los proyectos. También se presentan las contribuciones de los líderes comunitarios con sus consideraciones, críticas y sugerencias, basadas, inclusive, en lo que les fue reportado por los moradores.

5.4.1 - Entrevista del arquitecto Juan Pfifer responsable del proyecto de Parque Patricios

Esta es una síntesis de la entrevista realizada con el arquitecto Juan Pfeifer (J.P.) en dos oportunidades diferentes e iniciada el 28 de abril de 2010 en la oficina de PfZ Arquitectos, Buenos Aires:

En cuanto a los 6 tópicos sobre los cuales empezamos a reflexionar y que yo te agradecería que me comentaras incluyendo otros tópicos que sean pertinentes y con la mayor profundidad posible y que me indicara, oportunamente, alguna referencia de lectura, ¿qué aspectos creativos se pueden indicar en el Proyecto Parque Patricios/Monteagudo?

J.P.: Como te había comentado, no creo en el concepto de creatividad al estilo de "musas inspiradoras que iluminan el camino del artista". Es más, es muy discutible que a nuestra profesión -la del arquitecto- se la pueda comparar con la del artista. Consecuentemente, los aspectos o pautas que guiaron nuestro trabajo partieron de las necesidades planteadas por el MTL, la investigación - ¿qué hicieron otros frente a un problema de diseño similar?- y el "sentido común" -qué se espera de nosotros como profesionales y como personas sensibles a los dramáticos problemas de muchos semejantes-. Así es que el proyecto se basó en las siguientes pautas:

1) Lograr la máxima cantidad y calidad de viviendas que permita el presupuesto establecido.

2) Procurar la mejor orientación y disposición edilicia del conjunto.

3) Crear un conjunto arquitectónico que armonice con su entorno vecinal, considere la preservación de la memoria urbana y promueva la integración con el barrio.

4) Incorporar espacios de uso comunitario propios al conjunto y para el entorno barrial y preservar la morfología de la manzana con construcciones sobre la línea municipal con el objetivo de evitar espacios descontrolados.

1) El partido adoptado para las unidades de vivienda considera las medidas mínimas fijadas para cada ambiente por el Código de Edificación y la proporcionalidad 
requerida por el programa de necesidades con relación a los dormitorios necesarios para cada hogar. La resultante cuantitativa logra un índice elevado de viviendas sin perjuicio de la calidad de las distintas tipologías. El conjunto alberga 326 unidades de uno, dos y tres dormitorios distribuidos en edificios de 4 plantas, con una adecuada compacidad en sus fachadas, lo que permitió distribuir con eficacia el presupuesto asignado para el conjunto. Se ha adoptado para la resolución de los edificios una volumetría en tira y con viviendas a ambos lados del eje longitudinal. Cada 4 viviendas por planta -16 en total- comparten una escalera común, lo que lleva a submódulos funcionales de fácil mantenimiento y control. El proceso de ajuste en el diseño de las unidades de vivienda -realizado en conjunto con los usuarios- llevó a eliminar las divisiones entre cocina y comedor/estar, habida cuenta de responder a) a las costumbres de reunirse en torno a la mesa familiar y próximo a la cocina, y b) lograr la máxima economía con la eliminación de cerramientos innecesarios. Un gran número de viviendas de 1 y 2 dormitorios contempla un comedor/estar de dimensiones mayores a las requeridas por las normas para permitir, por medio de divisiones temporarias, la inclusión de un nuevo ambiente y atender las necesidades de posibles crecimientos familiares.

2) Las tiras, con orientación este-oeste, brindarán un óptimo soleamiento para el conjunto y viviendas saludables ya que todos los ambientes se iluminan y ventilan a espacios exteriores de escala urbana.

3) Se sumaron pautas al proyecto que se pueden resumir en el intento de superación de los prototipos desarrollados en los años 60/70 de monobloques y torres aisladas con el objetivo de evitar espacios residuales fuera del cuidado de los vecinos. El partido del conjunto es similar para ambas manzanas. Las tiras de edificios conforman patios, los que son interceptados por una trama perpendicular de circulación peatonal que vincula todos los edificios con sus halles de acceso. El espacio entre edificios -los patios- será apto para actividades comunitarias del conjunto y albergar el estacionamiento de automóviles. Conforma a su vez un espacio urbano propio de 12 metros mínimo de ancho que permite la integración de sus habitantes, al mismo tiempo que posibilita la intimidad de cada hogar. La volumetría resultante de la sucesión de tiras de edificios, eficaz cuantitativamente, pero rígida en su aspecto estético-morfológico, fue atenuada y enriquecida con "pórticos" que las vinculan entre sí sobre la línea municipal. Esta decisión permitió reconstruir el frente sobre las calles públicas, marcó el acceso a los pasajes desde el exterior y, dada la materialidad de los pórticos de ladrillo a la vista, incorporó el edificio existente, también de ladrillo a la vista, al conjunto.

4) En el perímetro sobre las calles públicas se localizaron los espacios cubiertos destinados al equipamiento urbano -salón de usos múltiples, locales comerciales, guardería, etc.- con el objetivo de que este uso también sirva al entorno urbano y se promueva la integración vecinal. En la esquina de José C. Paz y Monteagudo se proyectó una pequeña plaza pública que también servirá de expansión al jardín materno infantil.

\section{¿Qué puede comentar sobre el vínculo de los arquitectos proyectistas con las instituciones públicas -políticos, órganos de fiscalización/control de edificaciones-?}

J.P.: Las instituciones públicas guiaron nuestra tarea -profesionales, cooperativa del MTL, etc.- a partir de lo que dicta la Ley 341 de la Ciudad de Buenos Aires dirigida a promover soluciones habitacionales para familias en emergencia a partir de procesos de autogestión. Los controles los realizaba el Instituto de la Vivienda de la Ciudad y también los órganos municipales que tienen que vigilar la correcta aplicación de los Códigos de Planeamiento Urbano y de Edificación. Es de hacer notar que este conjunto de viviendas se realizó cumpliendo estrictamente con todas las normas urbanísticas y de edificación que rigen para todas las construcciones en la Ciudad de Buenos Aires, sin excepciones. También actuó el Banco de la Ciudad de Buenos Aires como entidad financiera. Con relación a los políticos, están los que apoyan 
estos procesos en los que intervienen organizaciones sociales y también de los otros, que buscan con oportunismo exacerbar contradicciones en el seno de comunidades diferentes en lugar de propender la integración solidaria.

\section{¿Y sobre los vecinos de las nuevas habitaciones proyectadas/ejecutadas y del MTL en general?}

J.P.: La relación de los arquitectos con los futuros moradores fue a través de una comisión liderada por Carlos Chile [entonces presidente de CTA]. En los comienzos se hacían reuniones de proyecto en nuestra oficina, donde los arquitectos presentaban sus propuestas, las que luego rediscutían, se observaban o se aprobaban. Fue así que se resolvió, entre otros temas, integrar la cocina al comedor/estar con el consecuente ahorro de una pared, ampliar el estar/comedor en las viviendas de 1 y 2 dormitorios por encima de la superficie mínima que dicta el código para estos ambientes con el propósito de permitir la inclusión de otro dormitorio que resuelva el crecimiento futuro de la familia, colocar un cierre de portones y rejas en los perímetros de ambos conjuntos con el objetivo de no dejar espacios sin control, permitir una circulación transversal al sentido de las tiras de viviendas a partir de halles abiertos, dejar una pequeña plaza como área común no sólo a los nuevos vecinos, sino para compartir con el vecindario del entorno, dejar previstos espacios y locales para la futura instalación de programas complementarios -jardín materno infantil, salón de usos múltiples, radio, locales comerciales-. Durante el transcurso de la obra se realizaban reuniones semanales entre los arquitectos, ingenieros, cooperativa y su empresa constructora con el objetivo de monitorear el correcto avance de los trabajos, del plan de obras, de las normas de seguridad e higiene; tareas que fueron armonizadas y perfeccionadas con el tiempo.

\section{¿Y sobre la vecindad en el entorno?}

J.P.: Los vecinos del entorno al comienzo se alarmaron con los propósitos del MTL de desarrollar en el lugar viviendas para familias en emergencia habitacional, aunque con numerosas reuniones en las que también participamos algunas veces los fantasmas agitados por algunos punteros políticos oportunistas prontamente fueron desapareciendo. Se comprendió que el nuevo conjunto habitacional, lejos de provocar un impacto negativo en el vecindario, traería nueva vida al barrio.

\section{¿Qué puede decir de la actuación/participación del grupo de ingeniería AHF?}

J.P.: Se limitó a realizar su tarea específica/técnica con una paciente labor en el sentido de clarificar en reiteradas oportunidades la necesidad de construir según lo que indican las normas. El tema de las características del suelo de baja calidad y arenoso, producto de antiguos rellenos, de poca resistencia y que impedía construir fundaciones directas fue uno de los temas de fricción con, por aquel entonces, el jefe de obra de la Constructora. Finalmente se aceptó la necesidad de fundar con pilotes, única solución estructural, pero que requirió de un subcontrato, ya que se trataba de una tarea especializada que no se podía realizar con el personal poco calificado con el que se contaba.

\section{¿Qué "cosas" propuestas, acciones, soluciones, no serían repetidas?}

J.P.: Las cosas que no deberían repetirse pertenecen al anecdotario de este proceso, son irrelevantes en el contexto final de esta experiencia y no han influido en el éxito de la obra.

¿Cómo viabilizar la reproducción en otros contextos similares de la exitosa experiencia de Parque Patricios/Monteagudo? 
J.P.: Depende en primer lugar de decisiones políticas, tanto de los estamentos de los gobiernos como de las organizaciones sociales. También es importante ensanchar la conciencia de profesionales y técnicos, así como de la sociedad en su conjunto acerca de la imperiosa necesidad de desarrollar mecanismos que posibiliten el crecimiento de procesos de autogestión, los que son fundamentalmente inclusivos y fomentan y promueven la cultura del trabajo y la solidaridad.

\section{¿Cómo transcurre la post-ocupación particularmente bajo la percepción de los "nuevos" moradores?}

J.P.: Este es un tema fundamental. Se lo debe analizar desde el punto de vista de la sostenibilidad de los elementos físicos -construcciones- y la permanencia de la organización social. Indudablemente, quienes mejor pueden opinar sobre ello son los habitantes.

\section{¿Qué puede decir al respecto del proyecto arquitectónico?}

J.P.: Monteagudo se comenzó a proyectar en el año 2003. En aquel entonces la normativa municipal permitía la construcción de edificios de cuatro niveles: planta baja más 3 pisos superiores sin ascensor, lo que luego fue modificado por la vigente ley de accesibilidad, que solo permite edificios sin ascensor de tres niveles. Creo que esta modificación de la norma mejoró la accesibilidad de los edificios en altura. Al mismo tiempo restringió del $25 \%$ al $33 \%$ la construcción de edificios sin ascensores. Este hecho es significativo en un sentido, en mi opinión, negativo, ya que se aumenta el costo de la construcción por la obligación de incorporar un elemento mecánico de alto valor relativo y el costo de mantenimiento general. Estos dos elementos impactan directamente sobre la viabilidad de Viviendas de Interés Social de media densidad, se aumenta el costo, además de afectar las posibilidades de sustentabilidad: en las VIS el costo de mantenimiento debe ser mínimo. En otro orden, edificios de 4 niveles y de 12 metros de altura son de una óptima proporción volumétrica si se analizan en conjuntos habitacionales, habida cuenta de que el espacio urbano mínimo para su asoleamiento y ventilación, por norma, también es de 12 metros.

En cuanto a su opinión al respecto del proyecto Parque Patricios, en respuesta a la encuesta Tipo 3 (direccionada al sector técnico -arquitectos, ingenieros, urbanistas etc.-) referente a los proyectos investigados en esta tesis, Pfeifer aportó que: dicho proyecto fue elaborado a lo largo de 2 años, plazo que al sumarse al de la ejecución no fueron suficientemente adecuados entre sí, considerando que Pfeifer optó por entender que hubo "alguna" adecuación, el segundo nivel más bajo en la escala de la encuesta. También las revisiones del mismo ocurrieron en un "proceso único y continuo" con mucha participación de los moradores seleccionados, que en la misma medida participaron como operarios de los servicios durante la ejecución del proyecto, además de que no hubo as built ni EPO del mismo.

Según el arquitecto Pfeifer hubo "alguna" (ver las opciones de las preguntas de la encuesta Tipo 3 adjunta) información y entrenamiento de los moradores con relación a la prevención y al combate de incendios. En la misma medida se observó 
que algunos de las estructuras públicas cuestionadas, es decir, guardería, comisaría, centro de salud y lugar de pagos, están lejos, a $1 \mathrm{Km}$ de la comunidad. Según el proyectista que hay suficientes espacios destinados al estacionamiento de vehículos de trabajo de moradores, como bicicleta, carretilla y similares vehículos de venta, como también para actividades económicas explotadas por los moradores, el cual también fue contemplado en el proyecto arquitectónico mediante la existencia de alguna de estas estructuras públicas dentro de la comunidad, destinadas a recreo/esparcimiento y a servicios: plaza, área deportiva y centro comunal.

Un ítem que se evaluó negativo por parte del arquitecto Pfeifer fue el de la regularización del lote y del inmueble residencial del morador, para cuya regularización el trámite fue "poco". Al igual que en Brasil, esta dificultad fue una de las más reclamadas por los moradores de las tres comunidades investigadas, los que refirieron angustia por la demora de la burocracia para la conclusión del referido trámite.

Los temas sobre los cuales el responsable del proyecto arquitectónico del proyecto Parque Patricios no dio respuesta argumentando que no tenía información al respecto están relacionados a: "el surgimiento de un potencial mercado inmobiliario informal en el interior de la comunidad con las nuevas viviendas"; "la aplicación en las nuevas viviendas de tarifas sociales a servicios de compañías públicas -energía, agua y teléfono-"; "el tipo de influencia que hubo o hay de la Canasta social y correlatos en la población adquirente de las VIS en el proyecto". Finalmente, cuando interrogado sobre "cuáles fueron los 5 ítems del proyecto más elogiados por los moradores y cuáles fueron los más criticados”, Pfeifer resumió: “Al decir de los moradores: son viviendas 'lindas'”.

Desafortunadamente, como fue mencionado en este trabajo, a pesar de inúmeras tentativas no se obtuvo en los otros dos proyectos investigados -Complexo Padre Mugica (Villa Lugano) y Complejo Luzuriaga (Barracas)- un conjunto cuantioso de información por parte de los responsables de los mismos, incluso en lo que toca a las instituciones públicas responsables por éstos, como gentilmente fueran aportadas por el arquitecto Juan Pfeifer y la presidente de MTL/CTA, señora Carmen Marisol. 


\subsection{2 - Consideraciones de los profesionales argentinos}

Sigue un resumen con los principales aportes, por categoría, según los seis ejes estructurales de esta tesis, informados por los profesionales argentinos. Conviene aclarar que, aunque no se haya obtenido una gran cantidad de encuestados este grupo de 6 personas aportó una muy rica e interesante contribución sobre la visión general sobre el tema de VIS basada en experiencias en diversas ramas de profesiones a partir de la realidad argentina, de donde se extraen importantes relatos de 3 arquitectos, 1 operador social, 1 geógrafo y 1 abogado con participación directa junto a los moradores de uno de los proyectos durante su ejecución. Así, para ser lo más fidedigno a las fichas de las encuestas, se hizo una adaptación utilizando las comillas, y aunque no se hayan identificado los encuestados, se puede seguir la línea de raciocinio de cada uno de ellos mediante la secuencia final de los números $1,2,3,4,5$ y 6 que les corresponde ${ }^{64}$.

\section{a) Proyecto arquitectónico}

\section{a.1 - Aspectos positivos:}

a.1.1 "definición de una tipología que luego se repite salvo las resoluciones en esquinas y los accesos al conjunto. Respecto de las tipologías, las repetís pero cuando llegas a las esquinas, probablemente haya que encontrar una solución particular y/o ajustar la tipología. Y con el acceso podría pasar algo similar... o en todo caso habría que jerarquizar el acceso..."

a.1.2 "la verticalización es una salida viable para los sectores populares que necesitan seguir viviendo en áreas centrales que pueden ser en la actualidad villas y asentamientos actualmente tugurizados y que deben formalizarse y urbanizarse como vía de construir el derecho a la ciudad. En el estado actual viven en casillas muy densamente pobladas y precarias lo que impide una disposición de los servicios urbanos y una convivencia aceptable. Considero a su vez que la verticalización tiene limitaciones en los casos de edificios de alto costo de mantenimiento como expensas por el mantenimiento de

\footnotetext{
${ }^{64}$ Los siguientes intimes no recibieron ninguna contestación, pues "NADA HA SIDO INFORMADO" cuanto a los mismos por los profesionales cuestionados: a.2.2, b.2.2, b.2.3, b.2.6, c.2.2, c.2.3, d.2.2, d.2.4, d.2.6, e.1.2, e.2.4, e.2.6, f.1.2, f.2.1, f.2.3, f.2.4, f.2.5 y f.2.6.
} 
ascensores, bombas elevadoras, etc. por las limitaciones económicas de las familias en el ciclo de vida de las mismas."

a1.3 "En este sentido, creo que este tipo de proyectos puede contribuir cuando incorpora resoluciones arquitectónicas creativas $y$, al mismo tiempo, resuelve reglas de juego y/o sistemas de adjudicación y gestión de los conjuntos de habitacionales de VIS que incorporan una temporalidad asociada a todo el ciclo de vida del conjunto (ej. se conciben esquemas de alquiler social que permiten controlar la correspondencia entre las necesidades de la demanda y las características de la oferta de las unidades funcionales y/o un mantenimiento del parque habitacional a cargo del estado, etc.)."

a.1.4 "A favor: 1) Los proyectos podrían facilitar la participación de los destinatarios de las viviendas en su etapa de diseño ajustando el mismo a las reales necesidades de los futuros habitantes; 2) Durante la ejecución algunos proyectos emplean como personal a miembros de las familias que vivirán en dichas unidades favoreciendo una más rápida apropiación del espacio; 3) La densificación permite que gran parte de la comunidad previamente constituida en otra parte pueda mudarse junto y conservar sus lazos sociales."

a.1.5 "A) Mayor rendimiento del suelo: En nuestras Ciudades uno de los bienes más escasos es el Suelo, aumentar la densidad permite un mejor uso de este recurso. B) Organización social: Generar pequeños consorcios, individualizados por las circulaciones verticales, de escala menor (hasta 4 niveles) permite afianzar conceptos de red social y organización comunitaria que favorecen a la integración de la trama social. C) Construcción de ciudad: Los conjuntos de pequeña escala y altura media, permiten reproducir la heterogeneidad del hábitat construido en las urbes. La incorporación de pequeños comercios en el nivel 0 , vinculados con patios de escala vecinal, fomentan esta situación."

a.1.6 "Contribuye: eficiencia en apilamiento y uso compartido de programas. Economía en servicios comunes y zonas de servicios sanitarios".

\section{a.2 - Aspectos negativos:}

a.2.165 "homogenización formal que impiden al usuario identificar su vivienda"; "Optimización de núcleos de escaleras, accesos y circulaciones"; "Optimización de núcleos húmedos" “Optimización orientación de locales (habitaciones) principales es decir para un edificio en

\footnotetext{
${ }^{65}$ Se aclara que quien colaboró con estas informaciones en la encuesta aprovechó para ofrecer en este tópico sugerencias para la optimización al combate de los problemas de esta naturaleza, encontrados generalmente, a su ver, en proyectos arquitectónicos de VIS.
} 
altura lo ideal y racional es que coincidan desde la $P B$ hasta el último piso... tengan una lógica de funcionamiento y de conjunto."

a.2.3 "Creo que los factores que más impiden para pensar proyectos arquitectónicos de VIS de 4 o 5 niveles en los grandes centros urbanos es la relación que pueden tener estos proyectos con la población objetivo y la administración o gestión de los mismos. En particular dado los desfasajes entre la demanda que no es estática y adquiere progresividad en el tiempo o frente a los requerimientos de ampliaciones de las viviendas dada la falta de la universalización de la política o la cobertura de la VIS."

a.2.4 "En contra: 1) Habitualmente no se toman ni aplican los beneficios enunciados arriba; 2) No se considera que habitualmente las viviendas de los sectores populares son al mismo tiempo unidades productivas, es decir, allí también se trabaja, se comercia, se realiza un oficio y la vivienda es también un taller; 3) El juntar muchas personas de una misma clase social, habitualmente segregada no facilita la mixtura social y termina generando guetos o trasladándolos de un lado a otro (antes era a la villa, ahora es el complejo habitacional); 4) Habitualmente las familias realojadas en un complejo habitacional no están acostumbradas a trabajar coordinadamente para, por ejemplo, preservar los espacios comunes del nuevo espacio habitacional profundizando conflictos interpersonales y acelerando el deterioro edilicio; 5) Cuando las tecnologías utilizadas para la construcción no son familiares a sus nuevos moradores obstruye las posibilidades de intervención para realizar arreglos y desalienta la implementación de mejoras y la apropiación del espacio en sí mismas (en algunos casos genera temores a incendios o derrumbes inminentes)."

a.2.5 “D) Requiere alto control de las áreas comunes: La pauperización de los códigos sociales en las últimas décadas nos indican que cualquier espacio residual se transforma en "tierra de nadie". Es necesario entonces trabajar con cubiertas con pendiente, evitando las terrazas comunitarias y el control de los accesos. E) Organización social: Así como estos conjuntos generan elementos que favorecen la interacción de las familias, un mal funcionamiento de esta relación se vuelve contraproducente en cuanto al mantenimiento y administración de los bloques. F) Identidad: Un mal diseño de los conjuntos corre el riesgo de la repetición masiva y anónima, que quita identidad al Hábitat, generando una sensación de no pertenencia."

a.2.6 "Impiden: cultura de vivir en un lote propio. Aislamiento social."

${ }^{66}$ Ver ítem a.1.5: secuencia A, B y C. 


\section{b) Presupuestario (costos)}

\section{b.1 - Aspectos positivos:}

b.1.1 "Menores costos de los materiales al aumentar la cantidad de viviendas. Costos competitivos."

b.1.2 "Respecto de los costos, entiendo que la verticalización puede ser una alternativa conveniente dado el crecimiento exponencial del valor del suelo. Los incrementos desproporcionados del valor del suelo hacen de la verticalización una opción conveniente, aunque entiendo que los costos constructivos pueden incrementarse. Mi experiencia ha dado que la gestión asociada con cooperativas y autoconstrucción han sido históricamente vías de gestión con bajos costos en relación a las vías por empresa privada o por administración. En ambos casos, pero principalmente por autoconstrucción, se plantean las limitaciones técnicas para ejecutar obras complejas por lo que la verticalización sería en pocas plantas."

b.1.3 "En principio éste es a mi juicio un factor positivo lo que contribuye al desarrollo de este tipo de propuestas, permite ciertas economías de escala, genera un uso más eficiente de la infraestructura urbana, puede habilitar intervenciones en los espacios centrales con mejor optimización del uso del espacio y ventajas de localización."

b.1.4 "A favor: Un proyecto a gran escala tiende a reducir los costos de construcción y reduce los tiempos de la misma."

b.1.5 “G) Infraestructura urbana: Los conjuntos de media densidad, tienden a reducir la incidencia de los nexos de infraestructura, respecto de aquellos que a igual densidad se extienden en el territorio. H) Sistematización: la ejecución de módulos que se replican en niveles disminuye la incidencia de grandes rubros de la obra, que determinan un mejor aprovechamiento de los recursos. I) El mantenimiento: La administración conjunta de los bloques facilita la carga presupuestaria del mantenimiento respecto de los lotes individuales, repartiendo esta carga en el conjunto de las familias que lo habitan."

b.1.6 "Contribuye: economía de recursos. Disminuyen los costos cuanto mayor el número de viviendas. De manera indirecta la producción en serie disminuye tiempos de ejecución y mejora la ecuación tiempo-costos".

\footnotetext{
${ }^{67}$ Ver ítem a.2.5: secuencia D, E y F.
} 


\section{b.2 - Aspectos negativos:}

b.2.1 "el mayor costo de las estructuras y costo de los ascensores, en el caso que sean solo 3 los pisos. Instalaciones sanitarias, gas, electricidad; gerenciamiento de la obra en cada etapa de proyecto, construcción, funcionamiento; gestión del edificio en la etapa de funcionamiento. Mantenimiento."

b.2.4 "En contra: 1) Los privados, empresas constructoras adjudicatarias o contratadas directamente, muchas veces cuentan con la connivencia de funcionarios públicos que les permiten sobrefacturar materiales y trabajos aumentando sensiblemente los costos $y$ tiempos de construcción; 2) Muchas veces no se establece qué materiales (tipo/marca/año/etc.) se utilizarán y la calidad de los que son utilizados es muy baja."

b.2.5 “J) Mantenimiento de áreas de servicio: Si bien las áreas comunes son de fácil mantenimiento, los conjuntos en altura requieren de atención en el mantenimiento de instalaciones especiales como las termo mecánicas. K) Sustentabilidad: En este tipo de bloques, la incorporación de elementos que favorecen la sustentabilidad de la arquitectura aún son de un costo muy elevado. L) Materialidad: En conjuntos de VIS se debe tener como premisa el bajo costo de mantenimientos, esto implica materiales y sistemas de alta perdurabilidad y niveles de terminación completos, lo que incide netamente en el costo de la construcción."

c) Suelo (para la construcción)

c.1 - Aspectos positivos:

c.1.1 "La construcción en altura contribuye a la optimización del costo del suelo; El aumento de la densidad optimiza el costo del suelo".

c.1.2 "Respecto al suelo es importante destacar que la verticalización puede ser adecuada a los predios de poca superficie pero que dada su ubicación central lo que brinda una inserción económica a sus pobladores inigualable, se torna imposible la relocalización. Estas pequeñas superficies suelen tener problemas de baja cota, pero podrían elevarse a un costo razonable. Son los casos de áreas adyacentes a cauces de ríos o arroyos o ramales de ferrocarril en desuso."

\footnotetext{
${ }^{68}$ Ver ítem b.1.5: secuencia anterior $\mathrm{G}, \mathrm{H}$ e I.
} 
c.1.3 "Como dije anteriormente, la posibilidad que brindan estas tipologías o proyectos constructivo en relación al suelo es un factor que contribuye. Es decir, la densidad permite mejor aprovechamiento del suelo, por tanto, en teoría y según las condiciones en las que se desarrolle la política habitacional, podría generar mejores condiciones de localización o inserción urbana de la VIS."

c.1.4 "la elección del suelo donde se construirá el conjunto urbano tiene directa relación con las futuras posibilidades de integración urbana."

c. $1.5^{70}$ “M) Mayor rendimiento del suelo: En nuestras Ciudades uno de los bienes más escasos es el suelo, aumentar la densidad permite un mejor uso de este recurso. Sobre todo, si se lo mixtura en los usos. N) La plusvalía: La recuperación de áreas degradadas desde lo urbano, que permiten valorizar el recorte urbano donde se insertan 0 ) Completamiento de la mancha urbana: Integrando sectores que se encontraban como marginales de la misma."

c.1.6 "Contribuye: la densidad, dinamiza los sectores urbanos, mejora la relación de programas de usos mixtos y sistemas de conexión (transporte)."

\section{c.2 - Aspectos negativos:}

c.2.1 "Alto costo del acceso al suelo con infraestructura; Escasez de tierra cercana a los núcleos urbanos."

c.2.4 "Habitualmente los suelos utilizados son rellenos sanitarios saneados, pero con un peligro latente de contaminación de la población. Los estudios de suelo no siempre son realizados con rigurosidad poniendo en riesgo la estabilidad y los edificios."

C.2.5 $5^{71}$ "P) Saturación de redes: Se debe tener en cuenta muy especialmente el estado de las redes de infraestructura en la zona, de manera de no saturar las mismas o en caso contrario que la incidencia de su ejecución haga inviable el proyecto de viviendas. Q) Saturación de la mancha urbana: Una mala elección de la localización del predio, podría devenir en una saturación, no solamente física sino del equipamiento social del sector."

\footnotetext{
${ }^{69}$ Vinculado a ítem a.2.4, punto 1, "En contra", 3.

${ }^{70}$ Ver ítem b.2.5: secuencia J, K y L.

${ }^{71}$ ver ítem c.1.5: secuencia $\mathrm{M}, \mathrm{N}$ y $\mathrm{O}$.
} 
c.2.6 "Impiden: contar con predios (terrenos) de mayor tamaño para la ejecución de edificios colectivos."

d) Tecnológico (conforme la tipología arquitectónica en altura)

\section{d.1 - Aspectos positivos:}

d.1.1 "No existen factores tecnológicos que impidan la construcción de edificios de 3 pisos de altura."

d.1.2 "En el caso de la verticalización, el factor tecnológico puede ser una limitante para las modalidades propuestas de modalidades de gestión mano de obra intensiva como autoconstrucción o cooperativas. De todos modos, la universidad está haciendo un aporte tecnológico considerable a estos actores sociales por lo que puede pensarse en una compensación de dicho atraso tecnológico."

d.1.3 "en términos potenciales tal vez podría ser un factor que contribuiría siempre y cuando la dimensión tecnológica se vuelva una variable de peso en las decisiones de política habitacional, siendo criterios claves la eficiencia constructiva los costos de los materiales, la sustentabilidad ambiental y la flexibilidad, adaptabilidad o practicidad constructiva. Esto sin embargo resulta paradójico exigírselo a la VIS, cuando en realidad, en el caso argentino, está muy poco desarrollado en el resto del parque habitacional."

d.1.4 "en la mayoría de los casos la tecnología ha favorecido la construcción en altura, con materiales más livianos y de rápida colocación."

d.1.5 "R) Utilización de sistemas de prefabricación liviana: Estos sistemas son ideales para la ejecución de módulos de esta magnitud, obteniendo una ejecución rápida, y la posibilidad de flexibilizar las plantas y darles una cobertura integral a las condiciones de confort en la relación exterior-interior. S) Instalaciones sistematizadas: Uno de los puntos críticos en la VIS es el desconocimiento del funcionamiento de las instalaciones, motivo por el cual se recomienda un sistema de fácil mantenimiento y de clara utilización. T) Respuestas acordes a las distintas situaciones: Trabajar mucho respecto de la orientación, tanto para el ahorro energético como para su acondicionamiento. $\mathrm{Y}$ al mismo tiempo dar diferentes respuestas a los diferentes requerimientos, inclusive en las caras de un mismo bloque."

\footnotetext{
${ }^{72}$ Ver ítem c.2.5: secuencia P y Q.
} 
d.1.6 "Contribuyen: a implementar tecnologías y sistemas a escala del proyecto, mejorando la situación de los tiempos de ejecución. Se puede aplicar una/varias tecnologías constructivas y repetirlas en todas las unidades."

\section{d.2 - Aspectos negativos:}

d.2.1 "Necesidad de mano de obra especializada; escasez de mano de obra; ausencia de aplicación de construcción industrializada."

d.2.3 "Por lo menos para el caso argentino me cuesta pensar cómo juega la dimensión tecnológica, si como un factor que impide o contribuye. Esto se debe a que en general todo el debate y la discusión tecnológica ha logrado permear escasamente el desarrollo concreto de la política habitacional argentina. Es decir, siempre ha habido aplicaciones tecnológicas o pruebas piloto de distinta naturaleza, pero con bajo impacto o poco alcance en el desarrollo de la política a gran escala."

d.2.5 “U) La mala interpretación de la sistematización tecnológica: En muchos casos la velocidad constructiva y la simpleza de un sistema juega en contra de los niveles de terminación, calidad y confort necesarios para estas viviendas, priorizando un tema de recursos simplemente. V) El abaratamiento de los espacios comunes: El no entender que el espacio común, tanto en los servicios como en los de recreación, es parte fundamental del Hábitat y que [sin] estos no existe la posibilidad de una vivienda acorde. W) La materialidad: Produce un gran problema el no entendimiento del uso de ciertos materiales respecto de la intencionalidad de la obra. Se debe trabajar con materiales de alto efecto y que respondan a una identidad y a una funcionalidad particulares en cada caso."

e) Gerenciamiento gubernamental (políticas públicas)

\section{e.1 - Aspectos positivos:}

e.1.1 "El déficit es una oportunidad para que esa política incluya planes, proyectos y presupuestos adecuados para la construcción de viviendas en altura."

e.1.3 "Podría ser un factor positivo si se apostara a desarrollar líneas de educación popular y acciones sistemáticas y sostenidas por parte del estado en generar colectivos capaces de a

\footnotetext{
${ }^{73}$ Ver ítem d.1.5: secuencia R, S y T.
} 
pesar de la escasez de recursos afrontar / administrar las relaciones de convivencia y tensiones urbanísticas entre el interés de los particulares y las necesidades colectivas."

e.1.4 "Es clave la posición respecto de las VIS de las personas que se desempeñan en agencias gubernamentales, por ejemplo, en la confección de pliegos de licitación, en la determinación del sistema constructivo que se va a implementar y sobre el rol que entienden que debe cumplir la VIS. Un gobierno comprometido con la mejora sustancial de las condiciones de vida de los más humildes seguramente tienda a realizar proyectos sostenibles y sensibles de las necesidades de la gente, un gobierno que piense pobremente para los pobres no tendrá el mismo interés por realizar obras públicas en las que cualquier persona se sienta a gusto de vivir en ella."

e.1.5 "X) Global: En este caso es difícil sintetizar en tres puntos. Solamente dejo algunas reflexiones. Hacer vivienda es hacer ciudad, con lo que no deben existir políticas públicas que no entiendan el problema de la marginalidad urbana por fuera de la problemática del conjunto de la ciudad. Uno de los errores más habituales es hablar de la "integración de las villas o favelas", cuando en realidad existen y son parte de las ciudades por varias décadas. Quizás el tema es repensar el paradigma y decir que las ciudades deben integrar a los barrios marginales' de manera tal de comenzar a cicatrizar estas heridas urbanas."

e.1.6 "Contribuyen: a la planificación de ejecución de programas de viviendas por etapas. Mejora la posibilidad de ejecutar de manera paralela obras mayores de infraestructura (cloacas, calles, tendidos de otros servicios, etc.)."

\section{e.2 - Aspectos negativos:}

e.2.1 "ausencia de políticas adecuadas para reducir el déficit habitacional; ausencia de presupuestos adecuados; ausencia de banco de tierras públicas; déficit existente a lo largo de décadas también es un desafío para seguir pensando en nuevas políticas públicas."

e.2.2 "Desde el punto de vista gubernamental, la verticalización ha sido una opción en otras etapas históricas (décadas del 50 al 80) donde el estado buscaba una vivienda social típicamente urbana sin pensar mucho en las condiciones de adaptación de los destinatarios quienes en gran mayoría eran migrantes rurales o de otras provincias o de otros países. Esto ha traído problemas de adaptación. En ese caso la verticalización no debería ser una

\footnotetext{
${ }^{74}$ Ver ítem d.2.5: secuencia $U, V, y$ W.
} 
modalidad exclusiva, sino que debería ser parte de una política pública que comprenda otras opciones de tipología de vivienda más adecuadas a este tipo de sectores sociales."

e.2.3 "En relación a los proyectos de VIS de 4 o 5 niveles en los grandes centros urbanos este tal vez sea uno de los principales obstáculos. Me refiero a en términos generales la propia lógica de las políticas públicas y en particular la tradición de la política habitacional ha llevado a que la acción del estado termina cuando termina la construcción de la VIS o de los conjuntos habitacionales. Es decir, el 'final de obra' supone desde la visión dominante de la administración pública la transferencia del parque habitacional a los propietarios o adjudicatarios, instancia a partir de la cual el Estado busca desentenderse del problema. De allí que la decisión de priorizar intervenciones de vivienda unifamiliares mínima con posibilidades de ampliación en lote individual haya sido en el caso argentino o bonaerense una estrategia de la política pública para disolver o minimizar los 'problema del día después'. La gerencia gubernamental puede ser un factor que impide cuando (el tipo de relación o) los esquemas de transferencia del parque habitacional a los usuarios generan tensiones entre la población objetivo (perfil de los adjudicatarios), sus prácticas (o comportamientos) y las posibilidades de mantenimiento. En otras palabras, al no haber una 'cultura' o fortalecimiento de los procesos de gestión de los consorcios o las relaciones de copropiedad."

e.2.5 “Y) Tomar a la intervención en vis como una cuestión netamente económica: El problema es profundamente social y la respuesta debe buscar una balanza de equilibro que pondere otras situaciones. Z) Los programas centralizados: Tal como sucede en Brasil con lo producido en el Programa Minha Vida Minha Casa [sic], producciones iguales para problemáticas distintas. Se debe diferenciar la producción según la particularidad de cada caso y de cada región donde se ubica. No existe una receta única y una buena gestión gubernamental debe comprender esta situación."

f) Legislación edilicia

\section{f.1 - Aspectos positivos:}

f.1.1 "Revisar los códigos de Planeamiento Urbano y el de la Edificación y detectar incongruencias o potencialidades para localizar la construcción en cuestión."

f.1.3 "no lo veo como impedimento ni como contribución."

\footnotetext{
${ }^{75}$ Ver ítem e.1.5: secuencia X.
} 
f.1.4 "Tanto la ubicación como las dimensiones y alturas de las viviendas son un fuerte límite a este tipo de proyectos y vienen dadas por la normativa edilicia (CPU y Código de Edificación). Muchas veces es necesario cambiar la zonificación de determinada área de la ciudad para permitir la construcción de viviendas de interés social. Otras veces el uso de determinadas tecnologías constructivas debe ser previamente aprobado y constar en el Código de Edificación del lugar. Sin embargo, resulta ser el mercado inmobiliario el factor determinante de la construcción de este tipo de proyectos. La ubicación en primer lugar, las comodidades que brinda en comparación con proyectos privados y en consecuencia el rol que se autoasigna el estado como desarrollador inmobiliario. Dentro del marco normativo que rige la materia no puede dejar de evaluarse los planes de desarrollo urbano y los estándares a los que deben adecuarse todas las viviendas incluyendo a las viviendas dentro [de] un plan coherente de desarrollo de la ciudad. Así la infraestructura debe estar garantizada antes de realizar el proyecto o por lo menos antes de su finalización, las redes de contención social (educación, esparcimiento, seguridad, salud) deben poder atender la demanda que dicho enclave urbano vaya a generar. Sin un marco regulatorio claro, comprensivo y coherente de desarrollo urbano alineado con las metas de la ciudad, las VIS podrían condenarse al fracaso antes de empezar."

f.1.5 "Tal como expresé en el punto anterior [e.2.5], cada programa debe tener su propia identidad, para esto es necesario contar con una Legislación amplia y flexible, que fije parámetros de calidad, tanto en superficies como en materiales adecuados y que se adapte a cada situación desde la normativa urbana."

f.1.6 "Contribuyen: a tener 1 título de propiedad para todo el edificio que luego debe escriturarse por cada unidad (propiedad horizontal)."

\section{f.2 - Aspectos negativos:}

f2.2 "Por mi experiencia, tanto la propiedad horizontal como los consorcios no son instituciones de fácil acceso a la comprensión y el consiguiente ejercicio de derechos por parte de la población popular. Esto trae aparejado conflictos entre vecinos por la dificultad estructural que se genera al imponer un mantenimiento colectivo vinculante de un edificio a un número de personas que tienen una situación económica y social heterogénea, cambiante y vulnerable propios de su situación de clase. Esta heterogeneidad social de conciencia y la discontinuidad e insolvencia económica se desadapta fácilmente de su destino vinculado colectivamente como copropietarios de un edificio al cual están obligados solidariamente a mantener para que esté operativo y brinde un servicio habitacional aceptable." 
De modo general, se constata que las opiniones de los profesionales argentinos tienden a converger tanto en los aspectos negativos como en los positivos, e incluso en las sugerencias, en cuanto a las seis categorías estructurales del tema. También en esta parte de las consultas, nuevamente se constata que, más allá de las diferencias existentes entre Argentina y Brasil, las similitudes son muy próximas en lo que se refiere a las VIS, ya sea con relación a sus problemas como con relación a las soluciones propuestas por los profesionales en ambos países.

Sin embargo, un punto que llama la atención es el relacionado a la mencionada Ley 962 del 5 de diciembre de 2002, de la CABA, en la que se prohíbe que cualquier construcción con más de 2 pisos además de la planta baja no disponga de un ascensor. A excepción del arquitecto Juan Pfifer, nadie se posicionó sobre la inconveniencia de esta ley, que si bien se preocupa por la accesibilidad de las personas, en especial de los ancianos, por otro lado hace la vista gorda en cuanto a la probable reducción de la producción de viviendas sin ascensor, en torno del 25 al 30\%, según constata Juan Pfifer, lo que se vuelve un problema, en especial para las familias de más bajos ingresos, y significa en la práctica un obstáculo más para el acceso a la VIS. Se desprende que esta medida prohibitiva sea un obstáculo para los sectores de más bajos ingresos para el acceso a las VIS, aunque para la gran mayoría de los 225 moradores que respondieron la encuesta la Ley 962 resultó ser satisfactoria (pregunta número 34 "¿A usted le parece válida la prohibición de la Ley porteña 962 de 2002 que impide la construcción en CABA de departamentos en edificios con más de 2 pisos además de la planta baja sin ascensor?"). Surge entonces la duda de si la pregunta 34 en cuestión haya sido mal redactada o poco clara para los moradores, tema que merece una mayor reflexión en el futuro.

\subsection{3 - Proyecto de la comunidad de Paraíso Azul/Recanto Feliz, Salvador}

Este proyecto estaba en fase final de su segunda etapa en diciembre de 2014, involucrando 184 unidades habitacionales, de las cuales 25 villages (casa unifamiliar con 1 piso además de la planta baja) y 128 departamentos distribuidos en bloques de 4 pisos además de la planta baja, sin ascensor y con 4 departamentos por piso. El padrón constructivo utilizado en la fundación fue de "estaca" coronada por vigas "baldrame" y de estructura autoportante. El terreno era del Estado de Bahia y los moradores lo ocuparon hace cerca de 30 años o más. Algunos de los proyectos fueron hechos por CONDER, otros por empresas privadas, y se tardó cerca de un 
año en concluirlo. Se estima que alrededor de 2000 personas de la vecindad fueron beneficiadas por las mejoras en la comunidad.

5.4.3.1 - Opinión de los profesionales del sector técnico: arquitectura, ingeniería y urbanismo de CONDER

Con relación a las dos revisiones por las que los proyectos pasaron en la segunda etapa, se dieron por los cambios que continuaron ocurriendo, después de empezadas las dos etapas, debido a nuevas ocupaciones.

En referencia a la participación de los moradores en las discusiones del proyecto, hubo un cierto desfasaje en las respuestas dadas por el grupo de profesionales que actuaron directamente en las obras: hubo quien dijo que no ocurrió ninguna participación, hubo quién respondió que existió alguna participación, y también quién afirmó que hubo mucha participación. Luego se explicó que después de entregada la primera etapa del proyecto, los moradores aportaron sus observaciones al equipo de CONDER, que las aprovechó para la implantación de la segunda etapa. Esto explica las divergencias entre las respuestas de los profesionales. Se observó, al analizarse las encuestas, que no todos participaron de las dos etapas y que en general las respuestas reflejaban la realidad vivida en ambas etapas indiferentemente, predominando el análisis sobre la realidad más reciente, es decir, la de la segunda etapa, aunque ambas son muy similares en prácticamente todo. Además, por el hecho de que la primera etapa ocurrió hace más o menos diez años, mucha información se encuentra sin registro o dicho registro se ha perdido. En relación con el acompañamiento y fiscalización de las obras, eran hechos diariamente por el equipo de CONDER, así como por la Comissão de Acompanhamento de Obras (CAO). También formaban parte de estos operativos las "Reuniones periódicas con líderes para socializar situaciones ocurridas en obra y detectadas durante la fiscalización".

Sobre la realización del as built de los proyectos, las respuestas también fueron divergentes, pues, por un lado, se dijo que no hubo, y, por otro, se informó que el mismo estaba en trámite y también, que no se aplicaba, pues la segunda etapa se encontraba en ejecución. También se dijo que sí hubo con relación al proyecto de implantación urbanístico, pero que sin embargo no lo hubo para las viviendas, pues no existieron alteraciones en el proyecto de éstas, que es padrón. Con relación al procedimiento de EPO, también no hubo unanimidad en las 
respuestas, pues se dijo tanto que no hubo como que alguna hubo. Se encontraron como aclaraciones entre las respuestas que el equipo de fiscalización de CONDER acompañó el proceso durante seis meses después de entregadas las viviendas, y que para más detalles se consultara al sector social. También fue dicho que, por el contrato entre CONDER y la constructora, ésta tendría que dar asistencia técnica en relación con la calidad y desempeño de las obras después de entregadas, pero nada consta sobre que este compromiso se extendiera a la EPO.

Sobre los motivos que justificaron los adicionales presupuestarios contractuales de la obra fue informado que, para la segunda etapa, los responsables fueron los ítems referentes al área de recreo -área deportiva, parque de infantes, plaza-, de almacenamiento de basura para reciclaje y la ejecución de contención de pendiente. Según dicha justificación, las mencionadas áreas no estaban originariamente previstas en el proyecto. Por otra parte, también se alegaron imprevistos como la revisión del proyecto, por ejemplo, en materia de electricidad, hidráulica y sanitaria, revisión que provocó atrasos de obra y aumento de costos, así como la remoción de familias y las demoliciones de sus precarias viviendas, lo que también sucedió en la primera etapa.

El porcentaje de participación de los moradores que fueron contratados por la constructora para realizar las obras, según uno de los encuestados, fue "suficiente", mientras que para otros fue "alguno" (el cuestionario tiene 4 opciones en orden ascendente: "ninguno", "alguno", "suficiente" y "mucho"). Fue informado que siempre que era posible la constructora contrataba los operarios entre los vecinos del público seleccionado para VIS, generalmente mediante indicación o solicitación del sector social de CONDER, con el apoyo de los representantes comunitarios. Incluso fue dada como información adicional que cerca del $20 \%$ de la mano de obra utilizada por la constructora para la ejecución del proyecto fue de moradores atendidos por el sector social de CONDER. En relación con el entrenamiento de los moradores (señalado por éstos como insuficiente), los profesionales tampoco convergieron en sus respuestas: uno mencionó que sólo al final de la segunda etapa se dio entrenamiento a los moradores, y en cuanto a la primera etapa, que no tenía conocimiento de que hubiera ocurrido. Otro contestó que no ocurrió ninguna acción en ese sentido, e informó que es común que CONDER entregue a los moradores panfletos informando sobre la ubicación de equipos de combate de incendios y procedimientos sobre el tema. 
Con relación sobre las cinco estructuras públicas -escuela, guardería, comisaría, centro de salud y lugar de pagos-, "algunos" de éstos están a más de 1 $\mathrm{Km}$ de la comunidad. Por otra parte, todos los encuestados fueron unánimes al afirmar que no hay ningún espacio en el proyecto destinado a guardar los vehículos de trabajo de los moradores, como bicicletas, carretillas y similares, etc., cuestión que toca muy de cerca al morador, lo que se hizo notar en la encuesta. Otro tema de cierta manera asociado a éste es el relacionado a la disponibilidad en el proyecto de espacios para actividades de renta para los moradores: la mayoría de los profesionales informó que, en la segunda etapa, al igual que en la primera, había, sí, por ejemplo, ocho quioscos dispuestos para comercio. En lo referente a los espacios colectivos, cuando cuestionados sobre la existencia de alguna de las tres estructuras públicas previstas en el proyecto -plaza, área deportiva y centro comunal- fue informado que, de la primera etapa, hay ya una pequeña plaza y un centro comunal que la comunidad usa para reuniones, y que en la segunda etapa está prevista la implantación de actividades sociales rutinarias, así como la implantación de una plaza más, un parque infantil y un área deportiva.

Sobre un comparativo de costos entre el valor previsto originalmente en el proyecto y el valor final, de los profesionales que contestaron, justificaron la diferencia debido a los imprevistos, con una estimativa adicional de entre el 10 y el $25 \%$ del valor original, basados en los datos y realidades de la segunda etapa, no habiendo mencionado nada más sobre la primera. Un tema asociado a éste es el de la adecuación de los plazos previstos y realizados, tema sobre el que hubo unanimidad, reconociendo que siempre hay desfase y generalmente debido a las dificultades del cronograma financiero del Estado, lo que en último momento significa retraso de pago a la constructora y aumento de costos.

Si hay un tema tabú en investigación de VIS, es el pertinente a negocios informales -compra/venta, alquiler- de las viviendas en cuestión. Es permitido comparar, y nadie se siente cómodo para comentarlo en público principalmente los moradores, excepto de manera individual y reservada. Aun así, entre los profesionales es sabido que la gente de la comunidad comenta este operar y hasta incluso se estima que ocurre en una muy alta proporción, en torno del $90 \%$, pero nadie lo comprueba, ya que es de difícil averiguación, además de que no es de competencia inmediata de la CONDER. Se comenta incluso que el hecho toma dicha proporción cuando el proyecto está implantado en un área "noble" de la ciudad, por lo que pasa por un gran nivel de especulación inmobiliaria. Incluso se 
sabe de la venta de casas anticipadamente al saber que el Estado programa hacer una intervención, tipo demolición, e incluso venden la casa nueva recibida por el proyecto inmediatamente después de tomar posesión. Relacionado a este tema hay otro no menos polémico, sumado al hecho de que hasta entonces es lo que más demora en ser concretado, es decir, la regularización del lote, donde generalmente la titulación de la vivienda está asociada a dicha regularización. Hay toda una burocracia en cuestión: jurídico-edilicia que demanda mucho tiempo y consecuentemente todo esto desmoraliza a los moradores que tienen sus expectativas insatisfechas en lo inmediato. Sumado a esta problemática, hay quien entiende que la política de eximir totalmente el pago de la financiación de la unidad habitacional tiene que ser revista para, sino impedir totalmente, al menos cohibir dicha práctica ilícita. Conviene aclarar que la regularización de la titularidad del inmueble, de responsabilidad de la CONDER, se encontraba en trámite aún en 2014 y 2015, período de las encuestas, para la primera etapa, de la cual se entregaron las viviendas en 2008.

Con relación a las tarifas de los servicios públicos básicos de energía eléctrica, agua y teléfono, no hay alguna rebaja específica para los moradores de VIS, excepto las que ocurren para todos los integrantes de la sociedad. Al final de las obras CONDER mantiene contacto con las empresas prestadoras de servicios para que, por su intermediación, los trámites sean agilizados entre los moradores y las empresas en cuanto a las instalaciones finales, por vivienda, para el cálculo de consumo y consecuente pago.

El efecto de la influencia de la canasta básica social, Bolsa-familia, entre la comunidad no es algo percibido por los profesionales del área técnica, los cuales contestaron con "ninguna" influencia, o que "no hay informaciones al respecto, excepto extraoficial". Uno afirmó que la mencionada influencia es "mucha", pero sin embargo no lo ha justificado.

Al pedirles a los profesionales del sector técnico que presentasen los ítems más elogiados y criticados del proyecto por parte de los moradores, se tiene obtiene el Cuadro 5.16: 
Cuadro 5.16 - Resumen de la opinión de la comunidad Paraíso Azul/Recanto Feliz expuesta a los profesionales del sector técnico de CONDER

\begin{tabular}{|c|c|}
\hline Elogios & Críticas \\
\hline $\begin{array}{l}\text { - Buen relacionamiento entre los } \\
\text { moradores y con el equipo de } \\
\text { profesionales de CONDER; } \\
\text { - } \text { Pasar a vivir en condiciones de } \\
\text { habitabilidad dignas (no más vivir } \\
\text { en vivienda precaria); } \\
\text { - Buena ubicación de la comunidad; } \\
\text { - Exención del pago de financiación } \\
\text { del departamento (para la } \\
\text { - } \text { Segunda etapa del proyecto); } \\
\text { - (prbanización de las calles } \\
\text { - Adquisición de una vivienda. }\end{array}$ & $\begin{array}{l}\text { - Pago en colectivo del consumo de } \\
\text { agua; } \\
\text { - Salida de una casa para pasar a } \\
\text { vivir en un departamento; } \\
\text { - Tamaño pequeño del } \\
\text { departamento; } \\
\text { - Ocurrencia de problemas en los } \\
\text { techos de los departamentos del } \\
\text { último piso (infiltración de agua de } \\
\text { lluvia); } \\
\text { - Error de ubicación del hidrómetro } \\
\text { en } 3 \text { bloques de departamentos; } \\
\text { - Piso interno del departamento } \\
\text { entregado por CONDER sin } \\
\text { revestimiento; } \\
\text { Cambio que ocurrió al cimentarse } \\
\text { un piso externo al bloque, que } \\
\text { originariamente estaba con } \\
\text { césped. }\end{array}$ \\
\hline
\end{tabular}

Fecha: julio de 2017.

Al solicitar a los profesionales que expusieran su opinión acerca de los aspectos positivos y negativos referentes al proyecto, se obtiene el resumen del Cuadro 5.17:

Cuadro 5.17 - Resumen de la opinión de los profesionales del sector técnico de CONDER de la comunidad Paraíso Azul/Recanto Feliz

\begin{tabular}{|c|c|}
\hline Elogios & Críticas \\
\hline $\begin{array}{l}\text { - Valorización/calificación del área } \\
\text { del entorno con la implantación } \\
\text { del proyecto; } \\
\text { - La desvinculación de atribuciones } \\
\text { del sector de regularización del } \\
\text { terreno (remoción de familias), } \\
\text { antes inherentes a la constructora, } \\
\text { pasada a CONDER, lo que facilita } \\
\text { el trámite de los trabajos de } \\
\text { ejecución; } \\
\text { El buen nivel de sociabilidad y } \\
\text { profesionalismo entre el equipo de } \\
\text { la constructora, de la fiscalización } \\
\text { y demás profesionales de } \\
\text { CONDER, lo que facilita el }\end{array}$ & $\begin{array}{l}\text { - La calidad de los proyectos es } \\
\text { insuficiente; hay equívocos. Hay } \\
\text { que mejorar; } \\
\text { - La existencia de violencia } \\
\text { alrededor de la comunidad y en el } \\
\text { interior de la misma; } \\
\text { - Abordajes a los profesionales por } \\
\text { parte de los moradores en } \\
\text { momentos no convenientes; } \\
\text { - La burocracia en la aceptación y } \\
\text { la demora en el pago por parte del } \\
\text { Estado a las empresas que } \\
\text { prestan servicios, debido a los } \\
\text { cambios necesarios en los } \\
\text { proyectos, lo que dificulta el buen }\end{array}$ \\
\hline
\end{tabular}




\begin{tabular}{|c|c|}
\hline $\begin{array}{l}\text { quehacer diario; } \\
\text { - La individualización del cálculo de } \\
\text { consumo y pago de agua por } \\
\text { habitación es algo positivo; } \\
\text { - La urbanización del área de } \\
\text { implantación del proyecto; } \\
\text { - Mejoría de las condiciones de } \\
\text { habitabilidad a favor de los } \\
\text { moradores; } \\
\text { - Atención a las familias de más } \\
\text { bajos ingresos; } \\
\text { - Ubicación de la comunidad; } \\
\text { - Exención [100\%] de pago por } \\
\text { parte de los moradores de la } \\
\text { financiación del departamento } \\
\text { (esto en la segunda etapa, no en } \\
\text { la primera). }\end{array}$ & $\begin{array}{l}\text { trámite de los servicios, } \\
\text { induciendo atrasos; } \\
\text { - Interrupción o morosidad de las } \\
\text { obras; } \\
\text { - Falta de cultura por parte de los } \\
\text { moradores en cuanto a la } \\
\text { convivencia en colectivo en } \\
\text { bloques de tipología } \\
\text { arquitectónica en altura; } \\
\text { Revisión de la política de } \\
\text { exención total del pago por parte } \\
\text { del morador referente al valor de } \\
\text { financiación de la vivienda, pues } \\
\text { favorece la tendencia a querer } \\
\text { vender el inmueble; } \\
\text { Alto índice de comercialización } \\
\text { ilícita (venta "en negro") tras la } \\
\text { entrega de la unidad habitacional } \\
\text { al morador. }\end{array}$ \\
\hline
\end{tabular}

Fecha: julio de 2017.

\subsubsection{2 - Opinión de los profesionales del sector social de CONDER}

Sobre la contribución financiera por parte del morador como contrapartida por la adquisición de su vivienda, fue dicho por el sector social que los vecinos de la primera etapa pagan mensualmente cerca del $10 \%$ de sus salarios, mientras que sobre los de la segunda etapa no se tenía entonces una definición sobre el tema.

En cuanto a la participación de los moradores seleccionados en el proyecto, la respuesta varió entre el nivel de "alguna" al grado inmediatamente mayor "el suficiente", con la observación de que "hay trabajos mostrando la importancia de la participación en las actividades, pero algunos [moradores] no perciben esta necesidad y no participan". Fue observado también que para el acompañamiento y fiscalización del proyecto fue importante la participación de la Associação de Moradores. Fue informado que hubo "alguna" EPO en la primera etapa, blanco principal de esta tesis, sin mayores detalles sobre ésta, así como sin previsión de fecha en la que se hará una investigación en este sentido sobre las viviendas de la segunda etapa que, como ya ha sido dicho antes, se encontraba en ejecución durante la aplicación de las encuestas. Sobre la participación de los moradores en las obras del proyecto, se supo que hubo "alguna", pero nada más ha sido agregado.

Sobre el tema del entrenamiento de los moradores para un eventual combate a incendios, no se informó nada al respecto de la primera etapa, además de que la segunda se encuentra en trámite. Ya sobre la capacitación de los vecinos sobre la 
administración/fiscalización de los conjuntos habitacionales después de que los mismos sean entregados por CONDER, se afirmó que está previsto un curso en este sentido, con carga horaria suficiente para la comisión de vecinos indicados para tal fin. Un dato importante dado por el sector social que conviene destacar se refiere a lo observado en tres bloques de la segunda etapa recién entregados, etapa donde se iniciaban las actividades para aclaraciones entre los moradores: una cultura individualista, sin preocupación por la convivencia en colectivo, lo que dificulta el trabajo del sector entre los moradores (situación también percibida entre algunos moradores encuestados durante la primera etapa de este proyecto y también del de la comunidad Perseverança, y con menor gravedad entre los moradores de la comunidad 27 de Abril/SINDOMÉSTICO).

Con relación a los cursos profesionales promovidos por CONDER para la capacitación de moradores, se supo que, con la conclusión del trámite de la empresa "prestadora", serían retomados.

Con relación a los servicios públicos, de los cuales sólo el de la red eléctrica cuenta con una tarifa social mediante catastro hecho por el sector social de CONDER, serían dadas instrucciones a los moradores para que puedan acceder con más agilidad. Fue informado que la comisaría y los lugares de pago están ubicados a más de $1 \mathrm{~km}$ del conjunto habitacional, al contrario de la escuela, de la guardería y del centro de salud pública, los cuales están dentro de la comunidad.

Al igual que los profesionales del sector técnico, el sector social afirma que la falta de presupuesto producida por el desfase de los intercambios entre Caixa Econômica Federal, órgano financiero federal brasileño, y el gobierno del Estado da Bahia, promueve retrasos de las obras, lo que, a su vez, se constituye en uno de los mayores problemas. $\mathrm{Y}$ en cuanto al aspecto financiero, el sector social desarrolla concientización entre los moradores, los que, en charlas privadas, declaran interés en vender o alquilar su inmueble, ya que esta comunidad se encuentra ubicada en un área muy valorizada comercialmente y de gran especulación inmobiliaria en la ciudad.

Otro problema detectado por el sector social se debe a la relación de conflicto entre los moradores de la comunidad y los vecinos del barrio en relación con la ubicación de la basura y las ocupaciones irregulares del área contigua, lo que contribuye con la "contaminación" ambiental y visual del lugar, situación muy criticada. 
Al pedirles a los profesionales del sector social que presentasen los ítems más elogiados y criticados del proyecto por parte de los moradores, se tiene obtiene el Cuadro 5.18:

Cuadro 5.18 - Resumen de la opinión de la comunidad Paraíso Azul/Recanto Feliz expuesta a los profesionales del sector social de CONDER

\begin{tabular}{|c|c|}
\hline Elogios & Críticas \\
\hline 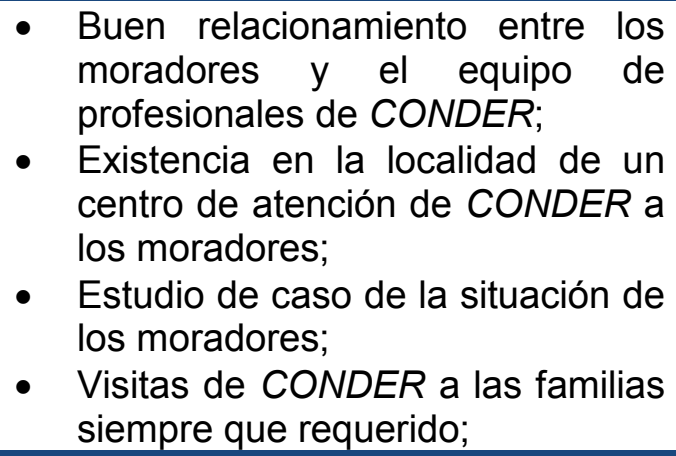 & $\begin{array}{l}\text { - Tamaño pequeño del } \\
\text { departamento; } \\
\text { - Demora en la entrega de las } \\
\text { viviendas por parte de CONDER; } \\
\text { - Servicio de agua -consumo y } \\
\text { pago- individualizado [problemas } \\
\text { en las instalaciones en } 2 \text { bloques } \\
\text { de } 3 \text { de la segunda etapa]. }\end{array}$ \\
\hline
\end{tabular}

Fecha: julio de 2017.

Al solicitar a los profesionales que expusieran su opinión acerca de los aspectos positivos y negativos referentes al proyecto, se obtiene el resumen del Cuadro 5.19:

Cuadro 5.19 - Resumen de la opinión de los profesionales del sector social de CONDER de la comunidad Paraíso Azul/Recanto Feliz

\begin{tabular}{|c|c|}
\hline Elogios & Críticas \\
\hline $\begin{array}{l}\text { - Valorización/calificación } \\
\text { urbanística del área del entorno } \\
\text { con la implantación del proyecto; } \\
\text { - La urbanización del área de } \\
\text { implantación del proyecto; } \\
\text { - Mejoría de las condiciones de } \\
\text { habitabilidad de los moradores; } \\
\text { - Atención a las familias de más } \\
\text { bajos ingresos - inclusión social; } \\
\text { - Existencia en la localidad de un } \\
\text { centro de atención de CONDER a } \\
\text { los moradores; } \\
\text { Oferta por parte del sector social } \\
\text { de CONDER a los moradores de } \\
\text { cursos de capacitación } \\
\text { profesional, lo que mejora la } \\
\text { calidad de vida de los moradores; } \\
\text { Accesibilidad. }\end{array}$ & $\begin{array}{l}\text { - Falta de regularización del lote } \\
\text { [demora]; } \\
\text { - Demora en la construcción de las } \\
\text { viviendas [retrasos]; } \\
\text { - La existencia de violencia } \\
\text { alrededor de la comunidad y en el } \\
\text { interior de la misma. }\end{array}$ \\
\hline
\end{tabular}

Fecha: julio de 2017. 


\subsubsection{3 - Opinión del líder comunitario de la comunidad}

El origen de los moradores es en parte del propio lugar y en parte de afuera. Hubo una demora para la adquisición de la vivienda: entre el período catastral de cerca de mil familias y de la entrega a los seleccionados pasaron cerca de diez años, es decir, entre 1995 y 2006, año de la inauguración con la entrega de las primeras viviendas, que se concluyó en 2008 (la gran mayoría vivían en situación muy precaria, similar a la de una villa miseria, requisito principal para la obtención de la vivienda). A las familias no contempladas inicialmente fue prometido por CONDER, según relato del líder de la comunidad, que serían atendidos en otra oportunidad, promesa que, según él, siempre está siendo postergada.

Hubo "alguna" participación de los moradores seleccionados en las obras mediante la presencia de miembros de la dirección de la Associação dos Moradores en general, y de otras pocas personas de la comunidad, pues, según el líder, no hubo un empeño suficiente por parte de CONDER para un número mayor de moradores en las obras (un total de cerca de 30 personas). Del mismo modo, en cuanto a la presencia de moradores en los trámites de acompañamiento y fiscalización de los servicios de ejecución del proyecto, pocos participaron, y de éstos, la mayoría fueron de la Associação.

No hubo "ninguna" EPO de los servicios para la primera etapa del proyecto, como no hubo "ninguna" información o entrenamiento para combatir incendios.

Para el resarcimiento de la obtención de la vivienda los moradores de la primera etapa deben pagar mensualmente alrededor de $\mathrm{R} \$ 70$ a precios de mayo de 2015, con corrección monetaria periódica.

Fue relatado por el líder que hubo "suficiente" capacitación de los moradores por parte del sector social de CONDER tanto para el ejercicio de la administración/comisión fiscal del condominio del bloque de viviendas como para la adecuación a la convivencia en colectividad de las familias en un mismo edificio residencial, así como también capacitación profesional a través de cursos para los cuales CONDER siempre acató las sugerencias y demandas de los miembros de la Associação de Moradores.

De las cinco estructuras públicas -escuela de primera enseñanza, guardería, comisaría, centro de salud y lugar de pagos- presentados en la encuesta para saber cuál(es) está(n) a más de $1 \mathrm{~km}$ de la comunidad, respondieron que la guardería, la comisaría y el lugar de pagos son los que así se sitúan. En cuanto al espacio en el 
proyecto destinado para guardar vehículos de trabajo de los moradores, fue informado que no ha sido previsto "ninguno", al contrario de lo que ocurrió con las actividades económicas, para las cuales fue destinado "algún" lugar, como también fue destinado "suficiente" -espacio- para la implantación de 1 plaza, 1 área deportiva y 1 centro comunitario para momentos de recreación dentro de la comunidad.

Fue ofrecida por CONDER "alguna" actividad destinada a la capacitación de los moradores con el objetivo de que puedan disponer de más agilidad en momentos de acceso a trámites con los servicios públicos -agua, energía eléctrica, telefonía y otros como los involucrados con la Justicia y el poder Legislativo-.

Los ítems que más fueron señalados y que más preocupan se refieren al largo período de retrasos entre el plazo original previsto de conclusión de las obras de las viviendas y el ejecutado, así como la inequívoca percepción mayoritaria sobre una potencial intención de hacer negocio -venta o alquiler- con la vivienda. Para ambos ítems fue admitido el grado máximo de las cuatro opciones de la encuesta: "ninguno", "alguno", "poco" y "mucho" (ante el potencial mercado inmobiliario de las VIS fue sugerida una tasa mayor que el 60\%).

En referencia al tema de la criminalidad, fue sustentado que no hubo "ninguno" cambio en la realidad de la seguridad pública en el interior de la comunidad después de la ocupación de las nuevas unidades habitacionales, es decir, el contexto quedó tal cual como era antes de la entrega.

En referencia a la demora de conclusión del trámite de regularización del inmueble se dijo que uno de los motivos está entre los propios moradores: que a veces no presentan en tiempo hábil toda la documentación exigida por la burocracia institucional, haciendo con que el trámite sea postergado aún más.

En cuanto a la aplicación de la tarifa social sobre servicios públicos, fue señalado que además del servicio de energía eléctrica, también se aplicó al agua, pero, debido a problemas de instalaciones equivocadas del hidrómetro en dos de los tres bloques de la segunda etapa, entregados en diciembre de 2014, y que se encontraban aún sin solución definida -entre CONDER, concesionaria y moradores-, dichas familias no estaban pudiendo usufructuar del descuento. En cuanto al tema de la "individualización" del consumo y cálculo para el pago del agua, basada en cada vivienda, conviene aclarar que este proyecto de VIS ha sido el primero en Salvador donde ha sido implantado el uso de medidores de agua por departamento. $\mathrm{Y}$, en este sentido, hay que tener en cuenta que: 
Los estudios muestran que el uso de contadores hizo descender el consumo de agua en torno del $20 \%$, e incluso más, en los hogares más modestos. También cabe mencionar que un menor consumo de agua significa menos aguas residuales y, por lo tanto, menos energía necesaria para tratarlas. (EDWARDS, 2009, p. 104)

Se admite que cerca del $40 \%$ de las familias de los tres citados bloques de la comunidad poseen canasta básica social (Bolsa-Família), lo que es un importante logro para quienes la consiguen.

Se afirmó que hay "alguna" relación entre los moradores de la comunidad y los vecinos "en un nivel mínimo de ocurrencia -de convivencia- en el trato del día a día".

Al pedirle al líder comunitario que presentase los ítems más elogiados y criticados del proyecto por parte de los moradores, se tiene obtiene el Cuadro 5.20:

Cuadro 5.20 - Resumen de la opinión de la comunidad Paraíso Azul/Recanto Feliz expuesta al líder comunitario

\begin{tabular}{|c|c|}
\hline Elogios & Críticas \\
\hline $\begin{array}{l}\text { - Que la nueva vivienda es mejor } \\
\text { que la antigua; } \\
\text { - Un lugar más interesante que } \\
\text { antes, con las actuales viviendas; } \\
\text { - La conquista de una casa propia. }\end{array}$ & $\begin{array}{l}\text { - La dificultad de accesibilidad } \\
\text { vertical en el interior de los } \\
\text { bloques [carece de ascensor]; } \\
\text { - La localización inadecuada en los } \\
\text { bloques del contenedor de } \\
\text { basura; } \\
\text { - La ausencia en el proyecto } \\
\text { [segunda etapa] de } 1 \text { centro de } \\
\text { salud [hay } 1 \text { en el interior de la } \\
\text { comunidad de la primera etapa]; } \\
\text { - Inexistencia de } 1 \text { comisaría en la } \\
\text { comunidad; } \\
\text { - La ausencia, en el proyecto } \\
\text { [segunda etapa] de } 1 \text { escuela [hay } \\
1 \text { escuela primaria en el interior de } \\
\text { la comunidad de la primera } \\
\text { etapa]; } \\
\text { La entrega de los departamentos } \\
\text { sin revestimiento en los pisos. }\end{array}$ \\
\hline
\end{tabular}

Fecha: julio de 2017.

Al solicitar al líder comunitario que expusieran su opinión acerca de los aspectos positivos y negativos referentes al proyecto, se obtiene el resumen del Cuadro 5.21: 


\begin{tabular}{|c|c|}
\hline Elogios & Críticas \\
\hline $\begin{array}{l}\text { - Que la nueva vivienda es mejor } \\
\text { que la antigua; } \\
\text { - Un lugar más interesante que } \\
\text { antes, con las actuales viviendas; } \\
\text { - La conquista de una casa propia. }\end{array}$ & $\begin{array}{l}\text { - La dificultad de accesibilidad -falta } \\
\text { pasamano en las escaleras del } \\
\text { interior de los bloques-; } \\
\text { - La falta de una guardería en el } \\
\text { interior de la comunidad; } \\
\text { - La falta de espacio para guardar } \\
\text { equipos de trabajo como carretilla, } \\
\text { por ejemplo; } \\
\text { - Falta de espacio adecuado para } \\
\text { contenedor de basura. }\end{array}$ \\
\hline
\end{tabular}

Fecha: julio de 2017.

5.4.4 - Proyecto de la comunidad de Luiz Inácio Lula da Silva/Perseverança, Salvador

El proyecto, que originalmente fue previsto para ser ejecutado en 360 días a partir de la fecha de la "orden de servicio" del 22 de febrero de 2010, pasó por un período de paralización de 1 año debido a ajustes en el proyecto de fundación y de contención de pendiente, así como por cambios necesarios en otras partes del proyecto. La fundación, que inicialmente fue prevista para ser en radier en tres torres, tuvo que ser ejecutada en estacas y dos torres por debilidades del terreno. En práctica, la obra fue empezada en 2011 y los departamentos entregados en mayo de 2013, con adicionales de plazo de más de 270 días sobre los 360 días iniciales, así como con los adicionales referentes a cerca del $22 \%$ sobre los $R \$ 1.939 .966,58$ y otros más, lo que totalizó algo como $\mathrm{R} \$ 2.424 .199,03$ para la ejecución de los 60 departamentos distribuidos en las dos torres con cinco pisos cada una ya incluída la planta baja. El proyecto fue realizado en conjunto entre el gobierno del Estado da Bahia y el Municipio de Salvador, que donó el terreno y se responsabilizó por la entrega de los proyectos en general y la regularización inmobiliaria, mientras que el Estado realizó la construcción. La selección de las sesenta familias fue realizada en su totalidad por el MSTS. 
5.4.4.1 - Opinión de los profesionales del sector técnico: arquitectura, ingeniería y urbanismo de CONDER

Si hubo consenso entre los encuestados sobre que varios proyectos tuvieron que pasar por ajustes, lo mismo no ocurrió en cuanto a la responsabilidad de la elaboración de estos, ya que, por un lado, se afirmó que corría por cuenta de la Municipalidad, por el otro, hubo quién dijo que era de la CONDER, sin embargo, al parecer, prevaleció esta última información.

En cuanto a la participación de los moradores, tanto en la elaboración de los proyectos como en las obras de ejecución, se aseguró que no hubo "ninguna", a excepción de los moradores nativos de la localidad, que integraron cerca del $60 \%$ de la mano de obra.

También se afirmó que en "ninguna" medida se realizó la EPO y que la fiscalización trascurrió dentro de la normalidad, y que se hizo el as built de las alteraciones de los proyectos, cuyas actualizaciones fueron elaboradas por la constructora y el cuerpo técnico de CONDER.

Según lo que fue dicho por los profesionales los moradores recibieron durante la entrega de las llaves informaciones de prevención y combate de incendios que, conforme relatos de diversos moradores no fueron suficientes.

Fue constatado que el proyecto no posee "ningún" espacio para guardar vehículos de trabajo de los moradores, así como "ningún" lugar previsto para pequeños comercios.

En cuanto a la ubicación, a más de $1 \mathrm{Km}$ de distancia de la comunidad, de las cinco estructuras públicas mencionadas en la encuesta -escuela, guardería, comisaría, centro de salud y lugares de pago-, hubo discrepancias, pues, uno dijo que "ninguno" se encuentra así, mientras que otro afirmó que "todos" están así.

El proyecto sólo previó el parque infantil, no una plaza, área deportiva, ni un centro comunitario. Fue aclarado que, incluso con los adicionales girando alrededor del $25 \%$ del costo original, los recursos fueron insuficientes para la implantación de otras estructuras además del parque infantil.

También en este proyecto, como en los demás investigados en Brasil, se confirmó, entre los profesionales, la percepción de la existencia del fenómeno del mercado informal involucrado de departamentos.

Según los profesionales consultados no se percibe "ninguna" influencia entre los moradores de la presencia de la canasta básica social (Bolsa Familia). 
Al pedirles a los profesionales del sector técnico que presentasen los ítems más elogiados y criticados del proyecto por parte de los moradores, se tiene obtiene el Cuadro 5.22:

Cuadro 5.22 - Resumen de la opinión de la comunidad Perseverança expuesta a los profesionales del sector técnico de CONDER

\begin{tabular}{|c|c|}
\hline Elogios & Críticas \\
\hline $\begin{array}{l}\text { - Ubicación de la comunidad; } \\
\text { - Exención [100\%] de pago por } \\
\text { parte de los moradores de la } \\
\text { financiación del departamento. }\end{array}$ & $\begin{array}{l}\text { - Tamaño pequeño del } \\
\text { departamento; } \\
\text { - Localización inadecuada en los } \\
\text { bloques del contenedor de } \\
\text { basura; } \\
\text { - Ocurrencia de problemas en los } \\
\text { techos de los departamentos del } \\
\text { último piso (infiltración de agua de } \\
\text { lluvia). }\end{array}$ \\
\hline
\end{tabular}

Fecha: julio de 2017.

Al solicitar a los profesionales que expusieran su opinión acerca de los aspectos positivos y negativos referentes al proyecto, se obtiene el resumen del Cuadro 5.23:

Cuadro 5.23 - Resumen de la opinión de los profesionales del sector técnico de CONDER de la comunidad Perseverança

\begin{tabular}{|c|c|}
\hline Elogios & Críticas \\
\hline $\begin{array}{l}\text { - Atención a las familias de más bajos } \\
\text { ingresos - inclusión social; } \\
\text { - Viviendas con padrón de dignidad; } \\
\text { - La ubicación satisfactoria del proyecto } \\
\text { (barrio cerca del centro); } \\
\text { - Satisfactorio padrón constructivo de } \\
\text { calidad; } \\
\text { - Baja densidad poblacional; } \\
\text { - Mejoría en la calidad de vida de los } \\
\text { nuevos moradores; } \\
\text { - Salubridad del espacio de la } \\
\text { comunidad; } \\
\text { Seguridad por la posesión de la } \\
\text { habitación. }\end{array}$ & $\begin{array}{l}\text { - Falta de cultura por parte de los } \\
\text { moradores para vivir sin peleas en } \\
\text { la colectividad; } \\
\text { - La "amnistía total" de pago que es } \\
\text { dada al morador favorece la } \\
\text { tendencia de que se sienta } \\
\text { propenso a vender informalmente } \\
\text { el inmueble; } \\
\text { - Conflictos entre moradores } \\
\text { adquirientes de las viviendas del } \\
\text { proyecto; } \\
\text { - Práctica de mercado informal de } \\
\text { las viviendas [alquiler o venta]; } \\
\text { Comprometimiento de la política } \\
\text { pública de VIS con la existencia } \\
\text { del mercado informal } \\
\text { [paradojalmente esta práctica está } \\
\text { siendo hecha por personas } \\
\text { seleccionadas por el MSTS]. }\end{array}$ \\
\hline
\end{tabular}

Fecha: julio de 2017. 


\subsubsection{2 - Opinión de los profesionales del sector social de CONDER}

Los moradores seleccionados del proyecto Perseverança tuvieron "alguna" participación en el mismo, por ejemplo, el acompañamiento de las obras, en el trámite de la Organização do Comitê Gestor y en el encaminamiento de los problemas de la Comunidad ante los órganos de prestación de servicios públicos. En cuanto a lo que se refiere al tema del acompañamiento/fiscalización de la ejecución de los proyectos en general, según respuesta a la pregunta $n^{\circ} 2$ de la Encuesta Tipo 4 del responsable del sector social del CONDER: "O MSTS conjuntamente com alguns beneficiários que foram selecionados para o Projeto, acompanhou o processo de construção do Empreendimento, opinando, discutindo e buscando alternativas de solução das demandas apresentadas. $A$ ex: adaptação no padrão habitacional de quatro unidades habitacionais, para atender aos beneficiários com necessidades especiais, rampa de acesso [peatonal] dentre outras reivindicações. En el mismo cuestionario incluso señaló como "ninguna" la opción de respuesta sobre las consultas, sobre si se hizo EPO, así como al respecto de la participación del morador en relación al financiamiento del proprio inmueble y también en relación al porcentaje de moradores como mano de obra en los servicios de ejecución del proyecto (preguntas $n^{\circ} 3,4$ y 5). Se aportó, incluso, como aclaración a la pregunta $n^{\circ}$ 4, que "Segundo informações da Coordenadora de Regularização Fundiária [de Tierras] da Prefeitura Municipal de Salvador, vai ser assinado um Termo de cessão [sic] entre a Prefeitura e os Beneficiários. Vale esclarecer que os beneficiários não vão pagar nenhuma prestação pelo imóvel". Es sabido que esta resolución se basó y fue consecuencia de un acuerdo entre el entonces gobernador de la provincia de Bahia y los dirigentes del MSTS, conforme relatos de representantes de dicha comunidad.

En cuanto al cuestionamiento sobre la manera en que se dio la información y entrenamiento de los moradores para el combate de incendios se contestó con "alguna", seguida de la justificación de que "Este tema foi abordado, de forma superficial, no momento das Reuniões de Preparação com os beneficiários". Sobre la capacitación de los moradores en relación al ejercicio en actividades de administración/comisión fiscal del condominio, se dijo que hubo "mucha", considerando que fueron ofrecidos varios talleres relacionados con el tema, abordando el concepto de condominio, registro en notaría y sus implicaciones, quién administra, tipos de asamblea, funciones y atribuciones del administrador, 
viceadministrador, consejo consultivo, suplentes, derechos y deberes de los condóminos, Ley de Condominio, entre otros.

Otro tópico que fue respondido como "mucho" se refiere a las actividades destinadas a la capacitación de los moradores en los anteriormente mencionados talleres para el ejercicio de la convivencia colectiva en un edificio de altura, tópico que fue visto recurrentemente por los moradores en los encuentros, antes y después de la entrega de las llaves, así como en los talleres ya mencionados y aún en el atendimientos individual en la sede de CONDER y durante las visitas domiciliarias de los representantes de ésta a la comunidad. No se tuvo la misma eficacia en las actividades relacionadas a la capacitación profesional de los moradores, ya que, según el sector social de CONDER, "ninguna" acción fue desarrollada en este sentido una vez que "Não foi realizado nenhum curso de capacitação profissional, em decorrência desse Proyecto não ter Recursos Financieros para o Desenvolvimento do Trabajo Social".

Según el responsable del sector social "todos" las cinco estructuras públicas escuela, guardería, comisaría, centro de salud y lugar de pagos- relacionadas a la pregunta $\mathrm{n}^{\circ} 10$ de la encuesta, están ubicadas a más de $1 \mathrm{~km}$ de la comunidad.

En cuanto a la disponibilidad de espacios para guardar los vehículos de trabajo de los moradores se dijo que hay "el suficiente". Por otro lado, se afirmó que no hay "ningún" espacio destinado a actividades económicas. Cuando se consultó sobre la existencia de estructuras públicas destinadas a esparcimiento/recreo, como plaza, área deportiva y centro comunitario, se declaró que hay "alguno", pues "No Projeto só existe um parque infantil".

Se afirmó que hubo "alguna" actividad dirigida a informar a los moradores al respecto de agilizar el acceso y trámites en las prestadoras de servicios públicos.

De los temas que fueron constantes en las respuestas de las tres comunidades de Brasil investigadas, ya sea por profesionales, moradores o líderes, formalmente en los cuestionarios escritos o informalmente durante las entrevistas: fue prácticamente unánime que hubo desfase entre el cronograma de obras previsto y el efectivamente ejecutado en las tres comunidades, lo que lleva a que se ratifique aquí que esta situación promovió descontento entre los adquirentes de los departamentos.

La mayoría de los encuestados confirmó que es "mucho" el potencial mercado inmobiliario informal -alquiler, préstamo o venta- en el interior de la comunidad con las nuevas viviendas. 
Otro aspecto mencionado es el reclamo de los moradores sobre constantes asaltos en la calle principal que da acceso a la comunidad.

Fue informado que es "mucha" la importancia de la canasta básica social entre los moradores y que, por otro lado, "Há uma rejeição por parte da população circunvizinha" en relación con los nuevos moradores de la comunidad (este fenómeno "socio-reactivo" fue relatado por los encuestados de las tres comunidades que enfrentaron de manera semejante dicha situación por parte de los vecinos del área, quienes exteriorizaron gran hostilidad por sentirse amenazados).

Al pedirles a los profesionales del sector social que presentasen los ítems más elogiados y criticados del proyecto por parte de los moradores, se tiene obtiene el Cuadro 5.24:

Cuadro 5.24 - Resumen de la opinión de la comunidad Perseverança expuesta a los profesionales del sector social de CONDER

\begin{tabular}{|c|c|}
\hline Elogios & Críticas \\
\hline - Adquisición de una vivienda. & $\begin{array}{l}\text { - Dificultad de acceso al proyecto } \\
\text { [por ser elegido a través del } \\
\text { catastro]; } \\
\text { - Dificultad de acceso a transportes } \\
\text { públicos; } \\
\text { - El área de servicio del } \\
\text { departamento es pequeña. }\end{array}$ \\
\hline
\end{tabular}

Fecha: julio de 2017.

Al solicitar a los profesionales que expusieran su opinión acerca de los aspectos positivos y negativos referentes al proyecto, se obtiene el resumen del Cuadro 5.25:

Cuadro 5.25 - Resumen de la opinión de los profesionales del sector social de CONDER de la comunidad Perseverança

\begin{tabular}{|c|c|}
\hline Elogios & Críticas \\
\hline $\begin{array}{l}\text { - Adquisición de casa propia de } \\
\text { forma legalizada; } \\
\text { - Implantación de servicios de } \\
\text { infraestructura -agua, energía } \\
\text { eléctrica, red de cloaca y } \\
\text { pavimentación; } \\
\text { - Atención a las familias de más }\end{array}$ & $\begin{array}{l}\text { - Falta de estructuras comunitarias; } \\
\text { - Falta de pavimentación del } \\
\text { acceso de la vía principal; } \\
\text { - Número significativo de vicios de } \\
\text { construcción en los } \\
\text { departamentos: y infiltración, } \\
\text { vaciamiento y equipamientos }\end{array}$ \\
\hline
\end{tabular}




\begin{tabular}{|c|c|}
\hline $\begin{array}{l}\text { bajos ingresos -renta de } 0 \text { a } 3 \mathrm{SM} \text {; } \\
\text { - Rescate de los moradores; } \\
\text { - Posibilitar a nuevas familias una } \\
\text { vida con más calidad/dignidad. }\end{array}$ & $\begin{array}{l}\text { dañados (inodoro, pileta, puertas, } \\
\text { ventanas, entre otros); } \\
\text { - Morosidad de la constructora para } \\
\text { efectuar los reparos detectados } \\
\text { por los moradores en el acto de la } \\
\text { inspección para la entrega de las } \\
\text { llaves de la vivienda; } \\
\text { - Falta de cruce de información } \\
\text { entre la base de datos de } \\
\text { CONDER y la de la Intendencia } \\
\text { de Salvador para impedir doble } \\
\text { adquisición de vivienda por una } \\
\text { misma familia. }\end{array}$ \\
\hline
\end{tabular}

Fecha: julio de 2017.

5.4.4.3 - Opinión del líder comunitario de la comunidad

Los sesenta moradores que constituyen esta Comunidad provienen de diferentes lugares de Salvador, donde vivían en habitaciones precarias, y para superar esta dificultad aguardaron por cerca de tres años hasta recibir en mano las llaves del departamento, a contar desde la inscripción en la Base de Catastro de la Intendencia de esta ciudad, mediado por el MSTS. No fueron informados los criterios adoptados para la selección de los sesenta vecinos. No hay informaciones sobre las propuestas para que los demás inscriptos puedan también adquirir su vivienda a través de otro proyecto estatal.

Fue dicho por el líder de la comunidad que los moradores hicieron sólo tres visitas al lugar de la construcción antes de recibir las llaves, así como que no hubo "ninguna" participación de los mismos en relación a la elaboración de los proyectos y la ejecución, ni para tomar/dar sugerencias o incluso fiscalizar y ni siquiera para trabajar como obreros durante la ejecución.

Fue confirmado que por arreglos políticos entre el gobernador del Estado de Bahia con el MSTS, los adquirentes de las habitaciones fueron exentos de cualquier pago en contrapartida de la mencionada adquisición.

Se dijo que no hubo "ninguna" información o entrenamiento por parte de la CONDER a los moradores al respecto de prevención y combate de incendios, capacitación profesional y convivencia colectiva entre varias familias en un edificio en altura.

El líder confirmó incluso que los ya mencionados tres encuentros ocurrieron entre gran parte de los moradores y el sector social de CONDER, con el objetivo de 
dar orientación sobre temas involucrados a la creación del Consejo Fiscal de la comunidad, compuesto por ocho personas de entre los moradores.

Según el líder de la referida comunidad, relacionado a la pregunta $\mathrm{n}^{0} 15$ de la Encuesta Tipo 7, no hay "ninguna" de las cinco estructuras públicas -escuela, guardería, comisaría, centro de salud y lugar de pagos- a más que $1 \mathrm{~km}$ de ésta. No hay "ningún" espacio destinado para guardar vehículos de trabajo, quiosco o similar con el objetivo de explotación económica, "ninguna" área de esparcimiento/recreo, plaza, área deportiva o centro comunitario (preguntas $n^{\circ} 17,18$ y 19). Con relación a este tema, se vio durante el período de las investigaciones que hay un pequeño parque de infantes, así como espacio de aparcamiento para aproximadamente 21 automóviles de paseo de los moradores.

Sobre si hubo alguna actividad de capacitación para facilitar el acceso y la celeridad de los vecinos con las empresas prestadoras de servicios públicos, la respuesta ha sido "ninguna".

Sobre si hubo alteraciones de fechas entre lo proyectado y lo ejecutado la opción dada ha sido "ninguna", seguida de la aclaración de que la que hubo se dio por algunos días debido al paro de los obreros de la construcción civil de la Ciudad. Considerando lo que dijeron los profesionales del sector técnico y del sector social de CONDER sobre el desfase de aproximadamente 1 año por causa de ajustes en los proyectos, o el líder de los moradores olvidó el hecho o no fue informado suficientemente al respecto.

Inquirido sobre la existencia de un potencial mercado informal inmobiliario involucrando los nuevos departamentos, ha sido estimado por el líder que en "alguna" medida esto sucede en cerca del $10 \%$ de las familias. Porcentaje que también fue pasado por un profesional del sector técnico, pero con la diferencia de que dicho profesional admitió que el fenómeno de alquiler o venta del departamento podría estar sucediendo con "mucha" intensidad.

Al respecto de la situación relacionada a la seguridad local con la llegada de los nuevos moradores, ha sido dicho que "ninguna", y que prácticamente la situación continúa como antes de la inauguración de los bloques con sus 60 departamentos.

El tema de la regularización de los inmuebles por el sector social de la intendencia de Salvador fue respondido como si el trámite siguiera en celeridad "suficiente", considerando que algún retraso existente se debió a la demora por parte de algunos vecinos en la entrega de los documentos necesarios exigidos por la burocracia institucional. 
Sobre la utilización de tarifa social entre los moradores, se informó que la mayoría de éstos la usufructúa sobre la energía eléctrica y el agua/cloaca. En cuanto a la influencia del uso de la canasta básica social, fue dicho que no hay "ninguna".

La relación entre los moradores y los vecinos de la localidad se da en nivel de "poca" intensidad, y ocurre esporádicamente con la estricta urbanidad necesaria.

Al pedirle al líder que presentase los ítems más elogiados y criticados del proyecto por parte de los moradores, se tiene obtiene el Cuadro 5.26:

Cuadro 5.26 - Resumen de la opinión de la comunidad Perseverança expuesta al líder comunitario

\begin{tabular}{|c|c|}
\hline Elogios & Críticas \\
\hline $\begin{array}{l}\text { - La ubicación satisfactoria del } \\
\text { proyecto (barrio cerca del centro); } \\
\text { - La fachada de las dos torres; } \\
\text { - La distribución de los ambientes } \\
\text { en el interior del departamento. }\end{array}$ & $\begin{array}{l}\text { - La entrega del departamento con } \\
\text { los pisos sin revestimiento [sólo } \\
\text { con el contrapiso]; } \\
\text { - Vicios de construcción en las } \\
\text { redes de agua, cloaca y de } \\
\text { energía eléctrica; } \\
\text { - Mucho calor en el período de } \\
\text { verano [todos los departamentos } \\
\text { tienen sus fachadas principales } \\
\text { orientadas hacia la puesta del } \\
\text { Sol]; } \\
\text { - En períodos de lluvias ocurren } \\
\text { azotes en las fachadas. }\end{array}$ \\
\hline
\end{tabular}

Fecha: julio de 2017.

Al solicitar al líder que expusiera su opinión acerca de los aspectos positivos y negativos referentes al proyecto, se obtiene el resumen del Cuadro 5.27:

Cuadro 5.27 - Resumen de la opinión del líder de la Comunidad Perseverança

\begin{tabular}{|c|c|}
\hline Elogios & Críticas \\
\hline $\begin{array}{l}\text { - La ubicación satisfactoria del } \\
\text { proyecto (barrio cerca del centro); } \\
\text { - La satisfactoria calidad de la } \\
\text { estructura y construcción de las } \\
\text { dos torres; } \\
\text { - La parte arquitectónica interna de } \\
\text { los departamentos [la planta baja- } \\
\text { tipo]; } \\
\text { - La entrega de copia heliográfica } \\
\text { de la planta arquitectónica del } \\
\text { departamento a cada familia; }\end{array}$ & $\begin{array}{l}\text { - La dificultad de acceso por la vía } \\
\text { principal, y única, a las dos torres } \\
\text { [ladera larga]; } \\
\text { - La presencia de mosquitos } \\
\text { constantemente en las } \\
\text { habitaciones [pasa enfrente a las } \\
\text { dos torres un pequeño y estrecho } \\
\text { arroyo a cielo abierto]; } \\
\text { - La entrega del departamento con } \\
\text { los pisos sin revestimiento [sólo } \\
\text { con el contrapiso]; }\end{array}$ \\
\hline
\end{tabular}




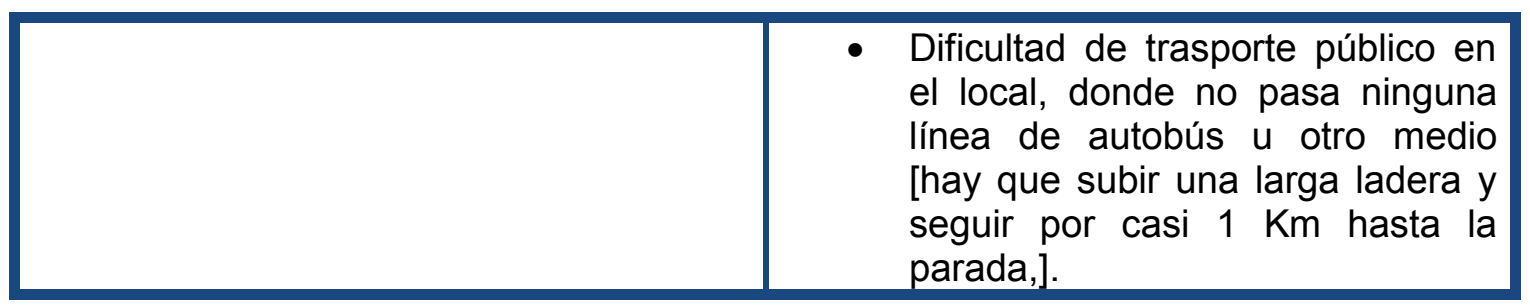

Fecha: julio de 2017.

\subsection{5 - Proyecto de la comunidad de 27 de Abril/SINDOMÉSTICO, Salvador}

En el proyecto institucionalmente firmado como "Casa da Gente", que fue promovido por el gobierno de Bahía a través del contrato $N .^{\circ} 128 / 10$ del 8 de junio de 2010 para la construcción de cuatro torres con cinco pisos cada una, incluyendo la planta baja, cuatro departamentos por piso, en un terreno del Estado da Bahia, en un área urbana con una densidad aproximada de 320 habitantes/ha. En 2010 se realizó la elaboración de los proyectos en un período de cuatro meses, con proyecto arquitectónico de autoría del sector técnico de CONDER. Tanto el proyecto de fundación como los proyectos de estructura y de instalación eléctrica, agua y cloacas fueron elaborados empresas privadas El plazo de ejecución se extendió desde junio de 2010 hasta agosto de 2012, y fue entregado a los moradores en el mes siguiente a su conclusión. Hubo un adicional de plazo debido a la necesidad de arreglos en el proyecto de fundación, el cual originariamente previa fundación en "zapata directa" y después fue sustituido por "estacas trado". Este cambio, según el líder del sector técnico de la CONDER, fue la principal justificación para el adicional financiero de la obra, que originalmente previa un valor de $R \$ 2.529 .461,29$ y luego aumentó a $R \$$ 3.152.879,92, a valores de agosto de 2012, fecha de la $15^{\mathrm{a}}$, y última, medición de servicios para el pago, diferencia de $\mathrm{R} \$ 623.418,63$ que equivale a un agregado del $24,65 \%$ sobre el valor previsto. Otro motivo para dicho adicional se debió a la ampliación del área revestida en azulejo de los baños y cocina de los departamentos, que inicialmente era menor; grosso modo, el valor total pagado equivale al valor de una de las 60 viviendas construidas, aproximadamente $R \$$ 39.411, a valores de agosto de 2012. 
5.4.5.1 - Opinión de los profesionales del sector técnico: arquitectura, ingeniería y urbanismo de CONDER

Según profesionales de la CONDER, los moradores tuvieron una "suficiente" participación, pues CONDER discutió los proyectos con ellos. Se dijo que el as built fue realizado pero que no sabían si había sido realizada la EPO y se sugirió que se buscara dicha información en el sector social.

En referencia a la participación de los moradores como mano de obra no se supo definir con exactitud el porcentaje, pero sí que seguramente hubo "alguno" sobre el final de las obras en el sector de limpieza/cerramiento.

Con relación a la presunta información o entrenamiento de los moradores sobre prevención y combate de incendios se admitió que "ninguna" fue realizada.

Al respecto de cuáles de las cinco estructuras públicas -escuela, guardería, comisaría, centro de salud y lugar de pagos- están a más de $1 \mathrm{Km}$ de la comunidad, se afirmó que sólo la comisaría lo está.

Según el líder del sector técnico de CONDER hay "mucho" espacio disponible para guardar vehículos de trabajo de los moradores, sin embargo, el proyecto no dejó definido y mucho menos se ha construido alguna estructura edificada para este fin. Fue contestado que no hay "ningún" espacio proyectado para que sea utilizado como quiosco para actividad comercial. Por el contrario, se informó que hubo "suficiente" espacio en el proyecto para esparcimiento/recreo de los moradores, como el destinado a una plaza, un área deportiva y un centro comunitario.

Sobre las diferencias entre costos previstos y efectivamente ejecutados se estimó que, en cuanto a los ítems dirigidos propiamente a las habitaciones, hubo un agregado de alrededor del $20 \%$ sobre lo previsto, mientras que para el ítem de la infraestructura de área externa se dio en torno del $5 \%$ del valor original. Estos adicionales se reflejaron directamente también sobre los plazos de las obras, en los que hubo retrasos no sólo debido a los arreglos en los cálculos de la fundación, sino también por cuestiones administrativas.

Con relación al tema de la posible aplicación de tarifa social sobre servicios públicos, como agua/cloaca y energía eléctrica, el profesional no agregó comentario alguno, así como con relación a la hipotética influencia del uso de canasta básica social por los moradores, donde dijo que no se percibe "ninguna".

Sobre un hipotético mercado informal de los departamentos, también dijo que no tenía "ninguna" percepción en este sentido, sin embargo, a pesar de la respuesta 
del líder del sector técnico, se escuchó, informalmente entre vecinos de la misma comunidad, que el fenómeno ocurre, pero de manera muy limitada. Según los relatos, comparado con los otros proyectos investigadas en Salvador, aquí el fenómeno se dio en menor grado e intensidad.

Sobre la regularización del inmueble, se informó que hubo "algún" nivel de celeridad del trámite mientras CONDER actuaba con actividades en la orientación de los moradores en la formación del Consejo Fiscal y del Condominio, así como sobre sus principales implicaciones prácticas y de documentación -escrituras- en fase de registro notarial.

Esta comunidad, de las tres investigadas en Brasil, fue la que presentó un mayor espíritu de lucha y organización, con interesantes logros colectivos. Dicha comunidad, así como también las otras dos, debería ser estudiada en futuros trabajos académicos por otros investigadores.

Al pedirles a los profesionales del sector técnico que presentasen los ítems más elogiados y criticados del proyecto por parte de los moradores, se tiene obtiene el Cuadro 5.28:

Cuadro 5.28 - Resumen de la opinión de la comunidad 27 de Abril/SINDOMÉSTICO expuesta al sector técnico de CONDER

\begin{tabular}{|c|c|}
\hline Elogios & Críticas \\
\hline $\begin{array}{l}\text { - La ubicación satisfactoria del } \\
\text { proyecto; } \\
\text { - El tamaño interno satisfactorio del } \\
\text { departamento -área-; } \\
\text { - Disponibilidad de espacio para } \\
\text { guardar vehículos. }\end{array}$ & $\begin{array}{l}\text { - El gran número de pisos en una } \\
\text { torre -cinco incluida la planta baja- }\end{array}$ \\
\hline
\end{tabular}

Fecha: julio de 2017.

Al solicitar a los profesionales que expusieran su opinión acerca de los aspectos positivos y negativos referentes al proyecto, se obtiene el resumen del Cuadro 5.29: 
Cuadro 5.29 - Resumen de la opinión de los profesionales del sector técnico de CONDER de la comunidad 27 de Abril/SINDOMÉSTICO

\begin{tabular}{|l|l|}
\hline \multicolumn{1}{|c|}{ Elogios } & \multicolumn{1}{c|}{ Críticas } \\
\hline - La ubicación satisfactoria del & $\begin{array}{l}\text { El número de cinco pisos en una } \\
\text { Proyecto; }\end{array}$ \\
- Disponibilidad de espacio para (incluida la planta baja -es \\
guardar vehículos. & inconveniente [Se sugiere que sea \\
& $1+3$, es decir: planta baja + 3 \\
& pisos arriba]-); \\
& Elevar el revestimiento en azulejo \\
& de las paredes de áreas frías - \\
& baño y cocina/servicio- hasta el \\
& cielo raso; \\
& Debería hacerse el revestimiento \\
& de los pisos del departamento \\
& antes de entregarlo a los \\
& moradores [en cerámica, por \\
& ejemplo].
\end{tabular}

Fecha: julio de 2017.

\subsubsection{2 - Opinión de los profesionales del sector social de CONDER}

Según el responsable del sector social, una característica que distingue este proyecto entre los demás fue la gran participación y compromiso de los moradores con el proyecto social. Otra particularidad del proyecto es que fue el primero en Brasil desarrollado exclusivamente para un grupo de mucamas, como ya fue mencionado, y que es el resultado de negociaciones políticas entre dirigentes del Sindicato dos Trabalhadores Domésticos da Bahia (SINDOMÉSTICO) y el gobierno del Estado da Bahia, mediado por políticos de partidos de izquierda. La titularidad de los departamentos es del $100 \%$ de mujeres mucamas, jefes de familia. Sobre esto llama la atención la asistente social de CONDER que contestó el cuestionario: "um aspecto primordial para o favorecimento do projeto é [un] necessário alinhamento entre a empresa licitada e a fiscal quando as equipes conseguem se ajustar e trabalhar na perspectiva de parceria, o trabalho tem mais possibilidades de sucesso [sic]".

La EPO ocurrió en un encuentro de cierre del proyecto social en el cual las familias fueron invitadas a hacer una evaluación oral mediante "dinámica de grupo" (la cantidad de familias participantes fue pequeña, motivo por el cual la asistente social informó en aquel encuentro que sería programado otro más, cuando se 
aplicarían las encuestas impresas de evaluación entre todas las familias del proyecto).

Sobre la participación de las moradoras como trabajadoras en las obras del proyecto en contrapartida por la financiación del inmueble, la respuesta fue "ninguna”.

Sobre alguna actividad de información y entrenamiento para la prevención y combate de incendios, la respuesta fue "ninguna".

Sobre la capacitación de las moradoras para ejercicio en la administración/comisión fiscal del condominio, fue informado que ocurrió de forma "suficiente", ya que fueron ofrecidos talleres al grupo gestor y al de apoyo, constituidos por moradoras que daban soporte en la gestión del condominio (se trabajaron diversos temas tales como: contabilidad de condominio, legislación tributaria y laboral). Una queja de muchas de las moradoras fue que fueron ofrecidos un año después de que se encontraran en actividad como gestoras del condominio y que les faltara menos de seis meses para el cierre del periodo de sus gestiones.

Con relación a la orientación sobre convivencia colectiva y administración de conflictos entre vecinos, el sector social de CONDER aprovechó para presentar estos tópicos durante los talleres desarrollados en función de la elaboración y aprobación del regimiento interno de la convención del condominio y de la elección del comité gestor, a través de un encuentro participativo. También en este ámbito fueron elaboradas actividades relacionadas con la definición de la tasa de condominio. También se informó que el taller destinado a la discusión del valor de la tasa de condominio tuvo su carga horaria reducida para dar lugar al comité pertinente a la rendición de cuentas del condominio. Según informó la asistente social, durante todo el trabajo de campo del sector social se abordaron transversalmente cuestiones sobre convivencia y organización comunitaria.

No se implantó "ninguna" actividad destinada a la capacitación profesional debido a que las moradoras, mucamas profesionales, como enfatizó en su respuesta la asistente social, presentaron cierta resistencia a que la guardería fuera utilizada para otros fines, como pretendía el sector social en horarios en que la guardería no estuviera ocupada por los niños.

Sobre cuál de las cinco estructuras públicas -escuela, guardería, comisaría, centro de salud y lugar de pagos- se encontraban ubicadas a más de $1 \mathrm{Km}$ de la comunidad, se afirmó que "algunos", como la comisaría, el hospital, un centro social 
urbano y comercios (supermercado, farmacias, tiendas de artículos de ropas, de materiales para la construcción, de electrodomésticos, zapatería, etc.).

Sobre si fue previsto en el proyecto un espacio disponible para guardar vehículo de trabajo, la asistente social interpretó la pregunta como si se refiriera a coche personal, respondiendo que hay espacio "suficiente": "há estacionamento dentro do projeto, contudo não o equivalente ao total de apartamentos [80] [sic]". Sobre los ítems relacionados a la pregunta $n^{\circ} 11$ de la Encuesta Tipo 4 (direcciona al sector social), no se vio in loco ninguna construcción destinada a los mismos. De igual manera, en el proyecto no se previó "ningún" espacio para que se desarrollasen actividades comerciales.

Sobre si hay en el proyecto plaza, área deportiva y centro comunitario, para esparcimiento/recreo, se dijo que existe el "suficiente", como la asociación de los moradores, área deportiva, cancha de futbol y un centro de salud.

Sobre trámites referentes a los servicios públicos, fue informado que CONDER en la fecha de entrega de las llaves de los departamentos invitó al atendimiento móvil de las concesionarias de agua/cloaca (EMBASA) y de energía eléctrica (COELBA) para que los vecinos pudieran solicitar su inclusión en el catastro.

Sobre los plazos del proyecto, la respuesta se direccionó específicamente hacia el proyecto social, informando que hubo una extensión de dos meses sobre el periodo previsto.

Sobre el fenómeno de un eventual mercado inmobiliario informal se contestó "mucho": "já fui abordada por terceiros questionando[-me] sobre a possibilidade de aquisição de um dos apartamentos do empreendimento [sic]".

Éste es uno de los principales temas que se deben discutir en las varias instancias y por los diferentes profesionales involucrados para que se puedan aportar eventuales soluciones a los constructores, gobernantes y a la justicia. Si las políticas públicas para VIS no son ampliadas, o peor aún, son restringidas, frente a la progresiva demanda de los sectores de más bajos ingresos que carecen de una habitación cuja situación se ve agravada por el crónico desempleo y la baja renta resultante de una política de distribución de renta perversa, el fenómeno del mercado informal sólo crecerá, trayendo consigo graves distorsiones sociales. En estas circunstancias el Estado se encuentra sin respaldo moral para condenar dicha práctica, contribuyendo también para que se perpetren situaciones ya registradas en Brasil, en el PMCMV, donde varias familias de baja renta contempladas por este 
programa se vieron obligadas por la fuerza por el crimen organizado a "ceder" sus casas a los delincuentes.

Con relación a la seguridad pública se dijo que ocurrió "alguna" alteración en el área de la comunidad investigada, una vez que "houve relativa intensificação [de la seguridad] a partir de demandas das famílias residentes [sic]".

Al respecto de la celeridad del trámite de la regularización del inmóvil, la misma asistente social contestó que hay "alguna”, justificando que "O processo está em encaminhamento. porém, a regularização ainda não foi concluída, uma demanda latente da comunidade. [sic]". Sobre la influencia de la canasta básica social, la asistente social no percibió "ninguna" y afirmó que "o cad único [catastro federal] não foi utilizado como criterio para seleção das [moradoras] beneficiárias [sic]".

Con relación al estado de convivencia entre los moradores y los vecinos, se afirmó que fue "mucho" pues, "os relatos são de que a princípio houve bastante resistência [por parte de las antiguas familias del barrio]. contudo, aos poucos, essa resistência foi diminuída, a partir de algumas estratégias adotadas pelo grupo gestor [del condominio] [sic]".

Al pedirles a los profesionales del sector social que presentasen los ítems más elogiados y criticados del proyecto por parte de los moradores, se tiene obtiene el Cuadro 5.30:

Cuadro 5.30 - Resumen de la opinión de la comunidad 27 de Abril/SINDOMÉSTICO expuesta al sector social de CONDER

\begin{tabular}{|l|l|}
\hline \multicolumn{1}{|c|}{ Elogios } & \multicolumn{1}{c|}{ Críticas } \\
\hline $\begin{array}{l}\text { La ubicación satisfactoria del } \\
\text { proyecto; }\end{array}$ & $\begin{array}{l}\text { La demora en el trámite de la } \\
\text { regularización del lote; }\end{array}$ \\
Talleres para la capacitación del & $\begin{array}{l}\text { Entrega de las torres sin la } \\
\text { grupo gestor del Condominio. }\end{array}$ \\
& $\begin{array}{l}\text { construcción del muro perimetral } \\
\text { del condominio; }\end{array}$ \\
& $\begin{array}{l}\text { La demora para empezar los } \\
\text { talleres sobre temas del } \\
\text { condominio y correlatos -desfase } \\
\text { de los plazos-. }\end{array}$ \\
\hline
\end{tabular}

Fecha: julio de 2017.

Al solicitar a los profesionales que expusieran su opinión acerca de los aspectos positivos y negativos referentes al proyecto, se obtiene el resumen del Cuadro 5.31: 
Cuadro 5.31 - Resumen de la opinión de los profesionales del sector social de CONDER de la comunidad 27 de Abril/SINDOMÉSTICO

\begin{tabular}{l|lll|}
\hline \multicolumn{1}{|c|}{ Elogios } & \multicolumn{2}{c|}{ Críticas } \\
\hline - Alto grado de compromiso y & $\bullet \begin{array}{l}\text { Elevado potencial mercado } \\
\text { participación de las moradoras } \\
\text { con las actividades del proyecto }\end{array}$ & \\
inmobiliario informal. & \\
social; & & \\
Disponibilidad de espacio para \\
guardar vehículos; \\
Buena relación entre la empresa \\
licitada para las actividades del \\
proyecto social y la fiscalía de \\
CONDER.
\end{tabular}

Fecha: julio de 2017.

\subsubsection{3 - Opinión del líder comunitario de la comunidad}

El tiempo de espera entre el catastro y el recibimiento de las llaves del departamento duró cerca de cinco años, entre 2008 y 2013. La realidad de cómo estaban las 80 jefas de familia antes de recibir su nueva morada en el proyecto es: un $50 \%$ vivía de alquiler y un $50 \%$ habitaba en la casa de su patrona. Las que vivían en casa de sus patronas reclamaron celeridad en la entrega de los inmuebles. Cerca de 200 familias estuvieron catastradas pleiteando una habitación, básicamente, había que satisfacer los siguientes requisitos: ser mujer y jefe de familia, ser trabajadora y asociada al SINDOMÉSTICO desde por lo menos 1 año y medio antes de la divulgación de la llamada para la inscripción. Las familias que no fueron aceptadas en este proyecto se encaminaron para otros dos proyectos de VIS, uno en Salvador, con expectativa de construcción de 500 unidades habitacionales en la Estrada do Aeroporto, y otro en Lauro de Freitas, ciudad del área metropolitana de Salvador, donde se espera que se construyan 250 viviendas. La representante encuestada declaró que, después de las elecciones mayoritarias de 2014, ambos proyectos sufrieron interrupciones por tiempo indeterminado.

Al respecto de la participación de las moradoras en este proyecto se dijo que no hubo "ninguna", y que el SINDOMÉSTICO fue quien intermedió oficialmente con CONDER. De esta manera, las moradoras tampoco participaron en "ninguna" fase del proyecto, ni en la elaboración, ni en la fase de ejecución, seguimiento o fiscalización de las obras. Esto fue objeto de críticas por parte de las moradoras, las que sugirieron que en próximos proyectos se llame a los interesados para participar 
de las propuestas y definiciones. Se afirmó que "ningún" porcentaje de las familias participó como mano de obra en el proyecto.

Después de casi 1 año de entregados los departamentos, bajo insistencia y reclamos de las moradoras, CONDER invitó a la realización de dos encuentros con el fin de que se realizara una evaluación de las habitaciones y se hicieran críticas, reclamos, elogios, sugerencias, etc. Según la líder comunitaria participaron unas 30 familias en cada uno de los encuentros. Según la líder comunitaria el hecho de la exención total del pago de la financiación del inmueble fue uno de los motivos por los que la mayoría se desestimuló a comprometerse con las cuestiones de interés colectivo de la comunidad. Esta indiferencia recuerda lo que sucede en Argentina con el consumo de gas natural utilizado para calefacción, donde hay una práctica de desperdicio particularmente arraigada en la capa social media que mantiene todos los equipos funcionando al máximo por más que la temperatura necesaria de confort en el interior del inmueble sea mucho menor. Tal desperdicio tiene que ver con la conocida política de subsidio que el estado argentino aplicó a los precios del gas, según registra Balter $(2015$, p. 156-157), política que, en esta década, está restringiéndose por el aumento de tarifas. Esta práctica ocurre también en Brasil en lo que se refiere al consumo de agua de las viviendas colectivas, en las cuales el gasto se divide por igual entre las unidades habitacionales de los condominios.

Hubo "alguna" información tocante al tema de prevención y combate de incendios, sin embargo, como enfatizó la líder, fue por propia iniciativa de las moradoras un año después de la entrega de llaves, aprovechando la recarga de los extintores por medio de una empresa privada para solicitar tal información. En lo que toca a la capacitación sobre administración/fiscalización del condominio, también se dijo que inicialmente no hubo "ninguna", pero que después de un año y medio en la comunidad, el Comité Gestor, pasando por dificultades prácticas con el tema, solicitó a CONDER que organizara un curso, que fue realizado cerca de seis meses después. Situación semejante ocurrió con la capacitación profesional, que no hubo "ninguna" a pesar de que el Comité Gestor lo solicitara a CONDER. De igual modo, no ocurrió "ninguna" actividad sobre administración y gestión de conflictos de convivencia colectiva. Debido a las dificultades existentes en la comunidad, el Comité consiguió que el sector social de CONDER realizara en dos domingos talleres/charlas sobre el tema, en el que participaron cerca del $50 \%$ de los moradores. 
Según la líder comunitaria no existió "ninguna" actividad relacionada a facilitar la celeridad de trámites con las empresas concesionarias de servicios públicos, como agua/cloaca, energía eléctrica, telefonía, ni con la constructora y la justicia, incluso habiéndolo solicitado a CONDER.

La comisaría es el único equipamiento de los cinco mencionados en la pregunta $\mathrm{n}^{\circ} 16$ de la encuesta que se encuentra a más de $1 \mathrm{~km}$ de la comunidad, la que, según la líder comunitaria, está a unos $10 \mathrm{Km}$.

Con relación a si hay espacio destinado para guardar vehículos de trabajo, la respuesta fue "ninguno" (pero hay cerca de 50 plazas para aparcamiento de coches). No hay "ningún" espacio para actividades comerciales, y al cuestionar sobre la necesidad de éste, CONDER argumentando la falta de espacio en el terreno del condominio. Al menos "alguna" de las tres estructuras -plaza, área deportiva y centro comunitario- fue detectada por la líder comunitaria, que citó la plazoleta, respuesta contradictoria, ya que, como fue indicado, otros encuestados indicaron también un área deportiva y un centro comunitario. Seguramente no incluye como perteneciente al condominio la cancha de futbol que está del lado de afuera del conjunto habitacional y abierta al uso de todo el barrio, así como el edificio que se destinó a la guardería, que algunas veces es utilizada para eventos de la comunidad.

Sobre el desfase de los plazos previstos y efectivamente ejecutados, hubo "mucho".

En cuanto al potencial mercado inmobiliario informal, aseguró que supo por terceros que tal vez se haya negociado una unidad habitacional.

En cuanto a cambios en la seguridad pública en el área a partir de la inauguración del proyecto fue informado que hubo "mucho" debido a que los vecinos comentan que antes no había problemas del tipo. Este hecho probablemente es uno de los motivos principales para justificar porque la líder contestó que no hay "ninguna" relación de proximidad entre moradores y vecinos. La líder también aseguró que algunos vecinos culpan a los moradores por haber perdido la cancha de fútbol que estaba en el terreno donde se edificaron las cuatro torres, motivo por el cual surgió una cierta animosidad entre moradores y vecinos.

Con relación a la regularización del inmueble, una de las principales preocupaciones de la comunidad durante la investigación, la líder respondió "ninguna". Regularización que se atrasó por falta de documentación interna en la base de datos del Estado de Bahia para el registro notarial del terreno, lo que 
inviabiliza el trámite con la intendencia de Salvador. Luego se supo por la líder comunitaria, un año después de la realización de la Encuesta, que las pendencias por parte del Estado fueron solucionadas y que el trámite de regularización seguía su trayectoria normal.

Entre 30 y 40 familias de las 80 existentes en la comunidad, conforme aclaró la líder comunitaria, poseen el Número de Inscrição Social (NIS), registro federal de control de beneficios sociales, que, a familias de bajos ingresos, garantiza derecho a la tarifa social de agua/cloaca y energía eléctrica en Salvador. Es interesante enfatizar que de la encuestada se entiende que el beneficio de las canastas sociales tiende a estimular una cierta acomodación entre algunas de las familias beneficiadas.

Al pedirle a la líder que presentase los ítems más elogiados y criticados del proyecto por parte de los moradores, se tiene obtiene el Cuadro 5.32:

Cuadro 5.32 - Resumen de la opinión de la comunidad 27 de Abril/SINDOMÉSTICO expuesta al líder comunitario

\begin{tabular}{|c|c|}
\hline Elogios & Críticas \\
\hline $\begin{array}{l}\text { - La adquisición de una vivienda } \\
\text { propia; } \\
\text { - La ubicación favorable; } \\
\text { - La satisfactoria división de los } \\
\text { ambientes internos del } \\
\text { departamento y el tamaño -área-. }\end{array}$ & 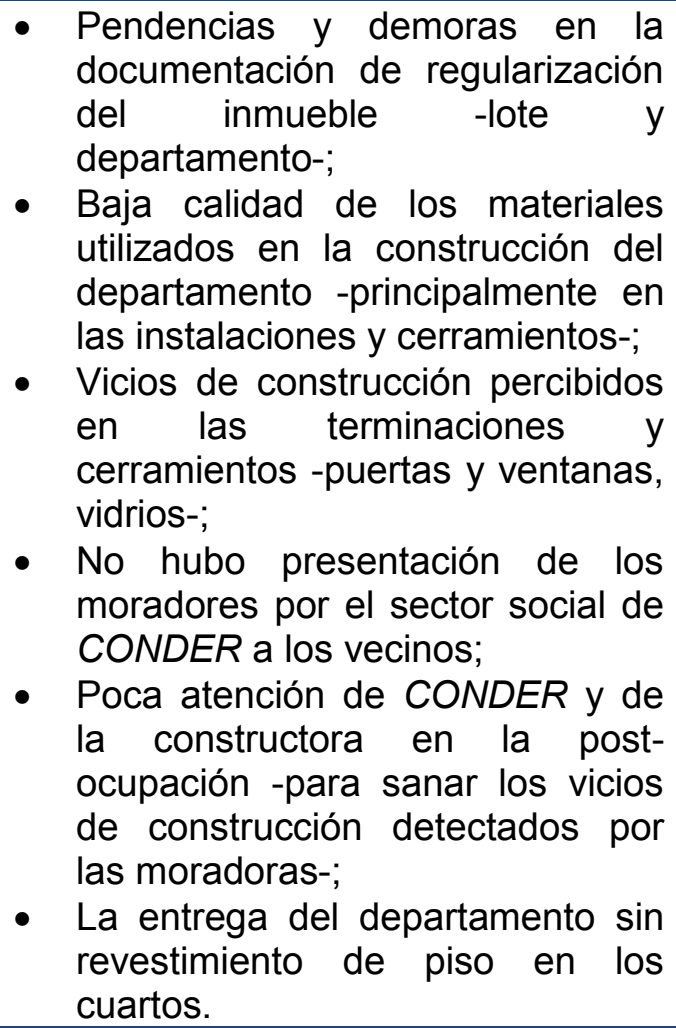 \\
\hline
\end{tabular}

Fecha: julio de 2017. 
Al solicitar a la líder que expusiera su opinión acerca de los aspectos positivos y negativos referentes al proyecto, se obtiene el resumen del Cuadro 5.33:

Cuadro 5.33 - Resumen de la opinión del líder de la comunidad 27 de Abril/SINDOMÉSTICO

\begin{tabular}{|c|c|}
\hline Elogios & Críticas \\
\hline $\begin{array}{l}\text { - La adquisición de una vivienda } \\
\text { propia; } \\
\text { - La satisfactoria división de los } \\
\text { ambientes internos del } \\
\text { departamento y el tamaño -área-. }\end{array}$ & 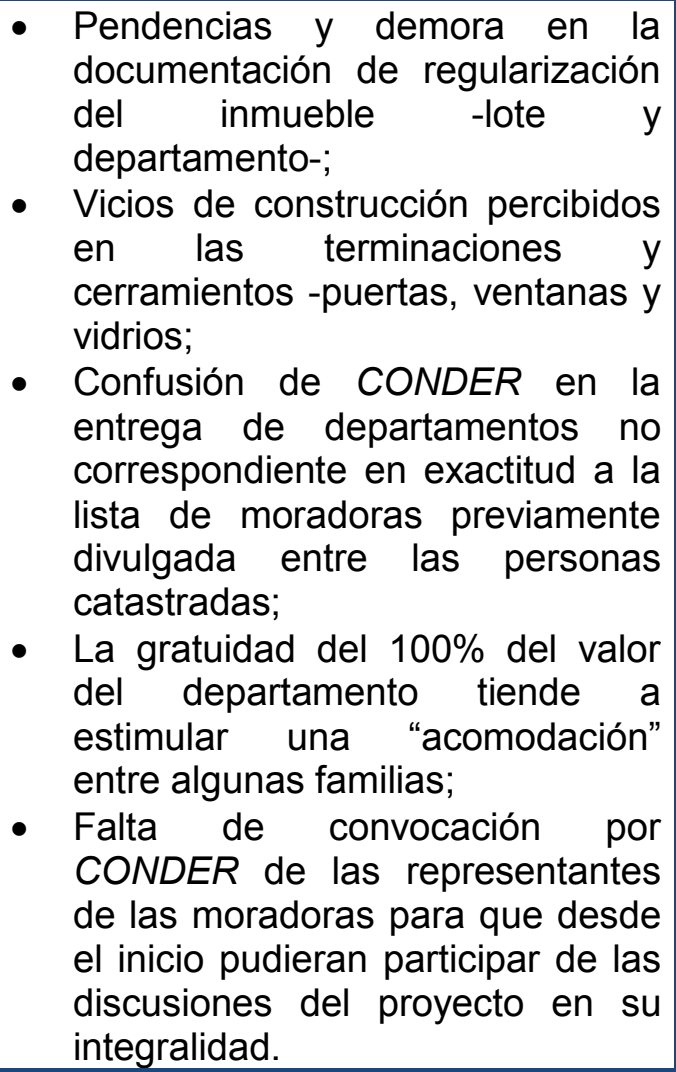 \\
\hline
\end{tabular}

Fecha: julio de 2017.

5.4.6 - Críticas y sugerencias de los profesionales sobre VIS

Al igual que como se hizo con las respuestas de la Encuesta Tipo 2 de los profesionales argentinos, siguen las respuestas de un conjunto de 19 profesionales brasileños, incluyendo arquitectos, ingenieros, urbanistas y operadores sociales (los cuales vienen actuando académicamente en su mayoría en Bahia, y en los estados de Alagoas, Pernambuco y São Paulo), siguiendo un orden alfanumérico, de A a F para los 6 ejes que estructuran esta tesis, y de 1 a 2 para los campo de Aspectos positivos y Aspectos Negativos, y de 1 a 19 para indicar el comentario del profesional, preservando así el anonimato. Cuando determinado profesional "nada dijo" al respecto de un determinado ítem, se colocó "-" adelante del orden numérico 
que al profesional se refiere. Se aclara que las informaciones traducidas del portugués al español corresponden con el máximo rigor posible a lo dicho y enviado por los 19 profesionales en la Encuesta Tipo 2, referido entre comillas y complementado de aclaraciones, entre corchetes, basadas en datos al respecto del tema y/o a partir de consultas hechas a algunos de los 19 profesionales $^{76}$ :

a) Proyecto arquitectónico

a.1. - Aspectos positivos:

a.1.1 "Consolida la relación de vecindad; Pensar colectivamente".

a.1.2 "Inserción más rápida de moradores (tejido urbano con infraestructura)".

a.1.3 "Facilita la construcción de una cantidad mayor de VIS; Facilita mayor agilidad en el proceso constructivo; Impide la ampliación de las unidades de VIS con material improvisado, lo que aleja la degradación de la tipología; Potencializa la seguridad de los moradores, siendo [la tipología] en altura".

a.1.5 "Facilita la construcción de un mayor número de viviendas ante la falta de espacio horizontal; Contribuye para que el Poder Público atienda a un mayor número de personas (con vivienda)".

a.1.6 "Facilita la construcción de un mayor número de viviendas en un espacio menor, atendiendo a un mayor número de personas [con vivienda]; Oportunidad de desarrollar la vida en comunidad".

a.1.7 "El modelo de construcción en altura de unidades habitacionales es cada vez más usado debido a la escasez de terreno".

\footnotetext{
${ }^{76}$ Al igual como se pasó entre los profesionales argentinos, también entre los brasileños, los siguientes ítems no recibieron ninguna contestación ya que para los mismo "NADA HA SIDO INFORMADO": a.1.4, a.1.9, a.2.4, a.2.9, a.2.15, a.2.16, b.1.4, b.1.6, b.1.7, b.1.8, b.1.9, b.1.12, b.1.13, b.1.15, b.2.4, b.2.5, b.2.6, b.2.9, b.2.10, b.2.11, b.2.15, c.1.4, c.1.5, c.1.6, c.1.7, c.1.8, c.1.9, c.1.12, c.1.15, c.2.4, c.2.5, c.2.6, c.2.9, c.2.10, c.2.11, d.1.5, d.1.6, d.1.7, d.1.8, d.1.9, d.1.12, d.1.13, d.2.4, d.2.5, d.2.6, d.2.7, d.2.9, d.2.10, d.2.11, d.2.12, d.2.13, d.2.16, e.1.1, e.1.4, e.1.5, e.1.6, e.1.7, e.1.8, e.1.10, e.1.11, e.1.13, e.2.4, e.2.5, e.2.6, e.2.9, e.2.10, e.2.13, e.2.15, e.2.16, f.1.4, f.1.5, f.1.6, f.1.7, f.1.9, f.1.11, f.1.13, f.2.1, f.2.4, f.2.5, f.2.6, f.2.7, f.2.8, f.2.9, f.2.10, f.2.11, f.2.13 y f.2.15.
} 
a.1.8 "La verticalización [construcción en altura] en espacio [lote] pequeño favorece la resolución [con VIS] de situaciones de ocupaciones [informales], por familias, imprevistas en lo mismo."

a.1.10 "La construcción en altura resuelve en parte el problema de espacio en los grandes centros urbanos".

a.1.11 "El padrón constructivo en altura atiende a una mayor demanda de vivienda para personas de baja renta".

a.1.12 "El padrón constructivo en altura promueve el aumento de las densidades y la reducción de los costos de urbanización, sobre todo en la infraestructura básica”.

a.1.13 "El padrón constructivo en altura favorece el atendimiento [de vivienda] a un mayor número de familias".

a.1.14 "Un proyecto bien hecho y bien pensado facilita la ejecución del emprendimiento [de VIS]".

a.1.15 "Conviene que se refuerce en los proyectos arquitectónicos la dotación de estructuras públicas (escuela, puesto de salud, etc.) y quioscos para exploración comercial (gomería, frutería/verdulería, taller para reparaciones de vehículos, etc.) por los moradores [Empleo y renta]".

a.1.16 "No se observan dificultades, incluso porque los pobres han resuelto su escasez de recursos con las famosas lozas que de a poco alcanzan diversos pisos en altura".

a.1.17 "El padrón constructivo en altura [de VIS] facilita el atendimiento de un mayor número de familias en áreas [terreno/lote] menores y más centrales; Se puede volver disponible [más racionalmente] una oferta conjunta de [prestación] de servicios [públicos]”.

a.1.18 "Posibilita la creación de espacios de esparcimiento; Mejor aprovechamiento del suelo viabilizando un mayor número de unidades [de viviendas]".

a.1.19 "Mejor distribución de unidades en un terreno; Posibilidad de aumentar el área de la unidad [habitacional] y posibilidad de incorporar estructuras públicas".

a.2 - Aspectos negativos: 
a.2.1 "Privatización de áreas comunes; Falta de conservación (degradación) de fachadas; Instalación de redes: agua, energía/luz y basura "privatizadas" habiendo desperdicios de estos servicios".

a.2.2 "Estimula una alta densidad habitacional; Riesgos de problemas de habitabilidad debido a la inexperiencia de proyectistas; Calidad estética dudosa de las VIS".

a.2.3 "Imposibilita la ampliación de la VIS por el morador (familia numerosa); Inviabiliza el uso de tipología fuera de padrón (variación de número de cuartos); Obstáculo de movilidad para personas ancianas o con deficiencia".

a.2.5 "Dificulta la convivencia [colectiva] de personas en condominios".

a.2.6 "Área pequeña de los departamentos; Conflictos de relaciones entre los moradores por causa de la administración del espacio (limpieza y cuentas a pagar) y de los espacios comunes a ellos; Dificultad de convivencia [entre moradores] por causa de las diferencias de nivel de escolaridad [diferencias de valores/culturales]".

a.2.7 "Dificultad de adaptación al padrón constructivo por parte de las familias [convivencia colectiva en edificio en altura] debido al histórico de morada [en casa]; Las familias externan al sector social descontento en cuanto al tamaño de las unidades habitacionales frente al número de componentes de la familia; La acústica [revestimientos de las paredes y ruido alto de voces y equipamientos electrónicos] es motivo de insatisfacción y conflictos en la convivencia comunitaria; La ventilación [deficitaria en las unidades habitacionales], la seguridad y la accesibilidad [a los condominios en áreas dificultosas] son motivo de insatisfacción de moradores [en especial] por parte de familias que tienen moradores con deficiencia y movilidad reducida; Las áreas comunes carecen de implantación de estructuras comunitarias (canchas deportivas, quioscos, plazas y parques) debido a la distancia entre los condominios y los grandes centros".

a.2.8 "La demora entre que se proyecta y se ejecuta el proyecto genera alteraciones [inconvenientes] obligatorias por causa de ocupaciones del terreno no previstas; La necesidad de construir en altura [las VIS] para atender en pequeños espacios [terrenos en barrios ya densificados] a las familias que ya están allí instaladas viene presentando situaciones difíciles [de conflicto], considerando la falta de práctica en acatarse las reglas de convivencia como base para convivir mejor colectivamente". 
a.2.10 "La inexistencia de elevador dificulta la vida del morador que envejece y pasa a tener dificultades de movilidad".

a.2.11 "La tipología 1+ 4 (planta baja + 4 pisos superiores [y/o +4 pisos inferiores]) es más inconveniente [generando trastornos diversos para atenderse un número mayor de personas] que la de 1+3; Debe tenerse más atención en la elaboración de los proyectos para evitarse los equívocos [muy comunes hasta entonces]".

a.212 "[Eventual riesgo a la] Seguridad: inexistencia de cálculo estructural; [Preocupación con las] condiciones de estabilidad de la edificación en pendientes escarpadas; [En situación de] Micro accesibilidad dificulta a los 'portadores de necesidades especiales'”.

a.2.13 "Agrupamiento [exceso] de personas en espacio mínimo [vivienda]; Compartición de una pared por más de 1 casa [Inconveniencia de vivienda pareada: conflictos de convivencia entre familias]".

a.2.14 "Un proyecto mal hecho y un proyecto padrón [seriado] dificultan [el éxito del emprendimiento de VIS]".

a.2.17 "Se vuelve difícil atender [satisfactoriamente] a los diferentes tipos de familia; [La dinámica de la realidad impone] la necesidad de que [los propios moradores no tengan que] sean hechas ampliaciones [en las unidades habitacionales]".

a.2.18 "El padrón constructivo en altura exige una mayor complexidad técnica [en la elaboración] del proyecto arquitectónico y en los demás; Hay una necesidad de disponer de más áreas de uso común debido a las características de edificación colectiva y de accesibilidad universal (portería, corredores, escaleras, rampas, ascensores [generalmente no utilizados en VIS en Brasil]); Dificulta que el morador ejecute ampliaciones [que se necesita/pretende hacer en el interior de la vivienda]".

a.2.19 "Necesidad de incluir ascender en el proyecto [cuando fuere el caso]; Dificulta la aplicación de soluciones más baratas en proyectos de instalaciones; Vuelve el proyecto estructural más complexo". 


\section{b) Presupuestario (costos)}

b.1 - Aspectos positivos:

\section{b.1.1 "Precio del terreno más barato".}

b.1.2 "Ampliar para las capas más necesitadas; Garantir más subsidios a los de más baja renta; Abaratamiento con socialización de las expensas".

b.1.3 "Reducción de costo final por unidad construida; Dilución del costo del terreno cuando el proyecto es en altura".

b.1.5 "Reducción de costo final por unidad construida en edificio colectivo [construcción en altura] al contrario de la unidad habitacional aislada [unifamiliar/sólo en planta baja]".

b.1.10 "Contribución de los incentivos fiscales [por parte del Gobierno Federal] mediante tratamiento diferenciado con base en las leyes N. ${ }^{\circ}$ 10931/2004 (con las debidas modificaciones impuestas por las leyes N. ${ }^{0} 12.024 / 2009$ y 12.350/2010, que estimulan la participación de entes privados en proyectos estatales de VIS a partir del 31 marzo de 2009 con valor máximo de $R \$ 60.000,00)$; Contribución de los incentivos fiscales por el municipio [de Salvador/BA]: Imposto de Tramitação Inter Vivos de Bens Imóveis (ITBI) en la adquisición onerosa de inmuebles destinados al programa de exención de IPTU y otros".

b.1.11 "La tipología constructiva en altura abarata los costos de la construcción de VIS desde que la fundación no sea onerosa [lo que tiene que ver con el alto costo de contención de terreno]".

b.1.14 - "Incorporar en la concepción del proyecto la importancia del costo de operación [construcción] y del costo de mantenimiento".

b.1.16 "No se constituye en dificultad para el gobierno financiar emprendimientos [de VIS]".

b.1.17 "Con el padrón constructivo [de VIS] en altura ocurre una reducción en los costos de vivienda, de los costos de infraestructura y de servicios [públicos]".

b.1.18 "Menor costo del terreno por unidad habitacional debido a la construcción en altura". 
b.1.19 "Aumento de la cuota [valor de financiación] del proyecto por el aumento de la oferta de las unidades [habitacionales] y dilución de los costos relativos a la infraestructura; Disminución del impacto del terreno en los costos".

\section{b.2 - Aspectos negativos:}

b.2.1 "Estructura predial e infra son costosas; Mantenimiento costoso de las viviendas".

b.2.2 "Alto costo (cuando [es] necesaria la instalación de equipamiento de movilidad)".

b.2.3 "Siendo el terreno de resistencia inconsistente se vuelve más costoso cuando el edificio posee más de 1 piso además de la planta baja”.

b.2.7 "El valor mínimo del 1,5\% del valor total de la inversión en los emprendimientos destinado al trabajo social es limitado [insuficiente] frente a los plazos de ejecución y de la dificultad [burocracia] de liberación de los recursos por parte de los órganos financiadores".

b.2.8 "El retraso por largo período del pago a la empresa [tercerizada que presta servicios al sector social de órgano público contratante] genera inconvenientes de interrupción [de los servicios] y desfasaje con la ejecución de la obra, perjudicando el proceso del proyecto".

b.2.12 "La baja renta de las familias y el poco acceso a la financiación dificultan el proceso de adquisición de la VIS; No existen datos [exactos] sobre los costos de la construcción [de VIS]".

b.2.13 "Falta de pago [retrasos en la liberación de dinero de la financiación] debido a vinculación [pareceres/laudos técnicos] con otros órganos [burocracia]".

b.2.14 "Es un equívoco pensar solamente en el costo inicial del proyecto sin tener en cuenta el costo total del mismo que envuelve también el costo de mantenimiento".

b.2.16 "Es una traba para que los auto-constructores dispongan de recursos financieros [para que construyan sus propias viviendas], dificultad que no existente para el Estado que financia [la construcción de VIS]".

b.2.17 "El costo del suelo urbano es un factor que dificulta [el atendimiento de un mayor número de unidades habitacionales]". 
b.2.18 "Mayor costo con la edificación (por unidad habitacional) y con la elaboración de los proyectos; Dificultad por parte de los moradores para honrar el pago de las tasas de condominio; Tiende a ocurrir [generalmente] desperdicio de agua y gas [y de energía eléctrica] cuando la medición [de consumo] no es hecha de forma individualizada [por unidad habitacional]".

b.2.19 "Aumentos de los costos por la fundación; Aumento de los costos relativos a los transportes de materiales y aumento del costo por la instalación de ascensor [cuando fuere el caso]".

c) Suelo (para la construcción)

c.1 - Aspectos positivos:

c.1.1 "Viabilidad de atender mayor número de familias (viviendas)".

c.1.2 "No carece de grandes lotes. Garante agilidad en la regularización de tierras a todos los moradores".

c.1.3 "Incluso en terrenos menores es viable atender varias familias con un mayor número de viviendas próximas a los centros urbanos; Mayor número de construcciones en lotes pequeños abarata el costo de éstos y facilita la obtención de financiación del proyecto".

c.1.10 "Ampliación del acceso a la tierra urbanizada por la población de baja renta; Articulación entre las políticas sectoriales de vivienda, medio ambiente, saneamiento básico, y movilidad urbana; Participación comunitaria en todas las etapas del proceso; Estímulo a la resolución extrajudicial de conflictos; Concesión [por la Unión, Estado o Municipio] de títulos [de inmueble/lote] preferencialmente a la mujer [en especial con personas dependientes: menores y/o ancianos]; Gratuidad [exención de costos y emolumentos] del registro de auto de demarcación urbanística, del título de propiedad y de las cuotas oriundas de la regularización de terreno de Interés Social".

c.1.11 "Optimiza [con la viabilidad de producción de mayor número de unidades habitacionales] la utilización del espacio, que es escaso en las grandes ciudades, en especial en los centros".

c.1.13 "Dar la titularidad del lote al órgano responsable por la implantación del proyecto [de VIS] facilita la ejecución del mismo". 
c.1.14 "La implantación de proyectos [de VIS] en áreas urbanas dotadas de servicios e infraestructura costa más caro, pero, puede ser más barato si se consideran los costos del entorno de la edificación [estructuras públicas: escuela, puesto de salud, transportes etc.]".

c.1.16 "La reforma urbana, como tantas otras, no es practicada con urgencia, facilitando así a los auto-constructores y al propio gobierno en la oferta de unidades habitacionales en altura, o no, para los interesados".

c.1.17 "No se ve alguna contribución del padrón constructivo en altura [de VIS] en lo que toca al tema de tierras".

c.1.18 "Mejor aprovechamiento y eficiencia en la utilización del área, o sea, se puede atender un mayor número de familia [con viviendas]".

c.1.19 "Aumento del radio de búsqueda por terrenos menores disponibles [mayor viabilidad para encontrarlos]; Mejor utilización del terreno [pequeño] a causa de la densidad de viviendas [mejora la relación costo $\mathrm{X}$ beneficio financieramente]”.

c.2 - Aspectos negativos:

c.2.1 "No existe área para cultivo y cría de animales".

c.2.2 "Falta de stock de tierras del municipio; Falta de programas de VIS en pequeños lotes urbanos; Alto costo de la tierra urbana con infraestructura".

c.2.3 "No se observa ningún punto negativo en cuanto al tema de tierras".

c.2.7 "La no conclusión de la titularidad [práctica común] del terreno [de la unidad habitacional] en la entrega del proyecto a los moradores es algo que ha generado expectativa [angustia/aprensión] en las familias".

c.2.8 "Durante una desocupación de un terreno perteneciente al Estado [ocupado por terceros que construyeron en él], el hecho del ente gubernativo, con base en valor referente, tener que pagar una indemnización por solamente lo construido en el local genera [retrasos y] trabas [burocrático-jurídicas] entre el Estado y al ocupante del terreno; El uso colectivo de agua y energía eléctrica [de áreas comunes de los edificios] es problemático entre moradores". 
c.2.12 "En general no existe una parcelación formal [del lote]. La 'posesión' o apropiación de lotes es de modo irregular, careciendo de regularización de la propiedad".

c.2.13 "La ocupación informal, por terceros, de lotes destinados a la implantación de proyectos [de VIS]".

c.2.14 "Lotes aparentemente más baratos localizados en la periferia de la ciudad, sin servicios o infraestructura, dificultan el éxito del proyecto [no siempre son la mejor opción, pues tienden a generar costos no previstos y diversos trastornos, como el transporte]".

c.2.15 “Los costos de 'recalificación' previa de asentamientos informales [contención de pendientes/escarpados] para la implantación de proyectos de VIS tienden a restringir el atendimiento [de vivienda] a un mayor número de familias demandantes".

c.2.16 "La ausencia de loteos para la población pobre influencia la invasión [ocupación informal]; Falta hacer una reforma urbana para facilitar la acción de los auto-constructores".

c.2.17 "La estructura de condominio [convivencia de varias familias en un mismo edificio en altura] no es parte de la cultura de las personas [de más bajos ingresos/instrucciónescolaridad]."

c.2.18 "Ocurre [generalmente] una mayor complexidad cuando [se trata] de la parcelación y de la incorporación del terreno para [la implantación de la] edificación colectiva."

c.2.19 "Impactos urbanos por la logística del transporte vertical de materiales; Disminuye el radio de búsqueda por terrenos [raros y pequeños] disponibles en condiciones de albergar el proyecto [costos de contención/fundación en terrenos escarpados]; Restringe la cantidad de terrenos disponibles por causa de normas [exigencias edilicias para que se respete la altura máxima de construcción en determinadas zonas de la ciudad] restrictivas."

d) Tecnológico (conforme la tipología arquitectónica en altura)

d.1 - Aspectos positivos:

d.1.1 "Rapidez en la construcción y atendimiento de las familias". 
d.1.2 "Accesibilidad de bajo costo en VIS en altura; Facilidad de individualización, por vivienda, del uso y del costo de energía y agua".

d.1.3 "Promueve agilidad en la construcción del proyecto; Viabiliza la utilización en serie de formas y materiales premoldeados en la construcción de las viviendas".

d.1.4 "en la mayoría de los casos la tecnología ha favorecido la construcción en altura con materiales más livianos y de rápida colocación".

d.1.10 "Utilización de calentamiento en ducha; La creación, por la Caixa Econômica Federal, en 2010, del Selo Azul da Caixa, una clasificación socio-ambiental para reconocimiento de proyectos habitacionales financiados por la Caixa y que adopten soluciones eficientes en la construcción; El referido Selo posee 53 criterios de evaluación y 6 categorías: calidad urbana; proyecto y confort; eficiencia energética; conservación de recursos materiales; gestión de agua; y prácticas sociales".

d.1.11 "El uso de la forma metálica [en serie] abarata el costo [de la obra] y facilita la practicidad y economiza tiempo de construcción".

d.1.14 "La utilización de sistemas constructivos adecuados, como albanaría estructural, estructura metálica o prefabricada".

d.1.15 "La selección criteriosa del terreno y del tipo de la infraestructura [fundación] a ser adoptada en la implantación del proyecto [VIS] tiende a optimizar el atendimiento [de vivienda] a un mayor número de familias; Es importante que se profundicen los estudios/investigaciones para que los costos, la calidad y cantidad de viviendas ofertadas sean mejores".

d.1.16 "Hay muchas tecnologías [para VIS] disponibles".

d.1.17 "Hay disponibilidad de diversos sistemas constructivos que posibiliten buenos resultados en el campo tecnológico [de VIS]".

d.1.18 "Posibilidad de utilización de tecnologías aplicables a edificios".

d.1.19 "No se ve impacto tecnológico desfavorable; Surgimiento de nuevas técnicas constructivas; Surgimiento de nuevos materiales y modelos logísticos para cantero de obras". 


\section{d.2 - Aspectos negativos:}

d.2.1 "Costo mayor que el de un proyecto unifamiliar [se refiere al alto costo de la fundación de la estructura del inmueble debido a que el terreno está en un área rellenada, lo que exigió una fundación más onerosa, en estaca profunda, no prevista inicialmente]”.

d.2.2 "Falta de inversión en investigación de materiales y tecnologías para abaratar viviendas".

d.2.3 "Algunos terrenos específicos como masapé [suelo de composición natural con gran contenido de arcilla, no favorable para soportar carga], o área rellenada, encarecen el costo de la fundación, lo que inviabiliza la construcción en altura, tornando más interesante la utilización de unidades habitacionales térreas [de planta baja] o con al máximo 2 pisos [incluyendo la planta baja]".

d.2.8 "La calidad de la terminación [de los servicios y materiales] ha sido motivo de muchas quejas entre beneficiarios y la empresa constructora".

d.2.14 "Cuando se computan los costos [con mayor precisión] se comprueba que construir en altura es más caro [teniendo en consideración la burocracia, las dificultades en general, el terreno y fallas en la proyección y ejecución]".

d.2.15 "La implementación de proyectos en áreas inconvenientes, como anegadizas, promueve el encarecimiento de los mismos, cuando sería más viable optimizarlos, implantándolos en áreas adyacentes, respetando el principio de mantenimiento de las familias próximas al asentamiento original; Las autoridades públicas deben mantener un mayor control/fiscalización de ocupaciones/asentamientos informales en áreas de riesgo, de reserva [ambiental] y de difícil posibilidad de construcción".

d.2.17 "Hay una dificultad en mantener el control del padrón de calidad [en la construcción de VIS]".

d.2.18 "Hay menos facilidad de utilización de sistemas constructivos novedosos y de bajo costo, los cuales normalmente son aplicables en casas térreas [de planta baja]".

d.2.19 "No veo impacto tecnológico desfavorable".

e) Gerenciamiento gubernamental (políticas públicas) 
e.1. - Aspectos positivos:

e.1.2 "La obligatoriedad de acciones (programas) para trabajo y renta: promueve la integración de las políticas sociales y de renta".

e.1.3 "Al adoptarse proyectos con edificios en altura se viabiliza la construcción de más unidades habitacionales, lo que promueve la reducción del déficit habitacional".

e.1.9 "Los [permanentes] diálogos entre el órgano ejecutor y el agente financiador son provechosos para el éxito del emprendimiento".

e.1.12 "Conviene [mantenerse en la dirección de] consolidar las ZEIS con el objetivo de enfrentar el tema [de mejoría] de políticas públicas [de VIS], a través de proyectos-piloto en las ZEIS, monitoreadas para evaluaciones futuras".

e.1.14 "La definición, por las gerencias gubernamentales, en cuanto a la necesidad de que se ocupen las áreas con infraestructuras y con servicios de la ciudad, por ejemplo, de las áreas centrales".

e.1.15 "La facilitación para creación de leyes (normas) específicas para VIS contribuye con un mejor atendimiento a las demandas".

e.1.16 "A partir de una reforma urbana se puede tener una gestión participativa, que facilitaría el proceso de construcción, comercialización y manutención [de VIS]".

e.1.17 "Es favorable el incentivo que el Estado da, por ejemplo, al PMCMV - MCMV, a otras posibilidades de acciones, como la autogestión y cogestión de acciones, las cuales son practicadas en este programa”.

e.1.18 "Un mayor ordenamiento y densidad poblacional proporcionan una mejora en las políticas [públicas] de transporte, educación y demás servicios urbanos".

e.1.19 "Posibilidad de aumentar la oferta de unidades [habitacionales]; Necesidad de terrenos con áreas menores y mayor posibilidad de utilización de predios [de propiedad] del gobierno". 
e.2 - Aspectos negativos:

e.2.1 "Falta experiencia en gestión de condominio por técnicos y moradores; Falta educación patrimonial y ambiental de moradores".

e.2.2 "La no integración entre las políticas públicas para atendimiento previo a las demandas de estructuras públicas (educación, salud, transportes etc.)".

e.2.3 "Con un mayor número de familias/personas juntas, esto dificulta la acción del trabajo social y la gestión del territorio, como para ofertar transporte público, escuela, guardería y puesto de salud".

e.2.7 "La integralidad de las políticas públicas, cuestión estratégica de la gestión de los programas habitacionales [de interés social] debe reforzarse objetivando asegurar derechos y empoderamiento de las familias para que éstas ejerzan la gestión de los proyectos".

e.2.8 "Falta de comunicación en tiempo hábil entre los diversos órganos públicos envueltos en el proyecto genera desencuentros entre éstos, lo que dificulta la resolución de problemas o la detección previa, en tiempo hábil, de éstos".

e.2.11 "Hay una [cultura de] dificultad de las familias adquirientes de VIS en la convivencia en condominio [colectivamente entre estas familias]; La Gerencia de Programas de VIS debe invertir más en el sector de proyectos y de investigación, con el objetivo de optimización de soluciones arquitectónicas y tecnológicas".

e.2.12 "No existen políticas públicas volcadas para apoyar las construcciones populares, principalmente las hechas directamente por los moradores".

e.2.14 "No hay dificultades originadas por parte de la gerencia gubernamental referentes a las políticas públicas".

e.2.17 "Hay dificultad por parte de los agentes estatales responsables al promoverse una fiscalización y control de las obras públicas [de forma más adecuada]".

e.2.18 "Ocurren posibles problemas con relación al pago de tasas de condominio e incluso de [consumo referente a servicios de] agua, gas y energía; Ocurren problemas en cuanto al mantenimiento [regular: preventiva y correctiva, a lo largo del tiempo de uso] de edificios en altura". 
e.2.19 "Aumento de la demanda de servicios públicos; Densificación poblacional en áreas menores y dificultad de los nuevos moradores para entender las nuevas condiciones de morada [convivencia colectiva genera conflictos]".

f) Legislación edilicia

\section{f.1 - Aspectos positivos:}

f.1.1 "La inexistencia de leyes específicas facilita la flexibilidad a la realidad".

f.1.2 "La obligatoriedad de reserva de áreas para estructuras y servicios públicos".

f.1.3 "La legislación más reciente del municipio permitió la construcción de edificios de hasta cuatro pisos además de la planta baja sin la necesidad de ascensor, lo que favoreció la construcción de más unidades habitacionales en el mismo terreno".

f.1.8 "La ley que establece la medición individual del consumo de agua y energía eléctrica [por vivienda/familia] evita problemas entre moradores; La imposición legal de área mínima por habitación [en el interior de la vivienda y en áreas comunes] en los proyectos, contribuye para un mejor atendimiento de VIS".

f.1.10 "La ley N. ${ }^{\circ} 11.977$ del 7 de julio de 2009 que dispone sobre el PMCMV- MCMV y la Regularización de Tierras de asentamientos localizados en áreas urbanas; Leyes municipales [de Salvador/BA] referentes al código de obras y la Lei de Ordenamento do Uso do Solo (LOUS) que se utilizan y flexibilizan [permitiendo excepciones] para atendimiento a los proyectos de VIS".

f.1.12 "Conviene que se invierta más en investigación sobre formas de regulación no convencionales, más novedosas [con el objetivo de mejorar/actualizar la legislación en cuanto al tema de VIS]".

f.1.14 "No se identifica ningún facilitador para la construcción en altura [de VIS] en cuanto al aspecto de la legislación edilicia”. 
f.1.15 "Fue muy positiva la obligatoriedad de que los proyectos [de VIS] establezcan la individualización de la medición/cobranza individual [por unidad habitacional] del consumo de agua".

f.1.16 "El rol de normas y recomendaciones municipales para construcciones en altura [de VIS] atiende perfectamente a las demandas".

f.1.17 "No se ve alguna contribución del padrón constructivo [de VIS] en atura en lo que se refiere al ámbito de la legislación edilicia”.

f.1.18 "El padrón constructivo en altura tiende a inhibir la realización [por parte de los moradores] de reformas irregulares, ampliaciones ilegales, etc., más en departamentos [en condominios en altura] que en casas".

f.1.19 "Mayor posibilidad de adecuarse a las normas urbanísticas".

\section{f.2 - Aspectos negativos:}

f.2.2 "La inflexibilidad en el aprovechamiento de pequeños lotes vacíos en áreas centrales; El no aprovechamiento de inmuebles en ruinas, en áreas centrales, ni de inmuebles de valor arquitectónico y cultural para VIS; La no existencia de parámetros impositivos para la implantación de estructuras en los proyectos de urbanización integrada desde el inicio de la construcción".

f.2.3 "La misma legislación que facilitó la construcción de un mayor número de unidades habitacionales a través de la construcción en altura del edificio dificultó la accesibilidad de personas ancianas y con movilidad reducida".

f.2.12 "La actual legislación edilicia no tiene en cuenta el modo de [auto]construcción de las viviendas de personas de baja renta".

f.2.14 "No se identifica ningún facilitador para la construcción en altura [de VIS] en cuanto al aspecto de la legislación edilicia”.

f.2.16 "Fuera del ámbito de las leyes municipales se corre riesgos, teniendo en cuenta que, en general, los auto-constructores se equivocan en este sentido, no obstante, es lo que se puede hacer, delante [del contexto] de que no tengan recursos financieros ni técnicos". 
f.2.17 "Existen conflictos entre normas y legislaciones locales, así como en la legislación federal, de los programas habitacionales; Si por un lado el Estado reduce el número de requisitos para [la aprobación de] proyectos y ejecución [de VIS], por otro, es poco flexible en cuanto [a la legislación para] lotes en áreas ya consolidadas [con asentamientos informales]; La calidad de los proyectos [de VIS] se ve perjudicada, pues, ocurren conflictos o flexibilización de una norma [en relación con otras]. Tal hecho ocurre, por ejemplo, con el PMCMV- MCMV, lo cual tiene por base las normativas del Ministério das Cidades, las cuales, en algunos momentos, coliden, o flexibilizan, con requisitos de las normas de la $A B N T$ algo que perjudica la calidad del programa; Programas de urbanización están subordinados a normas de uso del suelo que en muchos casos dificultan la implementación de proyectos [de VIS] novedosos".

f.2.18 "Hay una mayor complexidad y dificultad de aprobación de [proyectos de] construcción en altura en relación a los unifamiliares (casas) debido a reglas de [exigencias en cuanto al] confort, seguridad, medio ambiente y accesibilidad".

f.2.19 "Dificultad en la aprobación de proyectos por causa de normas [exigencias edilicias como la altura máxima de construcción en determinadas zonas de la ciudad] restrictivas y restricciones legales más rigurosas".

Resumidamente, por lo expuesto y mucho de lo que se eligió, criticó o sugirió entre los colaboradores de esta investigación, moradores, líderes comunitarios y profesionales vinculados al tema tanto en Brasil como en Argentina, se constata que, para un mejor aprovechamiento de los proyectos de intervenciones urbanas en comunidades de bajos ingresos, se debe evitar: interrupciones entre proyecto, obra y durante ésta; la no ejecución del concepto del proyecto previsto; acciones aisladas, inconexas a un proyecto específico para una determinada localidad/ciudad y sin continuidad, o disociadas de otros sectores circunvecinos; indefinición en cuanto a la regularización inmobiliaria -lote e inmueble- y urbanística; ausencia de actuaciones comunitarias vinculadas entre sí; inexistencia de servicios de mantenimiento urbanístico y de otros como el de seguridad, educación y de salud; indefinición de un sector responsable de acompañamiento de la pos-ocupación, inclusive con asesoría técnica -oficina pública- para los conocidos y recurrentes casos de reforma o ampliación/alteración de las viviendas; localización indebida del espacio para colecta de basura, así como escasez de paisajismo, de áreas de convivencia y de esparcimiento-recreo/deportes. Uno o más de estos desvíos se vuelven 
responsables por el mal resultado de un proyecto, generando insatisfacción de los moradores, además de desperdicio para el erario.

\title{
5.5 - El Teorema de Paretto
}

Este teorema fue inspirado en los estudios de fines del siglo XIX por el italiano Vilfredo Paretto, y dada su importancia, ha sido aplicado en el análisis de los datos recolectados en campo. Basicamente:

\begin{abstract}
O diagrama de Paretto foi desenvolvido por "(...) um economista e sociólogo italiano, que em 1906 lançou a teoria que existia uma má distribuição entre causas e efeitos, a qual poderia ser descrita estatisticamente [...] Este princípio é extremamente significativo, pois se trata de um instrumento eficaz de controle de qualidade, de leitura fácil, na forma de diagrama de barras horizontais, bastante utilizado na sintese dos aspectos positivos e negativos do ambiente construído, objeto da APO [EPO]. Segundo este princípio, os itens significativos em um dado grupo constituem uma porção relativamente pequena do número total de itens no grupo. Ou seja, se são diagnosticados, do ponto de vista dos usuários de um determinado ambiente construído, 100 problemas, falhas ou aspectos negativos, a análise de Paretto demonstrará que, via de regra, cerca de $20 \%$ deles são responsáveis por $80 \%$ dos custos dos erros e omissões, ou, mais ainda, que somente 10 a $15 \%$ dos mesmos precisam ser solucionados para reduzir de forma bem representativa os custos de qualidade, ou seja, em torno de $50 \%$. (ORNSTEIN, 1992, p. 94)
\end{abstract}

\subsection{1 - Análisis sobre lo que piensan los moradores a la luz del Teorema de Paretto}

A partir de la tabulación de las respuestas de los moradores de la Encuesta Tipo 1 de las seis comunidades investigadas, tanto en Brasil como en Argentina, se elaboraron dos nuevas tablas, la Tabla 5.5 y la Tabla 5.6, respectivamente, utilizando apenas la sumatoria del conjunto de opciones de las principales respuestas que evidenciaron el nivel más alto de insatisfacción, lo que ocurrió con la opción "Definitivamente no", con excepción de las interrogantes: 7 (demora con la burocracia para entrega de llaves), 24 (audición de sonido intra e inter departamentos), 29 (ocurrencia de inconvenientes en el interior del departamento en periodo de lluvias), 31 (inconveniencia de uso de espacios de escaleras y halls del bloque) y 33 (intención de venta del departamento), para las cuales se tomó el parámetro inverso "Muchísimo". En este contexto, las cuatro interrogantes iniciales de la encuesta, así como las 13, 14 y 15, no forman parte de estas tablas para la 
elaboración del gráfico de Paretto ya que no han sido puestas con intención de valoración y sí como información adicional.

5.5.2 - La realidad de los proyectos según los moradores brasileños

Para analizar los datos provenientes de las respuestas de los moradores a partir de la Encuesta Tipo1 bajo el Teorema de Paretto se adoptó utilizar los cuantitativos del grado más indeseable -Definitivamente No-, lo que corresponde a probables inconvenientes, con algunas excepciones, para gran parte de las interrogantes de la encuesta. El resultado se observa a partir de la Tabla 5.5 y de las Figura 5.1, Figura 5.2, Figura 5.3 y Figura 5.4. 
Tabla 5.5 - Índices de insatisfacción por ítem en Brasil según el Teorema de Paretto

\begin{tabular}{|c|c|c|c|c|}
\hline Interrogante & Temas abordados en la Encuesta Tipo 1 & Definit. & $\%$ & $\%$ \\
\hline 16.3 & Entrenamiento de combate... & 126 & 13 & $13 \%$ \\
\hline 30 & áreas de esparcimiento son... & 93 & 26 & $10 \%$ \\
\hline 18.1 & El revestimiento del piso... & 85 & 35 & $9 \%$ \\
\hline 24 & El revestimiento de las paredes... & $72^{* 1}$ & 44 & $7 \%$ \\
\hline 6 & Participación en el proyecto... & 73 & 51 & $7 \%$ \\
\hline 7 & La burocaria para la entrega... & $53^{* 1}$ & 59 & $5 \%$ \\
\hline 18.2 & Revestimiento en las paredes... & 46 & 64 & $5 \%$ \\
\hline 18.3 & Revestimiento en la cocina... & 41 & 69 & $4 \%$ \\
\hline 18.4 & Revestimiento del techo... & 37 & 73 & $4 \%$ \\
\hline 18.5 & Los herrajes... & 36 & 77 & $4 \%$ \\
\hline 16.1 & Acseso a la entrada... & 32 & 81 & $3 \%$ \\
\hline 17 & Facilidad de transportes públicos... & 27 & 84 & $3 \%$ \\
\hline 22 & El clima en Verano en... & 23 & 87 & $2 \%$ \\
\hline 12 & La fachada del edificio... & 19 & 89 & $2 \%$ \\
\hline 33 & Pretende passar as chaves [vender/alugar] de seu & $7 * 1$ & 91 & $1 \%$ \\
\hline 32 & Hay escuelas públicas, guardería, etc... & 17 & 91 & $2 \%$ \\
\hline 29 & En periodo de lluvia.. & 17 & 93 & $2 \%$ \\
\hline 19 & Los cerramientos... & 16 & 93 & $2 \%$ \\
\hline 9 & El tamaño de los ambientes es... & 15 & 95 & $2 \%$ \\
\hline 16.2 & Los equipamientos de combate... & 14 & 96 & $1 \%$ \\
\hline 27 & Las instalaciones de agua... & 14 & 10 & $1 \%$ \\
\hline 5 & Satisfacción en vivir en 3 a 4 pisos... & 13 & 10 & $1 \%$ \\
\hline 20 & La cuota mensual de la financiación... & 13 & 10 & $1 \%$ \\
\hline 21 & Las expensas para el mantenimiento... & 13 & 10 & $1 \%$ \\
\hline 10 & Los ambientes están distribuidos.. & 12 & 10 & $1 \%$ \\
\hline 26 & La ventilación es adecuada... & 12 & 10 & $1 \%$ \\
\hline 28 & Las instalaciones eléctricas... & 11 & 10 & $1 \%$ \\
\hline 31 & Los espacios de acceso ofrecen... & 10 & 10 & $1 \%$ \\
\hline 8 & La cantidad de los ambientes... & 9 & 10 & $1 \%$ \\
\hline 23 & El clima en invierno en el interior... & 7 & 10 & $1 \%$ \\
\hline 11 & El suministro de agua... & 7 & 10 & $1 \%$ \\
\hline 25 & La iluminación natural en el... & 5 & 10 & $1 \%$ \\
\hline Total & & 975 & & 100 \\
\hline
\end{tabular}

Fecha: diciembre de 2018.

*1 Ítems cuya inclusión en esta Tabla se dio con la suma de respuestas de la opción "Muchísimo" a la inversa de "Definitivamente no". 
Figura 5.1 - Gráfico de Paretto (Comunidades de Brasil)

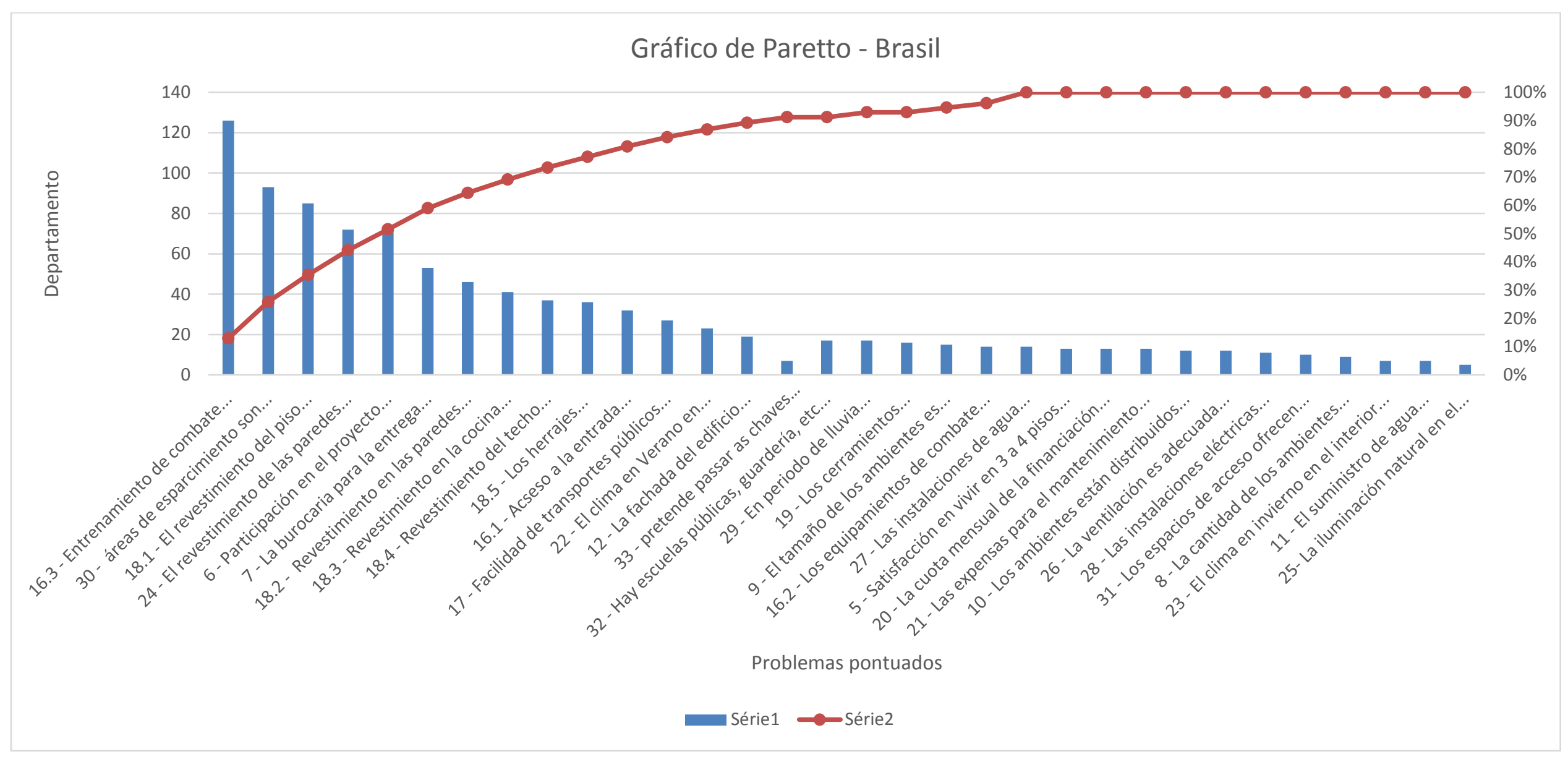

Fecha: diciembre de 2018 
Figura 5.2 - Gráfico del grado de satisfacción de las comunidades de Brasil

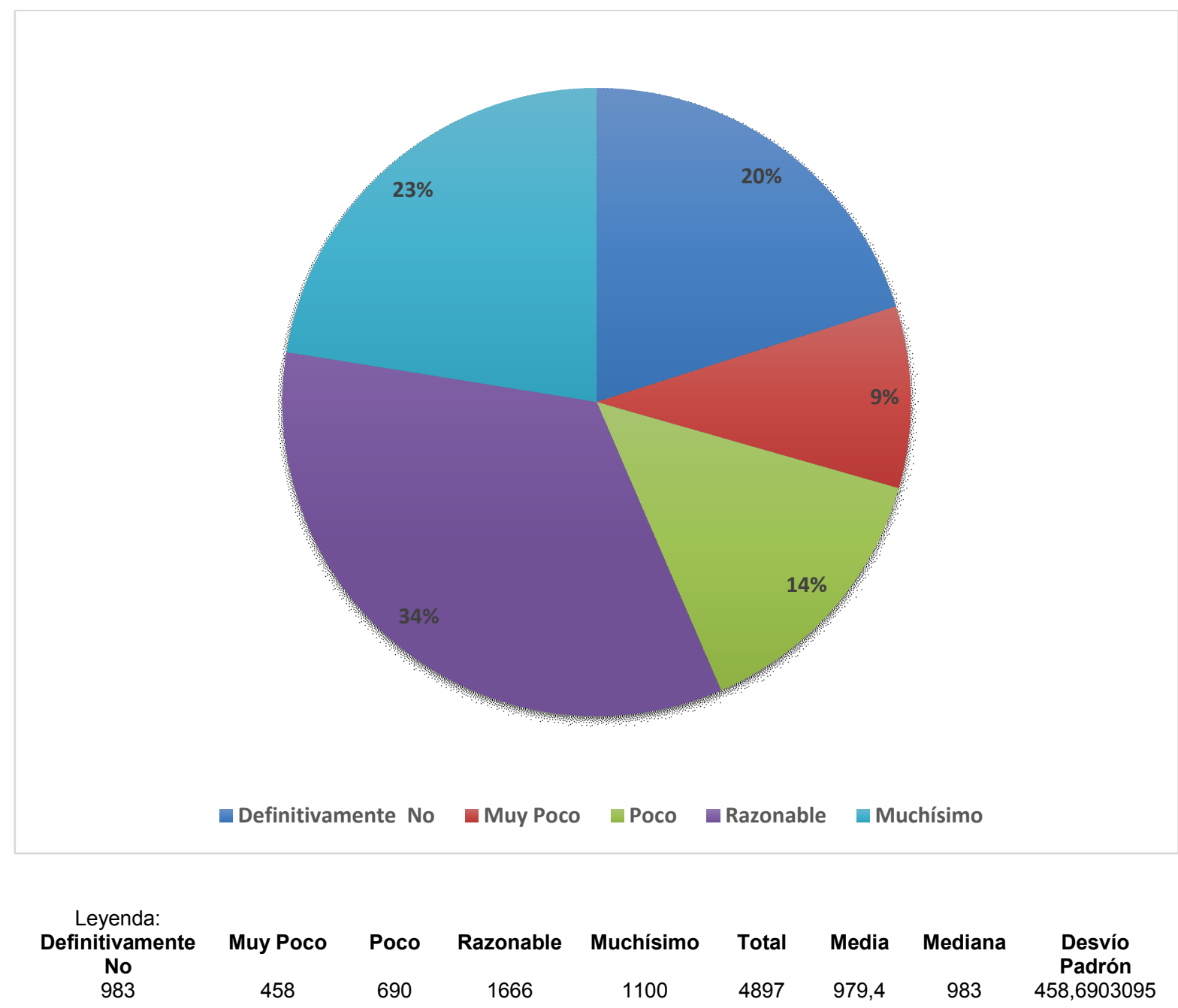

Fecha: diciembre de 2018.

Como se puede observar:

1 - Analizando el gráfico de sectores es fácil identificar que $57 \%$ de los encuestados están entre Razonable y Muchísimo satisfechos;

2 - El 20\% está Definitivamente No satisfecho;

3 - El 9\% está Muy Poco satisfecho;

4 - Se nota una vez más el principio de Paretto que sostiene que entre el $20 \%$ y $25 \%$ de los problemas necesitan ser solucionados para aumentar la calidad al $75 \%$ aproximadamente;

5 - Lo que más interfiere en el grado de satisfacción es la ausencia de entrenamiento de combate a incendios. 
Figura 5.3 - Tiempo de morada de los encuestados en las comunidades de Brasil

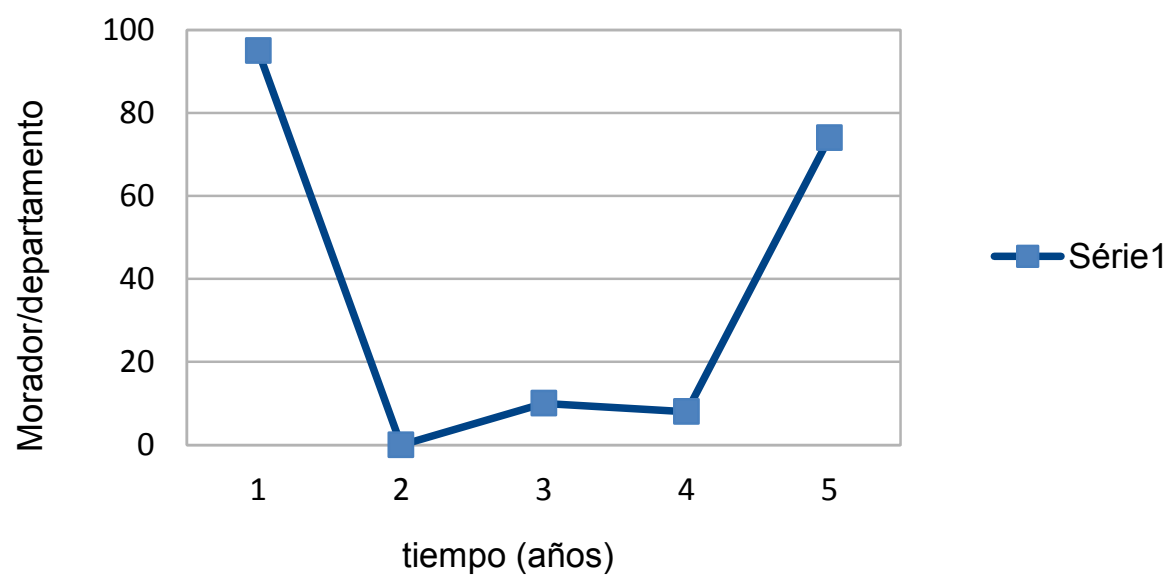

Fecha: diciembre de 2018

Figura 5.4 - Piso en que moran los encuestados en las comunidades de Brasil

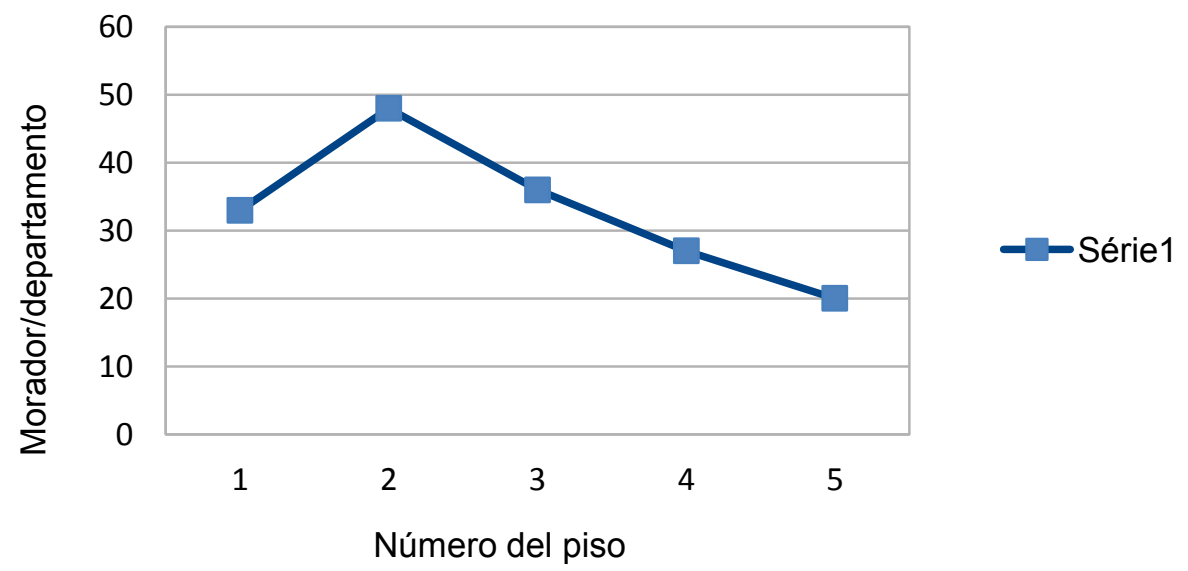

Fecha: diciembre de 2018.

5.5.3 - La realidad de los proyectos según los moradores argentinos

Al igual que como se hizo para analizar la realidad de los proyectos según lo que dijeron los moradores de Brasil, aplicándose el Teorema de Pareto, también se realizó para comprender la realidad de los proyectos según los moradores argentinos, lo que se confiere a partir de la Tabla 5.6 y de las Figura 5.5, Figura 5.6, Figura 5.7 y Figura 5.8. 
Tabla 5.6 - Índices de insatisfacción por ítem en Argentina según el Teorema de Paretto

\begin{tabular}{|c|c|c|c|c|}
\hline Interrogante & Temas abordados en la Encuesta Tipo 1 & Definit. & $\%$ & $\%$ \\
\hline 6 & Participación en el proyecto... & 165 & 7 & $7 \%$ \\
\hline 16.3 & Entrenamiento de combate... & 156 & 15 & $7 \%$ \\
\hline 5 & Satisfación en vivir en 3 a 4 pisos... & 113 & 22 & $5 \%$ \\
\hline 18.4 & Revestimiento del techo... & 112 & 27 & $5 \%$ \\
\hline 19 & Los "cerramientos"... & 111 & 32 & $5 \%$ \\
\hline 18.5 & Los herrajes... & 109 & 37 & $5 \%$ \\
\hline 30 & Las áreas de esparcimiento... & 109 & 42 & $5 \%$ \\
\hline 16.2 & Los equipamientos... & 108 & 46 & $5 \%$ \\
\hline 24 & El revestimiento de las paredes... & $108^{\star 1}$ & 51 & $5 \%$ \\
\hline 18.2 & Revestimiento en las paredes... & 104 & 51 & $5 \%$ \\
\hline 18.3 & Revestimiento en la cocina... & 104 & 56 & $5 \%$ \\
\hline 16.1 & Acseso a la entrada y salida del depart.)... & 103 & 60 & $5 \%$ \\
\hline 18.1 & El revestimiento del piso... & 89 & 65 & $4 \%$ \\
\hline 32 & Hay facilidad de escuelas públias... & 80 & 69 & $4 \%$ \\
\hline 7 & La burocaria para la entrega de las llaves... & $78^{* 1}$ & 73 & $3 \%$ \\
\hline 22 & El clima en el Verano en el interior.. & 74 & 76 & $3 \%$ \\
\hline 8 & La cantidad de los ambientes es suficiente... & 72 & 79 & $3 \%$ \\
\hline 9 & El tamaño de los ambientes es suficiente... & 71 & 83 & $3 \%$ \\
\hline 28 & Las instalaciones eléctricas... & 65 & 86 & $3 \%$ \\
\hline 27 & Las instalaciones de agua y cloaca... & 64 & 89 & $3 \%$ \\
\hline 12 & La fachada del edificio es agradable... & 39 & 92 & $2 \%$ \\
\hline 29 & En periodo de lluvia hay inconveniencias & 37 & 93 & $2 \%$ \\
\hline 23 & El clima en Invierno en el interior.. & 37 & 93 & $1 \%$ \\
\hline 34 & Concordancia con la Ley 962 de 2002. & 34 & 94 & $0 \%$ \\
\hline 11 & El abastecimiento de agua... & 23 & 94 & $0 \%$ \\
\hline 10 & Los ambientes están distriuidos... & 22 & 94 & $0 \%$ \\
\hline 17 & Facilidad de transportes públicos... & 13 & 97 & $0 \%$ \\
\hline 31 & Los espacios de acceso... & 13 & 97 & $0 \%$ \\
\hline 20 & La cuota mensual... & 9 & 98 & $0 \%$ \\
\hline 33 & Pretende passar as chaves [vender/alugar] de seu & $7^{\star 1}$ & 98 & $0 \%$ \\
\hline 21 & Las expensas para el mantenimiento... & 6 & 99 & $0 \%$ \\
\hline 25 & La iluminacipón natural. & 6 & 99 & $0 \%$ \\
\hline 26 & La ventilación es adecuada... & 1 & 10 & $0 \%$ \\
\hline Total & & 2242 & & \\
\hline
\end{tabular}

Fecha: diciembre de 2018:

*1 Ítems cuya inclusión en esta Tabla se dio con la suma de respuestas de la opción "Muchísimo" a la inversa de la "Definitivamente no"

*2 Muy discutible en cuanto a la concordancia o no con la Ley porteña 962 de 2002. 
Figura 5.5 - Gráfico de Paretto (Comunidades de Argentina)

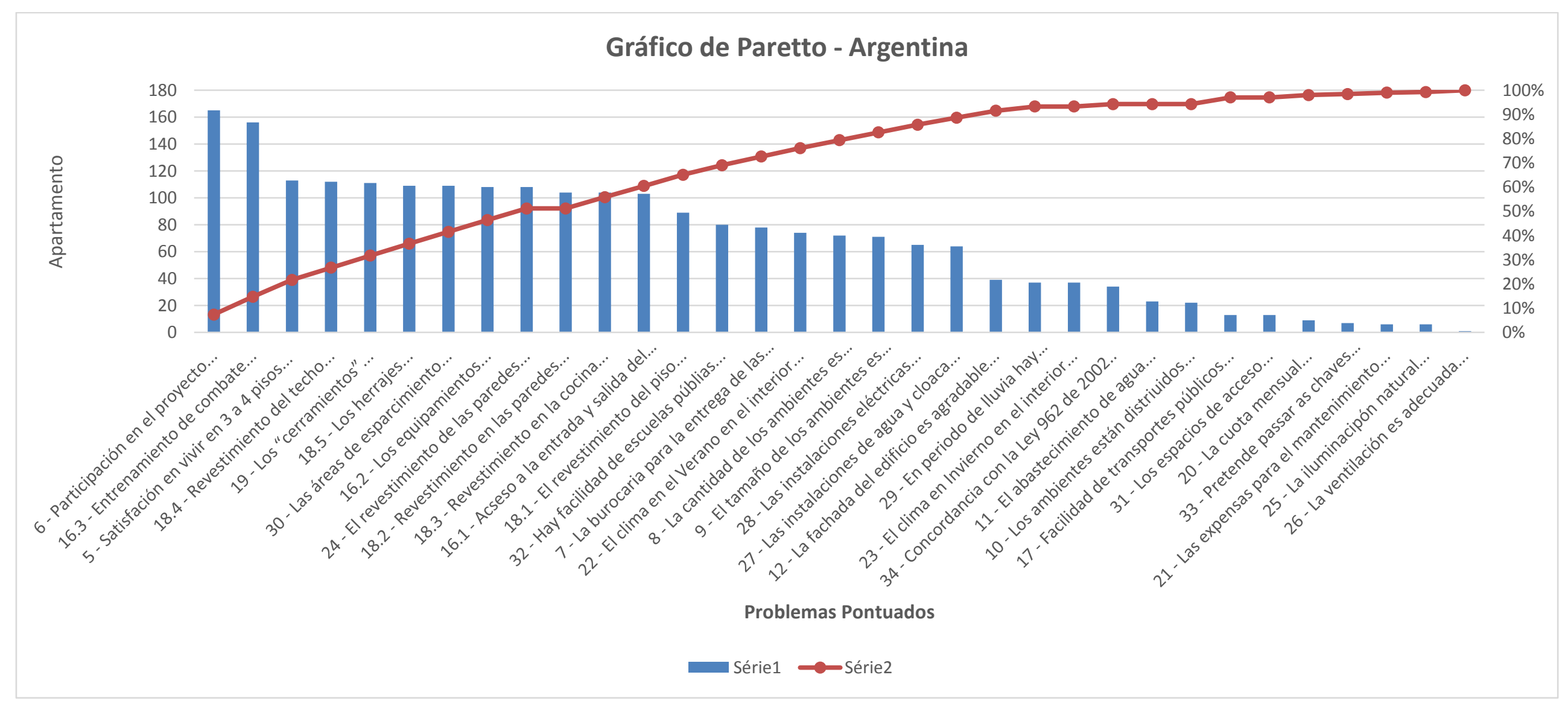

Fecha: diciembre de 2018 
Fig. 5.6 - Gráfico del grado de satisfacción de las comunidades de Argentina

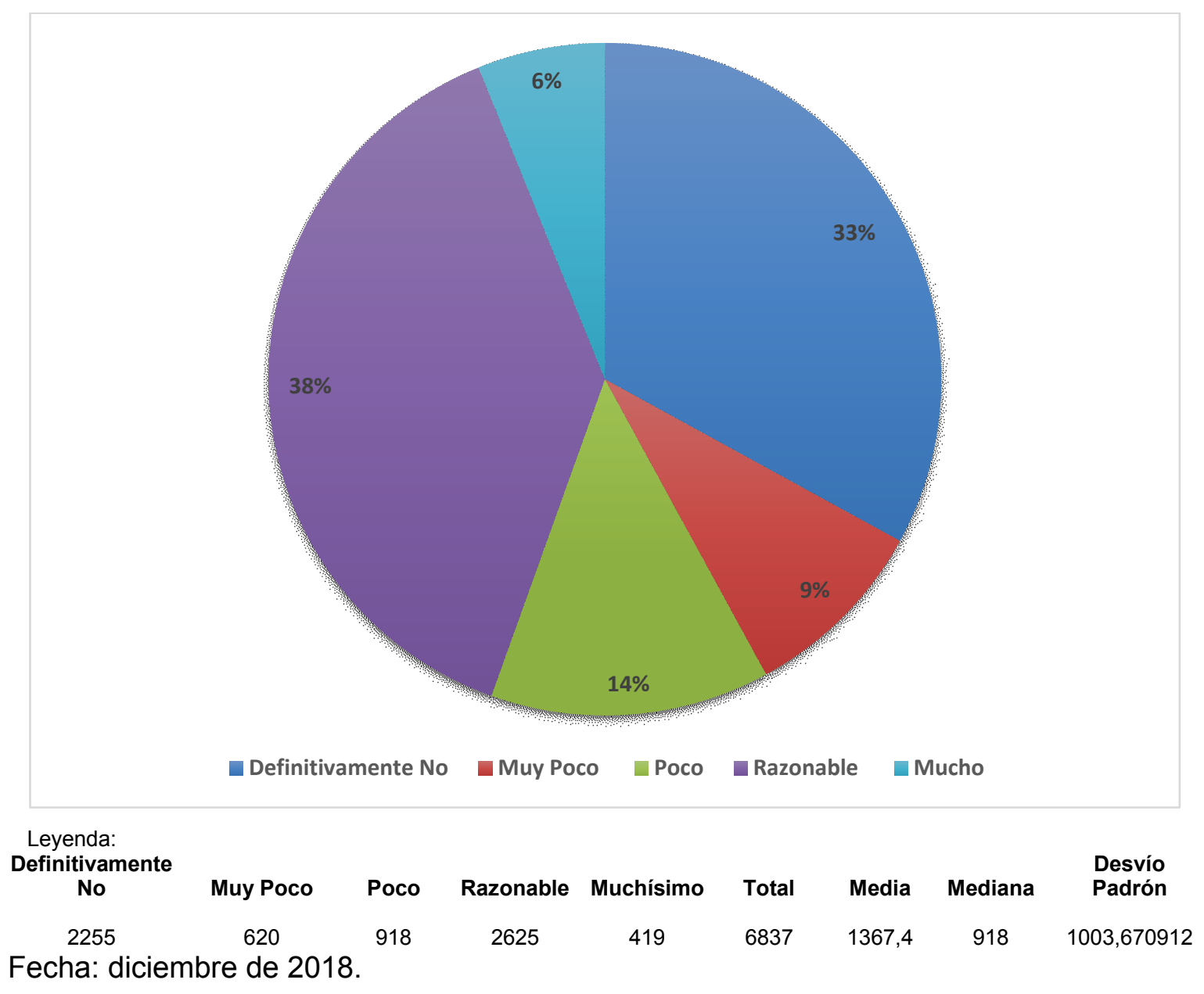

Como se puede constatar:

1- Analizando el gráfico de sectores es fácil identificar que el $44 \%$ de los encuestados están entre "Razonable" y "Muchísimo"

2- Se observa una vez más que el principio de Paretto que sostiene que entre el $20 \%$ y $40 \%$ de los problemas deben ser solucionados para aumentar la calidad al $60 \%$ de los atendimientos aproximadamente;

3 - El 33\% está Definitivamente "No satisfecho";

4 - Lo que más interfiere en el grado de satisfacción es la ausencia de participación en el proyecto de construcción. 
Fig. 5.7 - Tiempo de morada de los encuestados en las comunidades de Argentina

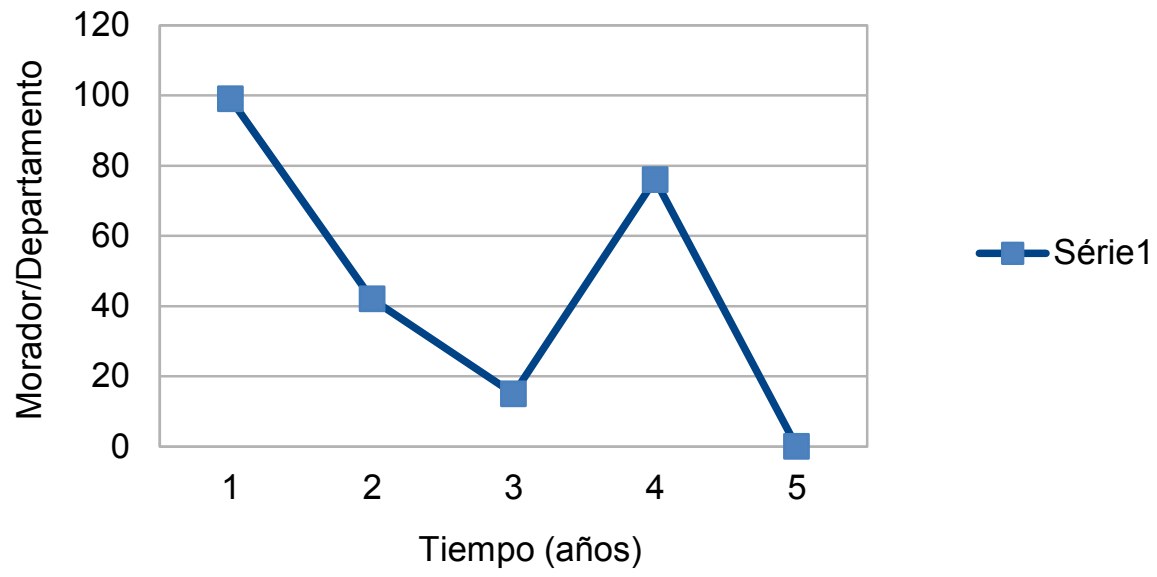

Fecha: diciembre de 2018.

Fig. 5.8 - Piso en que moran los encuestados en las comunidades de Brasil

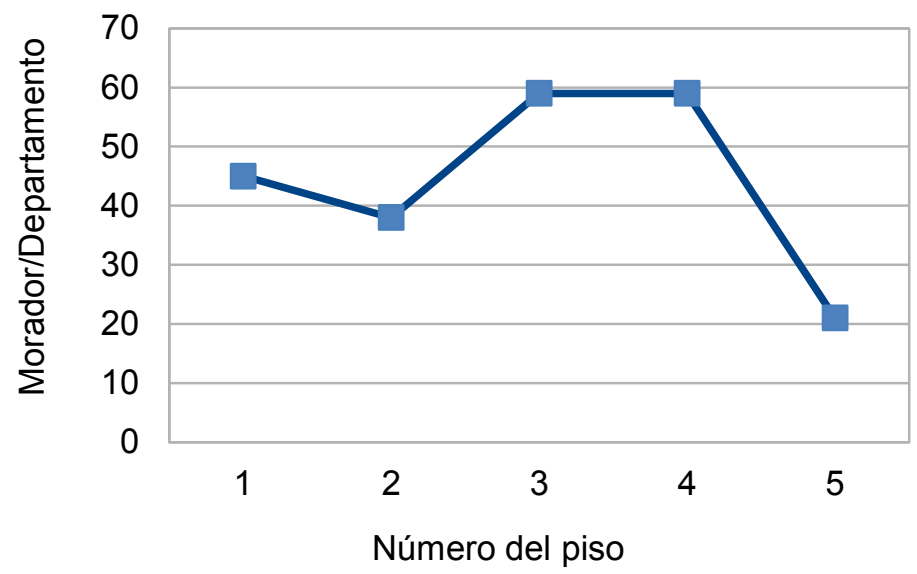

- Série1

Fecha: diciembre de 2018. 


\section{6 - CONCLUSIONES}

Con el copioso material recolectado y analizado en este Capítulo 5 se presenta lo que se constituyó en la parte esencial de la originalidad de esta tesis una vez que con lo mismo se consigueron conjugar tanto cuantitativa como cualitativamente preciosas informaciones del marco teórico investigado con las muy ricas contribuciones de la práctica provenientes directamente de los principales sujetos participantes de la implantación de los seis proyectos objetos de esta investigación y de cuyo marco teórico se extrae que durante el espacio temporal abordado, a pesar de que hubo avances progresivamente bajo varios aspectos cuanto a la implantación de proyectos públicos de VIS tanto en Argentina como en Brasil, desafortunadamente al menos dos importantes constataciones son muy actuales y presentes en ambos países: la de que el padrón de calidad y las dimensiones espaciales de las construcciones de aquellos proyectos sufrieron un descenso y que, al contrario, el déficit habitacional entre los sectores de más baja renta crece de forma alarmante pese las (buenas) intenciones y los esfuerzos de muchos.

En general, tanto por las respuestas directamente presentadas por los moradores como por los comentarios y críticas que varios de ellos manifestaron, reproducidos aquí de manera fidedigna, esta tesis ofrece una serie de informaciones relevantes para la intervención proyectual, urbanística y de gestión en aspectos críticos aquí expuestos, informaciones que se espera puedan incentivar un mejoramiento en futuros proyectos de VIS con tipología arquitectónica en altura.

Uno de los aspectos invariable y unánimemente reclamado por la mayoría de los moradores encuestados en las tres comunidades brasileñas se refiere a la baja calidad de los materiales utilizados en los revestimientos, así como la ausencia de revestimiento definitivo en el piso de las habitaciones. El retraso en la entrega de las viviendas fue otro motivo de insatisfacción de la mayor parte de los moradores. Reclamos por ruidos provenientes de viviendas laterales o superiores también fueron preponderantes entre los encuestados, que señalaron la necesidad de un revestimiento acústico adecuado, aunque implique un costo mayor, lo que se justificaría por la oferta de una mejor calidad de vida a los moradores que padecen este inconveniente diariamente. Con menor intensidad, estos reclamos también han sido efectuados por algunos de los moradores de la comunidad argentina del Complejo Padre Mugica. 
El sistema de red eléctrica y de provisión de agua, la adecuación al clima de verano y de invierno, la luminosidad natural en el interior de los departamentos y la ventilación fueron los ítems con mayores puntuaciones, aprobados por los moradores de las tres comunidades brasileñas, lo que indica el acierto de los proyectos y ejecución de los mismos a pesar de los inconvenientes relatados por los encuestados con relación a otros ítems. Una singularidad con relación a la ventilación se observó en la comunidad del Complejo Padre Mugica, donde varios moradores indicaron el permanente olor desagradable proveniente de los establos de caballos existentes en las proximidades, uno de los motivos alegados sobre su insatisfacción con la vivienda y por el cual manifestaron el deseo de querer mudarse para otro lugar apenas les fuera posible.

Sería interesante que en próximas intervenciones urbanas de esta naturaleza el sector social incorporase más charlas, encuentros, cursos de capacitación y entrenamiento entre sus atribuciones rutinarias, y que promoviera la participación de los futuros moradores desde la fase inicial de la concepción proyectual, durante la ejecución, y la pos-ocupación en conjunto con el sector de arquitectura e ingeniería, considerando la recurrencia con que este ítem ha sido mencionado por los moradores como insatisfactorio. Cerca del $40 \%$ de los encuestados brasileños desaprobaron el proyecto en este sentido. Insatisfacción también comprobada en las tres comunidades investigadas en Argentina, donde la comunidad de Parque Patricios/Monteagudo presentó un índice de cerca del 50\% de reprobación, el más bajo entre ellas. Se recomienda entonces que se mantenga la buena costumbre de aplicar la EPO en cada proyecto ejecutado sin olvidar, por supuesto, de utilizar instrumentos teóricos sencillos y de eficacia práctica asegurada, como, por ejemplo, el principio de Paretto.

Otro tema con el que también se debe tener mayor cuidado en la conducción de los proyectos y que fue muy criticado por los encuestados brasileños es la atención prestada por el sector social en relación al entrenamiento de los moradores para combatir incendios, ya que el rechazo a la forma como ha sido conducido este asunto fue del orden del $80 \%$ de los moradores, de los cuales varios expresaron verbalmente que se sintieron desamparados en este sentido, algo que, entre los argentinos, según los resultados de las encuestas, no obstante no haya alcanzado niveles tan altos de insatisfacción, demostró la necesidad de ser mejorado.

El fenómeno del mercado informal -préstamo, alquiler, compra/venta, contrato informal/ilegal-, que es un tema muy serio, debería ser discutido por todos los 
involucrados para encontrar una solución. Si las políticas públicas de VIS no se amplían, o peor, se restringen, frente a la progresiva demanda de los sectores de más bajos ingresos que carecen de una habitación, y con el agravamiento crónico del desempleo y la ínfima redistribución de renta, el fenómeno de la informalidad sólo crecerá, trayendo graves distorsiones sociales. En este contexto, el Estado se encuentra sin respaldo moral para condenar tal práctica, y contribuye así para que se perpetren casos como los que se registran ya en Brasil, en el PMCMV, donde varias familias de baja renta contempladas por el programa son obligadas por organizaciones criminales a "ceder" sus casas por la fuerza.

Por lo expuesto, hay que revisar los presupuestos de la elaboración de proyectos de VIS y su ejecución, buscando perfeccionarlos con el objetivo de ofrecer viviendas más confortables y adecuadas a las expectativas de los futuros moradores, aunque esto implique un costo mayor, lo que se justifica por una mayor calidad de vida.

Entre quejas y reticencias, la absoluta mayoría de los encuestados, en las tres comunidades brasileras, afirma que está satisfecha y muy conforme con la seguridad experimentada por la adquisición del propio techo y que no tenga que pasar las antiguas privaciones y vejámenes por falta de éste.

La percepción de los moradores sobre las condiciones del nuevo inmueble, a partir de las informaciones recolectadas durante la aplicación de las encuestas, demuestra que ellos, no obstante, no usufructuando de las ventajas de una vivienda unifamiliar, no demostraron mayores objeciones por vivir de forma colectiva en viviendas en altura multifamiliar (pregunta $n^{\circ} 5$ de la Encuesta de Tipo 1). En base a estos resultados podemos afirmar que se verifica la primera hipótesis de esta tesis sobre la tipología arquitectónica en altura para VIS, la que, siendo bien elaborada y ejecutada, incluyendo la participación, acompañamiento y fiscalización por parte de los futuros moradores en todas las fases del proyecto -proyección, ejecución y posocupación-, puede ser un interesante método de políticas públicas para enfrentar el déficit habitacional de los sectores de más bajos ingresos, tanto en Brasil como en Argentina. Aunque en CABA, que posee una topografía predominantemente plana, donde los encuestados no se sienten predispuestos a permanecer en una vivienda sin ascensor con tres pisos además de la planta baja, en Salvador, en porcentaje ínfimo han rechazado esta solución constructiva, incluso cuando se trate de bloques con cuatro pisos además de la planta baja, como son en gran parte los actuales conjuntos habitacionales de VIS en las ciudades más populosas de Brasil, como 
Salvador y Rio de Janeiro, entre otras, donde en la rutina de las personas, sus innumerables laderas y cerros tienden, como es razonable admitirse, a predisponer los vecinos a que vivan en edificios utilizando diariamente las escaleras, subiéndolas y bajándolas, a pie, sin mayores reclamaciones, algo un tanto impensable para los porteños.

Con los aciertos e infortunios hasta aquí mencionados, pudo ser constatada durante la investigación realizada la indudable aprobación por parte de la gran mayoría de las personas consultadas al respecto de la viabilidad del tipo arquitectónico en altura como un modelo de solución del déficit habitacional, tanto en Brasil como en Argentina, conforme las características propuestas en esta tesis, incluyendo aspectos no encuestados (profundizados), pero sí tratado por los autores, investigadores y catedráticos, que forman parte de los capítulos 1, 2, 3 y éste, como por ejemplo el mejor aprovechamiento de la tierra mediante la adopción de densidades medias de ocupaciòn, la posibilidad de menores distancias a los lugares de trabajo, adecuada provisión de redes de infraestructura de servicios con menores costos, mantenimiento de la relación de vecindad entre los habitantes provenidos de la comunidad, y otros. Resultado que hizo valer la pena el agotador y largo sacrificio en la búsqueda incesante de lo hasta aquí alcanzado. 


\section{CONCLUSIONES FINALES}

Las premisas iniciales, que basaron, el desafío para investigar y construir la fundamentación del objeto de esta tesis, han sido suficientemente verificadas bajo diferentes ángulos y niveles a través de los mencionados seis ejes privilegiados metodológicamente como guía de trabajo de esta investigación: a) el proyecto arquitectónico; b) el presupuestario (costos); c) el suelo (para la construcción); d) el tecnológico; e) el gerenciamiento gubernamental (políticas públicas); y f) la legislación edilicia. Las verificaciones fueron constatadas a través de harto registro bibliográfico para el período estudiado (1937 a 2017), así como por los registros orales y escritos a través de las encuestas aplicadas a los profesionales involucrados al tema, moradores y líderes de las comunidades consultadas, resultados que fueron comprobados tanto en Argentina como en Brasil.

En estos mencionados registros que atestiguan el contexto restrictivo de las políticas públicas de VIS, consonante con los intereses de los agentes inmobiliarios y en perjuicio de los que dependen de las políticas públicas para vivir, se destaca el problema de la posesión y uso del suelo urbano, que, dadas la progresiva escasez y especulación de éste, principalmente en los grandes centros urbanos, es uno de los factores más limitantes para las mencionadas políticas, considerando que el suelo participa, como es sabido, en gran medida, en el costo final de las obras. Y en este sentido conviene enfatizar que la tipología arquitectónica en altura, multifamiliar, defendida y comprobada en esta tesis como un importante instrumento para las políticas de VIS y para la solución del déficit habitacional, contribuye al utilizar una mayor densidad urbana y un menor costo unitario por metro cuadrado, en la gran mayoría de los casos, en relación a la tipología unifamiliar de planta baja.

De lo que hasta aquí ha sido señalado, el reflejo en los proyectos de VIS no fue tan alentador como se suponía, pues, fue prácticamente unánime entre los moradores, líderes comunitarios, e incluso los profesionales del área, el reconocimiento de falencias en dichos proyectos, considerando los varios tópicos en las seis comunidades investigadas considerados como insatisfactorios, principalmente por los moradores, aunque, en este sentido, deba resaltarse al Conjunto Parque Patricios/Monteagudo, el cual, en general, ha sido el mejor evaluado, ya sea en comparación con los otros dos argentinos, ya sea en relación a los tres proyectos brasileños. 
Así, las dos hipótesis han sido suficientemente confirmadas, considerando que los fuertes vínculos entre los agentes del sector inmobiliario con otros de la esfera pública conspiran, históricamente, para retardar la producción cuantitativa de VIS demandada, así como se refleje en la baja calidad del producto final que es ofrecido a la población, en especial a la de más bajos ingresos, la cual, casi siempre, no tiene otra opción para obtener una morada digna y con seguridad a través del mercado formal. Por la bibliografía consultada para esta tesis, se constató que, en Brasil, el PMCMV, a pesar de que presente una gran preocupación para con las capas sociales de más baja renta y que sea fuertemente subsidiado por el Estado, mantiene un alto grado de "financiación" asociado al gran espacio que se da en el atendimiento a las expectativas e intereses de la iniciativa privada en este programa.

Y todo esto sucedió, y aún sucede, infelizmente, en ambos países, aunque con detalles e intensidades diferentes, lo que permite que se diga, comprobado en este trabajo, que se encontró más semejanzas que diferencias entre los mismos en cuanto al tema de VIS investigado. Y en cuanto a las diferencias, la que más se destacó, a punto de ser una vez más mencionada, fue la de que, de forma casi unánime, de las tres comunidades argentinas investigadas, los moradores informaron su insatisfacción por vivir en comunidades construidas con la tipología arquitectónica defendida en esta tesis, mientras que, en la misma pregunta, y de forma muy semejante en la intensidad de la respuesta, los moradores brasileños informaron lo contrario: la absoluta mayoría se siente satisfecha de vivir en este tipo de vivienda. En este sentido, con escasas divergencias entre los dos países estudiados, las previsiones no se han confirmado plenamente, sin embargo, a pesar de esta divergencia, otra cuestión, la cual, de cierta manera, está asociada a la anterior, también llamó la atención, porque las tres comunidades argentinas siguieron conjuntamente en el mismo sentido e intensidad, por ejemplo, de las tres brasileñas, al informar que no están interesados en deshacerse de sus departamentos a pesar de todas las objeciones.

La relevancia del tema, que ha justificado este interesante y arduo trabajo, amerita que el mismo sea profundizado, y en este sentido, se espera que sirva para aumentar cuantitativa y cualitativamente el acervo de la Academia. Varios autores, tanto en Argentina como en Brasil, han discurrido mucho, no sólo en teoría, como en práctica, con sus incesantes contribuciones en sus respectivas áreas de conocimiento a lo largo de todo el siglo XX, que la tipología arquitectónica en altura, técnica y económicamente, de frente a la escasez de terrenos para construcción y 
del encarecimiento de la implantación de redes de servicios públicos en las grandes ciudades de este continente, es muy útil y necesaria para la solución del problema del déficit habitacional, en especial para la gran masa de población de más bajos ingresos. Delante de todo expuesto hasta aquí, este doctorando se siente hartamente satisfecho con los resultados econtrados los cuales comprueban indudablemente su tesis sobre la viabilidad del uso de la tipología arquitectónica en altura, según los parámetros defendidos en este trabajo, lo que en última instancia en el ámbito de esta investigación corrobora el objetivo principal de este doctorando con la misma, o sea, de demostrar la conveniencia de la adopción de la tipología arquitectónica de construcción en altura mediante un conjunto de informaciones y conocimientos apropiados, ofrecidos a las autoridades y demás responsables que actúen en la dirección de proyectos de políticas públicas de VIS. En este sentido conviene resaltar la originalidad de este trabajo al traer un rico y harto material provenido de las contribuciones de profesionales de diversas áreas del conocimiento y de los moradores encuestados de las viviendas de los 6 proyectos entre brasileños y argentinos. Lo que se pone en evidencia es que falta voluntad política asociada al necesario sensu cívico y de colectividad de gran parte de los que dirigen el dominio e interés de la iniciativa privada. 


\section{RECOMENDACIONES}

A efectos de cumplimentar más acertadamente con el objetivo de contribuir a mejorar las propuestas de proyecto y gestión en general, ofreciéndose un instrumento, a las autoridades y demás responsables que actúen con los proyectos de políticas públicas de VIS,.se presentan las siguientes recomendaciones avaladas por las encuestas hechas a los moradores, los líderes comunitarios y los profesionales:

a) Evitar, con fiscalización de y por todos los interesados, la creación de leyes inconexas con la realidad de los segmentos sociales de más bajos ingresos, que deberían ser los más beneficiados, y que, a veces, se sienten impedidos delante del exceso de burocracia y del desinterés del equipo técnico en el atendimiento al acceso a la vivienda a la que tienen derecho. Se puede recordar aquí la Ley $\mathrm{n}^{\circ}$ 11.888, Lei de Assistência Técnica Pública e Gratuita, de 2008, originada a partir del Proyecto de Ley $\mathrm{n}^{\circ}$ 6.981/06 del arquitecto Zezéu Ribeiro, cuyo alcance, en la práctica, no se corresponde con las demandas en Brasil. Argentina, en el campo de la legislación edilicia, y en especial de la VIS, carece de parámetros nacionales urbanísticos, como por ejemplo, del que se enfatiza con el Estatuto da Cidade, basado en lo que establece la Constitución de Brasil al respecto de la función social de la propiedad de la tierra, cuyo tema, por parte de los argentinos, está a cargo de la intendencia o de la provincia, generando, algunas veces, distorsiones o superposiciones en la aplicación de dichos parámetros.

b) Referente a la Ley de Usucapión, la realidad comprueba que su aplicación, tanto en Brasil como en Argentina, es mucho más eficaz en el papel que en la práctica, produciendo diferentes tipos de trastornos -costos, burocracia, tiempo etc.-, inviabilizando su efectividad para los que de ella necesitan.

c) Conviene que al pensarse en la elaboración y ejecución de proyecto de VIS se dé más importancia al fenómeno de las redes de solidaridad, que están asociadas a otro fenómeno, no menos importante, el del "capital de ubicación", tan comunes en este continente, y que actúan ya sea en el mercado formal inmobiliario o no. 
d) No se debe olvidar que en proyectos de esta naturaleza, además de que se consideren los aspectos ya abordados, los mismos sean concebidos con un tenor "sistémico", integrador, con tecnologías más adecuadas a la VIS, de bajo costo y practicidad en la ejecución y mantenimiento de la infraestructura, y que no sólo los aspectos técnicos sean trabajados en el más alto nivel, sino también los relacionados a las prácticas culturales de las comunidades involucradas, así como los referentes a las relaciones de vecindad y a las inevitables inconveniencias de vivir en colectividad.

e) Es primordial la participación de profesionales del sector de asistencia social en las fases de pre-proyecto, proyecto, ejecución y pos-ocupación, cuidando para que no se olviden de actuar en la elevación de la autoestima de los moradores que diariamente sufren presión por discriminación de varios sectores, conforme los relatos de Argentina y Brasil, como por ejemplo de las campañas de los medios de prensa, que los acusan de especular con la tierra y el inmueble, de pertenecer a grupos que fomentan actividades de narcotráfico, xenofobia, de evasión de impuestos por causa de los subsidios fiscales sociales recibidos, y, así, pasan también por otro tipo de violencia, que es la de la segregación, haciendo con que dicha población sea compelida a vivir en pésimas condiciones.

f) Otra cuestión con la que se debe tener mayor cuidado también en la conducción de los proyectos, y que ha sido muy criticada por los encuestados brasileños, se constató en cuanto a la atención prestada por el sector social al entrenamiento para combatir incendios, ya que el rechazo a la forma como fue conducido este tema fue del orden del $80 \%$ de los moradores, de los cuales varios expresaron verbalmente que se sintieron desamparados en relación al tema, algo que, entre los argentinos, según los resultados, aunque no a ese nivel, también fue desaprobado.

g) En cuanto a los aspectos arquitectónicos de los proyectos, fueron muy comunes en las críticas de los moradores y de los profesionales, ya sea en Brasil como en Argentina, los vicios de construcción -fisuras, hendiduras o grietas en techos, paredes, pisos o en otros elementos constructivos de la estructura, infiltraciones, escasez de paisajismo, habitaciones sin revestimiento definitivo, red de cloaca dañada, materiales de baja calidad, entre otros-, y el uso de planta en serie, repetitiva, homogénea, sin tener en cuenta suficientemente las diferentes culturas de 
los moradores, ni el diálogo con el contexto ambiental donde los proyectos fueron implantados. En este sentido no está de más recordar a los profesionales responsables de que mantengan la buena costumbre de aplicar la EPO a cada proyecto ejecutado sin olvidar, por supuesto, de utilizar la comprobada contribución teórico-práctica del importante y sencillo principio de Paretto, tan eficaz en el área de construcción civil.

h) Otra importante recomendación es la que se orienta hacia una buena utilización de la densificación de áreas centrales e intermediarias de las grandes ciudades, así como de la política de creación de "Carteras de Tierras", entre otras importantes medidas, como el uso, en estas áreas, del tipo arquitectónico defendido en esta tesis, para el éxito de las políticas públicas de VIS.

i) Para combatir la especulación inmobiliaria de las unidades de VIS financiadas por el Estado, así como el muy conocido "contrato de gaveta" en Brasil, se puede intensificar la fiscalización a través de un mecanismo jurídico-administrativo a través del cual, por ejemplo, el beneficiado que desista de la unidad habitacional tenga que devolver al erario el valor correspondiente del financiamiento al que tuvo derecho, o que dicho valor continúe vinculado al morador a través de una carta de crédito no negociable en el mercado. $Y$ en el caso de que la adquisición del inmueble sea a través de cooperativas o similares, por ejemplo, que el morador que desista del inmueble sea resarcido por los valores que haya anticipado a la cooperativa, ya sea monetariamente o por mano de obra, de modo que el inmueble retorne al control de la cooperativa, la cual indicará un nuevo adquirente, cobrando de éste los valores y tasas de ingreso a la comunidad. Estas medidas, además de evitar la especulación inmobiliaria, sirven también para mantener la cohesión de los miembros de la comunidad dentro de los principios cooperativistas y sociales. Téngase como ejemplo, en este sentido, la realidad de las cooperativas uruguayas.

j) Se invita a que profesionales e instituciones involucradas al tema de VIS puedan rever sus posiciones en lo que se refiere a contribuir con la divulgación de informaciones, en especial las entidades públicas responsables institucionalmente por esto, y no actúen como si las referidas informaciones pertenecientes a los proyectos habitacionales fueran un "secreto de estado", dificultando permanente e incomprensiblemente el avance de las investigaciones al omitirse datos esenciales, 
que, en sociedades republicanas, deberían ser de dominio público de todo ciudadano, como las plantas arquitectónicas, planillas de costos invertidos en los proyectos de VIS y los terrenos donde hayan sido implantados. Se reitera que este trabajo de investigación fue perjudicado desde el inicio hasta el final por lamentable realidad, que ocurrió en mayor o menor grado tanto en Brasil como en Argentina. Hay que repensar urgentemente tal triste realidad que, entre otras, sólo tiende a promover desalientos en trabajos de esta naturaleza y en provecho de una sociedad menos desigual en las oportunidades. 


\section{REFERENCIAS}

ABDALLA, S. (2015). Novo plano diretor de Curitiba irá impactar o mercado imobiliário: O incentivo a meios alternativos de transporte e a verticalização e adensamento de outras regiões podem criar oportunidades ao setor. Gazeta do Povo, Curitiba, 15 sept. 2015. Disponible en: <http://www.gazetadopovo.com.br/vida-e-cidadania/curitiba-cria-cota-paramoradia-de-interesse-social-1ig8jxlmmbgsvqorb7p4v9ma8>. Acceso: 18 jun. 2017

ABIKO, Alex Kenya y ORNSTEIN, Sheila Walbe (Edit.). 2002. Inserção urbana e Avaliação Pós-Ocupação (APO) da Habitação de Interesse Social. São Paulo: FAU-USP. (Coletânea Habitare/FINEP, vol. 1).

ALVES, José Eustáquio Diniz y CAVENAGHI, Susana Marta. (2006). Domicílios e Déficit Habitacional. In CONFEST 2006. Disponible en:

https://www.ibge.gov.br/confest_e_confege/pesquisa_trabalhos/CD/mesas_redondas/301 -1.ppt Acceso: 18 enero 2017.

ANTONELLI, Diego. (2013). Uma utopia socialista à beira do Ivaí. Gazeta do Povo, Curitiba, 31 maio 2013, Disponible en: https://www.gazetadopovo.com.br/vida-e-cidadania/umautopia-socialista-a-beira-do-ivai-Oaubiagxjvu6f1iqa5ns7b4ni/ Acceso en: 28 oct. 2018.

ARANTES, Otília; VAINER, Carlos y MARICATO, Ermínia. (2013). A cidade do pensamento único: desmanchando consensos. Petrópolis: Vozes.

ARGENTINA. ([s/f]). Proyección de la población por sexo y grupo quinquenal de edad. Ciudad de Buenos Aires. Años 2001/2020. Buenos Aires [Ciudad Autónoma]: INDEC. Disponible en: https://www.estadisticaciudad.gob.ar/eyc/?p=28017 Acceso en: Acceso: 14 enero 2017.

ARGENTINA. (1994). Ley Nr 24.374, de 7 de septiembre de 1994. Dispone sobre régimen de regularización dominial en favor de ocupantes que acrediten la posesión pública, pacífica y continua durante 3 años... Disponible en:

http://servicios.infoleg.gob.ar/infoleglnter net/anexos/0-4999/755/texact.htm\#1 Acceso en: 14 jul. 2017.

ARGENTINA. (1977). Ley $\mathrm{n}^{\circ} 21.499$, de 17 de enero de 1977. Dispone sobre expropiación de todos los bienes convenientes o necesarios para la satisfacción de la "utilidad pública", cualquiera sea su naturaleza jurídica, pertenezcan al dominio público o al dominio privado, sean cosas o no. Disponible en:

https://www.economia.gob.ar/concursos/biblio/LEY\%2021499-

77\%20EXPROPIACIONES.pdf Acceso en: 13 feb. 2017.

BALTER, Julieta. (2015). Sustentabilidad de edificios en altura en cuidades-oasis.

Carcterísticas arquitectónicas y ambientales para el caso de la ciudad de Mendonza. Tesis (Doctorado). Facultad de Arquitectura y Urbanismo de la Universidad Nacional de La Plata. Doctorado en Arquitectura y Urbanismo. La Plata.

BANCO CENTRAL DE LA REPÚBLICA ARGENTINA. ([s/f]) Evolución de una moneda.

Disponible en: http://www.bcra.gov.ar/PublicacionesEstadisticas/Evolucion_moneda.asp Acceso en: 26 nov. 2010. 
BANCO CENTRAL DO BRASIL. ([s/f]). Conversão de Moedas. Disponible en:

http://www4.bcb.gov.br/pec/conversao/conversao.asp Accesos en: 8 marzo 2018; 30 agosto 2017.

BANCO MUNDIAL. [s/f]. Participación en el ingreso del $\mathbf{2 0} \%$ mejor remunerado de la población. [s/l]. Disponible en:

https://datos. bancomundial.org/indicator/SI.DST.05TH.20?locations=AR-BR\&view=chart Acceso: 20 sept. 2108.

BARANCY, Olivier. Quando Le Corbusier redesenhou Paris. (2007). Le Monde Diplomatique Brasil. São Paulo. Ano 10 - № 114 - enero 2007, p. 34 y 35.

BARONE, Ana Cláudia Castilho. (2002). Team 10; arquitetura como crítica. São Paulo: Annablume.

BONDUKI, Nabil. (2011). Origens da habitação social no Brasil: Arquitetura Moderna, Lei do Inquilinato e Difusão da Casa Própria. São Paulo: Estação Lberdade. 5. ed. [1 ed: 1998].

BRASIL (2008). Ley $n^{\circ} 11.888$, de 24 de diciembre de 2008. Dispone sobre el acceso de las familias de bajos ingresos a la asistencia técnica pública y gratuita para el proyecto y la construcción de VIS. Diário Oficial da União, Brasília, 26 de diciembre de 2008. Disponible en: http://www.planalto.gov.br/ccivil_03/_Ato2007-2010/2008/Lei/L11888.htm Acceso en: 5 dic. 2014.

BRASIL. (2000). Propuesta sustitutiva adoptada por la Comissão de

Desenvolvimento Urbano, ao Projeto de Lei $n^{\circ} 3.057$, de 2000. Dispõe sobre o parcelamento do solo para fins urbanos e sobre a regularização fundiária sustentável de áreas urbanas, e dá outras providências. Brasília, 2005. Disponible en:

http://barreiros.arq.br/PL_3057.htm Acceso en 5 dic. 2014.

BRIAN Edwards. (2008). Guía básica de la sostenibilidad. Bracelona: Editorial Gustavo Gili, SL. (2 ed.) (trad. Sandra Sanmiguel Sousa).

BUENOS AIRES [Ciudad Autónoma]. (2006). Ley 962, de 13 enero de 2006. Dispone sobre la Sección 4 (del Proyecto de las Obras) del Código de Edificación: obligatoriedad de ascensores en inmuebles con planta horizontal... Disponible en:

http://www2.cedom.gob.ar/es/legislacion/normas/codigos/edifica/4_6b.html Acceso en: 27 de feb. 2017.

BUENOS AIRES [Ciudad Autónoma]. (2002). Ley n 964, de 5 de diciembre de 2002. Dispone sobre la regulamentación de tópicos "específicos" de la Ley n 341, de 24 febrero de 2000...Disponible en:

http://www2.cedom.gob.ar/es/legislacion/normas/leyes/ley964.html Acceso en: 27 de feb. 2017.

BUENOS AIRES [Ciudad Autónoma]. (2000). Ley n 341, de 24 febrero de 2000 (sanción). Dispone sobre la financiación para que personas o cooperativas adquieran VIS... Disponible en: http://www2.cedom.gob.ar/es/legislacion/normas/leyes/ley341.html Acceso en: 27 de feb. 2017.

BUENOS AIRES [Provincia]. (1977). Decreto-Ley 8912/77, de 24 de octubre de 1977. Dispone sobre el ordenamiento territorial y uso del suelo de la provincia de Buenos Aires. Disponible en: http://www.gob.gba.gov.ar/legislacion/legislacion/l-8912.html Acceso en: 17 feb.2017. 
CÂMARA. Marcos Paraguassu de Arruda. (1996). Exclusão especial nas regiões e fundações coloniais. In: SEMINÁRIO DE HISTÓRIA DA CIDADE E DO URBANISMO, 4., 1996, Rio de Janeiro. Anais... Rio de Janeiro: Universidade Federal do Rio de Janeiro/PROURB, 1996, 2v, pp. 585-589.

CASSAFORMA: Proceso constructivo. (2017). Youtube, 12 abr. 2017. Disponible en: https://www.youtube.com/watch?v=w2nY_COwBdo Acceso en: 28 agosto 2017.

CASTELLS, Manuel. (2000). A questão urbana. São Paulo: Paz e Terra S. A. (Coleção Pensamento Crítico; v. 48).

CASTRO, Javier Fernández. (2010). Barrio 31> Carlos Mugica; Posibilidades y límites del proyecto urbano en contexto de pobreza. Buenos Aires, Instituto de la Espacialidad Humana.

CICCOLELLA, PABLO. (2000). "Grandes inversiones y dinámicas metropolitanas: Buenos Aires ¿Ciudad global o ciudad dual del siglo XXI?" Mundo Urbano, Buenos Aires, Año 2000/Número 5 / Septiembre de 2000 in http://www.mundourbano.unq.edu.ar/index.php?option=com_content\&task=view\&id=58\&lt emid=43 (acceso: 21 oct. 2007).

CLICHEVSKY, Nora. (1996). Política social urbana; normativa y configuración de la ciudad. Buenos Aires: Espacio EDITORIAL.

COELHO, Luana Xavier Pinto. (2015). Plano de Curitiba: avançamos? Terra de Direitos, Curitiba, 23 enero 2015. Disponible en: <http://terradedireitos.org.br/acervo/artigos/planodiretor-de-curitiba-avancamos/16794>. Acceso: 10 marzo 2018.

COHEN, Michael; CARRIZOSA, María y GUTMAN, Margarita (edit.). (2016). Hábitat en deuda; veinte años de políticas urbanas en América Latina. Ciudad Autónoma de Buenos Aires: Café de las Ciudades.

COMPLEJO de Vivienda Monteagudo - Finalista 2008/Argentina. (s/f: [2008?]). World Habitat, Reino Unido. Disponible en: https://www.world-habitat.org/es/premios-mundialesdel-habitat/ganadores-y-finalistas/complejo-de-vivienda-monteagudo/. Aceso en: 11 agosto 2015

CONDER. (1992). Mapas Digitais. Salvador - 1:30.000 - 1992. Salvador. Disponible en: http://www.informs.conder.ba.gov.br/bases-tematicas/mapas-digitais/ Acceso en: 23 feb. 2017.

CORBUISER, Le. (2006). Mensajes a los Estudiantes de Arquitectura. Buenos Aires: Infinito. (10 ed). (1989). Principios de Urbanismo; la Carta de Atenas. Barcelona: Ariel.

COSOGLIAD, Hilda Noemi. (2003). Hilario Zalba; su obra. La Plata: EDULP.

COSTA, José Luiz Santos (2015). In Rádio Metróple FM 101,3, Salvador, 9 jul. 2015.

Entrevista del ing. Costa al radialista Mário Kertész, sobre la ejecución del último proyecto del arquitecto João Filgueiras Lima - Lelé, lo del Tribunal Regional do TrabalhoBA ( $5^{a}$ Região), en el Centro Administrativo da Bahia. Disponible en:

http://www.metro1.com.br/audios/151,jose-luiz-santos-costa.html Acceso en: 26 feb. 2017. 
CRAVINO, Maria Cristina. (2014). Las villas de la ciudad; mercado e informalidad urbana. Los Polvorines: Universidad Nacional de General Sarmiento.

. (2009a). Entre el arraigo y el desalojo; La Villa 31 de Retiro. Derecho a la ciudad, capital inmobiliario y gestión urbana. Los Polvorines: Universidad Nacional de General Sarmiento.

(organizadora). (2009b). Los mil barrios (in)formales; aportes para la construcción de un observatorio del hábitat popular del Área Metropolitana de Buenos Aires. Los Polvorines: Universidad Nacional de General Sarmiento. (ed. $1,1^{\mathrm{a}}$ impr.).

CYTED. ([s/f]). Objetivos. [s/l]. Disponible en: http://www.cyted.org/pt-pt/Objetivos Acceso en: 8 abr. 2018.

DEVOTO, Fernando y FAUSTO, Boris. (2008). Argentina - Brasil: 1850-2000; Um ensaio de história comparada. Argentina: Sudamericana.

DINIZ, Carolina; RODRIGUES, Samuel y KOVACS, Vera. (2104). "Drywall: entenda como funciona esse sistema de construção. Casa.com.br, São Paulo, 17 abr. 2014. Seção Materiais de construção". Disponible en: < https://casa.abril.com.br/materiais-construcao/drywall-entenda-comofunciona-esse-sistema-de-construcaol>. (acceso: 3 marzo 2018).

EDWARDS, Brian. (2009). Guía básica de sostenibilidad. Barcelona: Editorial Gustavo Gili, SL. (ed. 2.).

EL GOBIERNO porteño inauguró el complejo de viviendas Luzuriaga. (2015). Pura Ciudad - Buenos Aires Noticias, Buenos Aires, 27 feb. 2015, Disponible en:

http://www.puraciudad.com.ar/el-gobierno-porteno-inauguro-el-complejo-de-viviendasluzuriaga/ . Aceso en: 11 agosto 2015.

EI IVC ejecutó sólo el 53,5\% de los fondos para arreglar complejos habitacionales. (2018). EI Auditor, Buenos Aires [¿?], 24 oct. 2018. Disponible en: https://elauditor.info/informesde-auditoria/el-ivc-ejecuto-solo-el-53-5--de-los-fondos-para-arreglar-complejoshabitacionales_a5bd08a54f531797ef8f898ea Acceso en: 16 nov. 2018.

ENGELS, Friedrich. (1987). A questão da habitação. São Paulo: Acadêmica. (trad. Dainis Karepovs).

(1981). Contribución al problema de la vivienda. De las obras escogidas (en tres tomos) de Carl Marx y Friedrich Engels. Moscú: Editorial Progreso. Tomo 3 (pág. 347).

ENTREGAN viviendas sociales en el barrio Padre Mugica de Villa Lugano. (2011). VillaLugano.com, Buenos Aires, 11 feb. 2011, Disponible en: http://www.villalugano.com.ar/entregan-viviendas-sociales-barrio-padre-mugica-villalugano-h1044. Aceso en: 11 agosto 2015.

FERNANDES, Ana y SOUZA, Angela Gordilho (orgs.). (2004). Habitação no Brasil: refelexões, avaliações e propostas. Salvador: FAU-UFBA/PPGAU.

FRANCO, Ângela Maria de Almeida. (1983). Habitação popular e o solo urbano em Salvador. 1983. Dissertação (Mestrado em Ciências Sociais) - Faculdade de Filosofia e Ciências Humanas da Universidade Federal da Bahia, Salvador. 
FREIRE, Paulo. (1996). Pedagogia da autonomia: saberes necessários à prática educativa. São Paulo: Paz e Terra. (34 ed.), Coleção Leitura.

FREYRE, Gilberto. (2006). Sobrados e mucambos; decadência do patriarcado rural e desenvolvimento do urbano. São Paulo: Global. (16 ed.).

FUNDAÇÃO JOÃO PINHEIRO. Disponible en: http://www.fjp.mg.gov.br/index.php Acceso: varios.

FUNDAÇÃO JOÃO PINHEIRO. (2016). Minha Casa, Minha Vida deu certo? Veja pontos positivos e negativos. Portal de UOL 20 jun. 2016 (publicación). Disponible en http://www.fjp.mg.gov.br/index.php/fjp-na-midia/3550-19-6-2016-minha-casa-minha-vidadeu-certo-veja-pontos-positivos-e-negativos (acceso: 25 enero 2017).

FUNKE, Katherine. (2005). Habitação é Desafio. In: A Tarde, Salvador, 12 jun. 2005. Caderno Local, p. 3.

GAITE, Arnold. (2008). Vivienda social; el derecho a la arquitectura. Buenos Aires: Nobuko.

GOMES, Marco Aurélio A. de Filgueiras (Org.). (2009). Urbanismo na América do Sul: circulação de ideias e constituição do campo, 1920-1960. Salvador: EDUFBA.

GOMES, Nardele. (2014). In Rádio Metróple FM 101,3, Salvador, 21 mayo 2014. Homenaje póstuma, al arq.João Filguieiras Lima - Lelé. Disponible en:

https://soundcloud.com/grupometropole/21-05-14-materia-especial-homenagem-lele Acceso en: 4 jul. 2017.

GOOGLE Maps. ([s/f]). ([s/l]). Disponible en: (https://goo.gl/maps/izSj3c82psm);

(https://www.google.com/maps/@-34.6559012,-58.5315458,12z); (https://goo.gl/maps/arUTER7YXhC2); (https://goo.gl/maps/arUTER7YXhC2) Acceso en: 7 jun. 2018.

GORDILHO-SOUZA, Ângela. (2008). Limites do habitar: segregação e exclusão na configuração urbana de Salvador e perspectivas no final do século XX. - 2 ed. - Salvador: EDUFBA.

(1990). Invasões e intervenções públicas: uma política de atribuição espacial em Salvador, 1946 - 1989. 1990. Dissertação (Mestrado em Planejamento Urbano e Regional) - Universidade Federal do Rio de Janeiro, Rio de Janeiro.

GUIA Geográfico: Mapas da América. ([s/l]). Disponible en: http://www.americamapas.com/america-do-sul.htm Acceso en: 7 jun. 2018.

HAY problemas para escriturar los Conjuntos Habitacionales del IVC. (2018). El Auditor, Buenos Aires [ $¿$ ?], 31 oct. 2018. Disponible en: https://elauditor.info/informes-deauditoria/hay-problemas-para-escriturar-los-conjuntos-habitacionales-delivc_a5bd9bf61f531797ef8f93a87 Acceso en: 16 nov. 18.

HOLANDA, Sérgio Buarque de. (2012). O homem cordial. (Seleção de Lilia Moritz Scharcz). São Paulo: Penguin Classics Companhia das Letras.

HOWARD, Ebenezer. (1996). Cidades - jardins de amanhã. São Paulo: Hucitec.

INSTITUTO BRASILEIRO DE GEOGRAFIA E ESTATÍSTICA. Disponible en: https://www.ibge.gov.br/ Acceso: varios. 
LEFEBVRE, Henri. (2001). O direito à cidade. São Paulo: Centauro.

LIMA, João Filgueiras - Lelé. (2012). In Rádio Metróple FM 101,3, Salvador, 7 nov. 2012. Entrevista del arq. João Filgueiras Lima - Lelé al radialista Mário Kertész... Disponible en: https://soundcloud.com/grupometropole/07-11-2012-mk-entrevista-joao Acceso en: 4 jul. 2017.

LIMA, João Filgueiras - Lelé. (2009). In Rádio Metróple FM 101,3, Salvador, 3 agosto 2009. Entrevista del arq. João Filgueiras Lima - Lelé al radialista Mário Kertész... Disponible en: https://soundcloud.com/grupometropole/09-entrevista-lele Acceso en: 4 jul. 2017

LIMA, João Filgueiras - Lelé. (2000). João Filgueiras Lima - Lelé. Série Arquitetos Brasileiros. Lisboa: Editorial Blau/São Paulo: Instituto Lina Bo e P. M. BARDI.

LINCOLN INSTITUTE OF LAND POLICY. (2009). Gestión de los Mercados de Suelo Uban. Curso EAD, 5 oct.- 29 nov. 2009. Programa para América Latina y el Caribe.

LOMBARDI, Jorge; CREMASHI, Gustavo y MARSILLI, Luciana. (2004). Autogestión en vivienda: taller de arquitectura constructiva. La Plata: Universidad Nacional de La Plata.

LOS mudaron del Riachuelo al Complejo Mugica de Villa Lugano: de plomo en sangre a inmuebles con problemas estructurales. (2018). Pura Ciudad, Buenos Aires, 31 oct. 2018. Disponible en: https://www.puraciudad.com.ar/los-mudaron-del-riachuelo-alcomplejo-mugica-de-villa-lugano-de-plomo-en-sangre-a-inmuebles-con-problemasestructurales/ Acceso en: 9 dic. 2018.

MARICATO, Erminia. (2012). O impasse da política urbana no Brasil. Petropólis: Vozes. (2. ed.).

. (2011). Brasil, cidades; alternativas para a crise urbana. Petrópolis: Vozes.

(2000). Urbanismo na periferia do mundo globalizado: metrópoles brasileiras. São

Paulo em Perspectiva. São Paulo: Fundação SEADE, v. 14, n. 4, p. 21-33.

MASI, Domenico De. (2001). O Ócio criativo. Rio de Janeiro: Sextante.

MATERIAIS Avançados - Concreto flexível é capaz de se autoconsertar sem intervenção humana. (2009). Inovação Tecnológica, Campinas, 6 mayo 2009, Disponible en:

http://www.inovacaotecnologica.com.br/noticias/noticia.php?artigo=concreto-flexivel-ecapaz-de-se-autoconsertar Acceso en: 20 mayo 2014.

MATOS, Ariovaldo. (1988). Corta-braço. Salvador: Empresa Gráfica da BahiaEGBA/Fundação Cultural do Estado da Bahia.

MATTEDI, Maria Raquel Mattoso. (1979). As invasões em Salvador. 1979. Diseertação (Mestrado em Ciências Sociais) - Faculdade de Filosofia e Ciências Humanas da Universidade Federal da Bahia, Salvador.

MENEZES, Ednilson Luiz Santana. (2002). O processo de modernização de Salvador no início do século XX: transformações urbano-sociais impostas à Cidade entre 1900 e 1930. Disertación (Maestría). Faculdade de Arquitetura e Urbanismo da Universidade Federal da Bahia. Mestrado em Arquitetura e Urbanismo. Salvador. 
MIGUEL, Sebastián. (2010). Arquitectura sustentable; proyecto social en sectores marginales. Buenos Aires: Nobuko.

MORELLI, Ricardo y BENALLI, Lucas. (2017). Sistema constructivo Cassaforma: Perfiles Comechingones. Youtube, 4 abr. 2017. Disponible en:

https://www.youtube.com/watch?v=IwYdcHMeP_E Acceso: 28 agosto 2017.

OCESP/OCB (2017). Portal do cooperativismo. São Paulo, 2017. Disponible en:

http://ocesp.org.br/default.php?p=texto.php\&c=estatisticas Acceso en: 20 enero 2018.

OLIVEIRA, Margarete Rodrigues Neves. (2013). A produção de escassez do espaço urbano: um estudo sobre o boom do mercado imobiliário, uso de transcons e apropriação de mais-valia fundiária urbana em Salvador-BA (1968-2008). Tese (Doutorado). Universidade Federal da Bahia, Faculdade de Arquitetura e Urbanismo, Salvador.

ORNSTEIN, Sheila. (1992). Avaliação pós-ocupação do ambiente construído. Marcelo Roméro (colaborador). São Paulo: Studio Nobel - Editora da Universidade de São Paulo.

PELIGRO de Vida en el Conjunto Urbano Barrio Padre Mugica. (2018). Observatorio del Derecho a la Ciudad. Buenos Aires, 18 feb. 2018. Disponible en: http://observatoriociudad.org/?s=noticia\&n=168 Acceso en: 25 jun. 2018.

PfZ Arquitectos. (2007). Conjunto Habitacional Monteagudo. Buenos Aires [Ciudad Autónoma]. Disponible en:

http://www.pfzarquitectos.com.ar/obrasproyectos.php?codigo=9 Acceso en 28 abr. 2010.

PINSKY, Jaime (org.). (2017). O Brasil no contexto: 1987-2017. São Paulo: Contexto.

POSTIGO, Waldir. PDDU (2008). Salvador, escândalo da votação na Câmara de Vereadores. Youtube, 11 marzo 2008. Disponible en:

https://www.youtube.com/watch?v=2Ngr3gkBAJ8. Acceso en: 13 oct. 2009.

PRESTES, Anita Leocadia. (2015). Luiz Carlos Prestes; um comunista brasileiro. São Paulo: Boitempo.

PUNTEROS venden las casas de las Madres para talleres ilegales. (2012). Clarín, Buenos Aires, 2 dic. 2012. Disponible en: https://www.clarin.com/home/punteros-venden-madrestalleres-ilegales_0_HkFmQfpjv7l.html Acceso en: 9 dic. 2018).

RELOCALIZACIÓN a vecinos de la Villa 26, ubicada a orillas del Riachuelo. (2015). Pura Ciudad, Buenos Aires, 19 enero 2015. Disponible en:

https://www.puraciudad.com.ar/relocalizan-a-vecinos-de-la-villa-26-ubicada-a-orillas-delriachuelo/ Acceso en: 11 agosto 2015.

RODRÍGUEZ, María Carla. (2009). Autogestión, políticas del hábitat y transformación social. Buenos Aires: Espacio Editorial.

SAINT-PIERRE, Héctor Luis. (2004). Max Weber: entre a razão e a paxão. Campinas: Unicamp. (3 ed.).

SALVADOR. (2016). Lei $n^{\circ}$ 9.069/2016, de 30 de junio de 2016. Dispõe sobre o Plano Diretor de Desenvolvimento Urbano do Município do Salvador - PDDU 2016 e dá outras providências...Disponible en: http://www.sucom.ba.gov.br/wpcontent/uploads/2016/07/LEI-n.-9.069-PDDU-2016.pdf Acceso en: 27 feb. 2017 
SALVADOR. (2007). Lei $n^{\circ} 7.400 / 2008$, de 20 de febrero de 2007. Dispõe sobre o Plano Diretor de Desenvolvimento Urbano do Município do Salvador - PDDU 2007 e dá outras providências...Disponible en: http://www.sucom.ba.gov.br/wpcontent/uploads/2014/11/lei_7400_2008.pdf Acceso en: 27 feb. 2017.

SAMPAIO, Antônio Heliodório Lima. (2010). 10 necessárias falas; cidade, arquitetura e urbanismo. Salvador: EDUFBA/PPGAU.

(2001). A CIDADE VERTICAL (IN)VISÍVEL: lições da habitação popular In: Fórum Habitar 2000 - Fórum América Latina Habitar 2000. Salvador, PPG-AU.

(1999). Formas Urbanas: Cidade Real \& Cidade Ideal - Contribuição ao Estudo Urbanístico de Salvador. Salvador: Quarteto Editora; Programa de Pós-Graduação em Arquitetura e Urbanismo; Faculdade de Arquitetura da Universidade Federal da Bahia.

SÁNCHEZ, Sandra y BALDIVIEZO, Jonatan Emanuel. (2018). Informe Técnico sobre las Condiciones Edilicias del Conjunto Urbano Padre Mujica. Observatorio del Derecho a la Ciudad. Buenos Aires, 18 feb. 2018. Disponible en:https://www.academia.edu/35952546/Informe_T\%C3\%A9cnico_sobre_las_Condicion es_Edilicias_del_Conjunto_Urbano_Barrio_Padre_Mujica Acceso en: 25 jūn. 2018.

SANTANA, Mário Rubem Costa. (1994). Cotidiano da verticalização de favelas: uma alternativa habitacional em Salvador. Salvador. Dissertação de Mestrado apresentada ao MAU/FAUFBA.

SINDUSCON-BA/SINDICATO DA INDÚSTRIA DA CONSTRUÇÃO CIVIL NO ESTADO DA $B A H I A,[(s / f])$. Custo Unitário Básico-CUB/ $m^{2}$. Salvador. Disponible In: http://memoria.cub.org.br/p reports.php?sid=6\&id=38 Acceso: 24 enero 2017 y 20 marzo 2017.

SINDUSCON-MG/SINDICATO DA INDÚSTRIA DA CONSTRUÇÃO CIVIL NO ESTADO DE MINAS GERAIS. (2007). Custo Unitário Básico (CUB/m²): principais aspectos. Belo Horizonte: SINDUSCON-MG. Disponible en http://www.sinduscon-mg.org.br/ Acceso: 24 enero 2017).

SOUZA, Jessé. (2018). A Classe média no espelho; sua história, seus sonhos e ilusões, sua realidade. Rio de Janeiro: Estação Brasil.

SUMMA. (1979). Revista de arquitectura, tecnología y diseño. Buenos Aires: Ediciones Summa SACIFI. N. 136, may. 1979.

(1974). Revista de arquitectura, tecnología y diseño. Buenos Aires: Ediciones Summa SACIFI. N. 71, ene. 1974.

TAVARES FILHO, Arthur Campos. (2005). Reflexões sobre a Noção de Tipo Morfológico e o Programa Arquitetônico: Os Casos das Escolas Municipais Estados Unidos e República Argentina. Disertación (Maestría). FAU-UFRJ. Rio de Janeiro. Disponible en http://www.fau.ufrj.br/prolugar/arq_pdf/dissertacoes/dissert_arthur_tavares_2005.pdf. Acceso en: 23 abr. 2012 y http://www.gae.fau.ufrj.br/assets/dissert_arthur_tavares_2005.pdf Acceso en: 22 agosto 2017.

UNIVERSIDAD DE BUENOS AIRES. (2000). 90 años de vivienda social en la ciudad de Buenos Aires. Buenos Aires: Programa de Mantenimiento de Habitacional de la Facultad de Arquitectura, Diseño y Urbanismo de la Universidad de Buenos Aires. 
UNIVERSIDAD DE LA REPÚBLICA. (2008). Facultad de Arquitectura/Comisión Sectorial de investigación Científica - CSIC. Vivienda social: Evaluación integral, antes y después; Estudio comparado de nueve experiencias de la intendencia de Montevideo. Montevideo.

VALLADARES, Licia do Prado (org.). (1981). Habitação em questão. Rio de Janeiro: ZAHAR. ( 2 ed). (Biblioteca de Ciências Sociais - Sociologia).

VIVA Zapata! Dirección: Elia Kazan. Producción: Darryl F. Zanuck. Guión: John Steinbeck y Edgecumb Pinchon. Intérpretes: Marlon Brando, Jean Peters, Anthony Quinn, Joseph Wiseman, Arnold Moss y otros. [S.I.]: Twentieth Century Fox, 1952. 1 bobina cinematográfica (113 min.), son., bp., $35 \mathrm{~mm}$.

VIVIENDA POPULAR (Revista). (2013): Innovación y tecnología en vivienda popular. Montevideo: Facultad de Arquitectura - Universidad de la República. n. 23, jul. 2013. [Segunda época]. 93 p.

(Revista). (2012): Enseñanza universitaria y hábitat social. Montevideo: Facultad de Arquitectura - Universidad de la República. n. 22, ago. 2012. [Segunda época]. 121 p.

(Revista). (2011). Reducir costos?: ¿Cuánto, cómo, qué? Montevideo: Facultad de Arquitectura - Universidad de la República. n. 21, set. 2011. [Segunda época]. 89 p.

-----. (Revista). (2010). La Vivienda y el hábitat en los últimos veintecinco años.

Montevideo: Facultad de Arquitectura - Universidad de la República. POST 25, set. 2010. $107 \mathrm{p}$.

VUOTTO, Mirta. (2014). La economía social y las cooperativas en la Argentina. Voces en el Fénix (publicación del Plan Fénix), №38, oct. 2014. Buenos Aires: Facultad de Ciencias Económicas de la Universidad de Buenos Aires. Disponible en http://www.vocesenelfenix.com/content/la-econom\%C3\%ADa-social-y-las-cooperativasen-la-argentina Acesso: 20 enero 2018.

WEBER, Max. (1966). El sabio y la política. Córdoba: EUDECOR. (Biblioteca de Ciencias Políticas: Trad. Delia Garcia Giordano y J. L. B.)

WERNA, Edmundo et al. (2001). Pluralismo na habitação (baseado nos resultados do Projeto "O novo papel do Estado na oficina de habitação: parceira entre agentes públicos e não-públicos": convênio 63.96.0737.00 - Finep). São Paulo: Annablume. 


\section{BIBLIOGRAFÍA}

ABRAMO, Pedro. (s/f). O Mercado de solo informal em favelas e a mobilidade residencial dos pobres nas grandes cidades: notas para delimitar um objeto de estudo para a América Latina. Rio de Janeiro: IPPUR/UFRJ.

ACIOLY, Cláudio y DAVIDSON, Forbes. (1998). Densidade urbana; um instrumento de planejamento e gestão urbana. Rio de Janeiro: MAUAD.

ADOROCINEMA. Rio de Janeiro. Disponible en: http://www.adorocinema.com/ Acceso en: 20 oct. 2018.

ALFONSÍN, Betania de Moraes. (2009 [?]). Legalidad y llegalidad en la Producción del Espacio Urbano; Nuevas sendas para superar viejos caminos - Puerto Alegre y el Urbanizados Social. Gestión de los Mercados del Suelo Urbano en América Latina. Lincoln Institute of Land Policy. Educación a Distancia - Programa para América Latina y Caribe. (digitalizado).

ACERCA de la Ley 8912. (s/f). Instituto de Estudios y Gestión Urbanos, Territoriales y Ambientales del Colegio de Arquitectos de la Provincia de Buenos Aires. s/l. Disponible en:

http://www.cafedelasciudades.com.ar/imagenes85/ACERCA\%20DE\%20LA\%20LEY\%208 912.pdf Acceso en: 17 feb. 2017.

AMADO, Jorge. (19[80?]). Terras do sem fim. São Paulo: Círculo do Livro, s/f.

AMBASZ, E. (2008). ME PERGUNTO. (Um compêndio de perguntas que gostaria que me tivessem feito, e algunas respostas que nunca deveria ter pronunciado.) In NUTAU 2008, São Paulo. Entrevista al periódico La Nación... Disponible en:

http://www.usp.br/nutau/2008/ambasz_1.html . Aceso en 7 enero 2017.

ARAÚJO, Ubiratan Castro de (org.). (1999). Salvador era assim; memórias da cidade. Salvador: Instituto Geográfico e Histórico da Bahia.

BARBOSA, Elyana. (1996). Gaston Bachelard: o arauto da pós-modernidade. Salvador: EDUFBA.

BENEVOLO, Leonardo. (2001). A cidade e o arquiteto; método e história na arquitetura. São Paulo: Perspectiva. (2 ed.). (trad. Attílio Cancaian). (Coleção DEBATES).

BOURDIEU, Pierre. (2011). O poder simbólico. Rio de Janeiro: Bertrand Basil. (ed. 15). Trad. (Portugés de Potugal): Fernando Tomaz.

(2004). Os usos sociais da ciência: por uma sociologia clínica do campo científico. São Paulo: UNESP. Trad. Denise Barbara Cataani.

BUCK, Pearl S. (1964). O Cidadão. Porto Alegre: Globo. (The Townsman: versión original).

CAIXETA, Eline Maria Moura Pereira. (2002). "Uma Arquitetura para a Cidade: a obra de Affonso Eduardo Reidy". In https://www.ufrgs.br/propar/publicacoes/ARQtextos/PDFs_revista_2/2_Eliane.pdf (acceso: 29 dic. 2016). 
CARAVAJAL. Iris Luján. (2011). La evolución de vivienda argentina. Buenos Aires: Nobuko.

CARDOSO, Fernando Henrique y FALETTO, Enzo. (1977). Dependência e desenvolvimento na América Latina; ensaio de interpretação sociológica. Rio de Janeiro: ZAHAR Editores. (4 ed.).

CARLOS, Ana Fani Alessandri. (2008). A (Re)Produção do espaço urbano. São Paulo: Editora da Universidade de São Paulo.

CENTRO DE DERECHO A LA VIVIENDA Y CONTRA LOS DESALOJOS (COHRE). (2005). EI Derecho a la Vivienda en Argentina; desafíos para la promoción del derecho a la vivienda y a la tierra en Argentina (Informe Misión de Investigación, 2004). Genebra.

CHALOUB, Sidney. (1996). Cidade febril; cortiços e epidemias na Corte imperial. São Paulo: Companhia das Letras.

CLAVAL, Paul. (2001). A geografia cultural. Florianópolis: Universidade Federal de Santa Catarina/UFSC. (2 ed.). (trad. Luiz Fugazzola Pimenta y Margareth de Castro Afeche Pimenta).

CLOUX, Raphael Fontes. (2008). MSTS: A trajetória de Movimento dos Sem-Teto de Salvador/Bahia. Salvador: (auto) editado por el autor.

DEPARTAMENTO DE DICCIONARIOS DE SALVAT. (2001). Salvat léxico: Diccionario de la lengua. São Paulo: Salvat.

FAUSTO, Boris. (1978). A revolução de 1930, Historiografia e História. São Paulo: Brasiliense. (5 ed.).

FILMOW. Disponible en: https://filmow.com/ Acceso en: 20 oct. 2018.

FOUCAULT, Michel. (1992). Microfísica del poder. Madrid: Las Ediciones de La Piqueta. (ed. 3). (Colección Genealogía del poder: Edic y traduc. Julia Varela y Fernando Alavarez-Uría. Vol № 1).

FREYRE, Gilberto. (1985). Nordeste; aspectos da influência da cana sobre a vida e a pasiagem do Nordeste do Brasil. Rio de Janeiro: José Olympio / Recife: Fundação do Patrimônio Histórico e Artístico de Pernambuco - FUNDARPE. (5 ed.). (Coleção Documentos Brasileiros, vol. 4).

GAZZOLI, Rubén. (2007). Vivienda social: investigaciones, ensayos y entrevistas. Buenos Aires: Nobuko.

GEORGE, Pierre. (1979). Panorama do mundo atual. São Paulo: DIFEL/Difusão Editorial S. A. (7 ed.).

GOMES, Roberto. (1984). Crítica da razão tupiniquim. Porto Alegre: Mercado Aberto. (7 ed.).

GORDILHO-SOUZA, Ângela. (1997). Habitar contemporâneo; novas questões no Brasil dos anos 90. Salvador: UFBA/PPGAU-UFBA/Lab-Habitar.

HARVEY, David. (2005). A produção capitalista do espaço. São Paulo: Annablume (Coleção Geografia e Adjacências). 
INAIÁ, Carvalho y PEREIRA, Gilberto Corso (org.). (2008). Como anda Salvador e sua Região Metropolitana. Salvador: EDUFBA.

JAGUARIBE, Hélio. (1989). Alternativas do Brasil. Rio de Janeiro: José Olympio. 2 ed. (1978). Introdução ao desenvolvimento social. São Paulo: Círculo do Livro.

LACOSTE, Yves. (1979). Os países subdesenvolvidos. São Paulo/Rio de Janeiro: DIFEL. (14 ed.). (trad. Diva Benevides Pinho).

LÊNIN, V. I. (1987). Teses de abril; sobre as tarefas do proletariado na presente Revolução. São Paulo: Acadêmica.

LUBISCO, Nídia Maria Lienert y VIEIRA, Sônias Chagas. (2013). Manual de estilo acadêmico: trabalhos de conclusão de curso, dissertações e teses. Salvador: EDUFBA. 5. ed.

MAGALHÃES, Mário. (2012). Mariguella; o guerrilheiro que incendiou o mundo. São Paulo: Companhia das Letras.

MAGNAVITA, Pasqualino Romano. (2017). As três Existências ou Universos. Salvador: PPGAU-UFBA (Notas de aula da disciplina de Seminários Avançados I, do PPGAUUFBA) 2017.1 (Texto 1).

(2017). Estratos, Estratificação e Agenciamentos. Salvador: PPGAU-UFBA (Notas de aula da disciplina de Seminários Avançados I, do PPGAU-UFBA), 2017.1 (Texto 2).

(2017). Conceito Rizoma. Salvador: PPGAU-UFBA (Notas de aula da disciplina de Seminários Avançados I, do PPGAU-UFBA), (semestre) 2017.1 (Texto 3).

MAQUIAVEL. (198[8?]). O príncipe. São Paulo: Círculo do Livro S. A. (trad. Antonio D’Elia). MARCíN, Luis Ramos-Alarcón. (s/f) Libertad y conato de la multitud en Spinoza y Maquiavelo in https://www.academia.edu/763647/Libertad_y_conato_de_la_multitud_en_Spinoza_y_Maqui avelo (acceso: 21 agosto. 2016).

MASCARÓ, Lúcia (coord.). (1990). Tecnologia \& Arquitetura. São Paulo: Nobel.

MEDEIROS, Carlos Augusto de. (2009). Estatística aplicada à educação. Brasília: Universidade de Brasília.

MENEZES, Ednilson Luiz Santana. (2017). Habitação de Interesse Social - HIS verticalizada, uma opção de política pública que precisa ser revista: o que pensam os moradores e profissionais da área? In: II Seminário Internacional América Latina: Polítcas e conflitos contemporâneos - SIALAT, 2017. Belém. Anais...Belém: Universidade Federal do Pará, 27 a 29 de novembro de 2017.

(2017). A HIS verticalizada em Salvador vista por pessoas que ali (sobre)vivem. In: V Simpósio Brasileiro de Qualidade do Projeto no Ambiente Construído - SBQP, 2017. Anais...João Pessoa: Universidade Federal da Paraíba, 4 a 6 de outubro de 2017.

(2011). Falta Terra e Habitação Para os Mais Pobres nos Grandes Centros Urbanos da América Latina, mas, há Luz no Fundo do Túnel...!! In: XIV Encontro 
Nacional da Associação Nacional de Pós-Graduação e Pesquisa em Planejamento Urbano e Regional - ENANPUR, 2013, Rio de Janeiro. Anais...Rio de Janeiro, 23 a 27 de maio de 2011.

(2010). Centros Urbanos de América Latina: Ante la falta de territorio y viviendas para los excluidos, la construcción en altura (edificación vertical) es factible, Sí. 1er. Congreso Internacional de Arquitectura Latinoamericana, 2010. Buenos Aires, 17 a 20 de outubro de 2010.

. (2009). Soluções para habitação de interesse social: de Salvador a Buenos Aires verticalização edilícia, sim, uma alternativa para populações pobres em áreas metropolitanas adensadas. In: XIII Encontro Nacional da Associação Nacional de PósGraduação e Pesquisa em Planejamento Urbano e Regional - ENANPUR, 2009, Florianópolis. Anais...Florianópolis: Universidade Federal de Santa Catarina, 25 a 29 de maio de 2009.

. (2008). A essencialidade da melhoria do ensino brasileiro em prol da democracia da sociedade brasileira. In $6^{\circ}$ Congreso Internacional de Educação Superior - Universidad 2008. Havana.

MENEZES, Ednilson Luiz Santana y SANTANA, Marcos Jorge Almeida. (2007). Novos Alagados, Velhos Conflitos que Desafiam a Contemporaneidade da Antiga Salvador. In: XII Encontro Nacional da Associação Nacional de Pós-Graduação e Pesquisa em Planejamento Urbano e Regional - ENANPUR, 2007, Belém. Anais... Belém: Universidade Federal do Pará, 21 a 25 mai. 2007. (Sessão Temática 3, Mesa 4).

MENEZES, Ednilson Luiz Santana. (2005). Dignidade para se Habitar em Salvador: Uma velha questão que merece (novas) souções. In: VIII Semana de Mobilização Científica SEMOC, 2005, Salvador: Universidade Católica do Salvador, 17 a 21 de outubro de 2005.

(2003). Uma reforma demolidora em Salvador, na qual a Igreja levou fé!. (poster) In: X Encontro Nacional da Associação Nacional de Pós-Graduação e Pesquisa em Planejamento Urbano e Regional - ENANPUR, 2003, Belo Horizonte. Anais... Belo Horizonte: Universidade Federal de Minas Gerais, 26 a 30 mai. 2003. (Sessão Temática 5.2: Modernização e melhoramentos urbanos).

. (2001). In MACEDO, Paulo. Salvação do Mosteiro de São Bento. Correio da Bahia - Caderno Aqui Salvador, Salvador, p. 3 - 3, 09 nov. 2001.

(2001). Uma Reforma Urbana Demolidora em Salvador: O Caso do Mosteiro de São Bento. In: V Congresso de História da Bahia, 2001, Salvador: Instituo Geográfico e Histórico da Bahia, 4 a 10 nov. 2001.

NEVES, Laerte Pedreira. (2012). Adoção do partido na arquitetura. Salvador: EDUFBA ( 3 ed).

NUNES, Débora (org.). (2000). Salvador: o arquiteto e a cidade informal. Mestrado em Arquitetura e Urbanismo da Universidade Federal da Bahia/Lab-Habitar.

OLIVEIRA, I. C. E. de. (2001). Estatuto da cidade; para compreender... Rio de Janeiro: IBAM/DUMA. Disponible en: http://polis.org.br/wpcontent/uploads/estatuto_cidade_compreender.pdf Acceso en: 17 feb. 2017. 
PASCUAL, Guillermo Suazo. (2006). Conjugación de los verbos: manual práctico. Buenos Aires: Edaf del Plata (7 ed).

PEREIRA, Helena Bonito Couto. (2002). Michaelis: dicionário escolar espanhol (espanholportuguês; português-espanhol). São Paulo: Melhoramentos.

PINSKY, Jaime (org.). (2018). Brasil: o futuro que queremos. São Paulo: Contexto.

PIRES, Almícar de GIL e. (2009). Os conceitos de Tipo e de Modelo em Arquitetura. Lisboa: CEFA (Editorial da Faculdade de Arquitectura) y CIAUD (Centro de Investigação em Arquitectura, Urbanismo e Design) /Faculdade de Arquitectura da Universidade Técnica de Lisboa. Disponible en: http://hdl.handle.net/10400.5/1499. Acceso en: 23 abr. 2012.

REAL ACADEMIA ESPAÑOLA (org.). (2005). Diccionario del estudiante: 40000 verbetes. São Paulo, Moderna.

PEDRÃO, Fernando. (2002). A economia urbana. Ilhéus: Editus.

PEREIRA, Priscila Maria Santiago y ABIKO, Alex Kenya. (2002). Projeto Cingapura da Prefeitura de São Paulo: o Conjunto Habitacional Zaki Narchi. São Paulo, EPUSP (Boletim Técnico BT/PCC/309 2002).

PLOTINSKY, Daniel. (2015). Orígenes y consolidación del cooperativismo en la Argentina. Revista Idelcoop - №215 - marzo 2015. Buenos Aires: Instituto de la Cooperación/Fundación de educación, investigación y asistencia técnica. IDELCOOP _ ISSN: 03271919 - idelcoop.org.ar/revista/215. (pp. 157-178).

POPPER, Karl Raymund. (1994). O racionalismo crítico na política. Brasília/DF: Universidade de Brasília. (2 ed.). (trad. Maria da Conceição Côrte-Real).

PRADO Jr., Caio. (1993). Evolução política do Brasil; colônia e império. São Paulo: Brasiliense. (20 ed.). . ([1985?]). História econômica do Brasil. São Paulo: Círculo do Livro S. A.

QUEIROZ, Eça de. ([s/f]). A ilustre casa de Ramires. Rio de Janeiro: Ediouro.

QUEIROZ, Raquel de. (s/f: 19[90?]). O quinze. São Paulo: Círculo do Livro S. A.

RAMOS-ALARCÓN, L. M. (s/f). Libertad y conato de la multitud en Spinoza y Maquiavelo. Academia.edu, s/l. Disponible en: https://www.academia.edu/763647/Libertad_y_conato_de_la_multitud_en_Spinoza_y_Ma quiavelo. Acceso en: 21 agosto 16.

REAL ACADEMIA ESPAÑOLA y ASOCIACIÓN DE ACADEMIAS DE LA LENGUA ESPAÑOLA. (2017). Diccionario de la lengua española: edicion del tricentenario; actualización 2017. Diponible en http://dle.rae.es/?id=DglqVCc (accesos varios).

REIS, João José. (1991). A morte é uma festa; ritos fúnebres e revolta popular no Brasil do século XIX. São Paulo: Companhai das Letras.

REIS, Nestor Goulart. (2000). Contribuição ao estudo da evolução urbana do Brasil: (1500/1720). São Paulo: Pini. (2 ed.). 
REVISTA DE ARQUITECTURA. (2009). Buenos Aires: Sociedad Central de Arquitectos. N. 235: El Techo II, dic. 2009.

REZENDE, Vera. (1982). Planejamento urbano e ideologia; quatro planos para a cidade do Rio de Janeiro. Rido de Janeiro: Civilização Brasileira S. A. (Coleção Retratos do Brasil, vol. 159).

RIOFRÍO, Gustavo y DESCO. (2003). Tercer Curso de Gestión Urbana para América Latina. Lima, feb. 2003.

(http://info.worldbank.org/etools/docs/library/112219/peru/docs/ModuloV/Riofrio\%20Vivien da\%20feb2003.pdf, (acceso: 12 oct. 2007)).

RODRÍGUEZ, Alejandro Méndez (Coord.). (2006). Estudios urbanos contemporâneos. México: Universidad Nacional Autónoma de México/Instituto de Investigaciones Económicas.

SANTORO, Paula (org.). (2004). Gestão social da valorização da terra. São Paulo: Instituto Polis. (Caderno Polis, 9).

SANTOS, Milton. (2012a). O espaço do cidadão. São Paulo: Editora da Universidade de São Paulo (EDUSP).

. (2012b). A Natureza do Espaço: Técnica e Tempo, Razão e Emoção. 4 ed. São

Paulo: Editora da Universidade de São Paulo. (Coleção Milton Santos, vol.1). 384 p.

(2005a). Da totalidade ao lugar. São Paulo: EDUSP.

. (2005b). A urbanização brasileira. São Paulo: EDUSP (5 ed.). (Coleção Milton

Santos, vol. 6).

. (1996). Metamorfose do espaço habitado. 4. São Paulo: Hucitec.

SANTOS, Ulisses Pereira dos y OLIVEIRA, Francisco Horácio Preira de. (2008). Três fases da Teoria Cepalina: uma análise de suas principais contribuições ao pensamento econômico latino-americano. Análise, Porto Alegre, v. 19, n. 2, p. 4-17, jul./dez. 2008. Disponible en:

https://www.academia.edu/2137417/Tr\%C3\%AAs_fases_da_Teoria_Cepalina_uma_an $\%$

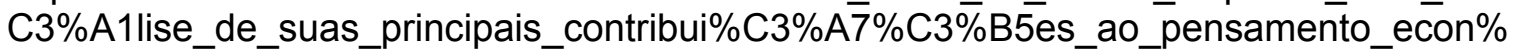
C3\%B4mico_latino-americano. Acceso en: 24 jul. 2016.

SARQUIS, Jorge (comp.). (2008). Arquitectura y técnica. Buenos Aires: Nobuko.

(comp.). (2008). Habitat para la emergencia social y ambiental: Villa El Monte, Quilmes. Buenos Aires: Nobuko.

(2006). Arquitectura y modo de habitar. Buenos Aires: Nobuko.

(1995). Programa del conjunto habitacional 'Ciclo vital'. Buenos Aires:

Secretaría de Investigaciones y Técnica - Facultad de Arquitectura, Diseño y Urbanismo UBA. Serie Difusión, nr.13.

SEGRE, Roberto. (2005). Arquitectura y urbanismo modernos: capitalismo y socialismo. La Habana: Félix Varela. (Tomo I y II). 
. (1980). La vivienda en Cuba en el siglo XX: República y Revolución. México/DF: Editorial Concepto.

SILVA, Maria Auxiliadora da y TOLEDO Jr., Rubens de. (2006). Encontro com o pensamento de Milton Santos; a interdisciplinaridade de sua obra. Salvador: Universidade Federal da Bahia/UFBA - Mestrado em Geografia.

SIMÕES, Antonio José Ferreira. (2011). Integração: sonho e realidade na América do Sul. Brasília/DF: Fundação Alexandre de Gusmão/FUNAG.

SINDOMÉSTICO BAHIA. SALVADOR. Disponible en:

https://sindomesticobahia.wordpress.com/2016/05/13/quem-somos/ Acceso en: 26 agosto 2017.

SINDOMÉSTICO-BAHIA- SINDICATO DOS TRABALHADORES DOMÉSTICOS DA BAHIA. SALVADOR. Disponible en: https://pt.foursquare.com/v/sindom\%C3\%A9sticoba-sindicato-dos-trabalhadores-dom\%C3\%A9sticos-da-bahia/512663cfe4b090cff2bac63d Acceso en: 26 agosto 2017.

SMOLKA, Martim. (2009 (?)). Acceso al suelo para los pobres urbanos. In: Mesa Redonda: Gestión de los Mercados del Suelo Urbano en América Latina. Lincoln Institute of Land Policy. Educación a Distancia - Programa para América Latina y Caribe. (digitalizado).

SOUZA, Amaury de y LAMOUNIER, Bolívar. (2010.). A classe média brasileira; ambições, valores e projetos de sociedade. Rio de Janeiro: Elsevier; Brasília, DF: Confederação Nacional da Indústria/CNI.

STEIN, Stanley J. y STEIN, Bárbara H. (1976.). A herança colonial da América Latina; ensaios de dependência econômica. Rio de Janeiro, Paz e Terra. (trad. José Fernandes Dias). (Coleção: Estudos Latino-americanos, vol. 4).

TODOROV, Tzvetan. (1993). A conquista da América; a questão do outro. São Paulo: Martins Fontes.

TORRE de David, a favela de 45 andares de Caracas. (2014). Veja, São Paulo, 4 abr. 2014. Disponible en: http://veja.abril.com.br/mundo/torre-de-david-a-favela-de-45-andares-de-caracas/ Acceso en: 16 jul. 2017.

VILLA Lugano: Ciudad restaurará el Barrio Mugica, denunciado varias veces por problemas edilicios. (2018). Pura Ciudad, Buenos Aires, 10 sept. 2018. Disponible en: https://www.puraciudad.com.ar/villa-lugano-ciudad-restaurara-el-barrio-mugicadenunciado-varias-veces-por-problemas-edilicios/ Acceso en: 9 dic. 2018).

VILLA, Simone Barbosa y ORNSTEIN, Sheila Walbe. (2013). Qualidade ambiental na habitação: avaliação pós-ocupação. São Paulo: Oficina de Textos.

VIVIENDA POPULAR. (Revista) (2012): Enseñanza universitaria y hábitat social. Montevideo: Facultad de Arquitectura - Universidad de la República. n. 22, ago. 2012, [Segunda época]. $121 \mathrm{p}$.

(2011): Reducir costos: ¿cuánto, cómo, qué? Montevideo: Facultad de Arquitectura Universidad de la República. n. 21, sept. 2011, [Segunda época]. 91 p. 
-----. (2008): Ley Nacional de Vivienda/40 años. Montevideo: Facultad de Arquitectura Universidad de la República. n. 17, nov. 2008. [Segunda época]. 108 p.

VOORDT, Theo J. M. van der e WEGEN, Herman B. R. van. (2013). Arquitetura sob o olhar do usuário; programa de necessidades, projeto e avaliação de edificações. São Paulo: Oficinia de Textos. Trad. Maria Beatriz de Medina.

WEBER, Max. (2006). Ciência e Política; Duas Vocações. São Paulo: Martin Claret. Trad. Jean Melville. 
ADJUNTOS 


\section{ÍNDICE}

LISTA DE DOCUMENTOS ADJUNTOS

.380

FUENTES

381

FILMOGRAFÍA SUGERIDA 383

DOCUMENTOS ADJUNTOS .386 


\section{LISTA DE DOCUMENTOS ADJUNTOS}

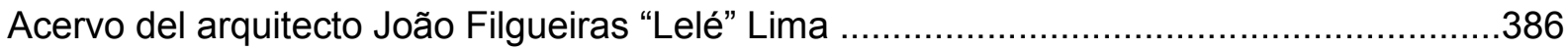

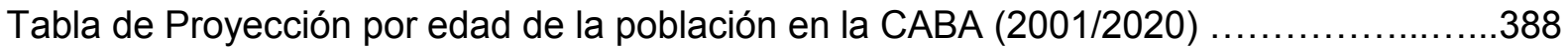

Tabla de Proyección preliminar de la población brasilera para 2020) ......................390

Resumen 1 del programa de Tv Entre aspas ......................................... 392

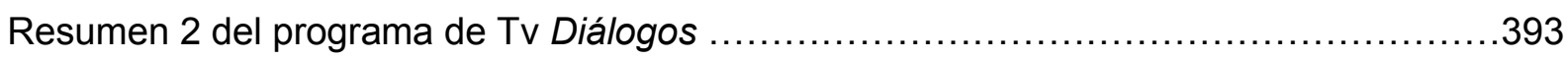

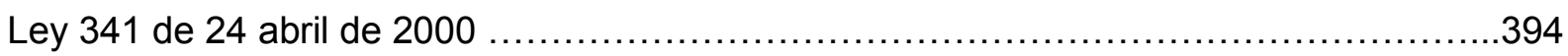

Código de Edificación de la CABA, Sección 4 (Ley 962 de accesibilidad del 05 diciembre de

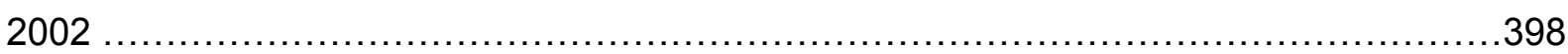

Encuesta Tipo 1: "Sondeo de los moradores de la comunidad" ..............................399

Encuesta Tipo 2: "Sondeo de los profesionales que actúan con VIS" . ......................403

Encuesta Tipo 3: "Al equipo de técnicos: arquitectos, ingenieros y urbanista" ..............405

Encuesta Tipo 4: "Al equipo de asistencia social” ...................................408

Encuesta Tipo 5: "Tópicos para la caracterización del Proyecto de Viviendas de Interés

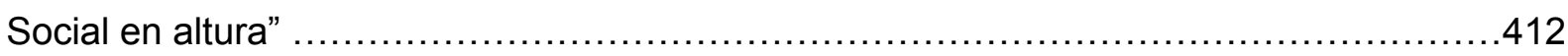

Encuesta Tipo 6: "Factores condicionantes que interfieren en la cuestión de lotes para la VIS

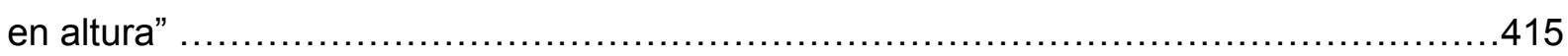

Encuesta Tipo 7: "A la Coordinación del Proyecto (Empadronamiento y atención a familias

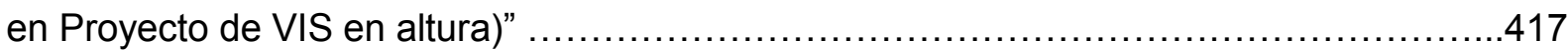

Plantas arquitectónicas de las comunidades encuestadas .............................421 


\section{FUENTES}

\section{1 - INSTITUCIONES}

Biblioteca Nacional Mariano Moreno (CABA)

CEPAL: Comissão Econômica para a América Latina e Caribe (Sede en Santiago/Chile)

CGT: Confederación General del Trabajo de los Argentinos (Sede en Buenos Aires/CABA)

CONDER: Companhia de Desenvolvimento Urbano do Estado da Bahia (Salvador/BA)

CTRS: Centro de Tecnologia da Rede Sarah (Filial de Salvador/BA)

FADA/UNA: Facultad de Arquitectura, Diseño y Arte (Universidad Nacional de Asunción/Paraguay)

FADU-UBA: Facultad de Arquitectura, Diseño y Urbanismo de la Universidad de Buenos Aires

FADU-UNL: Facultad de Arquitectura, Diseño y Urbanismo de la Universidad Nacional del Litoral (Santa Fé/SF: Argentina)

FaHCE: Facultad de Humanidades y Ciencias de la Educación (Universidad Nacional de la Plata)

FAU-UNLP: Facultad de Arquitectura y Urbanismo de la Universidad Nacional de La Plata FI-UBA: Facultad de Ingeniería de la Universidad de Buenos Aires

Fundação Mario Leal Ferreira (www)

Instituto Brasileiro de Geografia e Estatística (www)

Instituto Nacional de Estadística y Censos de la República Argentina (www)

Instituto de Investigaciones Gino Germani (Facultad de Ciencias Sociales de la Universidad de Buenos Aires)

Instituto de Letras da Universidade Federal da Bahia

IVC: Instituto de Vivienda de la Ciudad (Gobierno de la CABA)

MTL/CTA: Movimiento Territorial de Liberación/Central de Trabajadores de la Argentina (sede en CABA: Parque Patricios)

POLI/UPE: Escola Politécnica de Pernambuco/Universidade de Pernambuco (Recife/PE)

PPG-AU/UFBA: Programa de Pós-Graduação em Arquitetura e Urbanismo da Universidade

Federal da Bahia

SCA: Sociedad Central de Arquitectos (CABA)

SEHAB: Secretaria Municipal de Habitação (Prefeitura Municipal de Salvador/BA)

SINDOMÉSTICO-BA: Sindicato dos Trabalhadores Domésticos da Bahia (Salvador/BA)

UCSal: Universidade Católica do Salvador (Escola de Engenharia)

UdelaR: Universidad de la República (Montevideo: Facultad de Arquitectura)

Universidad Nacional de General Sarmiento (Los Polvorines: Argentina) 


\section{2 - PERIÓDICOS}

Clarín

Pura Ciudad

Summa

Vivienda Popular

3 - DOCUMENTOS

"ACERCA de la Ley 8912" (Argentina)

Decreto-Ley 8912/77, de 24 de octubre de 1977 (Argentina)

Estatuto da cidade (Brasil)

Ley $\mathrm{n}^{\circ} 21.499$, de 17 de enero de 1977 (Argentina)

Ley $n^{\circ} 24.374$, de 7 de septiembre de 1994 (Argentina)

Ley $n^{\circ} 341$, de 24 de febrero de 2000 (Argentina)

Ley $n^{\circ}$ 964, de 5 de diciembre de 2002 (Argentina)

Ley $n^{\circ}$ 962, de 13 enero de 2006 (Argentina)

Lei $n^{\circ}$ 11.888, de 24 de diciembre de 2008 (Brasil)

Lei $n^{\circ}$ 7.400/2008 de 20 de febrero de 2007 (Brasil)

Lei $n^{\circ}$ 9.069/2016 de 30 de junho de 2016 (Brasil)

PELIGRO de Vida en el Conjunto Urbano Barrio Padre Mugica (Argentina)

Propuesta sustitutiva adoptada por la Comissão de Desenvolvimento Urbano, ao Projeto de Lei $n^{\circ}$ 3.057, de 2000 (Brasil)

Informe Técnico sobre las Condiciones Edilicias del Conjunto Urbano Padre Mujica (Argentina). 


\section{FILMOGRAFÍA SUGERIDA}

Filmografía vinculada al tema y contexto desarrollados en la argumentación de esta tesis:

ACABOU a paz, isto aqui vai virar o Chile! Dirección: Carlos Pronzato. Producción: Carlos Pronzato. Guión: Carlos Pronzato. Documental. [S.I.]: La Mestiza Audiovisual, 2015. (60 min.), son., color., digital.

A FEBRE do Rato. Dirección: Cláudio Assis. Producción: Cláudio Assis, Marcello Ludwig Maia y Julia Moraes. Guión: Hilton Lacerda. Intérpretes: Irandhir Santos, Johnny Hooker, Juliano Cazarré, Maria Gladys, Mariana Nunes, Matheus Nachtergaele, Nanda Costa y otros. [S.I.]: Belavista Cinema y, Produção e Parabólica Brasil, 2012. 1 bobina cinematográfica (110 min.), son., bp., $35 \mathrm{~mm}$.

A GRANDE Feira. Dirección: Roberto Pires. Producción: Rex Schindler, Braga Neto y Glauber Rocha. Guión: Rex Schindler y Roberto Pires. Intérpretes: Geraldo Del Rey, Helena Ignez, Luiza Maranhão, Antonio Pitanga, Milton Gaucho y otros. [S.I.]: Iglu Filmes, 1961. 1 bobina cinematográfica (94 min.), son., bp., $35 \mathrm{~mm}$.

AUQARIUS. Dirección: Kleber Mendonça Filho. Produção: Emilie Lesclaux, Saïd Ben Saïd, Michel Merkt. Guión: Kleber Mendonça Filho. Intérpretes: Sônia Braga, Maeve Jinkings, Irandhir Santos, Humberto Carrão, Zoraide Coleto, Fernando Teiceira, Buda Lira, Barbara Colen y otros. [S.I.]: Cinema Scópio y SBS Films. Co-producción: VideoFilmes y Globo Filmes, 2016. (145 min.).

BIG Jato. Dirección: Cláudio Assis. Producción: Marcello Ludwig Maia. Guión: Hilton Lacerda y Anna Carolina Francisco. Intérpretes: Matheus Nachtergaele, Rafael Nicácio, Marcelia Cartaxo, Jards Macalé, Gabriele Lopes, Francisco de Assis y otros. . [S.I.]: 2016. (93 min.).

CABRA marcado para morrer. Dirección: Eduardo Coutinho. Producción: Zelito Viana y Eduardo Coutinho. Rotero: Eduardo Coutinho. Intépretes: Eduardo Coutinho, Ferreira Goulart y Tite de Lemos. [S.I.]: Mapa Filmes y CPC (Centro Popular de Cultura da UNE). 1984. (119 min.).

CENTRAL do Brasil. Dirección: Walter Salles. Producción: VideoFilmes, Mact Productions e RioFilme. Roteiro: Intérpretes: Fernanda Montenegro, Vinicius de Oliveira, Marília Pêra, Othon Bastos, Soia Lira, Caio Junqueira, Matehus Nachtergaele, Otávio Augusto, Rita Assemany y otros. [S.I.]: 1998. (113 min.).

DAWSON Isla 10. Dirección: Miguel Littín. Producción: Cristián de la Fuente y Niguel Littín. Guión: Miguel Littín y Sergio Bitar. Intérpretes: Benjamín Vicuña, Cristián de la Fuente, Luis Dubó, Matías Vega, Pablo Krögh, Sergio Hernández y otros. [S.I.]: 2009. (110 min.).

ENCONTRO com Milton Santos: O Mundo Global Visto do Lado de Cá. Dirección: Silvio Tendler. Producción: Caliban Produções Cinemtaográficas. Guión: Claudio Bojunga, Daniel Tendler y Silvio Tendler. Intérpretes: Milton Gonçalves, Fernanda Montenegro, Matheus Nachtergaele, Osmar Prado, Beth Goulart, Adirley Queirós y otros. [S.I.]: Documental. 2007. (89 min.).

ELEFANTE Blanco. Dirección: Pablo Trapero. Producción: Alejandro Cacetta, Juan Gordon, Juan Pablo Galli, Juan Vera, Pablo Trapero. Guión: Pablo Trapero. Intérpretes: Federico Benjamín Barga, Ricardo Darín, Jérémie Renier, Martina Gusman, Mauricio Minetti, Walter Jakob y otros. [S.I.]: Matanza Cine, Morena Filmes, Patagonik Film Group, 2012. 1 bobina cinematográfica (105 min.), son., color., $35 \mathrm{~mm}$. 
ERA o Hotel Cambridge. Dirección: Eliane Caffé. Producción: Rui Pires, André Montenegro, Edgard Tenembaum y Amiel Tenenbaum. Guión: Eliane Caffé, Inês Figueiró, Luis Alberto de Abreu. Intérpretes: José Dumont, Suely Franco, Carmen Silva, Isam Ahamad Issa, Guylain Mukendi y otros. [S.I.]: Aurora Filmes, 2017. (93 min.), son., color., digital.

EVA no Duerme. Dirección: Pablo Agüero. Producción: JBA Productions y Haddock Films. Tornasol Films S.A. (Co-producción). Guión: Pablo Agüero. Intérpretes: Gael García Bernal, Denis Lavant, Daniel Fanego , Imanol Arias, Sofia Brito, Nicolás Goldschmidt, Ailín Salas, Miguel Angel Sola y otros. [S.I.]: 2015 (87 min.).

EVITA. Dirección: Alan Parker. Producción: Dirty Hands Productions y Cinergi. Guión: Oliver Stone, Alan Parker y Tim Rice. Intérpretes: Madonna, Antonio Banderas, Jonathan Pryce, Jimmy Nail, Victoria Sus, Mark Rayan, Alan Parker, Mem Ferda, Billie Piper y otros. [S.I.]: Documental. 1997. (114 min.).

FLORES Raras. Dirección: Bruno Barreto. Producción: Paula Barreto y Lucy Barreto. Guión: Carolina Kotscho, Matthew Chapman. Intérpretes: Glória Pires; Miranda Otto; Tracy Middendorf; Treat Williams; Marcello Airoldi; Luciana Souza y otros. [S.I.]: Imagem Filmes; Telecine Productions; Globo Filmes; Telelmage; Globosat, 2013. 1 bobina cinematográfica (118 min.), son., color., $35 \mathrm{~mm}$.

http://globofilmes.globo.com/filme/floresraras/

GETÚLIO. Dirección: João Jardim. Producción: Copacabana Filmes. Guión: George Moura y João Jardim. Intérpretes: Tony Ramos, Drica Moraes, Alexandre Borges, Adriano Garib, Marcelo Médici, Thiago Justino, Alexandre Nero, Jackson Nero y outros. [S.I.]: Documental. 2014 (100 min.).

GONZAGA - De Pai pra Filho. Dirección: Breno Silveira. Producción: Eliana Soárez, Breno Silveira. Guión: Patricia Andrade. Intérpretes: Nivaldo Expedito de Carvalho, Júlio Andrade, Nanda Costa, Adelio Lima, Land Vieria, Silvia Buarque, Zezé Motta, Claudio Jaborandy, Ana Roberta Gualda, João Miguel y otros. [S. I.]: Conspiração Filmes, 2012. Biografía. (131 min.).

IARA. Dirección: Flavio Frederico. Producción: [¿?]. Guión: [¿?]. Intérpretes: [¿?]. [S.I.]: Documental. 2014. (91 min.).

LAMARCA. Dirección: Sergio Rezende. Producción: Morena Filmes. Guión: Sergio Rezende. Intérpretes: Paulo Betti, Carla Camurati, Roberto Bomtempo, José de Abreu, Carlos Zara, Ernani Moraes, Orlando Vieira, Nelson Dantas, Selton Mello, Deborah Evelyn y otros. [S.I.]: 1994 (129 min.).

MARIGUELLA. Dirección: Isa Grinspum Ferraz. Producción: Pablo Torrecillas y Rodrigo Castellar. Isa Grinspum Ferraz (Producción de set). Guión: Isa Grinspum Ferraz. Intérprete: Lázaro Ramos (narrador). [S.I.]: Documental. 2012. (100 min.).

NERUDA. Dirección: Manuel Basoalto. Producción: Manuel Basoalto y Robin Westcott. Guión: Manuel Basoalto. Intérpretes: José Secall, Alejandro Trejo, Paulina Harrington, Max Corvalán, Nelson Brodt, Catalina Saavedra, Luis Dubó, Fabián Cabada, Sergio Madrid y otros. [S.I.]: 2015 (100 min.).

NERUDA. Dirección: Pablo Larraín. Producción: Fabula Productions, AZ Films y Funny Balloons. Televisión Federal (Telefe) (Co-producción). Guión: Guillermo Calderón. Intérpretes: Luis Gnecco, Gael García Bernal, Mercedes Morán, Pablo Derqui, Jaime Vadell, Alfredo Castro, Marcelo Alonso, Micael Silva, Alejandro Goic, Amparo Nogueira, Cristián Campos, Diego Muñoz y otros. [S.I.]: 2016. (107 min.).

O HOMEM da Capa Preta. Dirección: Sergio Rezende. Producción: Morena Filmes y Embrafilme. Guión: Sergio Rezende y José Louzeiro. Intérpretes: José Wilker, Waldir 
Onofre, Chico Diaz, Marieta Severo, Jonas Bloch, Tonico Pereira, Carlos Gregório, Guilherme Karan y otros. [S.I.]: Documental. 1986. (120 min.).

OLGA. Dirección: Jayme Monjardim. Producción: Globo Filmes, Nexus Cinema e Vídeo, y, EUROPA FILMES. Guión: Rita Buszar. Intérpretes: Camila Morgado, Fernanda Montenegro, Osmar Prado, Caco Ciocler, José Dumont, Leona Cavalli, Pascoal da Conceição, Sabrina Greve, Eliane Giardini, Thelmo Fernandes y otros. [S.I.]: Documental. 2004 (99 min.).

Ó PAÍ, Ó. Dirección: Monique Gardenberg. Producción: Dueto Filmes; Dezenove Som e Imagem y Natasha Filmes. Globo Filmes (Co-producción). Guión: Bettine Silveira, Dudu Miranda, Márcio Meirelles y Monique Gardenberg. Intérpretes: Lázaro Ramos, Wagner Moura, Margareth Menzes, Luciana Souza, Emanuelle Araújo, Stênio Garcia, Daniela Mercury, Dira Paes, Tatau, Tânia Tôko, Rejane Maia, Vera Holtz, Lázaro Machado, Leno Sacramento, Auristela Sá y otros. [S.I.]: Comedia musical. 2008 (98 min.).

OS ANOS JK - Uma Trajetória Política. Dirección: Silvio Tendler. Producción: Terra Filmes. Guión: Silvio Tendler. Intérpretes: Othon Bastos (narrador) con dobladores (voces originales). [S.I.]: Documental. 1990. (110 min.)

QUE HORAS Ela Volta? Dirección: Anna Muylaert. Producción: Globo Filmes, Gullane Filmes y África Filmes. Guión: Anna Muylaert. Intérpretes: Regina Casé, Camila Márdila, Michel Joelsas, Karine Teles, Lourenço Mutarelli, Heklena Albergaria, Luis Miranda, Theo Werneck, y otros. [S.I.]: 2015. (112 min.).

RAÍZES do Brasil. Dirección: Nelson Pereira dos Santos. Producción: Regina Filmes y VideoFilmes. Guión: Miúcha y Nelson Pereira dos Santos. Intérpretes: Carlinhos Brown, Chico Buarque de Hollanda, Cristina Buarque, Silvia Buarque, Bebel Gilberto, Miúcha, Paulo Vanzolini, João Gilberto y otros. [S.I.]: Documental. 2004. (148 min.).

SOBRAL - O homem que não tinha preço. Dirección: Paula Fiuza. Producción: Casé Filmes y Canal Laranja. Guión: Paula Fiuza. Intérprete: Sobral Pinto y otros. [S.I.]: Documental. 2013. (87 min.).

TORRE de David. Dirección: Rodrigo Carvalho y Julio Molica. Producción: [¿?]. Guión: [¿?]. S.I.]: Intérpretes: [¿?]. [S.I.]: Globo News. Documental. 2012. (46 min.), son., color., digital.

VILANOVA Artigas: o Arquiteto e a Luz. Dirección: Laura Artigas y Pedro Gorski. Producción: Gal Buitone. Guión: Laura Artigas. Intérpretes: [¿?]. [S.I.]: Documental. 2015 (93 $\min$. .).

¡VIVA Zapata! Dirección: Elia Kazan. Producción: Darryl F. Zanuck. Guión: John Steinbeck y Edgecumb Pinchon. Intérpretes: Marlon Brando, Jean Peters, Anthony Quinn, Joseph Wiseman, Arnold Moss y otros. [S.I.]: Twentieth Century Fox, 1952. 1 bobina cinematográfica (113 min.), son., bp., $35 \mathrm{~mm}$.

ZANINE, Ser do Arquitetar. Dirección: André Horta. Producción: [S. I.]. Guión: Vivian Perl. Elenco: Carlos Vergara, Juarez Machado, Oscar Niemeyer, Ziraldo y otros. Documental. [SI]. 2016 (76 min.)

(www.canalcurta.tv.br/pt/filme/?name=zanine_ser_do_arquitetar).

* Créditos de las películas obtenidos gentilmente por el arquitecto Fausto de Oliveira Jr a partir de: <http://www.adorocinema.com> y <https://filmow.com/>. Acceso: 20 oct. 2018. 


\section{DOCUMENTOS ADJUNTOS}

Acervo del arquitecto João Filgueiras Lima "Lelé":

Material radiofónico producido por la Rádio FM Metrópole $(101,3)$ de Salvador en relación con el rico acervo profesional del arquitecto João Filgueiras Lima "Lelé":

a) Entrevista del 9 de julio de 2015 al empresario radial Mário Kertész, ex intendente de Salvador, del ingeniero José Luiz Santos da Costa, responsable por la ejecución del último trabajo de João Filgueiras Lima" Lelé", el proyecto del Tribunal Regional do Trabalho-BA ( $5^{a}$ Região) en el Centro Administrativo da Bahia:

COSTA, J. L. S. (2015). Entrevista al empresario radial Mário Kertész del ingeniero Costa sobre la ejecución del último proyecto del arquitecto João Filgueiras Lima "Lelé". In: Rádio Metróple FM 101.3, Salvador, 9 de julio de 2015. Disponible en: <http://www.metro1.com.br/audios/151,jose-luiz-santoscosta.html>. Acceso en: 26 feb. 2017.

b) Homenaje póstumo de la Rádio Metrópole FM 101.3 al arquitecto João Filgueiras Lima "Lelé" el 21 de mayo de 2014, editada por la reportera radial Nardele Gomes:

GOMES, N. (2014). Homenaje póstumo al arquitecto João Filgueiras Lima "Lelé". In Rádio Metróple FM 101.3, Salvador, 21 de mayo de 2014. Disponible en: $<$ https://soundcloud.com/grupometropole/21-05-14-materia-especialhomenagem-lele>. Acceso en: 4 jul. 2017.

c) Entrevista al empresario radial Mário Kertész del arquitecto João Filgueiras "Lelé" Lima del 7 de noviembre de 2012:

LIMA, J. F. (2012). Entrevista al empresario radial Mário Kertész del arquitecto João Filgueiras Lima. In: Rádio Metróple FM 101.3, Salvador, 7 de noviembre de 2012. Disponible en: <https://soundcloud.com/grupometropole/07-11-2012mk-entrevista-joao>. Acceso en: 4 jul. 2017. 
c) Entrevista al empresario radial Mário Kertész del arquitecto João Filgueiras Lima "Lelé" del 3 de agosto de 2009:

LIMA, J. F. (2012). Entrevista al empresario radial Mário Kertész del arquitecto João Filgueiras Lima "Lelé". In: Rádio Metróple FM 101.3, Salvador, el 3 agosto de 2009. Disponible en: <https://soundcloud.com/grupometropole/09-entrevistalele>. Acceso en: 4 jul. 2017. 
Tab.1 - Proyección de la población, por edad, de la CABA (Años 2001/2020)

\begin{tabular}{|c|c|c|c|c|c|c|c|c|c|c|c|}
\hline $\begin{array}{l}\text { Grupo de edad } \\
\text { (años)/Año: hab }\end{array}$ & $0-4$ & $5-9$ & $10-14$ & 15-19 & $20-24$ & $25-29$ & $30-34$ & $35-39$ & $40-44$ & $45-49$ & $50-54$ \\
\hline $\begin{array}{l}\text { 2001: } 2.995 .397 \\
\text { hab. }\end{array}$ & 73.862 & 171.648 & 179.940 & 04.449 & 238.561 & 237.311 & 213.341 & 197.045 & 189.105 & 183.684 & 175.371 \\
\hline 2002: 3.000 .966 & 181.196 & 171.102 & 177.177 & 00.633 & 234.043 & 243.899 & 17.502 & 197.701 & 129.975 & 188.923 & 175.535 \\
\hline 2003: 3.006 .179 & 187.852 & 170.665 & 175.538 & 196.626 & 228.645 & 249.253 & 222.523 & 198.938 & 188.767 & 182.525 & 175.790 \\
\hline 2004: 3.011 .694 & 193.751 & 170.956 & 174.735 & 192.493 & 223.380 & 252.455 & 228.050 & 200.969 & 188.782 & 182.108 & 176.008 \\
\hline 2005: 3.018.102 & 198.495 & 172.963 & 174.337 & 188.423 & 219.091 & 252.931 & 233.617 & 203.933 & 189.156 & 181.940 & 176.063 \\
\hline 2006: 3.025.772 & 201.067 & 177.887 & 174.096 & 184.869 & 215.727 & 250.453 & 240.007 & 207.587 & 189.725 & 181.933 & 175.810 \\
\hline 2007: 3.034.161 & 200.935 & 185.637 & 173.950 & 182.385 & 212.305 & 246.120 & 246.791 & 211.898 & 190.538 & 181.883 & 175.372 \\
\hline 2008: 3.042 .581 & 200.963 & 192.746 & 173.948 & 181.031 & 208.616 & 240.948 & 252.318 & 217.066 & 191.903 & 181.849 & 174.924 \\
\hline 2009: 3.050 .728 & 200.686 & 199.055 & 174.648 & 180.484 & 204.702 & 235.912 & 255.656 & 222.694 & 194.014 & 181.952 & 174.600 \\
\hline 2010: 3.028 .481 & 213.114 & 201.055 & 190.494 & 201.042 & 228.298 & 239.105 & 240.159 & 218.386 & 180.887 & 169.581 & 169.216 \\
\hline 2011: 3.03 & & & & & & & & & 185.582 & 169.125 & 168.544 \\
\hline 2012: 3.038 .860 & 210.881 & 207.018 & 187.679 & 196.475 & 217.537 & 240.221 & 239.799 & 226.458 & 191.550 & 169.043 & 167.385 \\
\hline 2013: 3.044 .076 & 210.242 & 207.913 & 188.773 & 193.778 & 212.014 & 240.537 & 238.748 & 229.203 & 198.148 & 169.673 & 166.004 \\
\hline 2014: 3.049.229 & 209.952 & 207.229 & 191.402 & 191.020 & 207.871 & 238.930 & 237.777 & 231.108 & 204.486 & 171.440 & 164.766 \\
\hline 2015: 3.054 .267 & 209.883 & 205.617 & 194.595 & 188.316 & 206.210 & 234.493 & 237.221 & 232.207 & 209.902 & 174.580 & 163.966 \\
\hline 2016: 3.059.122 & 209.174 & 204.345 & 197.767 & 186.431 & 203.983 & 229.377 & 237.445 & 232.409 & 214.302 & 179.233 & 163.550 \\
\hline 2017: 3.063 .728 & 208.194 & 203.314 & 200.467 & 185.416 & 201.483 & 223.561 & 238.200 & 231.768 & 217.891 & 185.140 & 163.496 \\
\hline 2018: 3.068 .043 & 206.987 & 202.637 & 201.321 & 186.460 & 198.709 & 217.947 & 238.445 & 230.684 & 220.599 & 191.674 & 164.141 \\
\hline 2019: 3.072 .029 & 205.585 & 202.308 & 200.590 & 189.040 & 195.869 & 213.717 & 236.770 & 229.679 & 222.473 & 197.947 & 165.908 \\
\hline 2020: 3.075 .646 & 204.007 & 202.200 & 198.935 & 192.179 & 193.088 & 211.953 & 232.275 & 229.085 & 223.548 & 203.306 & 169.027 \\
\hline
\end{tabular}




\begin{tabular}{|c|c|c|c|c|c|c|}
\hline Grupo de edad (años)/Año: hab. & $55-59$ & 60-64 & 65-69 & 70-74 & $75-79$ & 80 o más \\
\hline 2001: 2.995.397 hab. & 164.769 & 149.106 & 141.545 & 132.962 & 119.667 & 123.031 \\
\hline 2002: 3.000 .966 & 165.401 & 149.455 & 139.521 & 129.975 & 118.405 & 127.395 \\
\hline 2003: 3.006.179 & 165.749 & 150.322 & 137.620 & 127.553 & 115.968 & 131.845 \\
\hline 2004: 3.011.694 & 165.837 & 151.463 & 136.121 & 125.681 & 112.862 & 136.043 \\
\hline 2005: 3.018.102 & 165.747 & 152.552 & 135.302 & 124.227 & 109.757 & 139.568 \\
\hline 2006: 3.025.772 & 165.769 & 153.492 & 135.195 & 122.812 & 107.029 & 142.314 \\
\hline 2007: 3.034.161 & 166.053 & 154.219 & 135.683 & 121.238 & 104.839 & 144.315 \\
\hline 2008: 3.042 .581 & 166.411 & 154.678 & 136.629 & 119.788 & 103.120 & 145.643 \\
\hline 2009: 3.050 .728 & 166.712 & 154.864 & 137.816 & 118.671 & 101.827 & 146.435 \\
\hline 2010: 3.028 .481 & 158.949 & 147.380 & 128.814 & 107.833 & 89.321 & 144.847 \\
\hline 2011: 3.033 .639 & 159.668 & 148.109 & 130.410 & 108.959 & 88.429 & 145.218 \\
\hline 2012: 3.038 .860 & 160.606 & 148.558 & 132.007 & 110.285 & 88.310 & 145.048 \\
\hline 2013: 3.044 .076 & 161.531 & 148.867 & 133.514 & 111.750 & 88.772 & 144.609 \\
\hline 2014: 3.049 .229 & 162.109 & 149.225 & 134.843 & 113.291 & 89.580 & 144.200 \\
\hline 2015: 3.054.267 & 162.133 & 149.747 & 135.941 & 114.862 & 90.575 & 144.019 \\
\hline 2016: 3.059 .122 & 161.548 & 150.539 & 136.744 & 116.451 & 91.726 & 144.098 \\
\hline 2017: 3.063 .728 & 160.486 & 151.535 & 137.283 & 118.042 & 93.044 & 144.408 \\
\hline 2018: 3.068 .043 & 159.210 & 152.514 & 137.687 & 119.546 & 94.480 & 145.002 \\
\hline 2019: 3.072 .029 & 158.064 & 153.158 & 138.136 & 120.884 & 95.976 & 145.925 \\
\hline 2020: 3.075 .646 & 157.343 & 153.265 & 138.735 & 122.012 & 97.501 & 147.187 \\
\hline
\end{tabular}

Fuente: ARGENTINA. ([s/f]) e (INDEC. Serie Análisis Demográfico n 31 y 36$)$. 
Tab. 2 - Proyección preliminar de la población brasilera para 2020 (revisión 2008)*

\begin{tabular}{|c|c|c|c|c|c|c|c|c|c|}
\hline $\begin{array}{l}\text { Grupo de edad } \\
\text { (años)/Año: hab }\end{array}$ & $0-4$ & $5-9$ & $10-14$ & $15-19$ & $20-24$ & $25-29$ & $30-34$ & $35-39$ & 40-44 \\
\hline $\begin{array}{l}\text { 2001: } 173.808 .010 \\
\text { hab. }\end{array}$ & 17.230 .150 & 16.515 .858 & 17.179 .188 & 17.966 .396 & 16.344 .935 & 14.493 .961 & 13.743 .201 & 13.081 .958 & 11.168 .205 \\
\hline 2002: 174.632 .960 & 17.344 .060 & 16.594 .634 & 16.927 .698 & 17.919 .873 & 16.783 .403 & 14.723.194 & 13.813 .529 & 13.232 .375 & 11.583 .345 \\
\hline 2003: 178.741.412 & 17.387 .392 & 16.703 .357 & 16.709 .419 & 17.812 .320 & 17.166 .828 & 15.011 .694 & 13.896 .694 & 13.333 .970 & 11.983 .467 \\
\hline 2004: 181.105.601 & 17.331 .968 & 16.835 .138 & 16.542 .173 & 17.614 .610 & 17.515 .650 & 15.361 .953 & 14.003.227 & 13.409 .984 & 12.338 .174 \\
\hline 2005: 181.341.499 & 17.169 .672 & 16.992 .100 & 16.463 .412 & 17.357 .206 & 17.782.201 & 15.735 .323 & 14.144.075 & 13.479 .779 & 12.626 .798 \\
\hline 2006: 185.564 .212 & 16.911 .278 & 17.146 .719 & 16.483 .954 & 17.110 .667 & 17.830 .020 & 16.183 .389 & 14.326 .808 & 13.550 .118 & 12.843 .017 \\
\hline 2007: 187.641.714 & 16.581 .391 & 17.263 .594 & 16.563 .563 & 16.862 .028 & 17.787 .136 & 16.621 .980 & 14.558 .360 & 13.624 .658 & 12.996 .286 \\
\hline 2008: 189.612.814 & 16.203 .241 & 17.310 .305 & 16.673 .064 & 16.646 .523 & 17.683 .689 & 17.006 .228 & 14.848 .703 & 13.711 .956 & 13.101.744 \\
\hline 2009: 191.480 .630 & 15.794 .646 & 17.258 .602 & 16.805 .583 & 16.481 .929 & 17.490 .822 & 17.356 .378 & 15.200 .349 & 13.822 .402 & 13.182.196 \\
\hline 2010: 192.040 .996 & 15.375 .961 & 17.100 .245 & 16.963 .246 & 16.405 .425 & 17.238 .589 & 17.625 .114 & 15.575 .070 & 13.966 .841 & 13.256 .639 \\
\hline 2011: 194.932 .685 & 14.961 .793 & 16.845 .930 & 17.118 .567 & 16.427 .734 & 16.996 .900 & 17.677 .093 & 16.023 .867 & 14.152 .708 & 13.331 .654 \\
\hline 2012: 196.526 .293 & 14.565 .176 & 16.520 .179 & 17.236 .178 & 16.508 .799 & 16.752 .982 & 17.639 .024 & 16.463 .348 & 14.386 .848 & 13.410 .771 \\
\hline 2013: 198.043 .320 & 14.198 .952 & 16.146 .091 & 17.283 .716 & 16.619 .609 & 16.541 .891 & 17.540 .740 & 16.849 .052 & 14.679 .149 & 13.502 .419 \\
\hline 2014: 199.492.433 & 13.869 .189 & 15.741 .378 & 17.232 .958 & 16.753 .360 & 16.381 .329 & 17.353 .607 & 17.201 .035 & 15.032 .142 & 13.616 .827 \\
\hline 2015: 200.881 .685 & 13.577 .451 & 15.326 .242 & 17.075 .669 & 16.912 .154 & 16.308 .178 & 17.107 .360 & 17.472.296 & 15.408 .005 & 13.764 .722 \\
\hline 2016: 202.219.061 & 13.328 .797 & 14.915 .349 & 16.822 .506 & 17.068 .549 & 16.333 .105 & 16.871 .318 & 17.528 .638 & 15.857 .239 & 13.953 .452 \\
\hline 2017: 203.510.422 & 13.124 .551 & 14.521 .789 & 16.497 .953 & 17.187 .242 & 16.416 .335 & 16.632 .838 & 17.495 .545 & 16.297 .300 & 14.189 .825 \\
\hline 2018: 204.759.993 & 12.959 .544 & 14.158 .369 & 16.125 .067 & 17.235 .962 & 16.529 .091 & 16.426 .751 & 17.402 .546 & 16.684 .138 & 14.483 .633 \\
\hline 2019: 205.970.182 & 12.827 .486 & 13.831 .146 & 15.721 .537 & 17.186 .601 & 16.664 .650 & 16.270 .667 & 17.221.229 & 17.037 .647 & 14.837 .415 \\
\hline 2020: 207.143 .243 & 12.722 .166 & 13.541 .629 & 15.307 .539 & 17.030 .968 & 16.825 .080 & 16.201.252 & 16.981 .003 & 17.311 .107 & 15.213 .816 \\
\hline
\end{tabular}




\begin{tabular}{|c|c|c|c|c|c|c|c|c|}
\hline $\begin{array}{l}\text { Grupo de edad } \\
\text { (años)/Año: hab. }\end{array}$ & $45-49$ & $50-54$ & $55-59$ & $60-64$ & $65-69$ & $70-74$ & $75-79$ & 80 o más \\
\hline 2001: 173.808 .010 & 9.00 & 7.120 .457 & 5.584 .329 & 4.691 .464 & 3.544 .716 & 2.720 .481 & .918 & 1.667 .876 \\
\hline 2002: 176.303 .919 & 9.357 .711 & 7.407 .679 & 5.781 .282 & 4.768.811 & 3.695 .243 & 2.766 .446 & 1.852 .262 & 1.752 .374 \\
\hline 2003: 178.741.412 & 9.721 .972 & 7.707 .92 & 6.007 .021 & 4.838 .687 & 3.858 .135 & 2.807.165 & 1.953 .174 & 1.842 .196 \\
\hline 2004: 181.105.601 & 10.098 .153 & 8.022 .475 & 6.251 .768 & 4.924 .844 & 4.010 .555 & 2.861 .248 & 2.044 .276 & 1.939 .405 \\
\hline 2005: 183.383 .216 & 10.485 .826 & 8.351 .761 & 6.508 .346 & 5.044 .082 & 4.137 .717 & 2.940 .776 & 2.119 .353 & 2.044 .789 \\
\hline 2006: 185.564.212 & 10.888 .538 & 8.692 .194 & 6.775 .234 & 5.201 .068 & 4.234 .854 & 3.051 .416 & 2.175 .188 & 2.159 .750 \\
\hline 2007: 187.641.714 & 11.299 .674 & 9.040 .809 & 7.054 .571 & 5.390 .506 & 4.310 .718 & 3.186 .865 & 2.216 .428 & 2.283 .147 \\
\hline 2008: 189.612 .814 & 11.696 .518 & 9.399 .046 & 7.346 .875 & 5.607 .072 & 4.380 .518 & 3.332 .984 & 2.254 .242 & 2.410 .106 \\
\hline 2009: 191.480 .630 & 12.049 .293 & 9.769 .342 & 7.653 .346 & 5.841 .863 & 4.465 .584 & 3.470 .174 & 2.303 .523 & 2.534 .598 \\
\hline 2010: 193.252 .604 & 12.337 .724 & 10.151 .333 & 7.974 .368 & 6.088 .346 & 4.580 .996 & 3.585 .832 & 2.373 .815 & 2.653 .060 \\
\hline 2011: 194.932.685 & 12.555 .527 & 10.548 .370 & 8.306 .426 & 6.345 .096 & 4.730 .821 & 3.676 .065 & 2.469 .425 & 2.764 .709 \\
\hline 2012: 196.526 .293 & 12.711 .844 & 10.953 .916 & 8.646 .622 & 6.614 .039 & 4.910 .226 & 3.748 .568 & 2.585 .034 & 2.872 .739 \\
\hline 2013: 198.043.320 & 12.821 .428 & 11.345 .835 & 8.996 .400 & 6.895 .645 & 5.114 .506 & 3.816 .526 & 2.709 .121 & 2.982 .240 \\
\hline 2014: 199.492.433 & 12.906 .531 & 11.695 .116 & 9.358 .174 & 7.191 .008 & 5.335 .797 & 3.898.299 & 2.825 .874 & 3.099 .809 \\
\hline 2015: 200.881.685 & 12.985 .711 & 11.981 .970 & 9.731 .640 & 7.500 .457 & 5.568 .331 & 4.006 .835 & 2.925 .246 & 3.229 .418 \\
\hline 2016: 202.219.061 & 13.065 .425 & 12.200 .276 & 10.119 .989 & 7.820 .642 & 5.810 .877 & 4.145 .516 & 3.004 .429 & 3.372 .954 \\
\hline 2017: 203.510.422 & 13.149 .138 & 12.358 .919 & 10.516 .858 & 8.148 .838 & 6.065 .189 & \begin{tabular}{|l}
4.310 .118 \\
\end{tabular} & 3.069 .938 & 3.528 .046 \\
\hline 2018: 204.759.993 & 13.245 .125 & 12.472 .176 & 10.900 .856 & 8.486 .490 & 6.331 .678 & 4.496 .673 & 3.132 .542 & 3.689 .352 \\
\hline 2019: 205.970.182 & 13.363 .416 & 12.561 .626 & 11.243 .954 & 8.835 .981 & 6.611 .302 & 4.698 .561 & 3.207 .080 & 3.849 .884 \\
\hline 2020: 207.143.243 & 13.514 .574 & 12.645 .287 & 11.527 .023 & 9.197 .063 & 6.904 .328 & 4.910 .951 & 3.303 .926 & 4.005 .531 \\
\hline
\end{tabular}

Fuente: adaptación (a partir de IBGE/Diretoria de Pesquisas), 2018

* Partiéndose de grupos etarios quinquenales el $1^{\text {er }}$ de jul. de 1980 conciliada el 13 marzo de 2001; Fecundidad límite TFT=2,06; Con migración internacional mortalidad oficial $1980-2020$ proyección consolidada IBGE/FNUAP

IBGE/Diretoria de Pesquisas. Departamento de População e Indicadores Sociais. Divisão de Estudos e Análises da Dinâmica Demográfica. Projeção da População do Brasil por Sexo e Idade para o Período 1980-2050 - Revisão 2000. 


\section{Resumen 1 (adaptado) del contenido de informaciones vehiculadas en el programa de Tv Entre aspas}

Programa de entrevistas Entre aspas del 16 de septiembre de 2014 a las 22:30 hs, con la periodista Mônica Vadvoguel, de Globo News, el arquitecto y urbanista Cândido Malta (CM) y el director de FAU-Mackenzie, Valter Cadena (VC), sobre el problema de la vivienda en Brasil durante la violenta reintegración de posesión del antiguo edificio del Hotel Aquarius el 16 de septiembre de 2014 en el centro de São Paulo, en la icónica avenida São João, próximo a la esquina de la avenida Ipiranga.

- CM: A través del Impuesto Territorial Urbano es posible al Estado interferir en la regulación del precio del suelo urbano, lo que no ha sido hecho satisfactoriamente, usando lo que la legislación permite.

- CM: Históricamente en Brasil el tema de vivienda de los más pobres siempre fue descuidado por el Estado y la solución más utilizada ha sido la de la política de intentar abaratar el costo de la morada direccionando aquella población para áreas más lejanas del centro urbano y periféricas.

- VC: En cuanto a la especulación de tierras mediante la lógica del stock de las mismas, no dejándolas disponibles para el mercado, es un fenómeno más común entre algunas grandes constructoras, sin que esto sea una práctica generalizada entre todas, considerando que las medias y pequeñas constructoras, por su estructura, tengan como objetivo buscar el lucro inmediato, actuando en el mercado mediante la compra y venta.

- VC: El stock de tierra urbana puede ser también regulado por el Estado a través de la administración del índice del Factor Potencial de Terra.

- VC: De la población de la ciudad de São Paulo, el 15\%, cerca de 1,5 millones de personas, vive en morada precaria, incluidas las favelas, sub moradas y alquileres excesivos.

- VC: La tecnología desusada en la construcción de viviendas, la calidad de los proyectos arquitectónicos y otros y la facilitación de acceso al crédito para financiación para el comprador son factores que en Brasil deben ser mejorados para el abaratamiento de la construcción de vivienda.

- VC: Es una mentalidad equivocada de parte de la sociedad admitir que el tema de solución de morada en Brasil es un problema exclusivo de los que no poseen vivienda. Al Estado subsidiar o facilitar el acceso al crédito para los más pobres estaría solucionando un problema que es de toda la sociedad, la cual es afectada bajo varios aspectos en su calidad de vida con este problema. 


\section{Resumen 2 (adaptado) del contenido de informaciones vehiculadas en el programa de Tv Diálogos}

Programa de entrevistas Diálogos del 19 de septiembre de 2014 a las 17:30 hs. con el periodista Mário Sérgio Conti de Globo News y la arquitecta y urbanista Ermínia Maricato sobre el problema de la vivienda en Brasil durante la violenta reintegración de posesión del antiguo edificio del Hotel Aquarius el 16 de septiembre de 2014 en el centro de São Paulo, en la icónica avenida São João, próximo a la esquina de la avenida Ipiranga.

- En Brasil la función social de la propiedad está en la Constitución de 1988, en el Estatuto da Cidade (2001) y en los Planes directores de los municipios con más de 20 mil habitantes, sin embargo, no se aplica adecuadamente para solucionar el problema de la vivienda;

- En la ciudad de São Paulo hay cerca de 400 mil inmuebles vacíos en el centro de la ciudad que posee una interesante infraestructura, los cuales no son utilizados adecuadamente por la Intendencia para la solución del déficit de viviendas.

- La especulación inmobiliaria ocurre sin el control debido por parte del Estado, considerando el aumento de los índices del precio del metro cuadrado construido en la ciudad de São Paulo y en la ciudad de Rio de Janeiro entre 2009 y 2012, que fue del $154 \%$ y $181 \%$, respectivamente.

- Medidas presentes en las leyes (Constitución de 1988, en el Estatuto da Cidade (2001) y en los Planes Directores de los municipios con más de 20 mil habitantes) que no son aplicadas por las autoridades -gobernantes y Justicia- a los propietarios de inmuebles -tierras e inmuebles-, los que no respetan la función social de su patrimonio: dar un tiempo para la ocupación compulsoria, para aplicar el IPTU Progresivo, y en el caso de que ninguna de estas prácticas funcionen, aplicar la expropiación con pago a través de Título de Deuda Pública;

- Es curioso que cerca de 2 millones de personas ocupan áreas de manantial en la ciudad de São Paulo, bajo la complacencia de las autoridades que hacen la vista gorda, mientras que estas mismas autoridades actúan con extremo rigor y rapidez cuando algunos cientos de personas ocupan un inmueble de propiedad privada abandonado.

- Actualmente, en la ciudad de São Paulo, cerca del $62 \%$ de la población posee coche propio y en la misma ciudad las personas gastan en media cerca de dos horas y cuarenta y seis minutos al día en el transporte, sea mediante vehículo colectivo o privado.

- En la ciudad de São Paulo cerca del $30 \%$ de la población utiliza el coche, el $20 \%$ usa la bicicleta o anda a pie, mientras que el resto de los paulistanos, el $50 \%$, se desplaza por transporte colectivo.

- La industria automovilística y la de construcción son los dos vectores más importantes que tradicionalmente el Estado utiliza cuando piensa en resolver problemas de desarrollo económico industrial.

- Cerca del $20 \%$ de las mucamas que trabajan en la ciudad de São Paulo pasan en media tres horas para desplazarse de sus residencias, en la periferia, a su trabajo en la ciudad.

- Referente al tema de la vivienda, Brasil posee leyes urbanísticas y soluciones avanzadas, experiencia, y un cuerpo capacitado de expertos en el asunto, no obstante, continúa faltando una correlación adecuada de fuerzas que haga imponer el racionalismo y el buen sentido sobre los agentes económicos privados que detienen el poder en el área.

- Una solución viable para la cuestión de la movilidad en la ciudad de São Paulo sería la conjunción de creación de corredores exclusivos para Vehículo Liviano sobre Rieles (VLT) y la utilización de bicicleta. 
La Legislatura de la Ciudad Autónoma de Buenos Aires sanciona con fuerza de Ley

Artículo $1^{\circ}$.- El Poder Ejecutivo, a través de la Comisión Municipal de la Vivienda, instrumentará políticas de acceso a vivienda para uso exclusivo y permanente de hogares de escasos recursos en situación crítica habitacional, asumidos como destinatarios individuales o incorporadas en procesos de organización colectiva verificables, a través de cooperativas, mutuales o asociaciones civiles sin fines de lucro, mediante subsidios o créditos con garantía hipotecaria.

Artículo $\mathbf{2}^{\circ}$.- Se considerará "hogar" al grupo de personas, parientes o no, que vivan bajo un mismo techo, de acuerdo con un régimen familiar, compartiendo gastos de alimentación. Quienes viven solos constituyen un hogar.

Artículo $2^{\circ}$ bis. - Los beneficiarios deben presentar Documento Nacional de Identidad y acreditar residencia en la Ciudad Autónoma de Buenos Aires con una antigüedad no inferior a los 2 (dos) años. (Incorporado por Art. $5^{\circ}$ de la Ley $N^{\circ}$ 964, BOCBA 1606 del 10/01/2003)

Artículo $3^{\circ}$.- Los créditos podrán ser solicitados por:

a. Personas Físicas, para cada hogar.

b. Personas Jurídicas, para cooperativas, mutuales y organizaciones civiles sin fines de lucro, creadas por familias enmarcadas en procesos de organización colectiva verificables, a los efectos de satisfacer la necesidad de vivienda de sus miembros. El financiamiento deberá garantizarse con escritura hipotecaria a favor de la Comisión Municipal de la Vivienda.

c. Integrantes del servicio activo de las Entidades de Bomberos Voluntarios o que hayan logrado el subsidio mensual y vitalicio descripto en el Artículo $14^{\circ}$ de la Ley $\mathrm{N}^{\circ}$ 1240. (incorporado por Art. 18 de la Ley No 1240, BOCBA 1863 del 22/01/2004).

Artículo $4^{\circ}$.- Los créditos con garantía hipotecaria estarán destinados a financiar total o parcialmente, las siguientes operatorias:

a. compra o construcción de viviendas económica unifamiliar o multifamiliar.

b. compra de vivienda económica unifamiliar o multifamiliar y obras destinadas a ampliación o refacción.

c. obra destinada a ampliación o refacción.

d. compra de edificio y obras destinadas a su rehabilitación.

Artículo $4^{\circ}$ bis. - A todos los efectos, las viviendas que se construyan o refaccionen en el marco de la operatoria dispuesta por la presente Ley deben tener el mismo tratamiento fiscal y arancelario que la operatoria más beneficiosa que desarrolla la Comisión Municipal de la Vivienda a la fecha de sanción de la presente Ley. (Incorporado por Art. $6^{\circ}$ de la Ley $\mathbf{N}^{\circ}$ 964, BOCBA 1606 del 10/01/2003)

Artículo $5^{\circ}$.- Son beneficiarios de la presente ley, aquellos hogares que hallándose en algunas de las situaciones previstas en el Artículo $1^{\circ}$ de la presente, cumplan, los siguientes Requisitos:

a. no sean propietarios de inmuebles aptos para vivienda.

b. acrediten, mediante los mecanismos que el Poder Ejecutivo determine, no haber recibido indemnización originada en la expropiación por causa de utilidad pública. 
c. no hayan sido adjudicatarios de créditos o subsidios para la compra o construcción de vivienda en forma individual o mancomunada en los últimos diez años.

d. No encontrarse el solicitante inhibido para contraer crédito.

Artículo $6^{\circ}$.- Tendrán prioridad para acceder a los beneficios dispuestos por la presente, los hogares que se encuentren en algunas de las siguientes circunstancias: a) Pérdida de vivienda a causa de siniestro. b) Desalojo con sentencia judicial debidamente documentado. c) Estado de salud de uno de los integrantes del grupo familiar que requiera el cambio de las características de la vivienda. d) Situaciones de violencia familiar comprobada que pusieren en riesgo la integridad de alguno de los componentes. e) Habiten inmuebles afectados a obra pública. f) Familias enmarcadas en procesos de organización colectiva verificables. g) grupo familiar monoparental con hijos menores de edad. h) Pareja joven unida por lazos matrimoniales o consensuales con una edad promedio que no supere los 30 años. i) Exsoldados conscriptos que acrediten su condición de combatientes en el teatro de operaciones de las Islas Malvinas y Atlántico Sur. j) Integrantes del servicio activo de las Entidades de Bomberos Voluntarios o que hayan logrado el subsidio mensual y vitalicio descripto en el Artículo $14^{\circ}$ de la Ley 1240. (Inciso j) incorporado por Art. 18 de la Ley 1240, BOCBA 1663)

En aquellos supuestos en los que no esté expresamente mencionado, se dará prioridad a los hogares integrados con niñas, niños y adolescentes contemplados en los incisos anteriores. El Poder Ejecutivo, a través del organismo que corresponda y en un plazo no mayor de 180 días de promulgada la presente, será el responsable de reglamentar los criterios de ponderación para el otorgamiento de la vivienda, crédito o subsidio u otra prestación habitacional que incluya a los beneficiarios establecidos en el presente artículo.

\section{(Conforme texto Art. $1^{\circ}$ de la Ley No 4.042, BOCBA No 3863 del 01/03/2012)}

Artículo $7^{\circ}$.- El monto de los créditos a otorgar no podrá superar la suma de pesos cuarenta y dos mil (\$42.000) por grupo familiar destinados a financiar desde el $80 \%$ hasta el $100 \%$ de las operatorias previstas en el Art. $4^{\circ}$. La tasación oficial del bien a adquirir es suministrada por el Banco de la Ciudad de Buenos Aires. Facúltase a la autoridad de aplicación de la presente Ley a incrementar el límite establecido en este artículo en aquellos casos en que la variación de la situación económica general o modificaciones a las normativas edilicias vigentes así lo ameriten. (Conforme texto Art. $1^{\circ}$ de la Ley $N^{\circ}$ 964, BOCBA 1606 del 10/01/2003)

Artículo $7^{\circ}$ bis.- Al momento de reglamentar las condiciones de financiación el Poder Ejecutivo debe adoptar la matriz financiera que obra como Anexo I. Las cuotas cancelatorias de los créditos no deben superar el veinte por ciento $(20 \%)$ del ingreso total del hogar. (Incorporado por Art. $7^{\circ}$ de la Ley No 964, BOCBA 1606 del 10/01/2003)

Artículo $\mathbf{8}^{\circ}$.- En el marco de las operatorias implementadas por procesos de organización colectiva verificables, a través de cooperativas, mutuales o asociaciones civiles sin fines de lucro, las organizaciones solicitantes deberán acreditar la contratación de los equipos profesionales y/o técnicos interdisciplinarios correspondientes, integrados por profesionales y/o técnicos de las áreas social, contable, jurídica, de la construcción y de cualquier otra área que haga a los fines de la presente Ley. Las solicitudes presentadas para el financiamiento de las operatorias previstas en el Art. $4^{\circ}$ incluirán el programa de asistencia técnica interdisciplinaria con definición de metas cuyo cumplimiento en tiempo oportuno será condición necesaria a los fines de las certificaciones correspondientes. (Conforme texto Art. $2^{\circ}$ de la Ley $N^{\circ}$ 964, BOCBA 1606 del 10/01/2003)

Artículo $8^{\circ}$ bis. - Créase en el ámbito de la autoridad de aplicación el Registro de profesionales y equipos técnicos interdisciplinarios. Todos los profesionales y/o técnicos 
interesados en asesorar a las diferentes organizaciones, a solicitud de las mismas o por iniciativa propia, deben inscribirse en el presente Registro el cual debe ser de carácter público. La elección de dichos equipos interdisciplinarios es atribución exclusiva de las entidades solicitantes. (Incorporado por Art. $8^{\circ}$ de la Ley $N^{\circ}$ 964, BOCBA 1606 del 10/01/2003)

Artículo $8^{\circ}$ ter. - La Autoridad de aplicación debe verificar la idoneidad de los profesionales y/o técnicos considerando únicamente sus antecedentes profesionales. Los honorarios correspondientes a los mismos deben ser incluidos en la financiación de la operatoria y no podrán superar en conjunto el $10 \%$ del monto total del crédito destinado a obra. (Incorporado por Art. $9^{\circ}$ de la Ley No 964, BOCBA 1606 del 10/01/2003)

Artículo $9^{\circ}$.- La Comisión Municipal de la Vivienda aplicará los siguientes criterios en la definición de la solución habitacional para los diferentes beneficiarios: a) Cuando los beneficiarios percibieran ingresos mensuales por debajo de la línea de la pobreza, se promoverá la ampliación o refacción de vivienda propia, la compra, construcción u rehabilitación edilicia de vivienda económica en forma colectiva. Podrán disponerse subsidios cuando fuera indispensable para completar la cuota mensual correspondiente. b) Cuando los beneficiarios percibieran ingresos mensuales y superiores a la línea de pobreza, podrán acceder a los distintos programas considerados en el Art. $4^{\circ}$ de la presente Ley.

Artículo $10^{\circ}$.- Créase en el ámbito de la autoridad de aplicación, la Comisión de Control, Evaluación y Seguimiento de la Operatoria instrumentada por la presente Ley. El Poder Ejecutivo en las disposiciones reglamentarias de la presente norma garantizará la participación de las organizaciones, sólo en calidad de observadoras, en la mencionada Comisión. La misma tendrá por funciones:

a. llevar el registro de quienes reciban o pretendan recibir un subsidio o crédito destinado a financiar el acceso a la vivienda.

b. confeccionar un padrón de antecedentes de los beneficiarios según lo dispuesto en el artículo $2^{\circ}$ de la presente Ley.

c. disponer las tasaciones de los inmuebles a través del Banco de la Ciudad de Buenos Aires.

d. disponer el asesoramiento técnico y social a los beneficiaros que así lo requieran.

e. supervisar el cumplimiento del otorgamiento del crédito.

f. establecer las situaciones de prioridad establecidas en el artículo $6^{\circ}$ de la presente Ley

\section{(Conforme texto Art. $4^{\circ}$ de la Ley No 964, BOCBA 1606 del 10/01/2003)}

Artículo $11^{\circ}$.- La autoridad de aplicación debe establecer dentro de los sesenta (60) días de sancionada la presente Ley el conjunto de procedimientos a desarrollarse en el marco de la operatoria estableciendo claramente los plazos máximos de duración de cada etapa. (Conforme texto Art. $3^{\circ}$ de la Ley No 964, BOCBA 1606 del 10/01/2003)

Artículo $11^{\circ}$ bis. - La CMV o el organismo que la reemplace debe efectuar anticipos financieros a favor de las entidades previstas en el artículo $3^{\circ}$ Inc. b, siempre que el monto total de los mismos no supere el $15 \%$ del total determinado para la obra. Los anticipos financieros podrán ser desembolsados a solicitud de la entidad, previéndose su desacopio en forma proporcional a la certificación del cumplimiento de las distintas etapas de obra, conforme plan de trabajos y curva de inversión aprobados. Las mencionadas etapas objeto de certificación comprenderán no sólo el avance físico, sino también la conformidad de las mismas a la normativa edilicia vigente, así como el cumplimiento de las metas sociales comprometidas en el proyecto. (Incorporado por Art. 10 de la Ley No 964, BOCBA 1606 del 10/01/2003) 
Artículo $11^{\circ}$ ter. - En caso de que existiesen incumplimientos por parte de las entidades en la ejecución de los anticipos, el organismo de aplicación debe dar intervención a la Comisión de Control, Evaluación y Seguimiento, la que analizará las causas que produjeron los mismos, así como las alternativas que permitan continuar con el proyecto por parte de la entidad, considerando el principio de conservación del emprendimiento y continuidad de la obra. La autoridad de aplicación establecerá las normas de procedimiento aplicables en los supuestos incumplimientos, en la reglamentación correspondiente. (Incorporado por Art. 11 de la Ley $N^{\circ}$ 964, BOCBA 1606 del 10/01/2003)

Artículo $12^{\circ}$.- En caso de que el grupo familiar se viera afectado por la pérdida temporaria de trabajo podrá ser beneficiado con un plazo de gracia de hasta seis meses. Las cuotas que se devengaren en su transcurso, con sus intereses, serán satisfechas a la conclusión del término original, también en cuotas cuyo importe no supere el de la última abonada.

Artículo $13^{\circ}$.- En los casos de desalojos o pérdidas de la vivienda por desastre natural, el beneficiario tendrá derecho a una solución habitacional transitoria subsidiada total o parcialmente por el Gobierno de la Ciudad, hasta tanto se brinde asistencia financiera destinada a la vivienda definitiva. Este hábitat transitorio será provisto, en tanto existan vacantes, por asociaciones sin fines de lucro dedicadas a la prestación de este tipo de servicios. Dicha situación podrá extenderse por un plazo no mayor a seis (6) meses.

Artículo $1^{\circ}$.- Anualmente el Gobierno de la Ciudad Autónoma de Buenos Aires deberá fijar en la Ley de Presupuesto la partida correspondiente, a los fines de financiar el cumplimiento de la presente ley.

\section{ANEXO I}

\begin{tabular}{|l||l|l|l||l||l|}
\hline Deciles de Ingreso & $\mathbf{1 0}$ años & $\mathbf{1 5}$ años & $\mathbf{2 0}$ años & $\mathbf{2 5}$ años & $\mathbf{3 0}$ años \\
\hline Sexto & $0 \%$ & $1 \%$ & $2 \%$ & $3 \%$ & $4 \%$ \\
\hline \hline Quinto & $0 \%$ & $0 \%$ & $1 \%$ & $2 \%$ & $3 \%$ \\
\hline \hline Cuarto & $0 \%$ & $0 \%$ & $0 \%$ & $1 \%$ & $2 \%$ \\
\hline \hline Tercero & $0 \%$ & $0 \%$ & $0 \%$ & $0 \%$ & $1 \%$ \\
\hline \hline Segundo & $0 \%$ & $0 \%$ & $0 \%$ & $0 \%$ & $0 \%$ \\
\hline Primer & $0 \%$ & $0 \%$ & $0 \%$ & $0 \%$ & $0 \%$ \\
\hline \hline
\end{tabular}

(Conforme texto Art. $7^{\circ}$ de la Ley No 964, BOCBA 1606 del 10/01/2003)

Artículo15.- Comuníquese, etc.

ANIBAL IBARRA

RUBÉN GÉ

\section{LEY $\mathbf{N}^{\circ} 341$}

Sanción: 24/02/2000

Promulgación: De Hecho, del 16/03/2000 // Publicación: BOCBA Nº 928 del 24/04/2000

* Fuente: <http://www2.cedom.gob.ar/es/legislacion/normas/leyes/ley341.html>. Acceso en 17 fev. 2017. 


\title{
Código de la Edificación
}

\author{
SECCION 4 \\ DEL PROYECTO DE LAS OBRAS (CONTINUACION) [*]
}

\section{"4.6.3.7 Escalones en pasajes y puertas}

Todos los desniveles que se proyecten en la entrada de un edificio o bien en un pasaje o corredor serán salvados por escaleras o escalones que cumplirán con lo prescrito en el Art. 4.6.3.4. "Escaleras principales - sus características-" o por rampas fijas que cumplirán con lo prescrito en el Art. 4.6.3.8. "Rampas". Los escalones siempre serán complementados por rampas, ejecutadas según el artículo anteriormente mencionado o por medios alternativos de elevación, según lo prescrito en el Art. 5.11.4.2. "Uso de los medios alternativos de elevación" y el Art. 8.10.2.1." Finalidad y alcance de la reglamentación de ascensores y montacargas - Conceptos - Individualización", inciso c), ítem (3).

No se admitirán escalones en coincidencia con el umbral de las puertas y en su proximidad, antes de disponer cualquier desnivel se deberán observar las superficies de aproximación para las puertas, prescritas en el Art. 4.6.3.10., "Puertas" inciso g).

En caso de circulaciones con desniveles salvados con escalones, con cambios de nivel a distancias iguales o mayores que $1,20 \mathrm{~m}$, cada peldaño se deberá señalizar en las narices con bandas de color contrastante y el desnivel producido se salvará en forma complementaria por una rampa fija que cumplirá con lo prescrito en el Art. 4.6.3.8. "Rampas", o por medios alternativos de elevación, según lo prescrito en el Art. 5.11.4.2. "Uso de los medios alternativos de elevación" y el Art. 8.10.2.1." Finalidad y alcance de la reglamentación de ascensores y montacargas - Conceptos - Individualización", inciso c), ítem (3).

Quedan exceptuadas de cumplir con lo prescrito en los artículos 5.11.4.2 "Uso de los medios alternativos de elevación" y 8.10.2.1 "Finalidad y alcance de la reglamentación de ascensores y montacargas", las edificaciones a construir sobre ancho de parcela de 8,66 m o menos, de PB y 1 (un) nivel que contenga 4 (cuatro) unidades de vivienda o menos.

Quedan exceptuadas de cumplir con lo prescrito en los artículos 5.11.4.2 "Uso de los medios alternativos de elevación" y 8.10.2.1 "Finalidad y alcance de la reglamentación de ascensores y montacargas", las edificaciones a construir, de PB y 2 (dos) niveles que contengan hasta 12 (doce) unidades de vivienda o menos, considerados de interés social con una superficie máxima de hasta $80 \mathrm{~m} 2$ e incluidos en la tabla de Valores de Reposición de Edificios contenidos en la Ley Tarifaria vigente, categorizados con las letras "D" y "E", asimilables a la categoría $4^{a}$, consignada en el artículo 15, inciso 1.1 de la misma, debiendo dejar previsto el espacio necesario para la instalación de un ascensor con cabina tipo "0".

Se permitirá la construcción de más de una edificación, con las características enunciadas en el párrafo anterior, cuando la parcela por sus dimensiones así lo permita.

(Conforme Texto art. $1^{\circ}$ de la Ley No 1.205 BOCBA 1853 del 08/01/2004)"

["] Fuente: Adaptación del extracto de la Ley 962 de accesibilidad, sancionada el 05 dic. de 2002, y promulgada el 02 ene. 2003, la cual se encuentra en vigencia en la Ciudad de Buenos Aires desde el 23 may. 2003, y que actualizó la Sección 4 del Código de Edificación de esta Ciudad. A partir <http://www2.cedom.gob.ar/es/legislacion/normas/codigos/edifica/4_6b.html>. Acceso: 27 fev. 2017. 


\title{
Universidad Nacional de La Plata
}

\section{Facultad de Arquitectura y Urbanismo (Doctorado) Laboratorio de Tecnología y Gestión Habitacional - LATEC}

\author{
Doctorando/Investigador: Luiz Menezes \\ Director de tesis: Prof. Jorge Lombardi (FAU-UNLP) \\ Co-director de tesis: Prof. Marcos Jorge (UFBA/UCSal - Brasil) \\ Investigación sobre CONSTRUCCIÓN EN ALTURA para Viviendas de Interés \\ Social/VIS
}

\section{Encuesta tipo 1: "Sondeo junto a moradores de la comunidad" - jun. de 2014}

Cuestionario $\mathrm{N}^{\circ}$ Lugar de investigación Fecha de la encuesta:

Para cada pregunta tildar con un $\mathrm{X}$ en el espacio que corresponde:

1 - ( ) ¿Hace cuánto tiempo qué usted vive en su vivienda?:

+- 1 año o menos ( ) +- 2 años ( ) +- 3 años ( ) +- 4 años ( ) +- 5 años o más ( )

$2-(\quad)$ ¿En qué piso vive usted?:

planta baja ( ) $1^{\text {er }}$ piso ( ) $2^{\text {do }}$ piso ( ) $3^{\text {er }}$ piso ( ) $4^{\text {to }}$ piso ( )

3 - ( ) En la vivienda que usted vive hay:

ningún dormitorio ( ) 1 dormitorio ( ) 2 dormit. ( ) 3 dormit. ( ) 4 o más dormit. ( )

4 - ( ) ¿Cuántos metros cuadrados de área posee internamente su vivienda?:

+- $20 \mathrm{~m}^{2}$ o menos ( ) +- $40 \mathrm{~m}^{2}(\mathrm{)})+-60 \mathrm{~m}^{2}(\mathrm{l})+-80 \mathrm{~m}^{2}(\mathrm{)})+-100 \mathrm{~m}^{2}$ o más ( )

5 - ( ) ¿Usted cree que vivir en un edificio de 3 ó 4 pisos (además de la planta baja) es bueno?:

$$
\text { definitivamente no ( ) muy poco ( ) poco ( ) mucho ( ) muchísimo ( ) }
$$

6 - ( ) ¿Usted tuvo la oportunidad de participar de alguna manera en el proyecto o en la construcción de su vivienda?: definitivamente no ( ) muy poco ( ) poco ( ) mucho ( ) muchísimo ( )

7 - ( ) ¿Hubo demoras desde su registro en el Plan de Vivienda, con los trámites de papeles, hasta la entrega de su departamento?:

definitivamente no ( ) muy poco ( ) poco ( ) mucho ( ) muchísimo ( )

8 - ( ) ¿El número de habitaciones de su vivienda es suficiente para usted?:

definitivamente no ( ) muy poco ( ) poco ( ) mucho ( ) muchísimo ( )

9 - ( ) ¿El tamaño de las habitaciones de su vivienda satisface su necesidad?:

definitivamente no ( ) muy poco ( ) poco ( ) mucho ( ) muchísimo ( )

10 - ( ) ¿Las habitaciones de su vivienda fueron bien ubicadas en la misma según sus necesidades?:

definitivamente no ( ) muy poco ( ) poco ( ) mucho ( ) muchísimo ( )

11 - ( ) ¿Usted cree que el suministro de agua es satisfactorio a las necesidades suyas?: 
definitivamente no ( ) muy poco ( ) poco ( ) mucho ( ) muchísimo ( ) 12 - ( ) ¿Le gusta la fachada externa de su edificio?:

definitivamente no ( ) muy poco ( ) poco ( ) mucho ( ) muchísimo ( ) 13 - ( ) El sistema de portero eléctrico en su edificio, ¿qué características tiene?:

no existe ( ) sólo permite escuchar el sonido del timbre o hablar con el/la visitante ( ) permite abrir el portón de acceso ( ) permite comunicarse con los vecinos ( ) me parece bien que se deba ubicar un portero electrónico ( )

14 - ( ) La provisión de gas en su vivienda, ¿qué características tiene?: es manual tipo garrafa de $10 \mathrm{Kg}($ ) es de red con medidor individual ( )

15 - ( ) En cuánto al área disponible para el lavado de la ropa de los que viven en su vivienda:

es un lavadero dentro de su vivienda ( ) es un lavadero en espacio colectivo ( ) utiliza un lavarropa eléctrico dentro de su vivienda ( ) utiliza un lavarropas comunitario ( ) no hay ningún área prevista ( )

16 - Referente a la prevención de incendios, de combate a incendio, y de socorro en esa situación:

16.1 - ¿Los servicios, los espacios de acceso/salida (hall, pasillo, escalera, puertas...) y materiales utilizados en la construcción de su vivienda son confiables?: definitivamente no ( ) muy poco ( ) poco ( ) mucho ( ) muchísimo ( )

16.2 - ¿Los equipamientos (señalización, extintores, mangueras...) son confiables? definitivamente no ( ) muy poco ( ) poco ( ) mucho ( ) muchísimo ( )

16.3 - ¿Usted y las personas que viven en su casa tienen o tuvieron alguna información o entrenamiento básico sobre ese asunto?

definitivamente no ( ) muy poco ( ) poco ( ) mucho ( ) muchísimo ( )

17 - ( ) ¿Hay suficientes medios de transporte público en donde usted vive?: definitivamente no ( ) muy poco ( ) poco ( ) mucho ( ) muchísimo ( )

18 - ( ) Con referencia a los servicios y materiales utilizados en la construcción de su vivienda, ¿éstos son adecuados para su uso?:

18.1 - ( ) en el revestimiento de piso de todas las habitaciones:

definitivamente no ( ) muy poco ( ) poco ( ) mucho ( ) muchísimo ( )

18.2 - ( ) en el revestimiento de las paredes de las habitaciones, de la(s) sala(s), del pasillo: definitivamente no ( ) muy poco ( ) poco ( ) mucho ( ) muchísimo ( ) 18.3 ( ) en el revestimiento de las paredes de la cocina, de el/los baño(s) y del área de servicio:

definitivamente no ( ) muy poco ( ) poco ( ) mucho ( ) muchísimo ( )

18.4 - ( ) en el revestimiento en el techo:

definitivamente no ( ) muy poco ( ) poco ( ) mucho ( ) muchísimo ( )

18.5 - ( ) en el herraje (cerraduras, bisagras, cerrojos):

definitivamente no ( ) muy poco ( ) poco ( ) mucho ( ) muchísimo ( )

19 - ( ) ¿Los "cerramientos" (puertas, ventanas) de su vivienda funcionan bien?:

definitivamente no ( ) muy poco ( ) poco ( ) mucho ( ) muchísimo ( ) 
20 - ( ) ¿El valor de la cuota mensual qué usted paga por la financiación de su vivienda es apropiada para su presupuesto?:

definitivamente no ( ) muy poco ( ) poco ( ) mucho ( ) muchísimo ( ) $21-($ ) ¿El valor de las expensas para el mantenimiento de su edificio es accesible para sus ingresos?:

definitivamente no ( ) muy poco ( ) poco ( ) mucho ( ) muchísimo ( )

22 - ( ) ¿En verano, el clima es aceptable en el interior de su vivienda?: definitivamente no ( ) muy poco ( ) poco ( ) mucho ( ) muchísimo ( )

23- ( ) ¿El invierno, el clima es aceptable en el interior de su vivienda?: definitivamente no ( ) muy poco ( ) poco ( ) mucho ( ) muchísimo ( )

24 - ( ) ¿Se escuchan sonidos emitidos desde el exterior o de otro ambiente interior?: definitivamente no ( ) muy poco ( ) poco ( ) mucho ( ) muchísimo ( )

25 - ( ) ¿La iluminación natural (de día) en el interior de su vivienda es satisfactoria?: definitivamente no ( ) muy poco ( ) poco ( ) mucho ( ) muchísimo ( )

26 - ( ) ¿Está conforme con la ventilación en el interior de su vivienda?: definitivamente no ( ) muy poco ( ) poco ( ) mucho ( ) muchísimo ( )

27 - ( ) ¿Las instalaciones de agua y de cloacas de su vivienda son satisfactorias?: definitivamente no ( ) muy poco ( ) poco ( ) mucho ( ) muchísimo ( )

28 - ( ) ¿Las instalaciones eléctricas de su vivienda son satisfactorias?:

definitivamente no ( ) muy poco ( ) poco ( ) mucho ( ) muchísimo ( )

29 - ( ) ¿En periodos de lluvia ocurre debido a ésta algún inconveniente en el interior de su vivienda (o en el edificio)?:

definitivamente no ( ) muy poco ( ) poco ( ) mucho ( ) muchísimo ( )

30 - ( ) ¿Las áreas de esparcimiento (las plazas, los jardines, la cancha deportiva) cerca de su edificio son usadas por personas que viven en su vivienda?: definitivamente no ( ) muy poco ( ) poco ( ) mucho ( ) muchísimo ( )

31 - ( ) ¿Los espacios de acceso y de circulación (el hall, el pasillo, la escalera) del edificio ofrecen alguna dificultad para su uso?: definitivamente no ( ) muy poco ( ) poco ( ) mucho ( ) muchísimo ( )

32 - ( ) ¿Hay cerca de su edificio escuelas públicas, guarderías, puestos de salud, comisaría y lugar de pagos?:

definitivamente no ( ) muy poco ( ) poco ( ) lo suficiente ( ) muchísimo ( )

$33-($ ) ¿Usted tiene intención de vender o alquilar su casa ahora o en los próximos 5 años?:

definitivamente no ( ) muy poco ( ) tal vez ( ) probablemente ( ) sí ( )

34 - ( ) ¿A usted parece válida la prohibición de la Ley porteña 962, de 2002, qué impide la construcción, en la capital federal, de departamentos en edificios con más de 2 pisos (arriba de la planta baja) sin ascensor?

definitivamente no ( ) muy poco ( ) poco ( ) mucho ( ) muchísimo ( ) 
B - Si usted quisiera hacer algún COMENTARIO favor escríbalo el ítem (o varios) entre paréntesis ( ) y en las líneas siguientes abajo (USE UNA HOJA DE PAPIEL ADJUNTA A ESTA ENCUESTA SI NECESARIO):

C- Identificación del encuestado (opcional):

\begin{tabular}{|c|c|}
\hline Nombre: & \\
\hline Dirección: & \\
\hline Ocupación: & \\
\hline Grado de escolaridad: & Edad: \\
\hline $\mathrm{N}^{\circ}$ de personas en la vivienda & \\
\hline Cuota pagada (mensual) por su vivienda: & \\
\hline Ingresos familiares (por mes): & \\
\hline
\end{tabular}




\section{Universidad Nacional de La Plata Facultad de Arquitectura y Urbanismo (Doctorado) Laboratorio de Tecnología y Gestión Habitacional - LATEC}

Doctorando: Ednilson Luiz Santana Menezes

Director de tesis (FAU-UNLP): Arq. Jorge Lombardi

Co-director de tesis (UCSal, Brasil): Dr. Marcos Jorge Almeida Santana

"La construcción en altura como una opción eficiente para la vivienda de interés social en grandes ciudades: tipología y costos, de salvador a buenos aires (1937 a 2017)".

Encuesta Tipo 2: "Sondeo para profesionales que actúan con VIS"

Salvador, octubre de 2014

Preciado/a,

Como es de mi interés profundizar mis estudios sobre la viabilidad de construcción en altura de edificios con 3 pisos destinados a Viviendas de Interés Social (VIS) en los grandes centros urbanos, agradezco su apoyo y su respuesta a una encuesta que utilizaré en mi tesis de doctorado conjuntamente con las respuestas de otros colegas y profesionales:

1) Indique su opinión sobre los 6 ítems detallados a continuación, mencione 3 o más factores que más impiden y 3 o más factores que más contribuyen a la ejecución de construcciones en altura con 3 pisos de edificios:

A - Proyecto (arquitectónico):

B - Presupuestario (costos):

C - Suelo (predio): 
D: Tecnológico (según el partido constructivo):

E - Gerencia gubernamental (políticas públicas):

F - Legislación edilicia:

\begin{tabular}{|l|}
\hline Nombre: \\
\hline Formación: \\
\hline Institución: \\
\hline Función/cargo: \\
\hline Localidad/Fecha: \\
\hline
\end{tabular}

Agradeceré su valiosa colaboración y su amable orientación:

a) sobre los títulos/referencias y/o abordajes inherentes a este tema;

b) sobre su disponibilidad para concertar una entrevista con usted a fin de que podamos comentar un poco más sobre el tema en cuestión.

Saludo a usted atentamente y expreso nuevamente mi gratitud por su atención.

Luiz Menezes. 


\title{
Universidad Nacional de La Plata Facultad de Arquitectura y Urbanismo (Doctorado) Laboratorio de Tecnología y Gestión Habitacional - LATEC
}

\author{
Doctorando: Ednilson Luiz Santana Menezes \\ Director de tesis (FAU-UNLP): Arq. Jorge Lombardi \\ Co-director de tesis (UCSal, Brasil): Dr. Marcos Jorge Almeida Santana
}

"La construcción en altura como una opción eficiente para la vivienda de interés social en grandes ciudades: tipología y costos, de salvador a buenos aires (1937 a 2017)".

Encuesta Tipo 3: "Al equipo de técnicos: arquitecto/ingeniero/urbanista"77

Septiembre de 2014

Cuestionario $\mathrm{N}^{\circ}$ :

Profesional encuestado/a:

Comunidad:

Nombre del Proyecto:

Número de viviendas construidas:

1 - ¿El proyecto arquitectónico (y los demás) fue de autoría del equipo técnico de la empresa estatal contratante o de una empresa privada?:

ninguno ( ) alguno ( ) muchos ( ) todos ( )

2 - ¿Cuánto tiempo, en promedio, tomó la elaboración de los proyectos?:

3 - ¿Cómo se procesó la revisión de los proyectos? ¿Cuántas revisiones se realizaron antes de la implementación?

4 - ¿Qué tipo de participación los moradores seleccionados del Proyecto tuvieron en éste?: ninguna ( ) alguna ( ) suficiente ( ) mucha ( )

5 - Comente algo que entienda que sea importante sobre cómo se dio el acompañamiento/fiscalización, por parte de los habitantes, en el proyecto y ejecución de las viviendas en general:

$6-¿$ ¿Fue hecho el "as built" de los referidos proyectos?:

\footnotetext{
77 Esta encuesta sirvió de base para el Seminario referente a la conclusión de la asignatura Gestión y Coordinación de Proyectos/ set.- nov. 2014, impartida por el Prof. Silvio Melhado (Poli-USP), entre el 8 de sept. y el 11 de nov. 2014, en Recife, en Poli-UEP, cuya asignatura también hizo parte de las actividades desarrolladas por este autor, Luiz Menezes, como alumno en el curso de Doctorado de la Facultad de Arquitectura y Urbanismo de la Universidad Nacional de La Plata - Argentina, bajo la dirección de tesis del Prof. Jorge Lombardi (FAU-UNLP) y del prf. Marcos Jorge (Poli/UFBA; UCSal/Brasil), vice-director.
} 
7 - ¿Hubo evaluación pos-ocupación y en qué porcentaje de las viviendas construidas?:

8 - Comente algo sobre los valores e ítems más importantes que hayan sido responsables por aditivos contractuales y justifíquelo:

9 - ¿Qué porcentaje de los habitantes-registrados fue utilizado en la contratación para la construcción de las obras?:

ninguno ( ) alguno ( ) suficiente ( ) mucho ( )

10 - ¿Cómo se dio la información y entrenamiento (si hubo) de los habitantes en cuanto a la prevención y al combate de incendios?:

ninguna ( ) alguna ( ) suficiente ( ) mucha ( )

11 - ¿Cuál/cuáles de los servicios públicos a continuación se encuentran a más de $1 \mathrm{~km}$ de la comunidad, aproximadamente?: escuela, guardería, jardín de infantes, comisaría, centro de salud y lugar de pagos:

ninguno ( ) alguno/algunos ( ) muchos ( ) todos ( )

12 - ¿Hay en el Proyecto arquitectónico espacios destinados para el estacionamiento de los vehículos de trabajo de los habitantes (bicicletas, automóvil, etc.)?:

ninguno ( ) alguno ( ) suficiente ( ) muchos ( )

13 - ¿Hay en el Proyecto espacios disponibles para que los habitantes realicen actividades económicas/comerciales en la comunidad?:

ninguno ( ) alguno ( ) suficiente ( ) muchos ( )

14 - Comente sobre la existencia, en el Proyecto, de servicios públicos disponibles para la recreación y el entretenimiento: plaza, canchas deportivas, centro comunal, dentro de la comunidad:

ninguno ( ) alguno ( ) suficiente ( ) muchos ( )

15 - Haga una comparación de los costos (por unidad de vivienda y por $\mathrm{m}^{2}$ ) entre lo proyectado $\mathrm{X}$ ejecutado: 
16 - Comente algo sobre la adecuación de los plazos entre lo proyectado X ejecutado:

ninguna ( ) alguna ( ) suficiente ( ) mucha ( )

17 - Según su percepción, ¿cómo ha se dado la existencia de un potencial mercado inmobiliario informal, en el interior de la comunidad, con las nuevas viviendas?:

ninguno ( ) alguno ( ) poco ( ) mucho ( )

18 - ¿Cómo se realizó el trámite de la regularización del lote y del inmueble?:

ninguno ( ) poco ( ) suficiente ( ) muy satisfactorio ( )

19 - ¿Cómo ha sido la aplicación, en las nuevas viviendas, de la tarifa social de los servicios de electricidad, agua y teléfono?:

ninguna ( ) alguna ( ) suficiente ( ) mucha ( )

20 - ¿Qué tipo de influencia hubo/hay en Canasta básica (social), y correlatos, en la población que ha adquirido las VIS, en el Proyecto?:

ninguna ( ) alguna ( ) poca ( ) mucha ( )

21 - ¿Cuáles son los 5 ítems del Proyecto que, según es de su conocimiento, fueron los más elogiados por los habitantes y, cuáles son los 5 más criticados?:

22 - Podría mencionar y justificar, según su opinión y en términos generales, ¿Cuáles son los 5 aspectos positivos (avances) y 5 negativos (permanencias, o retrocesos) del Proyecto ya ejecutado? 


\title{
Universidad Nacional de La Plata
}

\section{Facultad de Arquitectura y Urbanismo (Doctorado) Laboratorio de Tecnología y Gestión Habitacional - LATEC}

\author{
Doctorando: Ednilson Luiz Santana Menezes \\ Director de tesis (FAU-UNLP): Arq. Jorge Lombardi \\ Co-director de tesis (UCSal, Brasil): Dr. Marcos Jorge Almeida Santana
}

"La construcción en altura como una opción eficiente para la vivienda de interés social en grandes ciudades: tipología y costos, de salvador a buenos aires (1937 a 2017)".

\section{Encuesta Tipo 4: “Al equipo de asistencia social”78}

Cuestionario $\mathrm{N}^{\mathrm{O}}$ :

Fecha de la encuesta:

Profesional encuestado/a:

Comunidad:

Nombre del Proyecto:

Número de viviendas ofertadas:

1 - Qué tipo de participación los moradores del público seleccionado del Proyecto tuvieron en éste?:

$$
\text { ninguna ( ) alguna ( ) el suficiente ( ) mucha ( ) }
$$

2 - Comente algo que entienda que sea importante sobre cómo se dio el acompañamiento/fiscalización, por parte de los moradores, en el proyecto y ejecución de las viviendas en general:

3 - ¿Hubo evaluación post-ocupación y en qué porcentaje de las viviendas construidas?: ninguna ( ) alguna ( ) el suficiente ( ) mucha ( )

4 - Cuál la participación del/de la morador/a en la financiación del proprio inmueble?:

ninguna ( ) alguna ( ) el suficiente ( ) mucha ( )

\footnotetext{
78 Esta encuesta sirvió de base para el Seminario referente a la conclusión de la asignatura Gestión y Coordinación de Proyectos/ set.- nov. 2014, impartida por el prf. Silvio Melhado (Poli-USP), entre el 8 de sept. y el 11 de nov. De 2014, en Recife, en Poli-UEP, así como hizo parte de las actividades desarrolladas por este autor, Luiz Menezes, en el curso de doctorado como alumno en la Facultad de Arquitectura y Urbanismo de la Universidad Nacional de La Plata - Argentina, bajo la dirección de tesis del prf. Jorge Lombardi (FAU-UNLP) y del prf. Marcos Jorge (vice-director, Brasil).
} 
5 - ¿Cuál la participación del/de la morador/a en la financiación del proprio inmueble?:

ninguna ( ) alguna ( ) el suficiente ( ) mucha ( )

6 - Cómo se dio la información y entrenamiento (se hubo) de los moradores cuanto a la prevención y al combate a incendios?:

$$
\text { ninguna ( ) alguna ( ) el suficiente ( ) mucha ( ) }
$$

7 - ¿Cómo se dio la capacitación de los moradores para el ejercicio en la administración/comisión fiscal, del condominio?:

ninguna ( ) alguna ( ) el suficiente ( ) mucha ( )

8 - ¿Cómo se procesó la(s) actividad(es) con moradores sobre su capacitación para convivencia en viviendas colectivas (en los edificios en bloques)?:

ninguna ( ) alguna ( ) el suficiente ( ) mucha ( )

9 - ¿Cuáles las actividades que fueron desarrolladas visando a la capacitación profesional (cursos profesionales/instituciones fomentadoras ...) de los moradores?:

ninguna ( ) alguna ( ) el suficiente ( ) muchas ( )

10 - ¿Cuál/Cuáles de los equipamientos públicos adelante están lejos además de $1 \mathrm{~km}$ de la comunidad, aproximadamente?: escuela, guardería, comisaría, centro de salud y lugar de pagos:

ninguno ( ) alguno/algunos ( ) muchos ( ) todos ( )

11 - ¿Hay en el Proyecto arquitectónico espacios destinados a la guarda (aparcamiento) de vehículos de trabajo de moradores (bicicletas, "coche" de ventas/de mano)?:

ninguno ( ) alguno ( ) el suficiente ( ) muchos ( )

12 - ¿Hay en el Proyecto espacios disponibles para actividades económicas a que sean exploradas por moradores en la comunidad?:

ninguno ( ) alguno ( ) el suficiente ( ) muchos ( ) 
13 - Comente sobre la existencia, en el Proyecto, de servicios públicos disponibles para la recreación y el entretenimiento: plaza, canchas deportivas, centro comunal, dentro de la comunidad:

ninguno ( ) alguno ( ) el suficiente ( ) muchos ( )

14 - ¿Hubo alguna actividad involucrada para la capacitación "ciudadana" (acceso/trámites en instituciones públicas: empresas de servicios (agua/cloacas, energía eléctrica, telefonía...), Justicia y Legislativo)?:

ninguna ( ) alguna ( ) el suficiente ( ) muchas ( )

15 - Comente sobre el desfase de plazos entre el proyectado $X$ ejecutado:

ninguno ( ) alguna ( ) el suficiente ( ) mucho ( )

16 - Según su percepción, ¿cómo se ha dado la existencia de un potencial mercado inmobiliario informal, en el interior de la comunidad, con las nuevas viviendas?:

ninguno ( ) alguno ( ) poco ( ) mucho ( )

17 - ¿En qué medida hubo alteración/cambio de la seguridad pública, en el interior de la comunidad, después de la ocupación de las nuevas viviendas?:

ninguna ( ) alguna ( ) poca ( ) mucha ( )

18 - ¿Cómo ocurrió/ha sido el trámite de la regularización del lote (del predio/suelo) y del inmueble habitacional del/de la morador/a?:

ninguno ( ) poco ( ) el suficiente ( ) muy satisfactorio ( )

19 - ¿Cómo ha sido la aplicación, en las nuevas viviendas, de la tarifa social junto a servicios de prestadoras "públicas": energía, agua e teléfono?:

ninguna ( ) alguna ( ) el suficiente ( ) mucha ( )

20 - ¿Qué tipo de influencia hubo/hay de la Canasta básica (social), y correlatos, delante de la población adquirente de las VIS, en el Proyecto?:

ninguna ( ) alguna ( ) poca ( ) mucha ( ) 
21 - ¿Cómo se dio/ha se dado la relación entre la población de los alrededores y los moradores de las nuevas VIS en la comunidad?:

ninguna ( ) alguna ( ) poca ( ) mucha ( )

22 - ¿Cuáles son los 5 ítems del Proyecto que, según es de su conocimiento, fueron los más elogiados por los moradores/as? y, ¿cuáles son los 5 más criticados?:

23 - Presente, en lo general, a su ver, 5 aspectos positivos (avanzos) y 5 negativos (permanencias, o incluso retrocesos), se posible con JUSTIFICATIVAS, sobre el Proyecto ejecutado: 


\section{Universidad Nacional de La Plata \\ Facultad de Arquitectura y Urbanismo (Doctorado) \\ Laboratorio de Tecnología y Gestión Habitacional - LATEC}

Doctorando: Ednilson Luiz Santana Menezes

Director de tesis (FAU-UNLP): Arq. Jorge Lombardi

Co-director de tesis (UCSal, Brasil): Dr. Marcos Jorge Almeida Santana

"La construcción en altura como una opción eficiente para la vivienda de interés social en grandes ciudades: tipología y costos, de salvador a buenos aires (1937 a 2017)".

Encuesta Tipo 5: "Tópicos para caracterización del Proyecto de las Viviendas de Interés Social (VIS) en altura"

- Proyecto (nombre):

$\checkmark$ Programa (nombre):

$\checkmark$ Ente(s) federativo(s) promotor(es):

$\checkmark$ Agencia(s) financista(s):

$\checkmark$ Entidad gestora (fiscalización):

$\checkmark$ Base legal/jurídica ( $N^{\circ}$ contracto-fecha/ BO-fecha):

$\checkmark \quad$ Número de pisos (incluyendo la planta baja)/bloque:

- Número total de viviendas (habitaciones):

- Áreas:

$\checkmark$ Del predio (terreno):

$\checkmark$ De cada departamento (vivienda):

$\checkmark$ De los compartimientos del departamento:

$\checkmark$ Verde/recreo:

$\checkmark$ Circulación (vía pública):

$\checkmark$ Aparcamiento (vehículos):

- Equipamientos públicos (área):

$\checkmark$ Parque de infante:

$\checkmark$ Guardería:

$\checkmark$ Jardines/plaza:

$\checkmark$ Área deportiva: 
$\checkmark$ Centro comunitario (boxes):

$\checkmark$ Salón de fiestas:

$\checkmark$ Otros:

- Densidad urbana (habitantes/ha):

$\checkmark$ Admitida en el Proyecto:

$\checkmark$ Del barrio (comunidad):

- Plazos (PREVISTO X EJECUTADO):

$\checkmark$ Proyecto (inicio - conclusión):

$\checkmark$ Ejecución/construcción (inicio - conclusión):

$\checkmark$ Adictivo (duración):

$\checkmark$ Entrega a los moradores (fecha):

$\checkmark$ Financiación del inmoble al/a la morador/a (duración):

- Costos (\$):

$\checkmark$ Costo total del Proyecto:

$\checkmark$ Costo del predio (lote):

$\checkmark$ Costo de la vivienda (construcción):

$\checkmark$ Costo da infraestructura:

$\checkmark$ Costo por $\mathrm{m}^{2}$ construido (vivienda):

$\checkmark$ Costo total por $\mathrm{m}^{2}$ construido (terreno + vivienda + infraestructura)

$\checkmark$ Costo de la Asistencia social (en el Proyecto):

$\checkmark$ Costo de la Administración:

$\checkmark$ Costo del Adictivo - si hubo - (ítem/justificativa):

$\checkmark$ Costo mensual (estimado) de la financiación del inmoble (a ser pagado por el/la morador/a):

$\checkmark$ Otros:

- Ejecutantes:

$\checkmark$ Proyectos (arquit., estructural, elétric., hidráulico y de cloacas) - oficinas:

$\checkmark$ Constructoras (responsables): 
$\checkmark$ Fiscalización:

$\checkmark$ Empresas subcontratadas (participantes tercerizadas):

- Padrón constructivo/tipología: TIPO de SOLUCIÓN TECNOLÓGICA aplicada (en los principales elementos estructurales de las viviendas

$\checkmark$ Base:

$\checkmark$ Estructura:

$\checkmark$ Albañilería:

$\checkmark$ Hidráulico-cloacas:

$\checkmark$ revestimientos (piso, divisoria, techo):

$\checkmark$ pintura:

$\checkmark$ herrajes/cerramientos:

$\checkmark$ contenciones/arrimo:

$\checkmark$ forro/cobertura:

$\checkmark$ cerramiento perimetral (del condominio):

- Número de familias/personas atendidas:

$\checkmark$ Directamente (moradores/as de las VIS del Proyecto)

$\checkmark$ En el entorno del Condominio (comunidad existente/vecindad)

- Histórico (resumido) del origen del asentamiento (vinculado al Proyecto):

$\checkmark$ fecha (año probable) del inicio del asentamiento:

$\checkmark$ localidad de origen de los moradores (antes de venir al asentamiento):

$\checkmark$ factores determinantes para la ocupación (surgimiento del asentamiento): 


\section{Universidad Nacional de La Plata \\ Facultad de Arquitectura y Urbanismo (Doctorado)}

Doctorando: Ednilson Luiz Santana Menezes

Director de tesis (FAU-UNLP): Arq. Jorge Lombardi

Co-director de tesis (UCSal, Brasil): Dr. Marcos Jorge Almeida Santana

"La construcción en altura como una opción eficiente para la vivienda de interés social en grandes ciudades: tipología y costos, de salvador a buenos aires (1937 a 2017)".

Encuesta Tipo 6: "Factores (condicionantes) que interfieren en la cuestión de lotes para la VIS en altura"

Septiembre de 2014

Proyecto:

Área del lote:

Área del inmoble (vivienda):

1 - Abordaje sobre la situación (de ocupación) anterior y la etapa actual (JURÍDICO):

a) Del lote:

b) Del inmoble (vivienda):

2 - Costos:

a) Del lote (adquisición):

b) Del inmoble (construcción de la vivienda):

c) De la regularización (de la propiedad) del lote:

d) De la regularización (de la propiedad) del inmoble (vivienda):

3 - Plazos/FECHAS de:

a) Adquisición/regularización del lote:

b) "Titulación" del inmueble (habitación):

4 - Condicionantes/factores (¿CUÁLES?/CÓMO?) que interfieren (EN QUÉ MEDIDA?) en el trámite:

a) Burocracia:

b) Instituciones vinculadas:

c) Aspectos facilitadores:

d) Aspectos que dificultan / impeditivos:

e) Proyectos (principales) de Leyes (parcelación urbana)

f) Ley 11.977/09 // 12424/11 (MCMV):

g) Ley 11888/08 (Oficina/TALLER pública de asistencia técnica): 
h) Ley porteña 962, de 2002 (que prohíbe edificio con más de 2 pisos, arriba de la PB, sin ascensor)

i) Lotes urbanos públicos (para fines sociales - VIS):

j) Base de datos (catastro de lotes):

k)Grupos marginales ("grilleros", "poseedores", "intermediarios", "terratenientes" ...):

5 - Cuantitativos (PREVISTOS X EJECUTADOS) de REGULARIZACIÓN ("títulos"/registro notarial):

a) Número de lotes:

b) Número de inmobles (vivienda):

6 - OTRAS (INFORMACIONES) referentes al tema: 


\section{Universidad Nacional de La Plata \\ Facultad de Arquitectura y Urbanismo (Doctorado) \\ Laboratorio de Tecnología y Gestión Habitacional - LATEC}

Doctorando: Ednilson Luiz Santana Menezes

Director de tesis (FAU-UNLP): Arq. Jorge Lombardi

Co-director de tesis (UCSal, Brasil): Dr. Marcos Jorge Almeida Santana

"La construcción en altura como una opción eficiente para la vivienda de interés social en grandes ciudades: tipología y costos, de salvador a buenos aires (1937 a 2017)".

Encuesta Tipo 7: “A la Coordinación del Proyecto (Empadronamiento y atención a familias en Proyecto de VIS en altura)"

Nombre del Proyecto:

Septiembre de 2014

Localidad:

Profesional encuestado/a:

Número de viviendas disponibles:

Fecha de la encuesta:

1 - Local de procedencia de los moradores:

2 - Tiempo de espera en media entre el empadronamiento y recibimiento de las llaves:

3 - Motivo principal asociado a la falta de vivienda para a obtención del inmueble:

4 - ¿Cuántas familias estuvieron empadronadas para la obtención de un inmueble de este Proyecto?

5 - ¿Cuáles son los principales criterios para la selección de las familias que obtuvieron el inmueble?

$6-$ ¿Qué propuestas fueron arregladas entre las partes involucradas en el Proyecto para que las personas no atendidas sean contempladas con un inmueble y cual el plazo previsto para esto? 
7 - Qué tipo de participación los moradores seleccionados del Proyecto tuvieron en éste? ninguna ( ) alguna ( ) suficiente ( ) mucha ( )

8 - Comente algo que entienda que sea importante sobre cómo se dio el acompañamiento/fiscalización, por parte de los moradores, en el proyecto y ejecución de las viviendas en general:

9 - ¿Hubo evaluación post-ocupación y en qué porcentaje de las viviendas construidas? ninguna ( ) alguna ( ) suficiente ( ) mucha ( )

10 - ¿Cuál la participación del/de la morador/a en la financiación del proprio inmueble? ninguna ( ) alguna ( ) suficiente ( ) mucha ( )

11 - ¿Qué porcentaje de los moradores seleccionados fue utilizada en la contratación para la construcción de las obras?

ninguno ( ) alguno ( ) suficiente ( ) mucha ( )

12 - ¿Cómo se dio la información y entrenamiento (se hubo) de los moradores cuanto a la prevención y al combate a incendios?

ninguna ( ) alguna ( ) suficiente ( ) mucha ( )

13 - ¿Cómo se dio la capacitación de los moradores para el ejercicio en la administración/comisión fiscal, del condominio?

ninguna ( ) alguna ( ) suficiente ( ) mucha ( )

14 - ¿Cómo se procesó la(s) actividad(es) con moradores sobre su capacitación para convivencia en viviendas colectivas (en los edificios en bloques)?

ninguna ( ) alguna ( ) suficiente ( ) mucha ( ) 
15 - ¿Cuáles las actividades que fueron desarrolladas visando a la capacitación profesional (cursos profesionales/instituciones fomentadoras ...) de los moradores?

ninguna ( ) alguna ( ) suficiente ( ) muchas ( )

16 - ¿Cuál/Cuáles de los equipamientos públicos adelante están lejos además de $1 \mathrm{~km}$ de la comunidad, estimativamente? escuela, guardería, comisaría, centro de salud y lugar de pagos:

$$
\text { ninguno ( ) alguno/algunos ( ) muchos ( ) todos ( ) }
$$

17 - ¿Hay en el Proyecto arquitectónico espacios destinados a la guarda (aparcamiento) de vehículos de trabajo de moradores (bicicletas, "coche" de ventas/de mano ...)?

ninguno ( ) alguno ( ) suficiente ( ) muchos ( )

18 - ¿Hay en el Proyecto espacios disponibles para actividades económicas a que sean exploradas por moradores en la comunidad?

ninguno ( ) alguno ( ) suficiente ( ) muchos ( )

19 - Comente sobre la existencia, en el Proyecto, de servicios públicos disponibles para la recreación y el entretenimiento: plaza, canchas deportivas, centro comunal, dentro de la comunidad:

$$
\text { ninguno ( ) alguno ( ) suficiente ( ) muchos ( ) }
$$

20 - ¿Hubo alguna actividad involucrada para la capacitación "ciudadana" (acceso/trámites en instituciones públicas: empresas de servicios (agua/cloacas, energía eléctrica, telefonía...), Justicia y Legislativo ...)?

ninguna ( ) alguna ( ) suficiente ( ) muchas ( )

21 - Comente sobre el desfaje de plazos entre el proyectado X ejecutado:

ninguno ( ) alguna ( ) suficiente ( ) mucho ( )

22 - Según su percepción, ¿cómo se dado la existencia de un potencial mercado inmobiliario informal, en el interior de la comunidad, con las nuevas viviendas?

ninguno ( ) alguno ( ) poco ( ) mucho ( ) 
23 - ¿En qué medida hubo alteración/cambio de la seguridad pública, en el interior de la comunidad, después de la ocupación de las nuevas viviendas?

$$
\text { ninguna ( ) alguna ( ) poca ( ) mucha ( ) }
$$

24 - ¿Cómo ocurrió /ha sido el trámite de la regularización del lote (del predio) y del inmueble habitacional del/de la morador/a?

$$
\text { ninguno ( ) poco ( ) suficiente ( ) muy satisfactorio ( ) }
$$

25 - ¿Cómo ha sido la aplicación, en las nuevas viviendas, de la tarifa social junto a servicios de prestadoras "públicas": energía, agua y teléfono?

ninguna ( ) alguna ( ) suficiente ( ) mucha ( )

26 - ¿Qué tipo de influencia hubo/hay de la Canasta básica (social), y correlatos, delante de la población adquirente de las VIS, en el Proyecto?

ninguna ( ) alguna ( ) poca ( ) mucha ( )

27 - ¿Cómo se dio la relación entre la población de los alrededores y los moradores de las nuevas VIS en la comunidad?

$$
\text { ninguna ( ) alguna ( ) poca ( ) mucha ( ) }
$$

28 - ¿Cuáles son los 5 ítems del Proyecto que, según es de su conocimiento, fueron los más elogiados por los moradores/as y, cuales son los 5 más criticados?

29 Presente en lo general, a su ver, 5 aspectos positivos (avanzos) y 5 negativos (permanencias, o incluso retrocesos), se posible con JUSTIFICATIVAS, sobre el Proyecto ejecutado: 


\section{ÍNDICE DE LAS PLANTAS ARQUITECTÔNICAS}

\section{1 - COMUNIDADES DE ARGENTINAS}

1.1 - Parque Patricios/Monteagudo: Planta tipo 422

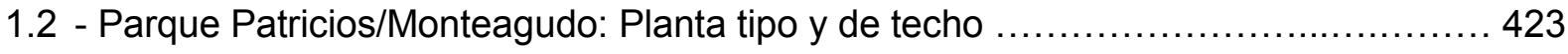

1.3 - Parque Patricios/Monteagudo: Planta tipo, baja y de techo ........................... 424

1.4 - Parque Patricios/Monteagudo: Planta vistas y cortes ............................ 425

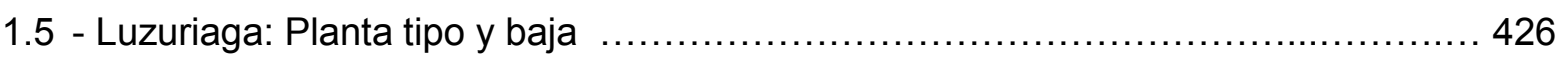

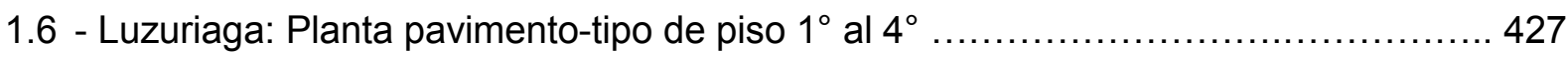

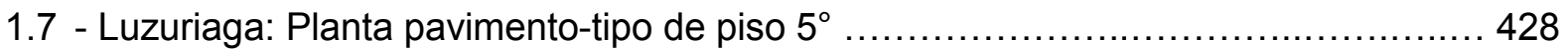

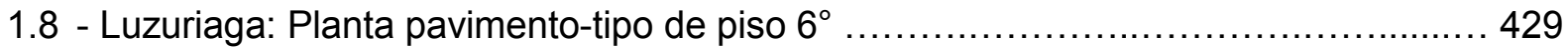

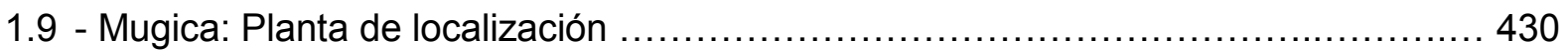

1.10 - Mugica: Planta de fachadas (principal y lateral), de eléctrica, de escalera y tipo . 431

1.11 - Mugica: Planta de cobertura (techo) ....................................... 432

1.12 Mugica: Planta tipo de $\operatorname{dept}^{\circ}$, de detalles (cocina y baños) y de eléctrica ............433

2 - COMUNIDADES DE BRASIL

2.1 - Paraíso Azul: Planta tipo y baja, de los pisos, de techo y de agua ..................... 434

2.2 - Paraíso Azul: Planta tipo y baja, de los pisos ......................................... 435

2.3 - Paraíso Azul: Planta tipo y baja, de eléctrica ........................................ 436

2.4 - Paraíso Azul: Planta de cloaca y detalle ......................................... 437

2.5 - Paraíso Azul: Planta de telefonía .............................................. 438

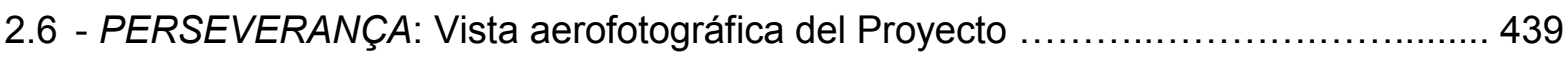

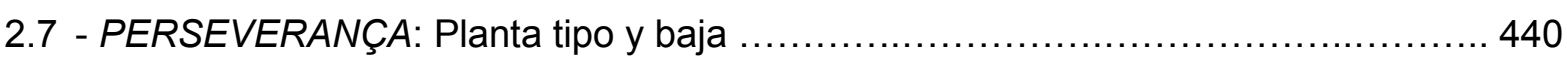

2.8 - PERSEVERANÇA: Planta tipo de cloaca ........................................ 441

2.9 - PERSEVERANÇA: Planta tipo de hidráulica ....................................... 442

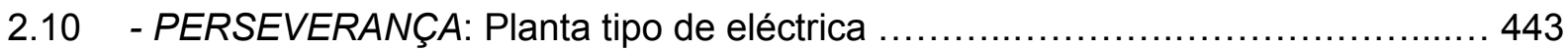

2.11 - 27 de Abril: Planta de situación y opciones de cierre del Condominio ............... 444

$2.12-27$ de Abril: Planta tipo, baja y techo ............................................. 445

$2.13-27$ de Abril: Planta de cortes A-A y B-B ........................................... 446

$2.14 \quad-27$ de Abril: Planta de vistas frontal y lateral ................................... 447

2.15 - 27 de Abril: Planta de guardería (planta baja, de cortes y vistas) ................. 448 


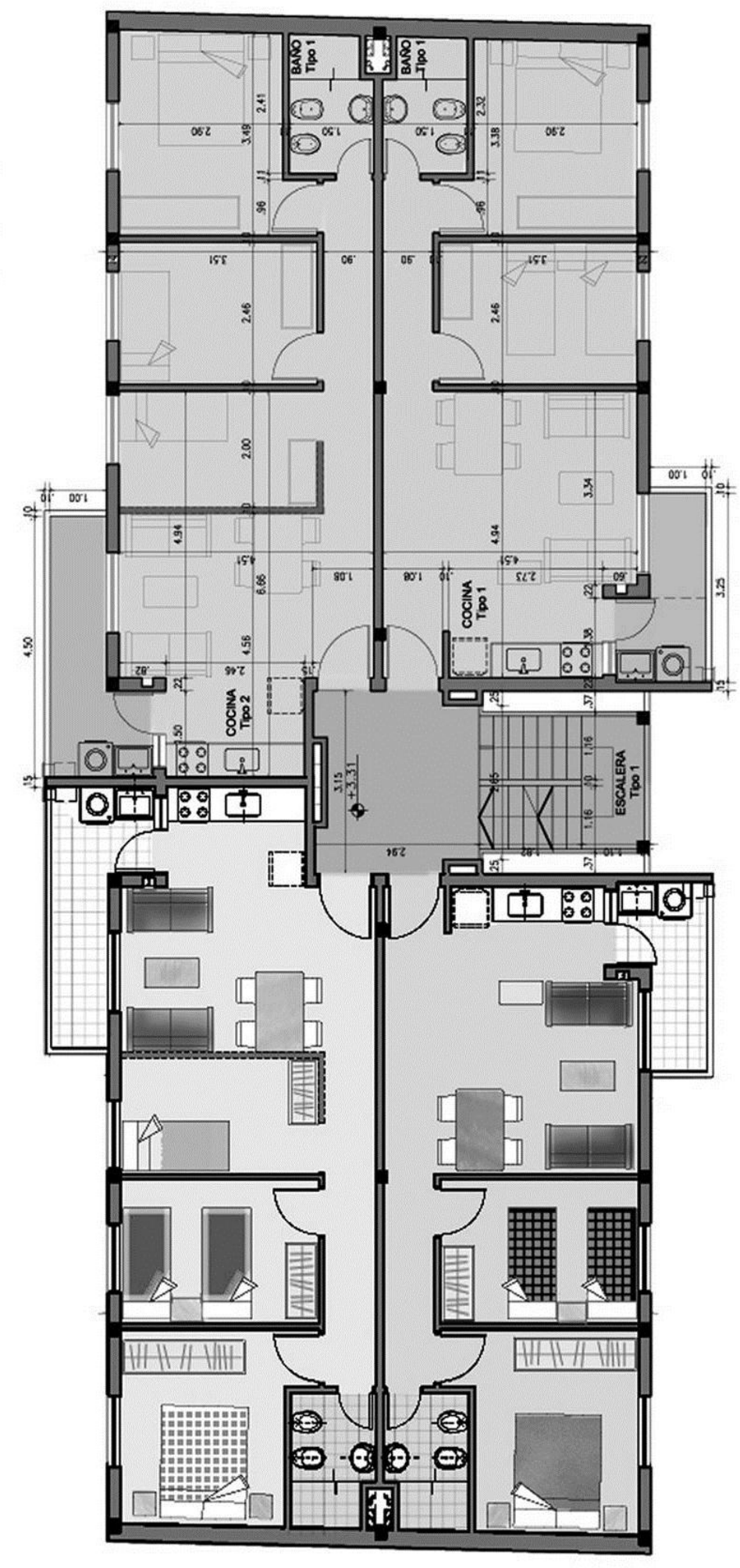

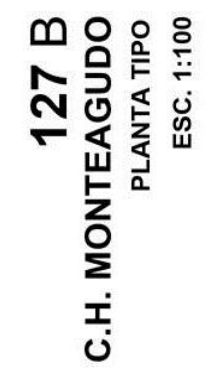




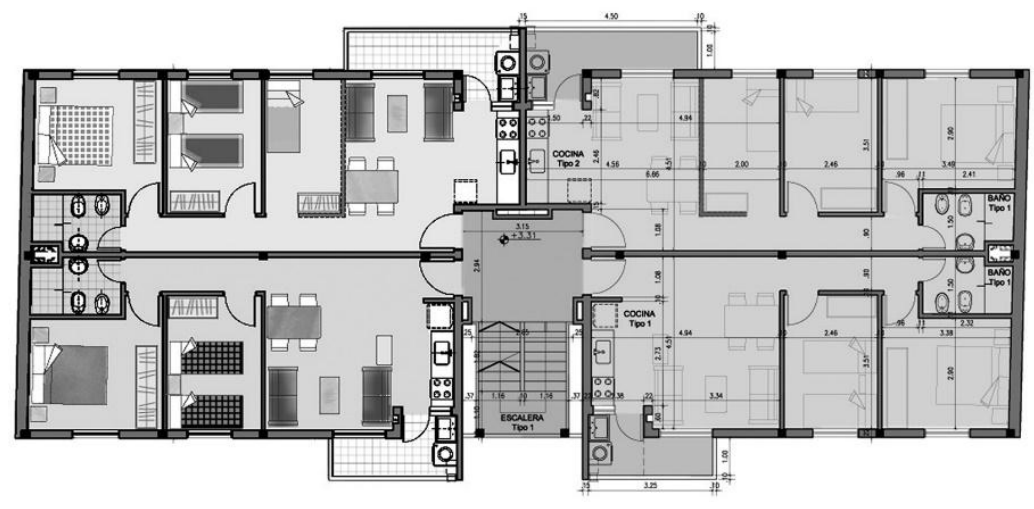

$127 \mathrm{~B}$

PLANTA TIPO

ESC. 1:100

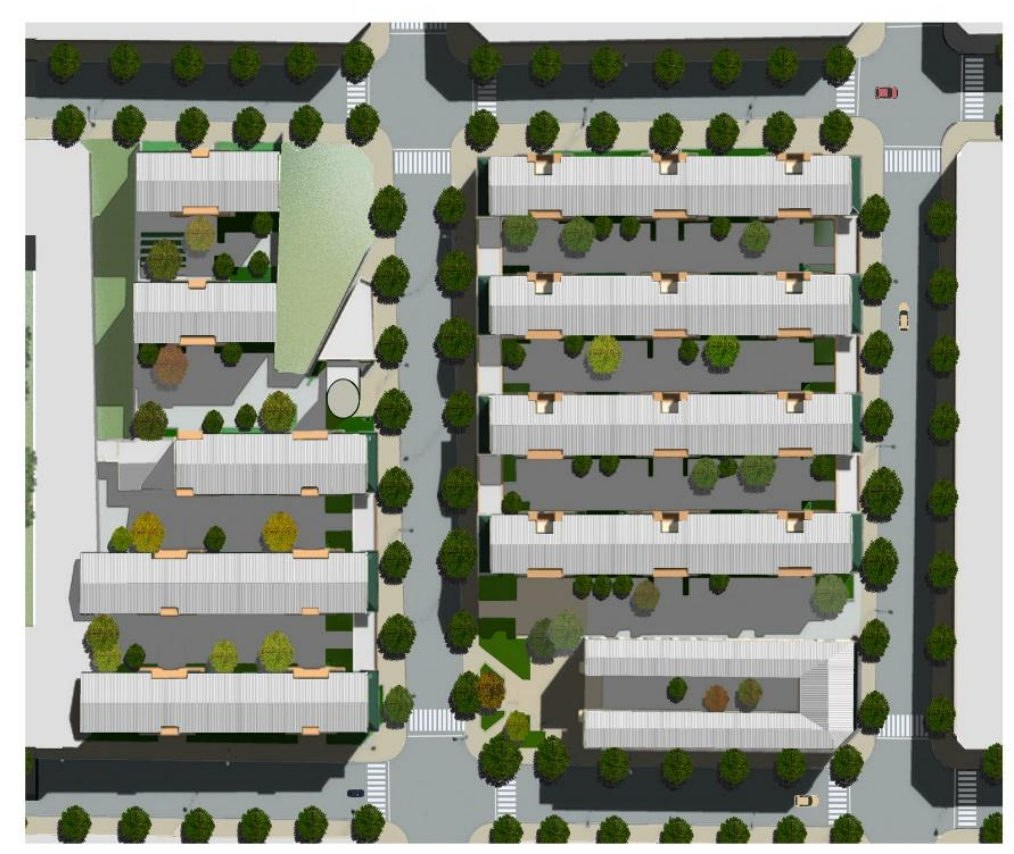

$127 \mathrm{~B}$

PLANTA TECHOS

ESC. $1: 750$ 


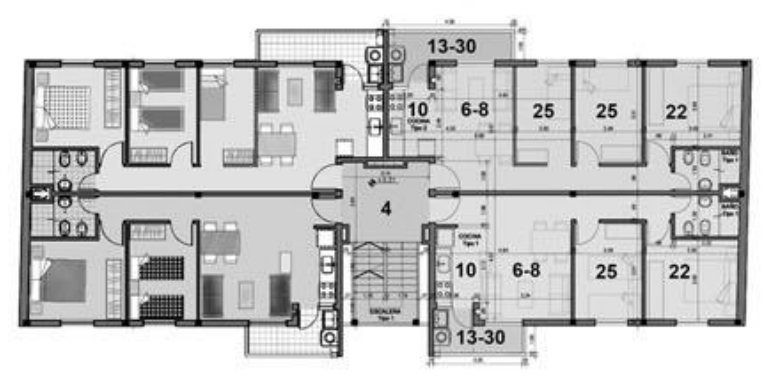

c.Mmorrenavoo -
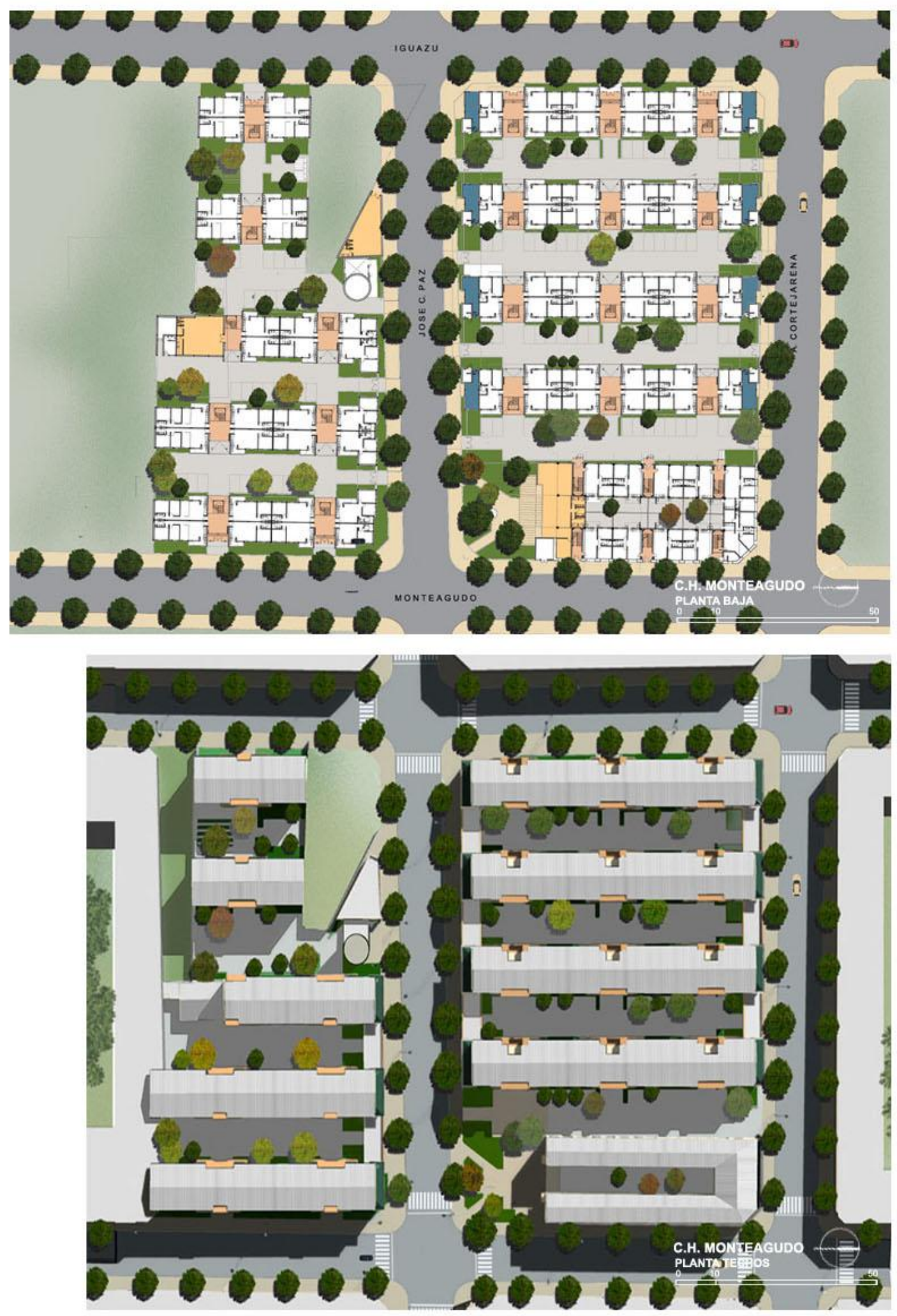

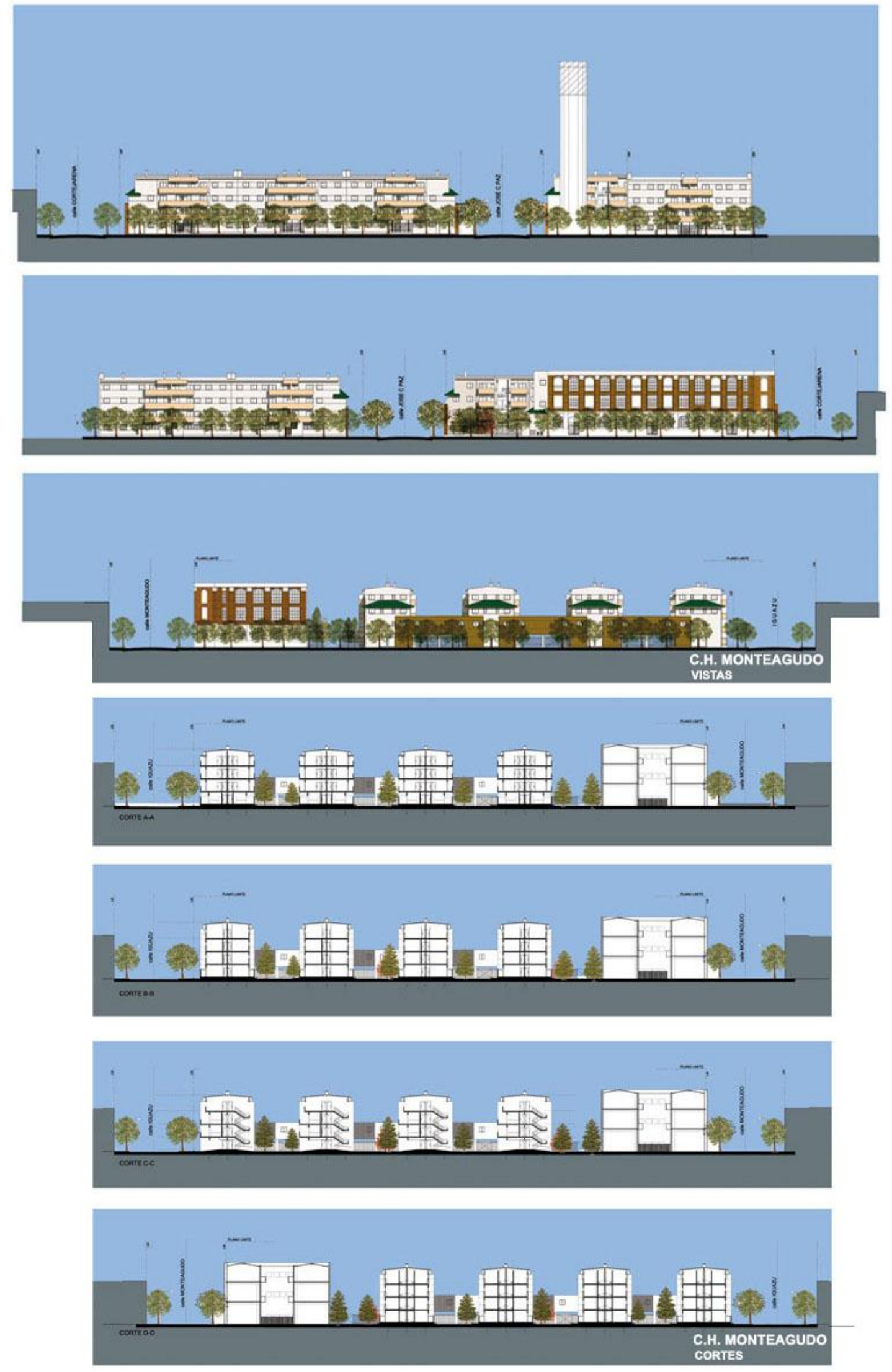


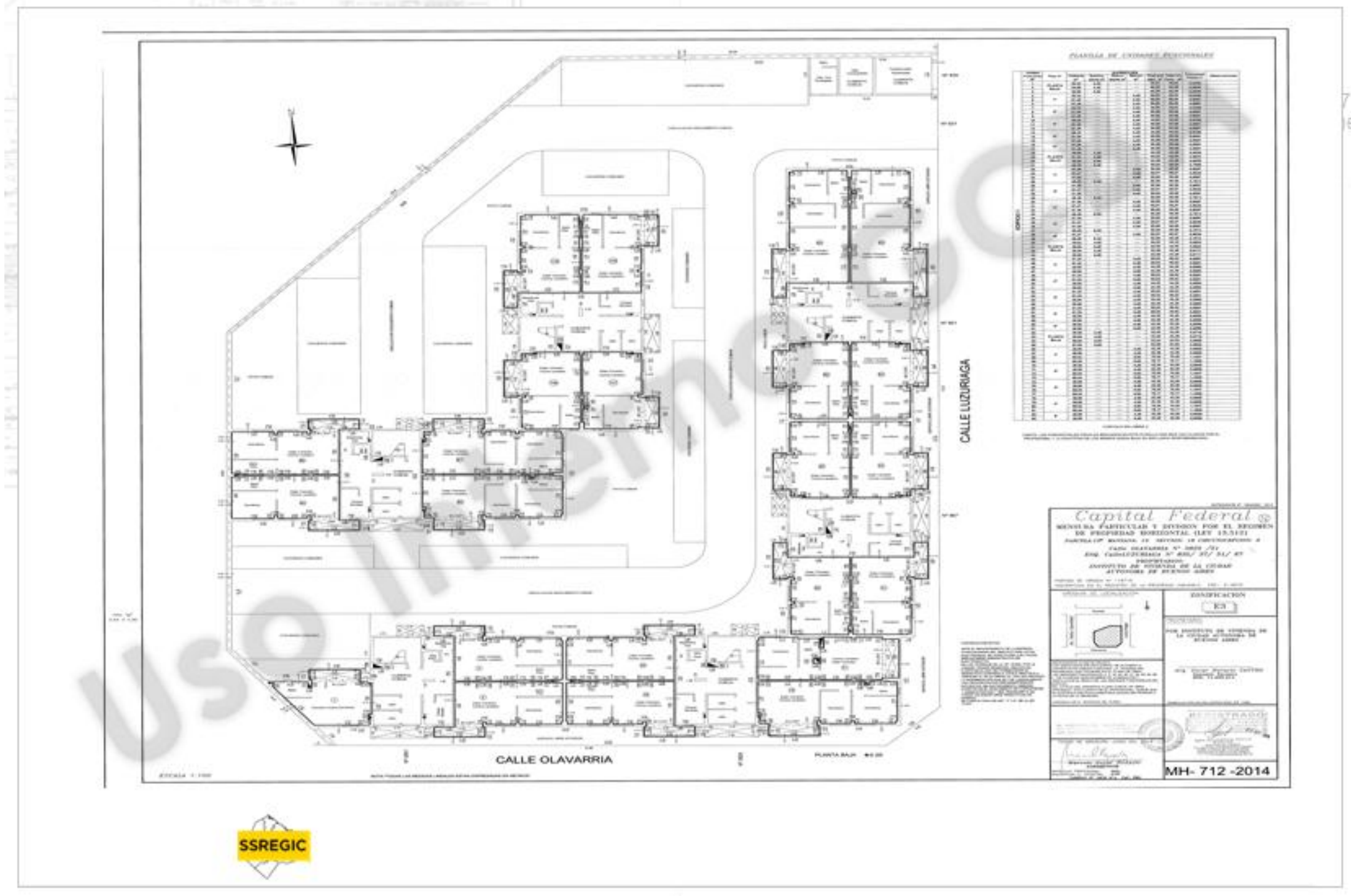




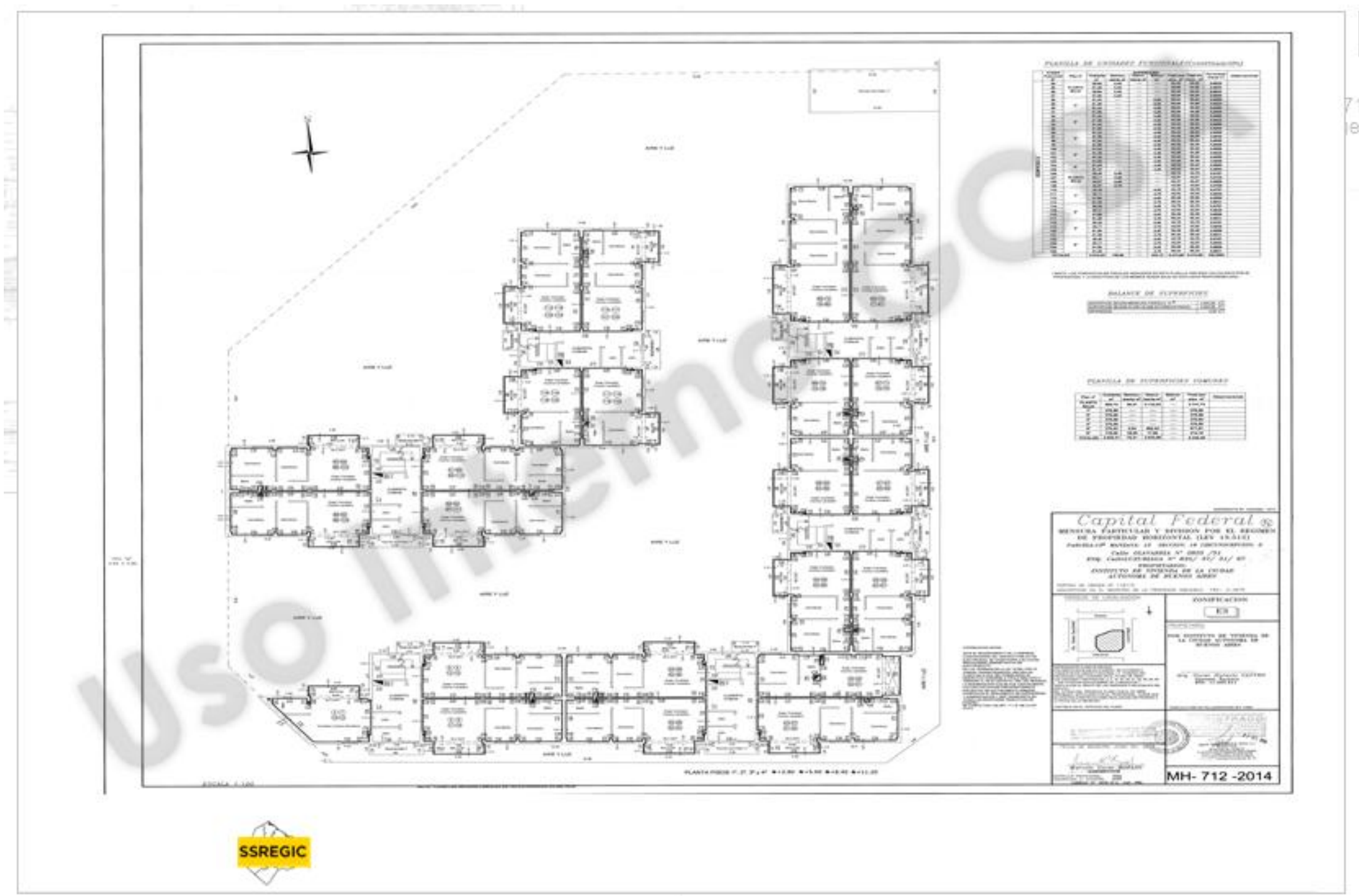




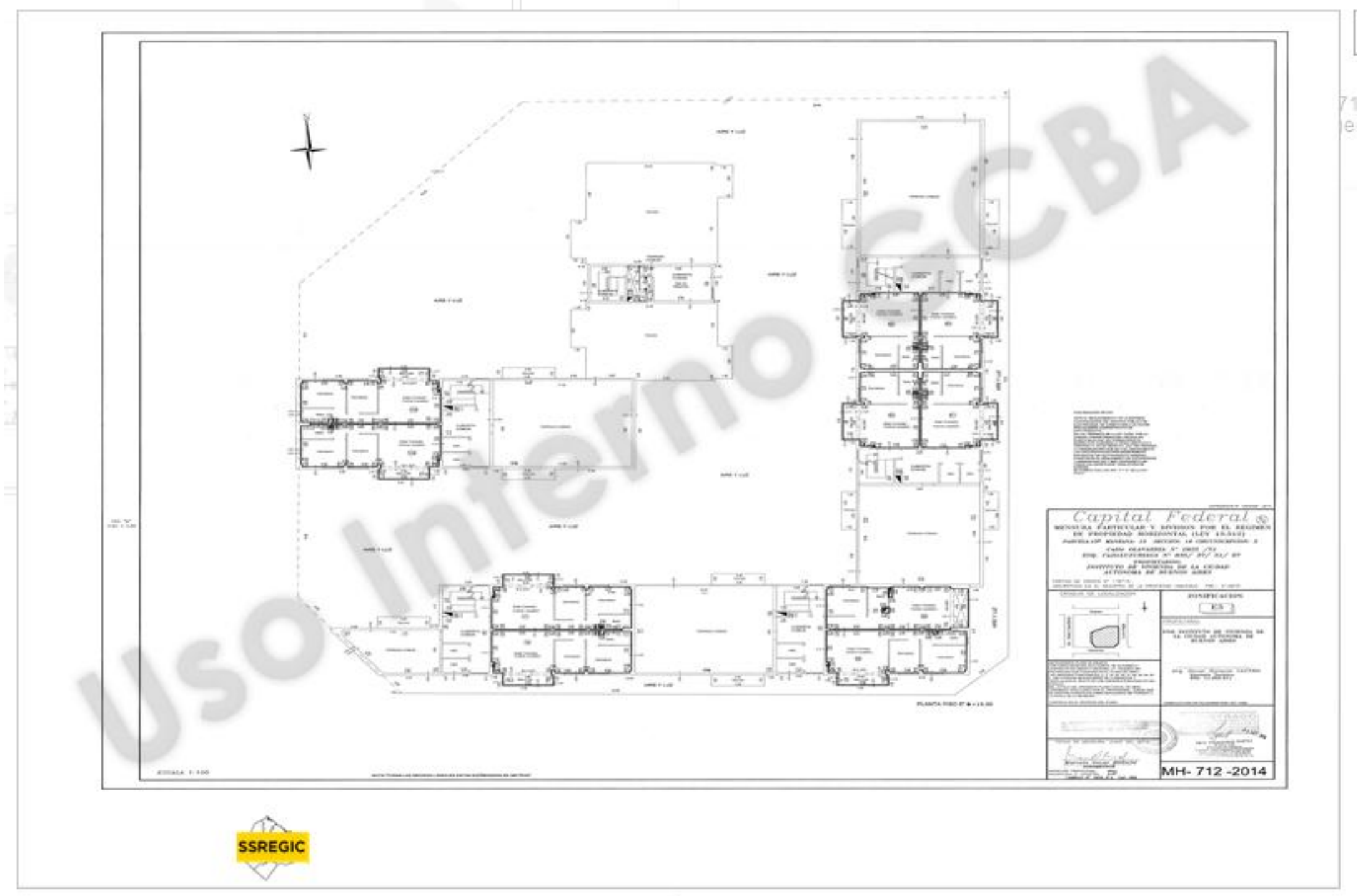




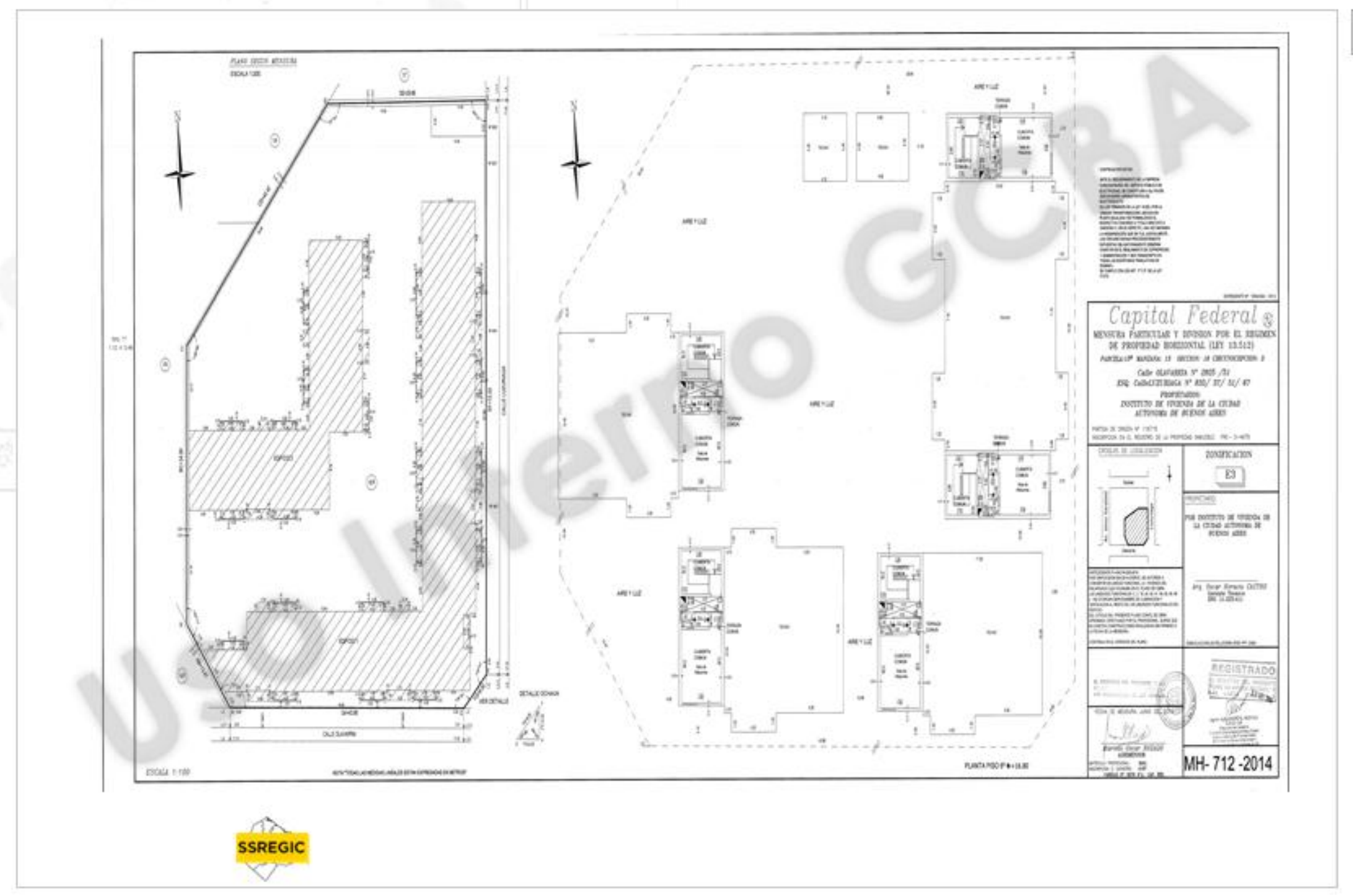




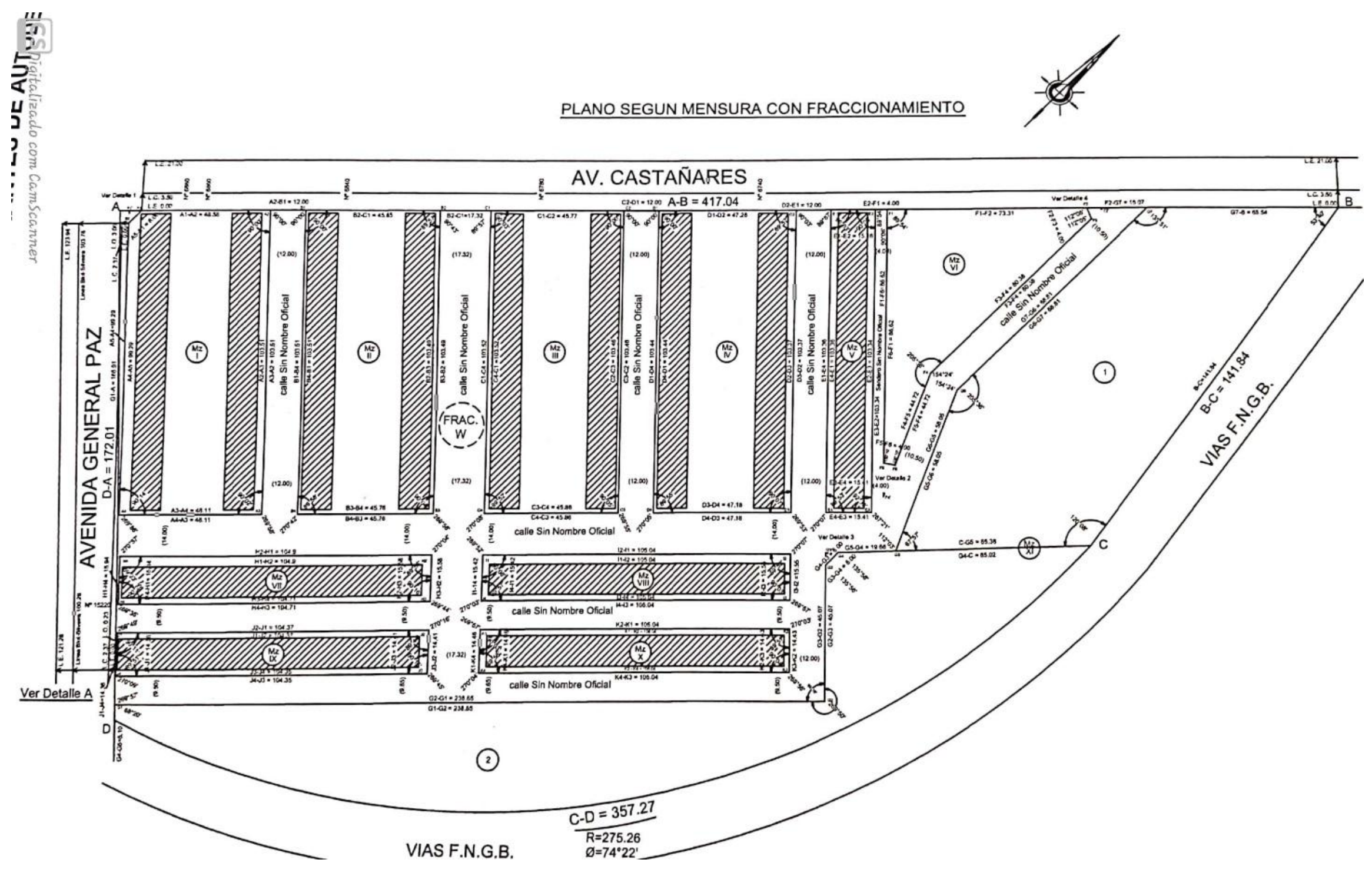




\section{int}

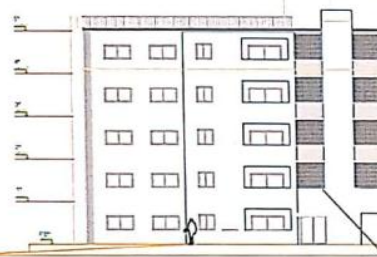

$-1$

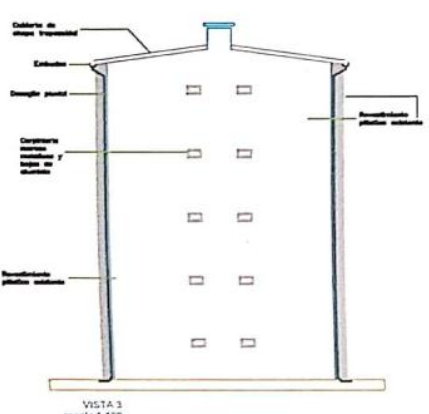

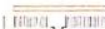

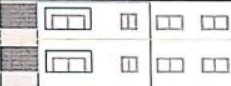

四口回

प⿴囗十丁口卄

四

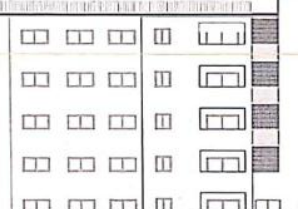

ㅁ口回四圆

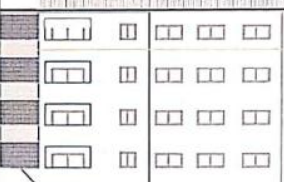

एव

$=$

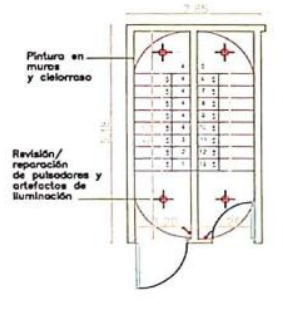

canbersentem ind

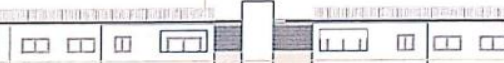
밈ㅁ물

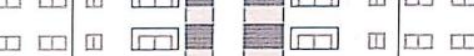

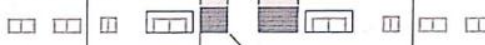
का एण $\square \square \square$ $==$

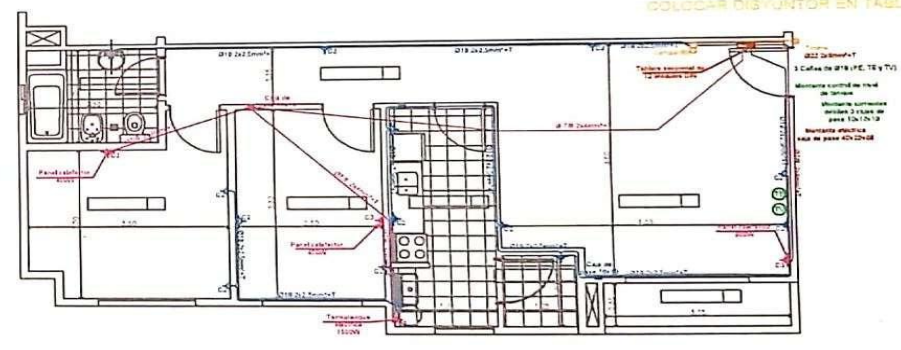



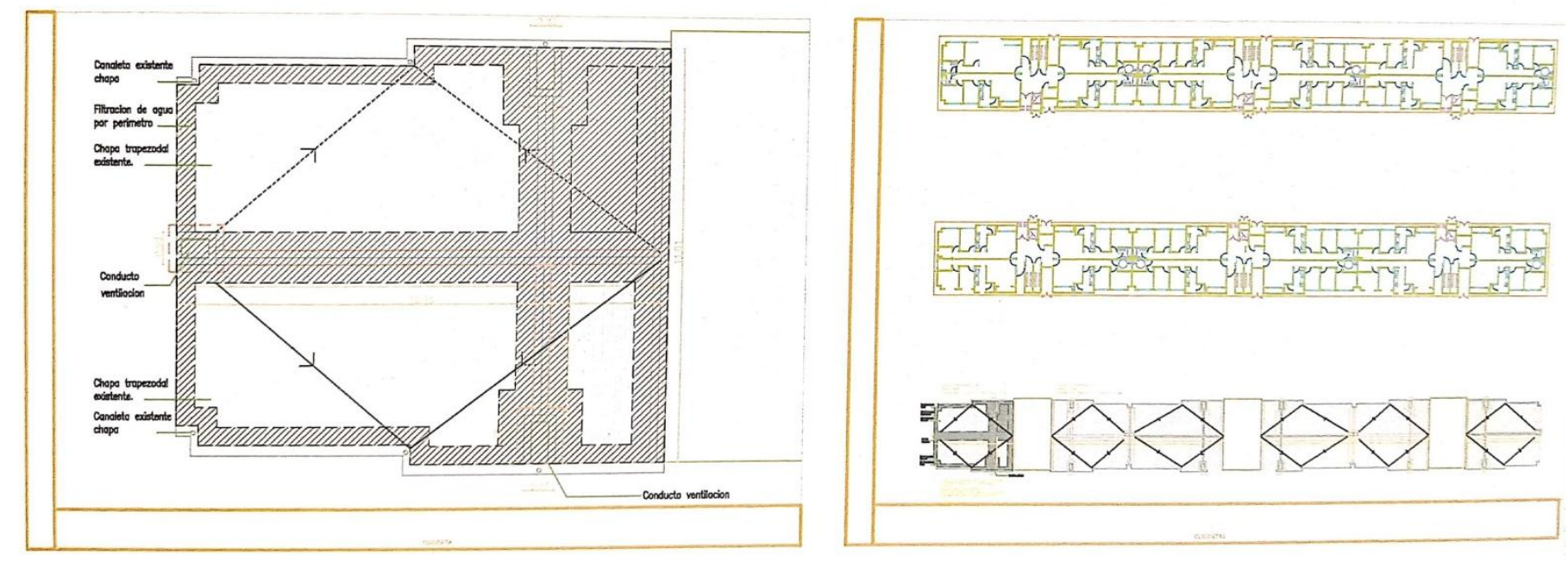

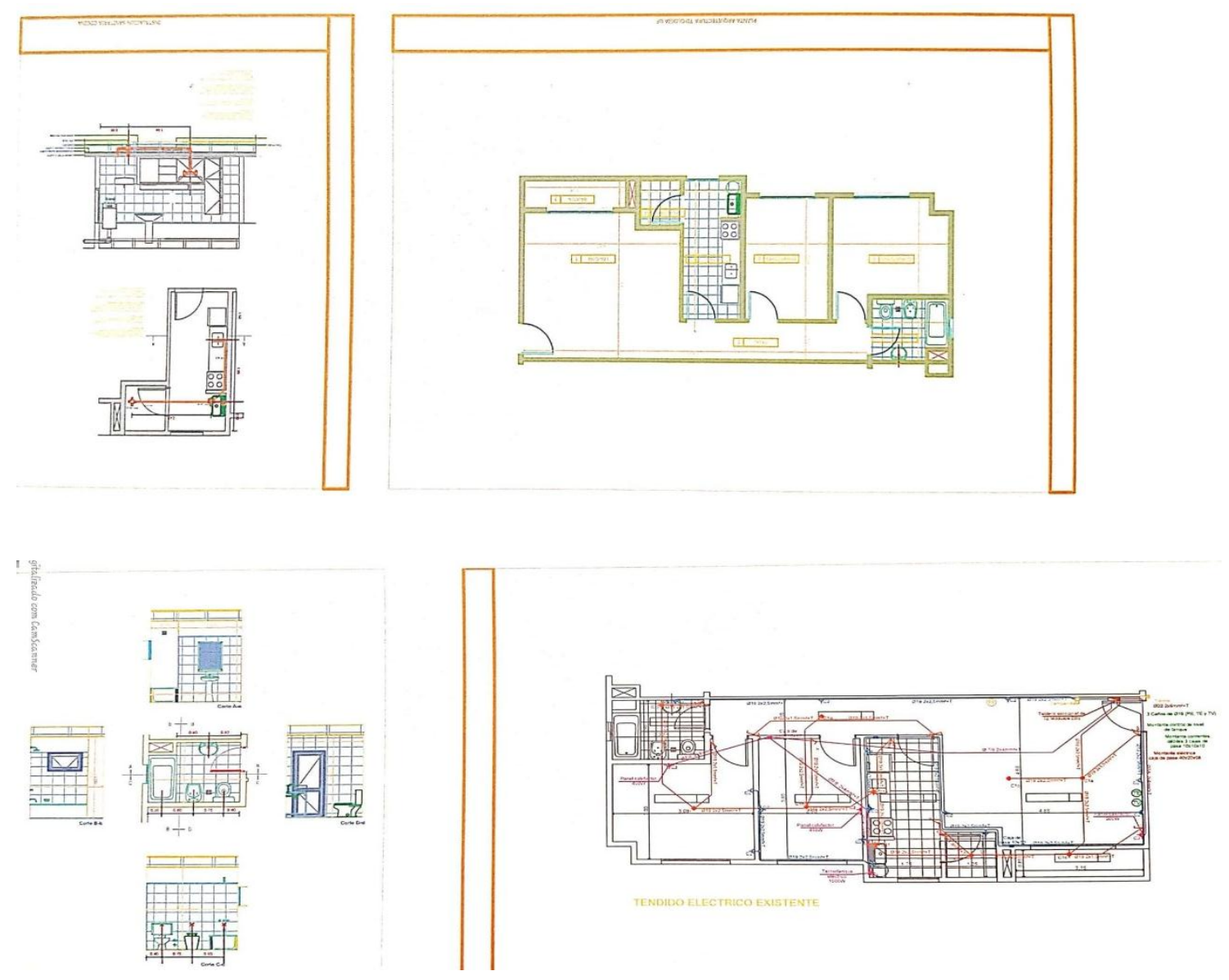

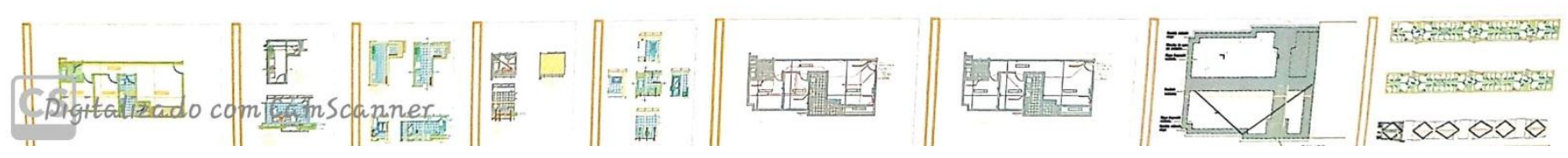



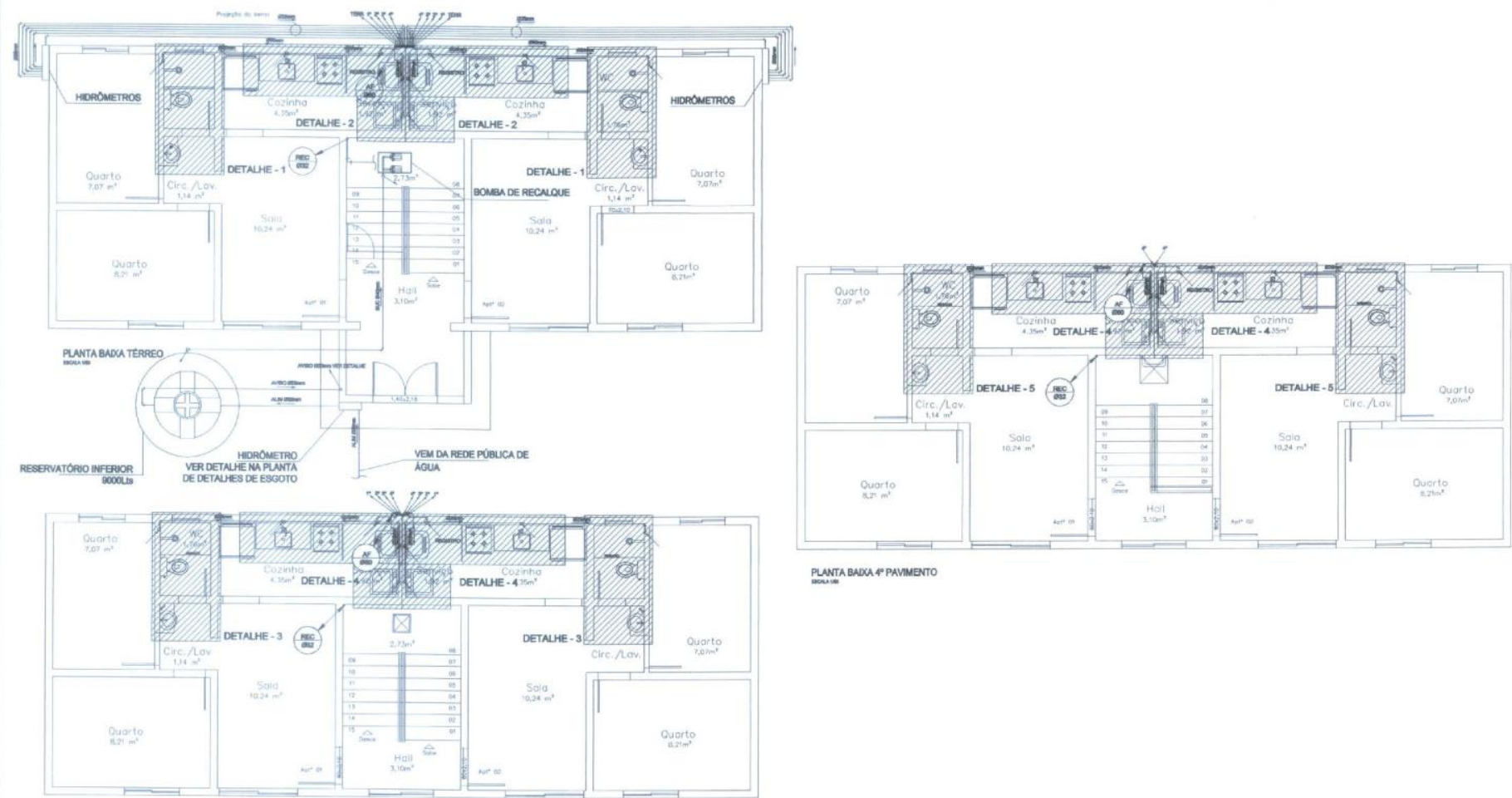

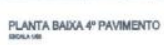

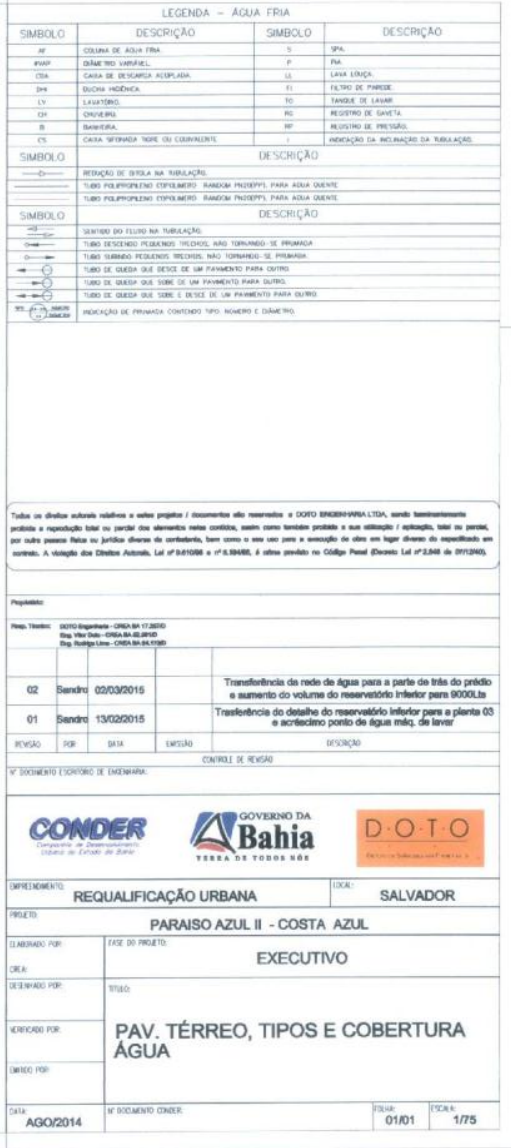




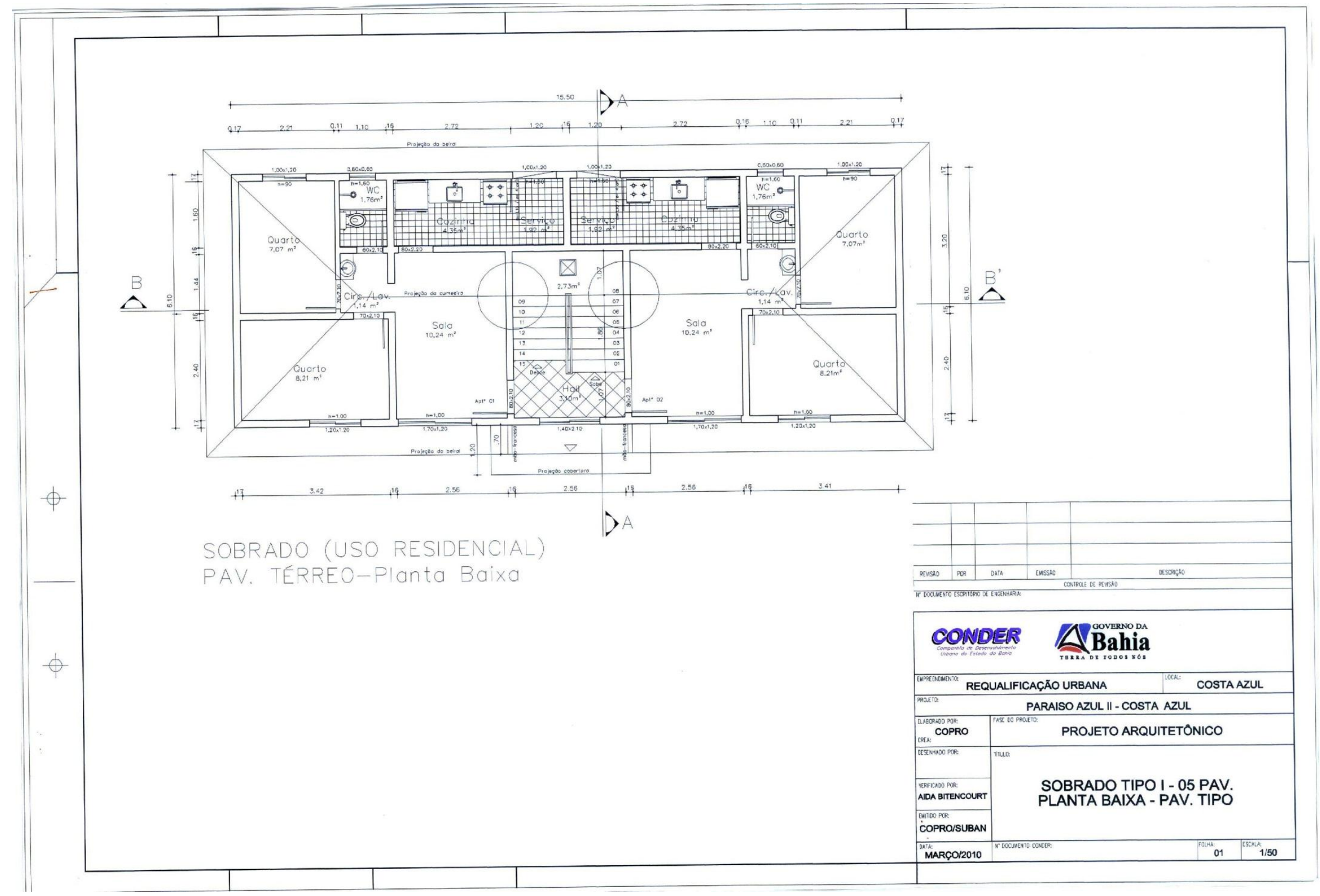



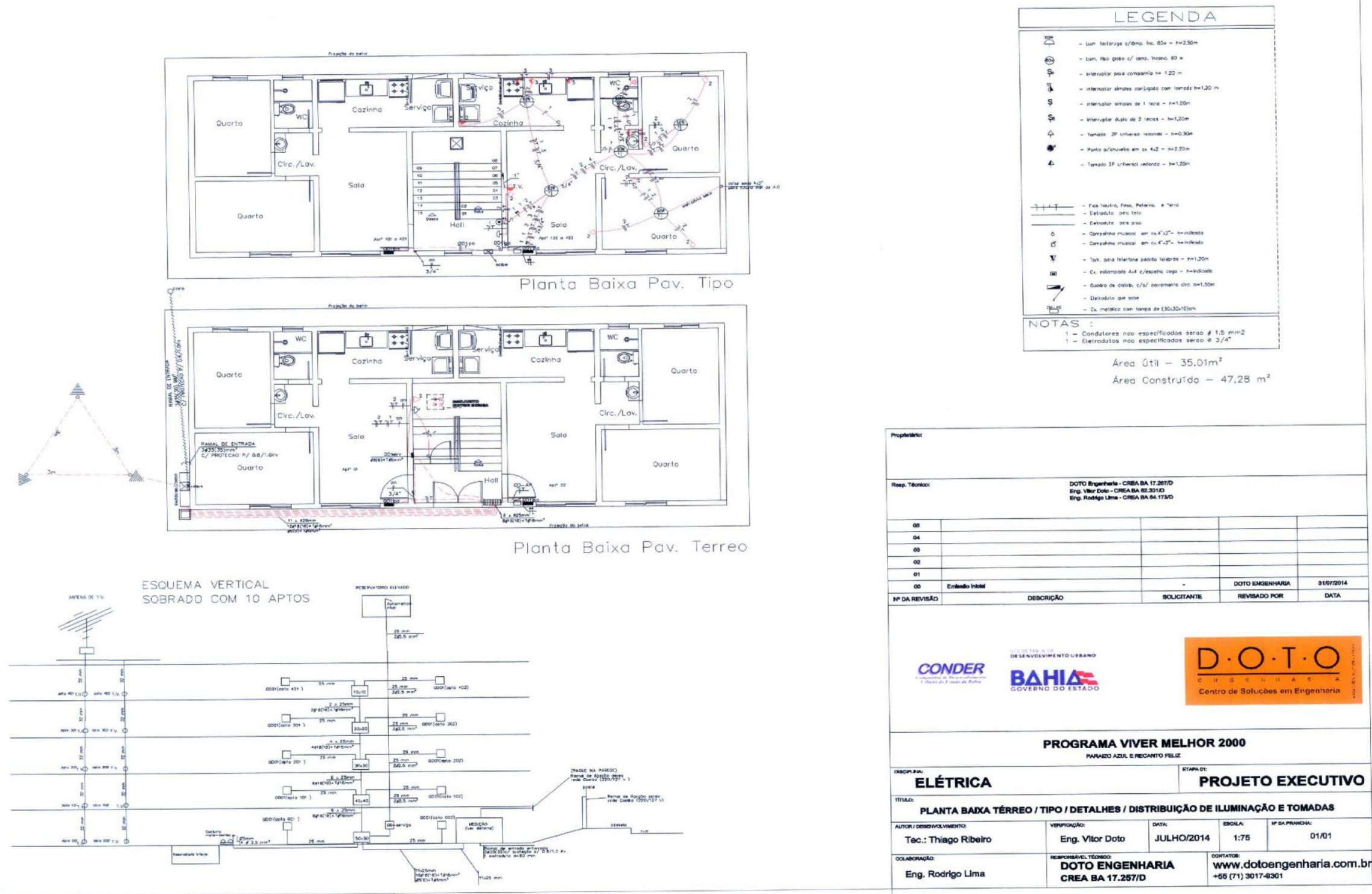

\begin{tabular}{|c|c|c|c|c|}
\hline \multicolumn{5}{|c|}{ 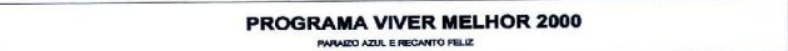 } \\
\hline ELÉTRICA & & \multicolumn{3}{|c|}{ PROJETO EXECUTIVO } \\
\hline \multicolumn{5}{|c|}{ PLANTA BADXA TERREO / TIPO / DETALHES / DISTRRBBUIGAO DE ILUMINAGAO E TOMADAS } \\
\hline Toc: Thago Ribero & Eng. Vitor Doto & mik & mat & ${ }_{0101}$ \\
\hline Eng. Rodrigo Lima & \multicolumn{2}{|c|}{$\begin{array}{l}\text { DOTO ENGENHARIA } \\
\text { CREA BA 17.257ID }\end{array}$} & \multicolumn{2}{|c|}{ 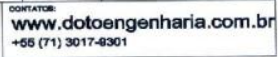 } \\
\hline
\end{tabular}




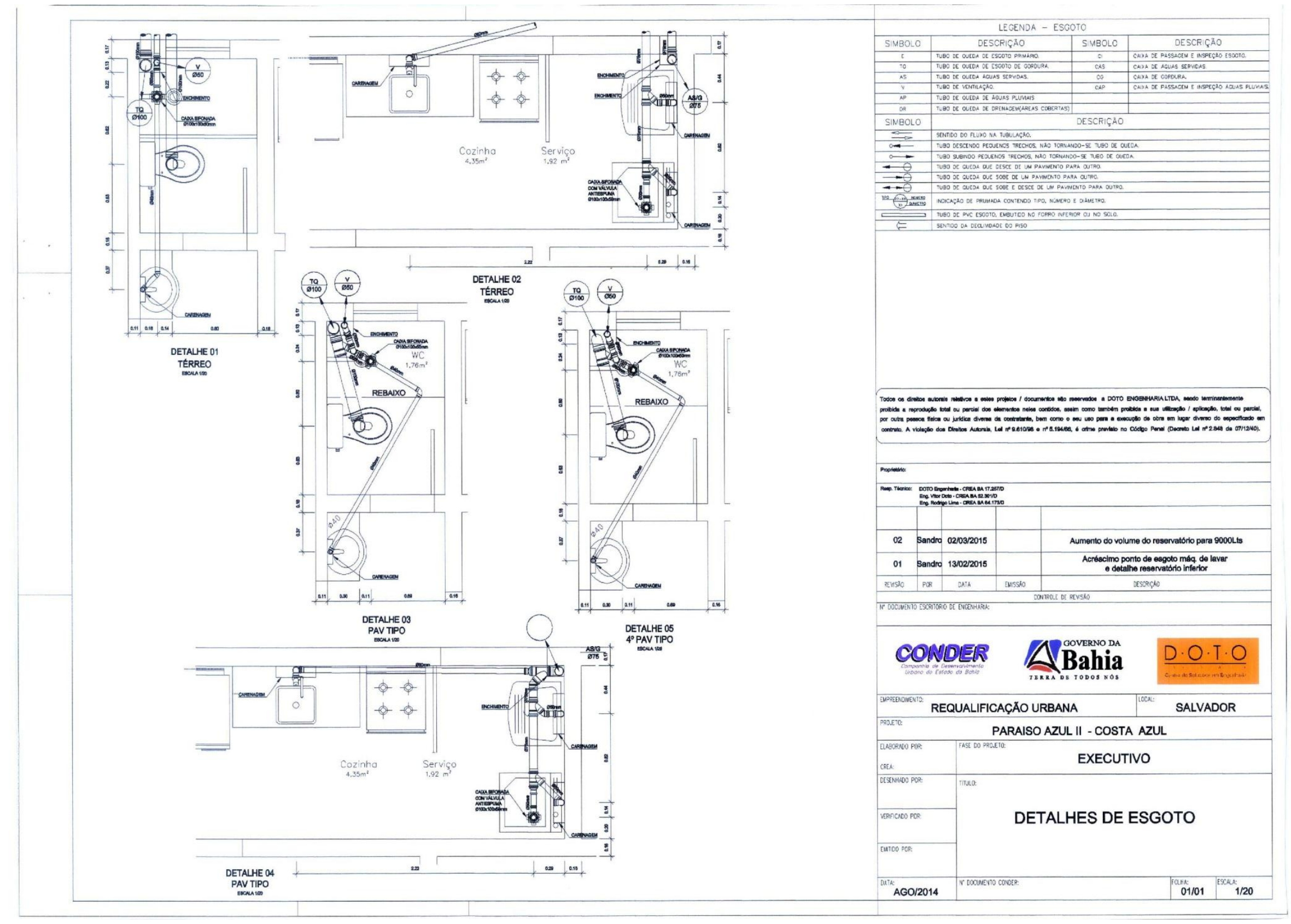




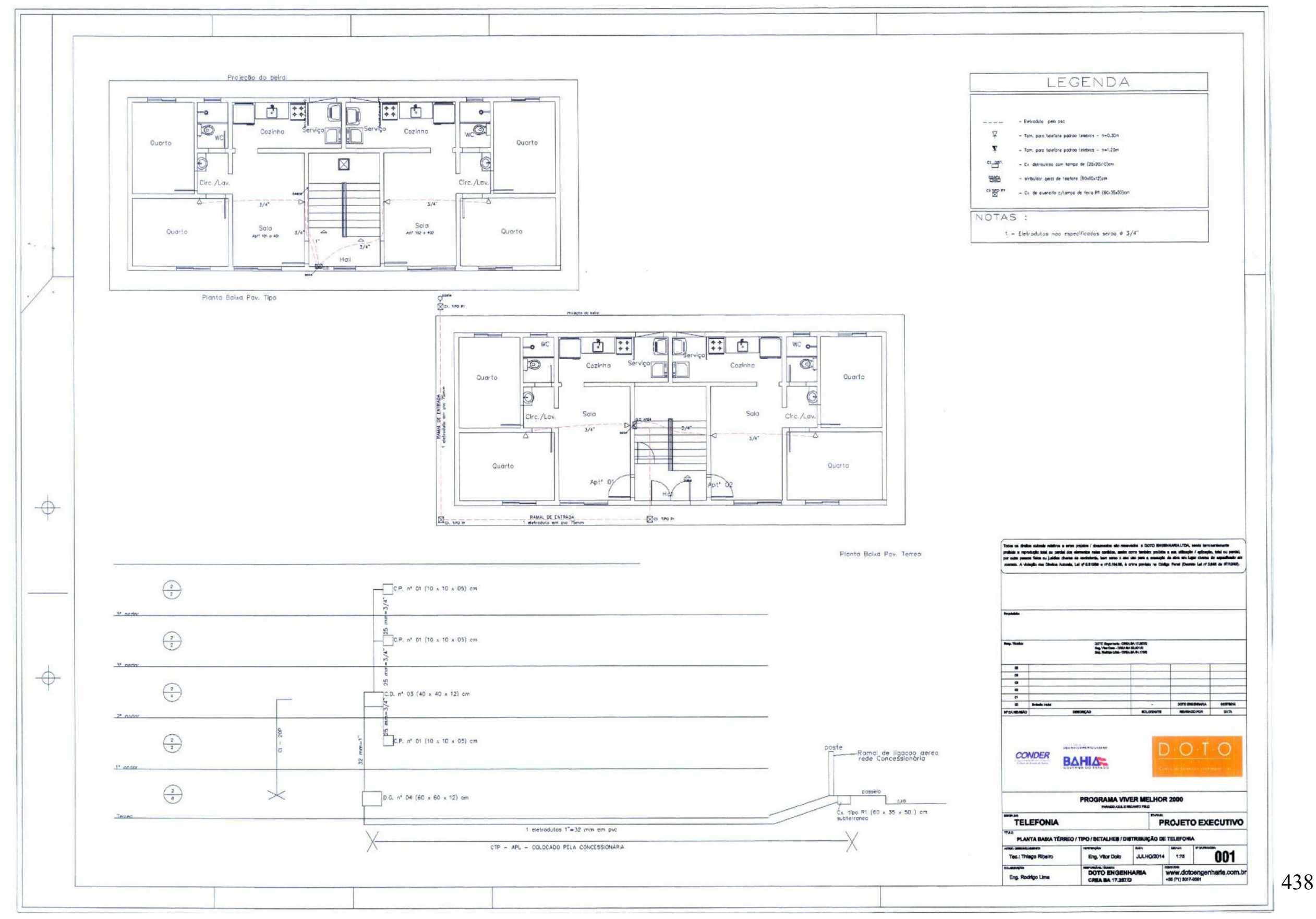




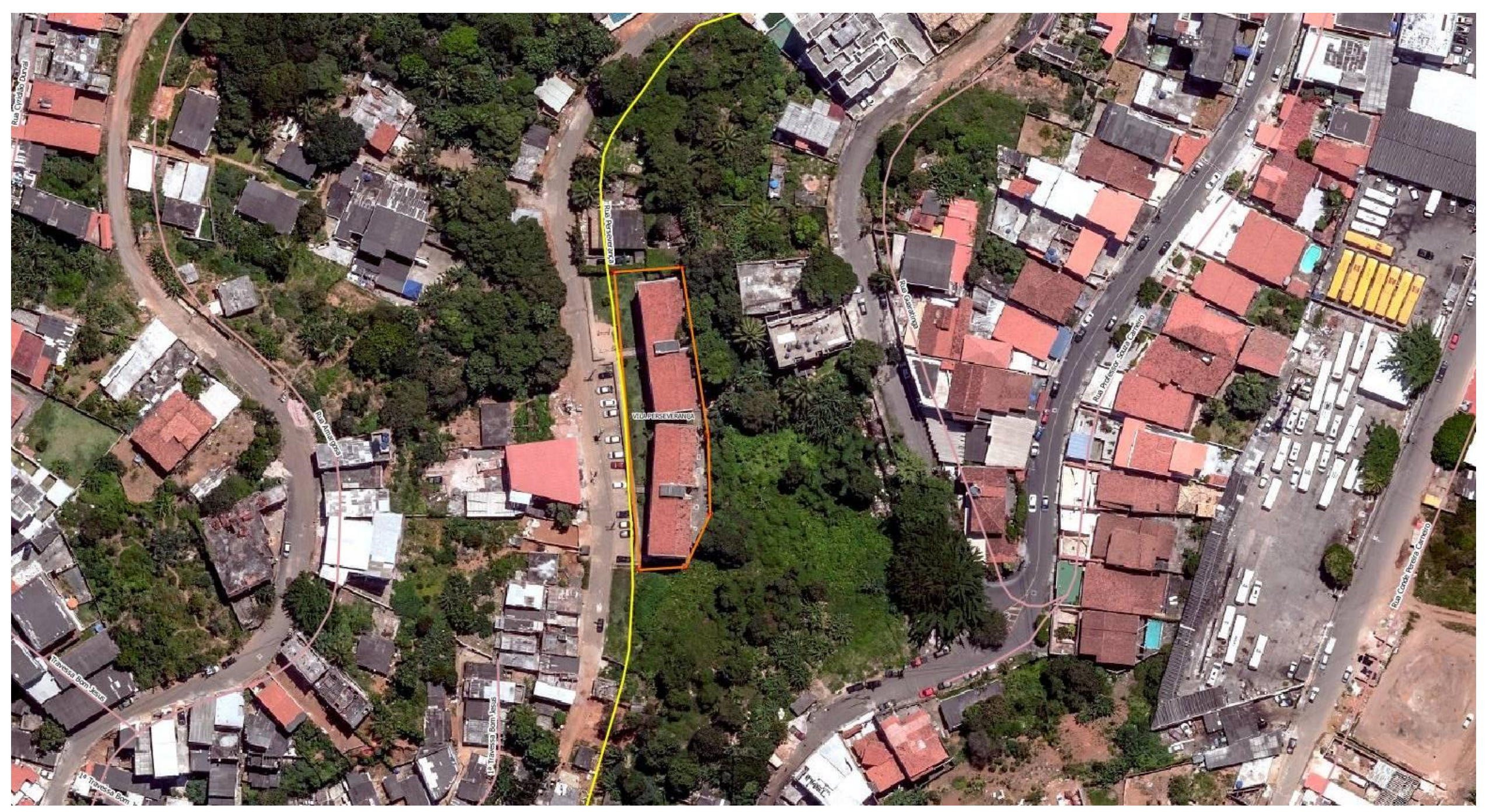




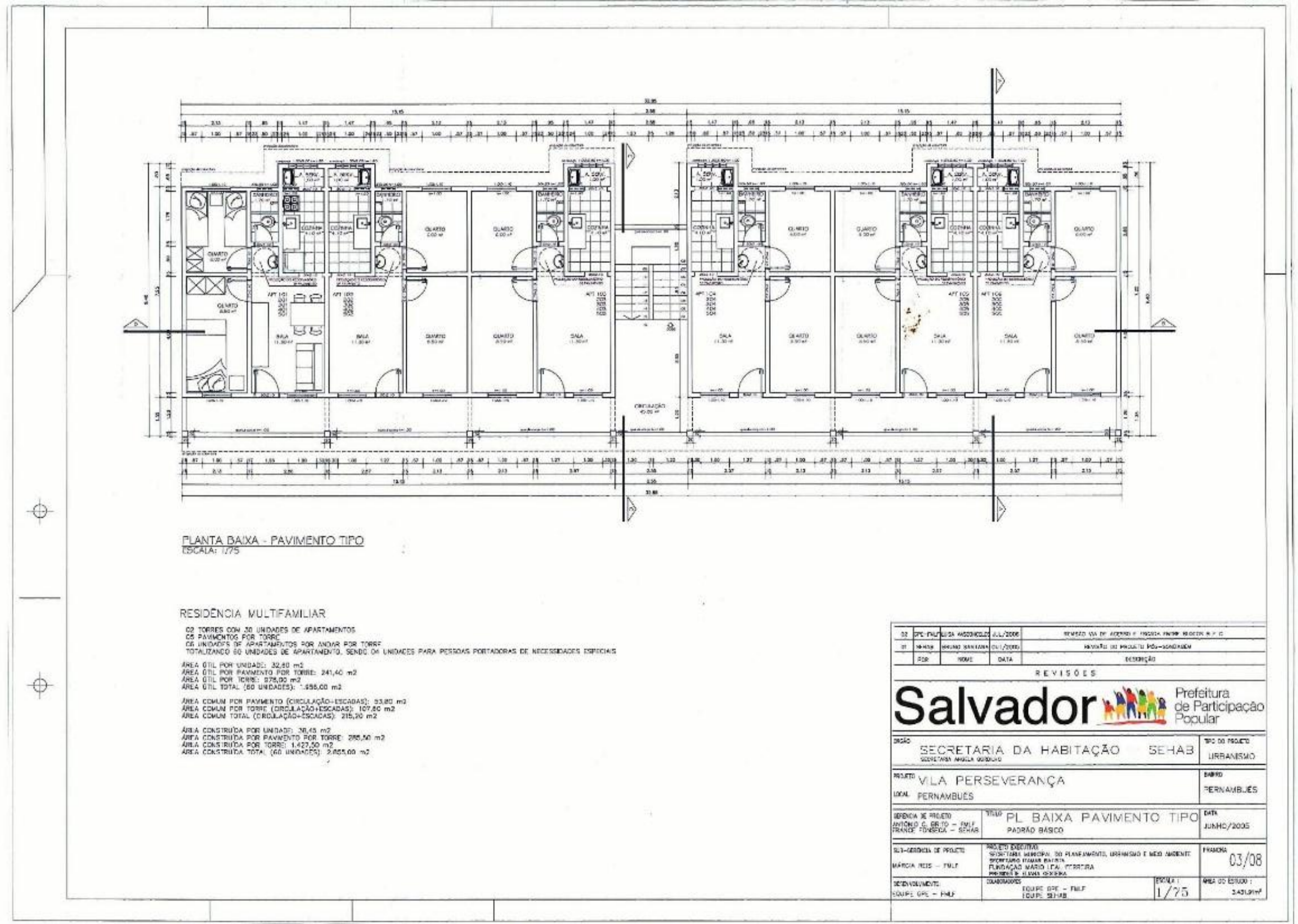




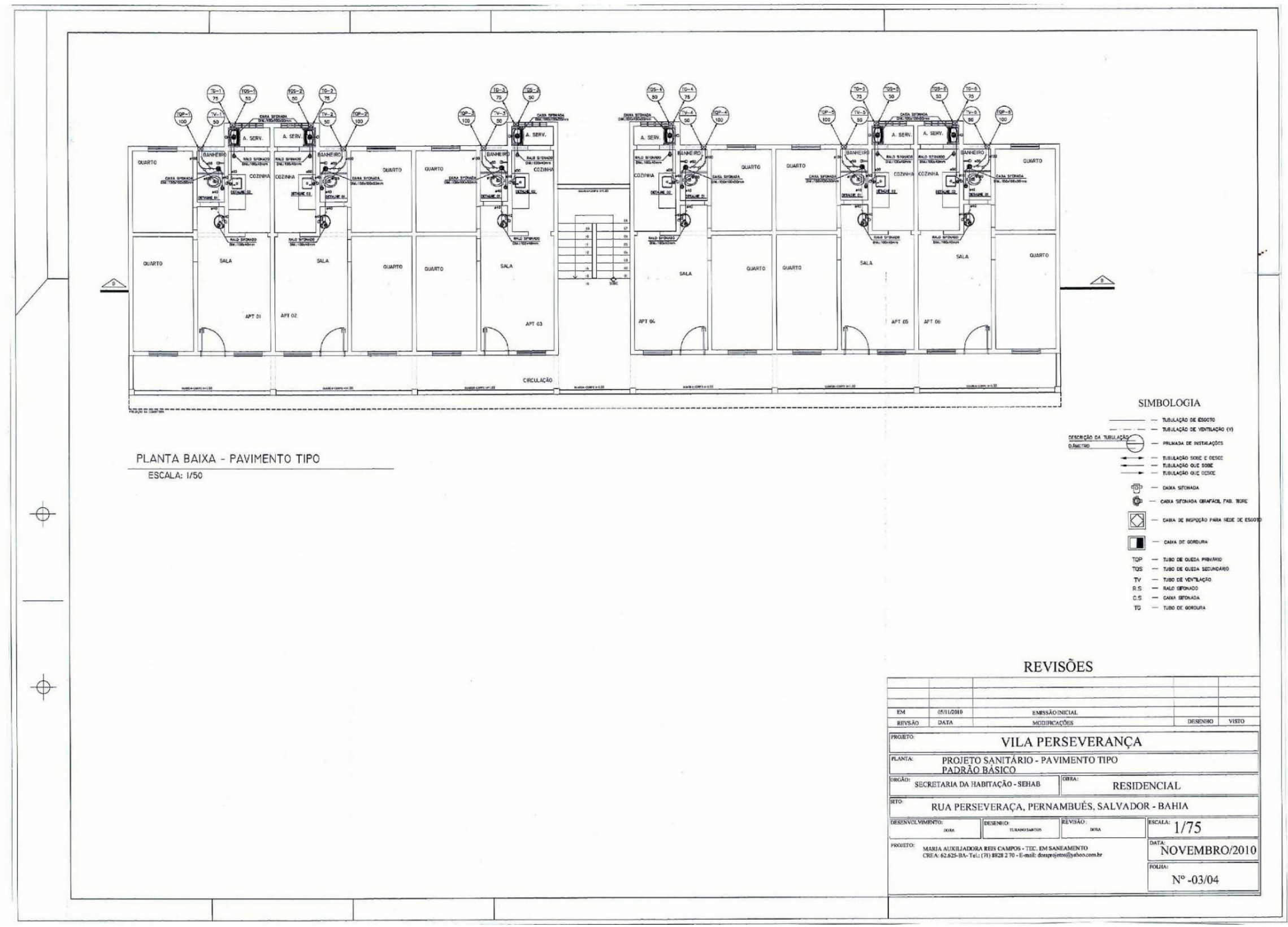




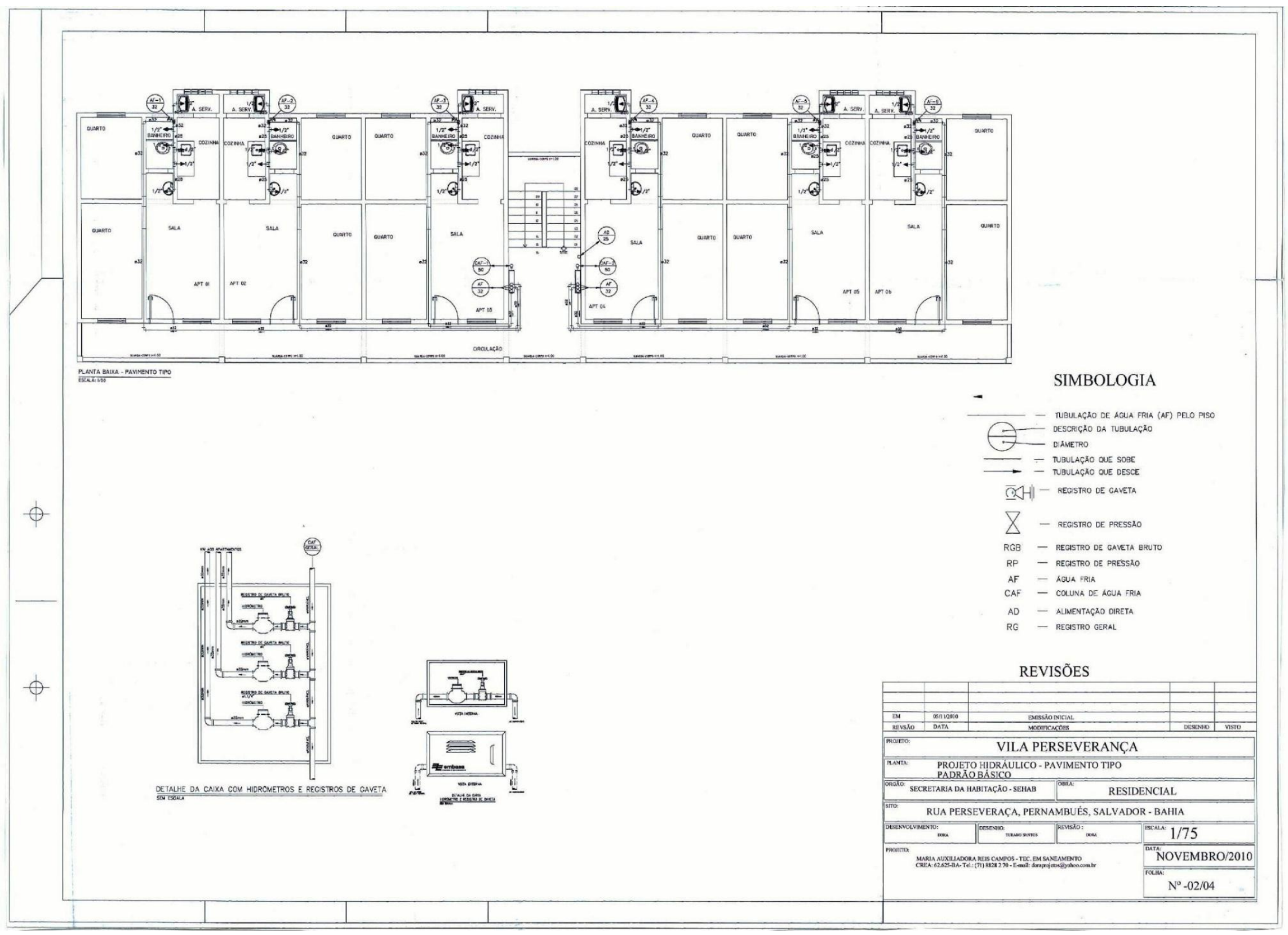




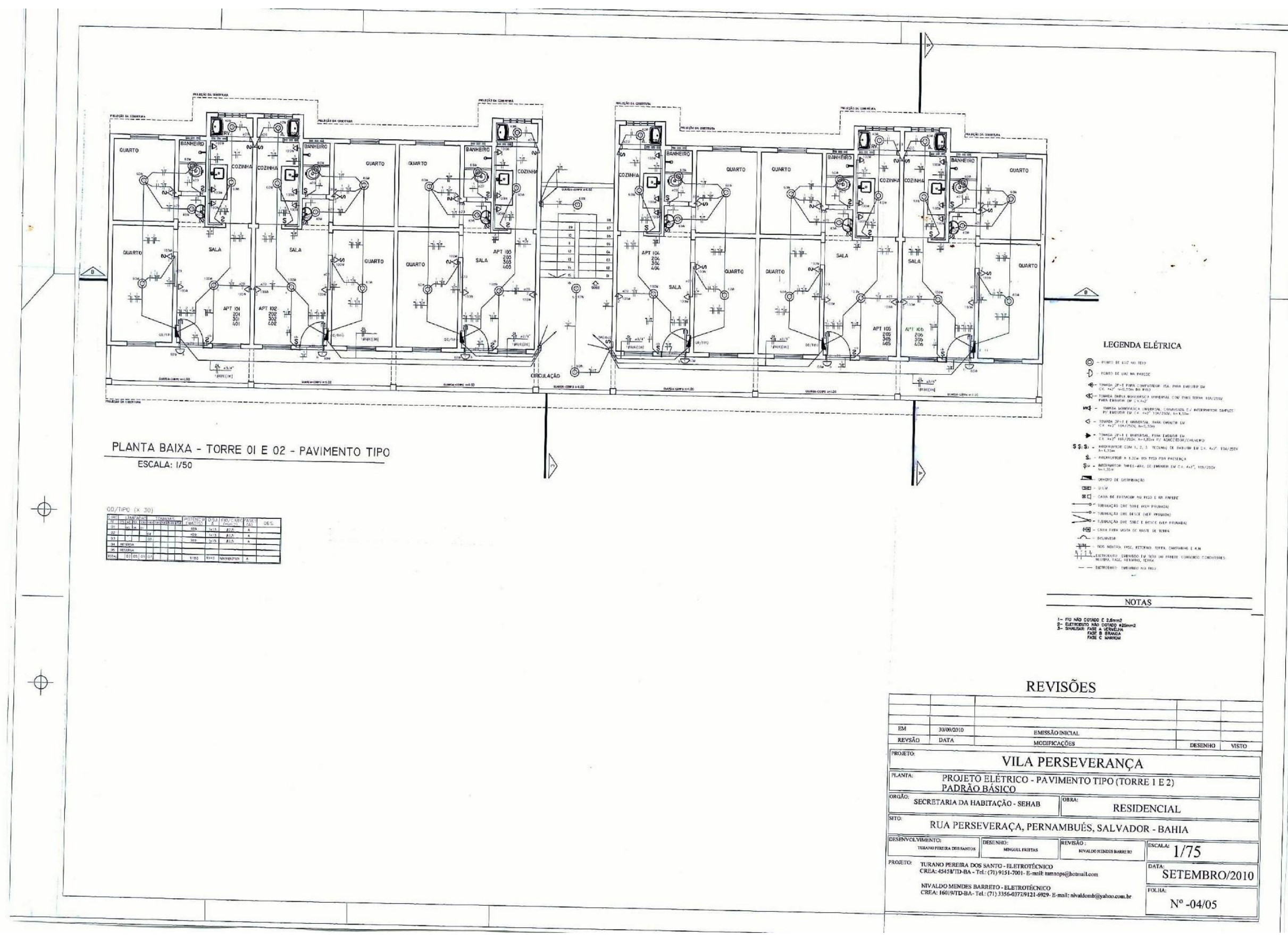




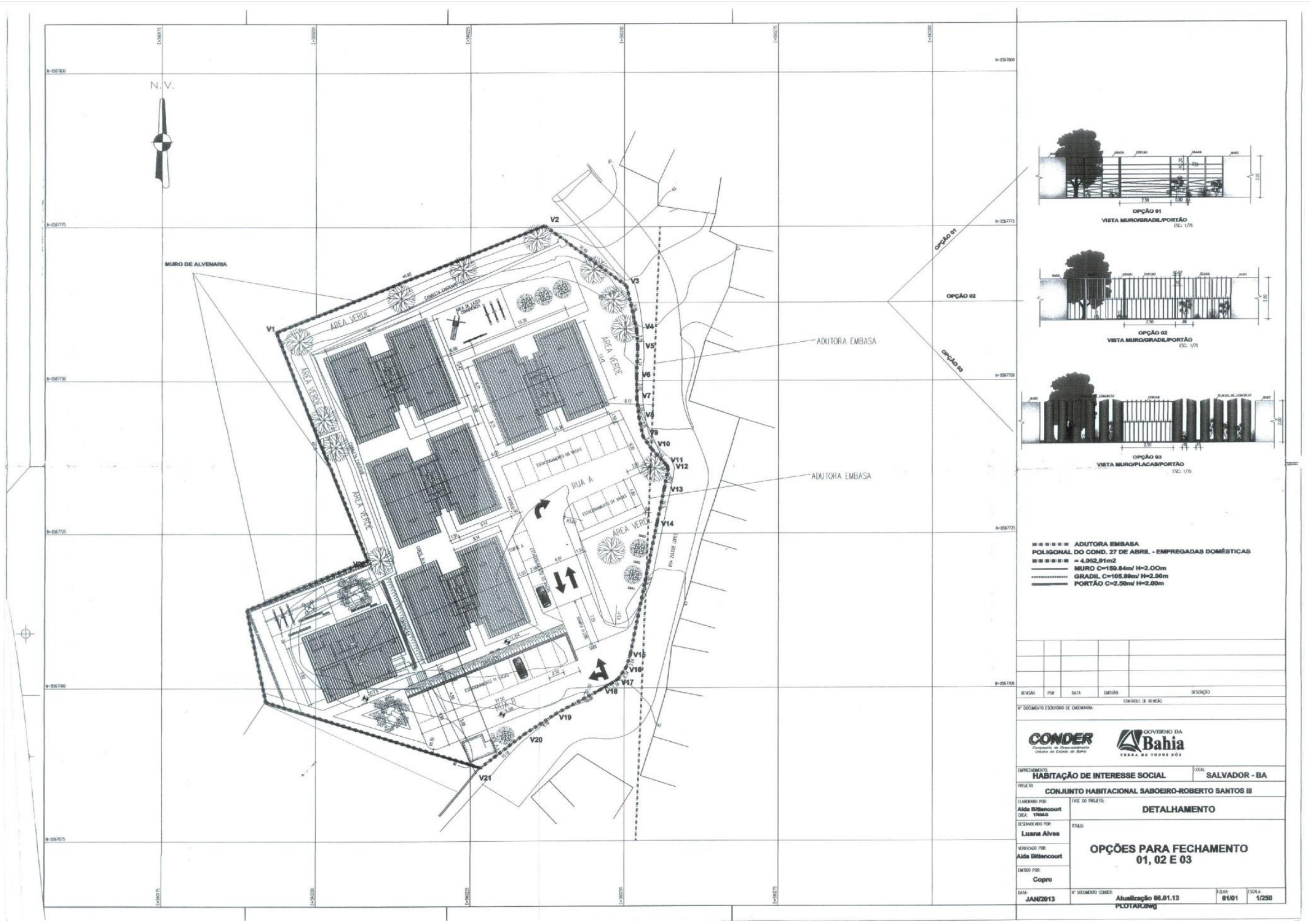




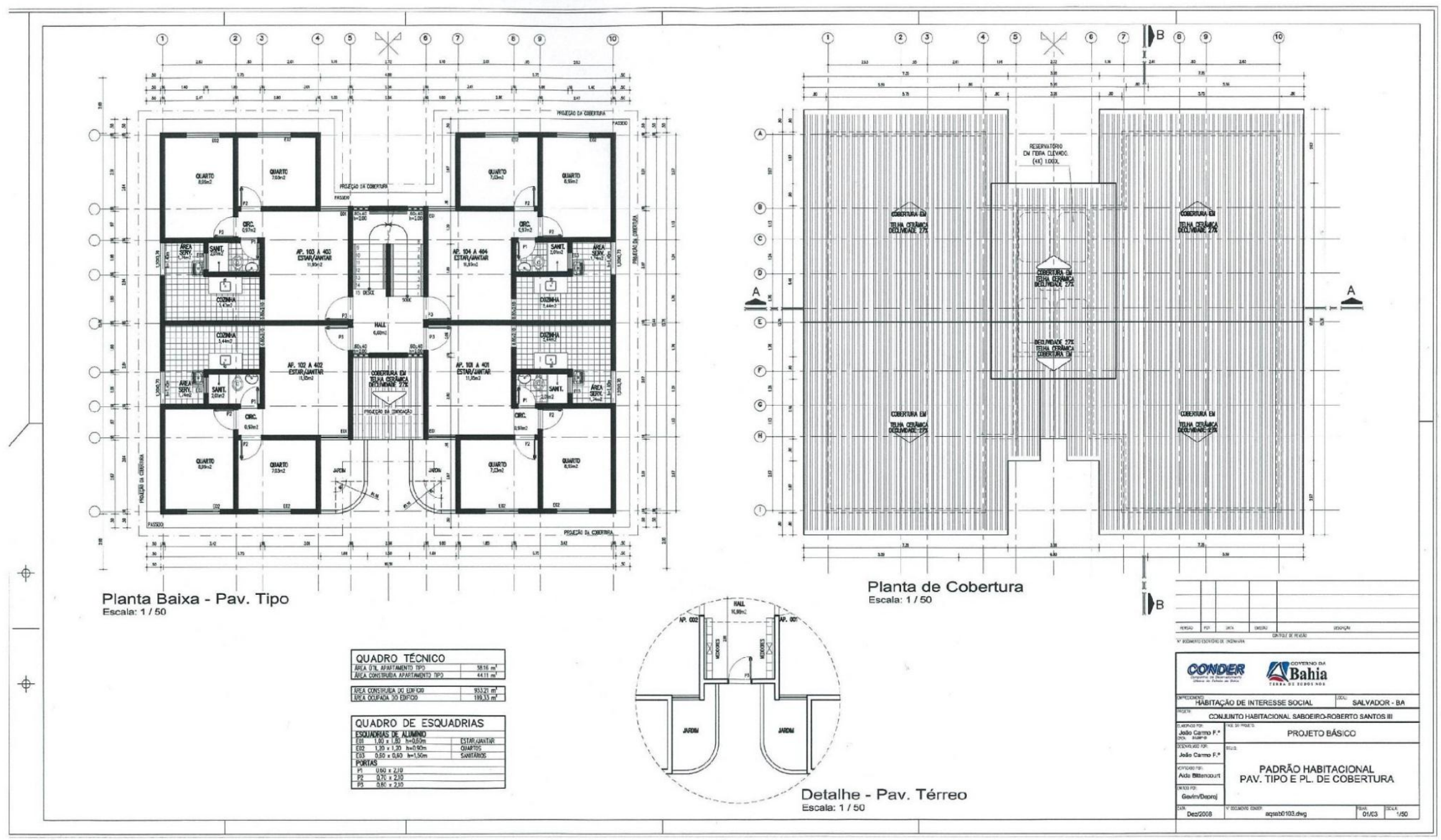




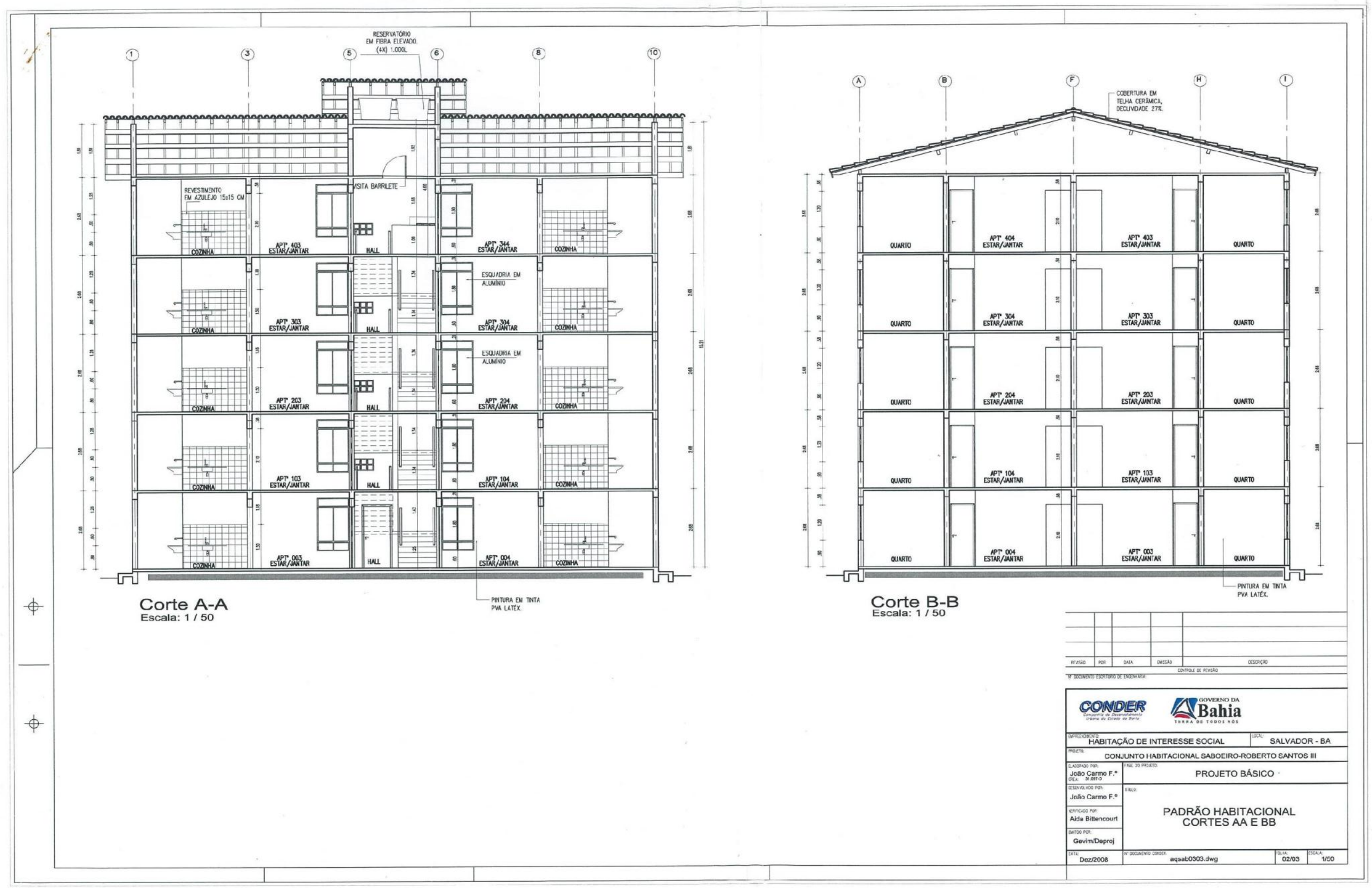




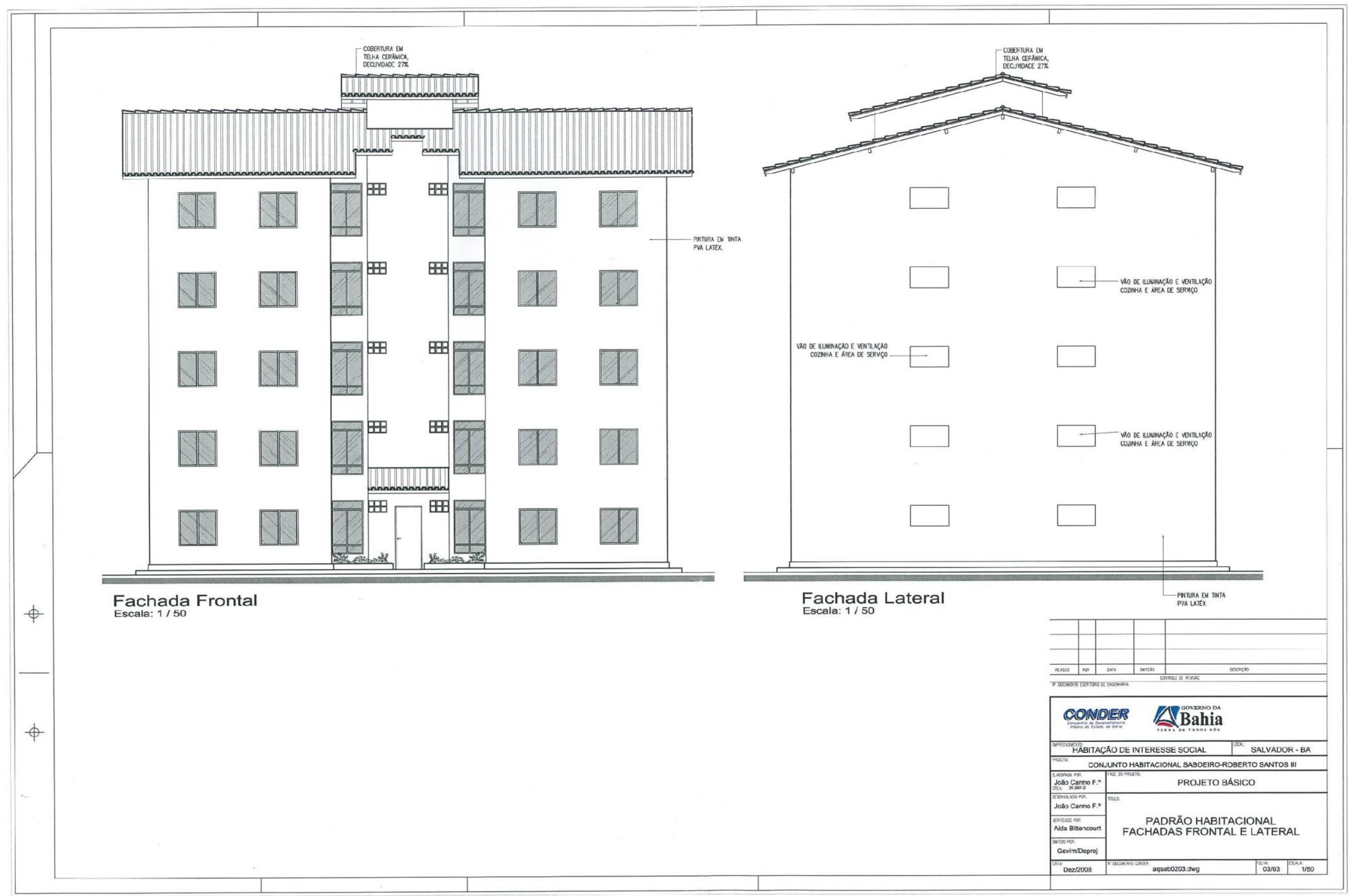




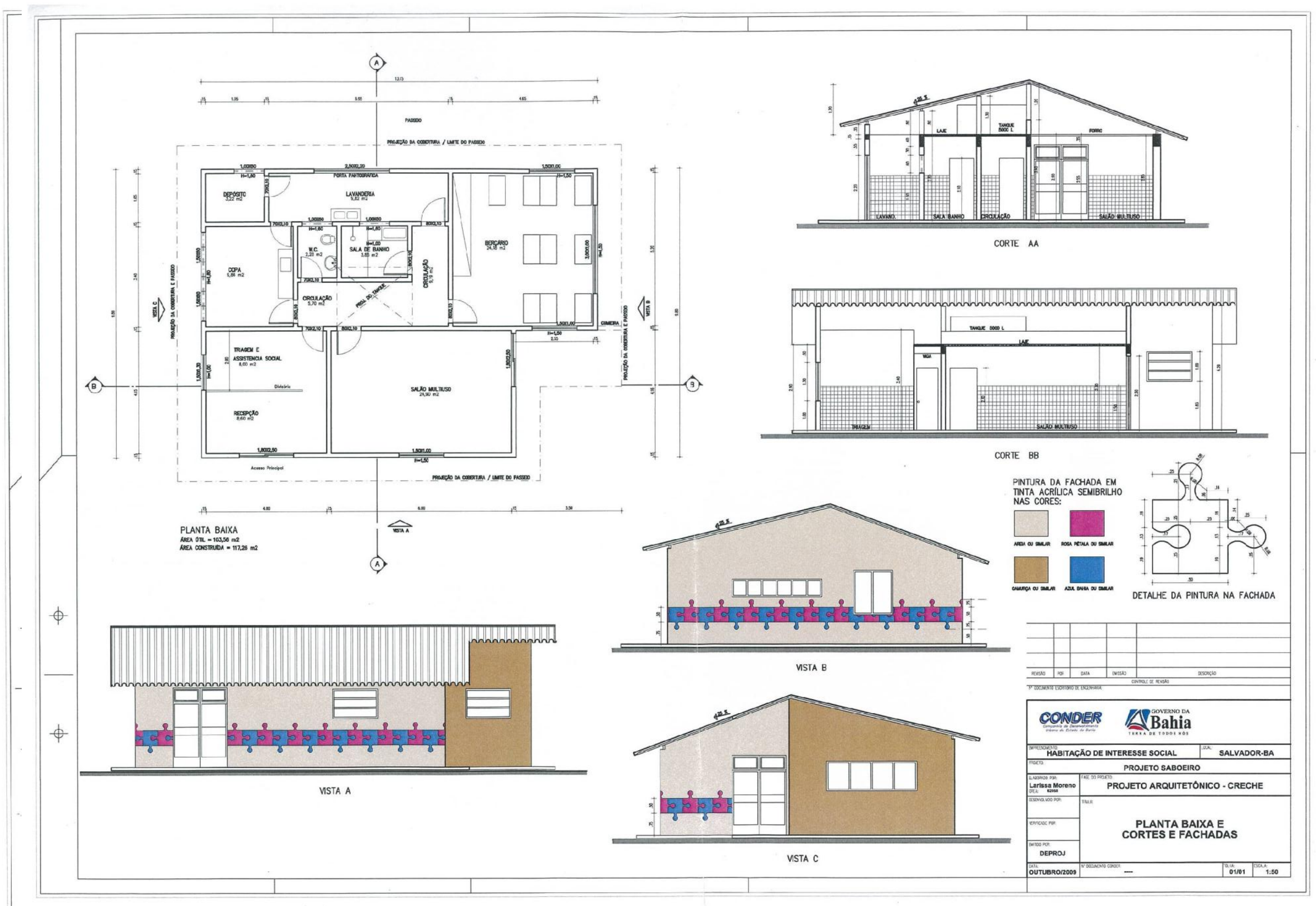

